\title{
TEXTUALIDADE \\ E MEMÓRIA \\ PERMANÊNCIA, ROTURA, CONTROVÉRSIA
}

EDIÇÃO

JOHN GREENFIELD

FRANCISCO TOPA 


\section{TEXTUALIDADE \\ E MEMORIA \\ PERMANÊNCIA, ROTURA, CONTROVÉRSIA}

EDIÇÃO

JOHN GREENFIELD

FRANCISCO TOPA 
Título: Textualidade e memória: permanência, rotura, controvérsia

Edição: John Greenfield, Francisco Topa

Comissão editorial: John Greenfield (U. Porto / Coordenador), Francisco Topa (U. Porto), Ingrid Kasten (F.U. Berlin), Laura Auteri (U. Palermo), Solange Fiuza Cardoso Yokozawa (U.F. Góias)

Design gráfico: Helena Lobo Design | www.hldesign.pt

Paginação: Carlos Gonçalves | www. carlosgoncalves.net

Imagem da capa: Fuselog - Gabinete de Design, Lda.

Edição: CITCEM - Centro de Investigação Transdisciplinar Cultura, Espaço e Memória

Via Panorâmica, s/n | 4150-564 Porto | www.citcem.org | citcem@letras.up.pt

Depósito legal: 454106/19

ISBN: 978-989-8351-96-8

DOI: https://doi.org/10.21747/978-989-8351-96-8/tex

Porto, dezembro de 2018

Produção: www.decadadaspalavras.com

Impressão e acabamento: Clássica, Artes Gráficas. Porto.

Trabalho cofinanciado pelo Fundo Europeu de Desenvolvimento Regional (FEDER) através do COMPETE 2020 Programa Operacional Competitividade e Internacionalização (POCI) e por fundos nacionais através da FCT, no âmbito do projeto POCI-01-0145-FEDER-007460. 


\section{SUMÁRIO}

NOTA DE APRESENTAÇÃO

John Greenfield e Francisco Topa

I. MEMÓRIA E AFINIDADES ELETIVAS 9

Textos para Maria João Reynaud 11

Albano Martins; Fernando Echevarrí; Fernando Guimarães; Mário Cláudio e Rui Nunes 13

A literatura em perigo?

Maria Luísa Malato Borralho

Memórias da Literatura

Rosa Maria Goulart

Ética e Estética em Raul Brandão

Álvaro Manuel Machado

Apontamentos sobre Os Pescadores de Raul Brandão, com lembranças para António Nobre e Luísa Dacosta

Paula Morão

Variação linguística em Húmus de Raul Brandão

Clara Barros

Poetas em fuga. Derivas da poesia (I)

Ana Paula Coutinho Mendes

As Servidões da Memória em Herberto Helder

João Amadeu Oliveira Carvalho da Silva

«As palavras do olhar»: Ekphrasis em Fernando Guimarães

Luís Manuel Tarujo

Meninas, de Maria Teresa Horta: Uma genealogia melancólica

Maria Graciete Besse

O velho e os livros: Passagens, de Teolinda Gersão

António Manuel Ferreira

Antropologia literária de José Tolentino de Mendonça: para uma poética da amizade na cultura pós-moderna

José Cândido de Oliveira Martins

Câmara escura: Memória obscura do tempo em Inês Lourenço

Cidália Dinis 
"Metamorfoses da escrita»: Alguns olhares sobre uma tradição da crítica literária em Portugal no século XX

Daniel-Henri Pageaux

Da leitura do texto ao texto da leitura: algumas considerações em torno do ensaísmo de Maria João Reynaud

Fernando Castro Branco

Retrato de um professor liceal, intelectual e oposicionista no Estado Novo: o caso de Óscar Lopes

Luís Grosso Correia

António José Saraiva epistológrafo

Ernesto Rodrigues

Desmistificação da origem das guerras na «Seara Nova» por Vitorino Magalhães Godinho (em 1945) Nuno Bessa Moreira

Os nibelungos em Germania Tod in Berlin de Heiner Müller: a «Misere» de uma matéria? John Greenfield

Amor, erotismo e falha: Eça e Machado

Isabel Pires de Lima

Qualquer coisa de intermédio. Da estesia à astenia: o sono abúlico, a morte e outras derivas intertextuais na poesia de Mário de Sá-Carneiro

José Rui Teixeira

O Brasil de Miguel Torga

Arnaldo Saraiva

Palavra, memória e identidade: velhice e condição feminina num conto de Lygia Fagundes Telles Francisco Topa

José Blanc de Portugal e o «descompasso» modernista

Fernando J. B. Martinho

A escrita e o olhar: Textualidade e memória no Ensaio sobre a Cegueira de José Saramago

Piero Ceccucci

Viajantes portugueses de hoje na África lusófona: entre memória e presente, que diálogos?

Maria de Fátima Outeirinho

Homossexualidade e homoerotismo na ficção de Valter Hugo Mãe 


\title{
NOTA DE APRESENTAÇÃO
}

\author{
JOHN GREENFIELD
}

FRANCISCO TOPA

Numa época dominada pela voracidade do tempo, parece fazer sentido a organização de um livro sobre Textualidade e memória: permanência, rotura, controvérsia. O pretexto foi a jubilação de uma Professora da Universidade do Porto, Maria João Reynaud, depois de uma longa carreira docente na área da literatura portuguesa, ao longo da qual, como escreve Isabel Pires de Lima, se revelou «uma sensível e exigente exegeta de poesia, designadamente contemporânea, e uma aguda leitora da narrativa oitocentista», ao mesmo tempo que introduziu a disciplina de Crítica Genética.

$\mathrm{O}$ volume está dividido em duas partes. A primeira, intitulada Memória e afinidades eletivas, abre com um conjunto de textos que cinco importantes escritores portugueses dedicaram a Maria João Reynaud. Seguem-se doze ensaios sobre temas e autores caros à homenageada, como sejam o ensino da literatura, abordado por Maria Luísa Malato Borralho; a literatura como guardadora de memórias e a forma do diário, por Rosa Maria Goulart; a obra de Raul Brandão, por Álvaro Manuel Machado, Paula Morão e Clara Barros; dois momentos e uma face similar da produção de Herberto Helder, por Ana Paula Coutinho Mendes e João Amadeu Oliveira Carvalho da Silva; a Ekphrasis na poesia de Fernando Guimarães, por Luís Manuel Tarujo; o tema da genealogia, da filiação e da herança numa coletânea de contos de Maria Teresa Horta, por Maria Graciete Besse; o jogo genológico e a abordagem da velhice em Passagens, de Teolinda Gersão, por António Manuel Ferreira; a representação da amizade em Tolentino de Mendonça, por José Cândido de Oliveira Martins; e o volume Câmara Escura, de Inês 
Lourenço, por Cidália Dinis. Na segunda parte, sob o título Memória: permanência e rotura, temos primeiro um conjunto de cinco poemas de Maria João Reynaud traduzidos para outras tantas línguas europeias por estudantes de mobilidade da Universidade do Porto. Seguem-se catorze artigos, sob temas diversos, mas unidos pela reflexão sobre a textualização da memória no período compreendido entre 1945 e 2015. Nos dois primeiros, de Daniel-Henri Pageaux e Fernando Castro Branco, o tema é o ensaio literário, tal como foi praticado por Vitorino Nemésio, David Mourão-Ferreira e Eduardo Lourenço, por um lado, e Maria João Reynaud, no segundo caso. Segue-se um longo estudo sobre a figura de Óscar Lopes, por Luís Grosso Correia, e um artigo de Ernesto Rodrigues sobre a epistolografia do outro coautor da História da Literatura Portuguesa, António José Saraiva. A abordagem dos mitos sobre a origem das guerras feita em 1945 por Vitorino Magalhães Godinho é o tema do trabalho de Nuno Bessa Moreira, ao passo que John Greenfield analisa o tratamento da matéria dos nibelungos na peça Germania Tod in Berlin, do dramaturgo marxista pós-brechtiano Heiner Müller. Os restantes oito artigos incidem sobre as literaturas portuguesa e brasileira: Isabel Pires de Lima trata o tema do amor, erotismo e falha em Eça de Queirós e Machado de Assis; José Rui Teixeira considera a obra de Mário de Sá-Carneiro numa leitura intertextual sobre o sono abúlico e a morte; Arnaldo Saraiva estuda as relações de Miguel Torga com o Brasil, ao passo que Francisco Topa aborda a velhice e condição feminina num conto de Lygia Fagundes Telles; a poesia de José Blanc de Portugal e a sua filiação no modernismo são o tema do trabalho de Fernando J. B. Martinho; Piero Ceccucci detém-se no Ensaio sobre a Cegueira de José Saramago; Maria de Fátima Outeirinho fala dos viajantes portugueses de hoje na África lusófona, interrogando-se sobre os diálogos entre memória e presente; e Carlos Nogueira encerra o volume com um artigo sobre homossexualidade e homoerotismo na ficção de Valter Hugo Mãe.

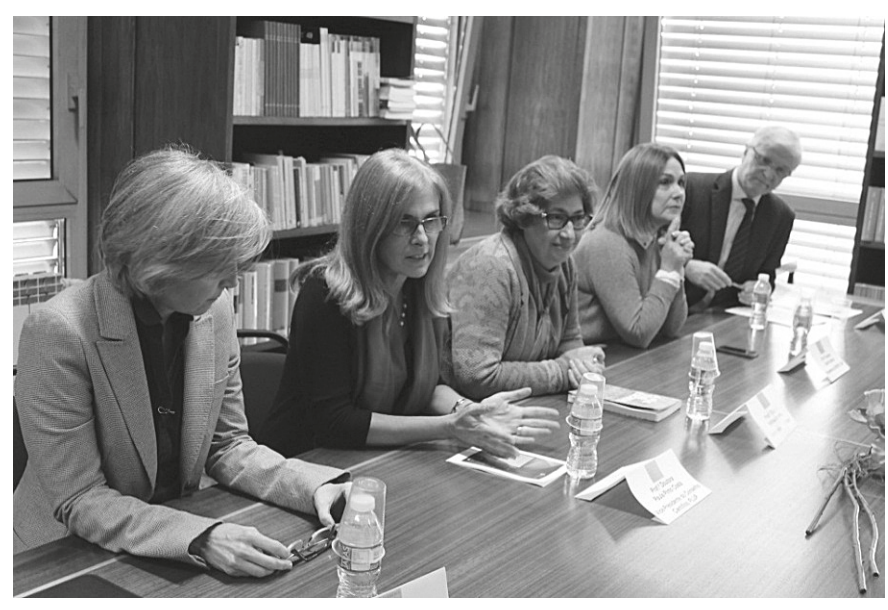

Fig. 1. Mesa da sessão de abertura do Colóquio, num momento em que usava da palavra a Vice-Presidente do Conselho Científico, Prof. a Paula Pinto 
$\mathrm{Na}$ sua diversidade de temas, formas, tempos e métodos de abordagem, cremos que este alentado volume de ensaios confirma a importância do tema da Textualidade e memória, seja ele marcado pela permanência, seja ele definido pela rotura e pela controvérsia.

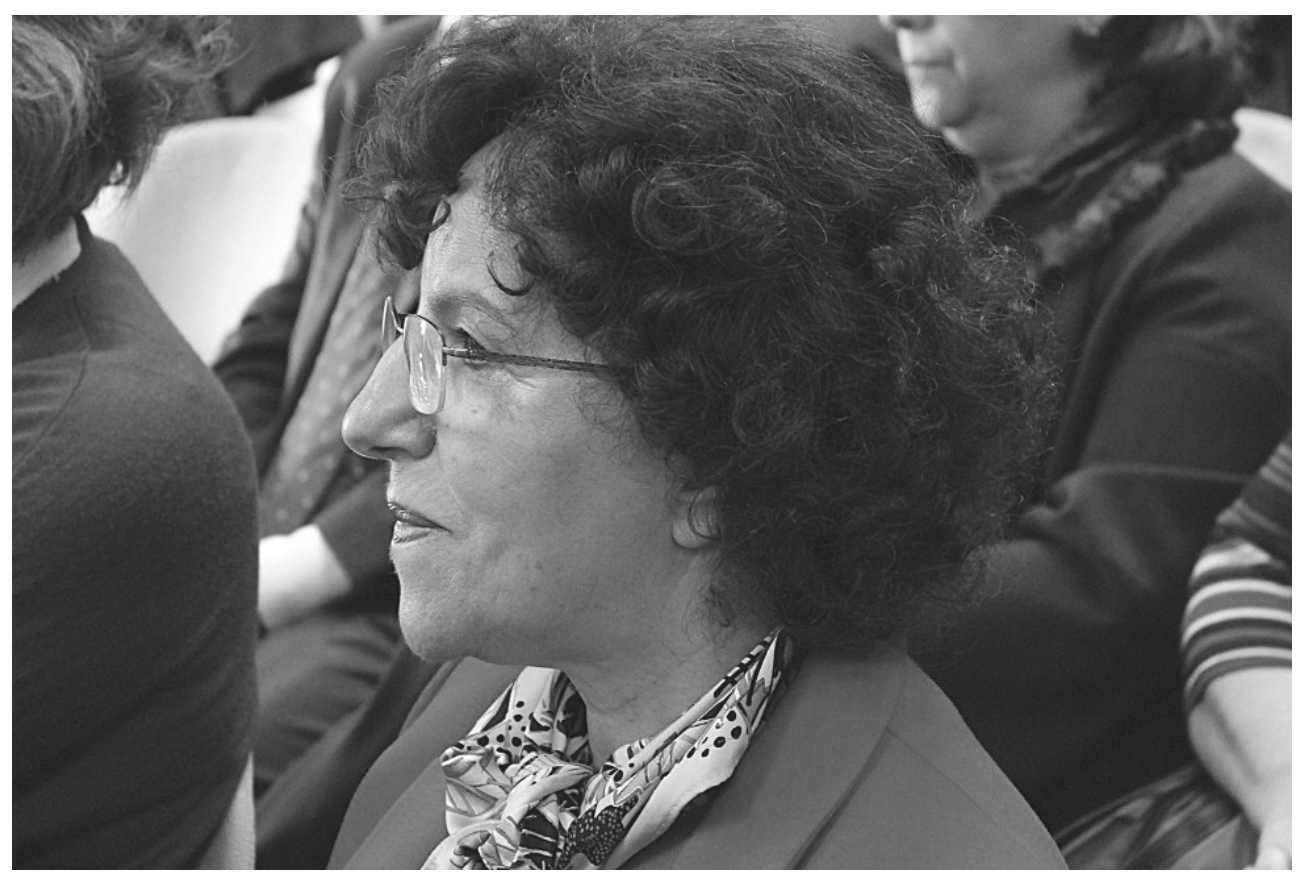

Fig. 2. Maria João Reynaud, na sessão de abertura do Colóquio

Porto, janeiro de 2018 John Greenfield Francisco Topa 



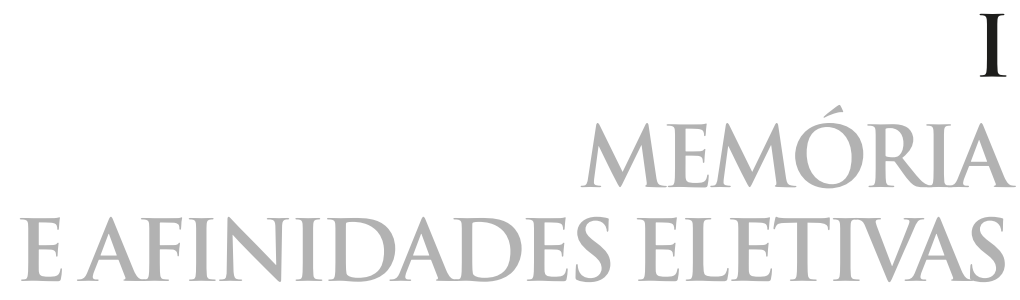





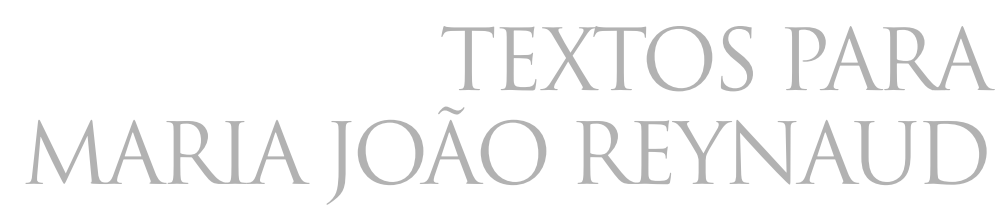



ALBANO MARTINS

\section{PALAVRA}

Instrumento, ela seria talvez harpa ou bandolim ou talvez antes guitarra. Entre o som e o sentido a palavra se desgarra. 
FERNANDO ECHEVARRÍA

FOME, ESPERANÇA, E AINDA

o pão quotidiano da fortuna.

Tudo é de todos: Deus no-lo prodiga.

Para que deles a substância nutra

a morte, trabalhada cada dia

por um ímpeto sóbrio de penúria.

Uma penúria que nos ilumina.

E àqueles de quem temos a fecunda

autoridade de pedir-nos, digna

por não ser nosso o emprestado. E sua

a luz que recebemos, na alegria

de devolvê-la, para haver só uma, eficiente e a subir, retida

pela iluminação que nos aduna.

E ergue a morte a graça transitiva.

A fonte de visão, ainda oculta. 
Nela assenta a apetência de um vagar que vai levando pela tensa mágoa de um ritmo cada vez mais eficaz. E ainda mais pobre. Que a eficácia abre um apuro de indigência tal que apenas pode colmatá-la a graça, onde a passividade avulta mais. $\mathrm{E}$, ao avultar, adquire forma. Vácua de sentido, por ora, mas a ansiar com toda a exultação a tomar alma, e, ao fundo dela, um júbilo de paz. Aí é que a penúria cumpre. Ganha plenitude de força. E oficia. Faz. 
abria-lhes, ao fundo da pobreza, a liberdade, a solidão dos campos.

E uma arguta tensão de inteligência que agia para lá de tudo quanto enclausurara o peso da tarefa.

Que a pobreza, de si, leva o trabalho a nomadismo. Começa

nos sacões sacudidos do arado para rasgar mais longe a natureza. Fica espírito livre. O desagravo, fundado nesse ofício de indigência, alhear-se podia dos atalhos para trilhar a pluridade imensa, aberta só àqueles que, entretanto, se despiram de tudo. Nem se pensam. 


\section{A POBREZA É UMA NOITE PROMETIDA}

a maior expansão de inteligência.

Desenvolve-se. Afunda a força viva.

E a altura operativa da promessa

vai expandindo o ímpeto que tinha

a apetência enigmática de festa.

Que conhecer é uma penúria activa com recurso a retiros de evidência.

Em cada um a solidão confirma

maior procura a quanto já se pensa.

E o que se pensa é uma abertura viva

a dar para pobreza mais aberta.

A noite transfigura-se. Deriva.

E a expansão aprofunda a inteligência. 
FOI POBRE SÓ PORQUE QUIS.

Procurou-se na pobreza para, por dentro de si, ser livre. Ter a indigência a abrir-se. E, ao se abrir, dar com a paciência plena de quem sabe que, por fim, haverá júbilo apenas.

O espírito, subtil, modula a altura. A surpresa dá-se, porque nada em si atrapalha. A inteligência é azul celeste, matiz de liberdade. O que pensa está despido de si.

Mas não da sua pobreza. 
ERA OPULENTO DE QUANTO,

não sendo seu, lhe retinha a surpresa agindo. $\mathrm{O}$ fausto da terra a narrar seu dia. E a narração ia entrando onde também a da brisa abria esplendor de campos à pobreza comovida.

Que a pobreza tinha um alto poder de sabedoria - nada era seu, nem obstáculo.

Só a liberdade convinha ao nomadismo. Os rebanhos eram de Deus. Dele ainda a luz a vir ao trabalho que em todos seria dia. 


\section{O PÃO ERA DE TODOS. OS QUE O DAVAM}

estavam a emprestar nada de seu.

Do alto viera aquela certa dádiva.

Em cada dia nossa. E a dever

ao trabalho rompido da lembrança

a memória da antiga lucidez.

Este de agora é-nos devido. Passa

pela pobreza de haver

um espírito afeito à indigência farta

que nos livra do mal. E de também sofrer a inteligência. Que faz falta.

Como o pão esperado, cada vez que plural o pedimos, para a graça vir eficaz. E de onde sempre vem. 
SÓ É POBRE QUEM QUER. É-O SOMENTE

quem, despido de si, tem a pobreza por dentro a trabalhar. Activa, até que lhe seja a liberdade paz imensa de espírito submisso a quanto deve o sentido exigir à obediência.

Que obediência e liberdade tendem. Sua nudez inicial é apenas o ponto de unidade onde convergem categorias de razão diversas. $\mathrm{E}$ a unidade é que conta. Dela se ergue o espírito liberto. A divergência sofre uma luz interior que a excede. A polariza no sentido. A pensa desde a sua raiz. E a funda sede de interioridade da pobreza. 
SÓ FORAM POBRES. E, AGORA, NUS,

sofrem aquela claridade imensa que de dentro lhes vem e os reduz a matéria sensível. A doença

quase gloriosa, embora a sua luz nem seja sua, mas razão intensa a remover-se, para fazer jus à penúria que só a si se pensa.

E, pensando-se assim, a intimidade vai sendo trabalhada pela empresa de se rarificar. Até a idade

não ser senão um corpo de pobreza que, acaso, se ilumina quando passa. Mas sem dar conta de lhe advir a graça. 


\section{CADA CASA PONTUA NO CAMINHO}

seu assento hospedeiro de lugar. Ali o repouso recompõe o espírito daquele que, alheando-se, no traz a pobreza. $\mathrm{O}$ grave nomadismo de quem procura quanto leva já. $\mathrm{E}$ isso nos doa, sem saber. E disso a casa se ilumina. E o lugar. A mesa posta, essa, à luz do vinho, expõe o incremento cereal do pão que se amassou. E vai abrindo o calor. O volume. Quanto dá viático esplendor a todo o sítio e enche a casa. A deixa a iluminar. 
a curtir a prudência da lavoura

e, sobretudo, o hábito de dar-se à compenetração. Trazem a roupa e a honradez de uma saúde grave que o trabalho talhou. E de onde aponta a independência, porque a liberdade sobe feliz se nenhum peso a apouca. De aí nos chegam. Os seus passos abrem a inteligência. Pela terra à volta sensíveis alargam arrabaldes interiores a estenderem fora a alheação de luzes eficazes. E dessa alheação surde ordem nova - a de uma intrepidez de liberdade assente na palavra que a coroa. 


\section{QUEM DÁ TEM O NATAL JUNTO À LAREIRA}

a abrir tesouros do que não é seu.

Do que se lhe emprestou: a inteligência

e quanto, por caminhos ínvios, vem

expor, munificente, a mesa aberta, com o vinho e pão a rescender.

A divulgar o coração da festa

que, por ser para todos, também é

lugar ausente, de memória certa

daqueles que se foram. Que já têm

na compenetração uma tarefa

repentina. De luz onde se fez

o mistério do Verbo que não cessa

de estar verbalizando, ou a fazer.

Mas nem por isso o seu Natal de ausência

deixou de ter lugar. E de ser seu. 
NATAL

UMA ALEGRIA INTERIOR FERMENTA.

Prepara a ceia onde já se expande o efeito do pão. E o calor da mesa, erguida à recente claridade dos que, à volta, nostálgicos, se sentam em memória de quantos, ao passarem, acrescentaram esta luz intensa, tocada por um júbilo tão grave.

Mas outros primam por uma outra ausência:

furam curvas de frio na cidade e rasgões aluados de pobreza, enquanto as luzes do conforto sabem ao interdito brilho das janelas. A alegria fermenta. A piedade, recolhida, se expande. Estende a mesa àqueles, generosos, que nos trazem apenas a abundância da pobreza. E o fermento da nova claridade. 
A exibição da pompa, o estandarte a dar sinal de estralejar no vento, mesmo que o vento lhes sacuda a imagem. No entanto, passam. Quase que só o feito de passar deslustrou essa passagem, de forma a haver um indelével gesto, um equilíbrio a sustentar a parte nadificada com que o nulo peso usa o verniz. E uma ordem quase cutânea de perfume, de ligeiro ritmo de falso pundunor dançante. $O$ fora era verniz de nada dentro. E o dentro tambor de vacuidade. 
FERNANDO GUIMARÃES

\section{A CASA CONSTRUIIDA POR WITTGENSTEIN PARA A SUA IRMÃ}

As paredes são altas. Quis pintá-las de branco para que a luz lhes pertencesse mais. Esta casa existiu no seu pensamento e, por isso, os quartos talvez se encontrem contidos uns nos outros e os corredores sejam o seu centro. Os alicerces foram cavados fundo só para que a noite pudesse descer sobre ela. Há uma sala maior que as outras. No meio, está uma mesa onde fica entreaberto o Tractatus. As janelas são atravessadas pelos pássaros, mesmo que tenham vidros, porque cada ave é um conceito. Sabemos que esta casa pode ser um raciocínio ou uma metáfora. $\mathrm{O}$ vento chega e fará com que as cortinas estremeçam. Ali tudo foi construído com rigor. De início foram as paredes apenas linhas num papel, mas depois cresceram como se fossem campos lavrados. Em cada sala existe um candeeiro sempre aceso. Continua esta casa a ser um pensamento? Acerca disto ninguém tem a certeza 
O QUE FREUD PODIA DIZER AO SEU NETO LUCIAN

Estou velho. Foi o tempo que desceu pelos meus olhos, a luz que se apagou há muito. Já não tenho sonhos: como posso saber ainda qual é o significado da noite? Ergo os olhos para que as aves passem no céu. Elas são como os instintos, essas veias abertas que trazem consigo o nosso calor. Ainda sei descobrir alguns segredos, revelar o que se torna noutro significado, o mais oculto. Tenho esse dom, tu possuis os teus. Sempre esperei que fosses diferente de mim. Por vezes fico a olhar os teus quadros. O que descubro neles? Uma voz afasta-se e, no entanto, ela traz-nos uma súbita certeza, as letras que ficam aqui escritas para que seja a verdade capaz de as apagar depois. Tu sabes que é assim... As cores, as linhas, os volumes chegam a uma tela e são apenas a nudez, o seu repouso. Reparo nestes corpos que são pesados. Em tudo deixas uma sombra que desce e depois se torna muscular. Os sonhos que interpretei podiam ser como estes quadros. Mas não. Sempre te pertenceu a seiva que nos corpos escorre, o modo como as roupas ficam caídas, as suas pregas. Agora, abro um dos meus livros. Sem que tenha pressa, folheio-o e no ar há um movimento como se junto de mim só tu o pudesses ler. 


\section{A MORTE}

Aqui, de todas as sementes

é a que mais pesa. Esperamos

por ela. Acolhemo-la e nada

podia ser tão nosso. Compreendemos

que no seu interior talvez exista

a última seiva, o rumor de outra

germinação só para que fique

próxima. Descai silenciosa

e devagar. A terra é o nosso corpo. 
MÁRIO CLÁUDIO

QUATRO VERBETES PARA MARIA JOÃO REYNAUD

Call me Ishmael

O menino estava suspenso, e o seu nome ninguém o sabia.

Perdido na noite de Janeiro, a mãe pensava em cerejas. «Só as do Chile», diziam-lhe, «as que ninguém adivinha». E os relógios da cidade arrefeciam lentamente.

No seu ventre de estrelas e teias, o menino continuava a sorrir. 
TEXTUALIDADE E MEMÓRIA: PERMANÊNCIA, ROTURA, CONTROVÉRSIA

\section{SUNDAY BLUES}

Por aí andam, e se existem, não sabem.

A casa basta, mas os amigos só chegam pela noitinha.

O velho alemão retira a peruca empoada, e diz: «Ser livre nada significa, tornar-se livre é divino». 
INSÓNIA

Abro a página, e aí comparecem, sentinelas brancas da dúvida.

Eternas como as ondas, um lobo as espreita, ou um diabo convulso.

Desdobro o pasmo das bocas comuns, sudário de estrelas compadecidas.

A cama emudece, a noite respira. 
TEXTUALIDADE E MEMÓRIA: PERMANÊNCIA, ROTURA, CONTROVÉRSIA

VESPERAL

Estou diante da tua campa, quadrado de terra entre japoneiras.

$\mathrm{O}$ nevoeiro apaga as cores do viravento que te guarda o sono. E a tarde derrama o teu nome no silêncio.

O sábio disse: «A luz do caminho é como a escuridão». 


\section{RUI NUNES}

Cemitério Judaico - Varsóvia

Placas, estelas, blocos de pedra, uns atrás dos outros, uns ao lado dos outros, subindo o morro, debaixo das árvores, inclinados para o caminho, apertando-o, tornando sinuoso o que é recto, um desvio, os melros não voam de lápide em lápide, basta-lhes saltar: asas ligeiramente abertas, pousam cautelosos, oscilantes, sobre os nomes gravados no mármore, alguns sujos de tempo, de fungos mortos sobre fungos mortos, outros de um dourado brilhante: ontem, ainda alguém os chamava e alguém respondia, nomes cheios da nitidez dos nomes que acabaram de morrer, pujantes, (pungentes?) de uma morte que não envelheceu, nomes encerrados entre duas datas, que o homem quase não consegue enxergar, todos eles sem rosto e sem história, equivalentes, amontoados em vida, no ghetto, amontoados na morte, aqui, não escapam à proximidade sufocante, às lagartixas que vão de pedra em pedra e se imobilizam de repente em palavras indecifráveis, no interior de um cheiro a musgo seco, a mofo e a podre, o mesmo cheiro (outro?) saía da grelha dos esgotos, desprendia-se das roupas enxovalhadas e acumulava-se na rua. Antecipava, neste cemitério, o hiato entre um ano e outro, entre 1939 e 1945. O homem sabe, o quê?, sabe que essa grande pausa o rodeia, construída de tudo o que falta: falta uma casa: e o vazio cresce, falta uma palavra e o vazio cresce. Falta-me o bilhete de comboio: e o vazio cresce, falta-me tempo: para ir às compras, para ir a um concerto, para jantar contigo, para dormir: e o vazio não pára de crescer: apanhará a mulher que acabou de parir, a criança que acabou de nascer, o velho que acabou de morrer. Contamina. Em redor, as árvores recortam o azul desmaiado, e nele enraízam. (aqui, não há pinheiros, nem abetos, nem castanheiros: há um nome quase abstracto: árvores.). A hera, verde concêntrico, enrola-se na pedra e torna-a cada vez mais pequena. Brutal, o que sobra: o gume: a memória fractura uma eternidade rudimentar. Como todas 



\title{
A LITERATURA EM PERIGO?
}

\author{
MARIA LUIISA MALATO BORRALHO*
}

Ensinar é continuar a aprender. Maria João Reynaud, 9 de março de 2015

Henrique conchegou a roupa a si; à falta de velador, pousou o castiçal no travesseiro e, abrindo um livro que trouxera de Lisboa, pôs-se a ler, para obedecer a um hábito adquirido.

Não teria lido ainda um quarto de página quando ouviu a voz da tia Doroteia, que the dizia de fora da porta:

- Ó menino, tu já te deitaste?

- Já sim, tia Doroteia.

- Olha se tens cautela com a luz. Eu tenho um medo de fogos!

- Esteja descansada, tia. Eu apago já.

- Então será melhor. S. Marçal nos acuda.

E afastou-se, rezando ao santo.

Henrique continuou a ler.

Daí a pouco a mesma voz:

- Tu já dormes, Henriquinho?

- Não, tia. Ainda não durmo.

- Olha que não vás adormecer sem apagar a luz. Eu tenho um medo de fogos! Não descanso enquanto não vejo tudo apagado em casa.

Henrique perdeu a paciência.

* Universidade do Porto/Instituto de Literatura Comparada Margarida Losa. Este artigo insere-se na investigação desenvolvida no âmbito do Programa Estratégico UID/ELT/00500/2013. 
- Pois pode sossegar. Olhe.

E apagou a vela, meio zangado.

- Fizeste bem, fizeste bem: isto já é tarde e é melhor fazer por dormir. Então muito boas noites.

- Muito boas noites - respondeu Henrique, quase amuado; e ajeitando-se na cama, dizia consigo: - E esta! Já vejo que nem ler me é permitido aqui. Olhem que vida me espera! E isto é que me devia curar? Que fatalidade!!

Se trago esta longa passagem aqui é porque parte da minha memória a guarda como antítese do que é dito ser o aluno de hoje, ainda nos cursos universitários de letras e humanidades. Lembro-me dela quando olho os resultados do último inquérito anónimo aos alunos do 1. ${ }^{\circ}$ ano deste ano letivo de 2015-2016: dezembro vai começar, e muitos não foram ainda à Biblioteca da Faculdade, nem para a bibliografia obrigatória das disciplinas que estudam. Muitos dizem estudar por apontamentos e ler os textos dos professores deixados nas aulas. Não veem necessidade de mais: fazem como sempre fizeram e deu resultado. Não reconhecem grande parte dos nomes de escritores portugueses e europeus canónicos, nem por uma obra, nem por uma época. Há quem acredite que Gutenberg é do século XX (será o nome do Projeto?). Dickens, sobre o qual se formou um grupo de trabalho por sugestão de uma aluna, é para quase todos os outros desconhecido, ainda que tenham ouvido falar vagamente de David Copperfield, e dois alunos o situem, um no século XVI e outro no IX. Garrett, até Garrett, na sua aldeia, reescrito agora «Garret», não é identificado por $72 \%$ dos meus mais recentes alunos, excluindo-se aqui os que afiançam ser ele o autor de Felizmente há Luar e de A Cidade e os Campos [sic]. Aparentemente é verdade o que dizem os próprios: estão em humanidades, alguns dizem que não gostam de ler e não leem, e num grupo de trabalho que trabalha sobre a relação de Manoel de Oliveira com a Literatura, os alunos acham estranha a minha surpresa por não conhecerem Fellini ou Visconti: é uma questão de generation gap, tranquilizam-me.

Não devo dizer aluno, etimologicamente «o que é alimentado», mas antes estudante, «o que estuda». O que estudou ele? O que esqueceu. O que estuda? O que esquecerá? Ou de que o posso vir eu a alimentar? Do que vomita, anorético ou bulímico, cansado de tanto alimento que o rodeia? De $5 \mathrm{em} 5$ anos, faço estes inquéritos sobre o conhecimento histórico-literário objetivo, desde que comecei a dar aulas na universidade: ordenação de eventos, identificação/reconhecimento de nomes de escritores, de obras, de elementos sintáticos da oração, resolução de problemas lógico-matemáticos básicos. Os resultados atuais são verosímeis, a crer nos anteriores ${ }^{2}$, mas fico cada vez mais preocupada com o

${ }^{1}$ DINIS, 1992: 35-36.

${ }^{2}$ V.g. BORRALHO, 1991: 91-128. 
que dizem não ter aprendido sequer, porque sei que é possível não terem dado conta do que pergunto entre tanta coisa que têm nos programas curriculares. Sei que continuo a ter leitores excelentes, sobrevivem a tudo, ansiosos como Henrique na pasmaceira da província. Mas alguma coisa foi mudando: talvez o aluno médio, o aluno comum. Na turma de Literatura, uma aluna afiança que a expressão «apetite pantagruélico»é usada pelo avô, com a $4 .^{\text {a }}$ classe, mas ela nunca soube bem o que ele queria dizer com isso, mas deve ser «muito»: é a única dos 25 que arrisca um sinónimo. Não se trata de terem lido Rabelais, Dante, Homero, Kafka ou Cervantes, mas de muitas vezes (sempre mais de 50\% dos estudantes) não conseguirem apontar um sinónimo para as expressões «visão dantesca», «feito homérico», «processo kafkiano» ou "perspetiva quixotesca».

Facilmente um professor partilha essa ideia de Todorov de que a própria Literatura se encontra hoje em perigo, quer porque é vista como um adorno cultural, prescindível e inútil para a vida, quer porque veicula, em versão light, os impulsos puramente individuais de alguém que escreve ${ }^{3}$. Estará ela em perigo? Os estudantes leem muito em geral, através de posts, twitters, e-mails, apps, pdfs, e-books, em RWP... Leem ainda o que lhes mandam ler, da forma que lhes mandam ler, forma ligeira e ritualizada, em que se pode adivinhar o texto d'Os Maias que vai sair no exame: o jantar dos Gouvarinhos (porque saiu no outro a cena do Hotel Central), a cena do Hotel Central (porque já saíram os Gouvarinhos). Olho-os aparentemente atentos, embora eu os saiba a manejar com perícia a internet debaixo das carteiras, anacrónicas. Circunstâncias pontuais, conforto-me: são 25 alunos naquela turma, já ao final da tarde, cansados, depois do pôr-do-sol marcado para as $17 \mathrm{~h} 15 \mathrm{~m}$, e os resultados são certamente exacerbados pela imprevisibilidade do teste. Como lhes vou falar de literatura? Da literatura que está (também) no passado e não necessariamente nos big books and bestsellers que tomam os escaparates das livrarias (onde não se vê um livro de Dickens ou Kafka). Como dar uma aula de Literatura numa época de profunda mutação da «lógica do mercado» dos livros ${ }^{4}$ ? Como entender uma aula de Literatura na universidade e num curso sobre Literatura e Linguagem?... Perante um cada vez maior universo comum de leituras, o problema do "Como» tornou-se menos importante do que "Para quê». Sendo o modelo da sala com estrado um palco anacrónico ${ }^{5}$, terei de dar aulas com power-point, quadro eletrónico, folhas volantes? Talvez tenha, talvez. Mas porquê? Porquê falar de Literatura? Porque será tão importante que os estudantes entendam o que estou a tentar transmitir-lhes, quando nem sequer me é possível responder cabalmente à pergunta «O que é a Literatura?» ou «O que é a boa literatura?». Sei que devo o meu gosto literário a obras que hoje não reconheço como canónicas e dou por mim a desprezar hoje a utilidade de algumas que me ocuparam durante anos e a quem

${ }^{3}$ Cf. TODOROV, 2007: 31 et passim.

${ }^{4}$ John Thompson, in AA. VV., 2015: 73-90.

${ }^{5}$ Cf. SERRES, 2012: 41. 
agradeço o tempo demorado que passei a decifrá-las. Os primeiros contactos com a Literatura estão cheios de maus porteiros, desenhos toscos de heróis de pacotilha. Óscar Lopes, Todorov, ou Umberto Eco falaram já da misteriosa chama da literatura menor... ${ }^{6}$

Devo eu proibir? Temer? Intimamente acarinho aquela persistência da tia Doroteia que não levava a sério o prazer que os livros podem dar. É que temo por vezes mais a imagem contrária: a de um professor que teima em fazer ler, que quer encher as mentes (perigoso desejo, faca de dois gumes) e à qual resiste um estudante adormecido, que depressa fecha os livros. Amo a liberdade que me dá conhecer o mundo mais vasto das coisas abertas e lidas e temo a morte que dá a ignorância. Mas muitas vezes só sei que as coisas terrivelmente livres se têm de arrumar depressa, e a literatura me ajuda a aguentar «a desordem estuporada da vida» de que fala Herberto Helder.

Mentalmente enumero as vantagens que dizem ter quem lê: a maior variedade do vocabulário; a maior facilidade nas questões da interpretação, que vão do texto de Português ao problema de Matemática; os conhecimentos de História, inclusive; as notas que naturalmente sobem por se saber mais... E eu nunca li por nenhuma destas razões. Qual a validade destas minhas recomendações para um aluno? Como tem ele a perceção de como é bom ter um vocabulário maior? Para que lhe serve um vocabulário maior se as ideias que tem lhe parecem caber como mão na luva? O que lhe posso eu dizer que ele compreenda, quando lhe falo da utilidade de um vocabulário maior? De que lhe serve falar de mais facilidade na interpretação, quando ele acha somente que há perguntas fáceis e outras difíceis, cabendo ao professor evitar as difíceis e a ele encontrar as fáceis? Melhores notas: o trabalho não vale o esforço, isso sabe ele desde o início, ainda o professor não tinha dado a nota. E não foi ele sempre passando? Recordo a resposta de uma aluna, já há muitos anos, escandalizada que eu fiquei por Garrett e Fernão Lopes serem para ela do século XII, preocupada por ela nada ir entender do que era o movimento romântico: «Sotôra, se eu cheguei até aqui não sabendo nada disso, é porque não é importante para eu estar aqui». De certa forma responde-lhe agora alguém que pode já ter sido sua aluna, alguém que já foi por ela alimentada, uma aluna do secundário que recusava qualquer conhecimento de História: «O que existiu antes da Daniela nada tem a ver com ela». Suspeito a provocação, valorizo o sentido rítmico que aproxima a Daniela da Poesia, imaginando aqueles que hoje mandam fechar os tablets, folhas de vidro que parecem limitar os livros aos facebooks... Sei que continuo a ter alunos extraordinários, cada vez mais extraordinários, mas assusta-me sobretudo, confesso, o aluno médio, o que vai passando e exercendo, ignorando cada vez mais a própria matéria de que foram alimentados, deixando-me ainda em cada ano uma interrogação pedagógica: como fazer sentir a falta do que se não teve nunca? Sinto eu falta de beber sumo de guava?

${ }^{6}$ LOPES, 1965: 5; TODOROV, 2007: 78; ECO, 2004. 
A primeira tentação que tenho é a de recriar essa clandestinidade da leitura, representada pela Tia Doroteia. Ou pelo menos não tornar a leitura uma obrigação. Jorge Luís Borges considerava a «leitura obrigatória» um oxímoro. Tão paradoxal quanto o "prazer obrigatório» ou o "prazer seguro» ${ }^{7}$. Recordo o tempo em que eu própria era obrigada a fechar a luz do candeeiro, quando levava uma lanterna para ler debaixo dos cobertores, encorajada pela clandestinidade das minhas leituras excessivamente noturnas. Ou o contexto em que li até meio da adolescência, numa ditadura de brandos costumes que amolecia a mente: "Chegou a Coimbra o livro, mas apreenderam-no logo das livrarias»..., «Esse livro não é para meninas»..., «Esse livro não é para a tua idade»..., «Não ias entender»..., «Aquilo é sobre X, mas nem vale a pena contar-te o final». O meu pai sabia de cor versos de Guerra Junqueiro de uma Velhice do Padre Eterno proibida. Ao meu tio, tinha-lhos ensinado um professor. Licenciado ou não, aluno que tivesse que ler Os Lusíadas podia não ter lido outra coisa de motu próprio, mas tinha lido o canto nono. Por alguma razão, que Deus no jardim do Génesis parece conhecer bem, a proibição excita a curiosidade. O ser humano parece valorizar o inacessível, sem dúvida Deus fez-nos utópicos. Mas não O evoquemos em vão: a proibição denuncia um valor (in)acessível e o medo de alguém tomar esse valor. Quanto mais não seja é uma forma de pudor que esconde uma parte do corpo para valorizar outro caminho para lá chegar. Ainda que só se anteveja, pois ler não é mais do que espreitar um horizonte que se afasta à medida que dele nos aproximamos.

Um estudante da turma recorda o momento em que, com 4 anos, concluiu a leitura d'O Principezinho. E Todorov-adulto, aos 8 anos de idade, teria registado no seu diário: "Aujourd'hui j’ai lu Sur les genoux de grand-père, livre de 223 pages, en une heure et demie» ${ }^{8}$. A leitura que provoca prazer, ao contrário da obrigatória, é uma reconstrução da Torre de Babel: uma hybris, uma insolência hercúlea que copia a omnipotência divina. Os escritores sabem-no bem. Utilizam preterições manhosas, só para poderem dizer o que não podem dizer: «Não vamos aqui descrever o entusiasmo que tomou posse do seu rosto», «não falaremos aqui da nobreza de sangue e das virtudes dos seus antepassados». Ou enunciam sensações que não se veem, ouvem, ou sentem... Falam do inefável, repetido através dos tempos, como se ler fosse sinónimo de amar. O conhecimento é, no seu melhor, uma forma de amor ${ }^{9}$. Que queres tu que te diga? Ler é sentir como se sentisse: um «fogo que arde sem se ver»: «É ferida que dói, e não se sente;/É um contentamento descontente;/É dor que desatina sem doer;/É um não querer mais que bem querer;/É solitário andar por entre a gente;/É nunca contentar-se de contente;/É um cuidar que ganha em se perder...» ${ }^{10}$. 
Talvez devêssemos usar mais vezes desse inefável da leitura, sumo de guava. Mas a estratégia é um pouco arriscada. De alguma forma, corremos o risco de a proibição ser obedecida. Ou de não se entender o que não é explicado. Ou ainda da solidão excessiva nos tolher. Assim sucede normalmente nos estados totalitários. Em que medida consegue o poder, desde logo o representado pelo professor, incentivar um espírito crítico? Também os cidadãos, leitores como qualquer outro, se contentam com pouco: obedecem por regra, agrada-lhes a clareza da chaveta, e não pedem explicações... Coisas que espantavam La Boétie quando discursava sobre as causas da servidão voluntária:

Digno de espanto, se bem que vulgaríssimo, e mais doloroso do que impressionante, é ver milhões de homens a servir, miseravelmente curvados ao peso do jugo, esmagados não por uma força maior, mas aparentemente dominados e encantados apenas pelo nome de um só homem cujo poder não deveria assusta-los, visto que é um só, e cujas qualidades não deviam prezar, porque os trata desumana e cruelmente ${ }^{11}$.

Mas o que tem a ver La Boétie com o ensino da Literatura? Talvez somente aquilo que Todorov evoca como sua função principal: a de cada leitor descobrir nela o que ainda não é, mas poderá vir a ser. Nada há de mais difícil na nossa vida que saber construir essa vida com os limites do possível. A Literatura parece ter em potência a capacidade de nos fazer questionar a ordem dada das coisas ou a de nos fazer acreditar numa outra ordem possível, ainda numa criança ou num adolescente. Todorov, já adulto, sabe que gostou de Literatura porque lhe dava a viver a liberdade da aventura, mas sem as frustrações sentimentais a que o jovem Todorov se sentia votado na vida real. Na Bulgária comunista, não estando Todorov motivado por nenhum desígnio da revolta, a Literatura permitia opor ao estado público da aquiescência o estado privado da interrogação, sem que para tal fosse necessária uma contestação aberta. Tratava-se pois somente de escapar, de estudar os textos aparentemente inócuos deixados pelo regime, e duvidar da sua inocência ideológica penetrando na porta para ela aberta: e assim «Je me suis engagé dans l'une des rares voies qui permettaient d'échapper à l'embrigadement général» ${ }^{12}$.

Proibiria hoje Rousseau os livros ao jovem Emílio para que, até aos 12 anos, na ausência de opiniões vinculativas, ele desenvolvesse o espírito crítico?

\footnotetext{
${ }^{11}$ LA BOÉTIE, 1997: 18.

${ }^{12}$ TODOROV, 2007: 9.
} 
La lecture est le fléau de l'enfance, et presque la seule occupation qu'on sait lui donner. À peine à douze ans Émile saura-t-il ce que c'est qu'un livre. Mais il faut bien au moins, dira-t-on, qu'il sache lire. J'en conviens: il faut qu'il sache lire quand la lecture lui est utile; jusquálors elle n'est bonne qu’à l'ennuyer ${ }^{13}$.

É certo que uma criança, no século XVIII ou no século XXI, pode ter muitas outras formas de conhecimento: a observação do mundo, desde logo, onde se incluem também as fotos do Instagram, os jogos de computador, os enigmas mais ou menos virais. Não há vácuo cultural: a ausência de transmissão de cultura é ainda a obtenção de um determinado estado de cultura.

Si votre élève n'apprend rien de vous, il apprendra des autres. Si vous ne prévenez lerreur par la vérité, il apprendra des mensonges; les préjugés que vous craignez de lui donner, il les recevra de tout ce qui l'environne, ils entreront par tous ses sens, ou ils corrompront sa raison, même avant quelle soit formée, ou son esprit, engourdi par une longue inaction, sabsorbera dans la matière. L'inhabitude de penser dans l'enfance en ôte la faculté durant le reste de la vie ${ }^{14}$.

Deve sublinhar-se também que Rousseau tinha alguma fé nas virtudes da Tia Doroteia:

J'ajouterai ce seul mot qui fait une importante maxime: c'est que, d’ordinaire, on obtient très sûrement et très vite ce quion n'est pas pressé d’obtenir. Je suis presque sûr qu'Émile saura parfaitement lire et écrire avant l'àge de dix ans, précisément parce qu'il m'importe fort peu qu'il le sache avant quinze $e^{15}$.

Mas pode um jogo (de computador ou não), consegue uma história (de um reality show ou de Colin Tellado) substituir a Literatura enquanto desvio normativo? Deve a escola dar o que o aluno encontra mais facilmente fora dela? Um estudante escreve no inquérito: «Espero que a Universidade me faça conhecer a Literatura». Comove-me o desejo. Necessário se torna um conjunto de reflexões sobre o que nos apanha à traição. De alguma forma, importa aqui tratar daquilo que a universidade visa questionar: a preguiça mental que nos leva a acreditar que «as coisas são como são» e a solução apresentada não tem alternativas. De certo modo, continuo a pensar com Óscar Lopes que a educação do gosto literário é um «problema social», e não

\footnotetext{
${ }^{13}$ ROUSSEAU, 1771: II, 265.

${ }^{14}$ ROUSSEAU, 1771: II, 267-268.

${ }^{15}$ ROUSSEAU, 1771: II, 268-269.
} 
somente um problema cultural: importa democratizar o gosto literário porque importa democratizar uma sensibilidade intelectual complexa ${ }^{16}$.

Reconheço que o título de Todorov, La Littérature en Péril, nos engana com a mesma arte da Literatura: diz-nos que é ela que está em perigo, talvez para que os leitores do ensaio a salvem, como heróis dos romances de cavalaria. Ao ler o ensaio de Todorov, diz-nos ele afinal que é ela que nos salva, é o cavaleiro que estava em perigo, ao não salvar a donzela. Os termos do Avant-Propos são sintomáticos. Se o regime abertamente ditatorial da Bulgária tinha revelado a Todorov a força resiliente da Literatura, o regime abertamente democrático da França revelar-lhe-á a possibilidade de a Literatura continuar a ser um exercício chauvinista ou umbilical, uma matéria encarcerada em estudos de determinada nação em determinada língua e num determinado tempo, grelhas periodológicas que ensinavam a ler uma obra num contexto histórico-espacial muito restrito. O que Todorov vai indiciando ao longo da sua história pessoal de enamoramento da Literatura é, uma vez mais, a capacidade nela oculta de questionar a preguiça com que era ensinada, valorizando ele, com Genette e Barthes, professores estranhos então, que se interessavam por essas questões um pouco bizarras, a possibilidade que the era dada de aproximar épocas e autores ${ }^{17}$, um exercício comparatístico a que as metamorfoses dos estudos de Literatura Comparada nos anos 70 e 80 não devem ter sido estranhas, nem como causa nem como efeito, pois datam daquela época os principais estudos de Tematologia e Intertextualidade - vistos aliás por Claudio Guillén em continuidade com os estudos de Morfologia e dos Géneros Literários, e desde logo incentivados pelo Formalismo Russo ${ }^{18}$. É essa proximidade entre épocas e autores que permitirá a Todorov satisfazer a sua intranquilidade de leitor, não só de textos literários mas de textos paraliterários, que dela recebiam a razão de ser: relatos de viagens, testemunhos, cartas, escritas com desespero por viajantes, conquistadores, prisioneiros ou exilados ${ }^{19}$. «Face ao extremismo», os «aventureiros do absoluto» confundiam finalmente os autores e os leitores, comummente empenhados num projeto tácito: a de uma vida ao serviço da beleza, e da revelação dos limites possíveis do mundo.

O que certas formas de democracia têm em comum com as ditaduras é, paradoxalmente, a preguiça mental de acreditar no carácter inevitável das coisas. O que nos cativa neste ensaio de Todorov é ele ter sido escrito num contexto temporalmente transversal, em que, aparentemente, e uma vez mais, no ensino universitário mas sobretudo no ensino pré-universitário, a literatura se tornou um fim, esquecendo que é um meio: tornou-se assim um tipo de discurso fictício, que os estudiosos acreditam sem utilidade

\footnotetext{
${ }^{16}$ LOPES, 1965.

${ }^{17} \mathrm{Cf}$. TODOROV, 2007: 12-13.

${ }^{18}$ GUILLÉN, 1985: 248 et passim.

${ }^{19}$ TODOROV, 2007: 15.
} 
prática, uma prática autónoma, que demonstra um contexto periodológico, uma escola teórica, ou uma ortopedia linguística. É provável que Todorov tenha afinal concluído, uma vez mais, que não ensina necessariamente literatura quem nela reconhece um papel preponderante na vida real ${ }^{20}$. Talvez nunca tenha havido muitos leitores como ele, nem antes, quando todos pareciam amar a literatura e servi-la como «fim em si»: Todorov vai falando da ausência de interlocutores, na Bulgária, na França dos anos 70, na Europa do século XXI, do ensino politizado da literatura de que se defende com as matérias inócuas, da história umbilical da literatura de que se defende com a teoria da literatura, da literatura teorizada de que se defende com o interesse pelos textos paraliterários ou não obviamente canónicos ${ }^{21}$. Estranho destino de uma arte que se definia como belas-letras, existindo o belo como fim em si mesmo, sendo o prazer estético gratuito e desinteressado ${ }^{22}$. Guyau distinguia o belo (forma) do poético (sugestão da forma): «Mais do que o belo, o poético encerra um conteúdo metafísico e humano que enriquece e apura as almas infantis», ou adultas, acrescentaríamos ${ }^{23}$. E Todorov vai questionando o mesmo enquadramento filosófico, atribuível aos alunos de Kant mais do que a Kant: se o conhecimento da Literatura, «n'est pas un fin en soi, mais une des voies royales conduisant à l'accomplissement de chacun», ficará ainda por saber em que medida podemos nós transmitir essa forma de conhecimento ${ }^{24}$.

No que à Didática da Literatura diz respeito, devemos pois perguntarmo-nos como conceber a metodologia dos estudos literários, as vias para esse conhecimento, ao definirmos desde logo que competências devem os alunos possuir no final do ano ou do semestre, e quais os objetivos visados, de maneira a que essas conhecidas competências e velhos objetivos ${ }^{25}$ se não confundam com os que devem ter para ensinar por sua vez a Literatura, de forma a fazerem parte do «embrigadement général», também omnipresente, omnipotente e invisível num estado livre.

Como conseguir novamente gerar um movimento de fricção, capaz de controlar a inércia do corpo que se arrasta movido por essa força? Há certamente o tempo e o espaço. O tempo e o espaço são elementos de fricção que vão imobilizando ou desviando o corpo em movimento, criando aquilo a que Todorov chamava um desejável "equilíbrio», desde logo entre a aquiescência externa e a interrogação interna, entre o dogmatismo teórico e a engenhosidade prática ${ }^{26}$. Toda a preguiça mental gera em alguns um estado de tédio que os leva a mover-se para além da natural inércia que lhes foi imposta pelos hábitos. À "preguiça» chamam os físicos inércia e deve ter-se

\footnotetext{
${ }^{20} \mathrm{Cf}$. TODOROV, 2007: 17.

${ }^{21}$ TODOROV, 2007: 9, 13, 15, 19, 27, 31 et passim.

${ }^{22}$ Cf. KANT, 1998: 91.

${ }^{23}$ COELHO, 1944: 19.

${ }^{24}$ TODOROV, 2007: 25, 41-43.

${ }^{25}$ Cf. MOODY, 1971: 6-13.

${ }^{26}$ Cf. TODOROV, 2007: 29.
} 
em mente que a inércia é característica de todos os corpos dotados de massa. A inércia refere-se à resistência que um corpo oferece à alteração do seu estado de repouso ou de movimento. Varia de corpo para corpo e depende da massa dos corpos. Não deixa de ser curioso que Todorov centre nos autores do século XVIII a chave para entender o ponto de equilíbrio entre as leis da natureza e as leis morais. É na Estética das Luzes - no enquadramento iluminista do pensamento kantiano mas sobretudo no que, ao longo dos séculos XVIII e XIX, Gusdorf identificou já, em Le Savoir Romantique de la Nature, como uma «Naturphilosophie» (1985) - que Todorov procura a redefinição da literatura, via de acesso a um conhecimento interessado sobre cada um de nós e os outros. À noção kantiana de «arte pura», Todorov propõe a de «poesia impura», poesia contaminada pelo mundo e desejosa de o contaminar ${ }^{27}$. Relendo Kant e a necessária ousadia do saber, recordando um capítulo da Crítica da Faculdade do Juízo e a defesa de um pensamento sistemático de simpatia para com todos os seres humanos, retomando, aliás, considerações já feitas aquando da organização no ano anterior, em 2006, da Exposição Lumières! Un héritage pour demain, e sistematizadas no seu livro L'Esprit des Lumières (2007), Todotov relembra o efeito (biblio)terapêutico que desde sempre levou autores a escrever, e leitores a ler:

Ce n'est pas qu'elle soit, avant tout, une technique de soins de l'âme; toutefois, révélation du monde, elle peut aussi, chemin faisant, transformer chacun de nous de l'intérieur. La littérature a un rôle vital à jouer; mais pour cela il faut la prendre en ce sens large et fort qui a prévalu en Europe jusquá la fin du XIXe siècle et qui est marginalisé aujourd'hui, alors qu'est en train de triompher une conception absurdement réduite ${ }^{28}$.

A conceção mimética da literatura, concebida como forma de verosimilhança icástica ou simbólica, retomada por Todorov ou por outros estudiosos como Northrop Frye, coloca em diálogo a natureza e a arte, permite um contraponto, simultaneamente acessível e complexo, entre o particular e o universal. Mais filosófica do que a história, a poesia/literatura permitiria discutir a universalidade e a particularidade das representações do real, pedindo essa discussão para um mais complexo entendimento do texto, ainda que não a impondo. «Depuis l'époque des Lumières, nous pensons que la vocation de l'être humain exige de lui qu'il apprenne à penser par lui-même, au lieu de se contenter des visions du monde toutes faites qu'il trouve autour de lui. Mais comment y parvenir? ${ }^{29}$.

${ }^{27}$ TODOROV, 2007: 47-55.

${ }^{28}$ TODOROV, 2007: 72.

${ }^{29}$ TODOROV, 2007: 75. 
Pouco interessando a Todorov uma «metodologia» do prazer literário — «Toutes les "méthodes" sont bonnes, pourvu qu'elles restent moyen au lieu de devenir fin en soi $»^{30}-$, cremos legítimo, ainda que de forma analógica, conceber aqui uma reflexão paralela sobre a preguiça e inércia do ensino da literatura de acordo com o que Newton parece ter concebido como leis da dinâmica, física ou mental, característico do seu pendor alquimista ${ }^{31}$. Reflexão pessoal e assumidamente subjetiva, ainda que não isenta do desejo de objetividade que nos impomos, num contexto (1945-2015) em que a textualidade e a memória não podem evitar permanências, roturas e controvérsias. A inércia é essa força brutal que, na enunciação de Newton, só pode ser interrompida por uma força de movimento contrário. Importa pois descobrir as forças de movimento contrário, capazes de contrariar a enorme força da inércia.

Primeira lei da dinâmica: «Todo corpo continua em seu estado de repouso ou de movimento uniforme em uma linha reta, a menos que seja forçado a mudar aquele estado por forças aplicadas sobre ele».

Creio que descuramos o papel do prazer. Tememo-lo porque associamos o prazer à falta de disciplina, ao espírito zombeteiro ou à libertinagem. Somos pudicos. Mas não compreender o prazer é ignorar ao que sujeita um pianista, um escritor ou um atleta. Traduzamos pois o prazer por alegria: «a alegria é a coisa mais séria do mundo» (Séneca). Jacinto do Prado Coelho escreveu sobre ela: «Creio esta qualidade de tal modo fundamental que diria dos professores tristes o mesmo que Santa Teresa das moças tristes que apareciam no convento: "Não servem. Procurem outra profissão" ${ }^{32}$. Mesmo a pedagogia do trabalho de Freinet se apoia numa conciliação do trabalho com o prazer/alegria como forma de se ultrapassar a passividade do estudo: «preparamos tecnicamente uma escola onde se constrói, onde se edifica, não apenas pelo estudo, mas pelo trabalho, único criador, e, à falta de melhor, por certos jogos que são os seus substitutos mais próximos» ${ }^{33}$.

Os estudos estatísticos quase sempre revelam é que se lê hoje muito mais, e que lemos, em cerca de $50 \%$ dos casos, por $\operatorname{prazer}^{34}$. E que a esse prazer se pode associar globalmente o gosto que os «consumidores» têm pelos «romances e os livros de crime, thriller, mistério», pressupondo-se aqui, é certo, que a poesia não é um bestseller e os romances são histórias amorosas ${ }^{35}$, mas descurando nós frequentemente o facto de

\footnotetext{
${ }^{30}$ TODOROV, 2007: 86.

${ }^{31} \mathrm{Cf}$. KRAGH, 1989: 11, 41 ss. et passim.

${ }^{32}$ COELHO, 1944: 9.

${ }^{33}$ FREINET apud FERRAN et al., 1979: 75.

${ }^{34}$ Gustavo Cardoso, in AA. VV., 2015: 96-97.

${ }^{35}$ Gustavo Cardoso, in AA. VV., 2015: 105.
} 
o suporte em papel estar associado (por ora mais do que o digital) a uma «fonte de prazer» e uma melhor "forma de nos envolvermos com o mundo que nos rodeia» ${ }^{36}$.

O prazer advém da nossa vitalidade, e disso devíamos falar mais vezes. Aristóteles, Morus ou Lipovetsky sublinham intemporalmente a nossa «aptidão para a felicidade». Mas a felicidade, como todo o bom epicurista sabe, é também a necessidade do nosso empenho racional como forma de a atingir. A felicidade é uma «apetência natural» em que devemos constantemente refletir e falar. Até porque a nossa humanidade se consubstancia na expressão verbal dessa humanidade. Como sublinharia Lyotard, num mundo conotativo, as palavras valem como intensidades e não como significados ${ }^{37}$. Ora, quanto mais não fosse, os mais recentes estudos de neurolinguagem sublinham a ligação indelével entre a linguagem e a narratividade. O Verbo é o ato e o dizer do ato, o Logos é o discurso e a razão que organiza esse discurso.

Longe de ser derivado de conjuntos de convenções culturais, o gosto por ficções mostra uma evidência clara da adaptação darwinista, por exemplo, de como até mesmo crianças muito novas conseguem lidar racionalmente com os aspectos fictícios das histórias, distinguindo os diferentes mundos das histórias e da própria realidade, com um elevado grau de sofisticação. Não é apenas a estrutura artística das histórias que apela às fontes darwinistas: é também o intenso prazer retirado dos seus temas universais, através do amor, da morte, da aventura, do conflito familiar, da justiça e das adversidades a ultrapassar ${ }^{38}$.

Associamos a esse prazer/alegria da criação, o prazer de ler ou ouvir ler ${ }^{39}$. Há nesse domínio a certeza do prazer, vendo-o, ouvindo-o, sentindo-o. No pai ou na mãe que lê. No professor que lê. Prazer visível no ato de ler. Há algo de lúdico, aparentemente inútil nas horas que tiramos ao sono para ler, nas horas que passamos embrenhados nas palavras dos outros, ignorando os que se afadigam à nossa volta. Mas como podemos pedir aos nossos filhos, aos nossos estudantes que leiam, se eles não nos veem ler, não nos ouvem ler, com o prazer de ler? Sinto falta da leitura em aula. Tive-as. Ainda na universidade e dos melhores professores que tive. Devemos ceder à tentação: é a melhor forma de a vencer. Leiamos então em voz alta, meus irmãos, como nos leram a nós, ou como não nos leram a nós. Não uma leitura correta, não soletrada, mas uma boa leitura em voz alta. Daquelas que põem todos os ouvintes calados. São raros, momentos extraordinários numa cultura que se tornou barulhenta ou emudecida pela escrita.

\footnotetext{
${ }^{36}$ Gustavo Cardoso, in AA. VV., 2015: 107

${ }^{37}$ Apud INNERARITY, 1995: 17.

${ }^{38}$ DUTTON, 2010: 15.

${ }^{39}$ BOYD, 2009.
} 
O prazer, com efeito, exige muito esforço, e alguma técnica. Um esforço desinteressado, certamente, mas ainda assim um esforço que leva o cientista a experimentar para além do óbvio, que desafia o atleta a ultrapassar os seus limites: mais longe, mais forte, mais depressa. Abala-me a diligência do ser humano que, desde o berço, cria e recria obstáculos: o guizo que atira para longe, as pedras negras ou linhas do passeio que não podem ser calcadas, os gradeamentos que não podem ser tocados pelo pau. Já Aristóteles constatava a curiosidade filosófica das crianças, que se diria inata, e depois tantas vezes abafada pelas rotinas da idade madura. Reencontro esta celebração em Schiller: «O homem só se afirma ludicamente quando é homem no pleno sentido da palavra, e só é plenamente homem quando sujeito de uma actividade lúdica ${ }^{40}$. Para Schiller, toda a Arte é um jogo, resultado de uma pulsão lúdica, Spieltrieb, resultado de uma conciliação entre a pulsão dos sentidos (que reclama mudança e que o tempo tenha um conteúdo) e a pulsão formal (que exigiria a supressão do tempo e a ausência de mudança): «a pulsão lúdica, portanto, tenderia para suprimir o tempo no tempo, para conciliar o devir com o ser absoluto, a mudança com a identidade» ${ }^{41}$.

Não a força bruta. Mas sempre a empatia, a capacidade de introduzir na memória de alguém outros pontos de vista, a gentileza de prescindir (ainda que provisoriamente) do seu território e deixar-se invadir. A sensibilidade à beleza de um texto é um fator de seleção de competências necessárias à nossa condição humana e não somente animal, à vida em sociedade, e não somente à sobrevivência física. Mais do que a seleção da Natureza, o próprio Darwin se sente fascinado pela seleção sexual, que implica um processo de autodomesticação complexo, que exige competências como imaginação, capacidade de criar estranhamento, simbolização do objeto animalmente inútil, estratégias de sublimação da consciência da morte ${ }^{42}$. De alguma forma, o que ensinamos em literatura, o que ensina grande parte da Arte, é uma inversão do real tal como ele nos é dado pela Natureza. Seremos poetas se quisermos ser humanos: seres que criam o meio. Evoluímos, não na medida em que eliminamos os mais fracos, mas em que sabemos vencer com as nossas fraquezas. A manha de Ulisses é mais complexa do que a fúria de Aquiles. A figura do estrangeiro, do velho, do sapo ou do cego são as personagens em que as histórias colocam a solução do enigma...

Confundimos amiúde, no ensino da Literatura, o Erotismo com a Pornografia, ou a Gastronomia com a Alimentação. Queremos atingir grandes objetivos em semestres e alimentar rapidamente o aluno. Mas sob muitos aspetos, a experiência literária ensina-nos a trabalhar e a demorar o prazer, a brincar com o inesperado. A literatura muda a nossa noção de tempo e espaço: torna mais lento o instante que passou a correr, ou reduz a duas horas uma saga geracional. A experiência que ela nos permite é gentil:

\footnotetext{
${ }^{40}$ AA. VV. 1989: 193-194.

${ }^{41}$ AA. VV. 1989: 192; cf. HUIZINGA, 2003.

${ }^{42}$ Cf. DUTTON, 2010: $\max$. 227-274.
} 
poupa-nos o corpo e a alma. Não temos de ver morrer para saber como dói a morte, não temos de ser marginalizados para sofrermos com a marginalização, aprendemos a amar melhor, lendo demoradamente como uma personagem ama bem ou mal.

Segunda lei da dinâmica: «A mudança de movimento é proporcional à força motora impressa, e é produzida na direção de linha reta na qual aquela força é impressa».

Começar cedo, de pequenino se faz o leitor. A infância, mais do que qualquer outra idade, é aquela em que mais eficazmente se há de fazer sentir a força da sensibilidade literária. Fazendo a mesma força sobre o carro de verdade e o de brinquedo resultarão acelerações visivelmente diferentes. Ao contrário de Rousseau, cremos na importância de ganhar hábitos de leitura bem cedo, de alguém ver mais tarde no livro - tenha ele a forma que tiver - um objeto evocativo dos prazeres da infância. Um livro é como um sabor, um perfume, entranha-se em nós de uma forma invisível, mas será ele também como uma madeleine mergulhada no chá. É tão fácil uma criança gostar de livros, das histórias, claro, mas também de tudo o que fará depois a força da retórica e da estética: os ritmos, os timbres, as intensidades, as melodias, a música. Se uma criança não deve abusar dos livros, pode abusar da memória. Uma boa memória, uma que lhe sirva para a vida inteira, há de estar cheia de enigmas, anedotas, adivinhas, lengalengas, quadras, pequenos poemas, canções... A música, «de la musique avant toute chose», glosando com Verlaine o princípio de toda a arte poética. Fidelino de Figueiredo concebe um sistema educativo que tivesse a música como «o eixo central ou a armação travadora» e a filosofia, pensar u-topicamente, como objetivo ${ }^{43}$. Ritmo binário, acertivo como um decassílabo heroico, adequado às marchas, aos provérbios. Ritmo ternário, instável como um decassílabo sáfico ou uma valsa. Falemos com música das coisas reais. Não muitas: antes coisas ruminadas. Como a «Nau Catrineta». Em 1988, Sophia de Mello Breyner confessava numa homenagem a essa infância:

antes de saber ler, ouvi recitar e aprendi de cor um antigo poema tradicional português, chamado Nau Catrineta. Tive assim a sorte de começar pela tradição oral, a sorte de conhecer o poema antes de conhecer a literatura.

Eu era de facto tão nova que nem sabia que os poemas eram escritos por pessoas, mas julgava que eram consubstanciais ao universo, que eram a respiração das coisas, o nome deste mundo dito por ele próprio.

Pensava também que, se conseguisse ficar completamente imóvel e muda em certos lugares mágicos do jardim, eu conseguiria ouvir um desses poemas que o próprio ar continha em si.

${ }^{43}$ FIGUEIREDO, 1954: 56. 


\section{No fundo, toda a minha vida tentei escrever esse poema imanente ${ }^{44}$.}

São quase as mesmas palavras de Teixeira de Pascoaes:

A infância é um sentimento em que todas as coisas regressam à Luz originária. Para os meus olhos de criança, as coisas não eram exteriores, não existiam; viviam a vida pura, que é só alma, intimidade, substância eterna, em vez de forma transitória ${ }^{45}$.

Há dias em que a palavra «janela» dita vinte vezes ensina mais sobre poesia que um verso d'Os Lusíadas. Ja-ne-la-ja-ne-la-ja-ne-la-ja-ne-la-ja-ne-la-ja-ne-la-ja-ne-laja-ne-la... Até que a palavra feche e abra. O pensamento evoluirá depois do concreto para o abstrato. Dos sons e das imagens que como estrangeiros ouvimos para os conceitos que como eruditos estudamos. Para então voltarmos ao concreto. Sentidos literais, metafóricos, analógicos, todos eles estão presentes já na linguagem infantil: a criança acredita que a cadeira tem pernas, braços e costas, que o sol queima, que se descascam os livros, que se arcoiriza o desenho ou se faça um quadro... Fala como um poeta e rimo-nos dela. Antes devíamos com ela aprender, para nunca acabarmos de ler o mundo. Os melhores livros leem-se como se alguém os reescrevesse de cada vez que os abrimos, porque neles sempre lemos coisas diferentes. Não tem que ser um poema simbolista: basta uma lengalenga. Alguma sabedoria há no Kama-Sutra ao recomendar o uso de lengalengas. A lengalenga é parecida com o amor: declina-se até nos enganarmos, mas se nos enganarmos podemos rir do erro, sem inferiorizar quem pelo mundo erra, e recomeçar uma vez mais.

Assim sendo, um professor nunca devia ensinar que as figuras retóricas são «adornos» ou «ornatos» do discurso: com mais propriedade, os gregos chamavam-lhes «temperos»: porque, sendo «figuras», são formas de ver o mundo e, sendo «temperos», mudam o sabor das palavras. O leitor - aquele que se alimenta (o aluno) ou que pela palavra professa (o professor) - deve saborear a palavra, digeri-la, porque será ela o alimento. Uma coisa dita através de uma metáfora não tem o mesmo sabor da catacrese. Mas até para saborear a catacrese é preciso paladar apurado: cada catacrese tem em si o sabor da metáfora em que foi marinada. A palavra «honestidade» conserva a memória das plantas que crescem eretas, sem buscarem o sol enroladas num tronco vizinho. A palavra «candura» é ainda branca. Da Rua das Teorias, no caminho para a Acrópole, a teoria é ainda uma prática de observação, um miradouro. Na Grécia, os camiões de transportes trazem ainda escrito «Metaphorai»... Se eu disser por outras palavras, passo a dizer coisas um pouco diferentes: traduzo ou parafraseio, arrasto,

\footnotetext{
${ }^{44}$ ANDRESEN, 2011: 848.

${ }^{45}$ PASCOAES, 1928: 51.
} 
escrevo ao lado. Ter o coração apertado não é bem o mesmo que estar preocupado. Perder tempo é um exercício de apropriação: perdemos tempo como perdemos a areia no punho fechado. Todas as palavras são literárias, ainda que não estejam num poema de Sérgio Godinho. Nunca desprezar «Um dia na estrada», um «sopro no coração», as muitas «horas extraordinárias», os «dias úteis», «a última sessão», uma «bomba-relógio»: dizer sempre «eu vou a jogo».

Em crítica literária, devemos teoricamente ver a máquina do mundo: «O espectáculo tem de ser explicado ao aluno como um sistema de signos organizados, densamente organizados $»^{46}$.

Terceira lei da dinâmica: «A toda ação há sempre uma reação oposta e de igual intensidade: ou as ações mútuas de dois corpos um sobre o outro são sempre iguais e dirigidas em direções opostas».

Negociemos. O cânone não é, nunca foi, um conjunto fixo de clássicos. Os clássicos de amanhã escrevem hoje, e um clássico «é uma obra que provoca incessantemente uma vaga de discursos críticos sobre si, mas que continuamente se livra deles $»^{47}$. Discutamos, pois. Lê-me tu o que tu gostas como eu te leio o que eu gosto. A força é a expressão física da interação entre dois entes: há sempre um par de forças a agir num par de objetos e não há força solitária sem a sua contraparte. Ação-reação: não devemos esquecer que a interpretação é sempre uma negociação de valores «inter+pretium», entre autores, entre leitores. "Como se vê, a leitura crítica [...], integra-se na génese da obra literária através de uma complicada dinâmica a que chamaremos opinião» ${ }^{48}$, e, ainda quando o mais possível objetivadas perante o leitor, alguma bondade crítica deve permanecer na hermenêutica, atividade sob a proteção daquele Hermes que protegia comerciantes, ladrões, tradutores e intérpretes.

Ler em voz alta é reaprender a função de ler em voz baixa: representamos. Devíamos pois também, para renovação da nossa alma, ouvir ler. Ouvir ler o que andam os estudantes a ler, nos tablets, através do Facebook. Ficaríamos admirados com o que leem por si. Até com alguma complexidade do que leem, sem que a nossa forma de falar da literatura os tenha ajudado. No inquérito de autodiagnóstico, um estudante de Literatura anda a ler Nietzsche por iniciativa própria e Anthony Bourdain como leitura obrigatória. Não tendo a certeza de que há leituras más, todas as leituras são possíveis. Mas temo que estejamos a ceder sem negociar. Se acreditamos na bondade da literatura, isto é, na literatura como um bem, corremos o risco de oferecer, na Universidade, um nível inferior ao que se encontra no Facebook. A nós, incumbe-nos o dever de transmitir às novas gerações uma herança frágil, aquelas palavras que aumentam a vida. Dar-lhes

\footnotetext{
${ }^{46}$ BARATA, 1979: 55.

${ }^{47}$ CALVINO, 1994: 10.

${ }^{48}$ LOPES, 1965: 15.
} 
como professores Shakespeare, Sófocles, Dostoievski, Proust ${ }^{49}$. Mas também desde logo apresentar-lhes Boccaccio, Jonathan Swift, Daniel Defoe, Perrault, Alexandre Dumas, Lewis Carroll, Saint-Exupéry, com toda a vantagem de lerem na idade adulta autores que nunca escreveram para crianças.

O ensino pode, deve, levar o estudante a escrever coisas próprias, não o alimentando de «copy paste». Escrever deve, pode, ser uma forma de ler devagar, de ler com a mão, ou o dedo, coisa que ele sabe numa cultura de "Read/Write», "Remix», «making art and commerce thrive in the hybrid economy» ${ }^{50}$ :

Quando eu escrevo, o complicado torna-se simples,

$O$ difícil parece fácil, os versos ganham requintes

Pessoais, são transmitidos aos ouvintes

que me dão força ou não para passar aos versos seguintes

Então, entro em sintonia, encontro o meu conforto

Como se a caneta e o papel fizessem parte do meu corpo,

Sistema nervoso e sanguíneo em comum

Às vezes chego a pensar que somos apenas $\mathrm{um}^{51}$.

Não importa que o diga MC Xeg. Não importa que a forma do livro mude, mudando com ela o que diz o livro ${ }^{52}$. Falemos sobre o que amamos. Depois, devemos esperar que a fala dê frutos: ouvir ler, ler, responder, mudar algumas leituras, não infantilizando. Creio que têm os dias contados as salas que dispõem de um estrado e pedem alunos sentados e silenciosos. Correremos o risco de abandonarem a catequese quando crescerem, por não acreditarem num Deus sentado numa nuvem. Acontece-lhes frequentemente não conseguirem passar das histórias mastigadas para Os Lusíadas, e desistem. Não há todavia sobrevivência assegurada. Há que fazer degraus. Tentar.

Eis que o semeador saiu a semear. E quando semeava, uma parte da semente caiu ao pé do caminho, e vieram as aves e comeram-na. E outra parte caiu em pedregais, onde não havia terra bastante, e logo nasceu, porque não tinha terra funda; mas, vindo o sol, queimou-se, e secou-se porque não tinha raiz. E outra caiu entre espinhos, e os espinhos cresceram e sufocaram-na. E outra caiu em boa terra, e deu fruto: um a cem, outro a sessenta e outro a trinta ${ }^{53}$.

\footnotetext{
${ }^{49}$ Cf. TODOROV, 2007: 89-90.

${ }^{50}$ LESSIG, 2008.

${ }^{51}$ MC Xeg - Quando Escrevo.

${ }^{52}$ Cf. ECO \& CARRIÈRE, 2010; DARNTON: 2012.

${ }^{53}$ Mt. 13, 3-8.
} 
Nada se ensina, tudo se aprende.

Velhas metáforas agrícolas de que eram feitas as metáforas da cultura. Serão em breve ilegíveis ${ }^{54}$ ? Ou nunca tudo será feito por máquinas, sem semeadores, sem aves, sem espinhos? O que deixaremos as máquinas fazer por nós irá definir a nossa humanidade, de uma forma talvez nunca tão radicalmente interpeladora. Luciano Floridi explicita:

- Se nos considerarmos o único agente inteligente que é capaz de fazer algo, e depois vem uma máquina que o faz melhor, então quem somos nós? Acontece no xadrez, ou a decidir o melhor caminho do ponto A para o ponto B. O computador faz isso melhor. Precisamos de entender melhor em que sentido somos únicos. Não é no sentido de que somos os únicos capazes de conduzir um carro, aterrar um avião, jogar xadrez, resolver um problema matemático. [...] A questão é: de que forma a humanidade é única, se tudo o que fazemos pode, em princípio, ser feito por uma máquina? ${ }^{55}$

A humanidade nunca é um dado adquirido. Babel ruirá: é feita de recomeços. Quando acabo de reler A Morgadinha dos Canaviais, percebo porque começava o romance com as leituras de Henrique. Afinal de contas, aquelas leituras eram ainda uma forma superficial de ler. Henrique estava física e culturalmente doente: sofria de «embrigadement général» e lia sem que a leitura o curasse. Mecanicamente lia. Perseguia lenços de assoar com o risco da própria vida, sem se dar conta dos mimetismos da vida. Entre as preces da Tia Doroteia e o riso sarcástico da Morgadinha, Henrique vive o paradoxo da Bovary: é ainda uma personagem literária que tenta destruir o efeito provocado pela literatura. O que seria de Henrique sem as leituras? Se «a literatura, como toda a arte, é a confissão de que a vida não basta», Pessoa devia ter acrescentado que a vida, como todo o gesto, é a confissão de que «a literatura não nos basta». A cultura livresca de Henrique não lhe garante uma melhor humanidade. E o tirano pode ser gente muito erudita, que de dia assina sentenças de morte e à noite lê o Fausto. Ah, mas quantas mais possibilidades há para o tirano que morre dentro de nós no dia em que entender o Fausto?

No final do romance, Júlio Dinis conta uma cena de em que a generosidade e o amor eliminam as diferenças impostas pela sociedade. Augusto beija a mão à Morgadinha, o irmão Ângelo beija as faces da irmã. E o escritor termina:

\footnotetext{
${ }^{54}$ SERRES, 2012: 7-10.

${ }^{55}$ «Público», (4 de jan. 2016) 7.
} 
Pobres crianças! Porque afinal eram crianças todos três, crianças a quem inda os romances namoram, sem que se lembrem de que, ao transplantá-los para a vida real, todos os desconhecem e censuram, e só regando-os de lágrimas é que as mais das vezes se consegue nutri-los ${ }^{56}$.

\section{BIBLIOGRAFIA}

AA. VV. (1989) - A Literatura Alemã. Textos e Contextos (1700-1900). O Século XVIII. Vol. 1. Sel., trad., introd., notas de João Barrento. Lisboa: Presença. (2015) - Os Livros e a Leitura: Desafios da Era Digital. Lisboa: FCG.

ANDRESEN, Sophia de Mello Breyner (2011) - Obra Poética. Ed. C. Mendes de Sousa. Lisboa: Caminho. BARATA, José Oliveira (1979) - Didáctica do Teatro. Coimbra: Almedina.

BORGES, Jorge Luís (2002) - Curso de Literatura Inglesa. Trad. E. Brandão. São Paulo: Martins Fonte. BORRALHO, M. Luísa Malato (1991) - «E tudo o vento levou», de William Shakespeare, Um estudo socio-pedagógico. «Fides. Direito e Humanidades», Porto, [s.n.], p. 91-128.

BOYD, Brian (2009) - On the Origin of Stories. Evolution, Cognition and Fiction. [S.l.]: Belknap Press. CALVINO, Italo (1994) - Porquê ler os Clássicos. Lisboa: Teorema, 1994.

CAMÕES, Luís de (1962) - Rimas, Autos e Cartas. Ed. A. J. Costa Pimpão. Porto: Civilização, 1962. COELHO, Jacinto do Prado (1944) - A Educação do Sentimento Poético. Coimbra: Coimbra Editor. COMPAGNON, Antoine (2011) - Para que serve a Literatura. Trad. J. A. Domingues. Porto: ILC/Quasi. DARNTON, Robert (2012) - Apologie du Livre. Paris: Folio/Gallimard.

DINIS, Júlio (1992) - A Morgadinha dos Canaviais. Lisboa: Círculo de Leitores (Obras Completas de Júlio Dinis, 3).

DUTTON, Denis (2010) - Arte e Instinto. Trad. J. Quina: Lisboa, Temas e Debates/Círculo de Leitores. ECO, Umberto (2004) - A Misteriosa Chama da Rainha Loana. Trad. Simonetta Neto. Lisboa: Difel. ECO, Umberto; CARRIÈRE, J.-C. (2010) - A Obsessão do Fogo. Lisboa: Difel.

FERRAN, P.; MARIET, F.; PORCHER, L. (1979) - Na Escola do Jogo. Trad. M. Assunção Santos. Lisboa: Editorial Estampa.

FIGUEIREDO, Fidelino de (1954) - Música e Pensamento. Lisboa: Guimarães Editores.

GUILLÉN, Claudio (1985) - Entre lo Uno y lo Diverso. Madrid: Ed. Critica.

GUSDORF, Georges (1985) - Le Savoir Romantique de la Nature. Paris: Payot.

HUIZINGA, J. (2003) - Homo Ludens. Lisboa: Edições 70.

INNERARITY, Daniel (1995) - La Irrealidade Literaria. Pamplona: Eunsa.

KANT, Immanuel (1998) - Crítica da Faculdade do Juízo. Trad. A. Marques e V. Rohden. Lisboa: INCM. KRAGH, H. (1989) - Introducción a la Historia de la Ciencia. Trad. T. de Lozoya. Barcelona: Ed. Critica. LA BOÉTIE (1997) - Discurso sobre a Servidão Voluntária. Trad. Manuel João Gomes. Lisboa: Antígona. LESSIG, L. Remix (2008) - Making art and commerce thrive in the hybrid economy. New York: Penguin. LOPES, Óscar (1965) - A Educação do Gosto Literário como Problema Social Português. Porto: Imprensa Social.

MANGUEL, Alberto (1998) - Uma História da Leitura. Lisboa: Presença.

MOODY, H. L. B. (1971) - The Teaching of Literature. London: Longman.

NUSSBAUM, Martha (1990) - Love'Knowledge. Oxford: Oxford University Press.

PASCOAES, Teixeira de (1928) - Livro de Memórias. Coimbra: Livraria Atlântida.

PICARD, Michel (1986) - La Lecture comme jeu. Paris: Ed. Minuit.

${ }^{56}$ DINIS, 1992: 503-504. 
TEXTUALIDADE E MEMÓRIA: PERMANÊNCIA, ROTURA, CONTROVÉRSIA

ROUSSEAU, J. J. (1771) - Emile ou De l'Education. CEuvres Complètes de... [S.l.: s.n.].

SERRES, Michel (2012) - Petite Poucette. Paris: Ed. Le Pommier.

TODOROV, Tzetan (2007) - La Littérature en Péril. Paris: Flammarion. 


\title{
MEMÓRIAS DA LITERATURA
}

\author{
ROSA MARIA GOULART*
}

A memória abunda em surpresas como nas velhas fotografias e nos espelhos. Jorge Luis Borges, Eu, Borges

Num tempo em que o texto digital tanto pode ser guardado e impresso como, por lapso, desaparecer num breve e impensado gesto, em que nós, os da formação académica sustentada na letra dos textos que líamos, somos assaltados por ideias de sentido contrário, no que à memória diz respeito, perguntamo-nos que futuro para a memória guardada nos livros, a que agora nos interessa, e para que servirá ela a este nosso tempo ávido de novidade e de avanço tecnológico.

Italo Calvino, Jorge Luis Borges, e Walter Benjamin podem ser aqui convocados como representantes de três modos, em parte coincidentes em parte diversos, da literatura como guardadora de memórias, exemplo do que ela sempre tem intentado fazer. Em "contar o conto», Borges, remontando, à semelhança de Italo Calvino, George Steiner e outros, aos textos da Antiguidade e da Bíblia como fundacionais, elogia a narração sob a forma de conto, por oferecer ao presente a recuperação de paradigmas antigos (Homero, Virgílio), quando a cisão entre poeta e narrador era inexistente. Prevendo, como tem sido repetido, que um dia o romance, com todas as experiências ousadas a que tem sido submetido, possa deixar de estar entre nós, o escritor argentino, algo nostálgico da épica, hoje arredada da literatura, vê na aliança de conto e poema uma forma de nobre sobrevivência de uma tradição que não morrerá ${ }^{1}$.

\footnotetext{
* Universidade dos Açores.

${ }^{1}$ Após anotar o pensamento de que o romance está a acabar (o escritor tem em mente a desestruturação do romance moderno), anota Borges: «Mas o conto, uma história tem algo que permanecerá. Não me parece que alguma vez os
} 
Walter Benjamin, por sua vez, num interessante texto sobre o narrador, a partir da obra de Nicolai Leskov, mostra o seu apreço pela narrativa, onde distingue dois modelos de narrador, inspirados em duas atividades arcaicas, o exemplificado pelo camponês sedentário e o representado pelo marinheiro comerciante, e põe em confronto essas narrativas e o imediatismo da informação que ganha relevo no presente. Também não lhe escapa o modelo épico como paradigma nem a autoridade sancionada pela tradição ${ }^{2}$, e considera o narrador dos contos de fadas como o autêntico narrador. «O primeiro narrador verdadeiro», afirma, «é e continua sendo o narrador dos contos de fadas. Esse conto sabia dar um bom conselho, quando ele era difícil de obter, e oferecer sua ajuda em caso de emergência» ${ }^{3}$. Italo Calvino, com a noção de enciclopédia, que aplica tanto ao romance do século XX (uma «enciclopédia aberta», diz), como, num comentário sobre Northrop Frye, à Bíblia, acentua que «a literatura não é feita só de obras individuais mas de bibliotecas, sistemas em que as várias épocas e tradições organizam os textos 'canónicos' e os 'apócrifos'»"

Permanece-nos então a ideia de memória como algo que textualmente se preserva, mesmo que texto se assuma com sentido metafórico e bem assim de mais amplo alcance, exercendo-se em suportes que não apenas o de papel impresso. E, mau grado uma certa ideia de desprestígio da memória, inclusivamente no ensino, ela visita-nos todos os dias, sob diversas formas, como visitou os autores que lemos, mostrando-se como obsessão de uns, fantasma de outros, impulso de representação de uns e outros.

$\mathrm{Na}$ literatura teremos em mente estas duas vertentes da memória, a de longo alcance, que traz a longínqua cultura do passado, enquanto texto escrito ou enquanto testemunho oralmente transmitido, ao mundo do presente, e a revelada, a nível intratextual, pelo narrador ou pelas personagens de ficção. Em algumas circunstâncias, é questionável a fiabilidade e o valor do que chega através de testemunhos orais ou escritos bem como as perturbações que o narrado pode sofrer, para não falarmos das memórias ficcionalizadas, como são as póstumas de Brás Cubas, quando o narrador/ memorialista já não podia sê-lo.

\footnotetext{
homens se cansem de contar e de ouvir histórias. E se, a par do prazer de nos contarem uma história obtivermos o prazer adicional da dignidade do poema, algo de grande terá acontecido [...]. Acredito que o poeta voltará a ser um fazedor, ou seja, contará uma história e também a cantará. E não como pensaremos estas duas coisas como diferentes, tal como não as consideramos diferentes em Homero ou Virgílio» (BORGES, 2002: 62-63).

${ }^{2}$ Cf. BENJAMIN, 1996: 202-203: «O saber, que vinha de longe - do longe espacial das terras estranhas, ou do longe temporal contido na tradição - , dispunha de uma autoridade que era válida mesmo que não fosse controlável pela experiência. Mas a informação aspira a uma verificação imediata. Antes de mais nada, ela precisa ser "em si e para si”. Muitas vezes não é mais exata que os relatos antigos. Porém, enquanto esses relatos recorriam frequentemente ao miraculoso, é indispensável que a informação seja plausível. Nisso ela é incompatível com o espírito da narrativa». ${ }^{3}$ BENJAMIN, 1996: 215.

${ }^{4}$ Esclarecendo que utiliza «apócrifo» no sentido etimológico da palavra, Italo Calvino conclui a argumentação sobre o assunto precisando que «a literatura é procura do livro escondido muito longe, que altera o valor dos livros conhecidos, é a tensão em relação ao novo texto apócrifo a encontrar ou a inventar» (CALVINO, 2003: 250).
} 
Cientes, portanto, de que a memória é uma faculdade do ser humano indispensável ao armazenamento, mais ou menos consciente, das suas aprendizagens, mas suscetível de apresentar um variado leque de manifestações, é que as várias áreas científicas têm colaborado em estudos pluridisciplinares de reconhecida vantagem para o conhecimento do homem e da sua cultura. No domínio das novas tecnologias, não se esquece esse precioso auxiliar de memória, que é a Internet, onde encontraremos vastíssima informação sobre o assunto, designadamente ensaios sobre a memória oral dos povos sem escrita, a memória lutuosa dos grandes dramas pessoais, a presente na História universal, à memória afetada pela doença, sejam elas memórias de longo e de curto alcance.

No âmbito da história literária, a fixação de escolas, períodos e respetivas estéticas, é reveladora tanto das continuidades como das roturas, mais ou menos bruscas que trazem o novo, ostentam novas visões do mundo e da arte, evidenciando outras formas de representação e mesmo novos suportes para elas. Mas, como a novidade só se percebe como tal quando oposta a uma tradição ou a uma anterioridade, uma qualquer forma de manutenção da cultura passada se há de manter, embora não possamos prever de que modo se manifestará. Se uma obra não lembra uma estrutura tradicional, o seu caráter inovador deixa de ser percebido, lembrou Iuri Lotman, e, da sua perspetiva de autorizado historiador e fino ensaísta, Fernando Catroga escreveu:

A recepção do novo não pode significar, porém, uma hospitalidade acrítica, pois ele vem morar numa terra já habitada por homens com racionalidade ética e com memória; e é pela comparação, logo suscitada pela pré-compreensão, que a densidade do "aumento de ser» que ele oferece deve começar a ser avaliada. Caso contrário, cair-se-á na reificação da novidade, como se o tempo fosse, tão-só, um infinito somatório de momentos sem passado e sem futuro entre si ${ }^{5}$.

Os clássicos da Antiguidade greco-latina continuam a impor-se à nossa consideração (não sabemos como será para os jovens de amanhã), enquanto noutras culturas se preserva uma tradição oral transmitida de geração em geração pelos contadores de histórias. Esse efeito mágico da narração de uma história, seja sob a forma de mito ancestral ou de conto popular, ocorrida em tempo e espaço indeterminados e longínquos, mediante um conteúdo que se enriquece com a figura do narrador, sua expressão corpórea, retórica discursiva e inflexão de voz, poderá, talvez, ser uma razão para que o presente ainda receba, e guarde com agrado algum resíduo de um passado onde essas histórias terão sido primeiro ditas e ouvidas e depois escritas e lidas. A «hora

${ }^{5}$ CATROGA, 2003: 161. 
do conto» enche salas de crianças que ouvem ler histórias, recontam as que leram, mas também, para as mais novas, as que não leram, mas ouviram e fixaram.

Quando, na sua conferência sobre a «leveza», Italo Calvino recorre a exemplos retirados de uma bem conformada memória cultural e literária para sustentar as suas teses bem como a opção de, com a escrita, retirar peso ao mundo, está implicitamente, apoiando-se também na ciência e na tecnologia coevas, a trazer para o presente todo um conhecimento anterior, dizendo-nos até que a ciência e a técnica estão atualmente em consonância com essa sua pretensão:

Hoje em dia todos os ramos da ciência parecem querer demonstrar-nos que o mundo assenta em entidades delicadíssimas: tal como as mensagens do ADN, os impulsos dos neurónios, os quarks, os neutrinos vagueando pelo espaço desde o princípio dos tempos...

E também a informática. É verdade que o software não poderia exercer os poderes da sua leveza senão por meio do peso do hardware; mas é o software que comanda, que atua sobre o mundo exterior e as máquinas, que só existem em função do software, evoluindo de modo a elaborar programas cada vez mais complexos ${ }^{\text {. }}$.

É ainda com o auxílio da sua memória como biblioteca que Italo Calvino resume a duas as vocações da literatura como representação do mundo através dos séculos, ideia que já encontramos noutros, a saber, que a arte prossegue no tempo levando consigo a memória dos tempos precedentes, agrupando-os segundo denominadores comuns altamente sintetizados, o que a rica e muito bem informada reflexão do próprio autor confirma:

Podemos dizer que duas vocações opostas disputam o campo da literatura através dos séculos: uma tem a tendência para fazer da linguagem um elemento sem peso, que flutua por sobre as coisas como uma nuvem, ou melhor, como uma finíssima poeira, ou melhor ainda como um campo de impulsos magnéticos; a outra tende a comunicar à linguagem o peso, a espessura, a concreção das coisas, dos corpos e das sensações ${ }^{7}$.

Sendo o espaço literário um campo de grandes e pequenas memórias, deter-me-ei num género que a elas muito se presta, o diário. Definido pelo registo do correr dos dias, ele propicia, no entanto, um constante retorno ao passado, por parte daquele que se narra fragmentariamente, mas se sabe um todo feito dos pedaços de tempo

${ }^{6}$ CALVINO, 2003: 22.

${ }^{7}$ CALVINO, 2003: 29. 
de toda uma vida. É esse recurso tanto mais relevante quanto vem acompanhado das referências culturais que um diarista culto e com mundo na bagagem nos traga, como nos é oferecido nos interessantes diários do escritor/diplomata Marcello Duarte Mathias. O próprio, nas várias anotações que deixa sobre o género, reconhece-o como lugar de memória e não é parco no relato das suas.

Em Encontro em Capri ou o diário italiano de Gorki, escreve o narrador/comentador, também assumido como ensaísta desse pretenso diário, misto de ficção e de referências histórico-geográficas, que,

como todo o diário, também este é uma recolha de memórias. Porque é espelho e confronto, lugar e percurso, passagem e testemunho. Não é o balanço da obraaqui, raras vezes mencionada, diga-se de passagem -, menos ainda um texto de intervenção ideológica, tema que era alheio a Gorki, embora a política aflore aqui e ali por força da relação com Lenine. É antes uma revisitação permanente do autor em busca de si mesmo, e, nas partes mais pessoais, uma procura de apaziguamento ${ }^{8}$.

Interrogando, através do falso diário de Gorki, um tempo que ficou memorável, o que antecedeu a Revolução Russa e o que lhe sucedeu, o nosso autor não só constrói, à sua maneira, o perfil de um intelectual que deixou nome na História e na Literatura como exercita através dele o gosto pelos grandes temas políticos e culturais do século XX, em reflexões que continua a desenvolver no século XXI. A sua formação e experiência de vida forneciam-lhe à maravilha as ferramentas para desempenhar, com o sucesso que se sabe, essa tarefa.

Os seus próprios diários, com títulos indicativos de um percurso pelo mundo e de regresso à Abuxarda ${ }^{9}$, são um repositório de encadeadas memórias em que a identidade não é mera aventura do «eu» solipsista, mas de um ser com os outros, muito embora nos pareça ver, uma ou outra vez, aflorar uma necessidade de reversão a si próprio para se proteger do ruído do mundo em que não pode deixar de estar, mas de que às vezes parece querer resguardar-se.

Quanto a Paris, cidade de cultura, é todo um fascínio e uma dívida que são declarados, mesmo quando ela já não é o centro da cultura europeia, mas trata-se de um amor de quem a viveu por dentro, atitude concordante com a sua memória que ele diz ser «feita da memória das palavras» ${ }^{10}$. "A leitura dos livros dos outros é a sua maneira de amar a Humanidade», escreve em Brevíssimo inventário ${ }^{11}$.

\footnotetext{
${ }^{8}$ MATHIAS, 2008: 28.

${ }^{9}$ Antes desse escrevera Diário de Paris e Diário da Índia, onde tinha residido como embaixador.

${ }^{10}$ MATHIAS, 2010a: 204.

${ }^{11}$ MATHIAS, 2010b: 36.
} 
Em Encontro em Capri, trata-se de pôr em relevo um tempo, uma figura intelectual, uma situação política, com os seus atores relevantes, uma boa oportunidade para fazer desfilar Lenine, em primeiro lugar, pelas relações de amizade com Gorki, Estaline, e, o que mais nos interessa, para evocar uma série de escritores, russos e não só, que a nossa memória cultural preserva e que Marcello Duarte Mathias terá guardado à sua maneira: Tchekov, Tolstoi, Stefan Zweig, D’Anunnzio, Pirandello, etc. São figuras alvo de comentário nos apontamentos de Gorki, a que acrescem os comentários intercalados do comentador do diário de Gorki.

Colocando-se nessa situação de leitor/comentador, o narrador acrescenta-lhe sentido, uma maneira de nos mostrar o pendor crítico-ensaísta presente no próprio diário de Marcello Duarte Mathias, igualmente sensível à situação política do nosso tempo, quer em Portugal quer no estrangeiro. Talvez seja de acreditar que, no muito que vai colocando de si neste texto, lhe seria grato pôr em contraste uma militância política que não subscreveria e a humanização do artista que ressuma de algumas páginas, algumas até com nítidos toques de lirismo:

Irregular, o diário reflecte todavia, em termos de unidade, um encadeamento subterrâneo. O flagrante de certos instantâneos, como de certas reflexões, comprova-o bem. É o mesmo olhar tanto na sua essência como na sua imediatez. Ora truculento, ora satírico, mas sempre embrenhado de ternura e compadecimento humanos. Alma iluminada pela compaixão, Gorki é a cada instante um sobrevivente. De si e dos outros. Sobreviver era o seu modo de estar ${ }^{12}$.

A atenção a este pretenso diário alheio (ele próprio confessa a sua mania dos diários), faz-nos pensar que as respetivas escolhas são em parte ditadas pelo seu gosto de diarista e respetiva conceção de diário. Sintomático é o modo como, ao contrário do que pensa o próprio, Marcello Mathias valoriza o diário de Vergílio Ferreira, exemplo de clareza (ao correr da pena ou «de torneiras abertas», diria Vergílio), em detrimento do romance, cuja escrita, «sem transparência e sem clareza», «sem claridade», não aprecia, posição que vem ao arrepio da maioria dos leitores vergilianos ${ }^{13}$ :

Poderia aqui citar inúmeras passagens desse teor, sem transparência e sem clareza. (Apetece-me quase acrescentar: sem... claridade.) Não é, contudo, o caso deste diário. Bem pelo contrário. Dou com muita coisa bem dita, e aqui e ali uma

\footnotetext{
${ }^{12}$ MATHIAS, 2008: 101.

${ }^{13}$ Marcello Duarte Mathias haveria mais tarde de corrigir esta opinião negativa, na apreciação feita, no Diário de Paris, a Para Sempre.
} 
gravidade atenta, uma simplicidade que seduz, uma expressão pessoal ordenada em torno da emoção ${ }^{14}$.

É uma questão de gosto, que não discutimos e que não partilhamos, devida, quem sabe (mas esta é mera hipótese interpretativa), a outros hábitos de leitura e à simpatia por uma narrativa clássica urdida segundo uma relação causal/temporal que a de Vergílio foi perdendo, ao mesmo tempo que o seu romance foi ganhando em frases mais curtas, lapidares, entrecortadas, a caminho do que ele considerava o «romance abstrato».

Num aspeto se aproximam, aliás, estes diaristas tão diferentes, mas com pontos de interseção não passíveis de serem aqui explorados, o da conceção de diário como lugar de aconchego e de contas consigo próprios, recetor das «aparas» e do «lixo» do quotidiano (Vergílio), ou «um livro de lacunas e de atalhos, soma de fragmentos, ferro-velho de palavras, puzzle para sempre incompleto por lhe faltar à partida o exacto desenho da sua configuração final» ${ }^{15}$.

Com uma voz muito própria, Marcello Duarte Mathias vai disseminando opiniões críticas sobre autores e tendências literárias, não curando de saber se os seus juízos são a contracorrente. Maria Gabriela Llansol tem um diário que lhe merece reservas e incompreensão, o que se percebe, porque dele está ausente a escrita despojada e cristalina do próprio Marcello Mathias. Raul Brandão, Fernando Pessoa, Almada Negreiros, Aquilino Ribeiro, Ruben A., para citar apenas alguns, são nomes que constam das páginas diaristas daquele autor. Aquilino, por exemplo, ainda não é o escritor imortalizado no Panteão Nacional (e ao autor de No Devagar Depressa dos Tempos interessará mais razões de outra ordem que não as vistosas celebrações públicas) e o retrato pessoano também lhe sai delineado com alguma ironia quando lhe destaca a condição de homem mortal, embora não se esqueça a certeira observação sobre aquela múltipla personalidade que, por ser muitos, se não encontra consigo próprio: «o poeta múltiplo e fingidor que até se parecia com o Kafka nos chapéus que usava e na mania dos labirintos, esse passou a vida a inventar-se destinos diferentes convencido que se iludia a si próprio e acabou por morrer como toda a gente, cheio de saudades de si» ${ }^{16}$.

A admiração por alguns estrangeiros, nomeadamente os de língua francesa, é bem exposta em algumas páginas diarísticas. Fica, a título de exemplo, este comovido elogio a Marguerite Yourcenar aquando do seu falecimento em 18 de dezembro de 1985:

\footnotetext{
${ }^{14}$ MATHIAS, 2010a: 174.

${ }^{15}$ MATHIAS, 2010a: 164.

${ }^{16}$ MATHIAS, 2010a: 323.
} 
Da Antiguidade Clássica à Renascença, amou a História e os homens que nela se perderam, porque a política é também ventura para aqueles que ambicionam servi-la livremente.

Intima do mundo grego como da moderna literatura japonesa, das lendas eslavas como dos poemas negros norte-americanos, dona de uma erudição forjada e fecundada no conhecimento dos clássicos, cozia no forno da sua casa o pão porque nada do que era humano the era indiferente ${ }^{17}$.

Percebe-se a atração do embaixador pelos livros dos outros bem como a formação que através deles foi adquirindo e daí se infere, até por breves anotações de passagem, a relação por ele estabelecida entre a formação assim adquirida, as viagens como aquisição de conhecimento alargado do mundo, e a personalidade do indivíduo, como se depreende destas perguntas retóricas sobre Adelino Amaro da Costa: «Por onde tem viajado? Que livros lê? Que figuras históricas admira? Que infância foi a sua? Sim, que homem é ele fora do combate ideológico?» ${ }^{18}$.

A literatura vem carregada de memória, como vem o escritor que lhe dá corpo, mas, se, de um lado, ela fica como valor documental historiável, por outro as múltiplas construções imaginativas a que procede - reinventando e conferindo realidade ao irreal, como bem nos ensinou esse genial inventor de falsas memórias, mas exímio guardador de cultura na sua prodigiosa memória, que foi Jorge Luis Borges - constituem um dos tesouros que ainda hoje ciosamente guardamos.

Essa herança recebida e transmitida, seja em forma de intertextualidade declarada, seja por outros expedientes, como o comentário crítico, o ensaio mais ou menos literário, é filtrada e valorizada segundo as diversas sensibilidades do leitor, mas a que não serão alheias tendências estéticas e teorias críticas dominantes. Daí resulta uma seleção que vive da relação memória/esquecimento, trazendo à luz o que se acha merecer voltar, deixando o resto na penumbra: uma estética ou um género dominantes, um livro de um autor, que fica como representante de todos os outros, etc. Uma breve referência, uma frase concisa, podem ser de uma eloquência ou uma poeticidade que ficam para a história.

Há mestres da contenção, como Valéry ou Jorge Luis Borges, que entusiasmam Italo Calvino, igualmente admirador das formas breves. Valéry é mesmo por ele eleito como paradigma de um dos valores que ele desejaria transmitir ao próximo milénio, este onde estamos: «o da uma literatura que tenha como apanágio o gosto da ordem mental e da exactidão, a inteligência da poesia e ao mesmo tempo da ciência e da filosofia, como a do Valéry ensaísta e prosador» ${ }^{19}$.

\footnotetext{
${ }^{17}$ MATHIAS, 2010a: 323.

${ }^{18}$ MATHIAS, 2010a: 120.

${ }^{19}$ CALVINO, 2002: 140.
} 
O elogio que Italo Calvino faz do aforismo, forma literária herdada do século XIX, tal como o poema em prosa o foi, encontra eco noutros contemporâneos, por ele ser o expoente máximo do raciocínio contido, mas pleno de significação. Entre nós, Vergílio Ferreira cultiva-o em Pensar e Escrever e elogia explicitamente a máxima, que, em termos enunciativos, lhe é próxima, como mensagem afirmativa que não deixa brechas. Marcello Duarte Mathias louva-o e cultiva-o igualmente no seu Brevíssimo inventário, que abre com duas epígrafes, uma de Agostinho da Silva e outro de Cioran.

Esse pensamento fragmentariamente anotado é hábil em mostrar o funcionamento da memória «por eclipses», como anota aquele autor, deixando uma parte da realidade na sombra, o que no género em questão não constitui problema, até porque a escrita não submetida a uma cronologia nem obrigada a um a sequência causal-temporal deixa margem para pensar ao acaso, como quis Vergílio Ferreira, ou para a memória do que se não viveu, como pretende Marcello Duarte Mathias:

Lembro-me de coisas que não vivi como se as tivesse vivido, por exemplo, o Tejo e as naus no Tejo em 1500 e a vida que então era a de Lisboa, com a sua população mesclada de mercadores, frades, artífices, jornaleiros, nautas estrangeiros, figuras da nobreza, vendedores e vendedeiras ${ }^{20}$.

Estamos com os grandes escritores que muito (bem) escreveram por muito (bem) terem lido, fazendo da sua criativa escrita uma viagem onde levam na mala a sabedoria alheia. É a imagem do escritor que se projeta na memória das gerações, são as frases memoráveis que se vão repetindo pelos tempos, com as reinterpretações que lhes acrescentam informação. Quem vier atrás há de testemunhar como será no futuro. Não somos sábios, mas reconforta-nos a perentória afirmação de Harold Bloom: «Lemos e refletimos porque temos fome e sede de sabedoria» ${ }^{21}$, o que será uma maneira de confiarmos ainda na memória dos livros.

É com George Steiner que concluo, ao recordar as suas palavras sobre a relação, na qualidade de leitor/crítico, com os livros dos outros como um ato de amor e de gratidão:

Toda a minha obra assenta na apreensão das vozes que se aproximam de mim. É por isso que escrevo na primeira linha de Tolstoi ou Dostoiewski, que toda a verdadeira crítica é um ato de amor. [...] Aos meus olhos, toda a boa leitura retribui uma dívida de amor ${ }^{22}$.

\footnotetext{
${ }^{20}$ MATHIAS, 2010b: 100.

${ }^{21}$ BLOOM, 2008: 245.

${ }^{22}$ STEINER apud JAHANBEGLOO, 2000: 81.
} 


\section{BIBLIOGRAFIA}

BENJAMIN, Walter (1996) - O narrador. Considerações sobre a obra de Nicolai Leskov. In Magia e técnica, arte e política. 10. ${ }^{a}$ reimpressão. São Paulo: Editora Brasiliense, p. 197-221.

BLOOM, Harold (2008) — Onde está a sabedoria? Trad. de Miguel Serras Pereira. Lisboa: Relógio d’Água. Título original: Where Shall Wisdom Be Found?.

BORGES, Jorge Luis (2002) - Este ofício de poeta. Lisboa: Teorema.

CALVINO, Italo (2002) - Seis propostas para o próximo milénio. 4. ${ }^{a}$ ed. Trad. de José Colaço Barreiros. Lisboa: Teorema, 1993. Título original: Lezione Americane - Sei proposte per il prossimo milennio, 1990.

(2003) - Ponto Final. Trad. de José Colaço Barreiros. Lisboa: Teorema. Título original: Una pietra sopra, 1995.

CATROGA, Fernando (2003) - Caminhos do Fim da História. Coimbra: Quarteto.

FERREIRA, Vergílio (1992) - Pensar. Lisboa: Bertrand.

MATHIAS, Marcello Duarte (2008) - Encontro em Capri ou o Diário Italiano de Gorki. Alfragide: Oceanos. (2010a) - Os Dias e os Anos. Diário 1970-1993. Lisboa: Dom Quixote. (2010b) - Brevíssimo Inventário. Lisboa: Dom Quixote.

STEINER, George; JAHANBEGLOO, Ramin (2000) - Quatro entrevistas com George Steiner. Trad. de Miguel Serras Pereira. Lisboa: Fenda. Título original: Entretiens avec Ramin Jahanbegloo, 1999. 


\title{
ÉTICA E ESTÉTICA EM RAUL BRANDÃO
}

\author{
ÁLVARO MANUEL MACHADO*
}

No texto de Introdução à recentíssima nova edição crítica de Húmus, de Raul Brandão, Maria João Reynaud (a quem quero, desde já, prestar a minha sincera homenagem) sintetiza brilhantemente, desde as primeiras linhas, o fundamento ético deste livro e, afinal, de toda a obra brandoniana. Depois de citar, em epígrafe, a célebre passagem do prefácio ao primeiro volume das Memórias (que deu título a um extraordinário romance do injustamente esquecido Augusto Abelaira) - «A nossa época é horrível porque já não cremos - e não cremos ainda. $O$ passado desapareceu, de futuro nem alicerces existem. E aqui estamos nós sem tecto, entre ruínas, à espera...» -, Maria João Reynaud afirma:

Com esta aporia, Raul Brandão define lapidarmente a condição trágica do homem moderno e aponta o fundamento ético da sua angústia existencial, a qual se projecta num horizonte temporal que, por fatalidade, reconhecemos como sendo o nosso próprio tempo. Sob o signo da ruptura, a sua escrita traz dentro de si o germe da destruição de qualquer sentido estável, de qualquer poder de edificação de um mundo possivel que fosse regido pelas leis da harmonia e da verosimilhança. Escrita 
que representa o irrepresentável, que revela o irrevelável, que dá a ver o invisível, que dá a ouvir o silêncio mortal que cerca cada palavra ${ }^{1}$.

Há, de facto, um «fundamento ético» que atravessa toda a obra de Raul Brandão. Mas qual é a relação entre esse «fundamento ético» e a criação, diria mesmo, no caso da surpreendente escrita fragmentária de Raul Brandão, a invenção estética? Será que nele a ética condiciona ou se sobrepõe à estética? E qual é a causa da formação desse "fundamento ético», paralelo, aliás, à adoção de determinados modelos literários estrangeiros que designaria, em termos comparatistas, por «produtores», especialmente o modelo literário de Dostoievski?

Tendo há muitos anos (mais de meio século) descoberto (ainda nos longínquos anos da minha adolescência, através do meu avô republicano e portuense da Foz, grande admirador e amigo pessoal de Raul Brandão) e, posteriormente, estudado com denodo e entusiasmo a obra do escritor, proponho-me aqui tentar responder a essas interrogações. Faço-o retomando em parte o trabalho de pesquisa, feito para a minha tese de doutoramento nos também longínquos finais dos anos 70 do século passado, que se prolongou e expandiu depois, ao longo de vários anos, em ensaios e comunicações. E assim, a nível sobretudo da história das ideias filosóficas e literárias, retomarei também, quer a relação que já estabeleci e aqui desenvolvo, entre Raul Brandão e Sampaio Bruno, quer as marcas do referido modelo literário estrangeiro decisivo para Raul Brandão que foi Dostoievski. Neste introito, faço ainda notar que, além dos textos fundamentais de Maria João Reynaud em geral (aos quais voltaremos), no que diz respeito especificamente à influência do pensamento de Sampaio Bruno, parece-me justo referir a notável comunicação (que é, de facto, um ensaio de 46 páginas), apresentada no colóquio Ao encontro de Raul Brandão, realizado no Centro Regional do Porto da Universidade Católica em 1999, por Afonso Moreira da Rocha, intitulada «Sampaio Bruno e a evolução estética de Raul Brandão»².

Disse que retomava pesquisas e ideias que vêm de longe. Faço-o porque acho sempre proveitoso retomarmos o que nos pareceu mais significativo como descoberta, não, claro, para repetirmos o que já foi dito por outras palavras, mas sim para (falando em termos brandonianos) descobrirmos ramos novos numa velha árvore...

\section{1. ÉTICA E ESTÉTICA NO IMAGINÁRIO FINISSECULAR}

Quando Eça de Queirós, num texto datado de 1886, que serve de prefácio ao medíocre livro de contos do seu amigo Conde de Arnoso intitulado Azulejos, exalta a Arte em si mesma, como um absoluto, afirmando que «A Arte é tudo - tudo o resto

* Universidade Nova de Lisboa.

${ }^{1}$ BRANDÃO, 2015: 7.

${ }^{2}$ ROCHA, 2000. 
é nada» ${ }^{3}$, levanta sobretudo a questão fulcral da relação entre estética e ética. Ou seja: considera que qualquer forma de arte (a literatura antes de mais, claro, mas também a música ou a pintura, a julgar pelos exemplos que dá) tem de criar uma linguagem que lhe seja própria e absolutamente exclusiva. Isto é: não dependa de qualquer outro processo criativo que implique, de uma maneira ou de outra, a intervenção de um juízo de valor não estético, o que incluiria o compromisso com doutrinas sociais (de que o realismo-naturalismo era exemplo na época), ideologias políticas ou doutrinas religiosas. E por isso, Eça acrescenta, logo a seguir, nesse mesmo texto: «Só um livro é capaz de fazer a eternidade de um povo» ${ }^{4}$. Mas qual será, afinal, o sentido preciso do conceito de ética aplicado à criação estética em geral e literária em particular?

Comecemos então, simplesmente, didaticamente, pela própria definição da palavra ética, seguindo um conceituado Dicionário de Filosofia:

Ética: (Gr. ta ethika, de ethos). Ética (também denominada filosofia moral) é o ramo do saber ou disciplina que se ocupa dos juízos de aprovação e reprovação, dos juízos quanto à rectidão ou incorrecção, bondade ou maldade, virtude ou vício, desejabilidade ou sabedoria de acções, disposições, fins objectivos ou estado de coisas. [...] Os juízos éticos dividem-se, de um modo geral, em duas classes: a) juízos de valor $[. .]$, b) juízos de obrigação $[. . .]^{5}$.

Esta definição, forçosamente elementar, leva-nos à pergunta não menos elementar mas igualmente inevitável: em que tipo de ética poderíamos classificar a obra de Raul Brandão no seu conjunto? Não, certamente, no do juízo primário sobre o verdadeiro e o falso, o bom e o mau, a retidão e a incorreção. Tudo nela é, pelo contrário, uma complexa reflexão, por vezes amoral no sentido nietzschiano do termo, sobre o fascinante e terrível abismo que é o ser humano, herança de Dostoievski e também de um certo imaginário finissecular oitocentista, o qual dá uma dimensão metafísica aos personagens, como se vê desde $A$ morte do palhaço:

Singulares criaturas devem nascer por este fim do século, em que a metafísica de novo predomina e a asa do Sonho outra vez toca os espíritos, deixando-os alheados e absortos. A necessidade do desconhecido de novo se estabelece. A ciência, que por vezes arrastara a humanidade, que a supunha capaz de ir até ao fim - bateu num grande muro e parou. Que importam o princípio e o fim? Ora é exactamente o princípio e o fim que importam 6 .

\footnotetext{
${ }^{3}$ QUEIROZ, 1966: II, 1441.

${ }^{4}$ QUEIROZ, 1966: II, 1441.

${ }^{5}$ RUNES, 1990: 128-129.

${ }^{6}$ BRANDÃO, 1981: 93-94.
} 
Esboça-se aqui, antes mesmo de Húmus, aquilo a que poderíamos chamar um certo misticismo e não propriamente um imperativo ético. Essa forma confusa, fragmentária, de discurso místico em Raul Brandão parece-me ter como origem sobretudo, para além de outras leituras, os textos teórico-críticos de Sampaio Bruno, o qual é amplamente referido nas Memórias. Ora, sem nos alongarmos em grandes elucubrações filosóficas e dando, em contrapartida, relevo à teorização literária, convirá definir essas ditas fragmentações de discurso místico brandoniano a partir do pensamento de Sampaio Bruno relacionado com uma teorização literária herdada sobretudo do primeiro romantismo alemão, via Hegel.

Walter Benjamim, numa obra que, apesar do teor académico, dado que constituiu a sua tese de doutoramento defendida em 1919, nada tem de convencional ou de datada, O conceito de crítica estética no romantismo alemão, aborda, como ele diz na Introdução, a «história das problemáticas» estético-filosóficas, focando em particular o «conceito de Romantismo». Problemática imensa e conceito fugidio, convenhamos, que Walter Benjamim concentra, de facto, diria até, cristaliza na teoria romântica da crítica em Friedrich Schlegel e, ainda mais especificamente, no sentido do absoluto metafísico através do fragmentário.

Assim, no terceiro capítulo, intitulado Sistema e conceito, em que são analisadas as ideias estéticas de Friedrich Schlegel como sendo as de um «filósofo artista ou então um artista que praticava a filosofia», estabelecendo-se um paralelo com as ideias estéticas de Novalis, Benjamim conclui que ele era «demasiadamente artista para se limitar ao sistemático puro». Nesse sentido, define assim o seu percurso "polimorfo»: "O absoluto surge, quer como cultura, quer como harmonia, quer como génio ou como ironia, quer ainda como religião, organização ou história» ${ }^{7}$. E, logo a seguir, Benjamim sintetiza o pensamento estético-filosófico de Friedrich Schlegel, na sua essência fragmentária, em termos que se poderiam aplicar a Sampaio Bruno, sobretudo o Sampaio Bruno de A Geração Nova, e também a Raul Brandão:

ele não procurava conceber o absoluto sistematicamente, antes procurava o sistema absolutamente. Eis a essência da sua mística [...]. Critica Kant pela atitude contrária [...]. Neste aspecto, Novalis encontra-se com Friedrich Schlegel quando diz que a filosofia "é uma ideia mística [...] penetrante, que nos leva incansavelmente até ao coração de tudo». [...] Eis por que para Friedrich Schlegel um fragmento - ainda um termo místico - , como tudo o que tem a ver com o espírito, é um elemento intermediário essencial da reflexão ${ }^{8}$.

${ }^{7}$ BENJAMIM, 2001: 79-80.

${ }^{8}$ BENJAMIM, 2001: 81-88. 
Na verdade, poderá dizer-se que, como nos Fragmentos de Novalis, há nos Fragmentos publicados na revista «Athenäum» por Friedrich Schlegel o culto duma terminologia mística que a própria fragmentação da teorização estética suscita e privilegia, ultrapassando a dicotomia pensamento sistemático-pensamento intuitivo.

Serão estas também as tendências gerais duma teorização estética e mais especificamente literária, que se pretende liberta da tradição folhetinista, na época de Sampaio Bruno e da formação intelectual e estética de Raul Brandão, ou seja, em finais do século XIX, particularmente a partir da publicação de A Geração Nova, recuperando-se, em parte, o pensamento estético-filosófico do primeiro romantismo alemão para o relacionar, sobretudo no caso de Sampaio Bruno, com um certo nacionalismo pós-romântico de alcance metafísico e de recusa do estrito positivismo comtiano.

Aliás, já em 1878, numa curiosa revista literária mensal publicada no Porto, "Museu Illustrado», dirigida por David de Castro e com colaboração, entre outros, de Camilo, Antero, Gomes Leal, Fialho, Leite de Vasconcelos ou Júlio César Machado, Sampaio Bruno publica uma série de artigos intitulada A propósito do Positivismo ${ }^{9}$. E num desses artigos, ao analisar a crise do pensamento positivista comtiano aplicado à própria estética, Sampaio Bruno sintetiza numa fórmula brilhante a sua atitude: «Reforme-se a Metafísica». Lembremos ainda que, antes mesmo da publicação de $A$ Geração Nova, num opúsculo sobre o livro Lira íntima de Joaquim de Araújo, publicado em Braga em 1884, Sampaio Bruno, ao analisar a evolução recente da poesia em Portugal, insurge-se romanticamente contra «essas aberrações grosseiras da chamada poesia científica, disparatada fusão do que é respectivamente inconciliável: a dedução lógica e o exaltamento apaixonado» ${ }^{10}$. E no ano seguinte, o da morte de Victor Hugo, Sampaio Bruno, na revista "A Folha Nova», exalta misticamente o poeta francês, considerando a sua obra os «Evangelhos do século XIX» e comparando a perda do escritor à de um segundo Cristo, pois Hugo tinha sido «o último grande homem que conseguiu comover a terra inteira» ${ }^{11}$.

Todavia, só com a publicação de A Geração Nova é que Sampaio Bruno desenvolveu em termos mais ou menos sistemáticos as suas ideias estéticas, aplicadas concretamente a obras e autores da literatura portuguesa, predominantemente seus contemporâneos. Note-se, desde já, que a definição de "geração nova» (a designação de «nova» poderá, aliás, considerar-se proveniente do artigo de Oliveira Martins publicado em 1875 na «Revista Ocidental» intitulado Os poetas da Escola Nova) refere-se, como afirma o próprio Sampaio Bruno, aos «dissidentes» da Geração de 70. Ou seja: àqueles que não aderiram à tendência realista-naturalista e ao positivismo comtiano. Mas convirá aqui estabelecer certas nuances: alguns autores, inclusivamente teóricos de uma maneira ou

\footnotetext{
${ }^{9}$ BRUNO, 1878: I, 195, 217, 241, 265-267.

${ }^{10}$ BRUNO, 1884: 6-7.

${ }^{11}$ BRUNO, 1885: 1.
} 
de outra ligados à Geração de 70, influenciaram as ideias literárias de Sampaio Bruno. Um deles, que de certa maneira se manteve marginal, é Júlio Lourenço Pinto. Sampaio Bruno faz, aliás, em A Geração Nova, uma crítica impiedosa ao seu romance de estreia, Margarida - Cenas da vida contemporânea (1879), assinalando, com razão, o seu cariz de romance datado e programático da escola realista-naturalista. No entanto, à obra de teorização e crítica literárias de Júlio Lourenço Pinto vai Sampaio Bruno buscar muitas das suas ideias, sobretudo à coletânea de ensaios intitulada Estética naturalista - Estudos críticos (1884), conjunto de textos publicados anteriormente na «Revista de Estudos Livres», dirigida por Teófilo Braga e Teixeira Bastos. Aí são expostos os fundamentos teóricos da chamada «escola moderna», baseados principalmente numa síntese dos pressupostos de Comte, Zola e Taine. É interessante notar que Júlio Lourenço Pinto, desde o prefácio do seu livro, afirma que, apesar da enorme importância da ciência, é necessário «determinar o modo como a arte se concilia com a ciência, ficando sempre independente» ${ }^{12}$. E sobretudo, Lourenço Pinto exalta a imaginação, distinguindo-a da fantasia, citando Taine e divergindo de Zola, no que se aproxima muito de Sampaio Bruno:

A imaginação, dissemos, é atributo capital do romancista, e neste ponto, como em outros porventura, estamos também em divergência com a teoria de Zola [...]. O romance positivo e experimental baniu a fantasia; mas a imaginação, considerada como faculdade de deslocar as ideias do campo da abstracção, de tornar sensiveis e vivas todas as coisas da vida real, não pode ser repudiada [...]. [...] A imaginação é o fogo que extrai a essência da ideia artística ou poética ${ }^{13}$.

Assim, diria que Sampaio Bruno em A Geração Nova, se por um lado se refere explicitamente aos «dissidentes» da Geração de 70, por outro lado acompanha, afinal, a fase finissecular dessa geração, ou seja: a passagem do seu período doutrinário realista-naturalista para o período decadentista de transição dos autodenominados «Vencidos da Vida». Nesse sentido, Sampaio Bruno alude sobretudo a Teófilo Braga e ao Eça da fase das Conferências do Casino e de O crime do Padre Amaro, situando à parte Antero e Oliveira Martins. Mas o mais significativo é que, ao longo da elaborada análise que empreende dos diferentes géneros de romance (romance histórico, romance «de intriga», «íntimo», «de costumes», «romance de intuito», «rural» e romance «realista» em geral), Sampaio Bruno releva a importância fulcral do romance russo, decisivo para a formação estética de Raul Brandão como romancista. Para Bruno, o romance russo inova em absoluto o romance europeu, na medida em que traz uma imagem da Rússia (imagem no sentido comparativista do termo, com as suas implicações

\footnotetext{
${ }^{12}$ PINTO, 1997 [1884]: 17.

${ }^{13}$ PINTO, 1997 [1884]: 77-79.
} 
culturais) que dá, efetivamente, um sentido novo ao romantismo europeu em geral, a descobrir no final do século XIX: «A Rússia é uma esfinge trágica. O novo Ocidente ignorava-a. [...] Mas, de repente, um clarão de incêndio iluminou tudo». E depois de citar Gogol, Turgueniev, Tolstoi e principalmente Dostoievski, Sampaio Bruno releva a «modernidade» desse romance russo, ainda quase desconhecido em Portugal, definindo um período de transição estética que é também um período de crise moral: «o novo romance é no mundo moderno uma ocorrência cognitiva, representa uma crise moral» ${ }^{14}$. Nesse sentido, Sampaio Bruno opõe o espiritualismo do romance russo, paralelamente ao panteísmo de Victor Hugo (outro modelo literário importante para Raul Brandão), ao naturalismo de Zola, "filho ingrato de Victor Hugo» ${ }^{15}$, criticando asperamente o romancista francês:

Nada se pode conceber de mais pueril do que o plano dos Rougon-Macquart, porque um mundo industrial, mercantil, político, operário não se revela pelo acidente de bambochatas dum ministro ou pelo grotesco dum janota. [...] Um livro como Os Miseráveis é um documento crítico valiosíssimo, por ser sintético, atando um feixe de traços essenciais ${ }^{16}$.

Assim, com A Geração Nova, Sampaio Bruno abre caminho na literatura portuguesa, quer para um decadentismo misticista, que começa a formar-se em finais dos anos 80 do século XIX (ou seja, num período de plena formação literária de Raul Brandão) e deriva, atingindo maior complexidade teórica, para o saudosismo neorromântico do início do século XX (Teixeira de Pascoaes e outros), quer sobretudo para a heteróclita modernidade dum Raul Brandão, que com ele teve algumas afinidades significativas (poderíamos até dizer eletivas).

\section{SAMPAIO BRUNO E RAUL BRANDÃO: CONVERGÊNCIAS E DIVERGÊNCIAS}

Passemos agora para uma análise breve mais específica da relação pessoal e literária entre Sampaio Bruno e Raul Brandão a partir, quer de uma ideia geral de modernidade aplicada sobretudo ao romance no final do século XIX, quer de um conceito de discurso fragmentário de caráter místico aplicado ao próprio conceito de literatura como herança finissecular do Romantismo.

Antes de mais, notemos, voltando às passagens mais importantes de A Geração Nova, o relevo que Sampaio Bruno e Raul Brandão igualmente conferem ao romance russo e, em particular, a Dostoievski. O autor de Crime e castigo era para Raul Brandão

\footnotetext{
${ }^{14}$ BRUNO, 1886: 299.

${ }^{15}$ BRUNO, 1886: 311.

${ }^{16}$ BRUNO, 1886: 314.
} 
a própria essência da modernidade, oposta às vanguardas modernistas, segundo ele mais ou menos superficiais no seu experimentalismo formal, como se pode facilmente constatar pelo testemunho deixado por Raul Brandão ao seu amigo Augusto Casimiro, em 1921:

Da literatura moderna pouco me interessa. É arte de exterioridades, estranha, ausente do que é essencial na vida... Folheie essas revistas... Coisas difusas, de superfície, habilidades, espuma. Só as páginas do capítulo inédito dos Possessos de Dostoievski, a Confissão de Stavroguine, marcam fundura de abismo, claridade de alturas, $o$ verdadeiro drama, a vida... O resto... ${ }^{17}$

Mas para lá desta afinidade essencial, que nos leva, aliás, a admitir ter sido através do próprio convívio com Sampaio Bruno que Raul Brandão conheceu e ficou apaixonado pela leitura de Dostoievski, notemos como Bruno é recordado por Raul Brandão nas suas Memórias. Trata-se de uma passagem particularmente significativa do terceiro volume, intitulado Vale de Josafat, volume que abre com esta frase paradigmática: «Ou a vida é um acto religioso - ou um acto estúpido e inútil» ${ }^{18}$.

Raul Brandão começa por evocar o convívio com Sampaio Bruno, ouvido como se ouve um mestre, um tanto excêntrico, aliás:

José Sampaio (Bruno), conversador extraordinário, corria altas horas as ruas denegridas e húmidas do Porto, com dois ou três amigos, falando, parando, discutindo até alta madrugada. Vinha tudo à baila: Deus, o universo, os filósofos e a política. Agregavam-se às vezes àqueles homens alguns rapazes, que o ouviam fascinados. Eu era um deles, e ouvi-lhe, uma noite, estas palavras que nunca mais me esqueceram:

- Escusam de procurar... a nossa ruína não vem dos políticos nem do regime. Mudaremos o regime e ficaremos na mesma. O mal é mais profundo - o mal é da raça.

- A raça? Mas, com esta raça, descobrimos o Mundo...

Não me lembro o que ele respondeu, nem mesmo se atendeu à interrogação. Sei que continuou:

- O mal é da raça. Se quisermos modificar o País, temos de fazer exactamente o mesmo que se faz com os cavalos, temos de mandar vir homens do Norte, ingleses, escandinavos ou suecos, e de montar aqui e além postos de cobrição.

Uma gargalhada acolheu a boutade ${ }^{19}$.

\footnotetext{
${ }^{17}$ Cf. «Seara Nova», n. ${ }^{\circ} 1457$ (março 1967).

${ }^{18}$ BRANDÃO, 1983 [1933]: 7.

${ }^{19}$ BRANDÃO, 1983 [1933]: 189.
} 
Logo a seguir, Raul Brandão revela divergências com Sampaio Bruno quanto a esta questão da raça:

Vi, mais tarde, que a causa principal da nossa decadência foi, não a raça mas a falta de elites. A raça, o povo, é o mesmo, com as qualidades e defeitos que sempre teve; as elites, duma origem diferente e superior, é que desapareceram, primeiro afogadas em sangue negro e, por último, no desastre de Alcácer Quibir ${ }^{20}$.

Claro que a proposta de Sampaio Bruno era uma boutade e também me parece óbvio que Raul Brandão está certo, é mesmo clarividente quando afirma que o que nos falta são elites, opinião que vai ao encontro das ideias anteriormente exprimidas pela Geração de 70, sobretudo por Antero, Eça e Oliveira Martins.

Para lá desta evocação brandoniana de certo modo circunstancial, embora significativa a nível histórico-cultural, o que realmente fica é a afinidade literária entre Sampaio Bruno e Raul Brandão a partir, não só dessa visão, digamos, religiosa da criação estética, mas também duma poética do fragmentário. Essa poética do fragmentário que Bruno cultivou nos seus ensaios e de que Raul Brandão fez, na obra de ficção, o essencial da sua modernidade, atingindo o ponto culminante nessa obra-prima que foi Húmus, obra que infelizmente Sampaio Bruno não pôde ler, pois foi publicada dois anos depois da sua morte.

Poderá dizer-se, portanto, que o pensamento filosófico e estético de Sampaio Bruno, na sua própria fragmentação de fundamento místico, foi decisivo para desencadear o processo criativo de Raul Brandão, passando pela descoberta e valorização de modelos literários estrangeiros, em particular o de Dostoievski. Não se tratou de uma influência doutrinária sistemática. Pode dizer-se que foi antes uma influência humanista existencial, a qual poderia ser sintetizada numa só frase de Sampaio Bruno, no final de $O$ Encoberto: «O herói não é um príncipe predestinado. Não é mesmo um povo. É o Homem» ${ }^{21}$. Por consequência, podemos até detetar algumas divergências ideológicas significativas entre Sampaio Bruno e Raul Brandão. Todavia, a influência exercida por Bruno no autor de Húmus foi decerto, como diz muito justamente Joel Serrão, «tão difusa quanto presente» ${ }^{22}$.

\section{CONCLUSÃO}

Em conclusão, será que poderemos afirmar que para Raul Brandão ética e estética se conjugam? Não me parece. Bem pelo contrário, se é verdade que um sentido ético de caráter predominantemente místico atravessa a sua obra, também é verdade que

\footnotetext{
${ }^{20}$ BRANDÃO, 1983: 190.

${ }^{21}$ BRUNO, 1983 [1904]: 332.

${ }^{22}$ SERRÃO, 1961: 262.
} 
esse sentido ético não se configura como «dever» mas sim como "consciência» que se interroga. É o próprio Raul Brandão, aliás, que o diz numa passagem bem significativa de Húmus:

Ponho-me a olhar para ti, consciência, e exijo que me fites nos olhos e me fales claro. Não entarameles a língua. Em primeiro lugar diz-me o que és e o que significas: medo, receio, uma voz que se cala se a miséria aperta ou a luxúria levanta a cabeça? [...] Estás em perpétua contradição. [...] Escusas de encher a boca com o dever. O dever não me interessa nada. A questão fundamental, a questão que eu debato com todo o meu ser, e de que não me consigo desligar, é a da morte eterna e a da vida eterna. [...] Se Deus existe eu sou um homem, - se Deus não existe eu sou outro homem completamente diferente ${ }^{23}$.

E aqui voltarei, para terminar, a Maria João Reynaud. Em Metamorfoses da escrita está exemplarmente definido o constante e dramático conflito entre ética e estética provocado pelo próprio conflito das contradições do autor-narrador (ou das suas várias vozes) na obra de Raul Brandão, particularmente em Húmus:

a obra não poderia deixar de ser afectada pelo espectro da contradição. Mas, se ela é atravessada por tendências estéticas de sinal contrário - que é costume referir através de pares opostos como apolíneo/dionisíaco, classicismo/romantismo, razão/ intuição, etc. -, afigura-se-nos que isso começa por ser o resultado mais evidente de uma tensão irresolúvel, experimentada a um nível muito mais profundo, entre a necessidade ética e a necessidade estética da escrita ${ }^{24}$.

Projetando esta «tensão irresolúvel», a vários níveis da escrita, na mais importante ficção portuguesa contemporânea, sobretudo a partir de meados do século XX, de Agustina a Vergílio Ferreira e a Mário Cláudio, a obra de Raul Brandão está bem viva, continuando a inquietar-nos com o fulgor do seu «espanto».

\section{BIBLIOGRAFIA}

BENJAMIM, Walter (2001) - Le concept de critique esthétique dans le romantisme allemand. Paris: Flammarion. (Champs).

BRANDÃO, Raul (1981) - A morte do palhaço e o mistério da árvore. Porto: Publicações Anagrama. (1983 [1933]) - Vale de Josafat - Memórias. Lisboa: Perspectivas \& Realidades, vol. III. (2015) - Húmus. Edição de Maria João Reynaud. Lisboa: Relógio D’Água Editores.

\footnotetext{
${ }^{23}$ BRANDÃO, 2015: 100-101.

${ }^{24}$ REYNAUD, 2000: 65.
} 
BRUNO, Sampaio (1878) - A propósito do Positivismo. «Museu Illustrado. Album litterario mensal». Porto, vol. I.

(1884) - Lira intima por Joaquim de Araújo. Braga: Tipografia de A. de Sá Pereira.

(1885) - «A Folha Nova», ano 5, vol. VII, n. ${ }^{\circ} 1$.

(1886) - A Geração Nova. Ensaios críticos - Os novelistas. Porto: Magalhães \& Moniz, Editores. (1983 [1904]) - O Encoberto. Porto: Livraria Chardron de Lello \& Irmão - Editores.

PINTO, Júlio Lourenço (1997 [1884]) - Estética naturalista - Estudos críticos. Lisboa: IN CM.

QUEIROZ, Eça de (1966) - Notas contemporâneas. In Obras Completas. Porto: Lello \& Irmão — Editores, vol. II.

REYNAUD, Maria João (2000) - Metamorfoses da escrita: "Húmus», de Raul Brandão. Porto: Campo das Letras, p. 65.

ROCHA, Afonso Moreira da (2000) - Sampaio Bruno e a evolução estética de Raul Brandão. In AA. VV. - Ao encontro de Raul Brandão. Actas do Colóquio. Porto: Lello Editores.

RUNES, Dagobert D., dir. (1990) - Dicionário de Filosofia. Lisboa: Editorial Presença.

«SEARA Nova», n. ${ }^{\circ}$ 1457, (março, 1967).

SERRÃO, Joel (1961) - Espanto, absurdo e sonho. «Gazeta Musical e de todas as Artes», tomo X, 2. a série, n. ${ }^{\circ}$ 122-123 (maio-junho de 1961). 



\title{
APONTAMENTOS SOBRE OS PESCADORES DE RAUL BRANDÃO, COM LEMBRANÇAS PARA ANTÓNIO NOBRE E LUÍSA DACOSTA
}

\author{
PAULA MORÃO*
}

De entre as mais recentes edições de obras de Raul Brandão, salientam-se a de Húmus, preparada por Maria João Reynaud (2015), e a de Os pescadores, a cargo de Vítor Viçoso (que assina também o prefácio) e Luís Manuel Gaspar (2014); os textos assim fixados permitem-nos voltar sempre e sempre ao autor de $O$ doido e a morte, pela mão de competentes editores. Limitar-me-ei nesta ocasião a alguns apontamentos sobre Os pescadores, enlaçando-o, ainda que muito brevemente, com outras obras que compõem um tríptico de que é aqui painel central ${ }^{1}$ : o Só de António Nobre e os dois volantes que na obra de Luísa Dacosta tematizam a faina pesqueira de A-Ver-o-Mar, na Póvoa de Varzim - A-Ver-o-Mar ${ }^{2}$ e Morrer a Ocidente 3 . Desde logo, o conjunto destas obras permite insistir em dois tópicos que ilustram superiormente, a saber: a representação do tempo, questão nodal para estes três autores; e a tradição, posta em jogo pela proximidade temporal de Nobre e Brandão e pela descendência claramente visível em Luísa Dacosta quanto a estes seus predecessores, que reconhece como matrizes.

Quanto a Nobre e Brandão, tem sido reiterada a coincidência de 1867 como ano de nascimento de ambos, aos quais se tem que acrescentar Camilo Pessanha para que

\footnotetext{
* Universidade de Lisboa/Centro de Estudos Comparatistas.

${ }^{1}$ À maneira da tradição ilustrada por A Vida - Esperança, Amor, Saudade, de António Carneiro (1900-1901), contemporâneo de Brandão.

${ }^{2}$ DACOSTA, 1980.

${ }^{3}$ DACOSTA, 1990.
} 
fique completa a aura luminosa dessa data. Reforçando os nexos entre os que viriam a ser autores do Só e de Húmus, acresce que foram amigos de juventude; sigamos um passo de Guilherme de Castilho, que a ambos biografou:

É a época em que no plano da convivência se vai direito àqueles que adivinhamos nossos irmãos na ânsia de descoberta [...].

António Nobre, Alberto de Oliveira, Justino de Montalvão e outros jovens aprendizes das letras têm o seu quartel-general num barco a boiar nas águas verdes de um rio de écloga pastoril. É para lá que Raul Brandão se dirige e é lá, no barco, no rio, nas areias das margens, nos rochedos do mar, que vai fazer o seu estágio de sonho, de "banhos em pelote", de poesia...

O futuro autor do Só, exactamente da sua idade, é de todos o que mais o impressiona $[\ldots]^{4}$.

Brandão deixará um impressivo e importante retrato do seu amigo nas Memórias ${ }^{5}$, além de ser um dos poucos que em 1892 se referem com entusiasmo à publicação original do livro de Nobre 6 . O que agora importa reter é, não apenas a amizade juvenil entre os dois autores, mas o seu interesse pelo mundo dos pescadores, dando depois lugar a trechos impressivos das obras respetivas. Aproximemo-nos, pois, dos textos, não sem antes ressalvar que no que a Raul Brandão diz respeito, me concentrarei em passos d'Os pescadores que tratam da costa norte de Portugal (Foz do Douro, Póvoa de Varzim, A-Ver-o-Mar, etc.), por ser esse também o centro de atenção dos versos de Nobre e dos volumes de Luísa Dacosta.

O livro de Raul Brandão inscreve-se no conjunto das suas páginas memorialísticas que, como aqui, suscita uma reflexão sobre questões genológicas. Na nota prévia, o próprio esclarece de que se trata:

Quando regresso do mar, venho sempre estonteado e cheio de luz que me trespassa. Tomo então apontamentos rápidos - seis linhas - um tipo - uma paisagem. Foi assim que coligi este livro, juntando-lhe algumas páginas de memórias. Meia dúzia de esboços, afinal, que, como certos quadrinhos ao ar livre, são melhores quando ficam por acabar ${ }^{7}$.

\footnotetext{
${ }^{4}$ CASTILHO, 1979: 18.

${ }^{5}$ Veja-se a entrada datada de «18 de Março de 1900» no volume I (ed. 1925, p. 78-81; ed. Perspectivas e Realidades, p. 56-58).

${ }^{6}$ Só, por António Nobre, «Correio da Manhã», (28 abr. 1892) apud BRANDÃO, 2013: 54-57.

${ }^{7}$ BRANDÃO, [s.d.]a: [37]. Nas suas várias ocorrências, grafa-se a referência a esta página com parênteses retos, por não estar numerada na edição utilizada (como é de regra nos proémios).
} 
Fixemo-nos primeiro na matéria da escrita («um tipo — uma paisagem»), e na consciência técnica do seu fazer: aos «apontamentos rápidos» se juntam «páginas de memórias», o que será corroborado por duas secções intituladas «Pequenas notas» ${ }^{8}$ e por outros traços a levantar o véu da escrita. O primeiro de entre eles observa-se nas didascálias datando alguns fragmentos, a mostrar a lógica de ordenação pensada da estrutura desta obra que «colig[e]» dispersos; se à primeira vista parece que os fragmentos se ordenam numa simples sucessão cronológica sem saltos, como num diário tradicional, percorrendo a costa desde Caminha até ao Algarve, logo isso é contrariado pela concatenação de entradas datadas de 1893 a 1900, 1921, 22 e 23. O segundo aspeto que logo fica claro neste breve texto introdutório é a extensão relativamente curta dos fragmentos, que pode ir do aforismo à narrativa ocupando várias páginas, o que deriva daquela oscilação declarada entre a brevitas dos «apontamentos» ou «notas» e as mais extensas "páginas»; importa observá-lo por causa das consequências disso na classificação genológica de Os pescadores, no corpo da obra brandoniana. Talvez a designação mais adequada seja, para este livro, aquela que Luísa Dacosta virá a adotar para subtítulo dos dois livros que aqui importam, também nisso herdeiros do autor de O pobre de pedir - crónicas; com efeito, este termo bifurca-se, no sentido da taxinomia de um subgénero narrativo, mas também e sobretudo como inscrição numa tipologia de inacabamento e de fragmentarismo, como expressamente sabe Brandão: «esboços [...] por acabar ${ }^{9}$, chama ele às peças que compõem este livro.

Uma terceira vertente apontada logo neste exórdio vem ao encontro daquele lugar impuro que a cada passo se reencontra na escrita do autor: refiro-me à posição do sujeito. Se ele «tom[a] apontamentos» ou redige «páginas de memórias», também age como editor que ordena os textos visando a publicação. Trata-se do sujeito que a si mesmo se representa no papel clivado daquele que tanto observa e recolhe o que vê e ouve, como de si se afasta duplamente: se o texto usa o presente, é para nele fazer confluir a síntese de tempos típica da autorrepresentação e do presente, conferindo exemplaridade e intemporal espessura histórica ao que se lê. Com efeito, ao lermos «Quando regresso do mar, venho sempre estonteado e cheio de luz que me trespassa», aí confluem o iterativo (todas as vezes que «regresso do mar»), o permansivo intensificador da sensação que se acentua ao repetir-se («venho sempre»), e mesmo o retrato do mais íntimo de um sujeito modificado (literalmente «trespassa[do]») pela luz, por sua vez redobrada pelo surgimento de uma linha fundamental - a figuração da memória. A leitura cruzada dos ecos deste incipit com os fragmentos torna claro o palimpsesto entre a representação de si num agora que afinal sumaria o acumular do passado, procedendo por amplificações encadeadas; como fica dito no segundo parágrafo deste proémio:

\footnotetext{
${ }^{8}$ BRANDÃO, [s.d.]a: 63-69, 111-114.

${ }^{9}$ BRANDÃO, [s.d.]a: [37].
} 
Estas linhas de saudade aquecem-me e reanimam-me nos dias de Inverno friorento. Torno a ver o azul, e chega mais alto até mim o eco prolongado... Basta pegar num velho búzio para se perceber distintamente a grande voz do mar. Criou-se com ele e guardou-a para sempre. - Eu também nunca mais a esqueci ${ }^{10}$.

Observe-se como a escrita corporiza e faz presente o que já foi, lenitivo da «saudade»: o que o sujeito viu e ouviu regressa e permanece "para sempre», constituindo uma força vital que «aquece»e «reanima». E note-se ainda a pregnância dos instrumentos sensoriais (visão e ouvido), não apenas aqui mas como veículos essenciais de toda a representação do mundo ao longo da obra, presente que está o sujeito como testemunha e participante, por isso mesmo com autoridade para registar aquele mundo. Tome-se como ilustração este passo, muito impressivo desse conhecimento em imersão literal no mundo da faina pesqueira:

Há três dias que ando metido na ria, com a barba por fazer, sujo como um ladrão de estrada, e fora de toda a realidade. Afigura-se-me que vivo num país estranho - amplidão, água e sonho. [...] Estonteado, encharcado de azul, cheio de sol e de luz, esqueci o passado e esqueci o presente. A vida é navegar na ria, comer da caldeirada de enguia e tainha, [...] É dormir no barco, [...]. É sair desta amplidão para a descoberta do charco, do canal, [...]. É assistir à transformação das águas e navegar à vela ao pé das casas e no interior das casas ${ }^{11}$.

Voltemos ainda ao valor vitalista da «saudade» a que se referia o exórdio, tópico que o livro amiúde glosa, notando que a nostalgia ocorre «nos dias de inverno friorento» ${ }^{12}$ - por sinal, a época mais difícil na vida das comunidades piscatórias, quando os homens e os barcos não saem e a fome mais aperta, como diversos fragmentos registam. Do ponto de vista do sujeito, no entanto, o «inverno» permite destacar um tópico que também comparece em Nobre: basta pensar em poemas como «Viagens na minha terra» ${ }^{13}$, com aquele impressivo incipit ${ }^{14}$, ou «Ao canto do lume» ${ }^{15}$ e outros ainda para deparar com o motivo melancólico da contemplação do lume no inverno, força regeneradora e operador da memória retrospetiva que magicamente opera $o$

\footnotetext{
${ }^{10}$ BRANDÃO, [s.d.]a: [37].

${ }^{11}$ BRANDÃO, [s.d.]a: 81-82.

${ }^{12}$ BRANDÃO, [s.d.]a: [37].

${ }^{13}$ BRANDÃO, [s.d.]a: 74-78.

${ }^{14}$ «Às vezes passo horas inteiras /Olhos fitos nessas braseiras,/Sonhando o tempo que lá vai;/E jornadeio em fantasia/ Essas jornadas que eu fazia/Ao velho Douro, mais meu Pai».

${ }^{15}$ Segunda estrofe: «Faz tanto frio (só de ver me gela, a cama...)./Que frio! Olá, Joseph! Deita mais carvão!/E quando todo se extinguir na áurea chama,/Eu deitarei (para que serve? Já não ama)/As cinzas brancas, o meu pobre coração!» (BRANDÃO, [s.d.]a: 104).
} 
regresso ao tempo em que se foi feliz. No texto de Brandão, a isso se junta o «búzio» que propicia o retorno em «eco» da «grande voz do mar», garantindo a permanência "para sempre» do som das águas, a que se colam as vozes dos que delas vivem, como os textos virão a abundantemente explanar.

Enfim, vale destacar neste rico exórdio o motivo da luz, consubstanciada nos «esboços», remissão não apenas para o inacabado e o intérmino, mas também para a pintura semelhante a «certos quadrinhos ao ar livre»; n’Os pescadores, névoas, neblinas e outras glosas da sombra são constante par da luz, da claridade, da paleta de cores, como bem sublinha Vítor Viçoso no prefácio à edição de $2014^{16}$. Pela minha parte, destacaria que a chamada «peinture de plein air» vem sendo praticada pelos artistas do século XIX, impressionistas e outros, como metodologia contraposta à "peinture d'atelier», o que se articula com a observação direta dos objetos e personagens a representar; como os álbuns ou cadernos de esboços dos artistas plásticos, também os escritores reduzem ao mínimo a parafernália de apetrechos, e podem estar entre as gentes com um caderno de apontamentos mais ou menos discreto - ou podem, simplesmente, registar na memória os elementos que depois plasmam no papel. Em Brandão, com efeito, é flagrante o uso reiterado de verbos como ver, ouvir, conhecer, enunciados na primeira pessoa para dar conta da observação direta, muito próxima das paisagens, dos tipos e das situações que representa, num verismo de contornos muito fortes. Mas a isso se sobrepõem a estesia e a composição: o eu testemunha redobra-se do eu artiste - e assim obtém o efeito, só aparentemente paradoxal, de uma representação espessa e persuasiva, levando quem lê a ver por sua vez o desfile dos barcos, das redes, dos homens e das mulheres, da paisagem. Há no Brandão de Os pescadores um impulso realista e mesmo de repórter, o que uma vez mais reconduz à aproximação com António Nobre, e nomeadamente com o dístico que fecha «Lusitânia no Bairro Latino»:

Qué dos Pintores do meu país estranho,

Onde estão eles que não vêm pintar ${ }^{17}$ ?

Raul Brandão glosa amiúde na obra em apreço a equivalência entre pintar e escrever, mesmo porque, como já se disse, olhar e audição constituem os principais instrumentos do seu trabalho de artista. Colhamos três exemplos:

Se eu fosse pintor dava isto com três brochas cheias de tinta - uma pincelada, maior, para o mar azul que não tem fim, até à linha doirada do areal - outra para o mar verde e raso dos milharais, na larga planície que vai de Montedor até

\footnotetext{
${ }^{16}$ Vejam-se as páginas 15-17, 20, 23-24, 26-27; nestas duas últimas páginas, o prefaciador enumera bastas referências da pintura europeia de marinhas, incluindo os portugueses Marques de Oliveira, Souza Pinto e João Vaz.

${ }^{17}$ NOBRE, 2000: 45.
} 
Viana, - outra enfim verde-escura para o biombo recortado que cinge esta faixa desde Caminha à foz do Lima. Por fim dois ou três toques para os montes ensaboados, muito ao longe, e um outro, lilás, para um ponto que tremeluz e é talvez Esposende, ou talvez não exista ${ }^{18}$.

Se eu fosse pintor passava a minha vida a pintar o pôr-do-sol à beira-mar. Fazia cem telas todas variadas, com tintas novas e imprevistas. É um espectáculo extraordinário ${ }^{19}$.

Tenho diante de mim o fulvo areal, a agitação do mar até onde a vista alcança e a agitação humana num quadro mais restrito. São quatro companhas e cada companha tem noventa e seis partes, entre homens que vão ao mar, homens da terra e mulherio para os cestos. [...]

O quadro é tão largo que se perdem as minúcias: concentro-me neste pedaço de areia de uns poucos de quilómetros [...], no azul do céu e na onda que enconcha e estoira, repercutindo-se em som e espalhandose em pó esverdeado ${ }^{20}$.

O trabalho poético faz-se na equivalência com a arte de pintar, usando as cores, os tons e os meios-tons de um modo que não pode deixar de convocar para o leitor Cesário Verde, e Nobre, e Pascoaes, e Teixeira Gomes, nomes exemplares de um tal processo na modernidade portuguesa. Mas o que nestes passos impressiona será sobretudo aquela interrogação dos limites da linguagem poética para representar as coisas, o mundo e o próprio sujeito. Afinal, quais são os limites da pulsão realista? Eles impõem-se pela vontade de ser exato e preciso na descrição, para tal desdobrando a paleta de cambiantes daquilo que se vê; no entanto, chega-se ao ponto em que a estesia se confronta com a impossibilidade do uno, do certo e do seguro - em vez disso instala-se a conjetura, o que «talvez não exista», a variação e a multiplicidade. Para obstar a esse princípio de imponderabilidade, usa-se um recurso: em vez do «quadro [...] largo», a delimitação de campo restrito, como se o pintor que escreve se servisse da quadrícula que os pintores desde sempre usaram para tratar com rigor o pormenor, o exato, "as minúcias». No seguinte passo, fica a claro essa capacidade de se centrar no detalhe, usando a «lente de aumentar» que já servira a Cesário Verde ${ }^{21}$ :

Há muitos traços que só descortino em sonho: uma velha com a boca desdentada sempre a rir-se para mim quando eu passava. Esqueci a figura, e a fisionomia

\footnotetext{
${ }^{18}$ BRANDÃO, [s.d.]a: 55.

${ }^{19}$ BRANDÃO, [s.d.]a: 63.

${ }^{20}$ BRANDÃO, [s.d.]a: 92-93.

${ }^{21}$ Cesário Verde, «O sentimento dum ocidental», secção III, estrofe 22: «E eu, de luneta de uma lente só,/Eu acho sempre assunto a quadros revoltados» (p. 152) (Sigo a edição VERDE, 1992).
} 
varreu-se-me de todo - mas a boca, só com um dente a escorrer ternura, levo-a comigo para a cova ${ }^{22}$.

Sobrepõem-se neste passo alguns exemplares processos da escrita: por um lado, a dialética entre lembrar e esquecer; por outro, a pormenorização, isolando na «figura» e na "fisionomia» reiteradamente vistas o detalhe impressivo, a «boca» desdentada na qual se salienta o palimpsesto entre o sublime e o grotesco, dualidade típica dos fantasmas brandonianos.

Aqui se cruzam duas direções pendulares: uma advém do «sonho» e do reconhecimento de que «O mundo que não existe é o meu verdadeiro mundo» (p. 39), ou de que «tudo, até as coisas, num dado momento, foram para mim seres de uma vida extraordinária» (p. 39); a outra linha é corolário da primeira, e consiste naquele fundo saber de que afinal existem apenas espectros, «fantasmas» (p. 44 e passim), sombras, «figuras em sonhos» (p. 44). Voltamos por esta via à problematização da memória e ao lugar do eu, tela de um gigantesco ecrã em que se projetam cenas e personagens num desfile sem fim talhado à imagem do Vale de Josafat (não por acaso, título do volume 3 das Memórias), auxiliado pela retentiva visual e auditiva, operador da hipotipose que produz diante dos olhos o que foi e já não é, e se sabe não voltar. Por isso ocorre com frequência o verbo ressuscitar, dizendo aquilo que radica no mais fundo e antigo alicerce do sujeito - a infância; como se vê por exemplo neste excerto:

É saudade, mas não é só saudade. Isto vem de muito fundo. Os meus actos são guiados por mãos desaparecidas e a minha convivência é com fantasmas. [...] Ressuscito as horas que perdi debruçado no velho muro e sinto o grão da pedra onde punha as mãos quando contemplava a engenhoca do meu vizinho António Luís [...]. Ressuscito as primeiras impressões.

A Foz está viva! Tenho-a diante de mim, a Foz de outrora, a Foz que já não existe, a Foz dos mortos, com o movimento, os tipos e a paisagem ${ }^{23}$.

O reino fantasmático caracteriza-se, pois, pelo poder que a memória tem de anular o tempo predador: tudo se funde na intemporalidade do presente, e o sujeito é palco daquela dança dos espectros que não o aflige, antes o torna amplo e sem fronteiras, como imensa tela. No Só de António Nobre surge em muitos passos uma questão análoga - basta considerar a presentificação encadeada de poemas como "António», «Lusitânia no Bairro Latino» ou «Viagens na minha terra»; sirva de ilustração a quarta

\footnotetext{
${ }^{22}$ BRANDÃO, [s.d.]a: 102.

${ }^{23}$ BRANDÃO, [s.d.]a: 44.
} 
estrofe deste poema, com o verbo «guardar» indiciando o papel da retentiva e o itálico «aqui» sinalizando a espacialização do eu:

Moinhos ao vento! Eiras! Solares!

Antepassados! Rios! Luares!

Tudo isso eu guardo, aqui ficou:

Ó paisagem etérea e doce,

Depois do Ventre que me trouxe,

A ti devo eu tudo que sou! ${ }^{24}$

A infância, o tal magma em que tudo tem origem, inscreve-se afinal na árvore genealógica deste sujeito mergulhado no mundo dos marítimos, como fica apontado logo no início de Os pescadores: o avô materno, embarcado num lugre, deixou «minha avó Margarida» à espera «desde os vinte anos até à morte» (p. 39), e a família tem a catraia «Senhora dos Navegantes», de cujo lançamento se dão abundantes pormenores (p. 42), enumerando os preparativos do barco e a sua bênção pelo abade, e sobretudo nomeando um a um os membros da companha de quinze homens (p. 42) que, com as suas mulheres, pela vez primeira deitam a catraia ao mar. Deste modo, as lides pesqueiras inscrevem-se como elemento fundador do sujeito, que as tem no sangue e delas a cada passo se dá conta. «Estes factos insignificantes impressionaram-me para sempre a retina e a alma», lê-se no mesmo fragmento que venho citando, e se «Muito tempo [os] perdi no tropel da vida, impõem-se-me hoje com um relevo extraordinário. Vejo outra vez tudo» (p. 42). Levanta-se aqui um ponto que muito importa considerar a propósito do realismo e da dignidade do que deve merecer o lugar de objeto literário. Como outros da sua linhagem (o poeta António Nobre, as cronistas Irene Lisboa e Luísa Dacosta, para nos atermos a casos evidentes), a Raul Brandão interessam os pobres, e de entre eles os pescadores, correndo o risco de tomar como objeto o insignificante, os «nadas que farão sorrir os outros» (p. 43), «certas coisas sem importância» (p. 44), os «Nadas» (p. 102), o universo do aparentemente banal que o preconceito tantas vezes excluiu.

Ora em obras como Os pescadores o que se nos depara é um mundo de conhecimento a que a estesia dá corpo e voz, não apenas por representar com minúcia de léxicos específicos as atividades das lides da pesca (barcos e redes ou outras artes, gentes e costumes, mentalidades e culturas formais ou informais), mas também porque ao fazê-lo se representa, afinal, um sujeito-a-escrever. Por exemplo, estabelecem-se e ilustram-se tipologias de embarcações, de homens, de mulheres, de redes e outros apetrechos, ou descreve-se a preparação, a saída e a chegada das jornadas da pesca. Em qualquer caso, ressaltam do descritivismo realista as cenas ou «quadros», o desfiar de figuras; mas por

${ }^{24}$ NOBRE, 2000: 74. 
entre a visível admiração por toda a panóplia de componentes, objetos, pessoas e lides, que a obra torna concretos, materializa e põe diante do leitor, nunca aquele que narra deixa de lado a consciência estética como princípio do sentido. Tomemos apenas um caso; ao traçar os retratos contrastados das mulheres da Murtosa, de Ílhavo e de Ovar, o narrador sobreleva dos elementos descritivos a própria questão da «beleza» e da «arte»:

Todas as mulheres da beira marinha são postas em destaque pela luz [...] No meu entender, a luz é o grande agente da beleza. [...]. O que aqui fica bem é o vestido escuro e a limpidez de sentimentos. Esta luz inteligente sabe muito bem que a arte é o encanto da vida e a mulher a suprema criação da arte $e^{25}$.

A «luz» personificada é, ela mesma, protagonista do processo representativo, fazendo a junção do que se descreve a partir da observação presumida do íntimo das personagens figuradas, num enlace que a alta consciência dos processos apresenta como a evidência transparente das coisas e da sua «alma delicada e extática» (p. 113), afinal espelho do artista narrador. A «arte» é o princípio da «suprema criação», a qual se não cinge ao que se pode ver («o vestido escuro»), antes descortina a «limpidez de sentimentos», entrando para dentro das personagens, como se as almas, sua e delas, formassem um só tecido inconsútil.

Ao longo deste artigo mencionei de passagem Luísa Dacosta, que nos deixou em fevereiro deste ano; quero terminar com um aceno à sua memória tão junta à dos marítimos de A-Ver-o-Mar a que deu uma vida que não perece; ilustremo-lo com um passo do volume de 1980 no qual perpassam as sombras protetoras de António Nobre e de Raul Brandão. N’Os pescadores, este atravessa a povoação em 1921 ainda designada Avelomar ${ }^{26}$ vindo da Apúlia e da Aguçadoira para chegar à Póvoa de Varzim; Luísa, por seu turno, passa temporadas no moinho sobre a praia. Assim abre o livro:

Ave de arribação, eu vinha só de ano em ano. Mas nunca fui perdedora, soube sempre guardar. A minha saudade, poita que lançais para a faneca, não está a mais de uma braça de vós, pescadores de sargaço. Mulheres, cujo luxo é o avental rodado e transparente de nylon, gastas a ter de parir para calar bocas famintas, os vossos filhos são um pouco meus [...]. Barcos, sei-vos os nomes. De mulher - Iliza, Maria Esabel — de ladainha - Senhora das Neves, Senhora de Monserrate - de jaculatória - Salvai-nos Senhor Aliaz Para Sempre. [... $]^{27}$

\footnotetext{
${ }^{25}$ BRANDÃO, [s.d.]a: 106.

${ }^{26}$ Cf. BRANDÃO, 2014: 241, nota.

${ }^{27}$ DACOSTA, 1980: 11 .
} 
A narradora guarda (quer dizer, conserva e presentifica; mas é ela mesma guardada, protegida) as gentes, os costumes, a praia e a terra em que se espelha o seu próprio retrato, num estilo próprio em que se reconhece a cada passo o espectro tutelar de Raul Brandão:

É o sol que se põe? É a lua que nasce? Os penedos anoitecem num mar de óleo e de cinza, laivado a coral. Os barcos dormem, abandonados ao fim do dia. Insidiosa, a bruma avança, [...] encurta a linha do horizonte, esconde a ciclópica, dinossáurica e agreste ponta de Sta André. Uma vela passa, esfuma-se, delida sombra [...]. Duas mulheres, encostadas ao ganha-pão, esperam ainda. Um barco? A noite? Alguém? O canto dum galo despluma-se, lá em baixo, na aldeia nova ${ }^{28}$.

Em homenagem a Maria João Reynaud, aqui deixo estes apontamentos, ecos de que «a luz é o grande agente da beleza» ${ }^{29}$ - a luz dos grandes textos.

\section{BIBLIOGRAFIA}

BRANDÃO, Raul ([s.d.]a) - Memórias. Lisboa: Perspectivas \& Realidades. 1. ${ }^{\mathrm{a}}$ ed. Paris/Lisboa: Aillaud e Bertrand, 1925, vol. I.

[s.d.]b - Memórias. Lisboa: Perspectivas \& Realidades. 1. a ed. Paris/Lisboa: Aillaud e Bertrand, vol. II. [s.d.]c - Memórias: Vale de Josafat. Lisboa: Perspectivas \& Realidades. 1. ${ }^{a}$ ed. Lisboa: Seara Nova, vol. III.

(2013) - A pedra ainda espera dar flor: Dispersos 1891-1930. Org. de Vasco Rosa. Lisboa: Quetzal. (2014) - Os pescadores. Edição de Vítor Viçoso e Luís Manuel Gaspar. Lisboa: Relógio d’Água. (2015) - Húmus. Edição de Maria João Reynaud. Lisboa: Relógio d’Água.

CASTILHO, Guilherme de (1979) - Vida e obra de Raul Brandão. Lisboa: Bertrand, 1979. (1980) - Vida e obra de António Nobre. 3. ${ }^{a}$ ed. revista e ampliada. Lisboa: Bertrand.

DACOSTA, Luísa (1980) - A-Ver-o-Mar. Porto: Figueirinhas. (1990) - Morrer a Ocidente. Porto: Figueirinhas.

NOBRE, António (1898) - Só. 2. a ed., revista e aumentada. Lisboa: Guillard, Aillaud e C. ${ }^{\text {. }}$ (2000) - Só. Reprodução tipográfica da 2. a edição (1898). Prefácio e edição de Paula Morão. Porto: Caixotim.

VERDE, Cesário (1992) - Obra completa. 6. ${ }^{\text {a }}$ ed. Estudo e organização de Joel Serrão. Lisboa: Livros Horizonte.

\footnotetext{
${ }^{28}$ DACOSTA, 1980: 82.

${ }^{29}$ BRANDÃO, 2014: 106.
} 


\title{
VARIAÇÃO LINGUÍSTICA EM HÚMUS DE RAUL BRANDÃO
}

\author{
CLARA BARROS*
}

O tema deste estudo, sobre Húmus de Raul Brandão, pretende ser uma homenagem à homenageada deste Colóquio. Mas é também motivado pela influência que esta obra de Raul Brandão reconhecidamente exerceu em autores da segunda metade do século XX. E cito as palavras de Maria João Reynaud, na Introdução à sua edição de Húmus: «A ficção brandoniana antecipa as experiências mais inovadoras efetuadas no âmbito da narrativa contemporânea...» ${ }^{1}$.

O objetivo do artigo é a análise da variação linguística que se pode detetar no texto de Húmus de Raul Brandão que só foi publicado em 1917, mas que vinha sendo elaborado desde muito mais cedo, havendo já anotações e notícias sobre a sua escrita desde $1909^{2}$. Decorrido um século desde a sua primeira edição, podemos pôr a hipótese da existência de palavras e fraseologias que terão caído em desuso. Sendo a variação e a historicidade da língua uma dimensão intrínseca e consubstancial, há sempre variação nas línguas. E temos consciência do fluir da língua no tempo, mas apenas quando objetivamos a sua análise e escapamos de algum modo à nossa condição de sujeitos falantes históricos, sincronizados com uma determinada fase da história da

\footnotetext{
* Universidade do Porto/CITCEM - Centro de Investigação Transdisciplinar Cultura, Espaço e Memória/Centro de Linguística da Universidade do Porto.

${ }^{1}$ REYNAUD, 2015: 8.

${ }^{2}$ Posteriormente foram publicadas mais duas edições, em 1921 e 1926 . A edição utilizada no presente estudo é a de Maria João Reynaud, 2015.
} 
nossa língua. Por outro lado, a língua está inscrita, de modo inerente, num processo dinâmico e é preciso ter em conta o seu diassistema em cada época. Nunca é fácil saber como as formas eram sentidas numa determinada sincronia, mesmo quando é próxima: porque nós temos o que foi escrito, mas não sabemos como era recebido, interpretado, sentido. Sendo assim, foi com alguma cautela que tentei fazer um levantamento de formas eventualmente sentidas pelo leitor de hoje como «datadas». Saliente-se que a consulta de dicionários nem sempre foi muito elucidativa, porque são necessárias longas décadas até que seja registado o caráter arcaizante das formas que neles figuram. Por vezes são referidas como arcaicas ou regionais e assinaladas no dicionário como tal. Outras vezes, mais raras, é assinalada a diminuição da frequência de uso.

No caso específico do léxico de Húmus aqui pesquisado, observa-se, nos dicionários da língua portuguesa consultados ${ }^{3}$, que raramente é assinalado o caráter «datado» das formas. Em toda a pesquisa realizada, só por três vezes encontrei a menção «desusado» num dos dicionários consultados, o Dicionário da Academia das Ciências ${ }^{4}$, em relação às palavras apegar-se, pélago e soldada, esta última também referida como "popular».

A designação de "regionalismo» surge quatro vezes: a palavra langonha é referida como vulgarismo e regionalismo no Dicionário Houaiss; botar, gadanho e tiborna são classificadas como regionalismos no Dicionário da Academia de Ciências. Já as classificações de «informal/vulgarismo», «familiar/coloquial» e «depreciativo/ pejorativo» contemplam diversas palavras do conjunto de termos de Húmus que foram pesquisados e em alguns casos sobrepõem-se; assim, bambúrrio, bur[u]andanga, cachimónia, esfrega (mulher da esfrega), estafermo, langonha, mistifório, penantes e quico são registados como termos informais/vulgares, enquanto bambúrrio, bulir, cachimónia, caco, esfrega, gasganete, lambisgoia, larica, mixórdia, tiborna, toutiço, traça, tranquibórnia, são consideradas léxico «familiar», também por vezes designado por uso «coloquial» 5 . A classificação como termo «depreciativo» ou «pejorativo» que, como foi referido, coocorre frequentemente com as anteriormente mencionadas, apõe-se a palavras como: cepos, enxurro, lambisgoia, perlenga e quintalório.

No plano lexical e semântico, a língua familiar distingue-se dos outros registos pela conotação, pela proporção diversa dos termos neutros e dos que implicam juízos

\footnotetext{
${ }^{3}$ Realizei a pesquisa em quatro dicionários da língua portuguesa: o Dicionário da Língua Portuguesa Contemporânea da Academia de Ciências de Lisboa, o Dicionário Houaiss da Língua Portuguesa, o Dicionário da Língua Portuguesa de Aurélio Buarque de Hollanda, o Dicionário Editora da Língua Portuguesa, e respetivas versões digitais. Consultei também, esporadicamente, outros dicionários, sempre que as quatro principais fontes não tinham nenhuma informação sobre a origem, a idade, ou o âmbito de utilização das palavras em estudo. Ocorreu frequentemente que nenhum dicionário destacava essas informações pretendidas. Dos dicionários disponíveis em formato digital foram ainda consultados: Dicionário Michaelis Moderno da Língua Portuguesa, Dicio - Dicionário Online de Português, Dicionário Priberam da língua Portuguesa e Dicionário Infopédia da Língua Portuguesa.

${ }^{4}$ O Dicionário da Língua Portuguesa Contemporânea da Academia de Ciências de Lisboa, 2001, refere como caídas em desuso estas três palavras, nas p. 287, 2803 e 3344, respetivamente.

${ }^{5}$ Parecem ser sinónimas as designações «familiar» e «coloquial», usadas por diferentes dicionários.
} 
apreciativos e depreciativos relacionados com a ausência de constrangimentos no meio familiar e de redes afetivas que marcam a comunicação.

Mas a mais frequente referência encontrada nos dicionários em relação ao léxico selecionado no texto do Húmus foi a classificação, algo imprecisa, de "popular». Há razões para crer que ela designa simultaneamente aspetos de variação regional, sociocultural e situacional do uso desses vocábulos. Diversos dicionários consultados registam o caráter "popular» de a bagadas, apegar-se, cachimónia, caco, cepos, cuia, cuidar que, esfrega, gadanho, gasganete, gorgomilos, lambisgoia, larica, mistela, mixórdia, penantes, perlenga, quico, quintalório, rançoso, traça, tibórnia, tranquibérnia. Estas, entre outras formas, parecem-me ser lexemas, expressões ou construções cuja frequência entrou, entretanto, em declínio. Diversas formas são descritas como populares/ regionais ou, simultaneamente, como de registo coloquial ou pejorativo - algumas são mesmo disfemismos - , no âmbito de um sentido geral de deterioração, desagregação ou decadência.

A meu ver, é a combinatória de algumas formas regionais com elementos de registo familiar ou de gírias diversas que inculca um cunho idiossincrático ao vocabulário de Húmus. Mas em relação a muitas outras palavras da seleção feita no texto, os dicionários não registam nenhuma peculiaridade, nenhum traço específico de pertença a um registo particular de língua. São portanto palavras normais, de uso corrente.

Não é possível confirmar o carácter arcaico, regional, ou familiar de todas as formas pouco comuns, embora a ausência de algumas delas no Dicionário da Academia das Ciências $(D A C)$ possa ser um indicador da sua queda em desuso, dado que se trata de um dicionário do português «contemporâneo».

Para além das formas referidas e classificadas como usos específicos, há neste texto certas palavras não assinaladas em nenhum dicionário como representativas de um uso particular, como: arredar, arrepanhar os vestidos, caligem, o par algures/ nenhures, ressungir, o bafo, saia de estamenha, vestido de lemistre, sapatos de ourelo, o xale, os coturnos, os mitenes, o saquitel da boroa, o ripolém, seis mil reis da soldada, arremedo, atascar-se, o carbone, por ora, feder, moicheia, a retrós, saguões, tabuado. Quer este léxico quer o uso do pronome vós como forma de tratamento frequente e não marcada, são traços que o leitor moderno «estranha» e que certamente assinalará: em alguns casos pelo desconhecimento, noutros pela sua raridade e especificidade de registo ou contextual. Tentei esboçar uma tipologia, mas verifica-se que muitas das palavras não estão ainda registadas. Há palavras com uso «datado» como ripolém ou ourelo, estemenha, ou cuia, mas é muito lento o processo de registo de formas caídas em desuso pela própria convivência de diferentes gerações de falantes numa comunidade, 
fenómeno que ilustra uma variação em tempo aparente ${ }^{6}$. As formas que integram o idioleto dos falantes das gerações mais velhas fazem também parte da norma.

Para um leitor contemporâneo, essas palavras causam algum estranhamento, conferem alguma opacidade ao discurso, aliás quase sempre esclarecida pelos contextos. Talvez se possam organizar por áreas semânticas. Há, por exemplo, um número elevado de palavras com semas que apontam para desagregação/deterioração, outras para elementos líquidos marcados por viscosidade. Por vezes, a caracterização não se apoia numa palavra, mas numa cadeia de lexemas em que as referências estão organizadas em linhas de coesão lexical em que se destaca a substituição sinonímica, como se pode observar na série mistela, mixórdia, mistifório, tiborna; no par gasganete, gorgomilos; no par traça, larica; ou na sequência langonha, viscosas, ranho; ou ainda tranquibérnia, burandanga, perlenga; ou bafio, mofo. Pode também apoiar-se numa proximidade semântica, numa sinonímia pelo menos parcial, como se pode observar nas séries: tresandar, feder, cheirar mal, rançosas; esgotos; ou puído, coçado, ressequido, mirradas; ou encardidas, trapos, enxurro; ou fel, vinagre, aziumado, vómito, podridão. Em todas estas isotopias estão presentes semas que apontam para uma avaliação axiologicamente negativa. A densidade dos vocábulos marcados por significados particulares imbuídos de juízos de valor depreciativos, de conotação negativa, cria no texto, em momentos determinados, um sentido geral negativo, talvez decadentista, com efeitos marcadamente disfóricos.

Para além da variação diacrónica, difícil de comprovar pela persistência e sobrevivência dos usos tradicionais, parece interessante observar a múltipla estratificação vertical e horizontal da língua no texto de Húmus, em que se verifica uma circunstância particular que é a relação intrínseca entre a variação diastrática e diatópica da linguagem utilizada e a própria construção discursiva. De facto, ocorrem nesta obra estilos linguísticos muito diversos, com caraterísticas variáveis.

É possível observar certas constantes: a linguagem cria o ambiente, as personagens são caracterizadas por modos de falar peculiares, que traduzem geralmente comportamentos individualizantes. Há um mundo sugerido e construído pela linguagem própria das personagens. $\mathrm{O}$ mecanismo de repetição, que estrutura o texto, como foi amplamente explicado por Maria João Reynaud, na esteira de Jacinto Prado Coelho, não nos deixa margem para dúvidas. São usadas repetidamente as mesmas palavras e as mesmas fraseologias. A esfera, o ambiente de certas personagens, como "as velhas», é caraterizado por arcaísmos e regionalismos, palavras assinaladas geralmente como populares, familiares, coloquiais. O discurso que carateriza «as velhas» oscila entre o tom coloquial e o pejorativo. Surge imbuído de juízos de valor depreciativos. Elas

${ }^{6}$ Conceito de W. Labov: a análise da variação em tempo aparente consegue registar a evolução em curso (ver LABOV, 2001: passim). 
são definidas por um conjunto de termos que sempre se lhes aplicam, com alguns disfemismos que traçam um ambiente sempre desagradável, de decadência, de miséria, com semas que apontam para desagregação ou degradação: cuia de retrós, quico, mistifório, gasganete, gorgomilos, lambisgoia, arreganhar os dentes, mixórdia, barafunda, langonha, viscosas, ranho, bambúrrio, tranquibérnia, burandanga, perlenga, mistifório, bafio, mofo, tresandar, feder, rançosas, mirradas, puído, desconjuntado, coçado, ressequido, encardidas, trapos, esgotos, enxurro, fel e vinagre, aziumado, vómito, podridão, mistela, coçado, desconjuntado, cuia postiça, traça, larica, entre outros.

Nessa caracterização das «velhas» surgem também termos metafóricos como caco, toutiço, crânio obtuso, cachimónia. E embora apareça ocasionalmente a palavra de uso comum, cabeça, é mais frequente o disfemismo. Por vezes a metáfora usa o recurso a realidades do mundo animal como: assomando-lhe ao focinho. Observa-se também o recurso a sufixos que alcançam diversos efeitos desvalorativos como em quintalório ou com valor afetivo/depreciativo: baixinho, folhinhas, cheirinho, cantinho, devagarinho, paninho, ou intensificador: molengão, ricaço.

No caso da personagem Joana, a mulher da esfrega, podemos observar igualmente que é a linguagem que cria a sua especificidade. Assim, a referência a ela surge no texto sempre acompanhada de um mesmo vocabulário marcado por palavras da linguagem familiar ou mesmo disfemismos que acentuam o caráter desagradável ou chocante da sua condição, da sua aparência, da sua vida, mas igualmente a sua dimensão de bondade. Há 60 referências a Joana, acrescidas de meia dúzia de vezes em que surge o substituto «a velha». Surge 21 vezes a expressão definitória: $a$ mulher $d a$ esfrega. A palavra esfrega apresenta dois significados e, com base nessa ambivalência, a condição desta personagem é revelada em duas dimensões que se intercetam: a do trabalho, fadiga, grande canseira, mas também repreensão, castigo, mortificação, sova, tareia. A referência a Joana está na proximidade de palavras e expressões como: velha; velha como as outras; velha estúpida; velhice; xale velho; trôpega; amachucada; farrapos; trapos; denegrida; unhas roídas; peles no pescoço; os olhos turvos; as mãos enormes; as mãos roídas; as mãos só dor; as mãos como cepos; a dar com a cabeça pelas paredes; chora sempre; chora por tudo e por nada; ri-se de si própria.

Mas há, por outro lado, na caracterização desta personagem, uma frequente ocorrência da palavra ternura: Por dentro a Joana é só ternura (p. 57); Misturou à vida ternura (p. 58); Conserva a ternura intacta (p. 125); diante desta criatura que não compreendo, de mãos roídas e um xale velho sobre o corpo mirrado de ternura. (p. 127); Está disposta a recomeçar a vida, a deitar mais ternura, a tirá-lo à boca para o dar aos outros (p. 132); Parece perdida, tão inútil no mundo! A ternura não lhe serviu de nada. (p. 135); Incutiram-lhe para sempre a subordinação, só lá tem dentro ternura (p. 167); Ao mesmo tempo a alma dorida, a ternura que a não larga (p. 168); Só a Joana conserva a ternura intacta (p. 212); A ternura da Joana modifica-lhe a fealdade, pega-se-lhe às 
mãos e aos trapos que a vestem (p. 213); A sua ternura é instintiva, a sua humildade é instintiva... (p. 213). Cerca de um terço das ocorrências desta palavra está na proximidade da personagem Joana. As restantes encontram-se distribuídas por sequências do texto geralmente pertencentes aos «Papéis do Gabiru». A Joana adquire então uma dimensão de grandeza: A Joana fala com o Sonho tu cá tu lá e atira-se ao Sonho (p. 135); A Joana debruça-se sobre uma grandeza com que não posso arcar (p. 213); a mulher da esfrega encontra enfim Jesus (p. 231).

Também no caso de D. Teodora a linguagem cria a personagem. Ocorre sempre no cotexto, anteposto ao nome próprio, o adjetivo majestosa, que, como a sua anteposição sugere, denuncia um uso não restritivo, mas definitório do adjetivo: a majestosa Teodora. Nas 22 ocorrências em que é referida a personagem, ela é quinze vezes majestosa, o que corresponde exatamente às 15 ocorrências deste adjetivo majestosa na obra: a majestosa Teodora, a Adélia, a Eleutéria das Eleutérias, o padre (p. 55); apertam o círculo em volta da majestosa Teodora. (p. 81); que durante os anos que durou a bisca defenderam a majestosa Teodora dum envenenamento (p. 82); a majestosa Teodora continue a viver mil anos e a impor-se (p. 107); A majestosa Teodora não pode escapar (p. 107); A majestosa Teodora pertence-lhes (p. 107); e a majestosa Teodora desatou de súbito aos ais, aos ais (p. 107); o quarto onde a majestosa Teodora agoniza (p. 181); Nenhuma admite que a majestosa Teodora escape (p. 182); Está ali um cordão de velhas como um cordão de sentinelas à porta do quarto da majestosa Teodora (p. 183); Agora aguenta-te, majestosa Teodora! (p. 184); enquanto a majestosa Teodora desata aos gritos, balouçada (p. 184); Está a inveja, e a inveja esverdeada torce-se sob o olhar da majestosa Teodora (p. 185); Está a paciência e a paciência sorri diante da majestosa Teodora; E a majestosa Teodora parece calcinada pelo fogo do inferno (p. 207).

A personagem D. Restituta, referida 25 vezes, vem 21 vezes acompanhada da expressão pois sim ou outra expressão sinónima ou semelhante: a D. Restituta, sempre a acenar que sim à vida (p. 56); a D. Restituta, de guarda-chuva na mão, acenando sempre que sim à vida (p. 81); a D. Restituta, tendo dito a tudo que sim, tendo dito a tudo e a todos que sim, já não pode dizer, com o mesmo esgar, senão que sim: - Pois sim... pois sim (p. 82); a Restituta vai mais uma vez dizer-lhe à pressa: - Pois sim... (p. 108). Igualmente característica desta personagem é a ocorrência duas vezes (p. 166), da expressão mete a viola no saco, expressão que institui uma polifonia com o aforismo conhecido, mas rapidamente o ultrapassa sendo recombinada nas expressões mete no saco; mete a alma no saco; mete o diabo no saco; mete pra dentro!; uma vergonha mete prò saco! desprezo, escrúpulo, fome; mete tudo prò saco! Para um saco sem fundo mete a vida, a dor dentro dum saco (p. 166) Estas expressões passam a estar completamente ausentes do texto depois do desaparecimento/suicídio da personagem. 
D. Leocádia, referida 55 vezes no texto, convoca formas como coçada, inteiriça, seca, e 30 vezes $^{7}$ surge no cotexto a expressão «o dever», D. Leocádia, o meticuloso dever foi a tua vida e agora descobres que o dever não existe (p. 110); Está aqui a D. Leocádia e o dever (p. 141), Oh D. Leocádia, como tu, educada sempre com as mesmas palavras e no mesmo dever, um dia de dever, outro dia de dever (p. 146), D. Leocádia, o dever é um contrato (p. 155); ó sórdida antropopiteca com uma cuia de retrós! O dever era frio e amargo e tu cumpriste-o; o dever era coçado e hirto e tu cumpriste-o. Foi a razão da tua vida. Azedoute e sustentou-te. (p. 156) A própria personagem afirma repetidamente: Cumpri sempre o meu dever! (p. 156); nesta página do texto a palavra dever surge diversas vezes: Cumprir o dever minucioso e exigir o dever minucioso; Subordinaste a tua vida ao dever, e o dever não existe; quando te compenetrares de que o dever postiço, o estúpido dever, fede que tresanda; A D. Leocádia é uma figura seca e coçada, enorme e seca, verde e grotesca, que desvia o olhar da vida, para cumprir, seja como for, o dever estúpido, o dever atroz. (p. 157), hirta e solene como o dever (p. 158).

A definição de personagens pela variação linguística é assumida pelo próprio narrador quando afirma: falo outra língua e julgo-me superior, sou outra casta de intrujão (p. 142).

Nas sequências do texto em que surge a personagem Gabiru, a linguagem varia de novo, acompanhando agora o discurso reflexivo, de pendor filosófico e metafísico da personagem, nos capítulos com o título «Papéis do Gabirú» e também no capítulo "O sonho» em que a linguagem tem um conteúdo rico e complexo revelador de uma atividade emotiva e intelectual, de um conhecimento especulativo, filosófico e de grande exigência espiritual. $\mathrm{O}$ vocabulário é mais selecionado, menos usual, marcado por construções sintáticas de influências clássicas, com alguns termos eruditos. Citando de novo Maria João Reynaud, o Gabirú «é o alquimista do sonho [...] cabe-lhe o papel semântico de introduzir uma dimensão onírica» ${ }^{8}$. E assim nas 15 vezes em que se observa a referência e o nome do Gabirú, surge uma isotopia de luz e oiro, de doirado entrelaçado com sonho ou em forma mais explícita, em coocorrência constante, sempre num cotexto próximo: e o Gabiru e o seu sonho (p. 57); Sonha, e os seus sonhos são sempre irrealizáveis (p. 66); Dentro disto sonho (p. 67); O Gabiru mistura, revolve, extrai sonho do sonho. (p. 68); o Gabiru não ouve, não vê, não sente. O sonho isolou-o (p. 68); O quintal escorre sonho como a alma do Gabiru (p. 69); O sonho transborda, o luar transborda - branco e dor - branco e sonho (p. 70); ou isto não passa dum sonho grotesco, de mais outro sonho grotesco? (p. 71); Este sonho hei-de levá-lo a cabo. Debalde lhe aconselho calma, o Gabiru insiste (p. 73); O que elas odeiam no Gabiru é a sua imensa capacidade de sonho (p. 92); Até as árvores são sonhos. Atravessaram o inverno

${ }^{7}$ Num total de 39 vezes que a expressão «o dever» ocorre na obra.

${ }^{8}$ REYNAUD, 2015: 26-31. 
com sonho contido, com o sonho humilde com que carregam há séculos. (p. 192); Papéis do Gabiru 20 de Novembro Mas o inverno é sonho. Só agora o compreendo. É sonho concentrado (p. 219); É tão necessária a este fluido a dor muda do cavador corno o sonho desconexo do Gabiru (p. 229).

O registo literário assume assim desvios em relação aos usos mais habituais, sendo utilizadas determinadas construções, escolhas vocabulares e combinatórias que não são muito frequentes noutros registos. Destacam-se as figuras de estilo e as palavras deliberadamente procuradas para criar ambientes específicos, conotações, dando-se uma importância acentuada às funções emotiva e poética da linguagem.

Esta utilização variada da língua verifica-se ao longo do texto de Húmus, em episódios inteiros em que se observam finalidades realizadas de natureza apelativa e expressiva. Observemos alguns excertos do capítulo «A velha e os ladrões». O ladrão mais velho pede, exorta a Joana, ordena que lhes franqueie a entrada na casa da patroa rica, sob ameaça de a sua filha perder a vida. Surgem itens lexicais carregados emotivamente, com valor conotativo negativo; ou mesmo um linguajar considerado como próprio de um grupo marginal; o estilo é próximo da mais pura oralidade:

Estafermo! Estafermo! Tu abres-nos a porta. À velha deito-lhe a mão ao gasganete e não dá pio. [...]. Ó pandorca! És um trapo! És pior que um trapo!... Só te deram restos e enchiam-se até aos gorgomilos. E tu apegas-te e tu defende-los!... Isso! Até me metes nojo! Isso! Até me fazes rir! Só tu calhordas eras capaz de me fazeres rir nesta hora aziaga. Pilhasse-te eu no meu tempo!... Não te cabe nesse caco que ninguém tem pena de ti. (p. 162-163)

Mas nesse mesmo capítulo cruzam-se momentos de estilo refletido, poético como:

A sombra da velha reduz-se a nada, a menos que nada, à sombra da dor. Por fim erguem-se, mergulham e dissolvem-se na caligem da noite, as três sombras dos ladrões e as sombras das mulheres, a quem não distingo as feições... [...]. E o silêncio é cada vez maior. Só a água fala nos buracos puídos das pedras, em diálogos que nunca cessam, num coro de vozes ininterruptas e indistintas - ameaças, súplicas e gemidos. [...] E lá deslizam no escuro, e o rio sempre a correr e a pregar sempre o mesmo presságio de dor no chape que chape onde se percebem ecos de todas as desgraças que sucederam no mundo, levando para o mar todas as lágrimas que se choraram no mundo. (p. 161-162)

Neste passo tornam-se marcantes: o ritmo, as rimas e as aliterações, numa projeção de semelhanças na sequência sintagmática, que invadem o campo da língua comum, numa clara manifestação da função poética da linguagem. 
São inúmeros os casos na obra. No capítulo «Céu e inferno»:

Este momento trágico, esta pausa, este horror em que cada um se vê na sua essência, em que cada ser se encontra sós a sós com a sua própria alma, reduzido sem artifícios à sua própria alma, só tem outro a que se compare, aquele em que cada um vê a alma dos outros; (p. 199)

em «Os Papéis de Gabiru 25 de Novembro»:

Cada vez fujo mais de olhar para dentro de mim mesmo. Sinto-me nas mãos duma coisa desconforme. Sinto-me nas mãos duma coisa embravecida pela eternidade das eternidades. Sinto-me nas mãos duma coisa imensa e cega - duma tempestade viva. (p. 223)

No capítulo «Terceira noite de luar»:

Os poentes são labaredas roxas com resquícios de escarlate e dois, três grandes jactos violetas que se estendem pelo céu - uma maravilha quimérica. (p. 227)

Diversos autores referem a prosa poética de Raul Brandão como, por exemplo, Maria João Reynaud e Óscar Lopes. É uma linguagem que se afasta frequentemente do estilo coloquial, que utiliza palavras e construções mais raras, as imagens, o ritmo, a rima. São processos próprios do estilo refletido, que não são exclusivos da poesia, e a que também Herculano de Carvalho, na Teoria da Linguagem faz referência falando de uma «Prosa justamente chamada poética como a de Bernardim Ribeiro ou a de Raul Brandão» ${ }^{9}$.

Mas em Húmus, o próprio narrador sublinha o poder de criação das palavras, o seu poder fundador: "As palavras criam sentimentos. As palavras formam uma arquitectura de ferro. São a vida e quase toda a nossa vida - a razão e a essência desta barafunda. É com palavras que construímos o mundo» (p. 205-206).

A variação linguística que observamos e a construção baseada nesse jogo de diversos registos explica-se então facilmente: as palavras constroem personagens; as palavras criam personagens; não evocam os ambientes, as palavras criam ambientes; as palavras criam outros mundos. E termino com uma última citação do Húmus: «É com palavras, que são apenas sons, que tudo edificamos na vida» (p. 206).

${ }^{9}$ CARVALHO, 1967: 345. 


\section{BIBLIOGRAFIA}

CARVALHO, J. Herculano de (1967) - Teoria da Linguagem. Coimbra: Atlântida.

COELHO, J. Prado (1969) - O Húmus de Raul Brandão: uma obra de hoje. In A Letra e o Leitor. Porto: Lello \& Irmão.

LABOV, William (2001) - Principles of Linguistic Change: Social Factors. Oxford: Blackwell.

LOPES, Óscar (1999) - 5 Motivos de Meditação: Luís de Camões, Eça de Queirós, Raul Brandão, Aquilino Ribeiro, Fernando Pessoa. Porto: Campo das Letras.

REYNAUD, Maria João (2015) - Introdução: Húmus de Raul Brandão: uma obra em devir. In BRANDÃO, Raul - Húmus. Ed. de Maria João Reynaud. Lisboa: Relógio d’Água, p. 7-40.

\section{DICIONÁRIOS}

Dicio - Dicionário Online de Português.

Dicionário da Língua Portuguesa Contemporânea da Academia de Ciências de Lisboa. Lisboa: Verbo, 2001.

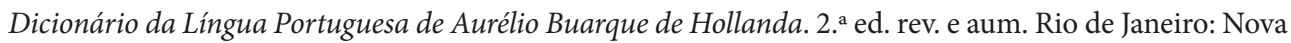

Fronteira.

Dicionário Editora da Língua Portuguesa. Porto: Porto Editora, 2013.

Dicionário Houaiss da Língua Portuguesa. Rio de Janeira: Objetiva, 2001.

Dicionário Infopédia da Língua Portuguesa.

Dicionário Michaelis Moderno da Língua Portuguesa. [S.l.]: Melhoramentos. Disponível on-line.

Dicionário Priberam da Língua Portuguesa - Dicionário Online de Português. 


\title{
POETAS EM FUGA. DERIVAS DA POESIA (I)
}

\author{
ANA PAULA COUTINHO MENDES*
}

\author{
E, desde aí, tenho-me banhado no Poema
}

Do Mar, infuso de astros, e lactescente,

Devorando o verde azul-celeste; onde, flutuante lívido

E arrebatado, um afogado pensativo, por vezes, aparece.

Rimbaud, Le bateau ivre ${ }^{1}$

Porque, quando se parte de um lugar, vai a gente a fugir, sempre.

Herberto Helder, Photomaton \& Vox

Falarei aqui de fuga como quem fala de exílio num sentido deliberadamente abrangente, apoiando-me na etimologia «ex-hilium» que acentua a ideia de «saída de» [um lugar/país de origem], e que tem acolhido conotações diversas, não raro paradoxais, todas elas suscitadas por uma experiência antropológica universal, narrativizada, por supremo e simbólico exemplo, nos textos sagrados das três tradições monoteístas (êxodo do povo hebreu; a Sagrada Família no Egito; a hidjra ou a fuga de Meca para Medina), como em muitos outros textos da literatura universal. E falarei também de «experiência exílica», não apenas no sentido de expatriação forçada, por «expulsão» ou por «banimento», mas também como autoexílio ou exílio voluntário, isto é, como abandono e ausência do país de origem por moto-próprio, mesmo se a montante existam sempre razões políticas, económicas, religiosas, culturais ou afetivas. É verdade que, do ponto de vista sociológico ou para efeitos de categorização estatística, estaremos perante atos e condições distintos, mas outro é o meu ângulo de análise que se foca na vertente experiencial do sujeito e, por conseguinte, no manancial heurístico de processos de subjetivação e de memória que acabam por ser comuns a todas essas experiências de

\footnotetext{
* Universidade do Porto/Instituto de Literatura Comparada Margarida Losa. Este artigo foi desenvolvido no âmbito do Programa Estratégico Integrado UID/ELT/00500/2013 e POCI-01-0145-FEDER-007339.

${ }^{1}$ Citado aqui na versão de Maria Gabriela Llansol, intitulada «Derivas de um Barco Ébrio» (RIMBAUD, 1998: 19).
} 
desterritorialização, de transgressão, de suspensão ou de descontinuidade na relação entre ser/estar e território ${ }^{2}$.

A minha proposta de leitura vai, pois, no sentido de articular a «experiência exílica» com a ideia de "fuga», de acordo com o modelo rimbaldiano de "mudança de vida» ou de manifesta insurreição existencial, diferente de um simples impulso romântico de evasão, e tem também como objetivo alargar a base de referência do exílio na poesia portuguesa pós-1950, para a fazer extravasar quer dos exemplos mais correntes de Manuel Alegre ou Jorge de Sena e respetivas idiossincrasias poéticas, quer das evocações pontuais a outros autores, mais por nota biográfica do que por referência e transfiguração poéticas.

Ao longo do século XX, a crítica foi progressivamente desvalorizando a ausência ou a «passagem de estar» ${ }^{3}$ fora de Portugal dos escritores (como, aliás, também de outros artistas). Durante o Estado Novo, fê-lo muitas vezes por censura, ou por autocensura, àquilo que inevitavelmente sugeria «falhas» no Regime, e poderia estimular a resistência, se não mesmo a "dissidência», dos seus intelectuais, quando não provocar a deserção, a alegada traição, dos «filhos da Nação». Depois da Revolução de 74, essa vertente considerada «extraliterária» continuaria a ser subestimada por fidelidade aos ditames da «Nova Crítica» que esconjurava incursões biográficas ou históricas, assim como as ditas falácias de intencionalidade autoral, umas e outras ligadas ao afã explicativo ou ao diletantismo impressionista da crítica tradicional, de indisfarçável pendor positivista. Os escritores, e muito em especial os poetas, tenderam também, por sua vez, a desviar-se da enunciação autobiográfica, chegando a omitir ou a silenciar uma eventual experiência exílica, fosse porque desejassem romper ou, pelo menos não quisessem ver-se associados a um confessionalismo lírico ou à «universal reportagem», como depreciativamente se lhe referira Mallarmé; fosse porque o «peso» real e simbólico das circunstâncias em que viviam ou tinham vivido o desenraizamento os impedia de escrever; fosse porque não tinham encontrado a forma literária ou poética para o dizer; fosse ainda porque estavam de antemão certos de que a censura acabaria por apagar tudo aquilo que pudesse de algum modo denunciar os motivos sociais e políticos que haviam levado ao abandono do país natal. Ou fosse ainda, a montante e a jusante de qualquer uma dessas razões, porque estivessem conscientes da cesura ontológica entre «as palavras» e "as coisas» que a modernidade havia definitivamente selado, e que tornara problemática qualquer representação da realidade.

\footnotetext{
${ }^{2} \mathrm{Na}$ sua reflexão sobre a condição do exilado na atualidade, Alexis Nouss (NOUSS, 2015) propõe o neologismo «exiliance» (que traduzo por exiliência) para abranger esses vários tipos de experiência de desterritorialização naquilo que todos eles pressupõem de condição e/ou de consciência de exílio.

${ }^{3}$ Uma expressão sugestivamente ambivalente que tomo de empréstimo a Maria Velho da Costa, no seu livro de crónicas escritas a partir de Londres, O Mapa Cor-de-Rosa (COSTA, 2002).
} 
À parte aquele que é um truísmo (direta ou indiretamente, a obra de arte está sempre ligada à vida do artista), e procurando evitar uma leitura mecanicista dos textos por ilustração biográfica, gostaria de contribuir para a reabilitação da hermenêutica da «experiência» na literatura, no seu sentido existencial e etimológico de «travessia de um perigo», um trajeto feito de «esquecimento» e de «lucidez»" ${ }^{4}$, procurando em concreto fazer ressaltar a vertente heurística da «experiência exílica» que, em si mesma, se abre a um aprofundamento dialético da existência, com contornos topográficos, identitários e até metafísicos. Utilizando o par lexical oferecido pela língua alemã e pela história poética e filosófica que dele foi sendo feito, interessa-me dar a ver como, nos textos, o exílio de alguns poetas passa do plano concreto, mais ou menos anedótico, da experiência enquanto «erfahrung», para o plano do «erlebnis», enquanto vivência interiorizada, fazendo com que o exílio não signifique (apenas) uma experiência a montante da poesia, mas que, através desta, absorva também um sentido «formal-existencial» de «poéthique» (pro-ética) como tem defendido o poeta e ensaísta Jean-Claude Pinson ${ }^{5}$. Julgo que este processo hermenêutico aberto a um pensamento dialético nos permite ultrapassar alguns impasses ou binarismos das «epistemologias sedentárias», pouco permeáveis à tensão, à instabilidade e negociação entre diferentes dimensões e perspetivas tanto da existência como da literatura. Ajudará, em todo o caso, a questionar os limites da abstração numérica das estatísticas e da generalização e rigidez de categorias de certos discursos históricos e/ou sociológicos sobre o exílio.

A epígrafe de Herberto Helder já deixava adivinhar que, nesta análise da «experiência exílica» na poesia portuguesa contemporânea, o caso herbertiano iria ser privilegiado, não obstante estarmos perante o poeta que mais expressa e continuadamente quis desvincular, e ver desvinculada, a obra da vida concreta do Autor. Não obstante, por ocasião da sua morte, assistiu-se a uma exposição (ou explosão...), completamente extra-ordinária e paradoxal ${ }^{6}$, porque em torno de um indivíduo que, como ele, durante quase seis décadas, quis desaparecer por detrás dos poemas, determinado a inventar a [sua] vida verdadeira ${ }^{7}$.

Mas se é certo que o Autor de Photomaton \& Vox recusou liminarmente ser vítima de qualquer facto hasteado como bandeira ilusória do conhecimento ${ }^{8}$, e evitou deixar-se apanhar "por tentações biográficas, a memória, os mitos»", também é verdade que não deixou de construir o seu próprio «ensaio concentrado» de rizoma autobiográfico,

${ }^{4}$ Recupero aqui uma pista de leitura apresentada por Yves Bonnefoy na sua releitura dos Tableaux parisiens de Baudelaire, e sugerida como ponto de partida de releitura de certos aspetos da poesia francesa moderno-contemporânea (BONNEFOY, 2002: 164).

${ }^{5}$ PINSON, 2002: 66; PINSON, 2013: 36.

${ }^{6}$ GEORGE, 2015.

${ }^{7}$ HELDER, 1995: 33.

${ }^{8}$ HELDER, 1995: 12.

${ }^{9}$ HELDER, 1995: 32. 
num tom onde a solenidade elíptica do percurso iniciático se confunde com a (auto) ironia, concorrendo assim, malgré lui, para a mitografia da existência suprema do sujeito poético, acima de todos os factos, atos ou deslocações:

Ao princípio era uma ilha. Em seguida o conhecimento de tudo: infância e adolescência. Depois venho por sobre as águas, caminhando em cima das águas sem me afundar. Chega Lisboa. Portugal é um mapa: vou daqui para ali; não gosto. E a Espanha, a França, a Bélgica, a Holanda. E a Inglaterra? Diz? Dizem que sim, que Londres. Ora, ora. Vai-se ver e a Europa já não está. Na Espanha, oh não. Na França a mitologia literária fica para além das revelações. A Bélgica cheira a batatas fritas. (No entanto, é bom chegar num comboio a Antuérpia, e depois haver muito frio, e se calhar tramarem-se coisas no nevoeiro. Não se sabe.) A Holanda é uma monarquia com vacas devagar para cá e para lá. De repente não se tem nada a ver com aquilo $[\ldots]^{10}$.

Respeitadas as distâncias, omissas as circunstâncias concretas, destacada a ironia e a autoironia, tudo em formas enxutas como despedidas rápidas, não pode deixar de ser significativo que os poucos topónimos que aqui surgem, como em geral na obra toda de Herberto Helder, digam respeito aos locais por onde o autor passou ou viveu no estrangeiro, primeiro no final da década de 50 e, depois, em inícios dos anos 70. Seria, contudo, redutor circunscrever a representação da «experiência exílica» na obra herbertiana a esse tipo de referência, mais da ordem do «erfharung» do que do «erlebnis». Aquilo que me parece mais significativo, em termos poéticos, é que os seus únicos livros em prosa (ou pelo menos discursivamente híbridos) - Os Passos em Volta (1963), Apresentação do Rosto (1968) e Photomaton \& Vox (1979) — foram os três publicados pouco depois (pelo menos o primeiro) da sua «experiência exílica» mais prolongada no estrangeiro: de 1958 a 1960. Além disso, com exceção de Apresentação do Rosto, que foi apreendido pela Censura e nunca reeditado por vontade expressa do Autor, os outros dois livros deram origem a várias edições, se bem que com menos alterações do que aquelas que mereceu sempre a sua poesia. Quer-me então parecer que não será forçado relacionar os seus afastamentos do país natal a etapas de ponderação (meta)poética, dando lugar a momentos de fuga - desvio pela prosa à procura de um estilo próprio. Essa autoconsciencialização de um «arte poética» individual ficaria assim indelevelmente marcada pela experiência da distância física de Portugal e de muitos dos seus atavismos à época, designadamente a nível literário, e mais em concreto, a nível poético.

${ }^{10}$ HELDER, 1995: 24-25. 
Lembre-se que, aquando da sua primeira «fuga», Herberto Helder havia publicado apenas Amor em visita, e depois disso, o seu trabalho poético demarcar-se-ia cada vez mais das «associações» e «conjeturas» da vida literária em Portugal. Desse ato de emancipação e de reconstrução pós-exílio, houve uma reconstrução-síntese em terceira pessoa que se deixava perceber no poema de abertura, autointitulado «Prefácio» do seu segundo livro, A Colher na Boca, vindo a lume já depois do regresso do poeta a Portugal:

Alguém trouxera cavalos, descendo os caminhos da montanha

Alguém viera do mar.

Alguém chegara do estrangeiro, coberto de pós.

Alguém lera livros, poemas, profecias, mandamentos,

inspirações.

- Estas casas serão destruídas ${ }^{11}$.

Ainda no mesmo livro, no poema intitulado «As Musas Cegas», que também apresenta um início raro no discurso herbertiano, porque geo-cronologicamente referenciado - «Bruxelas, um mês.» - destaca-se o facto de o poeta pretender como que redimir, fixando-a, a irrelevância ou impureza da sua vida pessoal:

- Cantar fixa e fria e intensamente

Sobre a minha vida suja,

Admirável vida ou sobre os campos transparentes e negros

De Bruxelas do Mundo ${ }^{12}$ !

Curiosamente, A Colher na Boca termina com o poema «Narração de um Homem em Maio», como se esse "Livro da poesia arrebatada» precisasse de um fio narrativo, de um espaço e de um tempo para acompanhar a metamorfose de um homem situado, se não mesmo sitiado, nas palavras e no pensamento. Ainda assim, o sujeito poético cala mais a experiência daquele que «saiu/violenta e violentamente para o campo» [entenda-se, um espaço aberto, por oposição às «casas» do início, baluartes de um poder firme e silencioso], do que propriamente a conta ou a expande, segundo os parâmetros habituais ao discurso narrativo. Não deixa, contudo, de enumerar uma série de atividades por que passou - verídicas, inventadas ou simbólicas, pouco interessa -, pelo que, no final (do livro da viagem/do exílio), já não é um homem

\footnotetext{
${ }^{11}$ HELDER, 1961: 13.

${ }^{12}$ HELDER, 1961: 100. No processo de constante reescrita a que foi submetendo a sua «poesia toda» ou o seu «poema contínuo», Herberto Helder viria a reformular estes versos finais, alterando curiosamente o topónimo inicial para uma expressão minusculada, interna ou intrínseca ao poema - «bruxelas do mundo», assim como «a minha vida suja», da edição de 1961, foi transformada em «a minha rasa/luminosa vida» (HELDER, 1990: 69).
} 
ou um poeta que mexe apenas a boca, ou os dedos, mas aquele que altera também a ideia de experiência, sem perdão ou esquecimento, podendo por isso verdadeiramente entrar na «Idade de poesia» ${ }^{13}$.

Será, pois, possível ler A Colher na Boca como o livro de um percurso iniciático a que não é de todo alheio o deslocamento, mais ou menos prolongado, de Herberto Helder para fora de Portugal, cuja narração simbólica iremos, depois, reencontrar no livro, a todos títulos híbrido, Os Passos em Volta (1963). Mas antes, e seguindo a ordem de publicação, deparamos em Poemacto (1961) com a insistência em utilizar a força criativa do esquecimento ${ }^{14}$, o talento teatral da transformação ${ }^{15}$, além de ser possível discernir, como que em palimpsesto, em Lugar, livro publicado na mesma altura, um dos textos mais simbólicos da tradição literária do exílio. Refiro-me ao Salmo 137 (136), recriado por muitos outros poetas que viveram o exílio, como Luiz de Camões. Na composição herbertiana, o poeta diz-se habitado pela pressão de cantar a sua experiência, "em cidades estranhas» ${ }^{16}$, mas ao contrário do silenciamento de reverência e de fidelidade à terra de origem do sujeito coletivo bíblico, opta claramente por um discurso individual de transformação violenta, condição para renascer das cinzas do vivido:

Canta - dizem em mim - até ficares

como um dia órfão contornado

por todos os estremecimentos.

E eu cantarei transformando-me em campo

de cinza transtornada.

Em dedicatória sangrenta ${ }^{17}$.

Operada a transmutação poética, expurgados os detalhes mais comezinhos da vida, a experiência exílica passa a poder ser partilhada «num amargo fundo de vozes/universais» ${ }^{18}$. Uma experiência individual de desterro e solidão, a montante, ressurge a jusante, depurada e transformada em condição partilhada, seja com o leitor, seja com todo aquele que se reconhecerá, refletido, na possibilidade aberta, não inscrita, não fechada, daquilo que lê:

\footnotetext{
${ }^{13}$ HELDER, 1961: 130.

${ }^{14}$ HELDER, 1990: 98.

${ }^{15}$ HELDER, 1990: 104.

${ }^{16}$ HELDER, 1990: 154.

${ }^{17}$ HELDER, 1990: 121.

${ }^{18}$ HELDER, 1990: 148.
} 
Alguém procura onde eu estou só, e encontra

o campo desbaratado

e branco da sua

solidão $o^{19}$

Retomando o poema-narração final de A Colher na Boca, o também último poema de Lugar, «Retratíssimo ou Narração de um Homem Depois de Maio», logo pelo superlativo absoluto e pela referência a um tempo posterior, multiplica os ângulos de observação do poeta metaforizado no «homem de Maio», dividido entre o exterior e a "pessoalíssima vida» ${ }^{20}$. Assim, ao invés de iluminar retroativamente os traços da existência, o poema enfatiza o facto de tudo ser oblíquo, invisível, incerto e misterioso. A condição de perenidade desse retrato do «eu» do poeta alterado, ou melhor alterizado em homem mudo, é a morte ${ }^{21}$ que, de certo modo, liga o «desaparecimento elocutório do poeta» proclamado por Mallarmé, àquela outra proclamação de «morte do autor», ficando o sujeito poético circunscrito ao instante da sua enunciação.

Logo a seguir, em 1963, Herberto Helder publicaria Os Passos em Volta, um livro que, num registo estranho ou de difícil categorização, sobretudo para a época, não deixava de evocar lugares do exílio do autor entre 1958 e 1960, alternando com outros espaços e breves narrativas alegóricas de deslocação e metamorfose. No que à representação da experiência exílica diz respeito, interessa sobretudo realçar o modo como Herberto Helder aí percorre alguns dos tópicos mais habituais às narrativas do exílio: o estranhamento, a despersonalização ou o desdobramento identitário a partir do qual o sujeito passa a ver-se e a dizer-se como um outro, uma personagem separada de si mesma, despojada de quase de tudo, inclusive de um nome próprio.

De notar que Os Passos em Volta não se limita a evocar o exílio de um indivíduo, mas representa muito concretamente o exílio de um poeta, para quem estar no estrangeiro significa deixar de escrever ou de procurar nomear quem o rodeia - «Ele próprio, visto estar destinado à inteira perdição, vai perdendo o nome pelo país adiante» ${ }^{22}$, deixando-se inclusive habitar pela ideia de expiação de alguma culpa insondável. No texto "Vida e obra de um poeta», escrito na primeira pessoa, deparamos com outras consequências da experiência exílica, designadamente a dispersão dos textos ${ }^{23}$, espalhados pelas mãos de conhecidos e desconhecidos em vários países; a cumplicidade entre exilados ${ }^{24}$; as condições de uma vida frugal nos limites da miséria, onde lugar

\footnotetext{
${ }^{19}$ HELDER, 1990: 148.

${ }^{20}$ Cf. «Narração de um Homem de Maio» (HELDER, 1990: 90).

${ }^{21}$ HELDER, 1990: 58.

${ }^{22}$ HELDER, 2001: 15.

${ }^{23}$ HELDER, 2001: 147.

${ }^{24}$ HELDER, 2001: 148.
} 
verídico e/ou simbólico, a retrete surge como o único espaço possível de isolamento, de refúgio criativo, com uma enumeração de traços metapoéticos que não escondem a autoderisão, como num último grau de desconstrução da aura poética:

O mundo não me tocara e fecundara em vão. Eu apurara a experiência, encontrara os meus centros. Levava tudo para a retrete: o amor, o terror, a grande cidade, o anjo da guarda com quem atravessar o bairro atulhado de putas. A minha obra nascia. Às vezes, no meio dos perigos, medos e vertigens destas experiências, olhava a cara num pequeno espelho de bolso, para ver se eu próprio me transformava por fora, ao sabor do sensivel movimento do espírito, este conhecimento que ia ganhando da vida e da poesia. Vi que $\operatorname{sim}^{25}$.

Não faltam também os repetidos tópicos da partida e do abandono (in «Lugar Lugares» e «Coelacanto»); as alusões à liberdade, à topografia das periferias e da marginalidade, como em Antuérpia ${ }^{26}$, à solidão, ao confinamento a um quarto, à sensação de perda, de errância e de dolorosa descoberta ${ }^{27}$ de tudo aquilo que começa por surgir ao exilado como difícil e estranho, além dos gestos tanto de solidariedade como de ludíbrio de que é lvo $^{28}$.

Apesar da fragmentaridade e da hibridez alegadamente louca do «estilo» de quem viu e ouviu muita coisa como «acontecimento excessivo» ( $v d$. texto inicial, intitulado «Estilo»), Os Passos em Volta não é uma mera recolha de textos (há quem lhe chame contos...), mas deixa perceber uma rigorosa estrutura interna que contempla um trajeto de ida e volta, começando pela estada no estrangeiro ( $v d$. «Holanda») e a acabar no regresso à terra natal, completando-se assim um círculo de «Trezentos e Sessenta Graus» - título do texto final.

De todas as referências a um pós-exílio do sujeito poético-narrativo, que chega a ser inclusive identificado como regresso a Lisboa (in «Escadas e Metafísica»), sobressaem quer a insatisfação existencial, quer a sensação de um generalizado absurdo, representadas como uma lepra ou como uma «memória mortal» ${ }^{29}$, formas de inquietação e de dúvida que tanto atingem o «homem estrangeiro» perdido nas ruas e ruelas de Antuérpia, como questionam e desestabilizam o lugar-nação de um sujeito coletivo: «Mas quem pode confiar em nós, que somos desta terra, e por isso tão pouco a conhecemos» - lê-se no final do «capítulo» «Descobrimento», numa versão singular, completamente interiorizada e perturbadora, de um ato particularmente caro à mitografia de Portugal.

\footnotetext{
${ }^{25}$ HELDER, 2001: 141.

${ }^{26}$ HELDER, 2001: 48.

${ }^{27}$ HELDER, 2001: 86.

${ }^{28}$ HELDER, 2001: 113.

${ }^{29}$ HELDER, 2001: 82.
} 
Mais adiante, no texto intitulado «Duas pessoas», o sujeito poético-narrativo, de regresso do estrangeiro, confessa-se farto de viagens ${ }^{30}$, rendido aos «espaços ascéticos», enquanto na versão seguinte da prostituta, é visto como «um ser minado, destruído» que «cheira a desespero a quilómetros de distância» ${ }^{31}$. Todavia, é no último texto «Trezentos e Sessenta graus» - , que vemos sublimemente representada a alegoria de qualquer regresso do exílio, ou seja, toda a complexidade de sensações e sentimentos de quem volta a casa, depois de uma ausência prolongada. Não faltam, por conseguinte, a inexorável passagem do tempo que tudo transforma, desde logo os progenitores, em «raízes exaustas»; a efetiva incomunicabilidade entre quem ficou e quem regressa; a interiorizada sensação de remorso e estranheza de quem volta com um «ganho obscuro» ${ }^{32}$; o apelo das origens como de um redil ${ }^{33}$; o «equívoco sentimento de plenitude» que o exilado sente «no comboio de regresso», como numa ilusão de paragem do tempo ${ }^{34}$; os cruzamentos espontâneos de memórias de casa e do estrangeiro e a sensação a um tempo reconfortante e angustiante de um voltar à teia familiar, representada pela figura incansável e terrível da «mãe velha» ${ }^{35}$, que sugestivamente surge a dominar um bordado transtemporal, a armadilha fatal da ligação de sangue, da força da imobilidade sobre toda a rede da existência ${ }^{36}$.

À parte algumas passagens de Photomaton \& Vox, nunca mais Herberto Helder voltaria à narrativa poética da «experiência exílica», a não ser talvez sob a forma de «Bebedor Nocturno», permeável ao dizer disseminado, babélico, do mundo.

É natural que, com a passagem dos anos, a sua experiência do estrangeiro acabasse por se transformar numa paradoxal teia de memória e esquecimento: por um lado, uma experiência destilada até à dissolução, por outro, uma experiência sempre latente, molde do seu distanciamento - ou exílio interno - em relação a tudo aquilo que sentisse invadir a sua solidão e liberdade criativas ${ }^{37}$. No entanto, no seu penúltimo livro publicado em vida, intitulado Servidões (2013), o poeta iria recuperar para abertura um texto em prosa que tivera, nos anos 90, uma primeira versão publicada na revista «A Phala» e num suplemento do «Diário de Notícias» do Funchal ${ }^{38}$. Trata-se de uma referência implícita à sua condição, a um tempo existencial e poética, de exilado da sua ilha natal, através da evocação do regresso a esse espaço. Pouco importa saber ou discutir se esse texto

\footnotetext{
${ }^{30}$ HELDER, 2001: 156.

${ }^{31}$ HELDER, 2001: 162.

${ }^{32}$ HELDER, 2001: 191.

${ }^{33}$ HELDER, 2001: 191.

${ }^{34}$ HELDER, 2001: 193.

${ }^{35}$ HELDER, 2001: 194.

${ }^{36}$ HELDER, 2001: 194.

${ }^{37}$ Dessa condição e necessidade de «exílio», testemunham inclusive algumas das suas cartas enviadas a Gastão Cruz, e que a revista «Relâmpago» publicou após a sua morte (cf. «Relâmpago», n. o 36/37 (abril-out. 2015) 147 e 164).

${ }^{38} \mathrm{Vd}$., a propósito, o depoimento do seu conterrâneo, António Fournier, intitulado «A ilha de todos os mitos» «Relâmpago», n. ${ }^{\circ}$ 36/37 (abril-out. 2015) 201-209.
} 
corresponde ou não à viagem que nos, anos 80, Herberto Helder fez ao Funchal, depois de quase três décadas de ausência. Mais importante aqui será saber que essa «viagem de regresso às origens» faz parte da nossa condição humana de exilados da infância, e atentar também no modo como à época se referiu Herberto Helder a essa efetiva viagem, numa das cartas enviadas a Gastão Cruz:

Não lhe falarei muito extensamente da viagem à Madeira, pois nem sequer sei muto bem o que representou para mim. Acho que qualquer coisa se transformou. Não estive lá todo o tempo que tencionava: apressei o regresso. Depois, acho eu, terei de falar ou escrever acerca disto. De qualquer modo, nunca mais voltarei à ilha. É tudo quanto posso dizer por enquanto ${ }^{39}$.

Talvez o texto publicado em 1995, revisto e integrado em livro em 2013, seja aquilo que, em 1984, o poeta não quis ou não pôde dizer. Em todo o caso, não poderá deixar de se prestar atenção a duas alusões muito sintomáticas na epístola citada: uma à transformação ocorrida, outra ao regresso. Quanto à primeira, não me parece óbvio que o poeta estivesse a apontar apenas ou fundamentalmente para mudanças na ilha; a segunda, inverte por assim dizer o sentido do regresso. Herberto Helder não se refere explicitamente a um regresso à Madeira, mas invoca a palavra para designar a viagem de volta a Lisboa, sugerindo assim que o laço umbilical com esse lugar genesíaco já estava definitivamente cortado... Mas, então, porquê voltar textualmente à ilha natal, vinte anos depois? Porquê escolher esse texto em prosa, essa «ficção da história que serve a verdade biográfica» para abertura daquele livro de poemas que foi considerado por muitos (e talvez pelo próprio Herberto Helder) como o seu último e testamentário livro, mesmo que depois tivesse publicado, ou deixado publicar, A Morte sem Mestre (2014)? Julgo que a resposta acaba por ser dada ou, pelo menos, sugerida no final dessa espécie de contraponto dos «Trezentos e Sessenta Graus» de Os Passos em Volta. Além de concordar com a ideia de que, ao recuperar este texto, Herberto Helder pretendia de algum modo despedir-se da ilha de todos os mitos ${ }^{40}$, parece-me que ele vem também confirmar o sentido epifânico de incorporação, de subjetivação da «experiência exílica» que, como aqui procurei mostrar, representou para Herberto Helder uma daquelas experiências enérgicas e fundadoras do ato poético, a que o próprio autor fez referência em Photomaton \& Vox.

\footnotetext{
${ }^{39}$ Cf. «Relâmpago», n. ${ }^{\circ}$ 36/37 (abril-out. 2015) 167.

${ }^{40}$ FOURNIER, 2015: 205.
} 
Neste sentido, esta derradeira deslocação textual à ilha natal não tem a ver com nostalgia, que significa literalmente «dor do regresso», representa antes o discernimento consumado de um projeto que é ao mesmo tempo de rutura e de aliança:

Compreendi então: cumprira-se aquilo que sempre desejara - uma vida subtil, unida e invisível que ofogo celular das imagens devorara. Era uma vida que absorvera o mundo e o abandonara depois, abandonara a sua realidade fragmentária. Era compacta e limpa. Gramatical ${ }^{41}$.

Mais uma vez, essa viagem não lhe permitia reencontrar ou recuperar um lugar há muito abandonado, mas antes aceder a um território hermenêutico de compreensão efetiva, unitária, das palavras, do mundo e da vida, uma visão plena que costuma ser privilégio de lucidez de quem da morte se aproxima, e que vem, neste caso, se não propriamente inaugurar, pelo menos acentuar uma escrita de «súmula existencial» ${ }^{42}$. E a existir regresso do exílio, leia-se, a haver resgate de uma rutura fundamental, a um tempo histórica e metafísica, talvez esse tenha sido literalmente o único regresso. O regresso possível e definitivo.

\section{BIBLIOGRAFIA}

BONNEFOY, Yves (2002) - Sous l'Horizon du Langage. Paris: Mercure de France.

COSTA, Maria Velho (2002) - O Mapa Cor-de-Rosa. Lisboa: Publicações Dom Quixote. 1. ${ }^{\mathrm{a}}$ ed. de 1984. FOURNIER, António (2015) - A ilha de todos os mitos. «Relâmpago», n. 36/37 (abr./out.), p. 201-209.

GEORGE, João Pedro (2015) - Herberto Helder: sociologia de um génio. «Observador», 8 de abril. Disponível em <http://observador.pt/especiais/herberto-helder-sociologia-de-um-genio/>. [Consulta realizada em 13/07/2015].

HELDER, Herberto (1961) - A Colher na Boca. Lisboa: Ática. (1990) - Poesia Toda. Lisboa: Assírio \& Alvim.

(1995) - Photomaton \& Vox. 3. a ed. Lisboa: Assírio \& Alvim. 1. a ed. de 1979.

(2001) - Os Passos em Volta. Lisboa: Assírio \& Alvim. 1. ${ }^{\text {e }}$ ed. de 1963.

NOUSS, Alexis (2015) - La condition de lexilé. Paris: FMSH.

PINSON, Jean-Claude (2002) - Sentimentale et Naïve. Nouveaux essais sur la poésie contemporaine. Syssel: Champ Vallon.

(2013) - Poéthique. Une autothéorie. Seyssel: Champ Valllon, 2013.

RIMBAUD, Arthur (1998) - O Rapaz Raro. Iluminações e Poemas. Tradução de Maria Gabriela Llansol. Lisboa: Relógio d’Água.

SOEIRO, Ricardo Gil (2014) - A utopia da palavra ou a demanda do idiolecto impossível: sobre Servidões de Herberto Helder. «Revista do CESP», vol. 34, n. ${ }^{\circ 52}$. Belo Horizonte: Centro de Estudos Portugueses da Universidade Federal de Minas Gerais, p. 29-38.

\footnotetext{
${ }^{41}$ HELDER, 2013: 18.

${ }^{42}$ SOEIRO, 2014: 32.
} 



\title{
AS SERVIDÕES DA MEMÓRIA EM HERBERTO HELDER
}

\author{
JOÃO AMADEU OLIVEIRA CARVALHO DA SILVA*
}

A memória de textos e autores, de vozes e sonoridades, de povos e culturas representou uma constante ao longo da obra de Herberto Helder, nomeadamente nos, já muito estudados, Poemas mudados para português. No entanto, em Servidões, livro publicado em 2013, a memória convocada representa uma variação significativa relativamente a um rumo mantido por seis décadas. $O$ estudo que a seguir apresentamos tem por objetivo entender as variações e a pertinência da memória pessoal e a sua conjugação com a criação do poema curto como representação do tempo vertical.

Referimo-nos a uma memória da sua vida de cidadão, realidade até aqui distante do seu universo poético. Todavia, o poeta tem a preocupação de não distanciar os dois mundos ao afirmar, logo no início, que «Quando os lemos lado a lado, a todos estes poemas, sabemos estarem eles entregues ao serviço de uma só inspiração» ${ }^{1}$. Com esta referência, reaproveitada de Edoi lelia doura: antologia das vozes comunicantes ${ }^{2} \mathrm{e}$ aplicada na altura a um conjunto de vozes de muitos poetas, Herberto Helder realça, no livro de 2013, alguns dados biográficos pertinentes por si e aí assumidos como que igualmente relevantes para a compreensão do seu percurso poético, confirmando a reduzida distância e a congerminação, que suspeitávamos, entre a biografia e a poesia.

\footnotetext{
* Universidade Católica Portuguesa.

${ }^{1}$ HELDER, 2013: 15.

${ }^{2}$ HELDER, 1985.
} 
Quase no termo da sua longa vida (1930-2015), aquela memória, que remete não somente para a sua infância na ilha da Madeira, mas também para um conjunto de referências mais próximas da atualidade, contribuirá em Servidões para a criação de um registo conciso, capaz de transmitir instantes entre o início e o termo de uma vida de palavras. Assim, o poeta, para além de interrogar-se sobre a relevância da obra e a existência, questiona os elos de dependência da sua poesia diante das circunstâncias e dos outros, quando se interroga sobre «que servidões carrega a minha vida» ${ }^{3}$.

\section{TEMAS DE UMA BIOGRAFIA}

Herberto Helder só enviesadamente permitiu que, na sua criação literária, transparecessem sinais de uma vida pessoal, com certeza considerados inapropriados ou insignificantes para a atividade maior da poesia. A clausura a que se entregou combinada com a rejeição de qualquer tipo de reconhecimento público exemplificado com a quase indisponibilidade para entrevistas, a recusa do prémio Fernando Pessoa em 1994 ou a publicação dos seus livros limitada a um número reduzido de exemplares por edição, foram opções que contribuíram para a criação da imagem de um poeta obscuro, recluso na palavra.

Organizadas, no livro de 2013, cronologicamente, as ineludíveis referências a experiências da infância, à ilha e à mãe, identificadas com datas ou idades, representam na obra de Herberto Helder um inesperado despudor por assuntos do quotidiano ao trazer a vida para o seio da palavra poética. $\mathrm{O}$ poeta assume que o amadurecimento facilita a perceção de que sempre houve uma vida que justificasse a cada instante a verdade desses dois mundos e que é chegado o momento de aproximar os cursos de água, já próximos de um «mar do norte atlântico» ${ }^{4}$.

Quando em Os passos em volta acordava que o estilo era um modo de lutar contra "a desordem estuporada da vida» ${ }^{5}$, estava já convencido de que, desde o início, "Vivemos demoniacamente toda a nossa inocência $»^{6}$. Dando conta agora das suas experiências, desde o princípio da sua existência transbordam de excesso, recolhendo-se imagens que anulam os limites e os contornos da realidade: «De tudo aquilo subia um perfume agudo, embriagador, doloroso. À noite tive febre. Havia qualquer coisa pérfida e perversa neste mundo das frutas muito fortes, dos animais esquartejados, dos cheiros, este mundo espesso e quente, um mundo de imagens orgânicas» ${ }^{7}$.

Torna-se necessário um modo peculiar de lidar com a violência da realidade, um estilo capaz de a ordenar. A violência das relações e das sensações transmitidas

\footnotetext{
${ }^{3}$ HELDER, 2013: 19.

${ }^{4}$ HELDER, 2013: 115

${ }^{5}$ HELDER, 1994a: 9.

${ }^{6}$ HELDER, 2013: 13.

${ }^{7}$ HELDER, 2013: 10.
} 
pelo quotidiano contribui, desde as primeiras experiências de vida, para a iniciação num universo interior perturbante e intenso, capaz de se expor por imagens que afetam profunda e dolorosamente os sentidos e assumem-se desde logo como «uma interminável preparação, uma aproximação ${ }^{8}$ aos mais profundos e obscuros meandros da vida e da poesia.

As imagens que traz do passado inscrevem-se num espaço simbólico que se mantém aqui coerente com toda a sua obra anterior. A ilha onde nasceu apesar de se impor como uma realidade física com algum desencanto, dela recolhe uma carga iniciática que potenciará as palavras do seu universo:

Encontrava-me agora na ilha onde nascera; muitos anos de ausência seguida, e estava ali. Para morrer? O meu centro, o âmago, era esta terra que afinal eu não reconhecia como esperava, com alvoroço, com uma emoção porventura amarga, difícil .

e mais à frente refere: «Esta ilha não se integrava na minha ordem espiritual e fora nela contudo que eu arrecadara os ganhos fundamentais, os primeiros, naquelas imagens $»^{10}$. Assim, apesar da centralidade, na sua obra, das experiências iniciáticas nos segredos da vida, o seu encontro recente com o espaço onde nasceu não terá provocado no poeta uma experiência arrebatadora ou perturbante. Não produziu, simbolicamente, o efeito de um regresso mítico à origem, nem se impôs como espaço de aconchego, qual entidade materna de onde ou de quem se ausentara muito cedo. "Quase me apetece escrever que a alimentação mítica, a minha, se fizera daquela substância mas os elementos tanto se haviam purificado, de tal maneira tinham sido dispostos, que constituíam um universo autónomo, irreferenciável, absoluto» ${ }^{11}$. O passado do poeta é antes o passado imemorial, como refere Silvina Rodrigues Lopes:

o passado daquele que escreve não é as recordações que leva consigo para o poema, mas o passado imemorial [...]. É um jogo contrário ao da biografia como género, que anula o tempo ao concebê-lo enquanto estrutura vazia (entre o nascimento e a morte), que a vida, na homogeneidade da sua extensão, vem preencher. 'Antibiograficamente', o poema cria a sensação de tempo-intenso-vertical-múltiplo - efeito vertiginoso que corresponde ao espaçamento do signo na escrita e ao jogo imparável de diferenças que por ele se desencadeia ${ }^{12}$.

\footnotetext{
${ }^{8}$ HELDER, 2013: 13.

${ }^{9}$ HELDER, 2013: 16.

${ }^{10}$ HELDER, 2013: 17.

${ }^{11}$ HELDER, 2013: 17.

${ }^{12}$ LOPES, 2003: 96.
} 
O tema da viagem, que concentra Os passos em volta, é retomado agora como tema de uma vida para reconfirmar uma aprendizagem pessoal, consubstanciada numa única ideia:

Compreendi então: cumprira-se aquilo que eu sempre desejara - uma vida subtil, unida e invisível que o fogo celular das imagens devorava. Era uma vida que absorvera o mundo e o abandonara depois, abandonara a sua realidade fragmentária. Era compacta e limpa. Gramatical ${ }^{13}$.

Interessam-nos particularmente estes contributos para a definição da sua poesia, fundados em experiências dilacerantes, fraturantes, que concorrem para a criação de uma realidade compacta e limpa, gramatical, capazes de determinar toda a obra de Herberto Helder: a realidade, apesar de presente, sujeitou-se ao filtro e à energia aglutinadora da palavra poética, distanciou-se, obscureceu-se.

\section{ABREVIATURA DO TEMPO (PASSADO) EM POEMA CURTO}

A revisitação do espaço onde nasceu e viveu durante os primeiros anos leva o poeta a sistematizar algumas das forças mais marcantes da sua obra e a formular aos oitenta anos de idade uma teoria sobre a relação entre os dois espaços, o do nascimento e o da palavra. Afirma o poeta que «a história é a minha biografia e os pontos onde vida e criação tocam pontos da história comum, pensando-se que há história comum, são contactos de que me sirvo não para a ficção da minha existência mas para a ficção da história que serve a verdade biográfica» ${ }^{14}$. Desta feita, o que se torna relevante é a ficção da história, enquanto se limita a fundamentar a verdade biográfica que será muito mais do que a soma dos pontos onde se toca a história e a biografia do poeta, já que estes elementos factuais são de reduzida relevância. Em seu lugar, impõe-se a verdade biográfica como «alimentação mítica» ${ }^{15}$ da sua obra, conseguida e construída à custa da purificação dos elementos apresentados de forma autónoma, em palavras. Daqui resultam as memórias filtradas, memórias da vida, como referimos, «compacta e limpa. Gramatical» ${ }^{16}$, memórias da vida desprendidas dos fragmentos da realidade.

No alinhamento dos poemas de Servidões e com base na concentração do tempo que comentámos, parece-nos de enorme relevância a proposta de poema curto referida insistentemente neste livro. A depuração das circunstâncias e a elevação de fenómenos da vida a uma categoria única permitem que se represente por palavras uma antiga e nova realidade agora depurada e breve. A poesia de Herberto Helder foi

${ }^{13}$ HELDER, 2013: 18.

${ }^{14}$ HELDER, 2003: 17-18.

${ }^{15}$ HELDER, 2013: 17.

${ }^{16}$ HELDER, 2013: 18. 
incessantemente a Poesia toda, Ou o poema contínuo, realizando-se em cada poema a imagem fulgurante do seu universo poético. Assim, a palavra poética esteve sempre toda ou completa de sentidos escondidos, apresentando-se como uma persistente e continuada revisitação de temas ao longo da obra, como aliás o poeta confirma quando refere que «queria sim escrever o meu poema fixo entre as palavras móveis» ${ }^{17}$. Mais do que a memória circunstancial, impõe-se a memória dos instantes essenciais e eternos que seja capaz de eliminar o transitório, as palavras móveis, e realçar de forma breve o que se identifique com o seu poema fixo.

No fim da vida, esta preocupação de Herberto Helder com o poema breve é ainda um contributo para identificar um estilo capaz de lutar contra as circunstâncias, o ruído e a desordem da vida. A brevidade da construção poética não corresponde, no entanto, à brevidade do sentido e o aumento gradual, na sua obra, da densidade da palavra e do verso reforça a relevância do símbolo e a sua relação com o mito. Pode assim o poeta reconhecer que «não quero senão perder-me nesse enigma:/um pequeno poema bastava para meter tudo lá dentro,/e a minha vida como nota,/rápida, ríspida,/nas margens, ${ }^{18}$. Contudo, este poema, ao contrário de representar a ausência de fôlego verbal, resulta, segundo o poeta, de uma densa meditação ${ }^{19}$ que lhe concederá uma mais longa vida ${ }^{20}$. E porque em Herberto Helder a vida pessoal se coloca ao nível da criação simbólica, tão abstraída está do quotidiano, essa maturidade e perenidade serão mais da palavra, assumida por antonomásia por vida do poeta, até porque, como defende, «o mundo era pequeno,/mais pequeno com certeza que um poema de um verso único,/universo:/oh nunca mais quero viver no mundo! ${ }^{21}$.

A limitação verbal, a rarefação de sentido e a redução do mundo tornam-se cada vez mais evidentes na poesia de Herberto Helder. Já em Do mundo o poeta discorria sobre esta necessidade de afastamento do circunstancial ao afirmar que «Tudo se purifica: o mundo/e o seu vocabulário. No retrato e no rosto, nas idades em que,/gramatical, carnalmente, me reparto" ${ }^{22}$. Ao descomprometer-se com o acidental, o poeta permite que o poema diminua o tempo de exposição e reduza os elos de ligação com as experiências e as imagens fortuitas, tornando-se o poema curto, completo e absoluto: «e que eu desapareça na luz delas [águas] -/só música ao mesmo tempo nos instrumentos todos, /curto poema completo,» ${ }^{23}$; «¿oh será que um poema entre todos pode ser absoluto?/: escrevê-lo, e ele ser a nossa morte na perfeição de poucas linhas» ${ }^{24}$.

\footnotetext{
${ }^{17}$ HELDER, 2013: 38.

${ }^{18}$ HELDER, 2013: 82.

${ }^{19}$ HELDER, 2013: 76.

${ }^{20}$ Cf. HELDER, 2013: 53.

${ }^{21}$ HELDER, 2013: 76.

${ }^{22}$ HELDER, 1994b: 77.

${ }^{23}$ HELDER, 2013: 55.

${ }^{24}$ HELDER, 2013: 58.
} 


\section{A ANTECÂMARA DO DESENRAIZAMENTO: O ARVOAR}

O percurso realizado ao longo do livro Servidóes conduz o poeta ao sentido de perda, norteado pela perceção de rarefação ou pela criação de um momento e espaço essenciais. A transmutação mítica do caminho leva o poeta a reconhecer a reduzida servidão da memória e a necessidade de incrustar alguns desses momentos fundamentais num poema absoluto como acabámos de comentar. Na sequência desta reflexão, deparamos com o verbo arvoar que, para além do significado que lhe está associado de, entre outros, entontecer, e uma origem etimológica controversa, poderia, no contexto que nos interessa, sugerir desenraizamento ou afastamento, elevação: ar e voar.

A recorrência do verbo arvoar na parte final do livro reforça uma imagem sugestiva perante o distanciamento das circunstâncias do quotidiano. Os liames que o poeta poderia criar com o passado foram mantidos. Deixou a ilha para trás, no entanto as experiências eternas da infância permaneceram e foram elas, porventura, a proporcionar a iniciação na ciência dos elementos primordiais, para que, no final da vida, pudéssemos ouvir o poeta a afirmar que «daqui a uns tempos acho que vou arvoar/através dos temas ar e fogo, ${ }^{25}$.

Esta disponibilidade do poeta para se abstrair das coisas concretas que o circundam e para se concentrar na palavra poética como único meio de representar a realidade é definitivamente uma marca da sua poesia. Em Do mundo (1994) podemos já confirmar essa vocação quando afirma que «Nos fulcros, à mesa, pelo fogo, onde as linhas se encontram nos grandes/objectos do mundo, sento-me,/e alimento-me, e a fruta adoça-se até ao oculto,/e eu sei tudo, e esqueço» ${ }^{26}$. Depois da alimentação, o esquecimento das circunstâncias promoverá o conhecimento, sendo o fogo o elemento fundamental dessa purificação, pela capacidade de transmutar as circunstâncias em palavra.

Em Servidóes, depois de contruir uma biografia e a depurar, depois de se agarrar às imagens e libertar-se delas, depois de se identificar e abreviar em poema curto, como hipótese de silêncio o sujeito poético dilui-se, no último poema do livro, com a assunção da «grande mão anónima». Deste modo, «por milagre, há algo em vez de nada, há um tempo vertical que não se confunde com a temporalização: o tempo da criação ou do acontecimento ${ }^{27}$ e esse tempo é sempre o princípio e o fim do poema:

talvez certa noite uma grande mão anónima tenha por mim, um a um, lado a lado, escavando, escrito os nomes, um a um escrito os nomes esquecidos,

${ }^{25}$ HELDER, 2013: 106.

${ }^{26}$ HELDER, 1994b: 52.

${ }^{27}$ LOPES, 2003: 28. 
e entre os nomes mais obscuros o mais desmemoriado deles todos, e eu esteja atrás vivendo desse próprio esquecimento, a mão cortada, cortado o nome, além da morte escrita, pelo buraco da voz o nome escoado para sempre ${ }^{28}$

\section{BIBLIOGRAFIA}

HELDER, Herberto, org. (1985) - Edoi lelia doura: antologia das vozes comunicantes da poesia moderna portuguesa. Lisboa: Assírio \& Alvim.

(1994a) - Os passos em volta. Lisboa: Assírio \& Alvim.

(1994b) - Do mundo. Lisboa: Assírio \& Alvim.

(2013) - Servidões. Lisboa: Assírio \& Alvim.

LOPES, Silvina Rodrigues (2003) - A inocência do devir. Lisboa: Edições Vendaval.

${ }^{28}$ HELDER, 2013: 117. 



\title{
"AS PALAVRAS DO OLHAR»: EKPHRASIS EM FERNANDO GUIMARÃES
}

\author{
LUÍS MANUEL TARUJO*
}

Diz Fernando Guimarães que «[o] olhar tem as suas palavras e há, sem dúvida, nestas um sentido» ${ }^{1}$. Motivados por esta aguda consciência da arte, decidimos aventurar-nos na realização de um projeto de investigação sobre a leitura ekphrástica da obra poética de um escritor português contemporâneo, o que nem sempre é fácil concretizar.

São poucos os críticos que, no panorama literário português, se aventuram a publicar ensaios consistentes sobre a correspondência das artes, sobretudo no que diz respeito às relações entre pintura e poesia pós-moderna. Face a esta situação, a presente comunicação, ainda que modestamente, tem como objetivo contribuir para revelar a obra de Fernando Guimarães à luz de um exercício ekphrástico profícuo. Quando as diversas artes quebram os seus próprios limites e ensaiam incursões em campos fronteiriços, as potencialidades que se criam são ilimitadas. Um novo mundo renasce e com ele vários desafios se colocam aos artistas que aceitam enveredar por este caminho fascinante. Segundo Virgínia Woolf, um escritor sempre se questionará sobre a melhor forma de fazer transportar o Sol para a sua página, ou como conseguir que o leitor veja a Lua enquanto ela se eleva no horizonte, apenas com recurso a uma ou duas palavras, conseguindo um efeito máximo, mas com recursos mínimos. Neste sentido, cremos que será possível, no curto espaço de que dispomos, traçar pistas

* Universidade Nova de Lisboa/Instituto de Estudos de Literatura e Tradição.

${ }^{1}$ GUIMARÃES, 2003: 7. 
capazes de dar uma resposta cabal a estas questões, da mesma forma que o pintor Charles Steele, com uma única pincelada negra, foi capaz de mudar o aspeto geral de uma paisagem que acabara de compor sobre uma tela.

Antes de iniciarmos uma análise consistente, mas não exaustiva, sobre a leitura ekphrástica da poesia de Fernando Guimarães, existe a necessidade, óbvia, de relembrar o conceito de ekphrasis.

O vocábulo ekphrasis (plural ekphraseis) tem como sentido primeiro «descrição». De acordo com Mário Avelar², a primeira aparição deste termo terá ocorrido no seio de uma série de estudos sobre retórica, possivelmente escritos por Dionísio de Halicarnasso.

Sob um ponto de vista restrito, ekphrasis poderá ser entendida como a descrição literária de uma determinada obra de arte visual. Num sentido mais amplo, porém, será possível considerar que ekphrasis é um vocábulo de origem grega que, na retórica antiga, designava qualquer tipo de descrição que possuísse a capacidade de colocar o objecto descrito perante os olhos do recetor, ou seja, aquilo que em latim se considera como evidentia. E são várias as definições de antigos autores que corroboram esta última aceção. Hermógenes, por exemplo, nos séculos II-III, define ekphrasis como uma composição que tem como finalidade apresentar diante dos olhos, com detalhe e de forma evidente, o objeto que se revela. Acrescenta ainda que é possível considerar, por exemplo, ekphrasis de personagens, de determinados acontecimentos, de circunstâncias, de lugares, de épocas. Alerta ainda Hermógenes ${ }^{3}$ para o facto de a ekphrasis depender sempre de duas qualidades do discurso do poeta: a clareza e a vivacidade, de tal forma que, acrescenta, a elocução, que age diretamente perante o ouvido, "quase provoque a visão do que se descreve». Da análise da sua elaborada definição, não se vislumbra qualquer referência às obras de arte consideradas como objeto a trabalhar durante o processo ekphrástico, apesar de serem reiteradas duas características sem as quais não é possível falar de ekphrasis: da parte do poeta, a vivacidade e o pormenor (nas palavras de Barthes, «l'effet du réel» ${ }^{4}$ ) relativamente ao recetor, a impressão é de tal forma conseguida que ele terá de ver o que lhe é apresentado. Foi necessário esperar pelo dealbar do século XVIII e, de uma forma sistemática, pelo século XIX, para que o termo fosse associado à descrição de obras de arte, sobretudo no que respeita ao mundo bizantino. Já nos anos 50 do século XX, Léo Spitzer importou o vocábulo para a literatura comparada, desvinculando-o da antiga aceção restrita do campo da literatura e da arte antiga $^{5}$. A sua definição de ekphrasis é clara: «the poetic description of a pictorial or sculptural work of art». A partir desta data, a atenção dos críticos voltou-se para este exercício de retórica e, ao mesmo tempo, figura de pensamento; mas foi na década

\footnotetext{
${ }^{2}$ AVELAR, 2006: 45.

${ }^{3}$ Apud KENNEDY, 2003.

${ }^{4}$ BARTHES, 1968.

${ }^{5}$ SPITZER, 1955: 72.
} 
de 90 que o termo ocupou um lugar proeminente no universo dos estudos literários, um pouco por todo o mundo, sobretudo ao nível dos países anglo-saxónicos. Os mais recentes estudos sobre a ekphrasis tomaram dois caminhos distintos: por um lado, a tentativa, ainda não concluída, de encontrar uma definição teórica do termo que seja abrangente e integradora; por outro lado, a construção de caminhos hermenêuticos que possibilitem a abordagem de textos específicos, sobretudo poéticos. Muito ainda estará por fazer neste campo que parece inesgotável. Há, sobretudo, necessidade de obter resposta para determinadas questões julgadas pertinentes: Será a ekphrasis uma descrição «literária» ou apenas «verbal»? Poderemos aceitar ekphrasis narrativas (ou será isso um paradoxo?) ou apenas descritivas? Que tipo de objetos artísticos poderão ser matéria da ekphrasis? Apenas os que são representativos de uma realidade ou qualquer outro, como uma ponte, uma coluna, ou até uma pintura abstrata? Poderemos considerar a descrição de um objeto que pertence ao mundo natural como ekphrasis? Que modalidades caberão neste exercício? Aquelas que Hollander propõe (nocional, latente, atual) ${ }^{6}$ ? Ou as de Robillard (depictive (pictórico), attributive, associative) $)^{7}$ ?

Não serão simples as respostas que se possam aventar no sentido de resolver as questões anteriormente formuladas e também não é este o objetivo central do presente estudo. No entanto, pretendemos mostrar que a obra de Fernando Guimarães, mormente o seu livro $\mathrm{Na} \mathrm{Voz}$ de um Nome, poderá contribuir para edificar algumas novas vias de abordagem do texto poético, no sentido de dissipar a complexidade do termo que temos vindo a definir.

Face ao exposto, poderemos concluir que a ekphrasis é um fenómeno artístico potencialmente fascinante no domínio das relações entre a imagem e as palavras, precisamente devido ao facto de ser um exercício que sobrevive num espaço fronteiriço, entre as artes. É a partir do estudo das suas particularidades, das modalidades de interpretação que sugere, da evolução que sofreu desde a Antiguidade, que os textos produzidos pelos poetas se tornarão mais ricos e apaixonantes. E a ekphrasis torna-se assim a aparição no poema do que existe de um outro modo, com outra forma, noutra parte.

Atentemos ainda para o surpreendente poema de Fernando Guimarães ${ }^{8}$ retirado da obra que irá prender de seguida a nossa atenção. Nele, o poeta apresenta o seu próprio conceito de criação ekphrástica comprometido com a transferência para a escrita das imagens que têm por referência objetos artísticos, neste caso, quadros, como se a pintura representasse um particular modo de ver. Deste modo, é possível abrir-se caminho para que, no campo das artes, se possa procurar, e encontrar, um ensejo de decifração ou de leitura.

${ }^{6}$ HOLLANDER, 1988.

${ }^{7}$ ROBILLARD, 1998.

${ }^{8}$ GUIMARÃES, 2006: 40. 


\section{EKFRASIS}

Apenas um quadrado branco sobre um fundo branco. É talvez o exercício para encontrarmos o silêncio que se torna maior, um gesto fugitivo que veio tocar qualquer corpo e deixar nele uma das mais leves feridas, a do nada. Poderia ser esta uma descrição? Alguém, ao pintá-lo, conhecia certamente a razão por que o tinha feito. Imaginamos as últimas rugas ainda visíveis nessa tela, uma aresta ao longo da mesma tonalidade, a mão desfalecida. Pensamos no frio que só o nosso peito acolhe, no desenho agora inclinado das veias. Não há dúvida que tinha de ser assim. Tudo se há-de tornar mais simples. As folhas invisíveis caem ao nosso lado.

Assim como não é simples esboçar uma definição tão completa quanto possível de ekphrasis, parece-nos extremamente complexo referir-nos às suas diferentes formas de representação, sobretudo no que diz respeito às teorias de leitura das representações visuais.

Em primeiro lugar, será importante assinalar que uma obra de arte visual é, ou poderá ser, objeto da ekphrasis ao mesmo tempo que se revela como representação. A dupla mimesis será fundamental nos textos ekphrásticos que, deste modo, poderão aludir a cenas figurativas nas pinturas, ou noutro tipo de suporte como a tapeçaria, por exemplo. Mas anteriormente já outros estudos reivindicavam uma distinção efetiva entre as duas artes, como Paragone (comparação, em italiano; no contexto da superioridade das artes, encerra o sentido de competição, luta - agon em grego), publicado por Leonardo da Vinci no final do século XV, e Réflexions Critiques sur la peinture, de J. B. du Bos, no século XVIII, se bem que o primeiro também considere a mimesis como a matriz comum entre duas artes que se consideram irmãs; por isso, parafraseando o artista, parece-nos lícito afirmar que a pintura é uma poesia vista e não ouvida e a poesia, por seu lado, uma pintura que é ouvida, mas não vista. Na sua perspetiva, a Natureza é obra de Deus, ao passo que a poesia é criação humana. A última dirige-se ao ouvido, um dos cinco sentidos do ser humano, desde sempre considerado menos perfeito que a vista, por não permitir uma perceção global e simultânea.

Em segundo lugar, é necessário resolver o seguinte problema que Lessing procurou debelar com o seu ensaio sobre o Laocoonte: como se pode expressar, através de um meio discursivo (sucessivo) uma cena representada por um meio visual (simultâneo) ${ }^{9}$ ? Problema inverso experimentam, por vezes, os pintores: como plasmar numa única imagem todo um processo narrativo?

Uma tentativa de resolução do problema pode passar pela compreensão de que a ekphrasis é, acima de tudo, descrição, mas não deixa de adicionar à cena contemplada pelo poeta os elementos que, apesar de não estarem representados pelo quadro, lhe conferem

${ }^{9}$ LESSING, 1766. 
um cariz narrativo. E vários são os casos que, ao longo dos tempos, têm contribuído para reforçar o anteriormente expresso. Por exemplo, os autores da progymnasmata consideravam como objeto da ekphrasis a pragmata, isto é, as ações. Inclusivamente, os artistas que se dedicavam à pintura de cenas mitológicas ou religiosas tinham a clarividência de que as suas obras iriam ser contempladas por um tipo de espectadores que se socorrerão da narração que surge associada à única cena representada na obra. E este processo é também materializado pela ekphrasis.

Em terceiro lugar, cabe aqui referir que a ekphrasis, pelo menos como a entendemos hoje, não tem de se referir obrigatoriamente a um objeto artístico real. Não será necessário pesquisar muito para chegar à conclusão de que o famoso escudo de Aquiles é fruto da fantasia fértil de Homero, sendo o termo «fantasia» tido no seu sentido etimológico grego (visio em latim).

De seguida, é importante considerar que existe um tipo especial de ekphrasis, praticado por diversos poetas portugueses contemporâneos, por exemplo, em que não se descreve uma obra de arte específica, mas uma cena natural, que pode ou não ser verídica (uma paisagem, por exemplo). Esta cena acaba por ser apresentada pelo poeta com mestria, como se de uma pintura se tratasse.

Esta enumeração não estaria completa sem a referência a certos marcos que apontam para a obra mencionada e que passam por alusões no título do poema, como a transcrição do nome do quadro ou mesmo do seu autor, chegando até a referir-se o caráter artístico da cena representada e colocando-se mesmo em destaque um determinado aspeto julgado essencial.

Em sexto lugar, e considerando um objeto descrito real, assiste-se a uma dupla intertextualidade: a que une o texto escrito a outros e a que o aproxima do seu referente visual. É evidente que esta situação exige do leitor uma atenção redobrada para que a possa compreender corretamente. Associado a esta situação considerada dupla, não se pode descurar o efeito que a obra provoca no recetor. Neste sentido, a ekphrasis terá de ser vista a um nível mais profundo que a afasta da simples descrição referencial. O fito do poeta não é apenas acumular no seu poema uma série de informações; pelo contrário, pretende desencadear sensações no recetor.

Em sétimo lugar, o exercício da ekphrasis, tendo em vista quadros imaginados pelo poeta ou reais, mesmo que o leitor não saiba identificar, prevê sempre a prevalência da autonomia dos textos face às obras de arte. A compreensão do texto não parece, pois, dependente do conhecimento prévio do objeto descrito. Os textos de muitos autores contemporâneos são prova desta realidade, uma vez que, por circunstâncias diversas, que passam pelos custos de produção do livro acrescidos se lhe apensarem imagens das obras de arte ou que poderão mesmo resultar da opção do poeta, não é possível ter os dois referentes em presença. Mesmo assim, a interpretação do texto não é minorada, 
podendo, inclusivamente, surgir interpretações válidas que, na presença da referida obra de arte, tenderiam a ser minoradas.

De seguida, é necessário dissecar um aspeto terminológico importante sob pena de não compreendermos a totalidade do exercício ekphrástico: falar de descrição de um objeto artístico não é totalmente exato. Por um lado, raramente há referência à totalidade da obra artística, quedando-se, muitas vezes, o poeta em pormenores, sugestões ou impressões que julga mais importantes. Não raro encontramos poemas em que um fragmento ou uma figura do quadro é considerado. Seria penoso exarar aqui todas as possibilidades que a ekphrasis permite, uma vez que cada texto é autónomo e rege-se por leis de seleção próprias. No mesmo sentido concorrem as relações imagem-texto que podem ser consubstanciadas em três modalidades essenciais: na situação em que um quadro pode dar origem a mais do que uma ekphrasis; quando vários quadros dão lugar a uma ekphrasis; ou, ainda, quando vários quadros permitem várias ekphrasis.

Finalmente, convém frisar que, num texto ekphrástico, o poeta coloca em relevo aquilo que Scott considerou como «mestria artística de outro autor» ${ }^{10}$. É certa uma identificação e equiparação do poeta com o pintor. Deste modo, é comum que os textos ekphrásticos tenham como tema o processo de criação artística. Notemos, por exemplo, o belíssimo poema de Fernando Guimarães intitulado "Arshile Gorki» ${ }^{11}$, em que existem referências invulgarmente originais, numa primeira parte, à técnica usada pelo pintor para conceber as suas obras. Deste modo, pulula no texto um vocabulário próprio das artes plásticas, retomado, por exemplo, noutro texto com o título «Como restaurar um quadro» ${ }^{12}$.

É uma evidência a relação da palavra escrita com o mundo das imagens. Esta aproximação, nem sempre amigável, perdura desde a Antiguidade. A figura de Horácio é, por isso, incontornável quando surgem trabalhos consistentes acerca da origem da teoria das relações entre as artes. A sua obra intitulada Epístola aos Pisões, considerada uma autêntica ars poetica por Quintiliano (inst. or., VIII, 3), dá realce à correspondência entre a poesia e a pintura. O seu texto é esclarecedor e merece ser transcrito pela beleza das suas palavras:

[Ut pictura poesis] Como a pintura é a poesia: coisas há que de perto mais te agradam e outras, se à distância estiveres. Esta quer ser vista na obscuridade e aquela à viva luz, por não recear o olhar penetrante dos seus críticos; esta, só uma vez agradou, aquela, dez vezes vista, sempre agradará13.

\footnotetext{
${ }^{10}$ SCOTT, 1987: 303.

${ }^{11}$ GUIMARÃES, 2006: 37.

${ }^{12}$ GUIMARÃES, 2006: 52.

${ }^{13}$ HORÁCIO, 1984: 109-110.
} 
Daqui se depreende que o autor desenvolve a ideia de que a poesia é capaz de produzir, através de uma linguagem natural, representações de índole visual. Assim, o poeta torna-se um pintor que "pinta» com as palavras.

A expressão ut pictura poesis, bem como o conceito aristotélico referente à ação de uma tragédia que a assemelha a um quadro, fizeram com que, desde o Renascimento até ao século XVIII, se constituísse um sistema das artes fundado na aproximação entre poesia e pintura.

Interessar-nos-á, porventura, aqui, socorrer-nos da expressiva metáfora que os iluministas utilizavam para se referirem às palavras e imagens. Para estes artistas, elas nada mais eram que meios transparentes (e atentemos para a riqueza do vocábulo utilizado) através dos quais uma determinada realidade é apresentada à nossa compreensão. Desta forma, à medida que a realidade que os tropos empreendem representar se torna mais complexa e enigmática, mais o deverão ser as palavras utilizadas pelos artistas. Daqui resulta uma dificuldade, para o leitor mais incauto, de uma obra de arte que se lhe depara.

Sem pretendermos, mais uma vez, traçar uma panorâmica histórico-cultural da evolução da ekphrasis, centremos a nossa atenção no período que se inicia na segunda metade do século XIX. A partir desta data, a pintura revela um afastamento gradual da figuração realista e daquele tipo de narrativa que podemos considerar francamente literária que era seu apanágio. Esta situação deve-se, fundamentalmente, ao aparecimento de novos instrumentos de representação do real, sejam eles a fotografia, o cinema, ou ainda a incorporação das novas tecnologias. O sucesso destes instrumentos leva a pintura a virar-se sobre si mesma. Por outro lado, com o cubismo, os pintores passam a valer-se das palavras para discorrer sobre as suas próprias obras, valendo-se dos processos pictóricos usuais. Desta forma, desconstroem a estrutura representacionista e ilusionista da pintura ao quebrar a noção de perspetiva, ao mesmo tempo que repudiam qualquer técnica realista de pintar. São os surrealistas que, chegando ao ponto de incluir o texto nos seus quadros (por exemplo, é bastante célebre a obra de René Magritte em que a imagem de um cachimbo vem acompanhada da legenda «ceci nest pas une pipe»), revelam bem (ou não) a complexa relação que estabelecem com a palavra e, especificamente, com o texto pintado. A pintura e a literatura chegam a confundir-se e a primeira deixa-se contaminar por esta. É, pois, com o movimento surreal que a palavra se demite de uma evocação da realidade visual pré-existente para recuperar a autonomia de discurso literário que, em certos períodos, se perdera.

Os críticos modernos, depois de muitas polémicas e visões um pouco contraditórias que caracterizavam outros estudiosos desta matéria, acabam por tender para uma forma convergente de aproximação de duas artes consideradas irmãs por Mário Praz ${ }^{14}$.

${ }^{14}$ PRAZ, 1982: 1. 
Num estudo como este, é, obviamente, fulcral a questão da relação entre a imagem e o texto que se tornou, atualmente, tão importante que somos autorizados a falar da linguagem como pintura ou da pintura como linguagem.

A influência de artistas plásticos e das suas obras é visível nos dois textos que iremos analisar de seguida. E se não fosse a assunção completa de Fernando Guimarães da aproximação da literatura, neste caso da poesia, às artes plásticas, o que o moverá a utilizar a língua ao nível figurativo, recorrendo a efeitos luminosos, odoríferos, musicais e até tácteis, «abusando», por vezes, de associações surpreendentes e de metáforas, a sua produção estaria bem distante daquilo que podemos considerar como uma verdadeira sinestesia presente em cada verso, em cada pormenor do seu texto. A sua construção poética revela uma plasticidade, um apelo visual muito intenso - formulação verbal ekphrástica em que o olhar é constantemente convocado. É evidente que a sabedoria maior do poeta não o deixa ficar por aqui, mas também parece óbvio que, ao procurar as equivalências que poderemos designar por homológicas entre sistemas distintos, $\mathrm{o}$ poeta acaba por verificar as correspondências possíveis entre esses procedimentos e, ao mesmo tempo, aferir as diferenças de operacionalização de recursos, de cada um dos meios expressivos, que se impõem.

A verdade é que, na relação da imagem com a escrita, Arheim destaca o facto de, apesar de terem sido afastadas durante um certo período de tempo, elas são inseparáveis desde a sua origem:

Embora a construção da imagem e a escrita se desenvolvam de maneira inseparável e nunca tenham sido de todo independentes, a sua recente atração mútua surgiu como a cura de uma ferida que as dividiu de forma malsã. [...]. Em suma, tanto a linguagem quanto a arte pictórica necessitavam de uma renovação como meios de expressão formal. Pode-se dizer que os desenvolvimentos estilísticos da arte moderna e da poesia moderna objetivaram exatamente tal renovação. Além disso, as artes visuais precisavam de ser enriquecidas por um retorno ao pensamento. Talvez, de uma certa forma, a poesia concreta cumpra esses objetivos. Ela renova a consciência da língua como veículo de expressão visual, e infere padrões visuais no pensamento expresso por palavras significativas ${ }^{15}$.

Quando falamos de literatura e artes plásticas e da sua relação, está em causa um aspeto basilar sem o qual todo o exercício ekphrástico periga. Referimo-nos à possibilidade que a escrita literária tem de poder figurar. O texto literário passa, assim, a ser considerado uma arte verbal que possui capacidade mimética.

${ }^{15}$ ARHEIM, 1989: 95-96. 
Philippe Hamon afirma que «la littérature a besoin des autres arts pour se definir elle-même [...] La comparaison, la métaphore, l'analogie sont donc inscrites nécessairement, non comme procédés décoratifs, mais comme moyens inévitables, au sein de cet acte même de définition» ${ }^{16}$. As suas palavras sublinham o facto anteriormente reiterado de que o poema amplia os seus domínios a outras modalidades da arte, através de uma série de recursos estilísticos que intensificam esse alargamento. Por este motivo, Octavio Paz declara que «comparações, analogias, metáforas, metonímias e os demais recursos da poesia: todos tendem a produzir imagens às quais se juntam isso e aquilo, o um e o outro, os muitos e o um» ${ }^{17}$. Para este autor, a função mais «antiga», «permanente» e «universal» do poema é precisamente «dar forma e tornar visível a vida quotidiana». No entanto, existe algo que afasta o poema do quadro: por ser um «objeto de linguagem», o poema desencadeia imagens mentais no leitor ou ouvinte, mas nada mostra no sentido aportado por Paz, quando refere que as imagens criadas pelo texto poético são como «criaturas anfíbias: são ideias e são formas, são sons e são silêncio» ${ }^{18}$. Daqui se depreende que, para Paz, a relação entre poema e pintura decorre da tensão mostrar/não mostrar. No entanto, na conceção de Jacqueline Lichtenstein, a relação poema/pintura ocorre de modo direto e apresenta-se como uma referência para a arte mimética em que a metáfora pictural é veículo predileto para expor diante dos olhos do espectador/leitor um determinado objeto. Esta apresentação desencadeará um sentimento de prazer no indivíduo que contempla as imagens geradas, pois o que é apresentado pode ser facilmente identificado, como, aliás, defendia Aristóteles. Desta forma se compreendem as palavras da autora: «escrever um poema consiste sempre em descrever uma representação visual», uma vez que «a escrita exige a apresentação de um dispositivo visual, onde o autor se transforma em ator para que possa acontecer o espetáculo da narrativa que quer escrever». E acrescenta que «a metáfora pictórica pode ser considerada a mais apta para designar a atividade poética em geral» ${ }^{19}$.

Costa Honorato, no seu Compêndio de Retórica e Poética, parece, em parte, ter a mesma visão. Ali, o autor reclama que a poesia «conserva, quando necessário, a vantagem de pintar, por meio da palavra, o pensamento e pôr os objetos sob nossos olhos». E, mais adiante, sem, contudo, fazer passar uma ideia de isenção relativa à tradicional rivalidade entre poesia e pintura, acrescenta: «A poesia é superior à pintura e à música, porque é a verdadeira arte do espírito, que se exprime pela palavra», uma vez que ela, «visto que tem por instrumento a palavra, reúne e resume as maneiras de expressão e as vantagens de outras artes» ${ }^{20}$. Evidentemente que a posição de Honorato

\footnotetext{
${ }^{16}$ HAMON, 1989: 7, 21.

${ }^{17}$ PAZ, 1993: 125.

${ }^{18}$ PAZ, 1993: 143.

${ }^{19}$ LICHTENSTEIN, 1994: 76.

${ }^{20}$ HONORATO, 1879: 201-202.
} 
se deve ao facto de este autor tentar privilegiar a poesia em detrimento das demais modalidades artísticas, uma vez que a sua intenção era menosprezar a poesia realista e fazer valer o código romântico.

Apesar de todas estas polémicas questões, a história mostra-nos que o diálogo entre a poesia e a pintura se efetivou, de facto. Retoma-se o tópico horaciano ut pictura poesis sobretudo no que diz respeito à tentativa dos poetas em conferir aos seus textos um colorido original, contornos bem definidos, volumes surpreendentes, para além de esfumar e sombrear a realidade. E esta prática tornou-se frequente ao ponto de vários vocábulos do campo lexical das artes terem sido apropriados pelos poetas que os usaram nos seus escritos: quadro, cena, pintura, óleo, restaurar, estilo, moldura, desenho, etc. Mesmo ao nível da dimensão gráfica dos textos, verificam-se inegáveis influências da pintura. Por exemplo, nas páginas de livros, revistas ou jornais, os poemas surgem guarnecidos por uma moldura que tanto servia para delimitar a área de grafismo, como cumpria a função de enriquecimento visual, enobrecendo a obra produzida. Através desta simples exemplificação, constatamos que a poesia contribuiu de forma fundamental para esbater a distância entre o «ler/ver» e «escrever/mostrar».

Estes exercícios, consubstanciados numa dimensão representativa, atribuem à linguagem poética mais plasticidade e dotam o poema de uma presença física e corpórea, regulada por processos sobretudo metafóricos com a pintura, a escultura ou a arquitetura.

Em guisa de conclusão, acrescente-se que esta tentativa de visibilidade poética transformou o poeta numa espécie de voyeur, uma figura de exposição e espectador de um mundo que o envolve, e o poema - que passa a ser um objeto-fetiche para o leitor - um quadro, um monumento arquitetónico, uma partitura ou até uma escultura. Esta mudança radical poderá quase fazer supor que, fora da dimensão do poema, tudo se resume a trevas e desordem.

Convém, neste momento, termos presentes as palavras do crítico Rudolf Arheim que ilustram de forma inequívoca o percurso, embora incompleto, que tentámos fazer ao trabalhar cada texto de Fernando Guimarães: «A leitura atenta de um poema exige muitos movimentos para a frente e para trás, não diferente da observação cuidadosa de um quadro, pois o poema só se revela na presença simultânea de todas as suas partes ${ }^{21}$.

O diálogo que Fernando Guimarães estabelece entre a poesia e a pintura baseia-se na convocação de ecos desse mesmo colóquio numa ekphrasis que assenta em equivalentes descritivos ou metafóricos (o que implica a interpretação do objeto pictórico). Lembremos que, enquanto exercício poético, a ekphrasis consubstancia-se na descrição de uma obra de arte, bem como na sua interpretação, o que, deste modo, sublinha a importância da presença constante do sujeito poético neste tipo de textos.

${ }^{21}$ ARHEIM, 1989: 99. 
Podemos elencar vários poemas que, na obra de Fernando Guimarães, cumprem este exercício. A própria referência clara a objetos pictóricos precisos, que o leitor conhece ou não, e que o poeta opta por não reproduzir no seu livro, prova o que se acabou de afirmar. Esta opção provoca no leitor a sensação de que a obra de arte está presente como referente do título, mas ausente como presença física no corpo do texto, que se autonomiza relativamente a ele. Desta forma, mais do que a simples descrição do objeto artístico, a mestria de Fernando Guimarães leva-nos a constatar, a partir das suas palavras, que é a experiência que colhe da sua observação o que importa destacar no trabalho poético. Assim, os ecos dos referentes pictóricos concorrem apenas para evidenciar o que o sujeito vai receber a partir da observação de um quadro ou de um retrato. É aquilo que a imagem lhe diz. O próprio termo ecos reenvia para um trabalho de distanciamento entre o que é observado e o que o poeta acolhe dessa contemplação. Ao lermos os textos da obra em análise, não iremos encontrar uma tradução, ainda que poética, de uma imagem pictórica, uma tentativa de, com recurso a palavras, revelar o que a imagem mostra, mas, pelo contrário, um muito mais interessante jogo que consiste em colocar sob a forma de discurso o efeito que a observação da imagem provoca no sujeito que se torna (inter)mediário na aproximação do leitor à obra de arte referida. Inclusivamente nas composições em que predomina a dimensão descritiva, o poeta pretende dar conta do olhar do sujeito sobre o quadro e do dizer esse olhar. Por outras palavras, assistimos à tentativa de verbalização daquilo que é específico de uma representação pictórica.

O primeiro texto do poeta português que pretendemos inscrever nesta categoria tem como título «Dürer: "Cristo entre os doutores" (da colecção Thyssen-Bornemisza)» ${ }^{22}$.

Albrecht Dürer viveu entre 1471 e 1528 e foi um dos mais importantes pintores renascentistas alemães. Começou a pintar com quinze anos. Procurou sempre tomar como modelos os pintores dos maiores centros artísticos europeus, nomeadamente de Itália e Holanda. No entanto, conseguiu superá-los. As suas longas viagens pelo continente europeu permitiram-lhe fundir as tradições góticas do Norte com a noção de perspetiva desenvolvida pelos italianos. Fortaleceu, na sequência, um interesse profundo pela matemática. Deste modo, a maior parte da sua produção artística resulta da influência nítida das teorias matemáticas, tais como a proporção e a perspetiva, esta última advinda do estudo sistemático da geometria. Não menos importante é a influência da religião no seu trabalho, que o levou a aderir ao Luteranismo e encontrar na fé a resposta para a salvação do homem. É assim que os seus quadros e desenhos emprestam um rosto a Deus, do mesmo modo que Miguel Ângelo O acolherá morto nos seus braços. De entre as suas obras, tornaram-se célebres quadros como «St. Jerôme», de 1521, e «Cristo entre os Doutores», de 1506.

${ }^{22}$ GUIMARÃES, 2006: 46. 


\section{DÜRER: «CRISTO ENTE OS DOUTORES»} (DA COLECÇÃO THYSSEN-BORNMISZA)

No meio estão representadas quatro mãos. Formam um quadrado. Qualquer gesto há de ocultar-se nelas. Este só pertence a quem as veio pintar; elas são a moldura dessa ausência. Conservam-se juntas e entreabertas. O espírito de quem ali se encontra procura um novo conhecimento. Há mesmo alguns livros e uma luz desconhecida principiou a iluminá-los. Numa das mãos de Cristo descai o indicador até ao polegar da outra e vê-se à sua volta espalhado o reflexo desse movimento sobre um manto que é verde. As outras duas são as de alguém que nesses livros há de encontrar uma nova pergunta para depois se receber o seu mistério. Como se víssemos em páginas diferentes o que nos podia ser explicado, o rosto de Cristo inclina-se um pouco e fita as quatro mãos. Elas são a resposta.

O título do poema que nos propomos analisar compromete o texto com as artes plásticas, ao designar uma obra (e o nome do seu criador) que faz parte do universo cultural do leitor ou, pelo menos, levá-lo-á a identificar a cena retratada no quadro e exarada no título. Trata-se do episódio relatado nos Evangelhos do Novo Testamento em que Jesus, questionado (e desafiado) pelos arrogantes doutores da Igreja do seu tempo, faz passar uma mensagem moral e ética que não lhes agrada, perpassando nos seus rostos laivos de afronta aos seus dogmas que julgavam inquestionáveis. Daí que tenham ignorado por completo a sua mensagem: o homem deve viver pelo espírito e não pela palavra da lei.

A nossa atenção é conduzida, logo no primeiro verso, para a parte central do quadro, onde «estão representadas quatro mãos». É precisamente o tópico mão que confere unidade ao poema, ao percorrê-lo até final. A mão exprime uma ideia de atividade, ligada ao poder e domínio. Será pertinente convocar aqui, porque nos parece adequado ao contexto em que surge no poema, esta parte do corpo humano, uma interpretação milenar relativa à mão, pretendendo ver nela um esforço de concentração espiritual, bem como uma «referência ao livre desenrolar da experiência interior num microcosmos que escapa ao condicionamento espácio-temporal $»^{23}$. Na tradição bíblica cristã, mão simboliza poder e supremacia. Ser tocado pela mão de Deus (aqui representado por Seu Filho), equivale, nessa mesma tradição, a receber a força divina através da manifestação (palavra com a mesma raiz de mão) do seu Espírito. Predomina, assim, no poema esta leitura: «O espírito de quem ali se encontra procura/um novo

${ }^{23}$ CHEVALIER \& GHEERBRANT, 1994: 437. 
conhecimento». Notemos a cesura propositada do verso, colocando em destaque o vocábulo "procura», referindo-se precisamente ao que os doutores estavam buscando neste encontro com o divino.

Resulta do encontro a junção das quatro mãos, duas divinas e duas humanas, formando um quadrado. O número quatro é um número fulcral e resolutivo. Dos vários significados que pode encerrar, um parece-nos adequado ao ponto de vista de Dürer: trata-se do número da totalidade do universo natural e da perfeição moral do ser humano. O conceito de um monge cartuxo do século XII, cuja identidade permaneceu anónima, foi seguido por este artista:

De facto, os antigos raciocinavam deste modo: tal como é na natureza, assim deve ser na arte; mas, em muitos casos, a natureza divide-se em quatro partes [...]. Quatro são, de facto, as regiões do mundo, quatro os elementos, quatro são as qualidades primárias, quatro os ventos principais, quatro são as constituições físicas, quatro as faculdades da alma e assim por adiante ${ }^{24}$.

A feliz opção de Dürer por uma das figuras geométricas mais universalmente usadas e o não menos afortunado aproveitamento do motivo por parte de Fernando Guimarães pretendem destacar neste símbolo fundamental os elementos terra e céu que se opõem, ou, a um nível mais profundo, «o universo criado, terra e céu, por oposição ao incriado e ao criador; é a antítese do transcendente» ${ }^{25}$.

A insistente referência a uma espécie de estatismo, convocado pelo sujeito poético, visível na seleção vocabular «ocultar-se», «ausência», «conservam-se», e que o próprio quadro, dada a sua natureza, conserva, tem como objetivo fixar esta transmissão que se dá entre o divino e o humano, entre o sagrado e o profano, entre o transcendente e o imanente, que ocorre desde os tempos mais remotos e que não termina. Daí o facto de as mãos permanecerem «juntas e entreabertas» como se a união entre os dois universos permitisse constantemente mais questões, mais aprendizagem, mais transmissão de conhecimentos, como veremos adiante. $\mathrm{O}$ estatismo que referimos pode agora ser visto como aparente. Afinal, da imagem fixa do quadro, que o poeta observou, parte-se para uma expansão imediata, para além da mera perceção visual. Reside aqui a magia da ekphrasis que Fernando Guimarães soube fruir ao conceber este belíssimo poema. Aliás, esta expansão que o poeta faz concorre com aquela que apenas pertencera ao pintor do quadro. $\mathrm{O}$ «gesto [...] só pertence a quem as [as mãos] veio pintar».

A inesgotável riqueza do texto não permitirá, em escassas linhas, esgotar tudo o que poderia ser dito à luz deste exercício ekphrástico. Porém, julgamos necessário

\footnotetext{
${ }^{24}$ Apud ECO, 2004: 77.

${ }^{25}$ CHEVALIER \& GHEERBRANT, 1994: 548.
} 
fazer vincar outros aspetos que nos parecem fundamentais no texto. À medida que o poema se aproxima do seu termo, o sujeito poético conduz-nos a pequenos detalhes que resultam de uma observação cuidada da obra de Dürer.

O primeiro aspeto a que convém atender diz respeito aos livros representados, verdadeiras fontes de conhecimento, talvez aqui conotados com as Sagradas Escrituras. Os vocábulos «conhecimento», «luz»e «iluminá-los» concorrem para mostrar que não basta possuir os livros. É necessário compreendê-los, interpretá-los - a isso chamamos vulgarmente conhecimento - e a fonte desse saber confunde-se com a «luz» adjetivada «desconhecida» que provém do divino. Por esta razão, o poeta acrescenta, mais adiante: «alguém que nesses livros há de encontrar uma nova pergunta/para depois se receber o seu mistério», isto é, a resposta dada por Jesus. Neste sentido se chega à leitura última do poema. Ao afirmar «Como se víssemos/em páginas diferentes o que nos podia ser explicado, o rosto de Cristo/inclina-se um pouco e fita as quatro mãos. Elas são a resposta,», o poeta pretende revelar que são as mãos de Cristo, juntamente com as dos homens, a resposta para as questões dos doutores, ou seja, as de toda a Humanidade. A expressividade da forma verbal utilizada «principiou» revela precisamente a primeira manifestação pública de Jesus, ainda jovem, e o ensaio inicial da sua doutrina que derruba o porte ameaçador dos doutores munidos de livros que garantem, julgam, a sua autoridade envolta em trevas até então.

Outro aspeto que convém adiantar refere-se aos dedos que se destacam nas mãos de Cristo: «descai o indicador/até ao polegar da outra». O emprego do verbo descair, que poderia levar-nos a pensar numa alusão a um movimento, ainda que breve, afinal manifesta-se apenas num «reflexo desse movimento sobre um manto que é verde.», talvez o próprio reflexo do poder divino (reforçado pela referência ao «manto») representado na cena por Cristo.

Os dedos destacados são o indicador que descai sobre o polegar da mão oposta como se Jesus estivesse gesticulando, manifestando o seu ponto de vista. A tradição fala-nos do indicador como o dedo da vida, oposto ao médio, o da morte; é também conotado com o julgamento, a decisão, o equilíbrio, o silêncio e ou autodomínio. O polegar é o símbolo de poder não só físico, como, sobretudo, mental para muitos povos. Deste modo, parece-nos lícito efetuar a seguinte leitura: a vida subordina-se ao poder, à autoridade espiritual. É essa a mensagem que Jesus pretende transmitir: os próprios doutores da Lei subordinam-se aos ensinamentos divinos. A ciência e a razão subordinam-se à fé. Cristo substitui-os na sua função e a posição dos dedos do Filho de Deus mostra claramente a sua atitude.

Para além das referências às mãos de Cristo e a dois dedos em particular, a única alusão ao Seu corpo encontra-se no penúltimo verso: «o rosto de Cristo». Chevalier refere que 
o rosto é um desvendamento incompleto e passageiro da pessoa [...]. Nunca ninguém viu o seu próprio rosto: só é possível conhecê-lo através de um espelho ou de uma miragem. O rosto não é, portanto, para si mesmo, é para o outro, é para Deus; é a linguagem silenciosa. É a parte mais viva, mais sensível [...] que, quer queiramos, quer não, apresentamos aos outros: é o eu intimo parcialmente despido, infinitamente mais revelador que todo o resto do corpo ${ }^{26}$.

Na linha da interpretação do poema, e seguindo a vertente religiosa que acompanha a poesia de Fernando Guimarães, é possível ler aqui que a exibição do movimento metonímico do rosto divino é a resposta silenciosa a todas as questões que o homem coloca perante as manifestações divinas. Quando lemos que «é o eu íntimo parcialmente despido», salientamos a exposição pública - a primeira - que Deus feito homem experimentou na tentativa de clarificar a Verdade suprema. Notemos mais uma vez o vocabulário selecionado que concorre para este efeito: «luz desconhecida»; «iluminá-los»; «reflexo».

Esta composição de verso longo e livre mantém uma musicalidade própria e um ritmo constante que se assemelha à própria interpretação do quadro de Dürer. Os valores plásticos do discurso de Guimarães encontram-se consignados numa discreta engenhosidade que recorre a efeitos espaciais («ali»; «à sua volta»), óticos (como a referência aos verbos ver e fitar) e icónicos («formam um quadrado»; «moldura»; «livros»; «manto [...] verde»). A subjetividade da linguagem denuncia a intervenção do sujeito, na sua (inter)mediação, na descodificação da intertextualidade ekphrástica que não se fica apenas pela descrição pura e simples da obra de arte.

A segunda composição selecionada para ilustrar o exercício ekphrástico que utiliza a pintura como referente do poema intitula-se «Suicídio de Séneca» ${ }^{27}$ e deverá ter como referente o impressionante quadro de Luca Giordano pintado por volta de 1684. Este pintor italiano nasceu em 1634 e faleceu em 1705. Todos os seus quadros foram produzidos com uma excecional rapidez, o que lhe valeu o epíteto de Luca Fa Presto (Luca que trabalha rapidamente). De entre a sua prodigiosa obra, marcada por estilos diversos que, rapidamente, eram absorvidos e suplantados, destaca-se o soberbo quadro intitulado Suicídio de Séneca. Neste quadro, Giordano representa os últimos instantes do filósofo Séneca rodeado dos seus discípulos. É a sua figura que domina o quadro. Amparado por um dos seus servos, Séneca ainda encontra forças para uma derradeira lição. $\mathrm{O}$ aspeto físico do filósofo faz-nos sentir piedade, o que contrasta grandemente com o seu olhar determinado. É precisamente a partir desta cena que Fernando Guimarães escreve um dos mais interessantes poemas do seu novo livro.

\footnotetext{
${ }^{26}$ CHEVALIER \& GHEERBRANT, 1994: 576.

${ }^{27}$ GUIMARÃES, 2006: 24.
} 
Mas, como é de seu apanágio, não se fica pela descrição simples do quadro. Vai muito mais além, como veremos de seguida.

\section{SUICIIDIO DE SÉNECA}

É no meu braço que uma veia se torna mais secreta. Ali posso encontrar a ferida que tinha a mim mesmo prometido. O tempo passa devagar como se nele uma ordem tivesse sido dada em vão. Agora está distante uma praia. Podemos julgar que a dor é a última das promessas. Deixo que se estenda o olhar para as ondas que ficaram imóveis. De nada podiam a areia e esta água ser acusadas. A respiração é a única maneira que tenho ainda de conspirar. Alguém espera o silêncio completo, o instante concedido a uma maior fidelidade. Serei eu mesmo? A verdade é fria. O meu sangue também. A morte já causou os seus estragos. Nada se compara aos seus leves combates. Mas eu não encontro quem possa ser o meu inimigo, porque já me confronto com uma espécie de vazio, a [sombra última que desce ao longo de mim mesmo. Assim principio a sentir apenas como se torna cada vez maior o abandono. A luz do dia há de ficar oculta nos meus olhos. Só as pálpebras é que veem; reconhecem a curva discreta do conhecimento, o seu significado. Tudo se esbate nesses confrontos que foram talvez inexistentes. De nada mais preciso.

Estamos perante um quadro que representa a morte. Morte como separação, como afastamento de tudo, enfim, uma morte tida como angústia individual própria do mundo cristão revisitado, mais uma vez, por Fernando Guimarães.

À semelhança do que acontece no quadro, a figura de Séneca chama a atenção do leitor, mais especificamente o seu braço, onde «uma veia se torna mais secreta». Sabemos que Séneca fez parte da conspiração de Piso que planeou o atentado contra Nero, o Imperador, uma vez que o filósofo pretendia tornar-se Imperador de Roma. Como foi descoberto, apenas lhe restou o suicídio. A metáfora utilizada pelo sujeito poético, ao referir-se à veia que «se torna mais secreta», pretende relevar uma morte lenta. Não será por acaso que o poeta escolheu o braço do filósofo como uma das partes mais importantes do seu corpo. Os membros superiores do corpo humano simbolizam a força e o poder, que agora começavam a desvanecer-se. É interessante convocar neste ponto a conceção simbólica que os Bambaras tinham do braço: na sua ótica, o braço era um prolongamento do espírito. Ora, o que concluímos, tanto ao observar o quadro de Giordano como ao ler o poema de Fernando Guimarães, é que o espírito de Séneca luta ainda contra a morte (ou contra os seus efeitos), seja na derradeira lição que dá aos discípulos, seja nos seus últimos pensamentos dotados de uma profundidade estoica surpreendente. São eles que, como veremos, mostram 
um homem (que se assume como o sujeito poético, pelo recurso à primeira pessoa) impassível na dor, firme no sofrimento, corajoso na adversidade, grandioso e digno face à inevitabilidade da morte (sustine et abstine, a máxima que deverá servir de chave à leitura do poema). No mesmo sentido, o sangue derramado simbolizará o fim da vida, pois este elemento é o seu veículo.

O propósito de Séneca em pôr termo à vida é corroborado pelo verso dois: «a ferida que tinha a mim mesmo prometido». A ferida de morte teve a sua origem na opção do filósofo, que foi voluntária. O homem é o dono da sua própria vida. A partir daí, nada mais pode fazer. E a dor que daí resulta é «a última das promessas», pois é ela que o acompanhará até ao fim. No entanto, aquilo que poderia ser uma questão de segundos, parece demorar uma eternidade: «O tempo passa devagar». E o poeta chega mesmo a duvidar da eficácia do seu ato: «como se nele [no braço] uma ordem tivesse sido dada em vão».

Como num delírio, o sujeito poético refere-se a uma praia muito distante e o seu olhar prende-se nas «ondas que ficaram imóveis.» A distância e a imobilidade de um elemento natural - as ondas - não se coadunam com a sua essência e parecem querer mostrar-nos o doloroso afastamento de Séneca do mundo que o vira nascer. O mar simboliza a dinâmica da vida. Ora, sem movimento não há vida.

É a dor que, apesar de suportada com coragem, domina todo o poema. A simples enumeração de vocábulos carregados de uma carga simbólica relacionada com o sofrimento é disto exemplo: «ferida», «fria»; «estragos»; «combates»; «vazio»; «sombra»; «abandono»; «oculta». No mesmo sentido, perpassa pelo texto um conjunto de termos relacionados com a luz. Há uma espécie de penumbra que se aproxima e envolve toda a cena descrita. Esta sombra (a própria morte), aqui associada ao vazio, executa um movimento de cima para baixo, atingindo todo o corpo de Séneca. Por outro lado, o que resta da luz do dia vai ficar apenas «oculto» nos seus olhos. E acrescenta: «Só as pálpebras é que veem; reconhecem a curva/discreta do conhecimento, o seu significado». Nada mais restará da sua vida, apenas memórias, recordações do que foi vivido anteriormente. É por isso que a luz que desce, o dia que termina, a noite que se aproxima esbatem os contornos, os do seu próprio corpo, os da sua própria vida.

A morte será, portanto, a singular realidade e, para além dela, nada mais interessa: os inimigos, as acusações, as pelejas. As forças começam a perder-se. Num dado momento, afirma-se: «A respiração é a única maneira/que tenho ainda de conspirar.» Notemos a expressividade do vocábulo «ainda» que torna a respiração, símbolo da vida, algo passageiro, efémero, prestes a acabar. $\mathrm{O}$ «abandono» que afirma sentir será a única certeza a partir desse momento.

Este poema desprovido de preocupações versificatórias é o exemplo de um discurso plangente, emotivo e triste que aborda a morte como o estado final do homem. Neste 
sentido, poderá servir como modelo de uma das inúmeras vertentes da poética de Fernando Guimarães que se apresentam nesta sua última obra.

O exercício ekphrástico não pode limitar-se ao estudo que acabámos de empreender, quando refletimos sobre poemas que descrevem ou interpretam objetos pictóricos. Existe um outro conjunto de interessantíssimos textos produzidos por Fernando Guimarães que, partindo da observação de um determinado objeto artístico, se concentram, sobretudo, numa reflexão em torno da pintura enquanto processo de representação. Sendo um rascunho de apropriação do mundo, a representação implica uma tradução do exterior através de uma linguagem, uma mediação que se consubstancia na distância, mas funciona também como a proximidade possível. Comprovaremos, de seguida, que a atenção do poeta recairá sobre as possibilidades intrínsecas à imagem de representar o mundo, isto é, os textos encontrar-se-ão impregnados de elementos que permitirão uma reflexão ulterior sobre as possibilidades e/ou limitações da representação pictórica. A arte visual exalta-se como criadora de uma imagem e não como a sua mera reprodutora. A tarefa do poeta consiste em procurar a imagem reveladora: não a reprodução do real, senão a vontade de mostrar o que no real se esconde. Elogia-se, assim, a arte pictórica enquanto revelação. O sujeito poético passa por um processo de aprender a ver e de se opor ao mais fácil, que seria o reconhecimento imediato. Assim, não podemos entender, neste contexto, a revelação da natureza, mas a metáfora daquilo que pode ser entendido como a do seu idêntico. Pelo fazer específico do desenho, o poeta chama a si uma presença outra das coisas que só se consegue a partir da imaginação, ao construir-se imagens para além das que se nos deparam quando contemplamos um objeto pictórico.

A paixão que o poeta sente pela imagem é a consequência de uma capacidade de representar o que está para além das meras formas exteriores, resultando, deste modo, numa revelação. Assim, urge entender a capacidade poética de dizer o que as imagens artísticas mostram para além das suas formas. A fidelidade do sujeito poético reside não na imagem, mas na sua verdade. No entanto, a revelação que o poeta experimenta quando observa a obra de arte é oposta à palavra. O texto só pode, portanto, mostrar o que lhe falta para recuperar a anterior experiência do olhar que resulta de uma tensão entre a presença das coisas que eles possibilitam e a própria ausência delas que eles igualmente são.

Com o firme propósito de ilustrar as afirmações acima explanadas, propomos a análise do poema intitulado "Arshile Gorki» ${ }^{28}$. Desta vez, não temos referência a nenhuma obra em particular, mas apenas ao pintor Vosdanik Adoian que nasceu em 1904, na Arménia, e que, com 16 anos, emigrou para os Estados Unidos da América, depois de ter começado a estudar arte arménia no seu país natal. Já em solo americano, continua os seus estudos numa escola de design. Em 1924, surge o seu primeiro quadro assinado com

${ }^{28}$ GUIMARÃES, 2006: 37. 
o pseudónimo que escolhera (Arshile Gorki). Pintor multifacetado, recebeu influências de várias escolas como o Impressionismo, o Cubismo e até o Surrealismo. Parte da sua vasta obra perde-se num incêndio. Acaba por se suicidar, impossibilitado de pintar pela doença e por um terrível acidente que lhe paralisara o braço.

\section{ARSHILE GORKI \\ Nos seus quadros por vezes ele usava o sumo de maçãs. Misturava-o com as tintas. Há quem pense que a acidez criava uma tonalidade inesperada. Não nos devemos espantar. Os pintores antigos sempre procuraram na natureza certos pigmentos, colorações raras. A própria terra, pólenes, óxidos e quantas outras substâncias... Era assim. Mas no caso de Gorki havia uma diferença. Em cada quadro podíamos sentir um odor conhecido. Ele chegava dos campos, dos jardins. Era trazido por um vento inesperado e circular que fazia estremecer as cores, um pouco aquecido pela incidência tranquila dos nossos olhos. Aproximava-se então o que talvez fosse a seiva, a sua transparência, esta humidade que lhe era anterior e devagar se espalha pelas telas. Havia pequenas flores num tronco erguido. Alguns frutos inexistentes abriam-se em duas metades. Podíamos conhecê-las melhor, agora divididas por veios ali misteriosamente desenhados. Na polpa ainda se reúnem as mesmas ondas; tornaram-se maiores, mas de súbito [chega o seu último movimento. As cores que nelas existem são iguais às dos quadros que depois se inclinaram em nossa direção. Oscilam um pouco mais e sente-se o seu odor quando se confundem com uma nova, estranha luminosidade. Vemos ainda mais próximos esses frutos. Apenas as sementes são por nós pensadas.}

Nesta composição, notamos que o autor se preocupa em fazer uma reflexão sobre a pintura, no caso, a de Gorki, enquanto processo de representação. Através de uma narratividade própria dos seus escritos, parecerá ao leitor mais incauto que estamos perante um texto que nada tem a ver com a poesia. No entanto, uma leitura mais atenta permitir-nos-á verificar que, para além do versilibrismo, o texto está repleto de recursos poéticos que o tornam numa das mais interessantes composições de Fernando Guimarães.

Ao longo dos versos do poema, é possível comprovar o objetivo do sujeito poético ao exaltar a imagem reveladora dos quadros de Gorki. Não é a reprodução do real que se pretende, como acima referimos, mas a revelação do que se esconde nesse mesmo real. Visa uma desocultação. Deste modo, inicia o poema uma referência à técnica que foi usada por Gorki na criação dos seus quadros: misturava sumo de maçã com as tintas com o objetivo de encontrar «colorações raras», o que parecia ser prática comum. No entanto, o poeta chama a nossa atenção, como se de uma conversa com o leitor se tratasse, daí o recurso à primeira pessoa, para a singularidade deste pintor. É aqui que ocorre uma 
espécie de transfiguração, ao serem invocadas sensações que saem do quadro e chegam até nós (ao poeta, numa primeira instância, depois a nós leitores por seu (inter)médio). E, numa espécie de euforia sinestésica, o poeta refere-se ao odor exalado pelo quadro que parece ser "conhecido», isto é, que presentifica uma realidade familiar a cada um de nós pela nossa experiência do mundo; mais tarde, refere-se às cores «estremecidas» por um vento que transportara o odor. E tudo isto acontece perante os olhos do poeta que, no momento presente, se tornam nossos também: «um pouco aquecido [o vento] pela incidência tranquila/dos nossos olhos». Existe neste texto aquilo que poderíamos designar por uma aprendizagem de ver, incisiva, persistente, apta a negar o reconhecimento imediato das coisas. E só deste modo tudo o que é observado ganha vida: há referências à «seiva», à "humidade» que eram anteriores ao quadro agora contemplado. Acresce ainda a menção às «flores»e, de seguida, aos «frutos» que delas resultam. Tudo isto só foi possível graças a um vento genesíaco que parece surgir como sinónimo de sopro, de influxo espiritual, divino, que esteve na origem primeira da criação da vida.

Progressivamente, descobre-se, nas formas desenhadas dos frutos que se abriam «em duas metades», um certo rigor enigmático até para o poeta: «Podíamos conhecê-las [às metades] melhor,/agora divididas por veios ali misteriosamente desenhados». A referência ao número dois poderá ter a ver com o dualismo sobre o qual são apoiadas as dialéticas relativas a movimentos, progressos, realidades como as que são apresentadas no poema. Não esqueçamos que a divisão tanto pode ter a ver com a multiplicação como com a síntese. E talvez seja essa a intenção do poeta ao revelar a realidade do quadro observado e os efeitos por ela produzidos.

O processo metafórico conseguido a partir de uma realidade que se cria (não esqueçamos os «frutos/inexistentes» que se «abriam em duas metades.») não resulta de uma presentificação/representação da natureza, mas de uma realidade que se agiganta ( «Na polpa/ainda se reúnem as mesmas ondas; tornaram-se maiores») e que se transfigura aos seus olhos, como se tudo tivesse, agora, uma outra presença. Tudo o que se observa é interior, ultrapassa as formas exteriores do quadro e ganha visibilidade através do olhar para dentro das coisas, das «telas», dos «frutos», dos «veios», das «ondas».

De repente, porém, esta espécie de miragem que o sujeito poético experimenta termina: "mas de súbito chega/o seu último movimento.» Tudo parece voltar à sua tranquilidade original (ou morre). Restam assim as sementes que «são por nós pensadas». Sementes dos frutos «inexistentes»; sementes do interior dos frutos que, em metades, as revelam; sementes que guardam em si a vida que poderá originar um novo ciclo da natureza, uma nova revelação dada pela obra de arte.

Relativamente à linguagem utilizada, cabe aqui um pequeno apontamento respeitante ao campo lexical da pintura («quadros»; «tintas»; «tonalidade»; «pintores»; «telas»), que aqui aparece majorado, de forma a comprometer o texto com o exercício ekphrástico que o motivou. 
Em jeito de conclusão destas breves considerações em torno da obra de um autor que aprendemos a admirar, cumpre-nos acrescentar que, quando falamos de Literatura e da sua relação com as Artes Plásticas, não podemos deixar de relevar a possibilidade que a escrita literária tem de figurar, o que lhe permite originais verbalizações. O sujeito poético acede assim a outras possibilidades de identidades que favorecem a sua perceção do mundo que o rodeia e de si próprio. O texto resultante da confluência das diversas artes, sobretudo no que respeita à ligação da poesia com a pintura, torna-se um instrumento dessa aproximação e deverá ser entendido como tal.

O nosso propósito ao conceber o presente estudo não se prendeu com uma análise exaustiva de todos os textos de Fernando Guimarães que têm uma ligação íntima com um qualquer exercício ekphrástico, mas apenas com uma tentativa de exemplificar a mestria do autor ao enveredar por este caminho. Deste modo, os textos analisados resultaram de uma seleção que se fundou em questões de gosto pessoal, tendo em conta a especificidade do trabalho que não permite uma análise mais prolongada de outros textos. Deste modo, pudemos abordar composições que possuem como referente a pintura e outras que refletem sobre pintura enquanto processo de representação.

O trabalho que agora se conclui é apenas um pequeno e modesto esboço suscetível de posteriores correções e atualizações. Assim, esperamos que este estudo, ao convocar uma tradição poética e reflexiva largamente difundida nos países anglo-saxónicos, possibilite uma tomada de consciência de que a ekphrasis começa a atrair cada vez mais poetas portugueses que ensaiam com mestria este exercício, produzindo verdadeiras obras de arte como as que encontramos em Fernando Guimarães, poeta multifacetado em cuja obra não faltam motivos para o considerarmos um dos maiores escritores contemporâneos.

\section{BIBLIOGRAFIA}

AGUIAR E SILVA, Vítor Manuel (1990) - Teoria e Metodologia Literárias. Lisboa: Universidade Aberta. ANDREW, Benjamin (1993) - Art, Mimesis and the Avant-garde. London/New York: Routledge.

ARHEIM, Rudolf (1989) - Intuição e Intelecto na Arte. São Paulo: Martins Fontes.

AUERBACH, Erich (1946) - Mimésis - La Représentation de la Realité dans la Littérature Occidentale. Paris: Editions Gallimard, 1946.

AVELAR, Mário (2006) - Ekphrasis, O Poeta no Atelier do Artista. Lisboa: Edições Cosmos.

BARTHES, Roland (1968) - L’effet de réel. "Communications. 11: Recherches Sémiologiques Le Vraisemblable», p. 84-89.

BECKER, Andrew (1995) - The Shield of Achilles and the Poetics of Ekphrasis. Boston: Rowman \& Littlefield Publishers Inc.

BENJAMIN, Andrew (1991) - Art, Mimesis and the Avant-Garde. New York: Routledge.

CHEVALIER, J.; GHEERBRANT, A. (1994) - Dicionário dos Símbolos. Lisboa: Teorema.

DENHAM, Robert (2010) - Poets on Paintings - A Bibliography. London: McFarland \& Company, Inc., Publishers.

ECO, Umberto, org. (2004) - História da Beleza. Lisboa: Difel. 
GARCÍA BERRIO, A.; HERNÁNDEZ FERNANDEZ, T. (1988) - Ut Poesis Pictura, Poética del Arte Visual. Madrid: Ed. Tecnos.

GEBAUER, Gunter; WULF, Christoph (1995) - Mimesis: Culture, Art, Society. Los Angeles: University of California Press.

GUIMARÃES, Fernando (2003) - Artes Plásticas e Literatura. Porto: Campo das Letras. (2006) - Na Voz de um Nome. Lisboa: Roma Editora.

HAMON, Philippe (1989) - Expositions: Littérature et Architecture au XIXe siècle. Paris: José Corti.

HEFFERNAN, James (1991) - Ekphrasis and Representation. «New Literary History», vol. 22, n. ${ }^{\circ} 2$. Baltimore: The John Hopkins University Press.

HOLLANDER, John (1988) - The Poetics of Ekphrasis. «Word \& Image: A Journal of Verbal/Visual Enquiry», vol. 4, n. ${ }^{\circ}$ 1, p. 209-219.

HONORATO, Manuel da Costa (1879) - Retórica e Poética. Rio de Janeiro: Tipografia Cosmopolita.

HORÁCIO (1984) - Epístola aos Pisões. Trad. R. M. Rosado Fernandes. Lisboa: Editorial Inquérito.

KENNEDY, George A. (2003) - Progymnasmata: Greek Textbooks of Prose Compositions and Rethoric. Leiden: Society of Biblical Literature.

LESSING, Gotthold Ephraim (1766) - Laocoon. London: George Routledge \& Sons, Limited.

LICHETENSTEIN, Jacqueline (1994) - A Cor Eloquente. São Paulo: Siciliano.

MICHAEL, Davidson (1983) - Ekphrasis and the Postmodern Painter Poem. «Journal of Aesthetics and Art Criticism», vol. 41, n. ${ }^{\circ}$ 1. Moorhead: Wiley.

MITCHEL, W. J. T. (1980) - The Language of Images. Chicago: University of Chicago Press.

PAZ, Octavio (1993) - A Outra Voz. São Paulo: Siciliano.

PRAZ, Mário (1982) - Literatura e Artes Visuais. São Paulo: Cultrix.

REYNAUD, Maria João (2004) - Sentido Literal - Ensaios de Literatura Portuguesa. Porto: Campo das Letras.

RIFFATERRE, Michael (1994) - L'Illusion d'Ekprasis. In La Pensée de l'Image: Signification et figuration dans le texte et la peinture. Paris: Presses Universitaires de Vincennes.

ROBILLARD, Valérie (1998) - Pictures into Words: Theoretical and Descriptive Approaches to Ekphrasis. Amsterdam: VU University Press.

SCOTT, Grant F. (1987) - The Sculpted Word: Keats, Ekphrasis and the Visual Arts. Hanover: Press of New England.

SOURIAU, Étienne (1969) - La Correspondance des Arts. Paris: Flammarion.

SPITZER, Leo (1955) - Essays on English and American Literature. Princeton: Princeton University Press.

STEINER, W. (1992) - The Colors of Rhetoric. Chicago: The University of Chicago Press.

WAGNER, Peter, ed. (1996) - Icons - Texts - Iconotexts, Essays on Ekphrasis and Intermediality. Berlin and New York: De Gruyter.

WALTON, K. L. (1990) - Mimesis as Make-believe. New York: Harvard University Press.

WELLEK, René; WARREN, Austin (1962) - Teoria da Literatura. Lisboa: Publicações Europa-América. 


\title{
MENINAS, DE MARIA TERESA HORTA: UMA GENEALOGIA MELANCÓLICA
}

\author{
MARIA GRACIETE BESSE*
}

\author{
... il n'est pas d'écriture [...] qui ne soit, \\ ouvertement ou secrètement, mélancolique. \\ Julia Kristeva, Soleil Noir \\ Depois das palavras estão as palavras. \\ Maria Teresa Horta, Meninas
}

Alguns autores contemporâneos mobilizam as temáticas da genealogia, da filiação e da herança como forma peculiar de remeter para as origens e de auscultar os laços familiares, ou a sua falência, interrogando uma identidade biológica e cultural quase sempre acompanhada por uma nova consciência do tempo. A inscrição numa genealogia implica e impõe um modelo arborescente cujo eixo prioritário é vertical. Se esta questão interessa desde sempre a literatura e conduz numerosos escritores a descrever a sua saga familiar, é contudo a partir de 1980 que, segundo Dominique Viart, as narrativas de filiação se começam a impor de forma diferente no panorama literário, enquanto sintoma de uma época ${ }^{1}$. Para o crítico francês, ao contrário da vontade de rotura inscrita nas vanguardas, a escrita pós-moderna revela uma certa preocupação arqueológica, questionando obsessivamente a ascendência familiar, de forma a «escolher» uma herança que, como observa Derrida, resulta sempre de um trabalho meticuloso ${ }^{2}$. Assim, ao entrar em diálogo com os espectros do passado, a narrativa de filiação interroga a memória das origens, muitas vezes de forma oblíqua, com o objetivo de melhor compreender a estruturação psicológica do sujeito e a sua construção identitária pois, ao evocar os seus familiares, nomeadamente os pais e os avós, o escritor fala sobretudo de si próprio, apresentando-se ao mesmo tempo

\footnotetext{
* Université Paris-Sorbonne/Centre de Recherches Interdisciplinaires sur les Mondes Ibériques Contemporains.

${ }^{1}$ VIART, 1999.

${ }^{2}$ DERRIDA, 1993.
} 
«despossuído da sua inscrição genealógica e possuído pelas vidas anteriores da sua ascendência», ou seja, identificando-se como um «herdeiro problemático» dotado de uma assinalável tonalidade melancólica, como já observou Laurent Demanze 3 .

A categoria filosófica, psicológica e estética da melancolia, favorecida por Saturno, o planeta do espírito e do pensamento, remete, desde a Antiguidade, para o que Hipócrates designa como a bílis negra, que reflete a estrutura de uma sensibilidade desequilibrada. A melancolia sofre uma mutação profunda na Idade Média em que os monges cultivam a acedia, utilizando-a como «um meio de conhecimento paradoxal da verdade divina», segundo Julia Kristeva ${ }^{4}$. Na perspetiva de Agamben, os doutores da Igreja colocam a acedia sob o signo da tristeza angustiada e do desespero ${ }^{5}$. Por seu lado, os românticos sublimam a melancolia enquanto estado de exceção genial. A ambiguidade do conceito de melancolia, que significa tanto uma desordem como uma superioridade intelectual, também interessou Jean Starobinski (2012), para quem a experiência melancólica atravessa toda a cultura ocidental, caracterizando-se por uma perda fundamental e por um sentimento de abandono, o que levou Freud a associar a melancolia a uma «hemorragia interna do eu» e ao luto impossível do objeto materno que parece não ter fim ${ }^{6}$.

É justamente este luto interminável que alimenta Meninas ${ }^{7}$, o volume de contos de Maria Teresa Horta, que se apresenta como uma travessia do sofrimento infantil sob a forma de uma catarse marcada pelo desamor materno, causador de uma grande violência afectiva. Na opinião de Agripina Carriço Vieira, nenhuma obra da autora «se dedicou de modo tão completo e intenso ao tempo da infância e da adolescência», apresentando «múltiplas facetas duma mesma personagem, a de uma menina que, à semelhança de Lilith, recusa ver a sua liberdade tolhida por qualquer ordem ou ascendência» ${ }^{8}$. Através de uma prosa intensamente poética, a presença fantasmática da figura materna funciona neste livro como objeto de incorporação e de ex-corporação (Jean-Luc Nancy), num tempo cristalizado pela dor que se partilha entre diversos fragmentos, cuja temática é recorrente, como se a narradora tivesse necessidade de repetir obsessivamente o laço doloroso que a liga a uma mãe inquietante, fortemente

\footnotetext{
${ }^{3}$ DEMANZE, 2009: 11-23. Consultar ainda DEMANZE, 2008.

${ }^{4}$ Segundo Julia Kristeva (KRISTEVA, 1987: 18), «les moines cultivent la tristesse: ascèse mystique (acedia), elle s'imposera comme moyen de connaissance paradoxale de la vérité divine et constituera l'épreuve majeure de la foi». ${ }^{5}$ AGAMBEN, 1994: 25.

${ }^{6}$ Para Freud (FREUD, 1968: 158), «La mélancolie emprunte [...] une partie de ses caractères au deuil et l'autre partie au processus de la régression à partir du choix d’objet narcissique jusqu'au narcissisme. Elle est, d'une part comme le deuil, réaction à la perte réelle de l'objet d’amour, mais, en outre, elle est marquée d'une condition qui fait défaut dans le deuil normal ou qui transforme celui-ci en deuil pathologique lorsqu'elle vient s'y ajouter».

${ }^{7}$ HORTA, 2014.

${ }^{8}$ VIEIRA, 2014: 13. Consultar também a recensão de Ana Raquel Fernandes (FERNANDES, 2015).
} 
sexualizada, e que se revela afinal mais mulher do que mãe $e^{9}$ No entanto, a postura melancólica da menina privada do amor materno pressupõe um sujeito sempre aberto à alteridade que se encontra no âmago da sua própria identidade.

Dividido em duas partes, o livro compreende 32 contos e um poema final, formando um todo orgânico e coerente em que as figuras infantis dialogam entre si mas também com personagens oriundas de diferentes universos artísticos e literários, como Henri Rousseau, Edward Burne-Jones, Shakespeare, Flaubert, Virginia Woolf, entre muitos outros. A partir de uma epígrafe de Clarice Lispector, outra figura da filiação, desta vez literária, a autora apresenta-nos uma série de meninas dominadas pelo traumatismo da mãe-morta que se encontra na base de grande parte dos contos, nomeadamente naqueles que se inserem na primeira parte do volume. O conceito de mãe-morta, desenvolvido por André Green, designa o desinvestimento de uma figura materna fisicamente viva, mas incapaz de amar a criança que faz dela o seu primeiro objeto de desejo amoroso:

L'objet est «mort» (au sens de non vivant, même si aucune mort réelle n'est survenue): il entraîne de ce fait le Moi vers un univers déserté, mortifère. Le deuil blanc de la mère induit le deuil blanc de l'enfant, enterrant une partie de son Moi dans la nécropole maternelle ${ }^{10}$.

A psicanálise ensina-nos que o desinteresse afetivo da mãe alimenta a ferida narcísica da criança que vive no pânico do abandono definitivo e acaba por desenvolver uma fantasmagoria no centro da qual se encontra uma figura materna intensamente idealizada. Ao estudar a relação de objeto, Lacan observa que o primeiro agente da frustração infantil é precisamente a mãe presente-ausente, permitindo a emergência da ordem simbólica que se distingue da relação real mantida com ela enquanto objeto de satisfação ${ }^{11}$. Por seu lado, Agamben considera que, na lógica melancólica, o objecto do desejo torna-se espectral, visto que:

dans la mélancolie, l'objet n'est ni approprié ni perdu mais approprié et perdu simultanément. Et de même que le fétiche est tout à la fois le signe de quelque chose et de son absence, cette contradiction lui conférant son statut fantomatique,

\footnotetext{
${ }^{9}$ Num estudo sobre a relação mãe-filha, Caroline Eliacheff e Nathalie Heinich (ELIACHEFF \& HEINICH 2002: 18) observaram justamente que «Toute femme accédant au statut de mère se trouve confrontée à deux modèles d'accomplissement, correspondant à des aspirations le plus souvent contradictoires: soit mère, soit femme».

${ }^{10}$ GREEN, 1994: 248.

${ }^{11}$ LACAN, 1994.
} 
de même l'objet visé par la mélancolie est en même temps réel et irréel, incorporé et perdu, affirmé et nié12.

Semelhante a uma Penélope moderna, Maria Teresa Horta vai tecendo, ao longo dos seus contos, uma teia de lembranças onde se inscreve um sofrimento precoce, ressuscitando assim a temporalidade descentrada da infância, de forma a revelar a «substância invisível do tempo» (Proust) a partir de situações recorrentes, evocadas por diferentes sensações sempre reativadas por cheiros, gestos, ruídos, e também pela tensão de um olhar espião que perscruta obsessivamente a figura materna, fascinante e demolidora, sobretudo na primeira parte do livro. A busca genealógica inclui ainda um pai distante, uma irmã de poucos meses e uma avó carinhosa, que funcionam como personagens secundárias, evocadas episodicamente.

Através de uma escrita extremamente fluida, que respeita a parataxe da emergência das reminiscências e o jogo das associações, Maria Teresa Horta resgata da sua memória mais íntima um segredo em que se enredam tanto o enlevo por uma mãe belíssima, sensual, insatisfeita e cruel, como as experiências que agravam a frustração infantil, fazendo alternar a primeira e a terceira pessoa, para desenhar uma justaposição de retratos de meninas mal amadas, por vezes insubmissas, pertencentes tanto ao domínio privado como ao espaço coletivo de que é exemplo a princesa Carlota Joaquina, protagonista de vários contos da segunda parte do livro, intitulados respetivamente $O$ retrato, A princesa espanhola, Inocência perdida e $A$ infanta princes $a^{13}$. A insistência nesta figura histórica acentua a solidão mas também a capacidade de rebeldia da menina de dez anos, caracterizada como «esquiva» (p. 197) e «venenosa» (p. 200) que, com a chegada da primeira menstruação, perde a sua liberdade e é obrigada a partilhar o leito conjugal. Numa entrevista dada pouco depois da publicação do seu livro, Maria Teresa Horta sublinha:

As meninas da primeira parte são eu, as da segunda também têm partes de mim, mas são sobretudo o reflexo daquilo que se tem feito ao longo dos séculos a várias meninas. A violência, por exemplo, em relação a uma Carlota Joaquina que as pessoas habitualmente detestam, esquecendo-se de que foi arrancada da sua casa, da sua família, do seu país e da sua língua para vir para Portugal, um país cheio de missas e de promessas e de rezas que ela não percebia, e casar-se com um monstrinho que era o D. João VI. Essa menina do retrato não tem nada que

\footnotetext{
${ }^{12}$ AGAMBEN, 1994: 49-50.

${ }^{13}$ Notemos que, na primeira parte do volume, no conto intitulado Efémera se encontra já uma breve evocação de Carlota Joaquina, quando durante um passeio com a mãe no Terreiro de Paço, em pleno mês de Agosto, a menina evoca a jovem princesa «que à socapa ia molhar os pés no Tejo» (p. 58)
} 
ver comigo, a não ser no desafio que também senti toda a vida: fazer aquilo que considero que tenho de fazer, doa a quem doer e doa-me a mim também ${ }^{14}$.

Apesar de serem caracterizadas por uma multiplicidade de nomes (Lucinha, Raquel, Matilde, Laura, Sara, Teresinha, etc.), todas estas crianças frágeis, solitárias e mal-amadas, revelam uma projeção autobiográfica da escritora e surgem como reminiscências do mito de Cronos, permitindo-nos estabelecer uma relação entre a melancolia e o que Starobinski designa como o styx íntimo, esse espaço do inferno infantil em que a criança se sente rejeitada ou devorada pela própria mãe, vivendo entre a abjcção e a sublimação.

Os 17 fragmentos que compõem a primeira parte do livro obedecem a uma cronologia bem definida, começando com a experiência da menina antes do nascimento (Lilith). Nesse momento deliciosamente fundador, o corpo a corpo com a mãe cria a unidade primitiva, mas logo a narradora intervém com um comentário metatextual para observar que «nesta história de amor e de morte» (p. 17), o ódio transforma o nascimento em luta com o corpo materno, enquanto a representação de Lilith salta da pintura de Henri Rousseau para «dialogar com os tigres» (p. 18). A figura mítica da primeira mulher de Adão corresponde a uma maldição mas também a uma afirmação de revolta que se vai manifestar noutros textos. O segundo conto (Daninha), mostra novamente a menina enclausurada no ventre materno, enquanto o discurso mobiliza novas figuras míticas (Deméter, Proserpina, Ariane) e remete para a ideia de uma escrita salvadora, capaz de reparar a melancolização dos laços familiares. Logo depois, em Recém-nascida, a menina encontra-se no seu berço e o primeiro olhar da mãe revela imediatamente a distância, provocando nela o medo do abandono e uma imensa «sensação de falha» (p. 32).

$O$ retrato que a narradora desenha da mãe aponta para uma mulher de grande beleza, toldada contudo por um certo sofrimento: «cabelo dourado [...] face macerada e muito pálida. Olheiras pisadas a afundarem-lhe o olhar de genciana azul» (p. 31), dando a entender ao leitor que a relação mãe-filha é parasitada pela condição sentimental de uma esposa que deixou de amar o pai da criança e acaba por sair de casa com um amante (Lápis-lazuli). Antes da partida da mãe, a menina espreita a cena primitiva por uma nesga da porta do quarto conjugal, vendo os corpos dos pais entrançados, ouvindo os gritos, os gemidos e o «rugido selvagem» (p. 69), que a leva a vomitar de nojo no conto mais erótico do livro (A espia).

Maria João Reynaud observa que, na poesia de Maria Teresa Horta, o erotismo começa por ser a denúncia da repressão sexual que pesa sobre a mulher, mas é também um discurso do prazer que, durante séculos, foi exclusivo do masculino, «não só dentro

${ }^{14}$ Entrevista de Maria Teresa Horta conduzida por Catarina Pires (2014). 
de uma ordem social e política discriminatória, mas também, e sobretudo, no interior de uma ordem simbólica, onde a própria linguagem é um instrumento de opressão» ${ }^{15}$. Para além desta afirmação do corpo na escrita, a narradora de Meninas estabelece frequentemente uma relação especular com a mãe, que se revela fundamental para a construção da sua própria identidade. Em Abismo, a figura materna é definida por uma «beleza rutilante iluminada pela chama do ódio» (p. 53), comparada a uma «loba jovem» (p. 54). Neste texto, Maria Teresa Horta mobiliza, com grande subtileza, o mito de Medeia, para inscrever um segredo tenebroso, em que a menina constata que a mãe mortífera, caracterizada como «mais inimiga do que mãe [...] sem compaixão pendura a filha do lado de fora do parapeito de mármore» (p. 52), com o intuito de a matar, num gesto de loucura afinal sem consequências dramáticas.

Através destes contos marcadamente autobiográficos, que se desenrolam no espaço solar lisboeta ou numa ilha dos Açores, Maria Teresa Horta apresenta uma menina que poderíamos considerar em excesso de mãe, capaz de idealizar a figura materna ao ponto de a imaginar «a emergir das águas como Vénus» (p. 83) ou ainda de a incorporar, engolindo as suas cartas (Perecível). Através de uma nova reflexão metatextual, a narradora confessa: «Mais tarde soube que um dia escreveria esta história, apesar de para isso ter de regressar ao inferno» (p. 112). Ao fazer da filiação uma "herança sem testamento» ${ }^{16}$, a escrita procura, entre memória e invenção, os índices do que foi quebrado, mas demonstra também uma arte de manter o fio e, ao mesmo tempo, de o cortar, graças à anamnese melancólica, que se revela, afinal, como uma experimentação multiplicadora do sujeito e uma manifestação da criatividade literária.

Para além da herança entendida como uma escolha ${ }^{17}$, Maria Teresa Horta propõe também ao leitor uma reflexão sobre a condição feminina enquanto arquipélago da submissão ancestral. Nesta perspetiva, a filiação pode contribuir para a desconstrução dos esquemas fixos da genealogia, de forma a preservar a diversidade, criando um processo de filiação baseado justamente na figura do arquipélago ${ }^{18}$, como pretende François Noudelmann, ao observar que:

Penser la filiation, c'est peut-être rechercher [...] la manière dont chacun [...] donne sens mais aussi la déplace, comment il participe au travail de représentation imaginaire, et comment à partir de ces schèmes il construit ses appartenances, ses relations au sein de sa supposée famille, de sa supposée communauté, de sa supposée humanité19.

\footnotetext{
${ }^{15}$ REYNAUD, 2001: 3.

${ }^{16}$ COLLIN, 1986.

${ }^{17}$ Consultar a este propósito DERRIDA, 1987: 417.

${ }^{18}$ No sentido de LYOTARD, 1983: 190.

${ }^{19}$ NOUDELMANN, 2004: 17.
} 
O percurso linear da narrativa de Maria Teresa Horta faz alternar uma tentação autobiográfica com um exercício de autoficção ${ }^{20}$, na medida em que a escritora, consciente das aporias da memória, procede por vezes a um deslocamento do sujeito, graças à ficcionalização das situações evocadas, criando uma outra forma de linhagem em que resgata, nos 15 fragmentos da segunda parte do volume, uma série de figuras históricas, como a princesa Carlota Joaquina, Erzsébet, a condessa sangrenta, «precoce aprendiza de feiticeira» (p. 156), ou ainda Kate Lewis, a menina pintada por Edward Burne-Jones, que aprendeu «a ler sozinha» (p. 233) e tanto fascinou Oscar Wilde, amigo de seu pai. Paralelamente à filiação biológica, Maria Teresa Horta recorre portanto a um outro tipo de linhagem, de ordem cultural, implicando uma relação intertextual com uma série de artistas bem conhecidos e com textos canónicos como a Bíblia ou o conto de fadas (Branca de Neve). Desta forma, a genealogia confronta a narradora dos diferentes contos com o reencontro e com a perda, projetando-a num ato sacrificial necessário, em que a impossibilidade de viver se transforma em possibilidade de dizer, mostrando ao leitor que a melancolia pode afinal revelar-se catártica e criativa.

A figura materna, de olhos prodigiosamente azuis, sempre indiferente à carência afetiva da filha que a espia com verdadeira adoração, faz parte de uma obsessão que atravessa grande parte da obra de Maria Teresa Horta ${ }^{21}$, saturada de escombros e de pequenas epifanias. No entanto, a tonalidade melancólica da sua escrita não se equaciona apenas como abatimento ou tristeza, mas apresenta-se também como uma forma de lucidez que se transforma em energia criadora ${ }^{22}$. A pulsão genealógica, tão presente em Meninas, revisita melancolicamente os arquivos da infância e os segredos familiares para revelar que a origem pode conduzir a um pousse-à-écrire (Lacan), isto é, a uma construção discursiva dotada de um estimulante potencial artístico.

Se durante muito tempo se negou às mulheres uma genealogia feminina, na medida em que a sua identidade foi sempre construída em associações ditadas pelo patriarcado, a verdade é que as escritoras contemporâneas começam a subverter cada vez mais a Lei do Pai. Ao analisar algumas obras produzidas por mulheres, Lélia de Almeida identifica uma genealogia temática em que

As mulheres que, historicamente, cumprem com demandas e papéis impostos socialmente, perguntam-se, principalmente ao longo do século passado e no momento presente, quem são, como desejam ser, como não querem mais ser ${ }^{23}$.

\footnotetext{
${ }^{20}$ Na perspectiva de Serge Doubrovsky que forjou este neologismo em 1977 (Fils), a autoficção difere da autobiografia, tal como foi definida por Philippe Lejeune, visto que mobiliza a ficção para traduzir a verdade do sujeito.

${ }^{21}$ Pensamos particularmente nos romances Ema (1984) e A Paixão Segundo Constança H. (1994).

${ }^{22}$ Cf. KRISTEVA, 1987.

${ }^{23}$ ALMEIDA, 2004.
} 
Ao resgatar em Meninas uma dupla herança, biológica e cultural, Maria Teresa Horta inscreve-se claramente nesta linhagem feminina, privilegiando uma melancolia obliquamente subversiva ${ }^{24}$, caracterizada pela sua força de resistência contra a ordem totalitária. Não é certamente por acaso que, no poema final, a escritora nos desafia para o domínio do voo, convidando-nos a «ver um anjo», enquanto «as mães/desesperam» (p. 301), mesmo sabendo que, como diria Rilke, o anjo é sempre o começo do terrível.

\section{BIBLIOGRAFIA}

AGAMBEN, Georgio (1994) - Stanze. Trad. do italiano por Yves Hersant. Paris: Rivages Poche.

ALMEIDA, Lélia de (2004) - Linhagens e ancestralidade na literatura de autoria feminina. «Especulo», n. ${ }^{\circ}$ 26. Disponível em <https://pendientedemigracion.uncm.es/info/especulo/numero26/linhagens. html $>$. [Consulta realizada em 09/06/2015].

COLLIN, Françoise (1986) - Un héritage sans testament. «Les Cahiers du Grif», vol. 34. Bruxelas: Complexe, p. 81-92.

DEMANZE Laurent (2008) - Encres orphelines: Pierre Bergounioux, Gérard Macé, Pierre Michon. Paris: Librairie José Corti. (2009) - Les possédés et les dépossédés. «Études françaises», vol. 45, n. ํ 3, p. 11-23.

DERRIDA, Jacques (1987) - Psyché. Paris: Galilée. (1993) - Spectres de Marx. Paris: Galilée.

ELIACHEFF, Caroline; HEINICH, Nathalie (2002) - Mères-filles. Une relation à trois. Paris: Albin Michel. FERNANDES, Ana Raquel (2015) - Recensão crítica a Meninas de Maria Teresa Horta. «Revista Colóquio/ Letras», n. ${ }^{\circ} 190$ (set.- dez.). Lisboa: Fundação Calouste Gulbenkian, p. 206-209.

FREUD, Sigmund (1968) - Deuil et mélancolie. In Métapsychologie. Paris: Gallimard. GREEN, André (1994) - Narcissisme de vie, narcissisme de mort. Paris: Minuit. HORTA, Maria Teresa (2014) - Meninas. Lisboa: D. Quixote.

KRISTEVA, Julia (1987) - Soleil Noir. Dépression et mélancolie. Paris: Gallimard.

LACAN, Jacques (1994) - Séminaire. Livre IV: La relation d’objet (1956-1957). Paris: Seuil.

LARUE, Anne (2001) - L’Autre Mélancolie: acedia, ou les chambres de l'esprit. Paris: Éditions Hermann. LYOTARD, Jean-François (1983) - Le Différend. Paris: Ed. Minuit.

NOUDELMANN, François (2004) - Pour en finir avec la généalogie. Paris: Léo Scheer.

PIRES, Catarina (2014) - Entrevista a Maria Teresa Horta. «Noticias Magazine». Disponível em <www. noticiasmagazine.pt/2014/maria-teresa-horta/>. [Consulta realizada em 09/06/2015].

REYNAUD, Maria João (2001) - Vozes e Olhares no feminino. Porto: Afrontamento.

STAROBINSKI, Jean (2012) - L'encre de la mélancolie. Paris: Seuil.

VIART, Dominique (1999) - Filiations littéraires. In Ecritures Contemporaines 2. Etat du roman contemporain, La Revue de Lettres Modernes. Paris-Caen: Minard.

VIEIRA Agripina Carriço (2014) - Histórias de meninas em tons de azul. «Jornal de Letras, Artes e Ideias», vol, 24, n. ${ }^{\circ} 12$, p. 13

${ }^{24}$ Esta perspectiva da melancolia foi particularmente desenvolvida por LARUE, 2001. 


\title{
O VELHO E OS LIVROS: PASSAGENS, DE TEOLINDA GERSÃO
}

\author{
ANTÓNIO MANUEL FERREIRA*
}

O título «O velho e os livros» é uma homenagem à famosa novela de Ernest Hemingway, O Velho e o Mar, publicada em 1952. O motivo que subjaz a este título tem duas justificações: em primeiro lugar, gostaria de recordar um dos exemplos universais da representação literária da velhice; e, em segundo lugar, congratular-me como uma época do século passado, ainda não contaminada pela higienização mental, exigida pelo pensamento politicamente correto. Nos nossos dias, a palavra «velho» tem uma carga pejorativa que a torna indesejável em quase todos os discursos, desde a medicina à comunicação social. Apenas nos domínios da arte, «velho» e «velhice» mantêm a dignidade linguística, filosófica e mesmo religiosa que lhes está associada desde as obras fundadoras da cultura ocidental: a Bíblia e os Poemas Homéricos.

Em $O$ Velho e o Mar, Hemingway utiliza sempre a palavra «velho» para se referir ao pescador Santiago; e Manolin, o rapaz que mantém com o pescador uma amizade sem mácula, também trata o amigo por «velho». Nem o escritor, nem as suas personagens demonstram qualquer falta de respeito. Muito pelo contrário, é a partir da noção de velhice como debilitação psicossomática que se constrói a história de resistência, esperança e orgulho que revitaliza o pescador. A luta de Santiago com o espadarte gigantesco e com os tubarões que lho roubam, pedaço a pedaço, é uma espécie de ritual de iniciação às avessas, porquanto este tipo de celebrações costuma ser mais comum na idade juvenil. Creio, todavia, que uma das grandes lições da novela de

* Universidade de Aveiro. 
Hemingway consiste precisamente na necessidade de não apartar a velhice da juventude. O adolescente Manolin diz ter ainda muito que aprender com o velho pescador, e é essa necessidade que lenifica a iminência da morte.

Não há, na novela do escritor norte-americano, nenhum sinal de complacência perante os sintomas do enfraquecimento físico e mental. O pescador sabe perfeitamente que está velho, mas estar velho não significa estar acabado para a vida. Por isso, talvez a frase que melhor sintetiza o diálogo da personagem com o seu corpo e com a natureza, em pleno mar, seja a seguinte: «E agora já não é ocasião de pensar no que não tens. Pensa no que podes fazer com o que há» ${ }^{1}$.

Creio que podemos interrogar as representações literárias da velhice a partir desta frase de Hemingway: «Pensa no que podes fazer com o que há». A noção de «fazer» é muito importante, porque permite estabelecer as diferenças entre duas formas de entendimento da velhice, ambas figuradas na literatura, em interdependência com as transformações socioeconómicas das sociedades ocidentais. Assim, temos, por um lado, as visões filosoficamente humanistas, que, não negando os malefícios da decrepitude, tendem a acentuar valores como a sabedoria, a experiência e o bom senso; e temos, por outro lado, uma visão socialmente assistencialista, que entende o velho como um indivíduo diminuído na sua capacidade de «fazer», ou seja, de interferir ativamente na vida e na ordenação do mundo.

Em termos um pouco simplistas, talvez possamos dizer que o marco que estabelece a fronteira entre as duas visões da velhice é constituído pela expansão dos «lares de idosos». Curiosamente, e de acordo com a ficção literária, nunca a palavra «lar» teve um significado tão desviado do seu sentido original, porquanto é muito difícil encontrar textos que atribuam à palavra «lar» as noções de família, conforto, segurança ou alegria de viver. Muito pelo contrário, o lar reifica, na literatura, o entendimento da velhice como uma espécie de doença, uma chaga que incomoda uma sociedade aceleradamente senescente, mas dominada por um paradoxal e absurdo culto da juventude.

A literatura portuguesa deu voz, ao longo dos séculos, a algumas figuras de velhos, que exemplificam o encómio entusiástico elaborado por Cícero no livro $D e$ Senectute. Basta pensarmos, por exemplo, na sabedoria profética do «Velho do Restelo» camoniano, na ternura serena da avó de Viagens na Minha Terra, de Almeida Garrett, ou no sobrevalorizado, mas sedutor, Afonso da Maia, de Eça de Queirós. E muitas outras personagens nobilíssimas se encontram em autores tão diferenciados como Júlio Dinis, Manuel da Fonseca ou mesmo Miguel Torga. Ainda no caso de Eça, considero admirável o modo como o romancista dá vida às suas personagens envelhecidas, transformando-as ora em inesquecíveis vultos grotescos, antecipando o expressionismo brandoniano, ora em personalidades hieráticas de irrepreensível solidez moral. Julgo

${ }^{1}$ HEMINGWAY, 2011: 94. 
serem particularmente impressionantes as personagens pertencentes ao primeiro grupo, porque estão mais próximas do natural desconcerto da condição humana.

Entre o riso ferino e a ironia melancólica, Eça de Queirós criou pessoas como Dona Felicidade, que, em O Primo Basílio, alimenta a necessária inquietação vital através do ardor erótico pelo Conselheiro Acácio. Esse erotismo exacerbado e outoniço não a diminui enquanto personagem feminina; muito pelo contrário, permite-lhe compartilhar com outras mulheres queirosianas (e também alguns homens) o desejo de viver para além da sobrevivência. De igual modo, é impressionante o remate de $O$ Crime do Padre Amaro, não apenas pela conversa diletante e acéfala perante a estátua de Camões com o seu «frio olhar de bronze»" ${ }^{2}$, mas também porque sabemos que Dona Maria da Assunção, velha beata rezingona, arranjou um criado novo, um jovem "carpinteiro que morava defronte» ${ }^{3}$ e que, certamente, lhe tornará mais leve o peso da idade. $\mathrm{O}$ mesmo se diga de Libaninho, um indivíduo melífluo e saltitante, que o narrador não condena ao ostracismo, recordando-o, ao invés, em cena escandalosa com um sargento do quartel de Leiria. Quando o escândalo passou, foi recompensado com «o lugar de sacristão, que é bem boa posta» ${ }^{4}$. Dir-se-á que tudo isto é produto da famigerada ironia do autor. Mas não é apenas isso. Sendo um tema recorrente, a questão da sexualidade configura um dos elementos da cosmovisão queirosiana.

Eça deu às mulheres e aos velhos o desejo de liberdade, nomeadamente no que concerne ao domínio erótico. Não lhes podia dar mais nada, porque a sociedade não o permitia. Surgiram apenas no século XX as condições económicas e sociomorais que permitiram a viabilidade desses desejos. Porém, pelo menos no nosso país, parece que a literatura nos apresenta diferentes visões, que contradizem os progressos da ética pragmática. Em outros territórios culturais, há ainda espaço para vivências jubilosas, como demonstra o último romance do escritor cabo-verdiano Germano Almeida, intitulado De Monte Cara vê-se o Mundo ${ }^{5}$, e que nos oferece, desde as primeiras páginas, o protagonismo de um velho fauno africano, em harmonia com a sua cidade, o percurso biográfico, e, sobretudo, com uma sexualidade energética, constantemente reforçada pela juventude das parceiras amorosas. Apesar das transformações sociais propiciadas pela globalização uniformizadora, em África ainda vai havendo lugar para os «mais velhos», uma expressão carregada de dignidade e prestígio. Nada disso acontece no livro de que pretendo falar aqui de forma breve: Passagens ${ }^{6}$, de Teolinda Gersão.

A execração da velhice, levada a cabo por Vergílio Ferreira, Eugénio de Andrade, Herberto Helder, e, de forma radical, pela magnífica Fernanda Botelho, encontra, nesta

\footnotetext{
${ }^{2}$ QUEIRÓS, 2005: 398.

${ }^{3}$ QUEIRÓS, 2005: 394.

${ }^{4}$ QUEIRÓS, 2005: 394.

${ }^{5}$ ALMEIDA, 2014.

${ }^{6}$ GERSÃO, 2014.
} 
obra, um desencantado paralelismo, que, em termos de memória literária, se afasta da ideia de permanência redentora e enfatiza as noções de rutura e controvérsia.

O livro de Teolinda Gersão é controverso logo a partir da determinação genológica. Como já tinha acontecido em outras obras, a escritora elide a informação de género, não adicionando qualquer indicação autoral que vá além dos protocolos consubstanciados no código ótico-grafemático. Mas mesmo neste domínio, a ajuda não é muita, porque deparamos com segmentos narrativos e monólogos de variadas personagens, cabendo aos segmentos narrativos uma espécie de função didascálica. Em meu entender, Passagens é uma novela composta de solilóquios. As personagens conversam de forma silente, e é através dessas conversas que a história se vai construindo. Sendo muitas, as personagens estão conexionadas pelos laços de família e relações adstritas, um facto que reduz a pluralidade romanesca e contribui para a concentração expansiva, definidora da novela.

$\mathrm{O}$ acontecimento que gera a reunião familiar é a morte da matriarca, Ana, figura central da narrativa e unificadora dos três capítulos do livro. Ana é uma mulher atraída pelo teatro. A ideia de teatralização é comum a outras personagens; havendo, por conseguinte, uma assinalável harmonia entre a semântica do texto e os processos estruturais e discursivos que a veiculam. Passagens é, portanto, uma obra esteticamente muito elaborada, que rendibiliza os recursos essenciais de diferentes campos modais e genológicos, dramatizando, isto é, colocando em cena, estratégias discursivas provenientes da narrativa novelística e romanesca, bem como da dramaturgia, do lirismo e da filosofia. O hibridismo estrutural do texto cumpre assim a noção basilar de instabilidade e oscilação, paratextualmente inscrita nas duas epígrafes orientadoras: uma extratada dos Ensaios, de Montaigne; a outra recolhida em Passagens, de Walter Benjamin. Segundo Montaigne, «O mundo é uma oscilação perene» e «mesmo a permanência não é senão uma oscilação constante» ${ }^{7}$. E Walter Benjamin conclui que «Um acontecimento vivido é finito, ou pelo menos encerrado na esfera do vivido, enquanto que um acontecimento lembrado não tem limites, é apenas uma chave para tudo o que veio antes, e depois» ${ }^{8}$. As duas epígrafes fornecem o título ao livro de Teolinda Gersão e justificam também a estrutura compósita, bem como a interrogação axial, que aborda a condição humana a partir do conceito de «passagem» dramatizada.

Confinada às paredes de um lar de idosos, Ana resolve ser atriz da sua própria vida, fingindo sofrer da doença de Alzheimer, uma atitude eminentemente controversa. O fingimento tem o propósito misericordioso de libertar a família da obrigação das visitas regulares e do desconforto da solicitude socialmente vigiada. Libertando a família, Ana vai, no entanto, desencadear o caos da memória individual, dando razão

${ }^{7}$ GERSÃO, 2014: 5.

${ }^{8}$ GERSÃO, 2014: 5. 
a Walter Benjamim, quando o filósofo afirma que «um acontecimento lembrado não tem limites, é apenas uma chave para tudo o que veio antes, e depois». Com efeito, o pretenso esquecimento da protagonista impele os seus familiares a um processo contínuo de recordação, e, como é sabido, recordar é, etimologicamente, voltar ao passado através do coração. Para os romanos, o coração era apenas a sede da memória; mas para nós não é só isso: o coração é o lugar do conflito. E quando se trata de relações familiares, não é incomum surgirem as tonalidades sombrias da distopia edénica, falsamente mitificada como paraíso, porquanto o Paraíso acabou quando Caim matou Abel.

Através da recordação, Ana e a família vão trazendo ao palco mentiras e ciúmes, fraquezas e ilusões. Também amor e solidariedade, é certo, mas o livro contém frases pesadamente assertivas, que, sem qualquer vestígio de retórica dulcificadora, afirmam coisas deste teor: «São puro teatro, as nossas relações» ${ }^{9}$; «O amor nas famílias faz sofrer ${ }^{10}$; «não há muitas mães felizes» ${ }^{11}$.

O primeiro contacto que temos com a protagonista, no capítulo inicial, é presentificado por um segmento narrativo, cujo princípio surge de forma abrupta, constituindo o incipit da obra:

Agora ela, Ana, estava deitada, rodeada de pessoas, no meio de uma sala, ou antes, num lugar que tinha aproximadamente a dimensão da sala de uma casa antiga, embora lhe faltasse, em absoluto, um ar doméstico ${ }^{12}$.

Ana ainda não percebeu que está morta, e que se encontra no seu próprio velório. O romance As Memórias de Um Espírito, de Germano Almeida, começa da maneira seguinte: "Morri precisamente às cinco da tarde de um dia 30 de Setembro» ${ }^{13}$. E o justamente célebre Memórias Póstumas de Brás Cubas ${ }^{14}$, de Machado de Assis, depois de um parágrafo inicial explicativo, oferece uma informação muito rigorosa: «Dito isto, expirei às 2 horas da tarde de uma sexta-feira do mês de agosto de 1869, na minha bela chácara de Catumbi» ${ }^{15}$. As três obras, da autoria de três escritores lusófonos muito diferenciados nas coordenadas geoculturais, partilham a mesma ideia inicial, que consiste no protagonismo ficcional de um morto. O escritor brasileiro Roberto Gomes utiliza o mesmo recurso no romance Alegres Memórias de um Cadáver, publicado em 2004, mas o incipit do livro afasta-se dos exemplos supracitados, embora se aproxime de Passagens, no que diz respeito à variedade estrutural. O mesmo se diga em relação

\footnotetext{
${ }^{9}$ GERSÃO, 2014: 29.

${ }^{10}$ GERSÃO, 2014: 143.

${ }^{11}$ GERSÃO, 2014: 175.

${ }^{12}$ GERSÃO, 2014: 11.

${ }^{13}$ ALMEIDA, 2001: 11.

${ }^{14}$ ASSIS, 1881.

${ }^{15}$ ASSIS, 1881: 10.
} 
ao livro Palestra para um Morto (2000), do moçambicano Suleiman Cassamo, cujo final do primeiro capítulo («ciclo primeiro») se assemelha, tematicamente, ao lirismo filosófico do remate do texto de Teolinda Gersão.

Referi estas obras das literaturas em língua portuguesa, com a intenção de sublinhar a originalidade e madurez estética de Passagens. Com efeito, trata-se de livros que, elaborando uma matéria algo parecida, são, todavia, muito desiguais, no que concerne à profundeza da cosmovisão, bem como à maturidade do discurso artístico. Curiosamente, ou talvez não, o texto que melhor se poderia irmanar com Passagens é Memórias Póstumas de Brás Cubas, de Machado de Assis. Em ambas as obras há uma semelhante tendência para a atomização estrutural, reveladora de um similar espanto perante o inapreensível sentido da vida.

No segundo capítulo da novela, intitulado «Noite», a estratégia do drama silente é levada ao extremo. A personagem divide-se em duas vozes, Ana 1 e Ana 2 e o primeiro diálogo diz o seguinte:

\section{Ana 1}

Deixaram-me sozinha. Apagaram a luz e foram-se embora. Todos.

Ana 2

Não estás sozinha. Mesmo no escuro, tens a tua própria companhia ${ }^{16}$.

Um pouco mais adiante, Ana 1 diz que «Ainda há mundos a descobrir, quando se está só o dia inteiro, sentada numa poltrona, no pequeno quarto de um lar» ${ }^{17}$. O segundo capítulo é precisamente um exemplo do poder da mente em contraponto à debilidade física. A partir do caixão, Ana segue o ensinamento de Brás Cubas e recorda os pais e a sua vida com eles, acabando por reafirmar a total teatralização da vida familiar: «Viveste sempre numa peça de teatro. Os teus pais eram actores. Estava-te no sangue, foi uma herança de ambos» ${ }^{18}$. Ao terminar o capítulo, apaga-se também a voz de Ana, pois o último capítulo do livro retoma a estrutura do primeiro, encenando o pensamento dos familiares. Importa, neste remate, prestar atenção à questão das «passagens». À pergunta de Ana 2 «Como imaginas a passagem?» ${ }^{19}$, Ana 1 responde:

Sem sobressaltos, previsivel. Apenas um regresso aos elementos, ao ponto de partida. Através do fogo voltar à terra, ao ar, à água. Continuar a fazer parte do ciclo da vida ${ }^{20}$.

\footnotetext{
${ }^{16}$ GERSÃO, 2014: 79.

${ }^{17}$ GERSÃO, 2014: 83.

${ }^{18}$ GERSÃO, 2014127

${ }^{19}$ GERSÃO, 2014: 129.

${ }^{20}$ GERSÃO, 2014: 129.
} 
Ana recusou os rituais religiosos - o que aflige Conceição, empregada do lar e uma das personagens mais fortes do livro - e pede apenas música de Bach. A recusa do acompanhamento religioso é totalmente coerente com o excerto supracitado. A morte é, portanto, entendida como uma passagem, «Talvez, quem sabe», pensa Ana 1, "para outras dimensões» ${ }^{21}$. Não creio, todavia, que o texto de Teolinda Gersão permita entender a morte como uma passagem, cuja natureza se possa assemelhar à vida. A música de Bach simboliza, naturalmente, a repetição e a variação, mas trata-se, neste contexto, de uma repetição da matéria e de possíveis variações igualmente materiais. A afirmação acerca do «regresso aos elementos, ao ponto de partida» não tem um sentido teleológico nem teológico. Uma das coisas em que a religião e a ciência coincidem é precisamente a ideia de que a morte é um regresso ao pó original. A divergência começa quando se pretende insuflar um derradeiro ânimo na insignificância do pó. O crente - e veja-se, por exemplo, o cristocentrismo arrebatado do poeta Daniel Faria - acredita que a passagem dá acesso a uma vida mais perfeita, mais verdadeira. $\mathrm{O}$ cientista ateu observa apenas uma reconfiguração da matéria.

No último capítulo de Passagens, quatro personagens apresentam uma espécie de relatório científico sobre o processo de desagregação de um cadáver, desde a paragem do coração até à única coisa que pode permanecer durante milénios: a mandíbula ${ }^{22}$. A opção da escritora pelas descrições cruamente realistas e desapiedadas é justificada pelo efeito catártico, mas também configura um entendimento da morte como simples fenómeno material, não havendo, portanto, lugar para considerações acerca da alma, do espírito ou qualquer outra entidade de natureza similar. Em termos filosóficos, diríamos que estamos perante um caso de permanência ou de repetição, porquanto todo o andamento final da novela reativa o epicurismo ateu divulgado por Lucrécio no longo poema filosófico e apologético De Rerum Natura. Nos versos 215 e 216 do Livro Primeiro, o poeta latino diz que «a natureza dissolve novamente/cada coisa nos seus átomos, mas não reduz as coisas ao nada» ${ }^{23}$. E Teolinda Gersão diz que "O que resta de nós será agora terra, água, ar, fará parte dos elementos» ${ }^{24}$.

Lucrécio afasta os deuses do destino dos homens, tanto na vida, como na morte, pretendendo, desse modo, eliminar o receio de viver e o medo de morrer, pois tudo se resume à orquestração dos átomos. Teolinda Gersão também não convoca Deus, mas a partida de Ana é acompanhada por flores e pela música de Bach. No remate do texto, finalizando uma bela digressão, a várias vozes, acerca das «mães», podemos ler o seguinte:

\footnotetext{
${ }^{21}$ GERSÃO, 2014: 129.

${ }^{22}$ GERSÃO, 2014: 158-160.

${ }^{23}$ LUCRÉCIO, 2015: 29.

${ }^{24}$ GERSÃO, 2014: 159.
} 


\section{Hugo}

enquanto elas entram dentro do fogo e desaparecem, diante dos nossos olhos, Marta

como se deslizassem suavemente para dentro do Sol

E assim termina o livro. A ausência de Deus dá lugar a um lirismo holístico, que talvez possa ser uma outra forma de falar de Deus. Um Deus desataviado da teologia e dos ritos religiosos, um Deus consubstancial ao segredo das coisas.

\section{BIBLIOGRAFIA}

ALMEIDA, Germano (2001) - As memórias de um Espírito. Alfragide: Editorial Caminho. (2014) - Do Monte Cara vê-se o Mundo. Alfragide: Editorial Caminho.

ASSIS, Machado de (1881) - Memorias posthumas de Braz Cubas. Rio de Janeiro: Typographia Nacional. LUCRÉCIO (2015) - Da Natureza das Coisas. Tradução de Luís Manuel Gaspar Cerqueira. Lisboa: Relógio D’Água.

GERSÃO, Teolinda (2014) — Passagens. Porto: Sextante Editora/Porto Editora.

HEMINGWAY, Ernest (2011) - O Velho e o Mar. Lisboa: Editora Livros do Brasil.

QUEIRÓS, Eça de (2005) - O Crime do Padre Amaro. Edição de Carlos Reis e Maria do Rosário Cunha. Lisboa: Editorial Presença. 


\title{
ANTROPOLOGIA LITERÁRIA DE JOSÉ TOLENTINO DE MENDONÇA: PARA UMA POÉTICA DA AMIZADE NA CULTURA PÓS-MODERNA
}

\author{
JOSÉ CÂNDIDO DE OLIVEIRA MARTINS*
}

\section{CONTORNOS DE UMA FILOSOFIA DA AMIZADE}

Assim, para se ser feliz são necessários amigos sérios

Aristóteles, Ética a Nicómaco

Consabidamente, para muitos observadores o narcisismo contemporâneo questiona e trivializa a essência e o lugar da amizade; e algumas das mais populares redes sociais contemporâneas, construídas e potenciadas a partir das novas tecnologias da comunicação, banalizaram as noções de «amigo» e de «amizade» ${ }^{1}$. Por isso, e muitas outras razões que não é imperioso mencionar agora, não surpreende que, neste contexto, mas recuperando antigas reflexões multisseculares, alguns pensadores de hoje, de quadrantes intelectuais e ideológicos distintos, se tenham debruçado sobre a natureza e o lugar da amizade nestes complexos e apressados tempos pós-modernos.

\footnotetext{
* Universidade Católica Portuguesa. Artigo desenvolvido no âmbito do PEst-UID/FIL/00683/2013 Projeto Estratégico do Centro de Estudos Filosóficos e Humanísticos (CEFH) financiado pela Fundação para a Ciência e Tecnologia (FCT). ${ }^{1}$ Não são necessários estudos sociológicos para concluir o que a evidência quotidiana nos mostra. Isso mesmo é referido por Miguel Esteves Cardoso (CARDOSO, 2001: 108), quando diagnostica o negativo impacto do atual culto do eu na sociedade contemporânea: «Os valores dominantes da nossa idade, que, de um modo geral, se contêm na ideia de uma máxima autonomia individual, que tem a sua expressão psicológica no culto do narcisismo [...], têm afectado as expectativas e investimentos que presidem às relações de-um-para-um, do amor, da amizade».
} 
Assim, nesta atmosfera de modernidade líquida, tal como a caracterizou o sociólogo polaco Zygmunt Bauman², um dos muitos sintomas reside nas mudanças aceleradas e imprevisíveis, bem como no clima de insegurança geral, com consequências esperadas ao nível das relações interpessoais - laços frágeis e efémeros, emergência de novos vínculos, ligações e proximidades virtuais, dificuldade de amar o próximo, enfim, inesperadas formas de sociabilidade. Estes «tempos de incerteza», de entretenimento e de «turistização», também mereceram ao filósofo Ives Michaud a designação de «estado gasoso» ${ }^{3}$.

Por outro lado, enfrentando na cidade atual, quotidianamente, o mal-estar e a incerteza, o medo do estrangeiro e do refugiado, o ser humano precisa de estabelecer contactos, estreitar laços ou «vínculos amigáveis», de modo a superar muros e segregações de novas formas de miséria social, solidificando formas de convivência amigável: «Podemos afirmar que as causas do perigo se mudaram para o coração da cidade. Os amigos, os inimigos e, acima de tudo, os estranhos esquivos e misteriosos, que oscilam ameaçadoramente entre os dois extremos, misturam-se e acotovelam-se nas ruas da cidade» ${ }^{4}$.

Como seria de esperar, a interrogação sobre a amizade é tão velha quanto o pensamento humano, pelo que a antiguidade clássica também pensou amadurecida e detidamente a amizade. Apenas a título de exemplo, o Livro VIII da Ética a Nicómaco de Aristóteles ${ }^{5}$ abre justamente com considerações genéricas sobre a amizade, nomeadamente quando afirma que a amizade «é do que mais necessário há para a vida. Pois ninguém há-de querer viver sem amigos, mesmo tendo todos os restantes bens. [...] Assim, tanto na miséria como nas desgraças, pensa-se sempre que os amigos são o nosso único refúgio. [...] Na verdade, com amigos, somos capazes de pensar e agir melhor».

Há alguns anos, o filósofo italiano Giorgio Agamben estabeleceu uma correspondência com o pensador francês Jean-Luc Nancy sobre o tema da amizade. Aliás, ao refletir sobre uma controversa passagem do referido livro de Aristóteles $(1170 \mathrm{a} 28-1171 \mathrm{~b})^{6}$, segundo G. Agamben, o pensamento filosófico é indissociável da ideia de amizade, estando esta na essência daquele, através dos conceitos de philos (amigo) e da polissémica philia (amizade). Qual memória cultural fecundante, essa longa tradição repercute-se depois, ao longo dos séculos, em sucessivas meditações ensaístico-filosóficas sobre a

\footnotetext{
${ }^{2}$ BAUMAN, 2004.

${ }^{3}$ Cf. MENDONÇA, 2010a: 72.

${ }^{4}$ BAUMAN, 2006: 59.

${ }^{5}$ ARISTÓTELES, 2009: 197.

${ }^{6}$ Como nos lembra Agamben (AGAMBEN, 2013: 8-9), J. Derrida escolhe como mote de um livro (Politiques de l'amitié) precisamente uma frase atribuída a Aristóteles, provavelmente apócrifa — «meus amigos, não há amigos». A passagem tem ecos em outros autores ao longo dos séculos, que a terão ido colher a Diógenes de Laércio (Vidas, Doutrinas e Sentenças dos Filósofos Ilustres, V, 21), mas aqui com uma variação bem significativa: «aquele que tem (muitos) amigos não tem nenhum amigo».
} 
amizade - de Aristóteles, Diógenes de Laércio e Cícero até Montaigne, F. Nietzsche ou J. Derrida, em Politiques de l'amitié.

Porém, quando hoje ambas parecem ter caído em certo descrédito - a filosofia e a amizade - cabe perguntar: ainda há filósofos e escritores que abordem tematicamente a amizade? Responde assertivamente G. Agamben: «A amizade e o amor foram sempre renegados pela reflexão filosófica». E logo de seguida: «a amizade é difícil de predicar» ${ }^{7}$. Desde logo, o mesmo Agamben ${ }^{8}$, ao deter-se numa afirmação paradoxal, que atraiu a atenção do referido Jacques Derrida, frase atribuída a Aristóteles — «meus amigos, não há amigos» - , propõe-nos uma cativante deambulação filológica e filosófica sobre o conceito de amizade, concedendo compreensível destaque ao pensamento aristotélico ${ }^{9}$.

Como sintetiza José Tolentino de Mendonça, G. Agamben «conseguiu refazer a história e perceber que o mote enigmático era afinal um clamoroso erro de copista. Em vez de "ó amigos, não existem amigos”, o sentido da lição original seria: "(para aquele que tem muitos) amigos, não existem amigos". Como a lembrar que a banalização da palavra amigo produz uma incapacidade de compreender (e de viver) amizades verdadeiras ${ }^{10}$. Infelizmente, embora tendo informado J. Derrida deste relevante esclarecimento filológico, G. Agamben ficou surpreendido quando o mencionado livro do pensador francês (Politiques de l'amitié) simplesmente ignorou a referida informação.

Dentro e fora da escrita literária propriamente dita ${ }^{11}$, a obra de José Tolentino de Mendonça configura um dos casos mais exemplares do atual diálogo entre o Cristianismo e Cultura, entre o pensamento filosófico e teológico. Sem proselitismos deslocados, a sua escrita associa particularmente Fé e Literatura, que consabidamente têm tanto em comum, desde logo o uso privilegiado da palavra (reflexiva ou narrativa), até à transmissão de uma sabedoria humana, de facto comum à criação estético-literária e à lectio divina das Escrituras ${ }^{12}$.

Os vários géneros cultivados por Tolentino de Mendonça unem-se quer pelas temáticas recorrentes, quer por uma vasta cultura humanista, quer ainda pela qualidade estético-literária da sua linguagem. Com uma escrita que se estende dos estudos bíblico-teológicos até à poesia e ao teatro, passando pelo ensaio, este autor desafia-nos

\footnotetext{
${ }^{7}$ AGAMBEN, 2013: 25, 29.

${ }^{8}$ AGAMBEN, 2013: 8.

${ }^{9}$ Curiosamente, o breve ensaio de G. Agamben atraiu a atenção do próprio J. Tolentino de Mendonça (MENDONÇA, 2015: 17-18), numa crónica intitulada «Ó amigos, não existem amigos»; e de Pedro Mexia (MEXIA, 2015: 15-18), num texto cronístico com o título de «Ó amigos, não há amigo».

${ }^{10}$ MENDONÇA, 2015: 17.

${ }^{11}$ Sabemos bem como não é fácil estabelecer uma fronteira entre o literário e o não literário, ou mesmo de género quando, perante autores atuais como José Tolentino Mendonça. De facto, nesta nova realidade da porosidade dos géneros, estamos perante uma singular escrita cronística e ensaística, cuja inegável qualidade estética a integra, de pleno direito, no domínio literário.

${ }^{12}$ Cf. MENDONÇA, 2013a: 26.
} 
a pensar hoje algumas das questões mais prementes à condição humana, no espaço da cultura dita pós-moderna ${ }^{13}$.

Consabidamente, esta cultura pós-moderna é marcada, entre outras grandes tendências, pela velocidade e pela fragmentação, pela radical questionação da ideia moderna de progresso, pela crise das grandes narrativas legitimadoras da cultura ocidental (do cristianismo ao marxismo), pela acelerada desumanização, pela relativização ética ou mesmo pelo vazio dos valores. A cultura pós-moderna mostra-se descentrada, atraída por tentadores simulacros, pela sedução de vários hedonismos ou pelo mais radical subjetivismo.

Ora, neste enquadramento ou mundividência que molda a atmosfera cultural em que respiramos, ganham particular acuidade algumas dominantes temáticas da obra de José Tolentino de Mendonça. Desde logo, a preponderância da palavra numa antropologia literária ${ }^{14}$ que, iluminada pela crença, pensa vários desafios que se colocam ao homem contemporâneo.

Outro traço dominante da sua escrita múltipla reside no constante e denso diálogo intertextual, nomeadamente com outros poetas e intelectuais, crentes e não crentes, portugueses ou estrangeiros ${ }^{15}$. Por isso, o seu leitor não se surpreende quando amiúde se cruzam fecundamente, num entrelaçamento de sentidos, autores tão diversos como São Paulo, os Padres da Igreja ou os poetas místicos (Angelus Silesius, S. João da Cruz ou Sta. Teresa), com homens e mulheres de cultura das mais diversas épocas - num assumido diálogo ecuménico das artes e dos saberes, com destaque para os contemporâneos $^{16}$. É notório que se respira uma vasta cultura teológica e filosófica, que subjaz e emerge na palavra literária de José Tolentino de Mendonça.

Genericamente, da poesia ao ensaio, é uma escrita de natureza meditativa e filosófica, que pensa e interroga, que provoca e gera esperança. Por exemplo, quando medita sobre o papel da palavra ou da função da beleza na sociedade contemporânea e no «misterioso mundo» em que vivemos ${ }^{17}$; quando evoca a arqueologia de algumas das mais velhas questões que têm afligido existencialmente o ser humano de todas as eras - o sentido da vida, do tempo, da morte, etc.; quando ironiza com alguns ídolos

\footnotetext{
${ }^{13}$ Cultura pós-moderna, tal como caraterizada pelos reconhecidos pensadores Gianni Vattimo (VATTIMO, 1987: 9 ss.; VATTIMO, 1991: 19); ou Jean-François Lyotard ([s.d.]), entre tantos outros.

${ }^{14}$ Emprega-se aqui a noção de antropologia literária no sentido que lhe atribuído por A. Blanch (BLANCH, 1995: 11 ss.; BLANCH, 2002), como sinónimo das expressivas imagens e visões que a literatura constrói do ser humano através do tempo.

${ }^{15}$ Tecido intertextual onde não faltam também as reminiscências da memória literária da tradição clássica, seja na convocação de Antígona (cf. MENDONÇA, 1999: 66-67); seja na detida revisitação da figura de Helena (cf. MENDONÇA, 2005a); seja ainda na referência simbólica ao mito de Dafne, na figura do velho Tirésias de Sófocles ou na mesma Helena de Troia (cf. MENDONÇA, 2013b: 15, 52, 59).

${ }^{16}$ De Paul Celan, Pasolini, Marianne Moore, Flannery O’Connor, John Coltrane, Simone Weil, Sophia Andresen, Eugénio de Andrade, João Miguel Fernandes Jorge, João Salavisa, Ilda David, Adília Lopes, entre tantos outros nomes. ${ }^{17}$ Cf. MENDONÇA, 2005a: 23.
} 
atuais e a sua «débil força messiânica» ${ }^{18}$; quando privilegia imagens e metáforas axiais que, na sua obsessiva recorrência, pintam argutamente a condição humana de hoje: corpo, desejo, casa, deserto, bosque, naufrágio, inquietação, errância, solidão, vazio, etc.; quando enfim questiona as hierofanias do sagrado no mundo que nos cerca, a par dos sintomas da nostalgia de absoluto (G. Steiner); ou ainda quando interroga as derivas do ser humano atual e o silêncio de Deus na paisagem cultural contemporânea.

Pelo que se deixa panoramicamente sugerido, sentimo-nos tentados a concordar com Eugénio de Andrade que, relatando a alegria e surpresa do primeiro encontro com esta escrita e com os «versos soberbos!», salientava elogiosamente essa «espécie de presença rara e ardente» da escrita poética do autor madeirense ${ }^{19}$, que ora se sente cosmopolitamente atraído por França, Itália ou EUA, ora evoca o velho mercado do Machico.

\section{PENSAR A AMIZADE HOJE}

E é possível fazer novos amigos, bons amigos, que estarão connosco pela vida inteira.

Z. Bauman, Confiança e medo na cidade

Os olhares literários sobre a amizade são bem mais frequentes do que se pensa. «Eu pretendo dizer da amizade o que Diógenes dizia do dinheiro: que ele o reavia dos seus amigos, e não que o pedia. Pois aquilo que os outros têm pelo sentimento comum não se pede, é património comum. Neste caso, a amizade». Assim escreve Agustina Bessa-Luís ${ }^{20}$, no seu habitual estilo aforismático e irónico. E em A Cidade e as Serras de Eça de Queirós ${ }^{21}$, relato assente na amizade sincera e indestrutível entre José Fernandes e Jacinto, fala-se elogiosamente nas «amizades puras e sinceras» ${ }^{22}$.

Cremos que está por fazer uma reflexão abrangente acerca do tema da amizade na longa História da Literatura Portuguesa e a sua presença fecunda ao longo de séculos de criação literária. O seu estudo crítico proporcionaria certamente conclusões curiosas sobre a permanência e sobre as visões acerca da amizade consoante o contexto cultural e sociológico, mas também de acordo com as convenções estético-literárias. E entre

\footnotetext{
${ }^{18}$ Cf. MENDONÇA, 2005a: 21.

${ }^{19}$ ANDRADE, 2001: 59; 57.

${ }^{20}$ BESSA-LUÍS, 2008: 17.

${ }^{21}$ QUEIRÓS, [s.d.]: 15.

${ }^{22}$ Porém, na disfórica descrição do cenário citadino (Paris), esterilizante e desumanizador, nem a amizade escapa ao pragmatismo interesseiro e falso: «As amizades nunca passam de alianças que o interesse, na hora inquieta da defesa ou na hora sôfrega do assalto, ata apressadamente com um cordel apressado, e que estalam ao menor embate da rivalidade ou do orgulho». Ora, é justamente neste ambiente afetivamente desolador da Cidade que mais se sente a falta da verdadeira amizade — «a presença, o conforto e o socorro da Amizade» (QUEIRÓS, [s. d.]: 87 e 97).
} 
outros tópicos, seria muito revelador verificar certas constantes intemporais acerca da amizade, desde as reflexões dos clássicos greco-latinos, como Aristóteles ou de Cícero.

$\mathrm{Na}$ impossibilidade de abordarmos a pluralidade e a complexidade das linhas de força da obra literária e ensaística de José Tolentino de Mendonça, selecionamos um aspeto nuclear da sua inspiradora antropologia literária - o modo como desenha e pensa o sentimento e a vivência da amizade, a sua natureza e função antropológica e social. Mas que sentido faz um autor contemporâneo deter-se a falar, poética e sobretudo ensaisticamente, na amizade?

Sendo a palavra amigo um termo com uma tão rica arqueologia cultural (desde a herança bíblica e literária, que a fazem equivaler a namorado e amante); e, ao mesmo tempo, uma palavra tão gasta nos dias, que parecem privilegiar a superficialidade das relações interpessoais (nomeadamente nas redes sociais, onde somamos inumeráveis «amigos»), é oportuna uma reflexão antropo-teológica sobre a amizade? Pode a vivência da amizade dar-nos a confiança, a alegria e a felicidade de que precisamos para viver uma vida plena de sentido? Sem esperar «receitas de auto-ajuda» ou similares, vale a pena conceder atenção a esta amadurecida sabedoria que nos fala, em tom cativante e denso, neste tema intemporal da amizade.

Desde logo, falar da amizade implica a interrogação sobre a que distância deixamos o coração ${ }^{23}$. Num dos primeiros livros de poesia de José Tolentino de Mendonça, De Igual para Igual, somos confrontados com um poema justamente intitulado «Os amigos», que, na sua sugestiva densidade, equivale a um texto programático sobre o tema da amizade:

Esses estranhos que nós amamos

e nos amam

olhamos para eles e são sempre

adolescentes, assustados e sós

sem nenhum sentido prático

sem grande noção da ameaça ou da renúncia

que sobre a luz incide

descuidados e intensos no seu exagero

de temporalidade pura

Um dia acordamos tristes da sua tristeza

pois o fortuito significado dos campos

explica por outras palavras

aquilo que tornava os olhos incomparáveis

${ }^{23}$ Cf. MENDONÇA, 1999: 41. 


\section{Mas a impressão maior é a alegria}

de uma maneira que nem se consegue

e por isso ténue, misteriosa:

talvez seja assim todo o amor $^{24}$

Para usarmos metáforas do poeta, feita de braços, tecida de olhares e alicerçada na alegria, a amizade ocupa um lugar insubstituível na vida de cada um de nós, como um capital humano e afetivo ímpar. Pensar a amizade como valor ou filosofia de vida na cultura atual pressupõe, entre outras inquirições pertinentes sobre o tema: o conhecimento histórico do tema da amizade; a reflexão sobre a conduta ética das pessoas envolvidas na amizade; a meditação sobre as diversas manifestações do sentimento da amizade.

Tal como o amor, também a amizade tem a sua «ciência»" ${ }^{25}$, com consequências e ritmos inesperados: «Pensamos que quando chegasse [o amor] as nossas vidas acelerariam/mas nem sempre é assim:/há emoções que nos aceleram/outras que nos abrandam». Na fase inicial da sua obra poética, em Baldios, no poema «Coisas tão felizes», Tolentino de Mendonça enuncia a mágica e fraternal compreensão da amizade que une dois seres: «Entre amigo e amigo/jamais se afastam/coisas tão felizes/os instantâneos de certas formas/os protestos inocentes à nossa passagem/a natureza fortuita, dizia eu/imortal, dizias tu/do vento? ${ }^{26}$. Porque amizade significa a confidência e os murmúrios, sem limites nem receios: «Paga-me um café e conto-te/a minha vida» - assim se inicia um poema, que se encerra com a reescrita do mote inicial: «Pago-te um café se me contares/o teu amor» ${ }^{27}$.

Como se deixa sugerido, para José Tolentino de Mendonça, a amizade precisa e merece ser pensada através da sua história e da sua ontologia, mas também de uma ética e de uma gramática, singulares e intemporais, sendo a sua urgência talvez mais exigida pelos tempos atuais. Essa preocupação indagadora e sistematizadora é especialmente patente no livro Nenhum Caminho Será Longo (Para uma Teologia da Amizade), obra paratextualmente encimada por um provérbio japonês: «Ao lado do teu amigo, nenhum caminho será longo» ${ }^{28}$.

Desde logo, impõe-se dizer a natureza da amizade, já que ela se pressupõe uma ciência ou ontologia da amizade. Tal como o amor, também a amizade tem a sua «ciência» ${ }^{29}$, com dimensões e ritmos inesperados: «Pensamos que quando chegasse [o amor] as nossas vidas acelerariam/mas nem sempre é assim:/há emoções que

\footnotetext{
${ }^{24}$ MENDONÇA, 2001: 21.

${ }^{25}$ Cf. MENDONÇA, 2012: 24

${ }^{26}$ MENDONÇA, 1999: 25.

${ }^{27}$ MENDONÇA, 1999: 44, 45.

${ }^{28}$ MENDONÇA, 2013a: 5.

${ }^{29}$ Cf. MENDONÇA, 2012: 24.
} 
nos aceleram/outras que nos abrandam». Na fase inicial da sua obra poética, em Baldios, no poema «Coisas tão felizes», Tolentino de Mendonça enuncia a mágica e fraternal compreensão da amizade que une dois seres: «Entre amigo e amigo/jamais se afastam/coisas tão felizes/os instantâneos de certas formas/os protestos inocentes à nossa passagem/a natureza fortuita, dizia eu/imortal, dizias tu/do vento?» ${ }^{30}$.

Desde o início, uma das recomendações de Tolentino de Mendonça é a de que se contrarie a banalização da palavra «amor» através da redescoberta e da valorização da experiência vital da amizade - «E se falássemos de amizade em vez de amor $»^{31}$. Não ignorando as significativas diferenças entre amor e amizade, o ensaísta traça um fundamentado panegírico da amizade como paradigma comportamental adequado quer às relações interpessoais, quer à relação dos crentes com Deus - amizade como sentimento de confiança genuína e de gratuitidade com o outro que nos é próximo ${ }^{32}$. Há mesmo um provérbio inglês que ensina: «viver sem amigos é morrer sem testemunhas». Na sequência do que Tolentino de Mendonça pergunta: «É possível descrever a amizade?». Uma coisa é certa - quem a vive sabe que «a amizade reinventa o mundo e a sua alegria! ${ }^{33}$. Neste sentido, não nos surpreende que os grandes clássicos (filósofos e escritores) enalteçam superlativamente a experiência da amizade. Ao ponto de Aristóteles ter defendido que, dada a sua excelência, não pode ser um bem banalizado: «aquele que tem (muitos) amigos, não tem amigos» ${ }^{34}$. A amizade é assim um privilegiado lugar de encontro. Já em plena Idade Média um pensador cristão exprimiu «o valor ontológico da amizade: todos os seres vivos [...] inclinam-se naturalmente [...] para a amizade» ${ }^{35}$.

Um segundo tópico diz respeito à arqueologia da amizade, pois este tema e/ou realidade afetiva tem uma riquíssima história, desde a Bíblia e a cultura greco-latina até aos nossos dias. Como sugerido, não por acaso, foi tratada por filósofos diversos, padres da Igreja e escritores ao longo dos séculos. Todos se detiveram a pensar a amizade, sua natureza e funções, as suas diversas formas e lugar ao nível das relações humanas, e até como virtude cívica, como salientado pelo autor da Ética a Nicómaco.

Como nos recorda Tolentino de Mendonça, «Para Cícero, para além da sabedoria, nada há superior à amizade, definida como um acordo perfeito de todas as coisas divinas e humanas, acompanhadas de benevolência e afeição $»^{36}$. Ainda do ponto de

\footnotetext{
${ }^{30}$ MENDONÇA, 1999: 25.

${ }^{31}$ MENDONÇA, 2013a: 11.

${ }^{32}$ Já o P. António Vieira (Sermões, XIII, 246), numa das várias reflexões aforismáticas sobre a amizade, escreve sobre o caráter superlativo desta singular forma de afeição: «Em todos os parentes o amor é acidente que se pode mudar; no amigo fiel é essência, e por isso imutável». No Sermão XIV do Rosário, o mesmo orador recordará que, segundo «os filósofos antigos», «a amizade verdadeira amizade» ou o autêntico amigo «é um outro eu» (amicus est alter ego). ${ }^{33}$ MENDONÇA, 2010a: 107-108.

${ }^{34}$ MENDONÇA, 2013a: 50.

${ }^{35}$ MENDOÇA, 2013a: 120.

${ }^{36}$ MENDONÇA, 2013a: 43. De facto, para Cícero, em De Amicitia, a excelência da amizade é superlativamente conceituada, quando anota, na abertura do Cap. VI sobre a sua definição e excelência, esta aproximação do humano e
} 
vista diacrónico, é impressionante o número de histórias concretas de amizade que foram decisivas para mudar definitivamente alguns rumos da História. Há um belo pensamento de Séneca, em Cartas a Lucílio, que diz: «Ter um amigo é ter alguém por quem morrer» ${ }^{37}$.

Ao mesmo tempo, as mais diversas manifestações da amizade constituem o que Tolentino de Mendonça designa como a gramática da amizade. De facto, a amizade constrói-se com uma infinidade de gestos e de falas, mas também de atitudes e até de silêncios. $\mathrm{O}$ amigo está sempre presente, mesmo quando afastado fisicamente. E tudo isto é visível na forma como os amigos conversam, como se riem, como se abraçam, como até integram o silêncio na sua relação cúmplice: «Com os amigos o silêncio nada tem de embaraçoso» ${ }^{38}$.

Como se vai adivinhando, a amizade tem como grande traço comportamental da sua gramática a gratuitidade. Surge e desenvolve-se sem explicação racional e de forma desinteressada: «De facto, a amizade é o dom que não se explica» ${ }^{39}$. Em face do afirmado, a amizade pode constituir «um perfeito milagre» na existência humana ${ }^{40}$. Para o efeito, ela encontra múltiplas formas de se expressar, com sabedoria, abertura e cumplicidade, gerando uma experiência afetiva fundacional do ser humano. A amizade verdadeira não é episódica; é antes um contínuo estruturante e omnipresente - os verdadeiros amigos são-no para sempre e da forma mais natural e gratuita que se pode imaginar ${ }^{41}$.

Segundo a reflexão de José Tolentino de Mendonça, a amizade também não é pensável fora de uma esperada ética. Do afirmado já se infere que a amizade é orientada por alguns princípios ou valores tacitamente aceites, vivenciados nessa relação: a

do divino: «a amizade é uma suma harmonia das coisas divinas e humanas, com benevolência e amor» — no original: «Est enim amicitia nihil aliud, nisi omnium diuinarum humanarumque rerum cum beneuolentia et caritate concensio» (CÍCERO, 1928: 13, VI-20).

${ }^{37}$ MENDONÇA, 2010a: 107

${ }^{38}$ MENDONÇA, 2013a: 22.

${ }^{39}$ MENDONÇA, 2013a: 29.

${ }^{40}$ MENDONÇA, 2013a: 31.

${ }^{41}$ Ainda que os amigos possam ser úteis aos seus amigos, o desinteresse e a gratuitidade do sentimento da amizade são afirmados desde os pensadores clássicos, como Aristótoles ou Cícero, que em De Amicitia, observa: «Parece-me também que aqueles que almejam apenas o interesse na amizade, afastam dela o seu mais doce vínculo. O que nos agrada não é a utilidade oferecida pelo nosso amigo, mas sim o carinho desse amigo; e tudo o que nos for oferecido por ele, nos será agradável, contanto que transpareça a dedicação» — «Atque etiam mihi quidem uidentur, qui utilitatum causa fingunt amicitias, amabilissimum nodum amicitiae tollere. Non enim tam utilitas parta per amicum, quam amici amor ipse delectat, tumque illud fit, quod aba mico est profectum, iucundum, si cum studio este profectum» (CÍCERO, 1928: 29, XIV-50).

A ideia da amizade como sentimento gratuito é repetida até aos nossos dias, por exemplo na escrita cronística de Miguel Esteves Cardoso (CARDOSO, 2001: 110): «Não interessa a quem não é interesseiro, nem é oportuno a quem não for oportunista, pensar um amigo com o pensamento de quem arrola e afere defeitos e qualidades. O amigo é outro eu e assim como temos os defeitos e qualidades que temos, já depois de nascermos, também o amigo os tem, já depois de ser amigo, muito depois de amigos sermos. O inevitável nunca põe como condição o aceitar». Amizade pressupõe dedicação, sinceridade e desinteresse. Parafraseando um conhecido pensamento místico de Angelus Silesius, poderíamos dizer que a amizade é sem porquê. 
fraqueza, a gratuitidade, a compreensão dos não-ditos e dos silêncios, a aceitação do outro nos seus limites; mas também a disponibilidade plena, a ausência de domínio sobre o outro e a liberdade.

De facto, a experiência da amizade deve brotar de forma genuína e não interesseira, pois a amizade não cobra nada, sendo gratuita e sem porquê. Neste sentido, a amizade pode gerar «o milagre quotidiano» na vida das pessoas, pelo seu enorme poder transfigurador: «Os amigos ajudam-nos a vencer tantas formas de esterilidade: tornam a nossa vida irradiante» ${ }^{42}$.

Como referido, na amizade não vale tudo. A sua vivência pressupõe valores e regras de conduta, a observância de deveres básicos, para se manter essa comunhão gratificante com alguém que é a nossa «alma gémea» (anima consors) - assim era tradicionalmente designado o amigo. Ora, como referido inicialmente, nestes «tempos de incerteza» a vários níveis que atravessamos, caracterizados pelo sociólogo Zygmunt Bauman como sociedade líquida, acentuando com isso a fragilidade dos atuais laços humanos, um dos caminhos de solução passa pelo investimento em sólidas relações e amizades. A falta dos vínculos de amizade convivial abre curso à nefasta ausência de afeto ou de compaixão (pietas), meio caminho andado também para as relações frias e até mesmo fratricidas (homo homini lupus).

Por fim, a proposta de Tolentino de Mendonça aborda uma teologia da amizade. Aliás, o ensaio antes mencionado - Nenhum Caminho Será Longo - possui justamente o subtítulo de «Para uma teologia da amizade». Justamente porque essa é a tese nuclear da obra, podendo ser enunciada deste modo: a amizade humana é passível de ser vista como uma escola para a relação do crente com Deus; ou, de outra perspetiva, a amizade pode constituir um caminho para redescobrir Deus nos outros.

Como nos lembra Tolentino de Mendonça, na Bíblia abundam imagens do campo da afetividade ou da amizade para caracterizar a relação do homem com Deus. Por isso, o autor propõe que «Amizade pode constituir um modelo criativo para o caminho do crente ${ }^{43}$. E ainda: «O paradigma da amizade, aplicado à nossa relação com Deus, pode resultar num efeito extraordinariamente libertador. A amizade é a aceitação positiva do limite» ${ }^{44}$. Por conseguinte, o convite ou desafio de Tolentino de Mendonça é aqui especialmente direcionado aos crentes: «Pensemos, então, na relação de Deus como uma relação de amizade» ${ }^{45}$.

\footnotetext{
${ }^{42}$ MENDONÇA, 2013a: 32.

${ }^{43}$ MENDONÇA, 2013a: 15.

${ }^{44}$ MENDONÇA, 2013a: 19.

${ }^{45}$ MENDONÇA, 2013a: 24.
} 


\section{PARA UMA ONTOLOGIA DO AFETO}

os amigos são o nosso único refúgio Aristóteles, Ética a Nicómaco

Terminemos esta breve incursão sobre a obra de José Tolentino de Mendonça com algumas brevíssimas reflexões. Em primeiro lugar, sendo o autor um padre católico, não se devia esperar que na sua escrita poética falasse mais de Deus? Como o autor tem insistido em algumas declarações, e se torna óbvio na sua escrita, na sua confessada in-visibilidade, Deus não deixa de estar presente, mas assume muitas formas e muitos rostos. Como escreveu o referido Eugénio de Andrade, ao abordar este tópico, «Deus está mais nas entrelinhas do que nas linhas do texto. Ou antes: Deus está oculto, e toda a busca espiritual consiste em caminhar na sua direcção: não há outra via» ${ }^{46}$. Parafraseando o citado e luminoso poeta, podíamos afirmar que a amizade é um dos nomes de Deus. Por outras palavras, esta é uma forma de «dizer Deus na pós-modernidade» ${ }^{47}$.

Um segundo pensamento radica num aspeto central da antropologia literária contemporânea: para que serve a palavra literária? Que desemboca na interrogação sobre $\mathrm{o}$ "destino da arte» ${ }^{48}$. Parafraseando Hölderlin, e à imagem de outros escritores atuais, também Hélia Correia ${ }^{49}$ se interroga sobre a função da palavra poética: «Para quê, perguntou ele, para que servem/Os poetas em tempos de indigência?». Ora, ao traçar os contornos mais críticos e agónicos da paisagem cultural de hoje, a escrita de Tolentino de Mendonça não se fica pelo diagnóstico da angústia, antes contrapõe uma vocação filosófica. Mais do que dar respostas, abre janelas iluminadas, apresenta questões existenciais, sugere símbolos grávidos de sentido, desenha caminhos de esperança, com os olhos focados no constante debate entre o enigma do mundo e o silêncio de Deus.

Afinal de contas, numa concisa arte poética, Tolentino de Mendonça assevera a natureza heterodoxa da palavra poética: «o poema devolve o inexprimível. O poema não alcança aquela pureza que fascina o mundo. O poema abraça precisamente aquela impureza que o mundo repudia» ${ }^{50}$. A escrita de Tolentino de Mendonça poderia parafrasear a célebre afirmação do latino Terêncio: «Homo sum; humani nil a me alienum puto» (Sou homem e nada do que é humano me é estranho). E a experiência antropológica

\footnotetext{
${ }^{46}$ MENDONÇA, 2001: 60.

${ }^{47}$ Cf. DUQUE, 2003.

${ }^{48}$ Cf. MENDONÇA, 1999: 24

${ }^{49}$ CORREIA, 2012: 7, 15, 23.

${ }^{50}$ MENDONÇA, 2005: 44.
} 
da amizade, profundamente necessária às relações interpessoais e à felicidade do ser humano, gera laços de afeição semelhantes aos do parentesco, como já lembrava Cícero.

Por fim, uma terceira reflexão sobre esta instigante poética da amizade para os tempos pós-modernos e a difícil travessia ou peregrinatio do ser humano, na floresta que nos foi dado viver, como se pode ler no incipit da peça teatral $O$ Estado do Bosque: «Peter: Qual é o sentido do trilho?/John Wolf: Não sei. Cada trilho conduz a mais do que um sentido»; e em outro passo: «Importa que saibas o que significa estar metido num caminho da floresta ${ }^{51}$. Além de companhia constante pelos caminhos da floresta - alegoria imemorial da existência —, o amigo desempenha a função de guia e conselheiro seguro, mesmo que se mostre ou nos pareça «cego» pelo afeto. E desde os clássicos, como Cícero, sabemos como na verdadeira amizade, tudo é genuíno, conferindo sentido à existência ${ }^{52}$.

Dito de outro modo, perante a banalização da amizade e dos seus simulacros de hoje, e sobretudo das consequências ao nível das relações interpessoais e sociais em tecidos frágeis e quebrados, todos somos interpelados a reconstruir uma renovada gramática do humano, construção primordial e inadiável, numa tarefa em que a família e a escola, a igreja e a sociedade devem desempenhar um papel insubstituível. Com o investimento nessa gramática do humano, repensa-se a ontologia do quotidiano, tão repleta de aparências e de futilidades, numa sociedade dominada pela ditadura da economia e da tecnologia, mas cada vez mais apressada, impessoal e inumana, sobretudo no mal-estar desta sociedade da deceção ${ }^{53}$ em que vivemos.

Afinal de contas, corporizando uma ontologia do afeto, os sentimentos da amizade e do amor distinguem-nos e enobrecem-nos como pessoas, iluminando a nossa existência e elevando-nos na nossa humanidade; ao mesmo tempo que concedem espessura de sentido e signo de transcendência, com se lê em dois passos de A Estrada Branca: «Os que te amam sejam como o sol/no cimo do seu esplendor»; e logo adiante: «Através da terra o amor/torna-nos estranhos à terra/liga-nos a uma divina linhagem/com seu tormento inapagável/suas velocidades enormes//O amor vive na ponta dos cabelos ${ }^{54}$.

\section{BIBLIOGRAFIA}

AGAMBEN, Giorgio (2013) - O Amigo. Mangualde: Pedago.

ANDRADE, Eugénio de (2001) - Posfácio. In MENDONÇA, José Tolentino - De Igual para Igual. Lisboa: Assírio \& Alvim.

\footnotetext{
${ }^{51}$ Cf. MENDONÇA, 2013b: 9, 15.

${ }^{52} \mathrm{Com}$ efeito, asseverando que é o amor que concede à amizade o seu nome, o autor de De Amicitia, escreve que «na amizade nada é fingido, nada dissimulado, tudo quanto nela há é verdadeiro e tudo provém da vontade» — « Nam utilitates quidem etiam ab eis percipiuntur saepe, qui simulatione amicitiae coluntur, et obseruantur temporis causa» (CÍCERO, 1928: 17, VIII-26).

${ }^{53}$ Cf. LIPOVETZKY, 2012.

${ }^{54}$ MENDONÇA, 2005b: 35, 36.
} 
ARISTÓTELES (2009) - Ética a Nicómaco. Lisboa: Quetzal.

BLANCH, Antonio (1995) - El Hombre Imaginario (Una antropologia literária). Madrid: PPC. (2002) - El Espiritu de la Letra (Acercamiento creyente a la literatura). Madrid: PPC.

BAUMAN, Zygmunt (2004) - Amor Líquido: sobre a fragilidade dos laços humanos. Rio de Janeiro: Zahar. (2006) - Confiança e Medo na Cidade. Lisboa: Relógio d’Água.

BESSA-LUÍS, Agustina (2008) - Dicionário Imperfeito. Lisboa: Guimarães.

CARDOSO, Miguel Esteves (2001) - O amigo. In Explicações de Português. Lisboa: Assírio \& Alvim, p. $108-112$.

CÍCERO (1928) - L’Amitié. Texte établi et traduit par L. Laurand. Paris: Les Belles Lettres.

CORREIA, Hélia (2012) - A Terceira Miséria. Lisboa: Relógio d’Água.

DUQUE, João (2003) - Dizer Deus na Pós-Modernidade. Lisboa: Univ. Católica Editora.

LYOTARD, Jean-François [s.d.] - A Condição Pós-Moderna. Lisboa: Gradiva.

LIPOVETZKY, Gilles (2012) - A Sociedade da Decepção. Lisboa: Edições 70.

MENDONÇA, José Tolentino de (1994) - As Estratégias do Desejo. Lisboa: Cotovia.

(1999) - Baldios 2. a ed.. Lisboa: Assírio \& Alvim.

(2001) - De Igual para Igual. Lisboa: Assírio \& Alvim.

(2005a) - Perdoar Helena. Lisboa: Assírio \& Alvim.

(2005b) - A Estrada Branca, Lisboa, Assírio \& Alvim.

(2010a) - O Hipopótamo de Deus e outros textos (Cristianismo e Cultura). Lisboa: Assírio \& Alvim.

(2010b) - Baldios. Lisboa: Assírio \& Alvim.

(2012) - Estação Central. Lisboa: Assírio \& Alvim.

(2013a) - Nenhum Caminho Será Longo (Para uma teologia da amizade). 6. ${ }^{\mathrm{a}}$ ed. Lisboa: Paulinas.

(2013b) - O Estado do Bosque. Lisboa: Assírio \& Alvim.

(2015) - Que Coisa São as Nuvens. Lisboa: Expresso.

MEXIA, Pedro (2015) - Biblioteca. Lisboa: Tinta da China.

QUEIRÓS, Eça de [s.d.] - A Cidade e as Serras. Lisboa: Ed. Livros do Brasil.

VATTIMO, Gianni (1991) - A Sociedade Transparente. Lisboa: Edições 70.

(1987) - O Fim da Modernidade - Niilismo e Hermenêutica na cultura pós-moderna. Lisboa: Presença.

VIEIRA, António (1944-1945) - Sermões. 16 vols. São Paulo: Anchieta. 



\title{
CÂMARA ESCURA: MEMÓRIA OBSCURA DO TEMPO EM INÊS LOURENÇO
}

\author{
CIDÁLIA DINIS*
}

A minha infância

cheira a soalho esfregado a piaçaba

aos chocolates do meu pai aos Domingos

à camisa de noite de flanela

da minha mãe

Ao fogão a carvão

à maquina a petróleo

ao zinco da bacia de banho

[...]

Inês Lourenço, Câmara Escura, p. 5

Fendem-se «os versos/com a lâmina Implacável do tempo», crava-se «o sabre rente às vísceras dos verbos», despedaçam-se «os músculos dos sentidos» e de um só gesto, de um só golpe rasga-se «a velha epiderme» ${ }^{1}$ : as palavras passam a desenhar-se no papel e a cada imagem captada pela "câmara escura», o poema vai revelando o espectro de um passado que o passar do tempo assassinou e a memória teima em reavivar.

Em Câmara Escura, breve antologia organizada por Manuel de Freitas ${ }^{2}$, assistimos já a uma poesia que, segundo, António Guerreiro, é «submetida a um filtro rigoroso e idiossincrático» ${ }^{3}$. De três décadas de publicações, desde Cicatriz 100\% (1980) a Coisas que Nunca ${ }^{4}$, foram selecionados somente 30 poemas. É como se de cada livro fossem apenas reveladas, à luz da "câmara escura», como o próprio título sugere, três ou quatro imagens, que deixando de fazer parte do contexto inicial, passam a (re)criar uma nova narrativa, sucessivas micro narrativas.

De facto, toda a sua progressão textual faz-se no sentido de «uma mais alta definição da voz poética, passando por experiências de dicção em que se podem distinguir essencialmente três momentos» cruciais $^{5}$ : uma primeira fase marcadamente

\footnotetext{
* CITCEM - Centro de Investigação Transdisciplinar Cultura, Espaço e Memória.

${ }^{1}$ LOURENÇO, 2010: 19.

${ }^{2}$ LOURENÇO, 2012.

${ }^{3}$ GUERREIRO, 2012.

${ }^{4}$ LOURENÇO, 2010.

${ }^{5}$ BRAGA et al., 2001: 92.
} 
engagée, feminista e contestatária, a que correspondem Cicatriz 100\% e Retinografias; uma segunda fase, da qual fazem parte Os Solistas, onde se assume uma atitude mais distante, descomprometida e mais irónica, sarcástica, em que se esboçam os vectores axiais da sua poética; e um terceiro momento, que se inicia com Teoria da Imunidade e se estende por Um Quarto com Cidades ao Fundo, A Enganosa Respiração da Manhã, Logros Consentidos, Disfunção Lírica e Coisas que Nunca, no qual Inês Lourenço opta, manifestamente, por uma poesia mais próxima da realidade, comprometida com o quotidiano, o minimalismo e umbilicalmente apoiada numa «acidez cortante de uma ironia iconoclasta» ${ }^{6}$.

Destes três momentos ressalta, segundo Isabel Allegro Magalhães, «um universo de sensações que são o lugar de arrebatamento, com o desejo e a imaginação a convocá-las, uma epistemologia dos sentidos, que constrói o erotismo e a sensualidade na relação com os seres, os acontecimentos, a corporeidade da existência» ${ }^{7}$. No seio dessa fixação com o comum da vida, onde são fotografados pequenos nadas, constantes do presente ou da «decantação da memória» ${ }^{8}$, o ritmo «involuntário» da vida invade-nos «docemente a alma». Desse ritmo «intensamente irregulado/ofegante ou sísmico» ${ }^{9}$ esboça-se Câmara Escura, livro feito de sucessivas reinvenções, de múltiplos sentidos ou sem-sentidos, da revelação de rolos fotográficos escrupulosamente guardados na memória, onde a voz da poeta pulsa como «lâmina implacável do tempo», despedaçando os «músculos dos sentidos»:

\section{Reescrita}

Fender os versos

com a lâmina implacável do tempo. No umbigo do poema cravar

o sabre rente às vísceras dos verbos, à linfa de adjectivos. Despedaçar os músculos dos sentidos. Abrir a rede viária do sangue. Romper a velha epiderme ${ }^{10}$.

Câmara Escura é, pois, o reflexo de uma voz que ao longo do tempo se foi delineando, num progressivo e contínuo amadurecimento, assente simultaneamente

\footnotetext{
${ }^{6}$ BRAGA et al., 2001: 92.

${ }^{7}$ SEIXO et al., 2001: 174-176.

${ }^{8}$ SEIXO et al., 2001: 174-176.

${ }^{9}$ LOURENÇO, 2010: 19.

${ }^{10}$ LOURENÇO, 2012: 39.
} 
numa poética de sabedoria e da emoção concebida pela razão. Desde sempre, e segundo valter hugo mãe, que «a escrita desta autora se faz desse estar acima parecendo levar o chão nos pés, ou vir ao chão suportando o céu nas mãos» ${ }^{11}$. É do encontro com a memória, a infância, o corpo, a cidade, o espaço, com a transfiguração do quotidiano e a circunstância que a sua poesia espelha uma (in)temporalidade renovada e inovadora:

\section{Coisa que Nunca - I}

Há coisas que nunca tivemos em criança e perdem o valor para sempre. Aquele sempre dos primeiros dez anos, onde o tempo, as pessoas, as coisas parecem enormes e indestrutíveis.

Disfarçar-se de relâmpago ou de outras coisas impossíveis, comer todos os chocolates, ter uma bicicleta igual à do estúpido do vizinho, fazer as coisas que os adultos escondem atrás da porta dos quartos, retribuir a bofetada aos nossos legítimos superiores, querer morder com justa causa tanta gente no mundo e só poder no escuro morder uma almofada ${ }^{12}$.

Aqui a memória pode apresentar-se em diferentes vertentes: como imagem poética, capaz de transcender a esfera do simplesmente vivido, para de acordo com Octavio Paz ser «metamorfose, mudança, operação alquímica», e como tal ser «limítrofe da magia, da religião, e de outras tentativas para transformar o homem e fazer "deste" ou "daquele" esse "outro" que é ele mesmo»" envolvente e aqui a poesia, ao mergulhar no terreno da memória mais profunda, mais obscura, dá conta da nossa condição enquanto seres humanos finitos, experienciadores de «tempos» que se sobrepõem, que se fundem, mesmo quando esse tempo é fugaz.

\footnotetext{
${ }^{11}$ MÃE, 2003a.

${ }^{12}$ LOURENÇO, 2012: 36.

${ }^{13}$ PAZ, 2006: 50.
} 
Relembro um poema de Miguel Torga, onde o autor descreve a angústia que enfrenta, face à fugacidade do tempo, quando a imagem se revela:

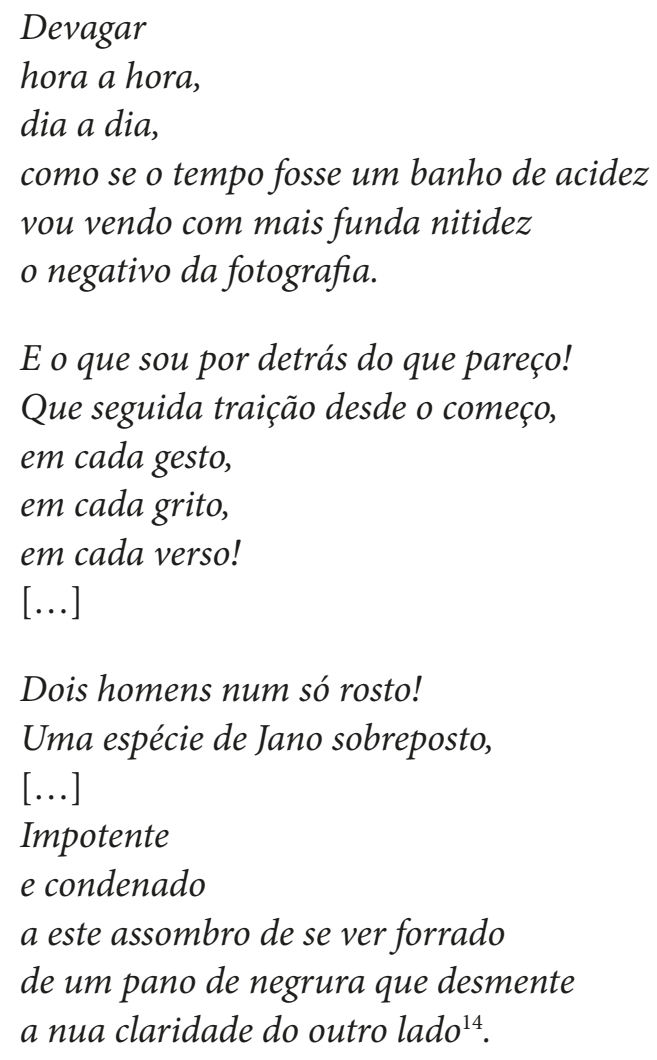

Dois homens num só rosto!

Uma espécie de Jano sobreposto,

[...]

Impotente

e condenado

a este assombro de se ver forrado

de um pano de negrura que desmente

a nua claridade do outro lado ${ }^{14}$.

Essa fotografia, captada pela «câmara escura» revela-se, assim, como uma imagem dupla: por um lado combina um tempo presente (do ato da perceção), por outro um tempo passado (o da lembrança). Contudo, uma das especificidades do tempo presente de uma imagem reside justamente no facto de que também ela evoca um futuro imediato (quando da sua revelação). Surge, então, na poeta, essa consciência do tempo fotográfico:

\section{Cavalo}

O arrumador de carros

agita os braços, indicando

${ }^{14}$ TORGA, 2014: 187. 
um lugar disponível. Junto

da praça da estátua equestre

recolhe com a mão magra

a gota de níquel, que mais logo

lhe correrá nas veias ${ }^{15}$.

Mas, a memória pode ainda apresentar-se sob a forma de diálogo com outros autores e artistas plásticos ou até mesmo com a pintura, a música, podendo ser entendida também ela como memória cultural e, portanto, de caráter coletivo:

\section{Thomas Bernhard}

Dediquei-lhe um poema, há mais de dez anos, para o qual certamente se estaria nas tintas, se o lesse. É um dos raros escritores que conseguiu a difícil lucidez de detestar a pátria, essa obrigatória e durável fonte de equívocos e mal-entendidos. Por isso ele gostava de passar temporadas em Portugal, não pelo mar, nem pela comida, nem pelos modos amigáveis para turistas. Mas sim porque podia escutar uma língua sem ter de entendê-la $a^{16}$.

É, portanto, desta noção de intertextualidade que se amplifica a ideia de memória enquanto palavra nua e crua, imagem, «tecido» ilimitado de ligações, afinidades, fragmentos.

Em Câmara Escura, mais do que uma recolha de "contida e rigorosa escrita», há antes uma alternância entre poemas curtos e longos, assentes numa lógica de sequencialidade orgânica e vincadamente serial, isto é, compõem-se de poemas claramente entrelaçados, numa límpida construção que prende e envolve de forma poderosa o leitor. Inês Lourenço é, desde logo, «criadora de ponderado verso, como verso calibrado por metrónomo, cortado por mão segura» ${ }^{17}$. Como uma faca. Sem paradas inúteis. Vertiginosamente, em que tudo é dito de forma lapidar e cristalina, mas sob um olhar simultaneamente ácido e sereno:

${ }^{15}$ LOURENÇO, 2012: 22.

${ }^{16}$ LOURENÇO, 2012: 32.

${ }^{17}$ MÃE, 2003b: 35. 
Arte Poética III

O poeta disse: a inspiração

não existe. De há muito, as musas

ficaram desempregadas. E desvendou

algum método de trabalho

à parca assistência, altivo e contemporâneo,

enquanto lá fora o mar e as altas palmeiras

resistindo ao tráfego do fim de tarde,

pouco se interessavam

pela carpintaria dos versos ${ }^{18}$.

Oscilando entre uma escrita marcada por um universo feminino, sem ser feminista, e uma apurada sensibilidade do mundo, os seus textos são o reflexo de uma voz que espicaça a moralidade caquética da sociedade pequena, do quotidiano repetitivo, de um tempo marcado pela disforia.

É nesta capacidade de conferir ao discurso um outro olhar sobre as coisas, sobre as circunstâncias do mundo, que a sua poesia se reveste de originalidade, inventando e reinventando-se:

Passageira

O poema que não

surpreende nem afirma

a inutilidade de si, nem ensina

a olhar a certa dissolução

das coisas, nem interroga

o desencanto

É uma espécie de prurido

nas nossas costas, coisa

irritante e passageira

que logo se esquece ${ }^{19}$.

Em Câmara Escura, mais do que uma atenta observação da realidade que a rodeia, realidade que é tempo, corpo, alma; a poeta estabelece um pacto com o leitor, reconduzindo-o não só pelos meandros da memória, como também confrontando-o

${ }^{18}$ LOURENÇO, 2012: 33.

${ }^{19}$ LOURENÇO, 2012: 33. 
com curiosos retratos dos anseios e das deceções do quotidiano. Aqui a palavra dá lugar a «emoções/e escárnios»:

\author{
Alternadeiras \\ Contigo, leitor, celebro \\ esta união sem facto, abro \\ este habitáculo, algumas gavetas \\ secretas para demorar contigo emoções \\ e escárnios. És, talvez, como eu \\ uma alternadeira de palavras, destas \\ que vendem no papel, os objectos \\ trucidados pelo olhar em lençóis \\ de falsa transparência e ficção \\ furtiva. Outras, mais reais \\ e mais humanas, professam \\ uma devastada arte de amar \\ e nós um devastado amor \\ à arte dos versos que ninguém \\ lê. Só nós nos lemos \\ uns aos outros, tal como elas \\ se vigiam sobre o 'trottoir" ${ }^{20}$.
}

Fernando Pinto do Amaral (1982) e João Barrento, entre outros, analisando a poesia portuguesa da pós-modernidade, diagnosticaram-lhe um generalizado e «difuso sentimento de melancolia» ${ }^{21}$. Ora, em Inês Lourenço não encontramos propriamente um fio condutor impregnado de melancolia, mas sim um turbilhão de sensações, resultantes de uma voz insubmissa e acutilante, que não esconde uma genuína vontade de transgredir, de sacudir mentalidades, recorrendo para o efeito a um tom sarcástico, mordaz, a uma ironia epigramática:

\title{
Sessão Literária
}

Falam de perfeição. De perseguir ao menos em verso, esse vórtice de luzes

e excelsa beleza ou

beatitude que logrará

${ }^{20}$ LOURENÇO, 2012: 26.

${ }^{21}$ BARRENTO, 1996: 79-94. 
a canónica obra. Velho

enredo já sem graça divina

nem humana.

Melhor falassem

das batatas novas, que

costumam aparecer

antes da Páscoa ${ }^{22}$.

Pedra angular da sua obra é também o pacto que a sua poesia estabelece com a força pura da palavra - o Verbo - a poesia enquanto «liberté libre» ${ }^{23}$, capaz de transfigurar, desmontar a realidade circundante. Com esse suave desmontar da realidade, Inês Lourenço, conquista o leitor e convida-o a participar na 'sabotagem' dos sentidos, dos temas, a envolver-se no poder salvífico da poesia. Só a poesia na sua plenitude poderá ser memória, recordação, lembrança no silêncio cortante:

Arte Poética II

(coda)

Poluída e rutila

é a beleza de um verso

cercado o movente sangue

sobre a neve,

lugar em bússola onde escassos chegam,

sem país, sem linho, sol ou noite $e^{24}$.

${ }^{22}$ LOURENÇO, 2012: 35.

${ }^{23}$ RIMBAUD apud ROSA, 1986: 28.

${ }^{24}$ LOURENÇO, 2012: 15. 


\section{REFERÊNCIAS}

AMARAL, Fernando Pinto do (1982) - Na Órbita de Saturno. Lisboa: Hiena.

BARRENTO, João (1996) - O Astro Baço: a poesia portuguesa sob o signo de Saturno. In A Palavra Transversal. Lisboa: Cotovia.

BRAGA, Daniela et al. (2001) - Inês Lourenço: Um Quarto com Cidades ao Fundo. «Apeadeiro, revista de atitudes literárias», n. ${ }^{\circ} 1$ (Primavera). Vila Nova de Famalicão: Quasi.

GURREIRO, António (2012) — «Recensão». «Expresso, Atual», (17 março).

LOURENÇO, Inês (2010) - Coisas que Nunca. Lisboa: \& etc. (2012) - Câmara Escura: Uma Antologia. Seleção de Manuel de Freitas. Lisboa: Língua Morta.

MÃE, Valter Hugo (2003a) - Métodos de Encantar Incautos. «Público, Suplemento Mil Folhas», (15 março). (2003b) - Inês Lourenço e José Emílio-Nelson: a poesia de 80 em dois exemplos fundamentais. «Esquina do Mundo - Centro de Estudos Ferreira de Castro», 1 (dez.). Vila Franca de Xira: Ed. Colibri.

PAZ, Octavio (2006) - Signos em Rotação. Trad. de Sebastião Uchoa Leite. 3. ${ }^{a}$ ed. São Paulo: Perspectiva. ROSA, António Ramos (1986) - Poesia Liberdade Livre. Lisboa: Ulmeiro.

SEIXO, Maria Alzira et al. (2001) — Inês Lourenço. In Vozes e Olhares no Feminino. Porto: Afrontamento. TORGA, Miguel (2014) - Antologia Poética. 7. a ed. Lisboa: Dom Quixote. 



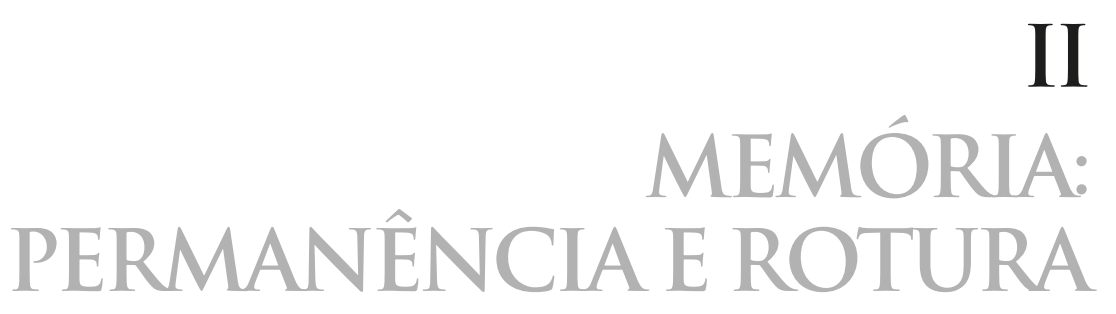





\section{LUZ DE INTIMIDADE: \\ POEMAS TRADUZIDOS DE MARIA JOÃO REYNAUD}





\section{SOMBRA}

Esta é a mão:

falo do que não sabes signo ou hieróglifo, sigma

com que pluralizo o gesto tão inútil de buscar-te. Quem és?

O que és?

Dreno desta ferida

em que me faço?

Ou cão de lume que me morde os passos? 


\section{SHADOW}

This is the hand:

I am talking about something unknown to you sign or hieroglyph,

a sigma

with which I pluralize the gesture

so worthless in seeking you.

Who are you?

What are you?

The drain of this wound

that I myself create?

Or a fierce dog

biting my steps?

Tradução de Erin McCombe. 


\section{CREPÚSCULO}

O amor oculta-se

na dobra do dia.

Ou, talvez, na outra

vertente da colina.

Mas à hora em que

a luz declina e o

mar se desfaz em

névoa, uma voz

térrea pergunta:

- Onde estarás? 


\section{CRÉPUSCULE}

L'amour se cache

dans les replis du jour.

Ou, peut-être, dans l'autre

versant de la colline.

Mais à l'heure où

la lumière décline et la

mer se défait en

brume, une voix

terrienne demande:

mais où donc es-tu?

Tradução de Thomas dos Santos. 
JANELA

Quantas vezes sua mão me salvou do abismo? A mãe tocava um estudo de Liszt, enquanto eu, debruçada na janela, via o dia ir-se embora num andamento triste. O Pai, à hora, dobrava a esquina. E a sua figura iluminava de tal modo a rua, que a janela deslizava para o precipício de luz. Invisível, sua mão mantinha-me segura. O Pai subia as escadas devagar, abria a porta. E o dia despontava no azul do seu olhar. $\mathrm{O}$ anjo vigilante então partia. 


\section{FINESTRA}

Quante volte la sua mano mi salvò dall'abisso? La madre sonava un brano di Liszt, mentre io, affacciata alla finestra, guardavo il giorno andarsene in una andatura triste. Il Padre, puntuale, girava l'angolo. E la sua figura Illuminava di tal modo la strada, che la finestra scivolava verso il precipizio di luce. Invisibile, la sua mano mi teneva sicura. Il Padre saliva le scale adagio, apriva la porta. E il giorno spuntava nell'azzurro dei suoi occhi. L’angelo custode allora partiva.

Tradução de Ada Ghizzo. 


\title{
DEIN ANGESICHT
}

À Margarida Losa

\author{
Teu rosto \\ rosa-dos-ventos \\ apontando \\ impossíveis pontos cardeais.
}

Teu corpo

rasando

a linha do horizonte

ou o rasto recente dos metais.

Teus dedos

tecendo

o fio azul do infinito.

Tua memória

num tempo rarefeito.

Dentro e fora de ti

o silêncio perfeito. 


\section{DEIN ANGESICHT}

von Margarida Losa

Dein Angesicht

Rose des Windes

deutet

in unmögliche Himmelsrichtungen.

Dein Körper

streift

die Linie des Horizontes

oder die frische Spur der Metalle.

Deine Finger

webend

den blauen Faden der Unendlichkeit.

Dein Andenken

in rarer Zeit.

Innen und außen von dir die perfekte Stille.

Tradução de Svenja Von Reuss. 
CASA

Os dias constroem a casa, sem pressa.

Os dedos amassam a cal

e alongam-se

na invenção dos espaços.

O sol, horizontal, dispõe as sombras

e hesita em acender o lume.

$\mathrm{O}$ vento traz o gemido e a semente.

A terra, o corpo

macio.

O sussurro da água

humedece o estio.

As lançadeiras descansam

a voz.

Os dedos pousam

na manhã tecida,

duros como mós.

E o silêncio cresce

nessa branca ferida. 
CASA

Los días construyen la casa, sin prisa.

Los dedos amasan la cal y se prolongan inventando los espacios.

El sol, horizontal, reparte las sombras $y$ vacila al encender el fuego.

El viento trae el gemido y la semilla.

La tierra, el cuerpo El susurro del agua humedece el estío. Las lanzaderas descansan la voz.

Los dedos se posan en la mañana tejida, duros como piedras.

$Y$ el silencio crece en esa blanca herida. tierno.

Tradução de Andrea Ucha Bouzada. 


\title{
"METAMORFOSES DA ESCRITA»: ALGUNS OLHARES SOBRE UMA TRADIÇÃO DA CRÍTICA LITERÁRIA EM PORTUGAL NO SÉCULO XX
}

\author{
DANIEL-HENRI PAGEAUX*
}

O título da minha comunicação é, evidentemente, uma alusão (um clin d'œil, como se diz em francês) à tese magistral de Maria João Reynaud, dado que, com este colóquio, queremos prestar-lhe uma homenagem. Todavia, a palavra «metamorfose» serve-me também para associar alguns nomes, que pretendo apresentar como estando ligados a uma tradição crítica das letras portuguesas: a do ensaio literário. Estou bem ciente da importância dos trabalhos já realizados sobre esse tema. Apenas gostaria de salientar uma tendência que considero original e fecunda. Nesse percurso, destacam-se os nomes de Vitorino Nemésio, David Mourão-Ferreira e Eduardo Lourenço. São nomes escolhidos de maneira não arbitrária ou pessoal, dado que se conjugam nas suas obras a dimensão crítica e uma dinâmica criadora.

No número especial de «Colóquio/Letras» em homenagem a David Mourão-Ferreira, intitulado Infinito pessoal, Vítor Aguiar e Silva publica um denso e notável artigo consagrado ao "ensaísmo literário de David Mourão-Ferreira» ${ }^{1}$. Esse texto ilustra magistralmente o tipo de trabalhos a que acabei de fazer alusão e poderíamos

* Sorbonne Nouvelle/Paris III.

${ }^{1}$ SILVA, 1997. 
mesmo considerar este contributo como sendo a base da minha própria intervenção. Mas aquilo que retém sobretudo a minha atenção é o ponto de partido cronológico escolhido, 1949, dando como exemplo a tese de concurso para Professor Extraordinário de Jacinto do Prado Coelho, intitulada Diversidade e unidade em Fernando Pessoa.

Interessam-me em especial duas características neste trabalho universitário, tal como apresenta Aguiar e Silva: por um lado, uma certa continuidade na reflexão («sem provocar propriamente uma ruptura com o magistério universitário de Hernâni Cidade e Vitorino Nemésio») e por outro lado, a originalidade do projeto. Como diz Aguiar e Silva: «era uma dissertação ensaística que se afastava deliberadamente do modelo lansoniano da erudita tese de história literária e do tipo de investigação considerada como "científica"».

É neste contexto e nesta espécie de filiação intelectual que Aguiar e Silva situa a formação intelectual de David Mourão-Ferreira, o qual, aliás, se voltou posteriormente para outros mestres (Leo Spitzer, Ernst-Robert Curtius, Helmut Hatzfeld, Dámaso Alonso e o new criticism anglo-norte-americano). Mas destaco duas palavras, dois advérbios de modo que me parecem significativos da linha de pensamento adotada pelo então jovem David Mourão-Ferreira: «Acolheu e soube criativamente [sublinho] utilizar a lição destes mestres». E ainda: «assimilou consistentemente [segundo traço importante] ideias novas do new criticismo». Esta aprendizagem livre justifica a imagem de scholar utilizada por Aguiar e Silva, que especifica: «é dotado de um fino espírito analítico e com uma exigência permanente de rigor mental».

Subscrevendo inteiramente esta análise, decidi, no entanto, escolher um outro ponto de partida e um outro nome: 1958, ano da publicação de Conhecimento de Poesia de Vitorino Nemésio ${ }^{2}$. Sei bem que o ilustre professor tem no seu ativo obras de ficção e estudos que são mais importantes. No entanto, esta coletânea de artigos, inicialmente publicados em São Salvador da Bahia, antes de serem publicados pela Editorial Verbo, parece-me emblemática de uma escrita que tento aqui definir. Além disso, esta coletânea, abrangendo uma grande diversidade de textos ao longo de dois decénios, é também a expressão de continuidade de uma certa reflexão crítica, pelo menos a nível individual, o que é o objetivo desta comunicação.

Sublinho, antes de mais, a palavra «conhecimento», a qual, para lá de um certo sentido de humor, nos introduz no âmago das questões levantadas por este tipo de crítica:

Assim, por conhecimento há-de entender-se o que uma receptividade pessoal comovida e afim possa revelar e aproximado à compreensão suficiente da criação alheia. Se nada se apurar, mesmo assim, apelarei poeticamente para o sentido bíblico,

${ }^{2}$ NEMÉSIO, 1958. 
nupcial, do conhecer. Ninguém me pode impedir de ter conhecido a Poesia, embora com abuso e violência. O resto é com o remorso e o perdão...

Trata-se claramente de realçar, antes de mais, uma certa «experiência poética» (sirvo-me aqui das palavras de poetas que são também críticos, como Jacottet ou Bonnefoy) considerada como critério e caução da abordagem crítica que Nemésio pretende levar a cabo.

Segunda declaração de intenções, que vai no mesmo sentido da primeira:

Se, como estudioso, procuro dissecar os textos pelos métodos que se me afiguram estilisticamente mais válidos, como escritor e poeta prefiro reagir às personalidades e às obras um pouco ao sabor do gosto e do modo pessoal como intuo a criação literária.

Sempre estabelecendo uma certa distância humorística, Nemésio diverte-se a jogar a uma variante do Dr. Jekill e Mr. Hyde, mas é óbvio que pretende evidenciar duas abordagens possíveis e que a escolha, sentimental e mesmo intelectual, incide sobre uma abordagem feita a partir do ponto de vista do criador. É esta atitude, esta escolha que pretendo relevar, pois vejo aí o fundamento de uma crítica «criativa», ou a que chamaria «re-criadora», e que justifico nos seguintes termos: fazer crítica de maneira a que o trajeto da leitura se aproxime mais do trajeto da escrita. Trata-se da conferência de abertura proferida no Congresso de Tours da SFLGC em 2012, intitulada Expérience critique et «expérience formelle», publicada em Lécrivain et son critique ${ }^{3}$.

Ideal crítico mais do que método crítico, inscrito no horizonte da investigação ou da reflexão, acrescente-se desde já, quer para Nemésio quer no que me diz respeito. Quanto a Nemésio, seria fácil considerar a sua escrita como «impressionista», ou antes, guiada pela «impressão», característica que, cada um à sua maneira, foi realçada por David Mourão-Ferreira e Eduardo Lourenço: estou a pensar sobretudo nas páginas de Canto do signo sobre "A conversação crítica de Nemésio»". E também os outros estudos do professor e romancista que são consagrados à história da literatura ou mesmo à biografia.

Limito-me aqui a observar, numa lista simples, alguns processos de escrita que ilustram, na minha opinião, aquilo que se poderá designar por «ensaio crítico» e que exprimem a liberdade de escrita e, antes de mais, de leitura por parte de Nemésio. Lembremos também que esses processos de escrita podem, sem dúvida, ser encontrados noutros escritores, mas em Nemésio inserem-se num texto pleno de referências culturais, 
exprimem uma cultura geral prodigiosa, que não faz alarde mas que confere ao texto um plano de fundo humanista, bem como uma autoridade e uma segurança na análise.

1. Próximo da história literária e de uma certa abordagem biografista, o paralelismo é uma maneira de identificar a originalidade ou a singularidade de duas obras ou de dois autores e de permitir perspetivas novas de releitura ou de reavaliação crítica. Exemplos: Jorge Guillén e Valéry ou ainda Cesário Verde e Afonso Duarte5:

O realismo proletário e ruralista de Cesário Verde ficaria isolado e desapoiado na literatura portuguesa sem o bucolismo vivencialmente aldeão de Afonso Duarte. São duas éticas e estéticas complementares: o urbano e o rústico da vida nacional captados por dois grandes poetas cristalinos.

2. A comparação que procura provocar o interesse do leitor pela sua imprevisibilidade ou mesmo pelo seu pitoresco e que obriga, também aí, a uma releitura. Exemplo: Mário de Sá-Carneiro:

Sá-Carneiro dispõe de uma versificação de pianista - mas como ele diz "o piano estala agoiro». A sua escrita lírica é muitas vezes tumultuosa, de uma instrumentação intensiva e inconexa. Daí a deficiente composição dos seus poemas, por assim dizer abertos no início e no fecho a correntes contrárias, que só conseguem acordar-se em confidência gradual nalgumas das suas últimas líricas.

3. Uma forma de comparação que é a alusão, simples sugestão que permite prosseguir livremente a reflexão, quer dizer, a leitura ou o conhecimento meditativo do texto poético. É assim que a coletânea Coral de Sophia de Mello Breyner Andresen ultrapassa as bases habituais do lirismo português e se abre a «domínios intuitivos e expressionais em que trabalhou certa poesia estrangeira, e da melhor. Ponho por casos: Rilke e Supervielle» ${ }^{7}$. Por vezes, a alusão transforma-se em abertura a outros domínios e o arbitrário é evitado graças a uma associação de ideias que parece $a$ posteriori evidente. Por exemplo, um «Nocturno» de Roberto de Mesquita suscita, apela, digamos, a alusão a Chopin: "O "Nocturno" que esteve a ponto de ser cristão, desfechou num "Nocturno" de Chopin.» ${ }^{8}$.

${ }^{5}$ MOURÃO-FERREIRA, 1969: 36-37, 158.

${ }^{6}$ MOURÃO-FERREIRA, 1969: 166.

${ }^{7}$ MOURÃO-FERREIRA, 1969: 214.

${ }^{8}$ MOURÃO-FERREIRA, 1969: 141. 
4. Último processo de análise textual, sem dúvida o mais evidente: a frase sintética, a capacidade de síntese demonstrada em algumas linhas, mas este processo tem a ver com a crónica jornalística, que obriga a ser breve: foi aquilo a que David Mourão-Ferreira chamou "crítica imediata» ou «discurso direto», expressão que lhe serviu para título de uma coletânea de ensaios e crónicas. Cite-se, para exemplo, o que é quase a conclusão de um artigo sobre Gomes Leal:

Na confluência literária do ultra-romantismo, do satanismo byrónico, do Parnaso e do simbolismo, Gomes leal deixou uma obra formidável, em que a versificação torrencial e de circunstância esconde, como uma selva, preciosas composições de grande surto, quer puramente líricas, quer satíricas, quer fundindo harmoniosamente os dois filões do seu génio?.

Neste exemplo, como em tantos outros, é através de um movimento inspirado da análise, de uma simples palavra, de uma imagem, de um achado de ordem poética (e não crítica), como neste caso a palavra «selva», que se reorienta o conjunto do texto, traçando, com a ajuda de uma classificação, novas orientações de estudo e novas perspetivas de leitura.

Leitura... Esta palavra é, de facto, essencial para a elaboração de um discurso crítico que tento definir. Assim, não deve ser considerada banal ou casual a frase de Aguiar e Silva ao apresentar David Mourão-Ferreira como «um culto, generoso e finíssimo leitor de outros escritores, sobretudo modernos e contemporâneos». A «leitura», tal como a pratica David, ou seja, como expressão de um ato crítico, é, antes de mais, uma certa «relação crítica», para utilizar a expressão cara a Jean Starobinski, concebida como «encontro», seguido de «diálogo», com o texto, evitando dois grandes obstáculos: a erudição e a paráfrase admirativa. É a invenção de uma espécie de terceira via, feita essencialmente de respeito pelo texto e de rigor na abordagem crítica. Ainda aí, remeto para um ensaio meu já publicado: «Portrait du critique en Vertumne» ${ }^{10}$.

Faço notar que David Mourão-Ferreira não hesitou em utilizar a palavra «leitura» como título de muitos dos seus ensaios: «Para uma leitura de O Barão de Branquinho da Fonseca» ${ }^{11}$, onde põe em relevo o processo de «digressão»; na mesma coletânea figura uma «Releitura de Húmus», que põe em evidência o caráter de «novo romance avant la

\footnotetext{
${ }^{9}$ MOURÃO-FERREIRA, 1969: 92.

${ }^{10}$ PAGEAUX, 2001.

${ }^{11}$ MOURÃO-FERREIRA, 1969.
} 
lettre» da obra-prima de Raul Brandão. Em Sob o mesmo tecto deparo com «Um convite à leitura de $A$ casa fechada de Vitorino Nemésio» ${ }^{12}$; enfim, em Tópicos recuperados há uma «Introdução a uma leitura do conto Gente singular de Teixeira-Gomes» ${ }^{13}$.

Tentando definir o que poderá significar a palavra «leitura», espécie de subgénero da literatura crítica, destacarei antes de mais a vontade de se cingir ao texto, apenas ao texto, na sua totalidade. Trata-se de mergulhar no texto, nas palavras do texto, de uma expedição íntima, de que ainda encontro o eco ou o rasto nessas outras «leituras» recolhidas na coletânea intitulada Vinte poetas contemporâneos. No prefácio, sublinho duas declarações de intenção particularmente simples e reveladoras do projecto de David: por um lado, a recusa de transformar o texto em "pretexto», «tendência cada vez mais em voga», é referida, não sem intenção polémica; por outro lado, o esforço no sentido de "criticar as obras por dentro». E precisa: «realizar ou tender para uma espécie daquela «crítica imanente» a que se refere Leo Spitzer» ${ }^{14}$.

Uma segunda característica da crítica praticada por David Mourão-Ferreira através do exercício da leitura é a da crítica «poética». Trata-se de entrar no texto e, depois de uma análise que designaríamos, prudentemente, por «estrutural», definir um ou vários processos essenciais à escrita do texto em questão. E para precisar o que entendo por abordagem "poética», recorro ao próprio David, numa reflexão feita à margem de um estudo sobre António Sérgio (ao qual devemos voltar, especificando melhor a dupla cronologia apresentada no início deste trabalho). Trata-se, como acontece frequentemente nos textos críticos e ensaísticos de David, de uma citação, de algumas palavras que, no seu fulgor, iluminam a problemática complexa que é abordada. David lembra uma frase de Dámaso Alonso, no seu prefácio à tradução espanhola de Theory of Literature de Wellek e Warren:

Somos muitos os que nesta primeira metade do século, espalhados pelo mundo, nos situamos perante o poema [...] para lhe perguntar algo de muito distinto do que no século XIX lhe perguntara: não porquê, como se originou, mas sim o que é 15 .

David acrescenta, para tornar mais precisa a ideia dessa mudança de perspetiva: «esse giro do genético ao estrutural». E considera António Sérgio como sendo «o primeiro», o que nos permite utilizar sem medo a palavra «estrutura»e, simultaneamente, nos estimula a rever a nossa cronologia...

Enfim, terceira e última característica da leitura como ato, prática crítica: ao utilizarmos a palavra «leitura» damos primazia à relação pessoal, subjetiva, com o

\footnotetext{
${ }^{12}$ MOURÃO-FERREIRA, 1989.

${ }^{13}$ MOURÃO-FERREIRA, 1992.

${ }^{14}$ MOURÃO-FERREIRA, 1960: 22.

${ }^{15}$ MOURÃO-FERREIRA, 1976: 157.
} 
texto, o que poderá parecer paradoxal para aqueles que se apressam a fazer da análise estrutural uma abordagem crítica dita «científica», neutra, objetiva, o que, evidentemente, não é. Quando a palavra «leitura» não é utilizada, deve-se destacar a palavra «retrato», que David utiliza sobretudo para a obra de Marguerite Yourcenar ${ }^{16}$, o que implica, obviamente, um desafio dirigido ao discurso crítico relativamente à obra original, uma tensão entre imitação (mimesis, reprodução) e recriação, invenção. Insistimos igualmente, de novo, na ideia de uma crítica que pratica com o texto uma espécie de princípio dialógico, de compreensão interindividual, de relação intersubjetiva, e que está pronta a adaptar-se em função de cada texto considerado na sua singularidade. E esta não é a menos importante das lições que, como crítico, David Mourão-Ferreira nos legou: não há uma chave universal para abrir todos os textos, não há um método único.

Se tivesse de caracterizar o processo (não ouso dizer método) de abordagem crítica de David com uma palavra, recorreria a um pequeno mas luminoso artigo de Jean Starobinski intitulado "Le texte et l'interprète», inserido numa obra colectiva intitulada Faire de l'histoire ${ }^{17}$. Devemos entender aqui a palavra «intérprete» num sentido quase musical, que implica, portanto, o respeito do modelo, do original, uma certa intimidade e proximidade do texto (ou da obra musical) e, ao mesmo tempo, a distância ou a diferença, simultaneamente criadora e traidora, um pouco como se diz a propósito do tradutor: traduttore tradittore. Jean Starobinski analisou profundamente a posição original do crítico, utilizando de maneira significativa o paradoxo e o oxímoro. Nesse texto, fala de uma «contemplação compreensiva» de uma «junção de rigor metodológico com disponibilidade reflexiva», em suma, uma atitude complexa e exigente referida, aliás, por Álvaro Manuel Machado no seu livro A arte da crítica ${ }^{18}$.

O que quis sublinhar, a partir de uma série de textos de Starobinski, série que começa em 1946 com um estudo sobre o poeta Pierre-Jean Jouve e que se prolonga até aos dois volumes de L'œil vivant, foi a diferença estabelecida por Starobinski entre a interpretação no sentido musical do termo e a interpretação considerada como abordagem hermenêutica, sobretudo em «Psychanalyse et littérature» ${ }^{19}$. A preferência de Starobinski vai, sintetizando, mais para a primeira possibilidade do que para a segunda, na medida em que esta pode levar, não a interpretar, mas a «sobreinterpretar». Trata-se, para o crítico, de saber acolher (como para o poeta) e de assegurar uma "passagem» (outra maneira de designar a leitura) na sua função de mediação e na sua razão de ser, que é um «acto de conhecimento». É a «metamorfose» do discurso crítico que leva à revelação do texto na sua originalidade, mas também na sua singularidade, conferidas pelo olhar, a relação crítica, o trabalho de leitura do crítico.

\footnotetext{
${ }^{16}$ MOURÃO-FERREIRA, 1988.

${ }^{17}$ STAROBINSKI, 1974.

${ }^{18}$ MACHADO, 2011.

${ }^{19}$ STAROBINSKI, 1970.
} 
A distinção estabelecida por Starobinski entre dois tipos de interpretação poderá, talvez, permitir-nos situar melhor, se não o que é a crítica para Eduardo Lourenço, pelo menos aquilo que creio perceber das intenções do crítico. De facto, é uma tentação situar Eduardo Lourenço numa perspetiva hermenêutica, dado o trabalho empreendido por este crítico e ensaísta desde há vários decénios. Mas é evidente que uma hipótese como essa perante uma obra tão densa e complexa deve ser devidamente esclarecida e aprofundada.

Notemos, antes de mais, que o discurso crítico de Eduardo Lourenço não exclui a prática judicativa, ou seja, o juízo de valor. Assim, por exemplo, ele não hesita em formular reservas quanto a este ou àquele romance. É o caso de Mudança de Vergílio Ferreira:

Um livro pode não ser perfeito e ser um grande livro. Mudança aparece-nos hoje, e em parte graças ao futuro do seu autor, como um romance ainda escravo de um passado que ele ajudara a sepultar. Contudo, é um grande romance ${ }^{20}$.

Além disso, a preferência dada às «leituras» não o impede de se dedicar a estudos que relevam de uma certa história literária, mas considerada como uma espécie de poética histórica, de história das formas (voltaremos a esta palavra fundamental). É assim que a última parte de $O$ canto do signo é consagrada àquilo a que chama «metamorfose da ficção portuguesa». Note-se, enfim, que se uma das características evidentes da crítica de Eduardo Lourenço é o discurso sobre «textos», obras, ele está, no entanto, longe de partilhar o fascínio ou o entusiasmo por aquilo a que chama "obsessão da textualidade», "o texto como textura»" ${ }^{21}$. Esclarece, portanto, a sua posição de crítico nos seguintes termos:

É inútil buscar na génese, na biografia, na realidade social o ser de uma «realidade» cuja matéria é linguagem em luta consigo mesma. [...] Não há, pois, outro horizonte que esse da Forma Literária [com maiúsculas, note-se!] — una e múltipla e indefinida - como referência do exercício espiritual da crítica ${ }^{22}$.

Desta maneira, fica circunscrito o quadro do trabalho intelectual tal como o entende Eduardo Lourenço. A atenção é dada prioritariamente ao elemento puramente

${ }^{20}$ LOURENÇO, 1994: 102.

${ }^{21}$ LOURENÇO, 1994: 67.

${ }^{22}$ LOURENÇO, 1994: 45. 
estético, ou melhor, poético: a Forma. E não resisto a citar esse princípio repetido por Marcel Raymond, chefe de fila de uma escola de críticos que, de facto, nunca o foi, a chamada «Escola de Genebra», ao afirmar que o ato crítico define-se a partir de uma proposta simples do historiador de arte Henri Focillon: «Tomar consciência é tomar forma», princípio que é válido quer para o trabalho de criação quer para o trabalho crítico, o qual, aliás, se situa na sequência daquele. Em segundo lugar, o próprio trabalho crítico é considerado um «exercício espiritual», fórmula que tende igualmente a eliminar qualquer fronteira entre a escrita poética e a escrita crítica.

Por interessantes que sejam estas declarações e estes princípios, continuamos sem ver o que pode justificar a dimensão hermenêutica atrás sugerida. Adiemos, de novo, a resposta possível, assinalando que um dos méritos da reflexão crítica de Eduardo Lourenço, fortemente marcada por uma consciência de autocrítica, é de estabelecer os limites de atividade crítica, que se revela, de facto, a um certo nível, como compreensão da obra. Eduardo Lourenço é o primeiro a duvidar e a pôr reservas a esta teoria, a esta pretensão de compreender totalmente a obra literária, que é a própria essência da crítica: «O verdadeiro crítico é aquele que não compreende [em itálico no texto] a obra e antevê (um pouco) as razões por que não pode compreendê-la» ${ }^{23}$.

Não acredito, de maneira nenhuma, que haja nesta afirmação uma espécie de jogo, de falsa modéstia ou ainda de coqueteria intelectual. E não resisto a aproximar esta declaração das de Starobiniski, o qual também se mostra reservado quanto àquilo que se designa por «compreender» um texto literário. A partir do momento em que se trata de apreender «formas» estéticas, tem de se admitir que aquilo a que chamamos o «sentido» de um texto literário, poético, não remete para qualquer significado, antes dizendo respeito essencialmente à lógica criadora, à escolha de uma forma, de um género, de uma opção temática, de uma orientação do imaginário. Precisemos ainda que a própria análise de uma pretensa «mensagem» passa pelo exame daquilo a que se poderá chamar, por comodidade, criação da forma. Até certo ponto, a atitude de Eduardo Lourenço pode ser comparada à do autor de Forme et signification, Jean Rousset ${ }^{24}$, o qual pratica uma leitura formal sem, no entanto, se submeter a qualquer formalismo.

Hermeneutismo situado apenas ao nível da «forma», da intenção formal, da lógica de uma invenção poética: eis o que poderia ser a resposta imediata possível ao problema que pusemos. Avancemos ainda um pouco, sugerindo que a atitude crítica de Eduardo Lourenço procede por «aproximações» sucessivas. A palavra remete para um crítico, o francês Charles du Bos, o qual, pelo seu psicologismo, não tem nada a ver com a abordagem da obra literária levada a cabo por Eduardo Lourenço. No entanto, retenhamos a palavra «aproximações» o que nos poderá permitir considerar um conjunto

\footnotetext{
${ }^{23}$ LOURENÇO, 1994: 51.

${ }^{24}$ ROUSSET, 1962.
} 
de artigos sobre uma obra ou um autor como «ensaios», esboços, no sentido pictórico do termo. Citarei, pelo menos, um exemplo que vai no sentido proposto. Ao falar do romance segundo Vergílio Ferreira, Eduardo Lourenço considera o personagem como um primeiro nível, um elemento essencial para entrar no universo do romance: «Já é um progresso nessa aproximação do que em princípio é e deve ficar impenetrável $[\ldots] \aleph^{25}$.

Devemos considerar o discurso crítico de Eduardo Lourenço como uma espécie de estratégia, uma tática de cerco, no sentido militar do termo, aplicada ao texto: daí os avanços sucessivos, por vezes os recuos ou as nuances, os desvios, mas o próprio objetivo de definir um projeto estético, poético, implica uma sequência sem fim verdadeiro de aproximações, que só terminará por decisão arbitrária do crítico. Perante esse romance inclassificável que é $A$ sibila, de Agustina Bessa-Luís, Eduardo Lourenço arrisca falar de «neo-romantismo»e, afinal, é esta intuição primeira que vai influenciar uma série de leituras. Mas há ainda a classificação de "desconcertante» aplicada a Agustina a propósito de outro romance, sendo a leitura levada a descobrir outros horizontes, sem, no entanto, pôr em causa a primeira abordagem. Assim, de artigo em artigo, uma sequência de aproximações permite cercar (volto ao termo militar) um texto, uma obra que, embora esteja em evolução permanente, se baseia em alguns princípios essenciais (uma escrita, um tema dominante...), princípios que perduram e, simultaneamente, se alteram, metamorfoses de uma escrita que justificam outras tantas, as das leituras sucessivas do crítico.

Poderemos ilustrar este princípio das «aproximações» através de leituras parciais com o conjunto de estudos consagrados por Eduardo Lourenço a Fernando Pessoa ${ }^{26}$. As diversas abordagens são outras tantas variações (no sentido musical do termo) sobre alguns elementos básicos de uma obra: por exemplo, a morte de Antero. Primeira abordagem ${ }^{27}$, contemporânea da coletânea (2000), na qual o tema da noite (o fascínio anteriano pela Noite) é associado e oposto ao da morte, que se exprime «no mais negro e inexpugnável verso da nossa língua: Morte, irmã coeterna da minha alma». Outra abordagem, na outra extremidade do volume, ligeiramente anterior: «A Morte - a nossa morte - não tem conteúdo. A poesia de Antero é a tentativa lograda e malograda para dar voz a essa intuição» ${ }^{28}$.

O ensaio crítico em Eduardo Lourenço deverá ser considerado nas duas aceções que tem em francês: género literário e ensaio/tentativa de se aproximar, não de um sentido mas talvez de uma verdade poética. Perante a impossibilidade de definir o género «ensaio», Starobinski recorreu a uma etimologia alusiva: de essai (ensaio) passa para essaim (enxame), propondo a ideia de um texto como «enxame verbal que

\footnotetext{
${ }^{25}$ LOURENÇO, 1994: 97-98.

${ }^{26}$ LOURENÇO, 1986; LOURENÇO, 2000.

${ }^{27}$ LOURENÇO, 2000: 12.

${ }^{28}$ LOURENÇO, 2000: 179.
} 
se liberta e expande em vários sentidos» ${ }^{29}$. Assim, cada ensaio de Eduardo Lourenço pode ser considerado uma tentativa, sempre surpreendente, de libertar, de expandir as palavras e as ideias, até as imagens, de maneira a aproximar-se mais intimamente de um texto que, em parte, permanecerá sempre secreto.

Não procurei, de maneira nenhuma, dissimular as características atribuídas aos trabalhos críticos aqui referidos no seu conjunto. Julgo, no entanto, que algumas linhas orientadoras predominantes se destacam, permitindo ler (e ligar entre si) melhor essas três formas de pensamento crítico através das quais o ensaio se exprime. Primeiro, uma vontade de privilegiar o texto literário, sem, no entanto, ignorar o contexto, mas também sem fazer intervir considerações estranhas ao domínio da escrita e da invenção poética. Em segundo lugar, uma abertura total às abordagens e métodos críticos conhecidos, sem dúvida nenhuma assimilados, mas não mobilizados quando se trata de levar a cabo a «leitura», a qual permanece uma espécie de... frente a frente a três: o texto, o crítico e o leitor, sendo o crítico, antes de mais, um leitor entre outros. Dessa maneira, é feito um contrato com este, contrato que, de maneira tácita mas imperiosa, obriga o crítico a cingir-se à realidade do texto. A palavra «contrato» pode, aliás, ser substituída pela palavra «relação», já utilizada e que foi consagrada por Jean Starobinski.

Voltemos, portanto, a esta palavra, a este conceito da crítica, tanto mais que a encontro nos escritos de Maria João Reynaud, no final da sua densa introdução à tese a que já aludi no início. A citação que faço agora e que me serve de conclusão, resume, parece-me, o essencial daquilo que foi o objetivo principal dos críticos evocados ao longo desta comunicação e define o tipo de crítico que tentei delinear:

A relação do leitor com o texto estabelece-se, pois, nessa pura distância que torna possível a sua comunicação com a intimidade da obra, até àquele grau de intensidade em que, ao tentar reconstruir «lexpérience hasardeuse du livre» [citação de Maurice Blanchot], o percurso de leitura se configura como uma segunda génese $e^{30}$.

Vê-se, assim, até que ponto esta relação implica, por parte do crítico, uma aposta audaciosa. Longe de ser a mera aplicação de uma teoria, de que o texto seria apenas uma ilustração, a leitura crítica assim concebida permanece um desafio perante esse mistério luminoso que é a criação literária.

\footnotetext{
${ }^{29}$ «Cahiers pour un temps» (1985). Paris: Centre Pompidou, n. ${ }^{\circ} 5$.

${ }^{30}$ REYNAUD, 2000: 58.
} 


\section{BIBIOGRAFIA}

«CAHIERS pour un temps» (1985). Paris: Centre Pompidou, n. ${ }^{\circ} 5$.

LOURENÇO, Eduardo (1986) - Fernando, rei da nossa Baviera. Lisboa: Imprensa Nacional - Casa da Moeda. (1994) - O Canto do Signo: Existência e Literatura. Lisboa: Presença. (2000) - A Noite Intacta: (i)recuperável Antero. Vila do Conde: Centro de Estudos Anterianos.

MACHADO, Álvaro Manuel (2011) - A Arte da Crítica. Lisboa: Presença.

MOURÃO-FERREIRA, David (1969) - Tópicos de Crítica e de História Literária. Lisboa: União Gráfica. (1976) - Sobre Viventes. Lisboa: Dom Quixote. (1960) - Vinte Poetas Contemporâneos. Lisboa: Ática. (1988) - Marguerite Yourcenar: Retrato de uma Voz. [Lisboa]: Rolim. (1989) - Sob o Mesmo Tecto: Estudos Sobre Autores de Língua Portuguesa. Lisboa: Presença. (1992) - Tópicos Recuperados: Sobre a Crítica e Outros Ensaios. Lisboa: Caminho.

NEMÉSIO, Vitorino (1985) - Conhecimento de Poesia. Bahia: Universidade.

PAGEAUX, Daniel-Henri (2001) - Portrait du Critique en Vertumne. In GAGNEBIN, Maurielle; SAVINEL, Christine, eds. - Starobinski en Mouvement. Seyssel: Champ Vallon. (2014) - Expérience critique et «expérience formelle». In CHARDIN, Philippe; ROUSSEAU, Marjorie, dir. - Lécrivain et son Critique: une fratrie problématique. Paris: Editions Kimé.

REYNAUD, Maria João (2000) - Metamorfoses da Escrita: Húmus, de Raul Brandão. Porto: Campo das Letras.

ROUSSET, Jean (1962) - Fome et Signification. Paris: Corti.

SILVA, Vítor Manuel de Aguiar e (1997) - O ensaísmo literário de David Mourão-Ferreira: o ensino, a crítica e o ensaio. «Revista Colóquio/Letras. Ensaio», n. ${ }^{\circ}$ 145/146, p. 338-344.

STAROBINSKI, Jean (1974) - Le texte et l'interprète. In NORA, Pierre; LE GOFF, Jacques, dir. - Faire de l'histoire: Nouveaux problèmes, nouvelles approches, nouveaux objets. Paris: Gallimard, t. II. (1970) - L'Eil vivant. Paris: Gallimard. 


\section{DA LEITURA DO TEXTO AO TEXTO \\ DA LEITURA: ALGUMAS CONSIDERAÇÕES \\ EM TORNO DO ENSAÍSMO DE MARIA JOÃO REYNAUD}

FERNANDO CASTRO BRANCO*

«A última página de qualquer livro, que é simultaneamente fim e princípio, configura-se como o lugar de uma troca simbólica que torna possível a sobrevivência imediata da obra enquanto expressão do desejo humano de infinito» ${ }^{1}$. É com estas palavras que segregam em si uma verdade poética e a ideia de poeticidade propriamente dita que Maria João Reynaud fecha a apresentação do seu livro de ensaios Sentido Literal. A leitura dos textos literários advém na ensaísta uma espécie decantada de textos da leitura e neste sentido esta sessão será tão-somente uma «última página» que assegurará um princípio sempre renovado entre a homenageada e os seus leitores.

É sabido que durante mais de quatro décadas Maria João Reynaud exerceu (e continua a exercer) de forma intensa um notável trabalho de explicação e divulgação da literatura e dos autores portugueses, quer pela palavra oral - no seu magistério pedagógico na Faculdade de Letras da Universidade do Porto - quer pela palavra escrita, através de estudos e ensaios trazidos a público, e os de maior destaque reunidos em obras tão marcantes como Metamorfoses da Escrita - Húmus de Raul Brandão, Fernando Echevarría - Enigma e Transparência, Sentido Literal e Matéria Poética.

A autora segue no seu ensaísmo uma linha de grande consistência e coerência metodológica e estilística, enveredando por um discurso de extrema limpidez retórica

* CITCEM - Centro de Investigação Transdisciplinar Cultura, Espaço e Memória.

${ }^{1}$ REYNAUD, 2004: 13. 
e analítica que ilumina os textos-fonte na justa medida que no-los dá a ver na sua esfera própria, no seu habitat natural; cercando-os, desvelando-os, expondo-os aos olhos do destinatário inteiros e intactos, puros em sua transparência e espessura; na sua génese, evolução, mundividência e identidade. A palavra que convoca é leve e firme, justa e elegante, dúctil e rigorosa. Ainda que em todo o momento socorrendo-se dos vastos conhecimentos e da autoridade da Professora de sempre, nem por isso as Lições que integram os seus livros se subordinam a uma retórica da autoridade, tão só uma partilha generosa, aceite pelos seus leitores, que veem esta «matéria poética» fundamentalmente partilhável, numa relação gnosiológica de carácter claramente interpessoal. Na introdução ao seu livro Matéria Poética, dirigida diretamente "Ao Leitor», pontua-se claramente esta comunhão cúmplice entre a ensaísta e o destinatário, subordinada a uma ética e a uma estética da proximidade, bem como a uma exímia retórica da fala.

Silvina Rodrigues Lopes ${ }^{2}$, lendo Derrida, afirma que

o ensino da literatura tende a fundar a sua prática num princípio que atribui à própria literatura: a retoricidade é, em literatura, a destruição da eloquência, e por isso a técnica de análise retórica é, no ensino da literatura, a destruição da eloquência.

Aqui, o crítico em vez de tomar o centro da cena literária confere toda a visibilidade ao texto. Mais do que apresentar um texto interpretado, Maria João Reynaud permite que o texto se deixe interpretar, melhor, ler, nos seus múltiplos planos constitutivos. Para isso, vai criando toda uma ambiência estética e contextual, clarificando os quadros de referência do seu surgimento e crescimento, com meticuloso rigor e extremada sensibilidade. Isto não significa que esta crítica seja neutra ou inocente, que nenhuma verdadeira crítica o é, como muito bem acentua Manuel Frias Martins. Trata-se simplesmente de uma questão de ponto de vista, do lugar propício e discreto de onde o fotógrafo se coloca para que a imagem surja como se unicamente por si mesma se desse a ver. Como se ao mostrar ao leitor o que vê nas obras que aborda, o colocasse num plano privilegiado para que ele (o leitor) visse por conta própria os seus próprios horizontes, que são sempre ilimitados quando, como é o caso, se apresentam autores de nível superior. Trata-se pois de «olhar» o texto: olhar minucioso, analítico no profundo sentido do termo. E nessa medida o olhar interno do texto irradia ao olhar do leitor, que olhando sobre esse olhar não deixa de olhar por si mesmo, mas já com outra profundidade radioscópica. É este olhar que vai assegurar a «singularidade da relação que se procurou estabelecer com cada texto», como nos adverte a autora na

${ }^{2}$ LOPES, 1994. 
abertura da obra Sentido Literal, ou quando cita neste contexto Fernando Guimarães: «Os olhos não têm pressa» (p. 310).

A ensaísta, nesse livro, refere as naturais «variações metodológicas que resultam de abordagens diversas, à luz das propostas teóricas que fomos ensaiando» (p. 11). Creio ter contudo fixado definitivamente as suas leituras críticas numa perspectiva de índole genética. Porém, não se trata de uma crítica exclusivamente genética, mas de aplicar o essencial desse método: visualizar, digamos assim, o perfil, a fisionomia do texto, para lhe dar visibilidade, para o tornar um texto sentido, o seu fenomenal sentido, a partir do sentido central da visão.

Trata-se de uma ontologia do questionamento, de uma pragmática que visa a identidade, a idiossincrasia do texto-fonte, não o mutilando, deformando, ou violentando, em operações estranhas ao mesmo. Constrói-se entre o crítico, o texto e o leitor uma espécie de "pacto de leitura» que, captando o texto nas circunstâncias em que surge, o apresenta sob as várias faces das suas sucessivas metamorfoses. O texto é sempre um objeto que nasce algures, passa por diferentes fases de realização e crescimento e não se fica em si mesmo, nem no interior da consciência que o originou, antes chega a outrem surpreendente, imprevisto, numa corrente interpessoal e intersubjetiva que lendo-o o relê, o reconstrói, o multiplica o amplia em seu horizonte recetivo. Desta forma, o trabalho hermenêutico de Maria João Reynaud centra-se sobretudo no que a obra é e não no que ela deveria ou poderia ser. Judicativamente sóbria e contida, dando, reitera-se, o centro do palco ao texto na sua fisionomia estética, ontológica, teleológica e gnosiológica. Nesse surgimento textual, que visa um leitor «implícito», o autor nunca se apaga, longe da utopia estruturalista da «morte do autor», este ocupa o lugar que lhe cabe no extrair da pedra bruta e indivisa da linguagem a obra estética. Mas esta, uma vez vinda a lume, só a ela devem ser pedidas contas dos sentidos que daí irradiam: plurívoca como toda a verdadeira obra de linguagem, oriunda dessa pátria polissémica de raiz universal. A literariedade da obra de linguagem não rasura as circunstâncias humanas que lhe deram origem, antes faz delas essa "matéria poética» que absorverá, dela se alimentará, como sucede aliás nos outros planos da arte. A experiência da linguagem é o ato que subjaz quer ao autor quer ao crítico. Maria João Reynaud sintetiza claramente este processo:

O acto de compreensão literária (ou o exercício da crítica) é sempre determinado por uma experiência fundadora de leitura, a qual constitui o sedimento da reflexão que a obra suscita. Esta reflexão não visa apenas responder à complexidade da obra, mas interrogar o próprio modo de ser da literatura (p. 11).

Elaboramos este estudo a partir do último livro publicado pela autora, Matéria Poética, para observarmos em concreto as considerações atrás expendidas; no fundo, 
uma modesta aproximação à sua arte ensaística. E dos diversos autores aí estudados, por uma questão pragmática inerente às limitações temporais de uma comunicação deste tipo, optamos por salientar a leitura de um autor que, em nossa opinião, marca decisivamente não só este livro, mas funciona como referência em relação a boa parte da obra ensaística de Maria João Reynaud: referimo-nos a Fernando Guimarães.

Assim, Matéria Poética abre com uma Introdução, que mais do que uma introdução ao livro, é uma introdução à idiossincrasia do discurso poético propriamente dito, à enunciação de algumas marcas que identificam e individualizam esta tipologia discursiva e aos elementos que a constituem, a que ela designa pelo termo abrangente de «matéria». Aponta ainda os novos caminhos para a poesia e para o facto perfeitamente identificável do esbatimento entre as tradicionais fronteiras dos géneros, que a modernidade literária e estética fez explodir em múltiplos estilhaços e a pós-modernidade deu continuidade, agora em implosão mais silenciosa, mas, quiçá, mais decisiva e radical. Implosão dos géneros literários e esboroamento dos seus muros estanques que parece acompanhar o próprio esbatimento das fronteiras entre as diferentes artes. Teóricos da literatura e da estética como Gerard Genette ou Mikel Dufrenne constatam que hoje unicamente nos será possível identificar a Arte, mas não as artes. Simultaneamente, introduz o «Leitor» nessa premissa angular de que «o trabalho do poeta consiste fundamentalmente em vencer a resistência da linguagem» (p. 7), até porque vencida essa resistência, «só a poesia é capaz de revelar todas as potencialidades da língua» (p. 8).

O primeiro ensaio do livro, «Poesia: Lugar de doação», cabe pois à obra poética de Fernando Guimarães, e constitui-se simultaneamente como a Lição apresentada no âmbito das Provas de Agregação, realizadas em outubro de 2004, e tem desde logo o extraordinário mérito de vincar a obra de um poeta maior da literatura portuguesa contemporânea, embora a relevância do crítico e do estudioso dos temas culturais e literários pareça por vezes deixar na sombra. Lição não só na sua estrutura e solenidade académica, mas igualmente na forma como nos dá a ver, cosmoramicamente, as várias componentes da poesia e da poética de Fernando Guimarães, com realce para a trazida a público no decénio que, tendo em conta a data da apresentação desta Lição, teria sido a publicada grosso modo entre 1994 e 2004. Lição também por, desde início, colocar, na senda de Paul de Man, entre outros, a questão central do ensino da poesia, e as dificuldades que esta atividade enfrenta num tempo em que a crise dos estudos literários parece ter, profeticamente, antecipado outras crises mais vastas. E neste horizonte de expectativas subordinado ao ensino da poesia, nada mais acertado que selecionar um poeta cuja atividade vive intensamente mergulhada na divulgação dessa mesma poesia, em prejuízo, tantas vezes, reitera-se, da divulgação da sua própria obra poética. Mas não só a problemática do ensino da poesia une, neste caso, ensaísta e ensaiado, como também o facto de uma das marcas mais vincadas e mais atuais da poesia e do ensaísmo de Fernando Guimarães convocar a própria figura do leitor. Dada 
a densidade deste ensaio de mais de meia centena de páginas e a matéria do mesmo, é uma tarefa inexequível sintetizar a vastidão e a complexidade do seu conteúdo no âmbito desta comunicação. Porém, será ainda de referir que a autora se serve do próprio pensamento crítico do autor de A Face Junto ao Vento expresso no ensaio «O problema da Expressão Poética», para colocar em primeiro plano a especificidade da linguagem da poesia e a forma como ela chega à esfera do leitor, à sua compreensão, sensibilidade, juízo de valor ou tão só juízo de gosto. Heidegger permanece em fundo do crítico e do poeta, em ambos os casos a palavra poética é o meio privilegiado de desvendamento do ser, das suas obscuridades, das suas complexidades, hermeticamente inacessíveis a qualquer outro tipo de linguagem. O ser habita pois a poesia de Fernando Guimarães nas suas matriciais funções "antológica, autotélica e dialógica» (p. 22) e nessa base a poesia assume-se igualmente como lugar habitável, pátria fora da qual o ser entra no espaço desabrigado do exílio, da errância. A abordagem da obra do autor de Lições de Trevas segue subordinada a mais três tópicos temáticos: 1 - «Narciso ou o outro nome da poesia», em que, partindo de um texto de 1952 de Fernando Guimarães, «Narciso e o Encontro da Morte», se toma o mito de Narciso - um dos principais mitos arcaicos alegórica e simbolicamente retomados ciclicamente pelo autor - como ponto de partida para uma reflexão poética e ontológica sobre a condição efémera do homem e, nessa medida, a referência ao poético como lugar simultaneamente de perda e redenção, porque ponto nevrálgico onde se imbricam sensível e inteligível, realidade e reflexo, imanência e transcendência, corporalidade e espiritualidade.

Segue-se o ponto 2, «Figuração Poética e Dialogismo»: trata-se aqui do carácter dúplice da linguagem poética, desdobrada sobre si mesma, modelando a realidade e o mundo, através da exploração do sentido oculto, invisível, para, precisamente, dar conta dessa realidade que recria, transpõe, transcodifica. O mesmo se passa na relação entre a linguagem denotativa e sua transformação na sua versão artística, poética, assente num modelo semiótico específico, como explicita Yuri Lotman. Esse diálogo, em Fernando Guimarães, abrange ainda o diálogo interartístico, ekfrástico, com outras artes, como as artes plásticas e a música. Diálogo igualmente entre o silêncio e o discurso, o «eu» e o «tu»; duplicação do sujeito enquanto espaço comunicacional que recusa do solipsismo.

Esta Lição termina, circularmente, com o tópico, que dá título ao ensaio «Poesia como Lugar de Doação», tomando a leitura igualmente como esse espaço intersubjetivo de «comunicação e comunhão» (p. 57), lugar de encontro, de alteridade, de cumplicidade entre o «eu» e o "outro», o que escreve e o que lê e que lendo reescreve, atribui sentido, alarga a mundividência da linguagem poética.

Elabora pois Maria João Reynaud o seu texto da leitura enquanto expansão e complemento do texto lido, como queria Benjamin. 


\section{BIBLIOGRAFIA}

LOPES, Silvina Rodrigues (1994) - A Legitimação em Literatura. Lisboa: Cosmos.

REYNAUD, Maria João (2004) - Sentido Literal. Porto: Campo das Letras.

(2008) - Matéria Poética: ensaios de Literatura Portuguesa. Porto: Campo das Letras. 


\title{
RETRATO DE UM PROFESSOR LICEAL, INTELECTUAL E OPOSICIONISTA NO ESTADO NOVO: O CASO DE ÓSCAR LOPES
}

\author{
LUÍS GROSSO CORREIA*
}

Falei de sabedoria e sofrimento, de escrúpulo e lealdade; gostaria ainda de falar, a propósito de Óscar Lopes, de simplicidade e pudor, pois nele é o que imediatamente vem à tona. Ora a simplicidade é como a verdade: vê-se. Quanto ao pudor, aqui, será menos equívoco chamar-lhe respeito por si próprio. Um tal sentimento é, em Óscar Lopes, cultivado até ao excesso. O seu primeiro movimento é apagar-se, tão isento ele é de narcisismo. Nunca ninguém o verá em bicos de pés para melhor se reflectir nas águas do nosso olhar.

Eugénio de Andrade, Duas notas sobre Óscar Lopes (a 15 de abril de 1974; cf. 1996)

«Ora essa! Disponha sempre, não é?»

Foi com esta frase espontânea e cortês que Óscar Lopes (1917-2013), depois da renovação do nosso agradecimento, rematou a entrevista de quase 205 minutos que, no âmbito da nossa tese doutoral sobre o Liceu Rodrigues de Freitas/D. Manuel II no período do Estado Novo ${ }^{1}$, gentilmente nos concedeu na sua residência particular, à Rua de Belos Ares, no Porto, no dia 2 de março de 2001.

Apesar de Óscar Lopes ter declarado, por duas vezes, estar «muito amnésico», a entrevista, salvo alguns lapsos de memória para com datas e nomes (facilmente reconstituíveis a partir de fontes de informação escrita) por parte do entrevistado, e, declare-se igualmente, do extenuante e permanente controlo do viés emocional que atravessava o entrevistador (afinal era interlocutor de um dos autores da obra canónica por onde aprendera a estudar a história da literatura portuguesa, de um dos intelectuais mais destacados da segunda metade do século XX e de um professor subalternizado, por motivos extraprofissionais, em cerca de 19 dos 24 anos que serviu o referido Liceu), decorreu de modo vivo, fluido, enredando assuntos noutros assuntos, tendo sido, inclusive, intervalada, por breves minutos, por um chá preparado e oferecido pela Dr. ${ }^{a}$ Maria Helena Madeira, esposa do nosso entrevistado.

*Universidade do Porto/Centro de Investigação e Intervenção Educativas.

${ }^{1}$ Cf. CORREIA, 2016a; CORREIA, 2016 b. 
Os critérios que, à época, nos levaram a investir Óscar Lopes como fonte de história imediata da nossa pesquisa, focada na organização escolar do referido Liceu, foram já descritos no pequeno apartado que a ele dedicamos em publicação anterior ${ }^{2}$, a saber: aluno do Liceu entre 1932 e 1934; filho de Armando Lopes, professor de Canto Coral no mesmo Liceu; longevidade como professor efetivo do $1 .^{\circ}$ grupo docente (19501974); professor-coordenador do jornal escolar «O Mensageiro», publicado no quadro das atividades circum-escolares da Mocidade Portuguesa, entre 1952 e 1955; detido preventivamente, para averiguação de crimes contra a segurança do Estado, pela Polícia Internacional e Defesa do Estado (PIDE) de 12 março a 15 de julho de 1955 e entre 17 e 20 de junho de 1963; suspenso da atividade letiva e de remuneração, por efeito da condição de arguido, entre 12 março de 1955 e 12 de junho de 1957, data em que foi absolvido das acusações por decisão do Tribunal Plenário do Porto e reintegrado no serviço liceal por imediata decisão do então Ministro da Educação Nacional, Francisco Leite Pinto; autor de inúmeras obras marcantes da história e ensaísmo literário e de estudos linguísticos; promotor e orador de múltiplos colóquios e de conferências de natureza cultural e literária; e, já aludido anteriormente, a subalternização das suas capacidades e competências profissionais no quadro do Liceu que, a partir de 1957/1958, é elevado à categoria de Liceu Normal.

Esta entrevista, mercê da riqueza e pertinência dos conteúdos de informação, pistas de pesquisa e perspetivação recolhidos, semeou em nós a vontade de, depois de cumprida a tarefa académica de defesa da tese doutoral, aprofundar o estudo sobre uma história de vida ímpar no contexto de um regime repressivo. Neste sentido, em janeiro de 2011 consultámos os 8 processos a ele dedicados pela $\mathrm{PIDE}^{3}$, juntámos a análise de várias obras suas publicadas no período em análise e somente agora, no quadro da iniciativa de estudos sobre Textualidade e Memória: permanência, rotura, controvérsia (1945-2015), em honra de Maria João Reynaud, amiga e colega de ofício (de uma área do conhecimento vizinha), é que inventámos o tempo necessário para organizar alguns dados no presente e breve estudo.

Devemos, antes de outros desenvolvimentos, tecer algumas considerações prévias de natureza metodológica. Não nos foi fácil fazer aportar o trabalho no ponto em que ele aqui se apresenta. Se, num primeiro momento, tivemos a sensação (quase eufórica) de que dispúnhamos de um manancial de fontes escritas ${ }^{4}$, vários e omnímodos trabalhos publicados por Óscar Lopes (cf. as diferentes entradas em referências bibliográficas) e sobre Óscar Lopes ${ }^{5}$ e fontes orais (a entrevista que realizámos ao próprio e a outros antigos professores e alunos do Liceu acima referido), o certo é que a tarefa de esboçar

${ }^{2}$ Cf. CORREIA, 2016a: 281-284.

${ }^{3}$ Cf. ANTT - PIDE/DGS.

${ }^{4}$ Cf. AHME; AESRF; ANTT - PIDE/DGS; AFLUP; «O Jornal»; «O Mensageiro».

${ }^{5}$ Cf. AA.VV., 1996; BRITO et al. org., 1997; SANTO et al., 2001; NEVES, 2005. 
a escrita de uma vida (bio-grafia) de um agente histórico com um trajeto denso, plural, rico, obrigou-nos a repensar o dispositivo inicialmente previsto para este estudo, ainda que de fôlego contido.

Assim, se a entrevista realizada a Óscar Lopes foi enquadrada por uma nossa preocupação inicial de dar voz, "em diligência puramente científica» ${ }^{6}$ a um professor-intelectual competente, subalternizado no Liceu D. Manuel II por motivo de perseguição política movida pela PIDE, no âmbito do presente trabalho tivemos de esboçar a tentativa de totalização do movimento da sua vida, guiados pela vontade de nada deixar passar em claro, ou de perder o menos possível ${ }^{7}$, com vista a levar a análise para além da descrição empírica, ou de fixação de memória, e de demonstrar os nexos e sentido que o seu trajeto de vida faz na ótica do investigador. Deste modo, tentamos (re)traçar uma descrição densa, feita de «sistemas entrelaçados de signos interpretáveis» ${ }^{8}$, construída e o mais coerente possível.

O retrato de Óscar Lopes que aqui construímos não é, assim, o da demora (analítica) de uma pintura a óleo, nem o do instante da photomaton. Será algo que se pode situar numa duração de exposição intermédia, na qual o nosso objeto/sujeito de análise é retratado por uma técnica artesanal de fotografia como, por exemplo, o daguerreótipo.

Em complemento de Convite para a URSS, obra publicada em 1973, Óscar Lopes respondeu ao designado questionário Proust (questionário colocado por Antoinette Faure, por volta de 1886, ao ainda adolescente Marcel Proust ${ }^{9}$ ). Em reposta à questão «Que profissão, que não fosse a de escritor, gostaria de ter exercido?», Óscar Lopes afirmou o seguinte (o sublinhado é nosso): «Tenho exercido e acumulado várias profissões: a de professor de vários graus, a de crítico ou ensaísta literário, a de investigador, não falando no distractivo do-it-yourself doméstico de várias espécies. Falo de tudo isto porque de tudo isto gosto, mas o modo como me sinto melhor é como uma espécie de estudante vitalício» ${ }^{10}$.

A partir dos vários registos de Óscar Lopes guardados no Arquivo da Escola Secundária Rodrigues de Freitas, podemos encontrar dados atinentes à sua condição de estudante liceal e de professor. Enquanto aluno do ensino não-superior: aprovou o exame da $4 .{ }^{\text {a }}$ classe do ensino primário com a classificação de 16 valores (Distinto) em 18.06.1928; como aluno do ensino particular, das professoras Rosa Gaudêncio de Campos Vieira e Irene da Purificação da Silva, propôs-se realizar o exame da então 3. ${ }^{\text {a }}$ classe do curso liceal no Liceu de Rodrigues de Freitas, no ano letivo de 1931/1932; na mesma condição de estudante externo, matriculado no Colégio da Nova, em Leça

\footnotetext{
${ }^{6}$ POIRIER et al., 1999: 14.

${ }^{7}$ Cf. DOSSE, 2005, 19.

${ }^{8}$ Cf. GEERTZ, 1978: 24.

${ }^{9}$ Cf. CARTER, 2013: 51-52.

${ }^{10}$ LOPES, 1973: 111.
} 


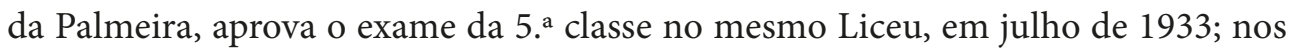
dois anos letivos subsequentes matricula-se como aluno interno da classe de Letras do Liceu Rodrigues de Freitas ${ }^{11}$, vindo a aprovar o $7 .^{\circ}$ e único ano do curso liceal em julho de 1935.

Da sua passagem pelo Liceu Rodrigues de Freitas, que à época ainda estava em fase de obras de acabamento, «de maneira que só existia a ala que está pegada à Igreja de Cedofeita» (da Entrevista), destaca um único professor que o marcou profundamente, tanto pedagógica como cientificamente:

Uma influência puramente didática, especialmente científica, linguística. Foi o Prof. Francisco Torrinha. [...] Um homem que ainda hoje considero excecional. E foi por influência das aulas dele [...] que eu segui o curso de Clássicas. Não me arrependo. Embora eu gostasse de vários outros. Poderia ter tirado outros cursos: Física, Matemática ou coisa parecida... A minha vocação era muito científica. Foi esse o professor do secundário que, de facto, exerceu influência em mim. Foi meu professor de Latim. Em grande parte sentia, quando era aluno, o magistério dele. Apropriei-me da maneira dele ensinar ${ }^{12}$.

A mudança para Lisboa, na condição de estudante universitário, vai impedi-lo de continuar a sua formação musical. Como estudante do ensino superior, vai cursar Filologia Clássica na Faculdade de Letras da Universidade de Lisboa, entre 1935 e 1939, e, ato contínuo, realizar e aprovar o Estágio Pedagógico (com Exame de Estado) para o Magistério Liceal no Liceu Normal Pedro Nunes, em Lisboa, de 1939 a 1941. Ainda na qualidade de estudante do ensino superior, vai aprovar todas as cadeiras de Ciências Histórico-Filosóficas em período que ainda não conseguimos determinar, mas que, a partir da entrevista realizada, podemos situar na década de 1940.

Do ponto de vista académico, Óscar Lopes estava, assim, habilitado com duas licenciaturas (Filologia Clássica e Ciências Histórico-Filosóficas) e, do ponto de vista profissional, para a docência profissional de Português, Latim e Grego ( $1 .^{\circ}$ grupo docente do ensino liceal) e, ainda que subsidiariamente, de História e Filosofia (4. ${ }^{\circ}$ grupo docente).

Porém, o nosso estudante vitalício não circunscreveu os seus estudos ao cursus honorum académico-escolar e profissional acima referido. $\mathrm{O}$ estatuto com que se autodefiniu tem a ver igualmente com os frutos das múltiplas pesquisas que desenvolveu, como iremos analisar mais adiante, na qualidade de historiador, ensaísta e crítico de Literatura, em particular de Literatura portuguesa, de investigador em Linguística,

${ }^{11}$ Cf. AESRF - Processo Individual do aluno Óscar Luso de Freitas Lopes, cx. s.n. ${ }^{\circ}$.

${ }^{12}$ Da Entrevista. 
ramo de investigação que foi induzido pelas problemáticas educativas e didáticas com que se confrontou na praxis do ensino da língua portuguesa, de divulgador cultural (através das múltiplas conferências e colóquios que proferiu e organizou), de editor literário da Editorial Inova a partir de 1966 e de, a palavra poderá ser exagerada, mas não encontramos, de momento, outra mais económica e adequada, pedagogo informado por um humanismo outro, como veremos mais adiante. Este humanismo foi por ele enraizado e treinado nas línguas e literaturas clássicas, matizado pelo devir histórico, a um tempo, da literatura ocidental e portuguesa, da língua portuguesa e da humanidade, em particular no período após a II Guerra Mundial (Guerra Fria, movimentos de reconstrução da paz internacional, descolonização, novos países independentes, novas problemáticas educativas, sociais e políticas, entre outros), e por princípios de liberdade, rigor, crítica, risco, criatividade e responsabilidade intelectual, social e científica (que constituem a marca de água dos seus trabalhos publicados).

Curiosamente, o nosso estudante vitalício cedo denotou relevante veia pedagógica e solidária para com os colegas de Liceu ao, assinando como Óscar Luzo Leça, e em conjunto com Alexandre Rocha Peixoto Amorim (nome talvez igualmente modificado), ter produzido uma sebenta das aulas do $7 .^{\circ}$ ano de Português da classe do professor José Barros Nobre, a qual foi titulada de Nótulas sobre História da Literatura Portugueza (61 páginas datilografadas). Esta sebenta, destinada aos alunos do ano letivo de 1936/1937, isto é, disseminada internamente no Liceu Rodrigues de Freitas, quando Óscar Lopes já estava a cursar o $2 .^{\circ}$ ano do curso superior de Filologia Clássica, em Lisboa, continha um propósito pedagógico conforme se pode ler na justificação patenteada na sua página de rosto, a saber:

Uma longa e edificante experiência revelou-nos quanto há de incomodo e improfícuo na canceira de tirar e passar apontamentos das aulas. Por isso, e sob os auspícios do Excelentissimo Senhor doutor Barros Nobre, por cujo patrocinio nos confessamos maximamente penhorados, consagramos boa parte das ultimas ferias á tarefa de dar forma e ajustar á mais recente orientação dos pontos escritos as "NÓTULAS SOBRE HISTORIA DA LITERATURA PORTUGUEZA», que o Senhor Doutor Barros Nobre nos ditara no curso de 33-34 ${ }^{13}$.

Um dos efeitos a médio prazo destas Nótulas foi a abertura de uma linha de trabalho pedagógico-didática na carreira de Óscar Lopes, ainda durante o Estágio Pedagógico. Essa linha tem a ver com a produção de livros escolares, em pareceria com Júlio Martins, destinados a estudantes dos ensinos liceal e técnico, como as Lições elementares de Literatura portuguesa (de 1941, com 191 páginas), o Manual elementar

${ }^{13}$ AESRF - Nótulas sobre Historia da Literatura Portugueza (por Alexandre Rocha Peixoto e Óscar Luso Leça). 
de Literatura Portuguesa (de 1941; originalmente publicado com 135 páginas, terá 5 reedições atualizadas até 1970 e, com isso, vindo a atingir as 237 páginas) ou a Breve história da literatura portuguesa (de 1945; brevidade de 397 páginas).

\section{PROFESSOR}

Mesmo antes de começar a sua carreira como professor do ensino liceal, o nome de Óscar Lopes, em parceria com Júlio Martins, já figurava em livros escolares dedicados à literatura portuguesa editados pela Livraria Avelar Machado, de Lisboa ${ }^{14}$. O professor debutante firmava, deste modo, o seu nome na paisagem da edição escolar e, a avaliar, por exemplo, pelas seis reedições do Manual elementar de Literatura Portuguesa ${ }^{15}$, no período em análise, com uma qualidade reconhecida pelos pares. Aliás, como se pode ler no primeiro parágrafo do Prefácio desta publicação, os autores visaram preencher uma lacuna curricular e editorial, a saber:

Pela primeira vez se publica, entre nós, um manual de literatura portuguesa destinado ao Ensino Técnico. Pretende-se, com êle, suavizar a tarefa bem árdua, de ensinar a alunos, cuja cultura é ainda muito deficiente, o essencial desta disciplina que, como se sabe, não tem programa definido no Ensino Técnico e, por isso mesmo, causa, muitas vezes, confusão a professores e alunos ${ }^{16}$.

Na edição de 1941, o manual elementar, que representou o número inaugural da «série B) Ensino Técnico» da coleção Avelar, era composto por Prefácio, Introdução, três partes ou «épocas» (medieval, clássica e romântica), as quais, em globo, se distribuíam por 9 capítulos ou «períodos», como são designados pelos autores, ao longo de 135 páginas. Na sua edição sexta, corrigida e atualizada, o livro é organizado em torno de uma Introdução seguida por 8 «fases» (partes), distribuídas por um total 27 «capítulos» ao longo de 237 páginas. Na primeira edição, o manual finalizava com o estudo da «literatura como elemento de agitação social e política» de autores realistas do século $\mathrm{XIX}^{17}$, ao passo que na sua sexta edição se estendia até às «novas orientações realistas» das «tendências contemporâneas», fazendo, por isso, menção a trabalhos de Aquilino, Agustina, Sttau Monteiro, entre outros ${ }^{18}$. Esta breve caracterização da morfologia serve para transmitir uma ideia sobre o labor de atualização e aditamento, por parte dos autores, do conhecimento substantivo veiculado e da evolução, em termos pedagógicos, da organização interna do manual ao longo da sua vida editorial no período analisado.

\footnotetext{
${ }^{14} \mathrm{Cf}$. LOPES \& MARTINS, 1941a; LOPES \& MARTINS, $1941 \mathrm{~b}$.

${ }^{15} \mathrm{Cf}$. LOPES \& MARTINS, $1941 \mathrm{~b}$.

${ }^{16}$ LOPES \& MARTINS, 1941b: 3.

${ }^{17}$ LOPES \& MARTINS, 1941b: 127-129.

${ }^{18}$ Cf. LOPES \& MARTINS, 1970: 216 ss.
} 
O outro livro escolar publicado em 1941 pela dupla Lopes-Martins, tinha o número de ordem 3 da «série A) Ensino Liceal» da mesma coleção Avelar, e destinava-se aos alunos do 7. ${ }^{\circ}$ ano. Apesar do título, Lições elementares de Literatura Portuguesa, tratava-se de facto de um manual escolar, com uma organização interna e conteúdos em tudo idênticos ao manual para o ensino secundário-técnico. As únicas diferenças residiam na sua extensão, de 191 páginas, e na particularidade de encerrar com o capítulo intitulado «idéia muito geral das tendências actuais» ${ }^{19}$. No Prefácio pode ler-se, num mesmo movimento, a crítica dos autores à extensão do programa curricular, ao método de ensino expositivo subjacente a essa mesma extensão, à técnica psíquica básica de memorização exigida aos alunos (domínio da aprendizagem), à função meramente instrumental da Literatura e, em semelhante quadro pedagógico-curricular, a explicitação do escopo do manual:

Quem tiver a seu cargo a lecionação de literatura no 7. ${ }^{\circ}$ ano do liceu e queira crer na possibilidade de fazer um ensino útil dessa disciplina, a-pesar-de todos os tropeços e barreiras (por exemplo, um programa extenso e que não é, certamente, impecável, para dar num máximo de 80 lições); quem acreditar, convictamente, que a literatura é qualquer coisa que pode vivificar espírito, humanizar o homem, e não um luxo mnésico, deve ser muitas vezes colhido pelo desânimo, se procurar, entre nós, um manual, adaptado à missão de ajudar o aluno na reflexão crítica e que atenda a todo o condicionalismo pedagógico desta disciplina, sobretudo à falta de tempo ${ }^{20}$.

Em agosto de 1955 foi impressa a terceira e refundida edição do Manual elementar de Literatura portuguesa destinado ao ensino técnico. A fusão anunciada por esta nova edição deverá ter sido induzida pela incorporação da estrutura e conteúdos do manual dedicado ao ramo liceal, por um lado, e do manual de formato académico publicado no mesmo ano por Óscar Lopes e António José Saraiva ${ }^{21}$. O manual para o ensino técnico apresentava, assim, a organização anteriormente definida para as lições destinadas ao ensino liceal e o aumento para as 199 páginas.

A partir do breve exercício comparativo entre os dois manuais publicados em 1941 e atento o facto de o manual para o ensino técnico ter sido adotado até, pelo menos, inícios da década de 1970, levantaram-se-nos algumas questões que aqui deixamos como pistas para ulteriores pesquisas. Considerando que a formação diferenciada oficialmente prevista para o ensino liceal (formação do escol escolar, para futuros quadros da administração pública, em regime de ensino pré-universitário a partir do $2 .^{\circ}$

${ }^{19}$ Cf. LOPES \& MARTINS, 1941a.

${ }^{20}$ LOPES \& MARTINS, 1941a: 5.

${ }^{21}$ Cf. LOPES \& SARAIVA, 1985. 
ciclo de estudos - $3 .^{\circ}$ ou $4 .^{\circ}$ anos) e para o ensino técnico (formação da mão-de-obra especializada para os cargos intermédios dos domínios comercial, industrial, agrícola e da saúde) significou e implicou, à época, uma sociologia igualmente distinta dos respetivos alunos, estariam os autores a pensar em igualizar o estudo da Literatura, não estabelecendo qualquer distinção pedagógica e educativa, entre os dois ramos do ensino secundário? E, se sim, à luz de que motivação: igualização sociopolítica dos ramos? Educação qualificada em termos literários independente? Ou ambas?

E se estendermos esta reflexão, em formato de questões, talvez com parte da resposta já incorporada, à História da Literatura Portuguesa, publicada pela dupla Lopes-Saraiva, em 1955, então com 888 páginas, perguntamos ainda: a génese desta obra não tem uma origem e motivação igualmente educativa - a qualificação do conhecimento literário de um público mais alargado?

Voltando a 1941, importa ainda destacar que a parelha Óscar Lopes e Júlio Martins ficou encarregada, desde 1940, da «direcção literária» da «série C) Autores nacionais» da coleção Avelar como se pode ler na badana da capa do manual elementar para o ensino técnico ${ }^{22}$. O primeiro número desta coleção foi dedicado a $O$ Palmeirim de Inglaterra, de Francisco de Morais, e teve «argumento e selecção dos episódios mais típicos da novela, com uma notícia sobre o autor e a obra por Júlio Martins» ${ }^{23}$.

$\mathrm{Na}$ qualidade de professor do ensino liceal, o registo biográfico de Óscar Lopes poderá ser (telegráfica e) administrativamente condensado da seguinte forma ${ }^{24}$ :

- Grupo docente: $1 .^{\circ}$ Grupo (Português, Latim e Grego);

- Ano de nascimento e naturalidade, por freguesia e concelho: 02.10.1917, Leça da Palmeira, Matosinhos;

- Estado civil e descendência: Casado, 2 filhos;

- Habilitações académicas e profissionais: Licenciado em Filologia Clássica pela Faculdade de Letras da Universidade de Lisboa, com todas as cadeiras de Ciências Histórico-Filosóficas da Universidade de Coimbra. Exame de Estado para o Magistério Liceal;

- Percurso docente (por categoria profissional, escolas e anos letivos): Professor Provisório: Serviço de Exames no Liceu Passos Manuel, Lisboa, em 1940; Serviço de Exames no Liceu Rodrigues de Freitas, Porto, em 1941. Professor Auxiliar: Liceu de Vila Real de outubro de 1941 a março de 1942. Professor Efetivo: Liceu de Vila Real, de abril de 1942 a 1945/46; Liceu Alexandre Herculano, Porto, de 1946/47 a 1949/50; Liceu D. Manuel II de 1950/51 a 1 de maio de 1974;

${ }^{22}$ Cf. LOPES \& MARTINS, $1941 b$.

${ }^{23}$ Cf. MARTINS, 1940.

${ }^{24}$ Cf. AESRF; AHME; ANTT; AFLUP; CORREIA, 2016a; CORREIA, 2016b; LOPES, 1972. 
- Cargos desempenhados: professor-orientador do jornal escolar "O Mensageiro» (1952-1955);

- Outras informações relevantes:

1. Suspenso do exercício e vencimento a partir de 12.03.1955 por Despacho Ministerial de 17.03.1955. O prazo de suspensão foi sucessivamente prorrogado, por períodos de 90 dias, pelos despachos ministeriais de 09.09.1955, 09.12.1955, 05.03.1955, 04.06.1956, 30.08.1956. 04.12.1956 e 01.03.1957. Por despacho Ministerial de 24.06.1957, comunicado ao Liceu D. Manuel II, através de ofício da Inspeção do Ensino Liceal datado de 25.06.1957, foi mandado arquivar o processo disciplinar;

2. Responsável de projeto de investigação pedagógica, apoiado pela Fundação Calouste Gulbenkian, entre 1967/68 e 1971/72, no Liceu Normal D. Manuel II e na Escola Preparatória Gomes Teixeira, no Porto.

No seu primeiro ano de serviço como professor profissionalizado (1941/1942) foi convidado pela Associação Escolar do Liceu Camilo Castelo Branco, em Vila Real, para proferir uma conferência sobre Camões no dia 10 de junho de 1942. A charla do professor Óscar Lopes começou com duas frases relativamente simples mas prenhes de desafio intelectual, na linha do escrúpulo metodológico que a demonstração científica requere e exige, por um lado, e de uma pedagogia cognitivamente densa, problematizada e crítica, por outro:

Antes mesmo de lermos Camões já sabíamos que êle é um génio; de maneira que não vou dizer que Camões é um génio: vou tentar explicar o que é um génio e porque Camões é um génio, para o que são precisas algumas divagações que parecerão até, em certos momentos, completamente alheias ao assunto. Peço portanto, antes de mais, que se esqueçam de que Camões foi um grande homem, para lhes interessarem sobretudo as razões pelas quais êle o foi; tal como peço nas aulas que se esqueçam das listas dos advérbios para aprenderem a compreendê-los ${ }^{25}$.

Depois de tecer considerações sobre a obra poética (à luz de suportes teóricos proporcionados por Platão, entre outros) e vida de Camões, incluindo nos seus planos sentimentais e de arruaceiro (Trinca-Fortes), remata a conferência com apelos à estimulação intelectual que tamanho escritor pode proporcionar:

Mas convém reparar que, se o Trinca-Fortes, actuou na história, foi porque o consumiu uma angústia de ver claro em si próprio, de ver claro nos problemas

${ }^{25}$ LOPES, 1942: 1. 
pátrios e nos problemas humanos. O Trinca-Fortes morreu em 1580. E Camões é ainda tão vivo que nos faz pensar. O homem de gênio é o que nos faz pensar ${ }^{26}$.

Esta sua conferência coincide com o período de adesão ao Partido Comunista Português: «Praticamente desde 42, desde a altura em que o Cunhal se tornou secretário. Eu só conheci o Cunhal muito mais tarde mas, nessa altura eu estava em Vila Real. Lá as coisas estavam um bocadinho tensas» ${ }^{27}$ (da Entrevista). Esta tensão política irá tornar-se mais aguda no ano de 1945, na proximidade da formalização do Movimento de Unidade Democrática, não tendo chegado, porém, a colher Óscar Lopes:

Por exemplo, no Liceu de Vila Real, em que eu estive, tive uma sorte medonha. Vim [embora] no ano em que lá se deram as perseguições, foram demitidos dois professores, dois ótimos professores... Eram da oposição, como eu era. [...] Eu estava cá no Porto, tive uma sorte medonha. [...] Vim, nessa altura, para o Alexandre Herculano, cujo reitor era das grandes amizades do Salazar. Eu tive várias conversas com ele. Ele procurava aliciar-me ou coisa parecida, mas eu não lhe dava grande troco. Mas não tinha má consideração por ele. No fundo não era má pessoa ${ }^{28}$.

Este período de tensão política foi acompanhado pela publicação de alguns trabalhos que registam a sua visão pedagógica, científica e crítica em relação ao ensino do Português ${ }^{29}$. Denota uma compreensão global da condição e dos ciclos de vida e atividade intelectual dos professores liceais («nos nossos tempos da Faculdade e do Estágio, uma certa combatividade» para na «última fase profissional a resmunguice volta-se para os rapazes, que são sempre piores que dantes $\left.»^{30}\right)$, contesta a abordagem pragmática com que os professores encaram a sua profissão («o professor prático é o que faz consistir a sua missão em preparar bem para os exames; o que não duvida dos métodos tradicionais; o que acha impraticáveis as experiências estrangeiras» ${ }^{31}$ ) e a conexa exaltação da experiência como garante do método e eficiência do ensino ( «A experiência é relativa aos quadros do espírito que a conduz. A experiência faz-se, é toda iniciativa condicionada, reacção complexa do indivíduo sobre o meio, e não simples acção do meio sobre o indivíduo» ${ }^{32}$ ). Na sua perspetiva de professor de ensino secundário, a responsabilidade profissional exige «pedagogos» com uma adequada preparação técnica e, acima de tudo e de «quaisquer modas», uma «educação

\footnotetext{
${ }^{26}$ LOPES, 1942: 18.

${ }^{27}$ Da Entrevista.

${ }^{28} \mathrm{Da}$ Entrevista.

${ }^{29}$ Cf. LOPES, 1943.

${ }^{30}$ LOPES, 1943: 4.

${ }^{31}$ LOPES, 1943: 4.

${ }^{32}$ LOPES, 1943: 4.
} 
humanística». A reabilitação da palavra Humanismo implica, no entanto, duas funções complementares. «Pedagògicamente porque, é pena, mas não se prescinde da sugestão, e sugestiona beneficamente ver-se consagrada por uma longa tradição a atitude de disciplina interna. Lògicamente porque o reconhecimento duma tendência para o mais humano ajuda-nos a compreender a história» ${ }^{33}$. Voltaremos mais adiante a este artigo, no quadro dos estudos em Linguística.

No prefácio que redigiu para a compilação de artigos escritos por Mário de Vasconcelos e Sá, professor liceal de Geografia, durante quarenta e cinco anos, e autor de manuais, que conheceu e com quem privou na sua passagem pelo Liceu Alexandre Herculano, Óscar Lopes demonstra o conhecimento e uma consciência clara sobre o devir das políticas de educação em Portugal, desde a República até inícios da década de 1960, e o impacto das mesmas no percurso de um professor forjado pelo ideário educacional republicano. Sobre o professor de Geografia, declarou:

a sua grande competência, distinção e comunicativa cordealidade, um professor querido e venerado por todo o corpo docente e discente da casa, um educador que se impunha, sem qualquer espécie de férula, pela simples finura e madurez de espírito, que inculcava conhecimentos pela mera dinâmica espiritual da reflexão e da comprova ${ }^{34}$.

Do ponto de vista do projeto político de unificação do ciclo de estudos inicial dos ramos liceal e técnico, o futuro Ciclo Preparatório do Ensino Secundário, que será oficialmente decretado em 1964, Óscar Lopes reconheceu a sua necessidade e pertinência no quadro da extensão da escolaridade gratuita e obrigatória até aos doze anos e da dotação do subsistema escolar com uma formação intermédia entre o então ensino primário e o ensino secundário. Ainda tomando o caso do professor de Geografia como referência, desenvolveu uma reflexão sobre o magistério liceal que, na nossa perspetiva, parece conter uma reflexão autobiográfica, a saber:

Depois de tantos anos de esforços, de entusiasmos e decepções, de frutos invisíveis ou imponderáveis como são os de todo o trabalho pedagógico mais sério, de incompreensões e até de injustiças, o autor deste livro tão oportuno conserva ainda um extraordinário dinamismo intelectual em matéria pedagógica ${ }^{35}$.

\footnotetext{
${ }^{33}$ LOPES, 1943: 5-6.

${ }^{34}$ LOPES, 1962: 10.

${ }^{35}$ LOPES, 1962: 9 .
} 
Este especial interesse e atenção para com Mário de Vasconcelos e Sá, professor muito dinâmico no quadro do ensino liceal feminino instituído no Porto pela República, a partir de 1914/1915 36; a par de Leonardo Coimbra, professor liceal e universitário, ministro da Instrução Pública na República, fundador da Faculdade de Letras da Universidade do Porto, visita da casa parental e com quem privou, enquanto criança e estudante liceal, também nas viagens da carreira 5 do elétrico, entre Matosinhos e o Porto $^{37}$; e ainda de Francisco Torrinha, professor da referida Faculdade e, após a sua extinção de facto em 1932, o professor do Liceu Rodrigues de Freitas que inspirou e influenciou a sua decisão em cursar Filologia Clássica; leva-nos a considerar que Óscar Lopes deve ser inscrito numa linha de continuidade (plural) da defesa do ideário da República, enquanto referência educacional e política. Aliás, Óscar Lopes declarou-nos:

Sou um patriota. A Portuguesa é uma coisa que me inflama, ao contrário do José Saraiva que embirrava com A Portuguesa... A bandeira. Tudo isso me entusiasma. Mas, isso não significa que diga que sim a qualquer personagem histórica, mesmo moderna ${ }^{38}$.

No Liceu D. Manuel II, Óscar Lopes vai ser convidado, em 1952, pelo reitor António Guerreiro para coordenar o jornal escolar «O Mensageiro», publicado sob os auspícios das atividades culturais do centro escolar da Mocidade Portuguesa (MP) instalado no referido liceu. Para tanto, o reitor teve de se desfazer em diligências junto do Comissariado Nacional da $\mathrm{MP}^{39}$. Em relação ao seu estilo de professor-coordenador do jornal, declarou-nos que reuniu com os alunos-redatores (Belmiro Guimarães, Eduardo Pinho, José Augusto Seabra e Vítor Alegria) e lhes apresentou a sua visão: «Eu não proíbo nada, vocês escrevem o que quiserem, inclusivamente podem escrever coisas que acarretem a influência da PIDE e eu vou para a PIDE ${ }^{40}$. No que tange à orientação editorial de «O Mensageiro», expôs, na entrevista publicada no número 2 do jornal, a sua interpretação do sentido formativo que a devia animar: evitar o estilo rico, a ênfase, a literatice, preferir reportagens concretas, informações incisivas à grande eloquência ou pretensão literária, falar sério e liso sem forçar a graça, fazer do jornal um eco das reais preocupações e aspirações dos estudantes ${ }^{41}$. «A minha orientação do jornal era essa, o que significa que eu dava conselhos. Havia certas coisas disparatadas,

\footnotetext{
${ }^{36}$ Cf. CORREIA, 2016c: 21-93.

${ }^{37}$ Cf. Entrevista; LOPES, 1996: 16.

${ }^{38}$ Da Entrevista.

${ }^{39}$ Cf. CORREIA, 2016a: 251-252.

${ }^{40} \mathrm{Da}$ Entrevista.

${ }^{41}$ Cf. LOPES, 1952: 7.
} 
por vezes, e nalgumas coisas consegui dar uma volta. Mas eram coisas que não tinham nada que ver com a política» ${ }^{42}$.

Esta experiência na imprensa escolar será por si evocada, em conferência de 1965, como exemplo de iniciativa de sucesso, dentro dos limites escolares, e demonstrativa do potencial que existia em vários setores da sociedade para a vivificação do associativismo de índole cultural. Segundo ele, o

jornal escolar $O$ Mensageiro, [...] inteira e livremente estudantil, que atingiu as 12 páginas ilustradas, o milhar de exemplares de tiragem, organizou uma exposição retrospectiva de história de pintura, sessões litero-musicais, fez autêntico jornalismo independente, crítica literária, cinematográfica, desportiva, etc ${ }^{43}$.

Em 1 de outubro de 1953, Óscar Lopes proferirá a oração de sapiência de abertura do ano letivo do Liceu D. Manuel II. O texto desta lição será publicado em 1958 sob a designação de As mãos e o espírito ${ }^{44}$. Apesar de o nosso interlocutor não se lembrar do "francês» que inspirou a ideia central da lição, podemos agora afirmar que se tratava do poeta e filósofo francês Paul Valéry (através dos seus Cahiers), membro da Academia Francesa e oposicionista do regime colaboracionista de Vichy durante a II Guerra Mundial. Valéry constatou, numa conferência perante um congresso de cirurgia, em 1938, que não havia um tratado geral sobre a mão e que, no entanto, ela, no quadro de uma concepção construtivista da epistemologia, era elemento central na cadeia cognitiva corpo-espírito-mundo ${ }^{45}$. Nesta linha, Óscar Lopes procede a um excurso sobre o processo de hominização e a evolução da humanidade, através de sínteses de largos períodos históricos reconhecidos, identificando as diferentes épocas pelos séculos respetivos (exceto nos três casos em que assinala especificamente o ano de 1870), remata a lição, em época de corrida armamentista no quadro da Guerra Fria, com um apelo:

seja a ciência, seja a arte; seja a imaginação, seja o progresso; seja a honra, seja o amor; sejam as crianças, sejam as rosas; seja a vida, seja o Espírito, no sentido mais autêntico, criador e digno da palavra espírito - tudo, mas absolutamente tudo, cabe hoje neste bem supremo, que é preciso salvar, a Paz, a "Paz áurea, divina», como diz Camões, no poema em que exalta a nossa coragem nacional ${ }^{46}$.

\footnotetext{
${ }^{42}$ Da Entrevista.

${ }^{43}$ LOPES, 1986b: 192.

${ }^{44}$ Cf. LOPES, 1958a.

${ }^{45}$ Cf. ADELL, 2015.

${ }^{46}$ LOPES, 1958a: 43.
} 
O facto de na sua lição ter apenas identificado um ano específico, o de 1870, e de o ter repetido por três vezes, levou-nos a indagar o conferencista se havia uma mensagem implícita que não poderia, à época, revelar publicamente. A resposta foi pronta: «Ah! Foi quando apareceram os primeiros socialistas em Portugal» ${ }^{47}$.

A detenção de Óscar Lopes, na sua habitação particular, pela PIDE, para averiguações de crimes contra a segurança do Estado, em 12 de março de 1955, teve por efeito a suspensão da sua atividade letiva liceal e respetiva remuneração até final do processo judicial em 12 de julho de 1957. Esta nova condição obrigou-o a procurar outros meios de sustento, como aulas particulares, reatualização de manuais escolares ${ }^{48}$ e tradução de livros ${ }^{49}$, para ajudar a equilibrar o orçamento da família, a qual já contava com dois filhos menores. Depois de absolvido em Tribunal Plenário foi reintegrado no Liceu e ressarcido, retroativamente, dos salários suspensos durante 28 meses.

Óscar Lopes foi um professor considerado e respeitado pela maioria dos seus pares liceais, a começar no próprio reitor, António Guerreiro, tido como figura de proa da Situação dentro do Liceu. Serve isto para dizer que, apesar da denegação do convite por parte de alguns colegas (entre eles o reitor), dois deles, já reformados em 1957, aceitaram e foram suas testemunhas abonatórias em sede de julgamento. Foram eles: João Ferreira Guedes, de 72 anos, professor de Inglês, reformado em 1954, e, segundo o nosso entrevistado, «um padre despadrado» ${ }^{50}$; e Augusto César Pires de Lima, de 74 anos, professor de Português, reformado em 1952, autor de manuais e seletas escolares, ensaísta literário, que, na perspetiva de Óscar Lopes, era «um homem conservador, de direita, mas um fulano correto ${ }^{51}$. Aliás, em artigo sobre a história do Liceu D. Manuel II, publicado em partes ao longo de diversos números de «O Tripeiro» de 1956 e 1957, Augusto Pires de Lima colocou Óscar Lopes na galeria dos professores notáveis que nele exerceram ou exerciam magistério ${ }^{52}$.

Este facto evidencia, na perspetiva da avaliação pelo outro, uma característica pessoal de Óscar Lopes: a de criar pontes, independentemente da orientação política dos seus interlocutores, a começar no contexto familiar.

Eu sou um homem de esquerda, não sou, como é que hei de dizer, muito exigente. Eu não sou mesmo nada exigente em relação às pessoas, aos meus amigos, etc. Uma pessoa pode ser minha amiga e não ser minha correligionária. A minha mulher, por exemplo, não é minha correligionária, nunca foi, nem nunca precisamos, e sempre

\footnotetext{
${ }^{47}$ Da Entrevista.

${ }^{48}$ Cf. LOPES \& MARTINS, 1955.

${ }^{49}$ Cf. WELLS, 1956.

${ }^{50}$ Da Entrevista.

${ }^{51}$ Da Entrevista.

${ }^{52}$ Cf. LIMA, 1956-1957.
} 
nos demos bem. [...] Eu por exemplo, não tenho inimigos. Deve haver pessoas que consideram que eu sou o inimigo mas eu não reconheço isso. Reconheço dissensões, divisões, etc., etc. mas, acredito sempre na possibilidade de comunhã $o^{53}$.

Após o regresso à docência liceal em 1957, Óscar Lopes experienciou a ditadura em formato de requinte administrativo e gestionário dentro do Liceu. Isto é, se até 1955 teve serviço distribuído compatível com as suas capacidades e competências a um tempo investigativas e pedagógicas, em Português, Latim e História, por exemplo, a partir de 1957 em diante, em contexto de forte crescimento da população escolar do Liceu $^{54}$, vê essas suas qualidades serem distribuídas pelos níveis escolares mais elementares do ensino liceal (cf. Quadro 1).

Quadro 1. Serviço docente de Óscar Lopes no Liceu D. Manuel II segundo as disciplinas, por grau escolar e número de turmas (1950-1965)

\begin{tabular}{|c|c|c|c|c|c|c|c|c|c|c|c|c|c|c|}
\hline \multirow{2}{*}{ Disciplinas } & \multirow{2}{*}{ Grau } & \multicolumn{13}{|c|}{ Anos letivos } \\
\hline & & $1950 / 51$ & 1951/52 & $1952 / 53$ & $\mid 1953 / 54$ & $1954 / 55$ & $1957 / 58$ & 1958/59 & 1959/60 & $1960 / 61$ & $1961 / 62$ & $1962 / 63$ & $1963 / 64$ & $1964 / 65$ \\
\hline \multirow{2}{*}{\begin{tabular}{|l|} 
Ĺngua e História \\
Pátria
\end{tabular}} & $1^{\circ}$ & - & - & - & - & - & - & - & 1 & 1 & - & - & - & - \\
\hline & $2^{\circ}$ & 2 & - & - & - & - & 3 & 2 & - & - & - & - & - & - \\
\hline \multirow{5}{*}{ Português } & $3^{\circ}$ & 1 & 1 & - & - & - & - & 3 & - & 2 & 2 & - & 3 & 1 \\
\hline & $4^{\circ}$ & - & - & 1 & - & - & - & - & 2 & 1 & 2 & 3 & - & 3 \\
\hline & $5^{\circ}$ & - & - & - & 1 & - & - & - & - & - & 1 & 2 & 3 & - \\
\hline & $6^{\circ}$ & 1 & - & 1 & - & 1 & - & - & 1 & - & - & - & - & - \\
\hline & 70 & - & 1 & - & 1 & - & - & - & - & - & - & - & - & - \\
\hline \multirow{2}{*}{ Latim } & $6^{\circ}$ & 1 & 1 & 1 & - & 1 & - & - & - & - & - & - & - & 1 \\
\hline & $7^{\circ}$ & - & 1 & - & 1 & - & 1 & - & - & - & - & - & - & - \\
\hline \multirow{2}{*}{ Grego } & $6^{\circ}$ & - & - & - & - & - & - & - & - & - & 1 & 1 & - & - \\
\hline & $7^{\circ}$ & - & - & - & 1 & 1 & - & - & - & - & - & - & - & - \\
\hline \multirow{5}{*}{ História } & $3^{\circ}$ & - & - & 1 & - & - & - & - & 1 & - & - & - & - & - \\
\hline & $4^{\circ}$ & - & - & - & 2 & - & - & - & - & 1 & - & - & - & - \\
\hline & $5^{\circ}$ & - & - & - & - & 2 & - & - & - & 1 & 1 & - & - & - \\
\hline & $6^{\circ}$ & - & 1 & 1 & - & - & - & - & - & - & - & - & - & - \\
\hline & 70 & - & - & - & - & - & - & - & - & - & - & - & - & - \\
\hline
\end{tabular}

Fonte: cf. Relatórios do Liceu D. Manuel II em AHME e AESRF para os anos letivos indicados

A juntar a esta situação, construída para condicionar e circunscrever a atividade letiva de Óscar Lopes, ou melhor dizendo, para o impedir de lecionar Literatura e História (especialmente da época contemporânea) aos graus escolares mais avançados, há ainda o caso de o Liceu D. Manuel II ter sido promovido à condição de liceu normal em $1957 / 1958^{55}$.

\footnotetext{
${ }^{53}$ Da Entrevista.

${ }^{54}$ Cf. CORREIA, 2016a: 201.

${ }^{55}$ Cf. CORREIRA, 2016a: 285-327.
} 
Nas nossas pesquisas realizadas nos arquivos da Escola Secundária Rodrigues de Freitas, do Ministério da Educação e através da entrevista à nossa fonte de história imediata, entre 1999 e 2001, nunca encontrámos documento ou testemunho, no fundo, aquilo que o historiador sempre busca, a prova, que nos permitisse demonstrar a validade e substância da seguinte hipótese: se o Liceu D. Manuel II é elevado à categoria de liceu normal em 1957/58, inaugurando a formação de professores do $1 .^{\circ}$ grupo docente (Português, Latim e Grego) a partir do ano letivo subsequente e tendo no seu quadro de nomeação definitiva um dos mais proeminentes investigadores em literatura portuguesa e linguística, por que razão não foi ele convidado pelo reitor António Guerreiro para assumir, de forma óbvia, competente e legítima, as então prestigiadas funções de professor-metodólogo?

Os documentos compulsados nos referidos arquivos e a resposta de Óscar Lopes não deram prova ou testemunho desta hipótese por nós logicamente formulada. Mas a intuição, subjacente à hipótese, manteve-se viva até à pesquisa por nós operada no fundo da PIDE, guardado na Torre do Tombo. Aqui, deparámo-nos com uma lacónica informação contida numa folha de cor amarela, sem timbre, datada de 20 de outubro de 1958, parecendo tratar-se de cópia de ofício emitido para o Ministério da Educação Nacional (MEN), que nos esclareceu a hipótese/interrogação levantada, nos termos que se seguem:

\section{Informa-se que:}

Foram, recentemente, nomeados, pelo Ministério da Educação Nacional, dois professores metodólogos, em Lisboa e Porto, que devem considerar-se suspeitos:

Dr. OSCAR LOPES - Crítico comunista, preso pela P.I.D.E. e julgado no Porto; $e$

Dr. MÁRIO DIONÍSIO - poeta e estecta [sic!] comunista, teorizante de crítica de arte comunista ${ }^{56}$.

A julgar pelo desconhecimento de Óscar Lopes da eventual indicação do seu nome para o cargo de professor-metodólogo, somos levados a pensar que o seu nome tenha sido, legitimamente, colocado em cima da mesa em sede da reitoria do Liceu Normal e do MEN como professor com perfil adequado ao desempenho do cargo de professor-metodólogo do $1 .^{\circ}$ grupo docente. Atendendo que a solução encontrada foi a da requisição, em comissão de serviço, de Francisco da Costa Marques, professor efetivo do Liceu Normal D. João III, em Coimbra, para o cargo, logo em 1957/58 (um ano antes da entrada em vigor), e de Maria Beatriz Silvestre, professora auxiliar, a partir de 1970/71 $1^{57}$, consideramos que se verificou uma gestão algo oportunista face

\footnotetext{
${ }^{56}$ ANTT - PIDE/DGS, Serviços Centrais, Processo 80 CI (1. ${ }^{\circ}$ volume), (NT 1156), Cd. ${ }^{a}$ n. ${ }^{o}$ 48/58, Proc. 2313 , f. 79. ${ }^{57}$ CORREIRA, 2016b.
} 
à situação profissional de Óscar Lopes nos dois anos letivos referidos. No primeiro caso, havia pouco mais de dois meses passados sobre a data da sua reintegração no Liceu após o arquivamento do processo disciplinar (24 de junho de 1957); no segundo caso, aos 52 anos de idade, qual jovem professor intelectual, humanista e combativo pela causa educacional, como afirmara em 1943, Óscar Lopes encontrava-se destacado na Escola Preparatória Gomes Teixeira a implementar, sozinho, um projeto de investigação educacional com autorização ministerial e bolsa atribuída pela Fundação Calouste Gulbenkian.

Esta leitura, aparentemente sofrida, que fazemos da situação de Óscar Lopes face ao mencionado cargo de professor-metodólogo seria válida se confinássemos a análise do seu trajeto de vida exclusivamente ao contexto do Liceu Normal D. Manuel II. Mais adiante, iremos relacionar este assunto com uma série de outras evidências tangíveis de outras dimensões da sua vida intelectual que nos ajudarão a matizar a perspetiva ora enunciada.

Mas 1958 não foi o único ano em que a PIDE recolheu e proporcionou informação sobre a conformidade de Óscar Lopes à Situação com o intuito de condicionar ou influenciar decisões do MEN. Em dois boletins de informação separados entre si por 28 anos a PIDE dava conta do seguinte:

— em 1941, que o "Candidato que concluiu o exame de Estado em 1941»: «É tido como simpatizante com a Situação»;

- em 15 de dezembro de 1969, tendo como destinatário a Direção-Geral do Ensino Superior e das Belas Artes, que o "Candidato para o lugar de encarregado de curso da Faculdade de Letras, da Universidade do Porto (CM)»: "Não oferece garantias de cooperar na realização dos fins superiores do Estado ${ }^{58}$.

O episódio pidesco de 1969, de nova interferência na carreira profissional de Óscar Lopes, é revelador, a um tempo, do intrínseco reconhecimento da grande qualidade da sua obra publicada e da densidade, pluralidade e valia das realizações registadas no seu curriculum vitae (enquanto professor, investigador, ensaísta, divulgador, editor, crítico, jurado de prémios literários nacionais e internacionais, entre outros ${ }^{59}$ ) e da necessidade de afastar semelhante candidato de concursos através de expedientes administrativos ilógicos.

Uma vez foi anulado o concurso; outras vezes obrigavam-me a apresentar um documento que estava no Ministério, e era o meu diploma de Curso. [...] Isto foi

\footnotetext{
${ }^{58}$ ANTT - PIDE/DGS, SC, Bol. 22794 (NT 7976).

${ }^{59}$ Cf. BRITO et al. org., 1997: 19-35.
} 
em 67, 68 e 69, quando a Faculdade de Letras [da Universidade do Porto] passou a ter a Secção de Filologia Românica, com Literatura Portuguesa e Latim, que eram coisas que eu podia ensinar porque estavam dentro da minha especialidade ${ }^{60}$.

Por ofício de 3 de maio de 1974, o Diretor-Geral do Ensino Superior informa o Reitor da Universidade do Porto que

por despacho do Delegado da Junta de Salvação Nacional, de 2 do corrente mês, foi designado o Lic ${ }^{\circ}$ OSCAR LUSO DE FREITAS LOPES para exercer as funções de professor do Estágio Pedagógico da Licenciatura do ramo educacional da Faculdade de Ciências e encarregado de assumir a direcção da Faculdade de Letras dessa Universidade ${ }^{61}$.

Com esta solução de nomeação rebuscada, que contém tanto de signo do processo revolucionário em curso, como de justeza avaliativa e reconhecimento oficial dos seus méritos científicos e pedagógicos, a carreira docente de Óscar Lopes enveredou pelo nível de ensino para o qual estava configurada e preparada desde há cerca de, no mínimo, vinte anos. O visado recebeu a ordem da Junta de Salvação Nacional para se apresentar como diretor da FLUP por telegrama chegado no Dia do Trabalhador de $1974^{62}$ (da Entrevista). Tinha, então, 56 anos de idade.

\section{OPOSICIONISTA}

A PIDE não registou apenas informações relativas à ação de Óscar Lopes no domínio educativo, como acima foi reportado. Aliás, os registos de natureza educativa são diminutos no conjunto dos oito processos consultados. O principal foco de atenção da PIDE foi colocado na sua atividade pública no âmbito de: i) organizações autorizadas pelo regime, como o Movimento de Unidade Democrática (MUD), em 1945, a Comissão Democrática Eleitoral (CDE) do Distrito do Porto, em 1969, a Comissão Nacional de Socorro aos Presos Políticos, em 1971; ii) como signatário de vários pedidos dirigidos ao Ministro da Presidência do Conselho de Ministros no sentido, por exemplo, de anulação do processo-crime levantado a Aquilino Ribeiro, em 1959; iii) no exame prévio da conformidade ideológica das suas publicações; ou ainda, iv) no controlo dos seus pedidos de autorização de deslocação, em missão científica, ao estrangeiro (vários ao longo da década de 60).

\footnotetext{
${ }^{60}$ LOPES, 1996: 27.

${ }^{61}$ Cf. AFLUP.

${ }^{62}$ Da Entrevista.
} 
No domínio da vigilância apertada dos passos de Óscar Lopes, desde 1945, a PIDE acabou por reunir um conjunto volumoso de registos. Apoiados por documentos escritos do arquivo da PIDE, passamos a sinalizar, a traço grosso, a atividade de Óscar Lopes tida oficialmente como subversiva e contra a segurança do Estado português. Para tanto, vamos seguir o fio cronológico dos factos percecionados e registados pela PIDE.

O resumo elaborado pela PIDE, em março de 1962, dos processos de Óscar Lopes rezava assim:

ÓSCAR LUSO DE FREITAS LOPES - Professor de liceu, nascido a 2/10/917, na freguesia de Leça da Palmeira, concelho de Matosinhos, filho de Armando Lopes e de Irene Celeste do Carmo Freitas Lopes.

Aderiu ao MUD em 1945, tendo feito parte da Comissão distrital de Vila Real;

Em Novembro de 1953 subscreveu o manifesto comunista «Pela Paz entre as Nações»;

Em Fevereiro de 1955 subscreveu a mensagem, de inspiração comunista, dos intelectuais portugueses dirigida ao secretário-Geral das Nações Unidas, pedindo a eliminação das armas de extermínio de recurso à guerra;

Em 12/3/955 foi preso pela PIDE do Porto, acusado de desenvolver actividades contra a segurança do Estado.

Através dos autos verificou-se que tanto ele como os demais arguidos faziam parte, como elementos activos, das organizações clandestinas denominadas «movimento de unidade democrática juvenil» (MUD juvenil) e «comissões de paz», organizações dirigidas e controladas pelo chamado "partido comunista português», pelo que os autos forma remetidos ao Juiz de Turno nos Tribunais Criminais da Comarca do Porto, à disposição de quem ficaram os arguidos (em 14/7/955);

Foi restituído à liberdade em 15/7/955, por ter prestado a caução de $20.000 \$ 00$ em cumprimento de mandado emanado do $1 .^{\circ}$ Juízo Criminal da Comarca do Porto;

Por acórdão de 12/6/957, o Tribunal Plenário Criminal do Porto julgou a sua acusação improcedente e não provada, pelo que foi absolvido.

Em 5/10/955 tomou parte no banquete comemorativo de "5 de Outubro", realizado no Café Pallatium, no Porto, durante o qual discursou;

Foi um dos signatários da exposição dirigida a Sua Ex. ${ }^{a}$ o Ministro da Presidência, em Abril de 1959, em que pediam para ser arquivado o processo-crime instaurado ao escritor AQUILINO RIBEIRO, por afirmações contidas no seu livro "Quando os Lobos Uivam», consideradas injuriosas ou ofensivas à Magistratura Portuguesa;

Desde 1959 que tem desempenhado prepondera[n]te papel na Associação dos Jornalistas e Homens de Letras do Porto, como dirigente de todo o seu movimento cultural e orientador dos colóquios literários ali realizados, a muitos dos quais tem presidido e procedido à abertura das respectivas sessões. A actividade desta 
Associação é altamente perniciosa posi [sic!] que, sempre que possível, ainda que veladamente, ataca o Estado e os seus dirigentes. Nos colóquios já referidos têm sido analisadas obras de vários escritores, de uma maneira geral adversários do Estado, alguns deles já estando presos por actividades subversivas, do que ressalta a intenção evidente, por parte do Dr. OSCAR LOPES, de popularizar alguns escritores, mesmo mediocres, que se notabilizaram pelas suas ideias contrárias ao actual regime político. Todavia, ultimamente, o Dr. OSCAR LOPES tem-se mostrado mais cuidadoso, não permitindo que os colóquios resvalem para o campo político;

É autor de um pequeno manual elementar de literatura portuguesa, intitulado «História da Literatura em Portugal», de nítida tendência marxista, embora habilidosamente apresentada;

Trata-se, portanto, de indivíduo que tem andado ligado a elementos comunistas e que tem desenvolvido actividades da mesma natureza ${ }^{63}$.

A atividade política desenvolvida entre 1962 e 1973 poderá ser reconstituída a partir de inúmeros registos elaborados pela PIDE. A reconstituição possível na economia deste trabalho dos factos reportados pelos agentes desta polícia, é a seguinte:

- dezembro de 1962, evento literário em Vila do Conde. Teve lugar «no salão do Clube Fluvial Vilacondense, um colóquio sobre a poesia de Fernando Pessoa, o qual era orientado pelo Dr. Óscar Lopes. Na mesa da presidência, tomou também lugar o presidente da direcção do Clube, Vítor Manuel Torres Pedra, funcionário da Caixa Geral de Depósitos daquela vila e irmão do recluso nesta Delegação, em cumprimento de pena, Manuel Torres Alves Pedra. Dados os antecedentes do orientador do colóquio e as condições especiais do presidente do Clube e da mesa, admitia-se que pudesse haver qualquer tentativa de desvirtuamento do tema, o que porém se não verificou, pois o conferente se limitou à apreciação da obra de Fernando Pessoa sob diversos aspectos», Relatório do sub-director do Porto ao Director PIDE, de 02.01.1963 (f. 25) ${ }^{64}$.

- 17.06.1963, detenção pela delegação do Porto para «averiguações de crimes contra a segurança do Estado", juntamente com Alberto Augusto Martins da Silva Andrade (profissional de seguros), Jorge Manuel Le Goullon Constante Pereira (estudante - ligado à International Amnesty), Luís de Seixas Ferreira Alves (delegado de vendas da Olivetti), Bernardino dos Santos Ferreira (sapateiro), Fernando José Pinto Seixas (estudante) e Alberto da Silva Proença (alfaiate). Todos recolheram às «prisões privativas» da Delegação. «Por não se terem confirmado as suspeitas que

${ }^{63}$ ANTT - PIDE/DGS, Serviços Centrais, Processo 80 CI (1. ${ }^{\circ}$ volume), (NT 1156), ff. 19-20.

${ }^{64}$ Cf. ANTT - PIDE/DGS, Serviços Centrais, Processo 80 CI (1. ${ }^{\circ}$ volume), (NT 1156). 
contra eles existia de actividades contra a segurança do Estado [...] foram restituídos à liberdade os nacionais arguidos». Óscar Lopes foi libertado no dia $20.06 .1963^{65}$.

- 01.08.1964, informação retirada do «Diário de Notícias» de 31.07.1964: «seguem hoje para o Brasil», via Rio de Janeiro, para conferências sobre o romance português contemporâneo, promovidas pela Embaixada de Portugal e pela Fundação Calouste Gulbenkian, em diversas universidades, Óscar Lopes, João Gaspar Simões, Joel Serrão e Luís Forjaz Trigueiros.

-28.04.1965, Lisboa, episódio dentro de avião da TAP: apesar da autorização prévia passada pela PIDE, «nesta data, pelas 15.00 horas, foi impedida a saída para Madrid, num avião da TAP, de harmonia com o determinado na O.S. $n^{\circ}$ 218/64", de 05.08.1964, disposição que interditava Óscar Lopes de sair de Portugal (cf.f. 189). Em requerimento de 29.04.1965, manuscrito, em papel selado de 5\$00, Óscar Lopes informava que a sua viagem se destinava a participar na reunião, a realizar em Saint-Raphael, França, como «membro do Júri do Prix International de Littérature, instituído por prestigiosas editoras de treze países ocidentais e anualmente atribuído. O júri é composto por algumas dezenas de escritores de cerca de vinte nacionalidades, e o signatário já no ano transacto participou das suas sessões, que então se realizaram na Aústria» $(f .188)^{66}$.

- 01.02.1967, foi um dos signatários do abaixo-assinado dirigido ao Presidente da República "contra o que considera «actos de arbitrária violência a coberto de pretextos inaceitáveis» que atingem o teatrólogo e romancista Luis de Sttau Monteiro que se encontra detido na cadeia de Caxias ${ }^{67}$.

- 31.01.1969, Comemoração do 31 de Janeiro, Porto, Pensão Chic, com a presença de cerca de 200 pessoas. Usaram da palavra: Mário Brochado Coelho, Armando Bacelar, Óscar Lopes, Lino Lima, Mário Sacramento, António Ribeiro da Siva, Virgínia Mora, Alexandre Ferreira Barros, Zeferino Antas Coelho e Joaquim Rocha Felgueiras (Rel. Confidencial, Del. Porto, Semana 26.01. a 01.02.1969, f. 139).

- 16.05.1969, II Congresso Republicano, com múltiplos oradores sobre diferentes temas: Justiça e Polícia (Francisco Salgado Zenha), comparação entre a República e Estado Novo (Raul de Castro), Socialismo e Ensino (Rogério Fernandes), Habitação (Eduardo Ribeiro), Indústria Têxtil (José Rabaça), Democracia e Agricultura (Flávio Martins), Previdência Social (Alberto Pedrosa), Teatro (Luís Francisco Rebelo), Economia e Sociedade (Armando de Castro), Tecnocracia (Vitorino Magalhães Godinho), Um conceito de Liberdade (Urbano Tavares Rodrigues), Processo Político (Armando Bacelar), Constituição de 1933 (Mário Soares), Escritores e Censura (Óscar Lopes, Egito Gonçalves e Marta Cristina Araújo), Liberdade (Mário Sottomayor

\footnotetext{
${ }^{65}$ Cf. ANTT - PIDE/DGS, Serviços Centrais, Processo PC 822/63 (NT 5514).

${ }^{66} \mathrm{Cf}$. ANTT - PIDE/DGS, Serviços Centrais, Processo 80 CI (2. ${ }^{\circ}$ volume), (NT 1156).

${ }^{67}$ Cf. ANTT - PIDE/DGS, SC, E/GT [Gabinete Técnico], Proc. 6391, (UI 1532).
} 
Cardia) - relatório do Inspetor-Adjunto, de 18.05.1969, que agregou diferentes relatórios do chefe de brigada.

- 22.05.1970, notícia de jornal «A Capital»: conferência-debate na Escola Preparatória Gomes Teixeira, no Porto ${ }^{68}$.

- janeiro de 1970: subscritor do pedido de libertação dos presos políticos dirigido à Presidência do Conselho de Ministros. Como anotação ao documento, a PIDE refere que não há presos políticos em Portugal: «ou são de emigração clandestina, ou estão ligados a "movimentos terroristas»" ou são "membros destacados das organizações subversivas» (Informação de 23-2-1970), cf.f. $11^{69}$.

- 01.07.1971, correspondência aberta e reproduzida: Convite do "Consul da Almenaha [sic!] e a Senhora von Schmeling-Diringshofen para um jantar, na Quarta-Feira, dia 13.10.71, pelas 20.30 horas na Rua do Padrão, 219 - 4º Foz Porto («Smoking») / O Consul da Almenaha [sic!] (von Schmeling) reenvia Convite do Departamento de Imprensa e Informação do Governo da RFA para visitar a RFA e solicita CV e a data mais adequada à viagem $»^{70}$.

- 11.08.1972, pedido de averbamento no seu passaporte e autorização para visitar a Polónia, República Democrática Alemã e União das Repúblicas Socialistas Soviéticas (f. 5). Foi «indeferida a sua pretensão para ir à Cortina de Ferro (Polónia, Alemanha Oriental e União Soviética)» a 22.08.1972. Novo requerimento, de 24.08.1972, anexando "xerocópia» da carta da União das Associações Soviéticas para a Amizade e as Relações Culturais com os Países Estrangeiros (remetida ao seu cuidado para a Editorial Inova, Porto, Portugal), na qual é confirmado o pagamento da viagem Paris-Moscovo-Paris (tendo de se dirigir ao Consulado local) e da estada na URSS. No requerimento alega que não teve qualquer informação acerca das razóes do indeferimento, que desejava «evitar uma situação a vários títulos inconvenientes» e que tinha projetado chegar ao consulado a 03.09.1972 (período de férias escolares, ainda). O objetivo da viagem era de natureza científica: «especial empenho em um encontro com especialistas soviéticos de linguística matemática e respectivas aplicações didácticas, assunto que actualmente trabalha como bolseiro da Fundação Calouste Gulbenkian e em regime de experiência pedagógica que reputa da maior importância». Solicitava ainda que fossem consideradas "as vantagens de um contacto de natureza científica acima de quaisquer fronteiras políticas ou ideológicas, autorizando a viagem requerida, a tempo de ela se poder realizar» (f. 2). O resultado desta exposição escrita foi diferente das outras múltiplas

\footnotetext{
${ }^{68} \mathrm{Cf}$. ANTT - PIDE/DGS, Serviços Centrais, Processo 80 CI (2. ${ }^{\circ}$ volume), (NT 1156).

${ }^{69} \mathrm{Cf}$. ANTT - PIDE/DGS, SC, E/GT [Gabinete Técnico], Proc. 6391, (UI 1532).

${ }^{70} \mathrm{Cf}$. ANTT - PIDE/DGS, Serviços Centrais, Processo 80 CI (2. ${ }^{\circ}$ volume), (NT 1156).
} 
exposições apresentadas anteriormente para efeitos idênticos, a saber: autorizado o averbamento (a 28.08.1972 $)^{71}$.

- 05.10.1972, comemorações do 5 de Outubro, pela Comissão Democrática Eleitoral (CDE) do distrito do Porto no restaurante Cantinho, em Grijó Compareceram cerca de 200 pessoas. "Presidiu o Dr. Óscar Lopes, secretariado pelo Dr. Mário Sottomayor Cardia e coadjuvado por três elementos da Comissão Democrática de Aveiro, dois de Braga e dois de Leiria» (Delegação do Porto, Relatório semanal n. ${ }^{\circ}$ 39/72-S.C., de 1 a 7 de Outubro de 1972), f. 41.

- 01.02.1973 e 08.03.1973, nas páginas do "Diário de Lisboa»: polémica com José Augusto Seabra, seu antigo aluno e um dos redatores do jornal escolar «O Mensageiro» no Liceu D. Manuel II (cf.p. 4 e 9 9 $)^{72}$.

- 9.03.1973, nas páginas do jornal República, artigo sobre Escolas Soviéticas - 2 - Escola Decenal Obrigatória (cf.p. 3 e 11) ${ }^{73}$.

Óscar Lopes apresentou-se como candidato, pelas listas da CDE do distrito do Porto, às eleições legislativas de 28 de outubro de $1973^{74}$. O principal foco da campanha foi centrado sobre o fim da guerra colonial em África e, à semelhança de várias petições anteriores, a libertação dos presos políticos. Ao contrário da campanha de 1969, só os candidatos pelas listas das organizações concorrentes é que podiam discursar na campanha eleitoral, aberta no dia 30 de setembro de 1973. O partido do governo, a então Ação Nacional Popular (ANP), foi o único que se apresentou a disputar, em todas as circunscrições eleitorais, os 150 lugares da Assembleia Nacional. A campanha decorreu na forma já experimentada em eleições anteriores: manifestos difundidos pelos círculos oposicionistas (corporizados pela CDE e pela Comissão Eleitoral de Unidade Democrática - CEUD) que concorriam às urnas; notas trocadas entre a ANP e a oposição, sendo as desta muitas vezes cortadas pela censura, total ou parcialmente, sobretudo quando se abordavam temáticas de política ultramarina; cartazes, vinhetas, comícios, sessões de esclarecimento, entrevistas e artigos na imprensa dos concorrentes oposicionistas ou de figuras de relevo, os quais também eram visados e escrutinados pela censura e, no caso das sessões ou comícios, por vezes, suspensos pelas autoridades policiais ${ }^{75}$. O resultado foi o habitual, a ANP venceu em todos os círculos eleitorais. Faltavam ainda cerca de cinco meses para chegar o mês de abril.

A 20 de abril de 1974 foi prestada uma homenagem a Óscar Lopes por cerca de 50 pessoas que estiveram presentes num restaurante da Aguda, concelho de Vila

\footnotetext{
${ }^{71}$ Cf. ANTT - PIDE/DGS, SC, Proc. 3239/70 SR (NT 3829).

${ }^{72}$ Cf. ANTT - PIDE/DGS, Serviços Centrais, Processo 80 CI (2. ${ }^{\circ}$ volume), (NT 1156).

${ }^{73} \mathrm{Cf}$. ANTT - PIDE/DGS, SC, E/GT [Gabinete Técnico], Proc. 6391, (UI 1532).

${ }^{74}$ Cf. LEMOS, 2012: 316.

${ }^{75}$ LEMOS, 2012: 298-304.
} 
Nova de Gaia. Na tarja estendida na parede, atrás da cadeira do homenageado, podia ler-se: «Não desisto das dimensões da minha cidadania aqui e agora» ${ }^{76}$. Quando por nós foi indagado sobre esta homenagem tal não lhe acudiu de imediato à memória. Mas, breves instantes depois, desfiou alguns dados relevantes, a saber:

Eu não sabia que a Revolução estava para já, mas havia lá pessoas que sabiam. A homenagem foi-me feita porque eu, no dia 31 de janeiro imediatamente anterior, tinha feito umas declarações no Cinema..., no Rivoli, bastante contundentes em que eu estudei muito bem a linguagem, mas os pides e os especialistas da oposição percebiam perfeitamente que aquilo era anticolonialista, antifascista [...]. Como sabe, a PIDE foi assaltada; foi tomada, grande parte, de assalto no dia 26 de abril de 1974. [...] O que eu posso dizer disto, em primeiro lugar... em primeiro lugar, isto foi convocado e realizado como se fosse de homenagem a mim mas, no fundo, era um comício. Falava-se de muitas coisas aqui e além... Eu próprio propus que se votasse pelo regresso imediato do Mário Soares e do Álvaro Cunhal. [...] Portanto, aquilo foi, no fundo, um comício; comício muito frenético, muito quente. Mal sabiam muitas pessoas o que dali ia sair. Eu sei que entre os papéis queimados na PIDE, no dia 26 de abril de 74, havia um que se referia a esta homenagem e que dizia: "Ainda não se tinha bebido o caldo e já havia pessoas a pedirem o regresso do Álvaro Cunhal e do Mário». Quem propôs fui eu, aliás, segui a ordem inversa, propus primeiro o Mário Soares e depois o Álvaro, porque percebi que a maior parte das pessoas que estavam eram socialistas e não queria destoar ${ }^{77}$.

Neste apartado sobre o perfil de oposicionista de Óscar Lopes, torna-se ainda pertinente incluir a análise um pouco mais circunstanciada dos processos das duas detenções para averiguações de crimes contra a segurança do Estado.

A detenção de 1955 é despoletada por ter constado, no quadro da detenção de um estudante em Lisboa, que Óscar Lopes pertencia ao "partido comunista português». A detenção é, assim, integrada e inscrita num fluxo de prisões que são feitas a partir de 25 de janeiro de 1955, no qual se incluíram, entre outros, António Agostinho Neto, Alcino Soutinho (estagiário de arquiteto), Vítor Alegria (candidato a operador dos CTT - Correios, Telégrafos e Telefones) e José Augusto Seabra (estudante da Universidade de Coimbra), todos detidos entre 9 e 12 de fevereiro de 1955. Os dois últimos nomes, lembremos, foram estudantes e redatores de O Mensageiro no Liceu D. Manuel II.

${ }^{76}$ Cf. AA.VV., 1996: 71-73.

${ }^{77}$ Da Entrevista. 
À data da detenção de Óscar Lopes, o processo contava já com $38 \operatorname{arguidos}^{78}$, vindo a atingir o número final de acusações contra 52 pessoas.

Sigamos a experiência de prisão preventiva segundo as palavras do próprio Óscar Lopes.

Fui preso durante aqueles cinco [quatro] meses e tal e completamente isolado dos outros. Creio que fui o único que esteve nessas condições. Puseram-me num quarto cá em baixo, sem luz, sem luz direta. Eu fiz um livro para ganhar dinheiro... ${ }^{79}$ Tinha que aproximar a folhinha onde escrevia, assim para ver, para escrever e para ler o que escrevia. [...] Completamente isolado, não tive contacto, enquanto preso e antes do julgamento, não tive contacto com mais nenhum coarguido. Eles estavam agrupados em grupos de cinco ou seis ou sete ou oito ou nove, ou qualquer coisa assim... Às vezes eram uma espécie de salas com uma data de pessoas. Eu nem sequer as conhecia. De muitas pessoas só soube lá dentro. Espreitava... O sitio onde estava tinha uma janela fosca e eu consegui fazer um buraquinho e por aquele buraquinho via as pessoas que passavam. E foi assim que consegui saber de algumas pessoas que lá estavam. A certa altura, apercebi-me que realmente eram muitas pessoas. [...] Interrogado fui muitas vezes. O que devo é ter chateado muito aquelas pessoas porque respondia sempre: «sou fulano de tal, idade, tudo o que queiram... não tenho qualquer declaração de ordem política a fazer. A minha ação... aquilo de que sou acusado não significa qualquer posição política». E daqui não saía. [...] De resto, acabei por sair [em liberdade]. Com umas dores de cabeça terríveis. Passei a usar óculos. Esta coisa de ler e escrever junto de uma lâmpada pequena deu-me cabo da vista ${ }^{80}$.

Na busca passada em casa de Óscar Lopes a 13 de julho de 1955, dois dias antes da sua libertação, a PIDE reportou o seguinte:

diversos documentos de propaganda subversiva, nomeadamente um editado pela «organização regional do norte do partido comunista português». Perguntado sobre as suas actividades políticas, recusou-se a responder. Da acusação que the é imputada consta o seguinte: Fazer parte duma chamada «comissão de paz» e como tal, ter tomado parte em diversas reuniões para ampliação dessa "comissão», recolha

\footnotetext{
${ }^{78}$ Cf. ANTT - PIDE/DGS, Serviços Centrais, Processo PC 47/55 (NT 5110), 1. ${ }^{\circ}$ volume - Processo n. ${ }^{\circ}$ Inicial 5-955 do Porto/da Directoria 47-55-S. Inv. Ano de 1955.

${ }^{79}$ Face à lista de publicações de Óscar Lopes em 1955 e 1956, julgamos tratar-se da atualização da terceira edição do Manual elementar de Literatura Portuguesa, coautorado com Júlio Martins (cf. LOPES \& MARTINS, 1941b: LOPES \& MARTINS, 1945; LOPES \& MARTINS, 1951; LOPES \& MARTINS, 1955; LOPES \& MARTINS, 1970).

${ }^{80}$ Da Entrevista.
} 
de fundos e distribuição de tarefas a cada um dos seus membros. Numa dessas reuniões foi sugerido que o arguido se deslocasse a Lisboa para assistir às reuniões periódicas da «comissão nacional de paz» como delegado da comissão do Porto. Passou a contribuir para fundos da «comissão de paz» com $20 \$ 00$ mensais. Recebeu no decorrer dessas mesmas reuniões várias quantias em dinheiro, provenientes da venda de postais alusivos à "paz». Elaborou um texto dum documento, para ser tirado copiógrafa por intermédio do co-arguido David Fernandes da Cunha, sobre as aspirações dos "partidários da paz» e da prisão do Alberto da Silva Proença. $O$ arguido manteve contactos com um individuo desconhecido, "funcionário do partido comunista português» que lhe foi apresentado pelo José Emílio Mendes da Silva Moreira. Reuniu numa casa arranjada na Póvoa de Varzim, várias vezes, em conjunto com o Moreira, rodeando essas deslocações à Póvoa, com todos os cuidados estabelecidos pelas directrizes do "partido comunista português» ${ }^{81}$.

Com uma acusação sem provas concludentes, Óscar Lopes foi levado a tribunal, no âmbito de um processo coletivo, e saiu absolvido. O processo coletivo contou com um total de 52 arguidos e o julgamento «durou mais de meio ano, pois começou a 10 de Dezembro de 1956 e teve a sua última audiência em 12 de Junho de $1957 »^{82}$, «por vezes com três sessões diárias, de manhã, à tarde e à noite» ${ }^{83}$. Entretanto, os arguidos foram alvo de apoio político através de panfleto clandestino (cf. Fig. 1) que circulou por alturas do julgamento no Tribunal Plenário do Porto.

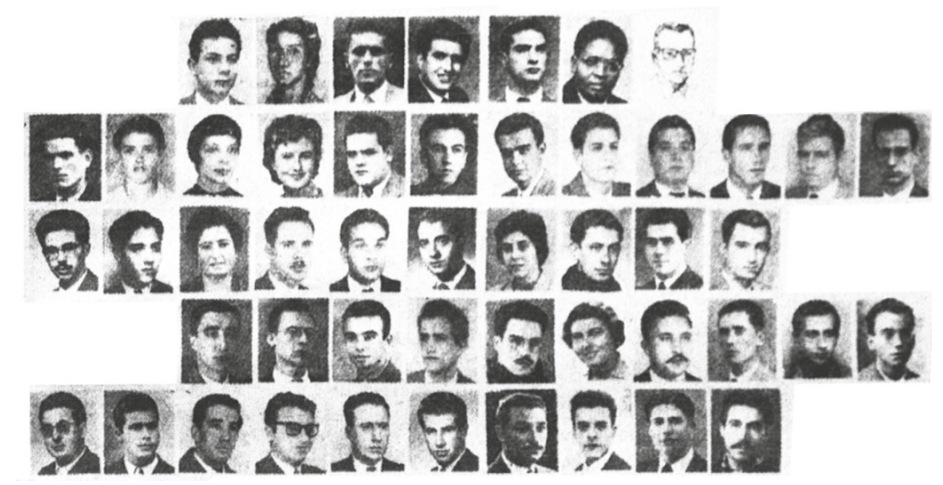

Fig. 1. Panfleto de circulação clandestina em 1956 e 1957 dando notícia do julgamento coletivo de 52 arguidos no Tribunal Plenário do Porto

Fonte: «O Jornal», ano V, n. ${ }^{\circ} 231$, de 28 de setembro de 1979, p. 29

Nota: Óscar Lopes é o primeiro a contar da direita na fila central

\footnotetext{
${ }^{81}$ ANTT - PIDE/DGS, Serviços Centrais, Processo PC 47/55 (NT 5110), 1. ${ }^{\circ}$ volume, Cad. 10846, (UT 3445).

${ }^{82}$ MACEDO, 1979: 28.

${ }^{83}$ COELHO, 2007: 10
} 
A finalidade deste processo de acusação teve por motivo, segundo as palavras de Óscar Lopes,

um grande movimento do MUD, o MUD juvenil [...]. O governo quis várias vezes atalhar esse movimento proibindo isto, proibindo aquilo e aqueloutro, mas não conseguia dar cabo... E a certa altura, foi precisamente no [momento] em que fomos presos, em 55, resolveu cortar a cabeça a uma porção de coisas. Foi o último momento do regime, digamos, de grande gana interna do governo de Salazar. Isso falhou-lhe. Porque as pessoas não acompanhavam, mesmo ministros; devia haver muita indecisão interna. Os homens que foram presos, as tais 52 pessoas, eu não os conhecia, quase nenhum, porque eram de muitas coisas diferentes ${ }^{84}$.

Segundo António Macedo, advogado que defendeu Agostinho Neto, Óscar Lopes foi arrolado num processo conjunto, com arguidos, na sua maioria, com menos de 30 anos de idade e oriundos de diferentes proveniências geográficas (Porto, Lisboa e Coimbra). Foi preso e julgado como cabecilha da Comissão para a Paz (juntamente com Silas Cerqueira, 25 anos, estudante da Faculdade de Letras da Universidade de Coimbra, e Orlando Juvenal, 41 anos, advogado da cidade do Porto), comissão esta que, no entender da polícia política, era subversiva e «ramificação» do então clandestino Partido Comunista. Os demais réus do processo foram acusados por pertencerem à comissão central do MUD Juvenil, «organização dissolvida e perseguida pela polícia de Salazar, sob a acusação (constante do libelo) de ser [...] uma ramificação do P.C.» ${ }^{85}$.

Desconhecemos se Aquilino Ribeiro se inspirou neste julgamento no Tribunal Plenário do Porto para redigir algumas passagens de Quando os lobos uivam, obra originalmente publicada em 1958, passagens essas que foram a causa do processo-crime que lhe foi movido em 1959. No entanto, não resistimos, para concluir com um toque literário a análise da fase de angústia e privação da vida de Óscar Lopes entre março de 1955 e junho de 1957, a citar uma dessas passagens.

Acudiu com vénia do Presidente o representante do Ministério Público a justificar a acumulação processual. E, como era de esperar, saiu-se com as razões costumadas, já clássicas, próprias do saber discricionário, o pressupor em qualquer levantamento das populações, qualificado em direito de "desobediência colectiva», o dedo de agitadores comunistas. Lá admitir que nas massas pudessem fermentar princípios de revolta, sponte sua, ao sentirem-se lesadas nos interesses ou contrariadas,

${ }^{84}$ Da Entrevista.

${ }^{85}$ MACEDO, 1979: 28. 
não queria admitir e negava-se a compreender. Tudo era obra das organizações clandestinas, apostadas a perturbar a leda paz do Eldorado de fartura e amor ${ }^{86}$.

No que tange à segunda e última detenção pela PIDE, durante quatro dias em junho de 1963, sigamos a descrição incisiva e desapegada feita pelo próprio detido:

Foi em 63 quando inauguraram a ponte da Arrábida, salvo erro. Quer dizer, é uma coisa estúpida, o governo entendeu que devia intimidar os portuenses e prendeu, sem qualquer razão, aí umas seis ou sete pessoas, quase todas elas morreram já, entre os quais eu. Eu não liguei nada a isso. Continuei na mesma, continuei isolado, não me colocaram juntamente com os outros. Os próprios pides tinham vergonha daquilo, não sabiam o que é que haviam de perguntar ${ }^{87}$.

Se não estivéssemos perante mais um episódio de humilhação injustificada, poderíamos, através da leitura e análise dos autos de busca e apreensão (efetuadas na sua habitação particular no dia 17) e de perguntas, juntar ainda, ao desapego, a perplexidade, em alguns aspetos a roçar alguma comicidade.

No auto da busca e apreensão foram reportados, entre outros: transcrições das sessões de 23 e 26 de junho de 1956 do Gabinete do Conselho Mundial da Paz; «um postal com a efige e uma mulher com uma espada na mão» do manifesto do diretório do Partido Republicano de 11 de janeiro de 1891; uma carta enviada de Bissau por seis militares; um panfleto coimbrão intitulado Aos estudantes com data de 9 de junho de 1962; «uma relação de diversas individualidades» portuguesas; «um rectangulo de papel branco, dactilografado, com o título Reunião Magna da Academia do Porto»; um texto, destinado aos estudantes universitários, assinado pela «Comissão de Consciencialização do Porto»; o livro Asamblea Mundial de la Paz, de 22 de junho de 1955; uma folha com o «Texto do Apelo do Secretário das Nações Unidas»; e duas folhas de papel «com o título O Movimento de Paz em Portugal» ${ }^{88}$.

No auto de perguntas do dia 17 podem ler-se as questões colocadas pelos agentes da PIDE e as respostas dadas por Óscar Lopes: se já esteve preso (sim, julgado e absolvido); se cumpriu «os seus deveres militares» («ficou isento»); que atividades «vem exercendo contra o actual regime político» (nenhumas); onde esteve no «último domingo» (em casa «a fazer um trabalho literário, que foi à noite pôr no Correio»); que pessoas amigas «o visitaram no aludido dia dezasseis» (não respondeu «por razões suas de escrúpulo moral», ao mesmo tempo que garantia «não ter tido quaisquer contactos

\footnotetext{
${ }^{86}$ RIBEIRO, 2014: 267.

${ }^{87}$ Da Entrevista.

${ }^{88}$ Cf. ANTT - PIDE/DGS, Del. Porto, PC, Processo 207/63 (NT 3189), Pasta 1, ff. 4-5-6f/v-8 f/v.
} 
com propósitos ilegais»). No dia 20 foi novamente sujeito a interrogatório, agora sobre os documentos apreendidos na busca domiciliária, realizada no dia 17, e respondeu:

os textos dactilografados são efectivamente da sua autoria e se relacionam quer com a origem, quer com a condução da defesa no processo em que foi julgado no Tribunal Plenário do Porto; quanto aos impressos subscritos por organismos do movimento mundial da Paz, procurou obtê-los através de advogados de defesa e dos co-arguidos a fim de melhor poder defender-se perante o Tribunal; quanto ao postal não se recorda ao certo se o recebeu pelo correio ou the foi oferecido em qualquer das campanhas eleitorais ${ }^{89}$.

Perante esta factualidade, reportada pelos documentos consultados, temos de concordar com a análise desapaixonada acima feita por Óscar Lopes. E a ponte da Arrábida lá se inaugurou, no 24 de junho de 1963.

Por entre os cerca de quatrocentos artigos de crítica literária que Óscar Lopes publicou, entre 1951 e 1967, nas páginas de "O Comércio do Porto» ${ }^{90}$, queremos aqui destacar aquele que foi publicado na edição do jornal de 14 de junho de 1955. Como nesta data Óscar Lopes se encontrava detido nos calabouços da delegação da PIDE no Porto há mais de três meses, presumimos que deva ter escrito o artigo sentado na cadeira colocada em cima da mesa para aproveitar ao máximo a luz muito fraca derramada pelo candeeiro de teto da sua cela. O artigo, intitulado O tempo na obra literária, foi incluído na compilação editada em Modo de ler: Crítica e interpretação literária ${ }^{91}$. $\mathrm{O}$ autor abriu o artigo dizendo que

uma obra de arte impõe-se-nos sempre como constituindo uma unidade orgânica - como um conjunto onde palpitam conflitos, onde se chocam linhas de força, mas tudo fazendo um certo sentido global, que em parte podemos compreender, analisar, em parte nos limitamos a sentir ou consentir ${ }^{92}$.

Mais adiante, reconheceu que «cada pessoa, cada geração, cada grupo mais ou menos coeso de homens tem a sua noção própria do tempo-lei das coisas, e tem por isso a sua medida própria de esperanças, de resignações, de frustrações conscientes e inconscientes» ${ }^{93}$. É curioso, e até tocante, verificar que Óscar Lopes, do ponto de vista intelectual, não estava sozinho na cela pois povoou a mente, o artigo, talvez a

\footnotetext{
${ }^{89}$ Cf. ANTT - PIDE/DGS, SC, E/GT [Gabinete Técnico], Proc. 6391, (UI 1532).

${ }^{90}$ Cf. LIMA \& MARTELO, 1997: 261.

${ }^{91}$ Cf. LOPES, 1969b: 54-57.

${ }^{92}$ LOPES, 1969b: 54.

${ }^{93}$ LOPES, 1969b: 55.
} 
cela, com referências a um friso de autores canónicos da literatura ocidental: Luís de Camões, Henri Bergson, Rainer Maria Rilke, Fernando Pessoa, Marcel Proust, James Joyce, William Faulkner e Thomas Mann. Perante esta situação, concordamos com Fernanda Irene Fonseca quando ela constata que «a escrita é o lugar da verdade, e os textos de Óscar Lopes anulam sozinhos» os conflitos de superfície, no caso vertente, da vida prática de um oposicionista do regime salazarista e membro de um partido político obrigado a resistir e a operar na clandestinidade.

Sob este prisma, do oposicionista político, é que devemos abordar a significação do remate do artigo:

Ponhamos melhor o problema: a arte opera sempre, ainda que não pareça, uma reconciliação com as suas frustrações, opera sempre uma transfiguração heroica, uma mudança do sinal menos no sinal mais que não vale menos para a hominização superior do que as conquistas que obtemos sobre o ritmo ou lei das coisas; mas não é exorcizando impotentemente os ritmos irreversíveis do mundo, não é reduzindo a mudança que "faz» ao ritmo daquela que dantes "soía», não é opondo ao tempo a duração íntima como sua mera inversão metafísica - não é só assim que nos transfiguramos em toda a nossa plenitude possível. E isso talvez explique a necessidade normal de outras categorias mais informes de arte - incluindo a arte quotidiana de simplesmente viver, decifrar as entrelinhas do jornal, falar ao vizinho de casa, ver cair a chuva e ter um programa, ou mais que um, de vida ${ }^{94}$.

\section{INTELECTUAL}

O escritor romeno Matéi Visniec afirma, logo a abrir O negociante de inícios de romance, que:

A primeira frase de um romance tem de conter a energia do grito inconsciente que provoca uma avalanche... Tem de ser a faísca libertadora de uma reação em cadeia... Por essa razão, a primeira frase nunca é inocente. Ela contém em si, germinativa, toda a história, a trama na sua integralidade ${ }^{95}$.

No estudo que fizemos sobre a obra publicada de Óscar Lopes no período em análise constatámos que, para além das publicações escolares acima analisadas, as suas linhas de investigação maiores foram corporizadas e gravadas nos seus primeiros trabalhos, publicados entre 1943 e 1946 . Considerando o fulgor e rigor desses trabalhos, consideramos que, em meados da década de 40 , já estava investido, do ponto de

\footnotetext{
${ }^{94}$ LOPES, 1969b: 57.

${ }^{95}$ VISNIEC, 2015: 13.
} 
vista filosófico, teórico, metodológico, empírico e praxeológico, de um conjunto de conhecimentos, problemáticas, capacidades e interesses de pesquisa que irá sendo confirmado, aprofundado, complexificado e reconhecido ao longo da sua carreira, mesmo em tempo de detenção pela PIDE, de subalternização em termos profissionais em sede do Liceu D. Manuel II ou da tentativa de condicionamento da sua visibilidade em termos internacionais (sobretudo, ao longo da década de 60).

Assim, recorremos ao escritor romeno para, metaforicamente, ilustrar a vitalidade, poder, significação e qualidade da sua obra intelectual encerra, desenvolvida na condição de professor de ensino liceal ou, por outras palavras, sem carreira académica e enquadramento científico compatíveis. Será a partir desses trabalhos de meados da década de 1940 que passamos a analisar as duas áreas de trabalho, Literatura e Linguística, que marcam o labor e identificação científica de Óscar Lopes, complementando-as com as traduções de monografias de História e o papel desempenhado na divulgação cultural.

\section{LINGUÍSTICA}

«O que vou ler tem uma intenção geral pouco especulativa; liga-se a assuntos escolares; falo como professor do ensino secundário ${ }^{96}$. Assim abre o trabalho intitulado Equívocos do velho humanismo onde, com o auxílio de um enquadramento histórico-cultural e teórico, Óscar Lopes foca a problemática do ensino da linguagem, mais propriamente a sua dimensão morfológica. Não obstante a sua juventude, declara taxativamente o seguinte: "Ouso afirmar que não está cientìficamente estudada a morfologia das línguas indo-europeias» ${ }^{97}$. Sinaliza, igualmente, o viés que tem levado a esta sua constatação:

Os gramáticos modernos, repetindo o êrro, a atitude incrítica dos romanos, ainda hoje pretendem encontrar em qualquer língua as categorias morfológicas que os ontologistas viram no Grego; como se, admitindo que houvesse substantivos gregos, barateando assim o sentido da palavra [...]. Ora substantivar, em linguística, significa, rigorosamente, encarar uma idéia como susceptível de variar em género, número, adjectivação, determinação possessiva, local, etc. Portanto, o substantivo grego é função das variáveis singular-dual-plural, feminino-masculino-neutro, etc; varia quando variam os valores destas oposições. Acontece que os valores destas oposições não são os mesmos em grego, em latim, em português, em inglês. Portanto, a única interpretação verdadeiramente fecunda da gramática é a funcional ${ }^{98}$.

\footnotetext{
${ }^{96}$ LOPES, 1943: 3.

${ }^{97}$ LOPES, 1943: 8.

${ }^{98}$ LOPES, 1943: 10.
} 
Destaca a necessidade de se atender à génese e evolução da frase, o seu particular estudo sob os aspetos morfológicos e sintáticos e a abordagem da linguagem como um sistema complexo e relacional:

A linguagem é um domínio de formas, de fenómenos interpretáveis independentemente dos fenómenos físicos, dos fenómenos fisiológicos, dos fenómenos psicológicos. Há em toda a frase uma ordem, um nexo complicado que se pode estudar abstraindo de condições de outra ordem, de outro sistema. Uma frase, de simples mímica, uma simples frase é um sistema de relações que implica outras frases, outros sistemas prévios da mesma natureza. Qualquer linguagem, mesmo a musical, constitui um tipo de experiência, uma intervenção constante de ideias feitas em ideias a fazerem-se, de ligações numa ligação actual ${ }^{99}$.

Óscar Lopes fixa, assim, em artigo publicado em 1943, a génese (escolar) da problemática (assim como as linhas teórico-metodológicas orientadoras) de investigação que vai, a espaços, desenvolvendo na área de conhecimento em Linguística ${ }^{100}$, de modo pioneiro e interdisciplinar, até ao seu trabalho mais reconhecido e de maior fôlego, publicado em 1971, a Gramática simbólica do português ${ }^{101}$.

No artigo Preliminares duma Gramática, publicado em revista dirigida por José Hermano Saraiva, que ocupará o cargo de Ministro da Educação Nacional à época do início dos trabalhos de intervenção e investigação que conduziram à referida gramática simbólica, Óscar Lopes continuará a explorar o veio dos estudos linguísticos sempre a partir do seu ponto de (observador-participante e) professor de Português. Explicita que o seu propósito é reagir contra os pré-juízos epistemológicos e pedagógicos inscritos no terreno escolar:

O nosso entendimento do que seja a linguagem está tão sugestionado pelos hábitos da análise gramatical escolar que, para rasgar caminhos de mais alcance neste assunto, convém abordá-lo de um lado menos batido. É preciso evitar a falsa clareza das idéias feitas ${ }^{102}$.

Confirma a sua concepção sistémica (inspirada em parte pela referência a Ferdinand Saussure), densificada por uma estrutura formal e metodológica, como abordagem matricial do estudo científico da linguagem:

\footnotetext{
${ }^{99}$ LOPES, 1943: 12-13.

${ }^{100}$ Cf. LOPES, 1944; LOPES, 1950; LOPES, 1958b; LOPES, 1970; LOPES, 1971a.

${ }^{101}$ Cf. LOPES, 1972.

${ }^{102}$ LOPES, 1944: 12.
} 
A linguagem vai, pois, interessar-nos neste trabalho como um conjunto ordenado de fenómenos, isto é, como um domínio de relações. Se nos preocupássemos com as coisas a que as palavras dizem respeito, e não apenas com as palavras, praticaríamos o mesmo êrro de método de um químico que, em vez de estudar as reacções do cloreto de sódio, andasse a inquirir da utilidade do sal na cozinha. [...] Não interessam, lingüisticamente as condições em que uma certa frase é pronunciada, sejam psicológicas, fisiológicas ou sociais. Dada a frase, abstraindo de tudo o mais (até mesmo de ser uma ou várias pessoas que a dizem), o linguista procura o que não varia, o que é constante, a ordem mais intima dessa frase ${ }^{103}$.

E, fundamentando na história das línguas fonéticas ocidentais e seu desdobramento e aplicação nas áreas do conhecimento científico-natural, evidencia a necessidade do recurso à ideação e representação gráfica no ensino da linguagem:

Anteriormente a escrita fôra constituída por sinais que representavam, não os sons, mas o desenho esquemático que constituía uma idéia; o chinês moderno é, ainda, ideográfico; as fórmulas científicas modernas voltam a ser ideográficas, sendo curioso assinalar que a cultura ocidental atingiu primeiro a ideografia científica mercê da maior simplicidade e poder de vulgarização da escrita fonética. Tão necessária é a cooperação social ${ }^{104}$ !

No período pós-II Guerra Mundial, Óscar Lopes vai aprofundar a sua concepção de estudos linguísticos à luz de, mais uma vez, novo humanismo à escala mundial, fundado em estudos científicos e respeitador da especificidade dos povos e das línguas que falam. Assim, em artigo publicado em 1950, com uma expressão marcadamente marxista, constata que

permanece o facto de que a civilização burguesa se tem exprimido sobretudo em idiomas áricos. Quando a história se fizer com espírito mais científico, quando o campo de análise e previsão científica em história disser respeito a mais do que às linhas gerais do desenvolvimento económico e social, então é possível que à evolução linguística (correlacionada com a das estruturas sociais, a da aparelhagem técnica a das ideologias, etc.) seja dada uma grande importância.

${ }^{103}$ LOPES, 1944: 13.

${ }^{104}$ LOPES, 1944: 13. 
História esta que tenderá a ser «mais exact» se articular «a estrutura morfológica das línguas com a estrutura técnica e social dos povos que as falam» ${ }^{105}$.

Perante a torre de Babel que esta perspetiva humanista comporta, Óscar Lopes defende e mete ombros à empreitada e

oportunidade de criar um humanismo, mas um humanismo autêntico, e não a generalização, como paradigma do "humano», dos gostos especiais e da abstracta moral que uma fracção geográfica da humanidade apurou. Isto põe um labirinto de problemas ${ }^{106}$.

Para tanto convoca a necessidade de metodizar o ensino da linguagem com recurso a ferramentas lógicas, claras e unívocas que podem ser encontradas no campo disciplinar da matemática:

O desenvolvimento da matemática, correlativo do das técnicas, e os primeiros esboços de linguística histórica e comparativa abriram, já no século XIX, caminho para uma radical transformação da análise linguística. Hoje, o desenvolvimento de certos ramos da matemática, como o cálculo proposicional, a teoria das estruturas, a topologia, deveria ter já reagido sobre a maneira como se estuda uma língua (nativa ou estrangeira) ${ }^{107}$.

Essa metodização do ensino da linguagem é guiada, no contexto socio-histórico acima referido, igualmente por um imperativo epistemológico, técnico, pedagógico e cultural, a saber: a gramática do humanismo tradicional desfigura também e gravemente, os próprios idiomas para que foi criada;

enche-nos a memória com classificações, subclassificações infindáveis, e não se apoia em nenhum sistema de símbolos que não sejam os da pontuação e da ortografia. Eis o mais claro indício de que o seu esforço se detem na simples construção de uma carapaça metafísica em torno de um trecho, uma carapaça que defende o texto escolar contra uma autêntica análise (por isso é que o texto escusa de ter qualquer interesse e pode até ser desmiolado de todo, como dos nossos "clássicos» fradescos do século XVIII); uma carapaça toda feitinha para nos fazer render ao texto em vez de o esventrar, de dissecar as relações fundamentais da sua estrutura ideológica. O diálogo entre o texto e o seu leitor estaca breve, com a análise gramatical corrente;

\footnotetext{
${ }^{105}$ LOPES, 1950: 1-2.

${ }^{106}$ LOPES, 1950: 2.

${ }^{107}$ LOPES, 1950: 3.
} 
não passa de superficial reconhecimento de substâncias, qualidades, acções ou estados, em concordância aparente ${ }^{108}$.

Para a construção de novo artigo, publicado em 1958, sobre o estudo das relações lógico-gramaticais em contexto escolar, Óscar Lopes volta a explicitar a pertinência da sua formação académica em Filologia Clássica (Latim e Grego), os temas de conferências e artigos apresentados desde os seus tempos de professor-estagiário (1939-1941), a sua experiência docente enquanto professor de Português, a observação da praxis de outros colegas no ensino do Português, os estudos de psicologia baseados em perspetivas biológicas e lógico-formais do pensamento (que, por exemplo, na Gramática Simbólica do Português, de 1971, vão aportar, entre outras, nas teorias cognitivistas de MerleauPonty, Wallon e Piaget) e as modernas metodologias para o ensino da Matemática. As teses do artigo publicado em 1958 são claras, válidas e fecundas do ponto de vista, a um tempo, epistemológico e educativo, a saber (o sublinhado é nosso):

1) - A análise gramatical corrente (morfológica e sintáctica) é insuficientemente adequada a um estudo científico moderno das relações lógico-gramaticais; estruturada originàriamente para o grego literário clássico e em conexão com uma determinada fase (a fase helénica) da história do pensamento científico, adaptada ao Latim clássico e, desde o Renascimento, às línguas indo-europeias (incluindo o Grego clássico), subordinando-os inconscientemente (e o mal reside sobretudo nessa inconsciência) a certos postulados metafísicos;

2) - A lógica simbólica moderna, com todas as suas variantes operacionais (cálculo das relações, das classes, das proposições, das modalidades) oferece os únicos métodos verdadeiramente científicos para estruturar a gramática histórica, a gramática comparativa, a gramática prática;

3) - A substituição criteriosa da análise gramatical corrente por alguns métodos elementares de análise logística teria consideráveis vantagens pedagógicas, contribuindo, quer para um aprendizado mais eficaz e fácil da língua materna, quer para uma comparação prática mais adequada e plástica entre variações de expressão morfo-sintáctica que se observam de idioma para idioma, quer para uma autêntica coordenação entre a didáctica linguística e a didáctica matemática ${ }^{109}$.

Advertia o autor que, apesar da fecundidade que reconhecia a estas suas teses, importava que a investigação fosse contínua, reticular e partilhada entre investigadores e especialistas de filologia, da lógica algébrica e da metodologia pedagógica a fim de

\footnotetext{
${ }^{108}$ LOPES, 1950: 3-4.

${ }^{109}$ LOPES, 1958b: 69-70.
} 
«erguer estes problemas acima do nível de amadorismo de que não me é possível sair» ${ }^{110}$. Perante esta formulação, pouco comum na sua escrita, perguntamo-nos, se este artigo constituiu uma tangível declaração científica com um duplo propósito de: i) explícita e cientificamente, marcar a sua identidade diferenciada como investigador no quadro dos estudos linguísticos; e ii) implicitamente, afirmar publicamente os seus conhecimentos, capacidades e produções como forma de, pessoal e moralmente, ultrapassar a situação de professor efetivo que foi subalternizado, por motivos extraprofissionais, no quadro do Liceu Nacional D. Manuel II, que acabara de ser elevado à exclusiva categoria de liceu normal em 1957.

Neste quadro, concordamos com Fátima Oliveira quando afirma que a faceta de linguista

está de acordo com a sua personalidade. Afinal, foi uma forma de resistir à proibição de ensinar Literatura, e para resistir é preciso recomeçar vezes sem fim. Mas a Linguística é também para Óscar Lopes uma das formas de tentar encontrar respostas às muitas perguntas que se faz sobre o homem e sobre a vida. A busca de sentido e o sentido que a vida faz ${ }^{111}$.

«De qualquer modo», esclarece-nos Óscar Lopes, anos mais tarde:

aproveito para declarar mais uma vez que não perfilho nem a estética, nem a filosofia, nem a política da ambiguidade. Por muita confusa e indecisa que seja a nossa experiência humana, palavras como eu e nós carregam toda a experiência de uma complexa história unificada de assimilação ou acomodação, e palavras como aqui e agora ligam-se à evidência dos enquadramentos, dentro dos quais se nos impõe fazer qualquer coisa, aqui e agora entre um passado que está ainda presente sob a forma de resultados e representações, e um futuro evidenciado por um presente de expectativas a ponderar, ou de alternativas a escolher. Um texto é, assim, uma condensação da experiência social activa. Todavia ler ou escrever um texto denso é passar por uma vivência de profunda solidão, porque o texto poético, fictivo, ou radicalmente meditativo, suspende o dispositivo quotidiano da comunicação ${ }^{112}$.

A investigação conducente à monografia Gramática simbólica do português (um estudo) foi desenvolvida em contexto escolar. Começou a ser ensaiada por Óscar Lopes, com o apoio de uma bolsa de investigação atribuída pelo Centro de Investigação Pedagógica da Fundação Calouste Gulbenkian, na turma A do primeiro ano do Liceu

\footnotetext{
${ }^{110}$ LOPES, 1958b: 70.

${ }^{111}$ OLIVEIRA, 2005: 32.

${ }^{112}$ LOPES, 1986a: 22-23.
} 
Normal D. Manuel II (em 1967/1968 e 1968/69), tendo por foco a disciplina de História e Língua Pátria ${ }^{113}$.

Com a efetiva entrada em vigor do Ciclo Preparatório do Ensino Secundário a partir de 1968/69, a pesquisa será também alargada a duas turmas deste novel ciclo de estudos (que funde a base dos ramos liceal e técnico do ensino secundário e que passa a constituir, desde 1964, o topo da escolaridade obrigatória) da Escola Preparatória Gomes Teixeira, à Praça da Galiza, no Porto, até 1971/72. O professor-investigador, com a finalidade de realizar «experiências de coordenação das disciplinas de Língua Portuguesa e de Matemática» ${ }^{114}$, antecipa-se e participa, deste modo, no processo que, mais tarde, o Ministro da Educação Nacional José Veiga Simão apodará de democratização da educação ${ }^{115}$. Para tanto, fundamenta a pertinência da sua pesquisa no diálogo profícuo entre a investigação científica e a intervenção pedagógica.

Do ponto de vista científico, afirma que o

mero aprendizado da fala dota uma criança com a mais complexa instrumentação simbólica até hoje criada. Portanto o uso de diagramas e símbolos matemáticos não vem instaurar o pensamento simbólico: vem despegá-lo do espírito das crianças, na altura em que já é oportuno que elas vejam as palavras, as frases, os textos, como coisas de uma até então despercebida categoria: coisas com que, mentalmente, se agarram as outras coisas mais óbvias ${ }^{116}$.

No que concerne à dimensão pedagógica, defende que «para melhor consciência de um texto oral ou escrito» o professor pode seguir, do ponto de vista metodológico, os «trâmites de uma lógica essencial que hoje se apreende em termos de topologia, cálculo de conjuntos e de relações» ${ }^{117}$ como alternativa à praxis de um ensino assente num, volta a lembrar, «luxo mnésico de classificações inoperantes (ou pior: nocivas)», feito de «hábitos secularmente inveterados que causam grandes prejuízos e que só um esforço colectivo poderá erradicar» ${ }^{118}$. Neste quadro, e atento o facto de se tratar de uma experiência-piloto orientada para a qualificação e eficiência do ensino da linguagem num ciclo de estudos que, por força da expansão da escolaridade obrigatória, vai sofrer um afluxo massivo de alunos com uma «preparação cultural inferior à da antiga frequência do Primeiro Ciclo liceal ou técnico» ${ }^{119}$, acaba por traçar as linhas maiores da atividade do professor numa aula de língua nos seguintes termos:

\footnotetext{
${ }^{113}$ Cf. LOPES, 1970; LOPES, 1971a.

${ }^{114}$ LOPES, 1972: VII.

${ }^{115}$ Cf. CORREIA, 1998: 84-85.

${ }^{116}$ LOPES, 1972: 1.

${ }^{117}$ LOPES, 1972: 3.

${ }^{118}$ LOPES, 1970: 13.

${ }^{119}$ LOPES, 1970: 139.
} 
O papel de um professor consiste fundamentalmente em reduzir toda a experiência cultural humana a uma série ordenada de dificuldades crescentes que exercitem $e$, quanto antes, conduzam o aluno aos problemas do nosso (e, de preferência, $e$ quanto possível) do seu tempo. Já a nível pré-primário se põem as crianças a pensar e a brincar com diagramas topológicos, conjuntistas ou relacionais, antes que elas saibam teoreticamente que o fazem. O fazer precede o saber, que surge depois na fase em que já é indispensável saber para fazer melhor. Ao nível do actual Ciclo Preparatório está-se precisamente no início de tal fase ${ }^{120}$.

Com este lastro de labor e inovação científico-pedagógica seria de prever que a comunicação intitulada Perspectivas de uma gramática simbólica, que Óscar Lopes, integrado na comitiva do Liceu Normal D. Manuel II, apresentou ao VI Congresso do Ensino Liceal, realizado em Aveiro, em abril de 1971, fosse aguardada com expectativa e, talvez, tenha estado na origem do rápido esgotamento de stock da monografia da Gramática simbólica do Português, logo após o seu lançamento, em junho seguinte, obrigando, por isso, a uma segunda edição corrigida em 1972.

O professor-investigador de linguagem que, por razão de oposição ao regime, nunca ocupou o cargo de professor-metodólogo do $1 .^{\circ}$ grupo docente liceal no seu Liceu de referência, viu, deste modo, as suas competências profissionais reconhecidas e retribuídas pelos seus pares, apesar da cerrada vigilância que lhe era movida pela PIDE.

\section{LITERATURA}

$\mathrm{Na}$ sua tendência característica para enquadrar toda a vida nacional em determinantes políticas, Teófilo Braga datou da Convenção de Gramido (1847) uma literatura ultra-romântica sentimentalista, desolada, egocêntrica que reagiria ao regime de força dos Cabrais, e depois à administração corruptora da primeira Regeneração de 51, refugiando-se no devaneio dos lakistas e de Millevoye, no egotismo descabelado de René, Werther, Obermann, Antony, Lelia, Manfredo, nas molezas da poesia de alcova - Folhas Caídas, 1853 -; mas nem a cronologia do chamado Ultra-Romantismo se mostra subsequente à sufocação da Patuleia, visto que a Noite do castelo é editada em 1836, Os Dois Renegados representam-se em 39 e o Trovador sai em 44; nem se lobriga um nexo perfeito entre o factor político e o facto literário; nem, sobretudo, se aponta um nítido caráter distintivo da geração seguinte à de Garrett e Herculano que não seja o da quase total mediocridade ${ }^{121}$.

\footnotetext{
${ }^{120}$ LOPES, 1972: 3.

${ }^{121}$ LOPES, 1946: 5.
} 
Esta é a frase inicial do ensaio literário, sobre Realistas e Parnasianos, que Óscar Lopes deu a lume em 1946. Se considerarmos a dimensão escolar dos manuais publicados em 1941 e do texto da palestra realizada no Liceu de Vila Real em 1942, acima analisados, poderemos datar de 1946 o seu primeiro trabalho de maior fôlego na área dos estudos literários. A escala, foco, método e ritmo da análise foram claramente estabelecidos em 1946 e vão demarcar os futuros trabalhos do autor:

Em vez de estabelecer vagas correspondências entre o estado mental e o estado político do País; em vez de meramente encaminhar as investigações ao reconhecimento de repercussões nacionais da cultura estrangeira, que de resto só têm revelado um alto índice de refrigência portuguesa deante das influências europeias, julgamos preferível partir da consideração da problemática (quer dizer: da cultura) portuguesa como um todo e estudar a nossa vida literária relativamente às condições básicas na nossa vida total ${ }^{122}$.

Apesar de centrado sobre o estudo da literatura nacional de Novecentos, Óscar Lopes não deixou de, através de uma escrita fluida, prenhe de dinâmica própria de um discurso oral, estabelecer, em termos de análise, comparação e interpretação histórica, filosófica e estilística, os nexos dos diversos autores e obras abordados (Garrett, Herculano, Soares dos Passos, João de Lemos, João de Deus, Bulhão Pato, Alexandre da Conceição, Castilho, Lopes de Mendonça, Camilo, Arnaldo Gama, Mendes Leal, Junqueiro, Tomaz Ribeiro, João Penha, Eça, Ramalho, Teófilo, Oliveira Martins, Antero, entre outros) com as influências estrangeiras, mormente francesas e alemãs (Hugo, Lamartine, Dumas, Bury, Vera, Quinet, Michelet, Proudhon, Renan, Baudelaire, Heine, Nerval, Schiller, Byron, Sue, Sand, Poe, etc.). Desenvolve, por isso, um método de análise literária apelativo, de densa urdidura teórica e empírica, e focado na dimensão societal da criação artística. Numa perspetiva mais larga, poderemos afirmar que este é o primeiro texto do processo de contribuição de Óscar Lopes para o perpétuo movimento de corporização do cânone literário nacional (feito de acumulação/filiação ontológica, confrontação, tensão, estranheza, ousadia, vida e novidade ${ }^{123}$ ). Por exemplo, quando se refere à influência do «eu lírico» de Alphonse de Lamartine (1790-1869) entre os autores portugueses, afirma que

o subjectivo é, não uma «substância», mas o resíduo de espontaneidade melhorada do já definido, e não se sabe conter numa sóbria vibração; desloca e utiliza essa vibração, colhida numa paisagem, num caso vivido, como pretexto de rapto

\footnotetext{
${ }^{122}$ LOPES, 1946: 6.

${ }^{123}$ Cf. BLOOM, 2013: 20-37.
} 
auto-contemplativo, amoroso e, em última instância, religioso, servido por certa musicalidade verbal sempre insinuante ${ }^{124}$.

Mas haveremos de voltar ao assunto do cânone literário mais adiante.

Em 1948 é publicado o texto da conferência proferida no Clube dos Fenianos Portuenses, no quadro da comemoração do centenário do nascimento de Oliveira Martins, em 14 de maio de 1945. Neste texto Óscar Lopes demonstra a sua capacidade de produzir pontes (entre conteúdos político-sociais e científicos, por exemplo), como se pode comprovar na seguinte passagem:

Antero de Quental, hegeliano, fortifica em Ol. M. o senso das antinomias; vencer efectivamente os problemas morais e sociais seria encontrar e realizar a sintese sempre difícil de teses e antíteses que cumpria igualmente respeitar, como a Liberdade e Autoridade, a Teoria pura e a Prática impura ${ }^{125}$.

Afirma ainda que

Antero de Quental e Ol. M. ao tempo da Teoria do Socialismo (1872), tinham aportado ao anarquismo de Proudhon, última fase do liberalismo consequente, forma extrema daquilo a que se chama o atomismo sociológico, pois reduz a sociedade a um conjunto fluido de átomos individuais. A história explicava-se, assim, como uma libertação progressiva da consciência individual, sede definitiva da Razão, da Beleza e do Bem ${ }^{126}$.

É neste encontro com os primeiros socialistas portugueses em tempo de monarquia liberal que Óscar Lopes fundou, do ponto de vista argumentativo e semiótico, muitas das suas intervenções públicas em lições de sapiência escolares, sindicatos ${ }^{127}$ e até, como veremos mais adiante, em comícios públicos ${ }^{128}$.

Aliás, se atentarmos nos autores referidos no ensaio de 1946 e na conferência publicada em 1948, vários deles, como, por exemplo, Lamartine, Proudhon, Eça, Oliveira Martins e Ramalho, cruzam a produção literária (prosa e/ou poesia) e filosófica com atividade política e institucional.

\footnotetext{
${ }^{124}$ LOPES, 1946: 9.

${ }^{125}$ LOPES, 1948: 25.

${ }^{126}$ LOPES, 1948: 27.

${ }^{127}$ LOPES, 1958a.

${ }^{128}$ Cf. LOPES et al., 1969.
} 
À data da primeira detenção de Óscar Lopes pela PIDE a monografia sobre a História da Literatura Portuguesa ${ }^{129}$ «já estava pronta» e o António José «Saraiva estava emigrado em Paris ${ }^{130}$. A estrutura desta obra comunga das características de um manual científico. Daí se conseguir compreender as treze edições (com atualizações regulares) que vai conhecer durante o período em análise, por um lado, e a sua continuação e enriquecimento, como obra viva que é, tal como a literatura que estuda, até aos nossos dias pela mão de outras investigadoras investidas que foram pelos autores originais (Isabel Pires de Lima e Leonor Curado Neves ${ }^{131}$ ), por outro.

O propósito desta obra volumosa, densa, construída por dois historiadores, é registado explicitamente em sede do seu Prefácio (original), a saber:

A história literária portuguesa tem sido nos últimos decénios objecto de trabalhos de investigação que, em certos casos, alteram profundamente alguns dos seus domínios.

Acontece, porém, que se não tem, correlativamente, actualizado a teoria da nossa história literária. O último grande esforço interpretativo realizado neste campo continua a ser o de Teófilo Braga, integrado na orientação geral da historiografia romântica; e, embora a monumental síntese que ele construiu seja muito esquecida ou colocada em segundo plano, depois das rectificações devidas, entre outros, a Fidelino Figueiredo, a verdade é que nenhuma outra veio substituí-la.

Tendo em vista estas duas circunstâncias, os autores do presente volume esforçaram-se por colocar ao alcance dos estudantes, dos estudiosos e do público em geral as aquisições mais recentes da investigação erudita, mas procurando apresentar os dados da nossa história literária num encadeamento inteligível de acordo com as tendências actuais da teoria da literatura e da história geral das sociedades e da cultura $^{132}$.

Tendo sido concebida como um manual científico, os autores tiveram ainda o cuidado de construir uma Introdução Geral constituída por dois subcapítulos. O primeiro, de reflexões preliminares, é organizado em torno dos conceitos operatórios de literatura, obra literária, crítica e história literária, por um lado, e pela relação entre literatura, cultura e nacionalidade, por outro. $\mathrm{O}$ segundo subcapítulo refere-se às origens e evolução da língua portuguesa: desde a sua raiz latina até ao papel desempenhado por gramáticos, dicionaristas e escritores, passando pelas linguísticas românica, hispânica

\footnotetext{
${ }^{129}$ Cf. LOPES \& SARAIVA, 1985.

${ }^{130}$ Da Entrevista.

${ }^{131}$ Cf. LOPES et al., 2000

${ }^{132}$ LOPES et al., 2000: 5.
} 
e galaico-portuguesa ${ }^{133}$. Os autores tiveram, assim, o cuidado de fornecer as chaves de decifração metodológica dos conteúdos insertos na sua obra. Acresce ainda referir que, para além destes aspetos, os autores também se interessaram em promover uma reflexão, a um tempo, integrada e emancipadora do fenómeno literário:

não podemos deixar de reflectir sobre conceitos fundamentais como os da literatura e obra literária, e sobre as relações existentes entre a crítica e a história do gosto literário, entre a literatura e a língua, entre a história da literatura e a história geral e nacional ${ }^{134}$.

A importância que esta monografia granjeou, ao longo de sucessivas reedições e atualizações, no panorama das publicações sobre a história da literatura nacional fazem dela uma peça fundamental na fixação do cânone literário português.

$\mathrm{Na}$ economia do presente estudo torna-se impossível abarcar os trabalhos de história, ensaio e crítica literária publicados por Óscar Lopes até 1974, pelo que passaremos, doravante, a convocar algumas das suas obras sempre que as mesmas concorrem para a compreensão mais fina dos assuntos que se seguem.

Como já referimos anteriormente, as cerca de quatro centenas de artigos publicados na coluna A Crítica do Livro do suplemento Cultura e Arte do jornal diário portuense «O Comércio do Porto», representa uma outra faceta singular de Óscar Lopes. Isto é, o historiador também lê, reconhece e avalia a literatura que se produz no seu tempo. Se se juntar a este facto a sua preparação em Filologia Clássica, os estudos em Linguística e a prática de ensino liceal, temos então um ecletismo cognitivo de qualidade invulgar, associado a uma grande capacidade de trabalho, reunidos numa mesma pessoa. Interessa-nos com isto sinalizar que algumas das peças publicadas na coluna de crítica literária foram reunidas em monografias de autoria do próprio, como os dezanove artigos em Modo de ler. Crítica e interpretação literária ${ }^{135}$, ou os treze artigos reunidos nos volumes 1 e 3 de Estrada Larga, organizados por Costa Barreto ${ }^{136}$.

O ofício de articulista, parametrizado pelo espaço a ele especificamente dedicado na página do jornal (ou, como hoje se diz, em tempos de aplicações microinformáticas de processamento de texto, pelo número de caracteres), obriga a um outro tipo de exercício de análise e de escrita. Segundo Óscar Lopes, «a disciplina do articulismo tanto convida à superficialidade, ao brilharete ou ao truísmo, como estimula um enérgico espírito de síntese, de jerarquização de ideias, de autêntica e sempre difícil perspectivação mental», isto pelo lado da confeção. Já pelo lado do significado societal

\footnotetext{
${ }^{133}$ LOPES et al., 2000: 7-31.

${ }^{134}$ LOPES et al., 2000: 7.

${ }^{135}$ Cf. LOPES, 1969 b.

${ }^{136}$ BARRETO org., 1958-1963.
} 
da sua coluna de crítica literária, lamenta que não exista nos jornais nacionais o «efectivo jornalismo da cultura», facto que, coligado com a decisão editorial de autonomizar a vida artística e literária em cadernos específicos dos jornais, acaba por alimentar e «manter uma nossa obsessão, já tradicional, que consiste em subestimar o aspecto humanista dos problemas científicos, técnicos e pedagógicos que numa boa cultura fazem corpo com os problemas estéticos» ${ }^{137}$.

Neste pequeno excerto, Óscar Lopes explicita as linhas que melhor definem o perfil que aqui dele estamos tentando esboçar: preocupação e escrúpulo teórico-metodológico, clareza de pensamento, capacidade de síntese (interdisciplinar, com a história, música, matemática, filosofia) e abordagem, a um tempo, computacional e humanista de problemas científicos, técnicos, pedagógicos, estéticos, sociais, culturais, ideológicos e políticos, entre outros.

A partir da análise comparada (ainda que em fase sincrética) entre os vários trabalhos, a produção de Óscar Lopes no que tange a assuntos linguísticos denota um comportamento comunicacional, linguagem e mobilização de dispositivos teóricos, metodológicos e técnicos algo distintos da sua atividade de historiador e ensaísta literário. Porém, as suas capacidades e competências de investigador mantêm-se intactas em ambas as áreas pois denota: uma formação competente e comprometida com um programa de estudos próprio (e, por vezes, como se lamenta em Gramática simbólica do Português, muito solitário ${ }^{138}$ ); elevado reconhecimento em cada um das suas áreas de especialização; gera e acrescenta novo conhecimento, num processo cumulativo e contínuo, ao conhecimento já construído por outros; respeita protocolos e padrões de evidência e argumentação reconhecidos pela comunidade científica; capacidade de pesquisa constante, a nível empírico e conceptual, conducente ao aprofundamento do(s) campo(s) de conhecimento; prestação pública de contas dos resultados e sua divulgação pela(s) comunidade(s) científica(s) de referência para efeitos de utilização por terceiros.

A caracterização do perfil do investigador Óscar Lopes foi bem delineada por Fernanda Irene Fonseca, a saber:

Linguista rigoroso e apaixonado e, ao mesmo tempo, profundo conhecedor dos textos literários com que (con)viveu toda uma vida, Óscar Lopes nunca quis assumir explicitamente a conjugação dessas duas paixões que em si coexistem, a da Linguística e a da Literatura. [...] Num plano mais profundo - o da sua escrita - Linguística e Literatura são inseparáveis e convivem intensamente. A escrita é o lugar da verdade, e os textos de Óscar Lopes anulam sozinhos esse conflito de

\footnotetext{
${ }^{137}$ LOPES et al., 1959: 14.

${ }^{138}$ Cf. LOPES, 1972.
} 
superfície. Conflito que excedem excedendo-se e indo situar-se no lugar teórico em que Linguística e Literatura se fundem num só saber: o saber totalizador acerca da linguagem e da criação poética que é o único saber possível acerca do Homem e do seu misterioso poder sobre o Real ${ }^{139}$.

\section{TRADUÇÃO}

Óscar Lopes foi responsável pela tradução e notas, a partir do original em língua francesa, da monografia de Paul Hazard, intitulada A crise da consciência europeia (1650-1715), publicada em 1948 na coleção Marcha da Humanidade (dirigida por Vitorino Magalhães Godinho) das Edições $\operatorname{Cosmos}^{140}$. Sobre o labor do historiador (da cultura, da literatura, da linguagem), aqui investido da função de tradutor, podemos assinalar o escrúpulo e a pedagogia vertidos em várias notas de rodapé em ordem à clarificação do sentido do texto, das expressões ou das palavras no original francês e das dificuldades sentidas do ponto de vista técnico-linguístico e/ou cultural. Nesta publicação portuguesa do trabalho de Paul Hazard temos ainda a reportar, como marca da inquietude e vitalidade intelectual na defesa de um novo humanismo, a existência de uma peça assinada por Óscar Lopes: o Posfácio do Tradutor. Voltaremos a este posfácio mais adiante ${ }^{141}$.

Um segundo trabalho de revisão linguística, a partir da tradução realizada pelo brasileiro Anísio Teixeira dos três volumes de A História Universal de Herbert Georges Wells $^{142}$, foi realizado por Óscar Lopes durante o período de suspensão da atividade letiva e de vencimento. A mesma inquietude já anteriormente sinalizada é relevada nas cinco páginas da Introdução, nas notas esclarecedoras e numa peça exclusiva da tradução portuguesa que foi a construção de uma Tábua cronológica e cartas do tempo, expendida ao longo das 30 páginas finais do terceiro volume. O Prefácio de Óscar Lopes constitui uma peça de detida análise do trajeto biobibliográfico de Wells (1866-1946) e de fina argúcia para a compreensão de como um professor inglês de Ciências, sem preparação historiográfica prévia, decidiu, no contexto do rescaldo da I Grande Guerra e do questionamento sobre o processo de reconstrução social e da paz internacional, reorientar a sua carreira literária no sentido de aprofundar, através de fascículos publicados a partir de 1918-1919, a síntese da história da humanidade. Nota Óscar Lopes que a obra literária de Wells (em particular: A máquina do tempo, 1895; O homem invisivel, 1897; A guerra dos mundos, 1898; Os primeiros homens na Lua, 1901) contribuiu para a afirmação na Grã-Bretanha do

\footnotetext{
${ }^{139}$ FONSECA, 1996: 108.

${ }^{140}$ Cf. HAZARD, 1971.

${ }^{141}$ Cf. LOPES, 1971b: 345-348.

${ }^{142}$ Cf. WELLS, 1956.
} 
ideal de um humanismo científico em oposição àquele humanismo clássico das camadas dirigentes britânicas que tem tido os alicerces implantados nos métodos educativos das Public Schools. Se durante vários séculos se digladiaram na Grã-Bretanha uma cultura aristocrática de tradição greco-latina e uma cultura burguesa, puritana, de tradição bíblica, Wells é um representante de um novo tipo de cultura, correspondente às profundas modificações que a industrialização capitalista trouxe à sociedade britânica, e estreitamente relacionada com o desenvolvimento do movimento trabalhista e com a doutrinação socialista da Fabian Society, à qual Wells esteve um tempo ligado, tal como Bernard Shaw ${ }^{143}$.

Nesta passagem, Óscar Lopes, que à época do labor de revisão do livro de Wells se encontrava a aguardar julgamento como arguido, consegue sintetizar o seu programa de vida como: crítico e ensaísta literário; historiador da cultura e da literatura; investigador na área de conhecimento em Linguística; professor genuinamente interessado em aliar a dimensão gnosiológica (como ele preferia nomear, em vez de epistemológica) com o múnus do magistério secundário-liceal; cidadão cosmopolita orientado para a construção da paz universal (aliás, a sua afiliação em movimentos para a paz foi a acusação/argumento mais imediata/o da PIDE para a sua detenção em 1955 e em 1963); e cidadão com pensamento político bem fundado. Continuava o prefaciador:

como Wells diz, a orientação política de um homem não passa da sua ideia do passado posta em acção, e era necessário despertar a consciência de toda a gente, no sentido de se evitarem futuras hecatombes, agravadas pelo desenvolvimento da técnica e pela intensificação dos conflitos sociais e económicos ainda latentes sob a máscara dos incidentes políticos mais superficiais ${ }^{144}$.

Óscar Lopes não se limitou a rever a tradução, a anotar e prefaciar a edição portuguesa. Na contracapa de qualquer um dos três volumes pode ler-se que a coleção foi «completada por uma tábua cronológica elaborada expressamente pelo Dr. Óscar Lopes». A cronologia construída por Óscar Lopes começa em 800 a.C (fundação de Cartago), passa pela morte de Camões (1580), pelos nascimentos de J. S. Bach e Haendel (1685), pela Declaração de Independência dos Estados Unidos da América (1776), pela tomada da Bastilha (1789), terminando com a referência que, em 1955, «manifestações populares impedem a adesão da Jordânia ao Pacto de Bagdá (19/12)» ${ }^{145}$.

\footnotetext{
${ }^{143}$ LOPES, 1956: 6.

${ }^{144}$ LOPES, 1956: 7.

${ }^{145}$ Cf. WELLS, 1956: III, 368-398.
} 


\section{DIVULGAÇÃO CULTURAL}

A atividade de divulgação cultural abraçada por Óscar Lopes na cidade do Porto, entre os finais das décadas de 1950 e de 1960, através da organização de colóquios e conferências, é um dado importante no seu trajeto de vida. Estas iniciativas visavam, explicitamente, segundo o seu promotor, preencher um vazio e um fosso: a criação de comunidades de públicos informadas e críticas quanto ao valor e qualidade das produções artísticas e a aproximação dos criadores ao(s) seu(s) público(s) e com eles interagir em contextos comunicacionais imediatos, tangíveis, diretos, respetivamente.

Se, tal como a PIDE interpretou e se preocupou, estes eventos serviam igualmente, e implicitamente, como veículo gerador da tomada de consciência e posição, pelo menos, face aos efeitos das políticas culturais empreendidas pelo Estado Novo, tal efeito seria expectável mercê da sua orientação e exclusividade ideológica ou subfinanciamento.

Através de ofício de 11 de julho de 1960, a Delegação do Porto reporta ao diretor da PIDE que a atividade cultural da Associação dos Jornalista e Homens de Letras do Porto (AJHLP), do ano de 1959/1960, terminou no dia 2 do referido mês de julho.

Pela sua biblioteca passaram vários escritores e artistas, tendo sido proferidas 38 conferências e colóquios, conforme relação que se junta. Dirige todo o movimento cultural da Associação, o professor do Liceu D. Manuel II OSCAR LUSO DE FREITAS LOPES, elemento esquerdista julgado já no Tribunal Plenário desta cidade ${ }^{146}$.

A referida lista de colóquios e conferências, anexa ao ofício, dava conta das datas, intervenientes e temas (plurais) abordados, a saber:

14/4 - 1958 - Victor de Sá - conferência sobre Amorim Viana.

6/2 - 1959 - António Reis e outros artistas - Colóquio sobre artes moderna (de jovens artistas em exposição na Associação).

14/2 - 1959 - Agustina Besa Luís - Colóquio sobre a sua obra.

26/2 - 1959 - Eugénio de Andrade - Colóquio sobre a sua poesia.

6/3 - 1959 - escultor Gustavo Bastos - Colóquio sobre artes plásticas.

14/3 - 1959 - José Rodrigues Miguéis - Colóquio sobre a sua obra.

19/3 - 1959 - Revo. Dr. Xavier Coutinho - Colóquio sobre artes plásticas.

21/3 - 1959 - Acúrcio Pereira - Conferência.

1/4 - 1959 - Colóquio sobre «Camilo Pessanha» por Dr. Óscar Lopes.

16/4 - 1959 - Colóquio sobre artes plásticas do escultor Henry Moore. Introdução a cargo do escultor Lagoa Henriques.

\footnotetext{
${ }^{146}$ ANTT - PIDE/DGS, Serviços Centrais, Processo 80 CI (1. ${ }^{\circ}$ volume), (NT 1156), Ofício n. ${ }^{\circ} 2.674-S . R .$, ff. $60-61$.
} 
17/4 - 1959 - Dr. Sousa Costa - Conferência sobre «Camilo na Assmbleia Portuense».

20/4 - 1959 - Dr. Alberto Uva - Conferência sobre o retrato de alguns poetas.

23/4 - 1959 - Colóquio sobre a escultura Henry Moore.

30/4 - 1959 - Gustavo Bastos - Arte esquimó.

9/5 - 1959 - Dr. Mário Sacramento - Colóquio sobre Fernando Pessoa.

8/6 - 1959 - Tomás Ribas - Colóquio sobre ballet.

9/6 - 1959 - Dr. Carrington da Costa - Conferência sobre orientação profissional. 13/6 - 1959 - Luís Veiga Leitão e Fernando Echevarría - Colóquio sobre as suas poesias.

6/7 - 1959 - Matilde Rosa Araújo - Conferência sobre Irene Lisboa.

13/10 - 1959 - Dr. Norberto Lopes - Conferência sobre jornalismo.

24/10 - 1959 - Dr. Joel Serrão - Conferência sobre Sampaio Bruno.

31/10 - 1959 - Fernando Namora - Colóquio sobre a sua obra.

28/11 - 1959 - Dr. Armando Bacelar - Colóquio «Há progresso na literatura?».

12/12 - 1959 - Debate sobre a construção dum cinema. Usaram da palavra os Snrs. Eng. Mário do Carmo, António Pedro, Óscar Lopes, Cerveira Pinto, etc.

16/12 - 1959 - Dr. Dinis Jacinto - Colóquio sobre teatro e público.

30/1 - 1960 - Egito Gonçalves e António Reis - Colóquio sobre as suas obras.

6/2 - 1960 - Ferreira de Castro - Colóquio literário no Teatro Nun’álvares.

13/2 - 1960 - Bernardo Santareno - Colóquio sobre as suas obras.

12/3 - 1960 - Fernando Correia de Oliveira - Colóquio "porquê música dodecafónica? Porquê música electrónica? Porquê simetrismo sonoro?».

9/4 - 1960 - Dr. Sant’Ana Dionísio - Colóquio «O sentido satírico do génio de Pascoais».

15/4 - 1960 - escritor Manuel Mendes - Colóquio literário sobre as suas obras. Neste colóquio interveio também o Dr. Óscar Lopes, como crítico.

1/5 - 1960 - David Mourão Ferreira - Colóquio "A Poesia da geração de 50».

3/5 - 1960 - Dr. Hernâni Cidade - Conferência «O Infante D. Henrique - Homem Barca».

6/5 - 1960 - Dr. Urbano Tavares Rodrigues - Conferência "A maior dívida do Brasil a Portugal — A maior dívida de Portugal ao Brasil».

14/5 - 1960 - Dr. Jaime Cortesão - Conferência "A maior dívida do Brasil a Portugal - A maior dívida de Portugal ao Brasil».

11/6 - 1960 - Dr. ${ }^{a}$ Fernanda Botelho - Colóquio sobre as suas obras.

2/7 - 1960 - Dr. João de Araújo Correia - Colóquio sobre as suas obras.

19/12 - 1959 - Fernando Lopes Graça - Colóquio sobre música popular folclórica ${ }^{147}$.

${ }^{147}$ ANTT — PIDE/DGS, Serviços Centrais, Processo 80 CI (1. ${ }^{\circ}$ volume), (NT 1156), Ofício n. ${ }^{\circ}$ 2.674-S.R., ff. 60-61. 
Este relatório sobre a atividade cultural da AJHLP regista ainda que ela

é altamente perniciosa, pois sempre que lhe é possivel, ainda que veladamente, ataca as Instituições Vigentes e os seus dirigentes. Nos últimos tempos, o DR. ÓSCAR LOPES tem procurado evitar aqueles ataques, sem dúvida alguma por saber que elementos da Polícia assistem aos colóquios, mas esta, não pode evitar e muito menos controlar o convívio dentro da Associação, em que tomam parte grande número de jovens ${ }^{148}$.

A prolixidade temática, a qualidade das trinta e oito sessões ora citadas, que podemos deduzir dos perfis biobibliográficos dos participantes, numa mescla de gerações, diz bem da imagem pública e vitalidade de Óscar Lopes no domínio da divulgação cultural na cidade do Porto. A organização de colóquios foi continuada por Óscar Lopes no quadro da sua presidência da Delegação do Norte da Sociedade Portuguesa de Escritores (SPE), a qual, segundo Egito Gonçalves, somada à atividade na AJHLP representou, em globo, mais de oitenta iniciativas realizadas, até ao encerramento da SPE em 1965, em vários outros espaços da cidade do Porto: Livraria Divulgação, Clube dos Fenianos Portuenses, Ateneu Comercial do Porto, entre outros ${ }^{149}$. Diz Egito Gonçalves que os colóquios «constituíram um esforço insano e heróico - sempre com a PIDE às canelas», só possível devido às qualidades pessoais de Óscar Lopes: capacidade de trabalho, «de diálogo, o seu empenho, a sua maneira de vencer as adversidades», incluindo «o humor comunicativo com que via entrar os pides para assistir aos colóquios e o descaro do estenógrafo pidesco» ${ }^{150}$.

Os colóquios realizados por Óscar Lopes entre 1959 e 1965 foram, segundo o próprio, acima da centena, «acarretaram a venda de uns milhares de livros» que

levaram numerosos autores de diversas tendências a enfrentar pela primeira vez o público; e que, com poucas excepções, todas elas perdoáveis, nos ensinara a nós a trocar ideias sobre literatura e arte, com correcção, cada vez com mais método e propriedade, e até não poucas vezes com inteligência e com muito tacto ${ }^{151}$.

O sentido de se aprofundar a capacidade de apreciação estética por parte de públicos cada vez maiores era um desígnio social de Óscar Lopes. E se o fez, mesmo com objetivos políticos implícitos, com maior intensidade ao longo da sua quarta década de vida, talvez visasse gerar a coalização de sinergias que combatesse algo a que

\footnotetext{
${ }^{148}$ ANTT - PIDE/DGS, Serviços Centrais, Processo 80 CI (1. ${ }^{\circ}$ volume), (NT 1156), Ofício n. ${ }^{\circ}$ 2.674-S.R., ff. 60-61.

${ }^{149}$ Cf. GONÇALVES, 1996: 98.

${ }^{150}$ Cf. GONÇALVES, 1996: 98-99.

${ }^{151}$ LOPES, 1986b: 212-213.
} 
ele, nos seus ofícios de professor, investigador e crítico literário, teve de habituar-se e que queria, por razões estéticas, de economia e de saúde, evitar, a saber:

A crítica da mediocridade cansa. A crítica e o ensino de uma literatura que não seja de primeira ou, pelo menos, de segunda qualidade cansam, porque obrigam a um esforço de simpatia imaginativa capaz de suprir as insuficiências de expressão. E a simpatia literária é, suponho, tão extenuante como a melhor caridade cristã: só uma vigilância intensa a impede de cair na frase feita, na moenda ideológica apenas ilusoriamente esclarecedora e, no fundo, desgarrada daquilo de que realmente se deve tratar $^{152}$.

Em A educação do gosto literário, conferência proferida no Clube dos Fenianos Portuenses, em 1965, Óscar Lopes tece considerações com um propósito, a um tempo, construtivo, provocador ou estimulante sobre algo que, declara, ter alguma dificuldade em «discernir em absoluto e aprioristicamente: "o que é bom em literatura" ${ }^{153}$. A prudência e sensibilidade com que expõe o conceito de «belo estético», como uma «tessitura de relações unificadas por uma consciência, exigindo, por isso, um grande dinamismo pessoal» ${ }^{154}$, denotam o lastro de um denso trabalho de reflexão feito a partir dos frutos do seu labor de historiador da literatura portuguesa, crítico literário, investigador-linguista, professor liceal de Português, História, Latim e Grego e ativista cultural. Estas comprovadas capacidades cognitivas fazem de Óscar Lopes uma das mais importantes referências na construção do cânone literário português, por um lado, e, considerando a sua defesa da, entre outras, integração da literatura estrangeira traduzida nos curricula dos ensino secundário (Homero, Eurípides, Plutarco, Goethe, Schiller, Cervantes, Lope de Vega, Dante, Petrarca, Manzoni, Tolstói, Dostoievsky, Ibsen, Kipling, D’Anunzio, Ésquilo, Xenofonte, Cícero, Horácio, Tito Lívio, entre outros), como divulgador do cânone literário ocidental, à época ${ }^{155}$, por outro.

A propósito da redescoberta das «heranças que fazem a trajectória duma literatura» nacional, José Cardoso Pires, afirma que os autores «portugueses do passado que Óscar Lopes soube trabalhar com um olhar novo e naturalmente lúcido para os reimplantar na paisagem do presente» foram teorizados por quem (re)conhece «com gosto os autores do presente». «Sim, com um historiador e crítico ensaísta desta dimensão o estudo da nossa Literatura atingiu uma dignidade de coisa viva, questionadora» ${ }^{156}$.

\footnotetext{
${ }^{152}$ LOPES, 2001: 21.

${ }^{153}$ LOPES, 1986b: 178.

${ }^{154}$ LOPES, 1986b: 179.

${ }^{155}$ LOPES, 1986b: 182-184.

${ }^{156}$ PIRES, 1996: 135-136.
} 
O nosso argumento, em relação à posição central de Óscar Lopes no aprofundamento crítico do cânone literário, é robustecido pela interseção de leituras cruzadas (e, necessariamente, contraditórias) que fizemos entre o que a PIDE procurava vislumbrar ou confirmar nas intervenções públicas e nos escritos de Óscar Lopes e o que Harold Bloom afirma constituir e corporizar o cânone literário ocidental. Afirma Bloom que a

liberdade para apreender o valor estético pode surgir do conflito de classes, mas o valor não é exactamente igual à liberdade, mesmo que não consiga ser alcançado fora daquela apreensão. Por definição, o valor estético é engendrado por uma interacção entre artistas, um processo de influência que é sempre uma interpretação. A liberdade de ser artista, ou crítico, surge necessariamente da apreensão sensorial. Mas a fonte ou a origem da liberdade da apreensão sensorial, não sendo irrelevante para o valor estético, não é, contudo, exactamente igual a ele ${ }^{157}$.

Bloom explicita o que entende por cânone literário de modo algo convergente com o que Óscar Lopes referiu como belo estético, a saber:

o Cânone, uma palavra religiosa nas suas origens, tornou-se uma escolha entre textos em luta uns com os outros pela sobrevivência. Este facto mantém-se independentemente de se interpretar a escolha como resultado de grupos sociais dominantes, instituições de educação, tradições de crítica ou, como eu acho, como tendo sido feita por autores que chegaram depois, e que se sentem eles próprios escolhidos por determinadas figuras ancestrais ${ }^{158}$.

Continua, Bloom, afirmando que o

movimento de dentro da tradição não pode ser ideológico ou colocar-se a si próprio ao serviço de quaisquer fins sociais, por mais moralmente admiráveis que eles possam ser. Só se irrompe no cânone graças à força estética, que é essencialmente constituída por um amálgama: domínio da linguagem figurativa, originalidade, poder cognitivo, saber, exuberância de dicção ${ }^{159}$.

Rematando de forma taxativa que o «estudo da literatura, seja qual for a maneira de o levar a cabo, nunca poderá salvar um indivíduo ou melhorar a sociedade» ${ }^{160}$.

\footnotetext{
${ }^{157}$ BLOOM, 2013: 37.

${ }^{158}$ BLOOM, 2013: 33.

${ }^{159}$ BLOOM, 2013: 42.

${ }^{160}$ BLOOM, 2013: 44.
} 
Mas, segundo Óscar Lopes, o estudo da literatura deve, em contextos de aprendizagens formal e informal, ser objeto de trabalho mais metodizado com vista ao desenvolvimento de leitura orientada e crítica, a qual

consiste em dinamizar no educando uma auto-educação à qual os mais elevados padrões estéticos apenas servem como modelo de exercício (um modelo abstracto, porque externo à sua sinceridade, à sua integridade evolutiva), e não como términus a atingir ${ }^{161}$.

Sublinhando ainda que «a leitura crítica constitui o método por excelência da educação literária. É mesmo fácil mostrar que a leitura crítica está inerente à própria criação literária» ${ }^{162}$.

Neste sentido, podemos alinhar o pensamento de Óscar Lopes tecido em 1965 pelo de Harold Bloom, dado a lume em 1994, quando este reforça que devemos «distinguir o poder e a autoridade estéticos do Cânone Ocidental de todas e quaisquer consequências espirituais, políticas ou até mesmo morais que ele possa ter encorajado. Embora a leitura, a escrita e o ensino sejam necessariamente actos sociais, até mesmo o ensino tem o seu aspecto solitário, uma solidão que só dois podem partilhar» ${ }^{163}$, a qual neste quadro envolve: escritor-leitor, leitor-escritor, professor-aluno, aluno-professor.

Neste quadro, consideramos que o marxismo que Óscar Lopes evidencia em parte da arquitetura metodológica e argumentativa, nos seus trabalhos e intervenções públicas, no quadro de um regime político vigilante e repressor, é matizado pela especificidade epistemológica dos próprios objetos de estudo (Literatura e Linguística). Este dado é, assim, convergente com o esforço desenvolvido em prol de uma crítica e ensaísmo literários e de um estudo da linguagem mais estruturados, atualizados e científicos, que observe a herança cultural e patrimonial e lhe acrescente valor. Esta nossa opinião é convergente com a concepção dialética da história, no âmbito de uma sociedade aberta e democrática, deixada em manuscrito por Walter Benjamin, perto da sua morte, em 1940, a saber: «Em cada época, é necessário refazer a conquista da tradição, contra o conformismo que está em vias de a neutralizar» e que a «luta de classes que um historiador formado pela escola de Marx tem sempre no espírito é um combate pelas coisas brutas e materiais sem as quais as coisas subtis e espirituais não existem» ${ }^{164}$.

Nesta linha de argumentação, parece-nos que os censores e os estenógrafos da PIDE não lhe conseguiam apanhar afirmações literais contra a Situação política do país porque a liberdade patenteada nesses atos (escritos ou intervenções) era de natureza

\footnotetext{
${ }^{161}$ LOPES, 1986b: 187.

${ }^{162}$ LOPES, 1986b: 186.

${ }^{163}$ BLOOM, 2013: 49.

${ }^{164}$ BENJAMIN, 2013: 60 e 57, respetivamente.
} 
diversa: brotavam de um modo de estar próprio de um estudioso e investigador íntegro; eram estruturadas por uma densa e rigorosa argumentação científica, literária, cultural, empírica e intelectual; e,

caso raro, raríssimo, é daí que lhe vem a agilidade criativa do seu modo de ler [...] uma solidez cultural que não se avaliza com exibicionismos de erudição nem se passeia com galhardetes cosmopolitas para ganhar um coro de aplausos magazinescos (afinal, outra face do «bem pensar» a que ele se refere algures) ${ }^{165}$.

Serve isto ainda para dizer que, mesmo em intervenções de cariz político, como, por exemplo, o discurso pronunciado no comício da Comissão Democrática Eleitoral (CDE) do distrito do Porto, realizado no Coliseu do Porto, a 22 de outubro de 1969, no âmbito da oposição democrática concorrente às eleições legislativas no mesmo mês, Óscar Lopes denotava uma construção argumentativa sólida, clara e empiricamente fundada, de nítida matriz marxista ${ }^{166}$. Nesta intervenção, sobre o estado da educação e cultura em Portugal, Óscar Lopes recobre o período das décadas de 1920 a 1960, argumenta, exemplificando, com os casos de intelectuais forçados à demissão ou ao exílio (Bento de Jesus Caraça, Abel Salazar e Ruy Luís Gomes), do fruste investimento público e da desigualdade social no sector educativo, da crise literária e artística, da falta de equipamentos e de apoio à instalação de companhias de ópera, bailado e teatro no Porto. Deste discurso retiramos algumas frases que se quadram com o desfiar do nosso raciocínio sobre a incapacidade operacional da PIDE face à resiliência e criação intelectual, a saber (o sublinhado é nosso):

A repressão já não sabe ao certo quê ou quem reprimir, porque paradoxalmente os repressores precisam vitalmente daquilo mesmo ou daqueles mesmos que ainda reprimem ${ }^{167}$.

Estamos a entrar num mundo onde se impõe o estudo permanente, onde se impõe círculos frequentes de reaprendizagem colectiva para todas as produções e graus sempre superiores de iniciativa. De responsabilidade e portanto de liberdade. Nada disto é concebível sem a liberdade associativa estudantil, professoral e outra, sem o saber espontâneo do grupo. Os governantes anti-democráticos debater-se-ão sempre nesta contradição e só nós democratas poderemos ser, nisto, inteiramente consequentes. Nós dispomos dos meios, e mais do que isso, nós é que somos os meios ${ }^{168}$.

\footnotetext{
${ }^{165}$ PIRES, 1996: 136.

${ }^{166}$ Cf. LOPES et al., 1969.

${ }^{167}$ LOPES et al., 1969: 54.

${ }^{168}$ LOPES et al., 1969: 58.
} 
Para uma compreensão mais profunda do sentido da atividade política em Óscar Lopes, seja do ponto de vista operacional e filosófico, seja do ponto de vista subjetivo, importa atentar na declaração que nos prestou em 2001:

Nunca me considerei grande orador ou pessoa que influenciava as outras pessoas, em termos meramente emotivos ou a lisonjear as pessoas... Eu fui sempre muito pouco político nesse sentido. Era político nas minhas convicções. As minhas convicções eram aliás, convicções bastante flexíveis. Isto permite-me ter acompanhado o Partido e acompanhá-lo ainda. Eu posso dizer que filosoficamente acompanho em grande parte a filosofia do Partido Comunista mas, em primeiro lugar, não sei bem até onde vai essa filosofia. Em segundo lugar, não acredito que possa estar de acordo com outro filósofo qualquer... Por exemplo, eu posso dizer-me materialista, que não acredito na sobrevivência individual. Quanto à sobrevivência coletiva, já acho isso um grande problema. Até 1927, portanto até à altura em que comecei a frequentar as escolas secundárias, eu era todo católico, etc., etc. Mas em religião eu tinha muitas razões para duvidar. É que eu conheci a Igreja de dentro. Os meus pais destinavam-me inicialmente a ser padre. E eu, inicialmente, tive um pouco essa convicção, depois é que me despi... Coisa curiosa. E, todavia, simpatizava bastante com o padre da minha freguesia, mas não acreditava na sinceridade dele... e, se calhar, cumpria. Mas indo ao ponto em questão, à sobrevivência, eu acredito que a autoconsciência individual, o facto de as pessoas poderem dizer "eu» e dar sentido a esta palavra, é qualquer coisa de bastante importante, embora as pessoas só aprendem a dizer "eu» aí perto dos 3 anos e com certas indecisões ${ }^{169}$.

\section{CODA}

Em O Aleph, publicado originalmente em 1949, Jorge Luis Borges escreveu, entre outros contos, a Biografia de Tadeo Isidoro Cruz (1829-1874). Das atribulações passadas pelo vaqueiro, assassino, soldado raso, pequeno proprietário e sargento da polícia rural Tadeo, retiramos e realocamos no contexto deste trabalho a seguinte frase: «Qualquer destino, por longo e complexo que seja, consta na realidade de um só momento: o momento em que o homem sabe para sempre quem é» ${ }^{170}$.

Consideramos que este momento borgeano, de reconhecimento do eu, poderá ser situado, no que concerne ao percurso vital de Óscar Lopes, em meados da década de 40. Neste período, para além da habilitação profissional para a docência do $10^{\circ}$ grupo do curso liceal (Português, Latim e Grego) obtida, em 1940/1941, com a aprovação do Estágio Pedagógico com Exame de Estado, cursado no Liceu Normal Pedro Nunes, em

\footnotetext{
${ }^{169}$ Da Entrevista.

${ }^{170}$ BORGES, 1998: 582.
} 
Lisboa, e, em termos pessoais, do casamento com Maria Helena Gaspar Madeira (que nunca foi sua correligionária) em 1941, são produzidos trabalhos e assumidas decisões, por um jovem adulto, na casa dos 25 a 29 anos de idade, que vão (de)marcar o trajeto da sua vida futura. A nível profissional verifica-se o início simultâneo da carreira de docente de Português, Latim, Grego (e, mais tarde, de História e Filosofia) do ensino secundário-liceal e de coautor de livros escolares de literatura portuguesa; no campo da investigação, os trabalhos em Literatura (história, crítica e ensaio) e em Linguística; no domínio da intervenção cultural, a realização de várias conferências públicas; do ponto de vista político, a sua adesão ao Partido Comunista Português em 1942; em termos editoriais, o trabalho de tradução acompanhado, característica indelével, por um trabalho/texto seu como prefácio, posfácio ou tábua cronológica. Neste nicho vital do momento dos anos 40 temos ainda de alocar o curso de licenciatura em História pela Universidade de Coimbra e a não-aceitação das duas propostas de lecionar Latim, na Faculdade de Letras da Universidade de Lisboa, que lhe foram apresentadas por Hernâni Cidade: «Não aceitei porque ficava separado da minha mulher e isso custava-me muito. Há anos, era condenar-me a ser professor de Latim. Eu gosto de Latim. Mas não me interessa fundamentalmente» ${ }^{171}$.

A qualidade e polivalência da obra, a inteireza e claridade do seu percurso vital, fazem de Óscar Lopes um caso diferenciado e específico na intelligentzia portuguesa e no processo de resistência e luta antifascista no período em análise. Considerámo-lo, no âmbito do nosso ofício de historiador, como o arquétipo mais conseguido daquilo que Franco Ferrarotti definiu como universo singular: «totalizado e ao mesmo tempo universalizado pela sua época, que ele retotaliza ao se reproduzir na sua singularidade» ${ }^{172}$.

Ou ainda, aprofundando o significado da palavra sentido, palavra tão cara a Óscar Lopes, na perspetiva da teoria da história, podemos afirmar, apoiados em Jörn Rüsen, que ele, quer pela sua agência e intervenção como professor, intelectual e opositor político do Estado Novo, quer pelo pensamento demonstrado nos seus trabalhos publicados, cumpriu cabalmente com os processos mentais de constituição de sentido dedicados à orientação da sua experiência vital no tempo histórico em análise. Para decifrar

esse desempenho mental como fundamento da consciência histórica humana, a atividade mental da constituição de sentido pode ser desmembrada em quatro componentes naturalmente interdependentes, mais ainda, imbricados: experiência ou percepção, interpretação, orientação e motivação ${ }^{173}$.

\footnotetext{
${ }^{171}$ Da Entrevista.

${ }^{172}$ FERRAROTTI, 1990: 59.

${ }^{173}$ RÜSEN, 2015: 42.
} 
Estas componentes podem ser representadas numa sequência temporal: a geração histórica de sentido é acionada pela experiência de uma mudança temporal; essa mudança coloca em questão o ordenamento da vida dos sujeitos e carece, por conseguinte, de uma interpretação; esta interpretação inserir-se-á na orientação cultural da existência humana através de um duplo movimento e efeito - orientação interna (identidade) e orientação externa (praxis); da «experiência interpretada do tempo podem surgir, no quadro mesmo da orientação, motivações para o agir humano». A busca de sentido é, assim, um processo que requere a atividade otimizada da interconexão interna dos quatro componentes. Sentido será, então, um ponto de equilíbrio, uma unidade coordenadora «que serve de critério fundamental da interpretação do homem e do mundo, e tal unidade equivale ao desempenho da cultura na vida humana» ${ }^{174}$.

Em Óscar Lopes é difícil deslaçar as diferentes dimensões da sua atividade docente, intelectual e política. Funcionam em sistema, como um organismo vivo, como a seguir passamos a sintetizar.

As questões de Linguística brotam de tangíveis problemas com que se deparou na praxis no ensino de Português e dos conexos postulados e dispositivos ideológicos (em matéria social e educativa, por exemplo) no uso da linguagem e de textos literários. Por exemplo, em Preliminares de um gramática, Óscar Lopes afirma que

é possível uma de duas atitudes perante a linguagem. Ou a concebemos como simples convenção, e a distinguimos das coisas e das ideias; ou então nos embrenhamos a estudar as relações entre os sinais como se não existissem coisas ou ideias em si mesmas, isto é independentes dos sinais. Esta segunda atitude é inatacável logicamente; só temos consciência de coisas ou ideias mediante sinais ${ }^{175}$.

Os seus ensaios literários conduzem ao questionamento das condições históricas, materiais, sociais, políticas, culturais e educativas da produção, circulação e debate da literatura em contextos, por exemplo, de ideologia liberal (século XIX). Afirma Óscar Lopes que o «móbil da poesia clássica é o eufemismo, o amaneiramento, a 'fuga à tangente', que Ortega y Gasset arvora corajosamente em razão última de ser toda a poesia» ${ }^{176}$. Considerando a sua intervenção política (quer de conspiração clandestina, quer de intervenção pública) e de divulgação cultural e literária, pensamos que essa afirmação se quadra com a estratégia de resgate da dimensão humanista de Óscar Lopes no período do Estado Novo. E, atenção, esta maneira poética, segundo a nossa perspetiva, de estar na vida política de Óscar não é orientada por «versalhada

\footnotetext{
${ }^{174}$ RÜSEN, 2015: 43.

${ }^{175}$ LOPES, 1943: 12.

${ }^{176}$ LOPES, 1946: 10.
} 
lamecha» ${ }^{177}$ ou um «teclado restrito» ${ }^{178}$ de leitura, análise e interpretação da situação da Oposição no país. Bem pelo contrário. A análise que faz, por exemplo, da polémica chamada Questão Coimbrã e, em particular, do sentido agregador «de tendências que em comum quase só tinham uma vontade renovadora» ${ }^{179}$ das Conferências do Casino de 1871, em estudo de 1946, lembremos, é testemunho do exercício de «aquele agudo senso do real», que afirma, modestamente, faltar-lhe em resposta ao questionário Proust cerca de quarenta anos mais tarde ${ }^{180}$. "Quer dizer», a fim de melhor precisar esta nossa asserção, recorremos novamente ao mesmo autor, «os poetas portugueses da geração de 70 em regra [...] servem uma ideologia revolucionária mesmo quando pretendem só fazer arte; e a cada passo, fazem arte inconscientemente infiéis à sua ideologia» ${ }^{181}$.

A história, enquanto trajeto da humanidade, em articulação com os estudos literários e linguísticos, alimenta o espírito humanista, marxista e universalista que denota nos seus trabalhos. Atente-se, por exemplo, na seguinte passagem do Posfácio do Tradutor na obra de Paul Hazard, em que explicita a sua visão quanto ao sentido emancipador, de autoconsciência, autodeterminação e agência que o estudo da História proporcionam:

São os homens que fazem a história, porque a história só se torna inteligivel, só deixa de ser um caos, se a concebermos como o processo de uma humanidade fazendo-se a si própria, libertando-se pela consciência e controlo progressivos das leis naturais que a determinam, consciência e controlo que lhe permitem determinar-se voluntariamente segundo a sua necessidade intima: o domínio das coisas é que permite e, em parte, sugere a sua orientação no sentido dos valores humanísticos ${ }^{182}$.

Se atentarmos num outro exemplo, o do verbete sobre as Conferências Democráticas ${ }^{183}$, publicado no Dicionário de História de Portugal, dirigido pelo também então professor liceal Joel Serrão, verificamos que ele encerra, para além da dimensão informativo-empírica, um modelo de ação cultural (que poderá ter inspirado Óscar Lopes para as dezenas de colóquios e conferências realizados) e de protesto e recurso contra os presos políticos pelo Estado Novo. Tal como Alexandre Herculano se solidarizou com os protestos contra a proibição das Conferências em junho de 1871 também Óscar Lopes contestou a processo-crime instaurado contra Aquilino Ribeiro em 1959.

\footnotetext{
${ }^{177}$ LOPES, 1946: 23.

${ }^{178}$ LOPES, 1946: 27.

${ }^{179}$ LOPES, 1946: 21.

${ }^{180}$ Cf. LOPES, 1973: 113.

${ }^{181}$ LOPES, 1948: 21.

${ }^{182}$ LOPES, 1971: 345.

${ }^{183}$ Cf. LOPES, 1963: II, 152-153.
} 
A intervenção política declarada publicamente, quando, tomando as palavras de empréstimo a Carlos Drummond de Andrade, «é tempo de meio silêncio,/de boca gelada e murmúrio,/palavra indireta, aviso/na esquina. Tempo de cinco sentidos/num só. O espião janta connosco» ${ }^{184}$, está eivada de referências históricas (31 de janeiro de 1891, situação de bancarrota portuguesa na década de 1890, atrasos industrial e capitalista nacionais, imperialismo inglês, emigração portuguesa, implantação da República), autores como Camões, Almeida Garrett, Alexandre Herculano, Oliveira Martins, Teófilo Braga, Antero de Quental, António Sérgio, Jaime Cortesão, Aquilino Ribeiro, e cientistas como Rui Luís Gomes, Abel Salazar e Bento de Jesus Caraça ${ }^{185}$.

Óscar Lopes foi um marxista que não fez do passado tábua rasa e nem, por isso, renunciou à ideia de revolução. Aliás, fundou na memória do passado e na história (da literatura e cultura portuguesas; dos primeiros socialistas em Portugal; nos republicanos eleitos para a Câmara de Deputados em 1870, entre eles o patrono do seu Liceu quando aluno, José Rodrigues de Freitas, por exemplo) e na representação de um futuro vigoroso a resiliência ao regime político repressivo do seu tempo, a sustentação do seu trajeto vital, intelectual e profissional durante o Estado Novo. Daí o facto de, por formação eclética, consciência histórica e observação do escrúpulo metodológico, ter investido em temas e abordagens que se tornaram, a um tempo, inovadoras, complexas, canónicas e com potencial de transmutação e evolução científica e pedagogicamente sustentadas (cf., por exemplo, a História da Literatura Portuguesa, a Gramática simbólica do Português).

A juntar a estes traços da personalidade de Óscar Lopes é nossa convicção que devemos ainda relevar a importância e influência que os estudos musicais tiveram na sua atividade intelectual e até política. Tendo nascido numa família de músicos (mãe violoncelista e pai pianista, ambos igualmente professores desses instrumentos), matriculado como aluno externo do Conservatório de Música do Porto (classe de piano), a ponto de afirmar que «se não tirei um curso de música foi porque isso se tornou incompatível com a Literatura e a Linguística», e de que conservava em casa um piano e nele «ainda tocava há anos com frequência» ${ }^{186}$, consideramos que também na música poderemos encontrar algumas chaves para compreender o pensamento de Óscar Lopes em relação, por exemplo, aos estudos linguísticos. Se considerarmos que a notação musical é constituída por símbolos ideográficos, regrada e estilizada do ponto de vista gráfico, parametrizada por dispositivos lógico-formais na sua concepção e registo, os quais nada têm em comum com a perceção sensorial do som produzido, tal como a notação matemática, podemos afirmar que, desde tenra idade Óscar Lopes teve diante dos seus olhos parte das soluções que vai teoricamente advogar e, tal como um instrumentista, metodicamente executar nos seus estudos linguísticos. $\mathrm{O}$ facto de

\footnotetext{
${ }^{184}$ ANDRADE, 2015: 153.

${ }^{185}$ Cf. LOPES, 1969 c.

${ }^{186}$ LOPES, 1996: 23.
} 
ter estudado piano e de, por exemplo, em múltiplas entrevistas ter declarado o gosto por peças de música contemporânea (lembremo-nos que a compilação de alguns dos seus artigos em Uma arte de música e outros ensaios foi publicada pela Oficina Musical, associação portuense orientada para o estudo e divulgação da música do século XX e também ensemble de reconhecida carreira), leva-nos ainda a considerar, metaforicamente, entenda-se, que a prática de dissociação do trabalho das mãos do pianista executante (por exemplo, a mão esquerda trabalha de forma diferente da direita) poderá igualmente ser importante para a compreensão do jogo de contrários ou de harmonias (tonal/atonal), de dinâmicas musicais diferenciadas (por exemplo, intensidade enérgica, um molto fortissimo, numa mão e mais dissimulada ou quase inaudível, um molto pianissimo, na outra), que poderemos reconhecer, de modo mais vincado, na atividade política de Óscar Lopes durante a repressão salazarista e marcelista e, ainda, na espécie de música de que ele entrevia e retribuía na poesia.

A poesia, arriscámo-lo afirmar, parece configurar igualmente um locus privilegiado para a compreensão do trajeto de vida que Óscar Lopes trilhou em regime político ditatorial. Esta pista da poesia foi-nos sugerida pelo próprio em dois lugares da sua escrita. O primeiro reside na passagem do ensaio, mais um, que dedicou à poesia de Eugénio de Andrade e onde parece falar um pouco de si próprio, a saber:

não gosto da solidão como assunto de queixume. Mas gosto dos seus frutos. [...] É um modo de realidade-esperança, o modo da mais íntima e apaziguante esperança que eu conheço. Uma esperança impensável, a não ser talvez em música e em poesia para-musical ${ }^{187}$.

O segundo lugar apresentamo-lo com a finalidade dupla de deixar em aberto o processo de descodificação de uma história de vida densa, íntegra e complexa, a desenvolver, necessariamente, no quadro de um trabalho mais dedicado e sistemático, e de encerrar este estudo. Assim, sugerimos a leitura da definição de poesia que Óscar Lopes, aos 28 anos de idade, fixou em Realistas e Parnasianos e convidamos à sua releitura através do pequeno exercício de substituição dos substantivos poesia e poeta por vida e homem (ou investigador), respetivamente, e do adjetivo poética por vital:

A poesia é aventura, é sortida fora do recinto, do já formulado e assente, mas por isso mesmo não prescinde de contacto com o ponto de partida; o poeta deve exibir um santo-e-senha do pensar da sua época ou do seu meio; ninguém o seguirá na sua aventura sem que reconheça nos primeiros passos uma ideologia aceite. A poesia não se exime à necessidade de continuidade dialéctica que dá sentido à

${ }^{187}$ LOPES, 2001: 35. 
cultura humana. Qualquer experiência poética prende-se a um conceito admitido, tanto pode ser o segundo sentido abstracto e personificado da palavra "coração", como um certo quadro de valores estéticos ou éticos ${ }^{188}$.

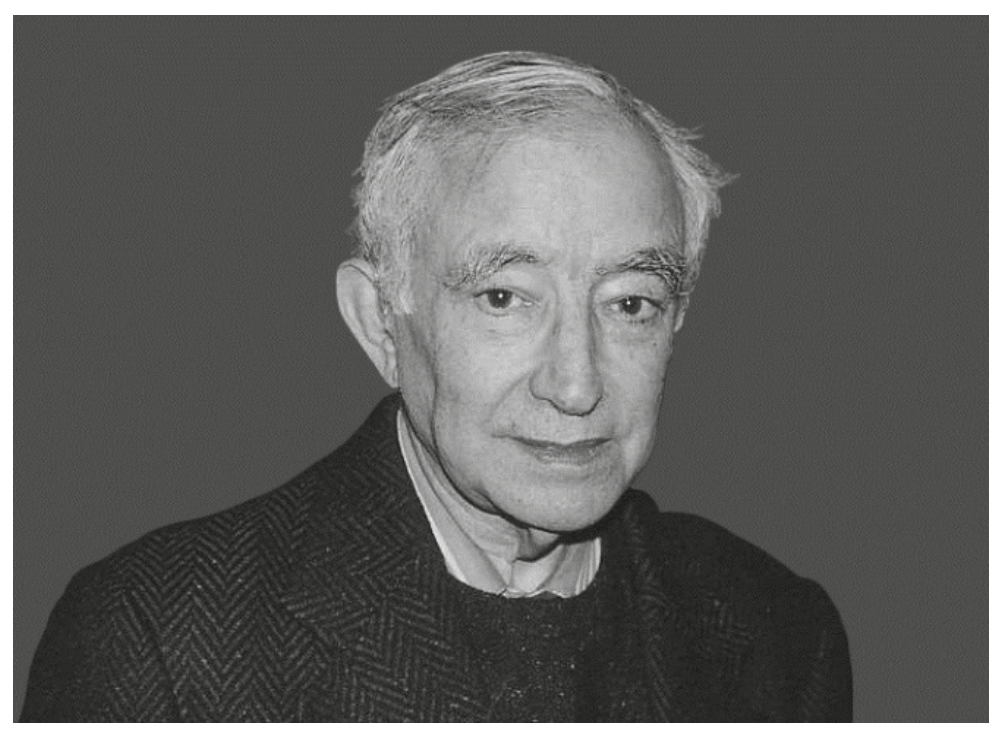

Fig. 2. Óscar Lopes, em 2 de março de 2001

\section{FONTES}

Oral

— Entrevista a Óscar Luso de Freitas Lopes, Porto, 02.03.2001 (duração total: 204,38 minutos).

\section{Escritas}

Arquivo Histórico do Ministério da Educação (referências em 1998)

AHME - Relatório do Liceu D. Manuel II de 1950/51: Relatórios dos Liceus, Relatório n. ${ }^{\circ}$ 304, Caixa n. 38. AHME - Relatório do Liceu D. Manuel II de 1951/52: Relatórios dos Liceus, Relatório n. ${ }^{\circ} 319$, Caixa n. 39. AHME - Relatório do Liceu D. Manuel II de 1952/53: Relatórios dos Liceus, Relatório n. ${ }^{\circ} 360$, Caixa n. ${ }^{\circ} 44$. AHME — Relatório do Liceu D. Manuel II de 1953/54: Relatórios dos Liceus, Relatório n. ${ }^{\circ}$ 384, Caixa n. ${ }^{\circ} 46$. AHME - Relatório do Liceu D. Manuel II de 1954/55: Relatórios dos Liceus, Relatório n. ${ }^{\circ} 419$, Caixa n. ${ }^{\circ} 49$. AHME - Relatório do Liceu D. Manuel II de 1955/56: Relatórios dos Liceus, Relatório n. ${ }^{\circ} 462$, Caixa n. ${ }^{\circ} 52$. AHME - Relatório do Liceu D. Manuel II de 1956/57: Relatórios dos Liceus, Relatório n ${ }^{\circ}$ 475, Caixa n. ${ }^{\circ} 53$. AHME - Relatório do Liceu D. Manuel II de 1957/58: Relatórios dos Liceus, Relatório n. ${ }^{\circ} 499$, Caixa n. ${ }^{\circ} 55$. AHME — Relatório do Liceu D. Manuel II de 1958/59: Relatórios dos Liceus, Relatório n. ${ }^{\circ} 520$, Caixa n. ${ }^{\circ} 57$. AHME — Relatório do Liceu D. Manuel II de 1959/60: Relatórios dos Liceus, Relatório n. ${ }^{\circ}$ 528, Caixa n. ${ }^{\circ} 58$.

${ }^{188}$ LOPES, 1946: 11. 
Arquivo da Escola Secundária Rodrigues de Freitas (referências em 1999)

AESRF — Folhas de informação do Pessoal em exercício neste Liceu em Abril de 1956 (registo biográfico), Livro s/ n. ${ }^{\circ}$.

AESRF - Folhas de informação do Pessoal em exercício (registo biográfico), 8 Livros s/ n. ${ }^{\circ}$.

AESRF - Nótulas sobre História da Literatura Portugueza (por Alexandre Rocha Peixoto Amorim e

Óscar Luzo Leça), documento disperso.

AESRF - Processo Individual do aluno Óscar Luso de Freitas Lopes, cx. s/n. ${ }^{\circ}$.

AESRF - Relatório do Liceu de 1960/61: Relatórios do Liceu, Pasta n. 2725.

AESRF - Relatório do Liceu de 1961/62: idem.

AESRF — Relatório do Liceu de 1962/63: Relatórios do Liceu desde 1959-1960, Maço n. ${ }^{\circ} 261$.

AESRF — Relatório do Liceu de 1963/64: idem.

AESRF — Relatório do Liceu de 1964/65: idem.

AESRF — Relatório do Liceu de 1967/68: idem.

Arquivo Nacional Torre do Tombo

ANTT - PIDE/DGS, Serviços Centrais, Processo 80 CI (1. ${ }^{\circ}$ volume), (NT 1156), 147 folhas.

ANTT - PIDE/DGS, Serviços Centrais, Processo 80 CI (2. ${ }^{\circ}$ volume), (NT 1156), 249 folhas.

ANTT - PIDE/DGS, Serviços Centrais, Processo PC 822/63 (NT 5514), 29 folhas.

ANTT - PIDE/DGS, Serviços Centrais, Processo PC 47/55 (NT 5110), $1^{\circ}$ volume, 477 folhas.

ANTT - PIDE/DGS, Del. Porto, PC, Processo 207/63 (NT 3189), Pasta 1, 63 folhas.

ANTT - PIDE/DGS, SC, Proc. 3239/70 SR (NT 3829), 11 folhas.

ANTT - PIDE/DGS, SC, Bol. 22794 (NT 7976), 2 folhas.

ANTT - PIDE/DGS, Cad. 10846, (UT 3445), 1 folha.

ANTT - PIDE/DGS, SC, E/GT, Proc. 6391, (UI 1532), 24 folhas.

Arquivo da Faculdade de Letras da Universidade do Porto

AFLUP - Seç̧ão de Pessoal, Processo Individual de Óscar Luso de Freitas Lopes, Pastas s/n. ${ }^{\circ}$.

Imprensa

— «O Jornal», ano V, 231 (28 de setembro de 1979).

— «O Mensageiro», 15 números (1952-1955) (jornal escolar do Liceu Nacional D. Manuel II).

\section{BIBLIOGRAFIA}

ADELL, Nicolas (2015) - Introduction: La part de la main. Des rapports entre la main et l'esprit en anthropologie. «ethnographiques.org». 31 (dez.). Disponível em <http://www.ethno-graphiques. org/Introduction-La-part-de-la-main>. [Consulta realizada em 15.09.2016].

ANDRADE, Carlos Drummond de (2015) - Antologia poética. 5. ${ }^{a}$ ed. Lisboa: Edições D. Quixote. Ed. original de 1962.

ANDRADE, Eugénio de (1996) - Duas notas sobre Óscar Lopes. In AA.VV. - Uma homenagem a Óscar Lopes. Matosinhos: Câmara Municipal de Matosinhos / Edições Afrontamento, p. 100-102.

AA.VV. (1996) - Uma homenagem a Óscar Lopes. Matosinhos: Câmara Municipal de Matosinhos / Edições Afrontamento.

BARRETO, Costa, org. (1958-1963) - Estrada larga. Antologia dos números especiais, relativos a um lustro, do Suplemento «Cultura e Arte» de «O Comércio do Porto». Porto: Porto Editora, 3 vols.

BENJAMIN, Walter (2013) - Sur le concept d'histoire. Paris: Éditions Payot et Rivages. Ed. original de 1942, manuscrito de 1940. 
BLOOM, Harold (2013) - O Canône Ocidental. 5. ${ }^{a}$ ed. Lisboa: Temas e Debates. Ed. original de 1994. BORGES, Jorge Luis (1998) - O Aleph. In Obras Completas. I. 1923-1949. Lisboa: Editorial Teorema, p. 551-651. Ed. original de 1949.

BRITO, Ana Maria et al., org. (1997) - Sentido que a vida faz. Estudos para Óscar Lopes. Porto: Campo das Letras.

CARTER, William C. (2013) - Marcel Proust: a life. 2. ${ }^{a}$ ed. New Haven: Yale University Press.

COELHO, António Borges (2007) - «Prefácio». In LOPES, Óscar - As mãos e o espírito. Porto: Campo das Letras, p. 5-9.

CORREIA, Luís Grosso (1998) — «Portugal pode ser, se nós quisermos, uma grande e próspera nação». O sistema educativo no Estado Novo. «Ler História», 35, p. 71-107.

(2016a) - Récita do Liceu. O Liceu Rodrigues de Freitas/D. Manuel II no Estado Novo. Lisboa: Edições Colibri / Agrupamento de Escolas Rodrigues de Freitas.

(2016b) - Récita do Liceu. O Liceu Rodrigues de Freitas/D. Manuel II no Estado Novo. Volume de Anexos. Porto: Edições Colibri / Agrupamento de Escolas Rodrigues de Freitas/Faculdade de Letras da Universidade do Porto, 2016b. Disponível em <http://ler.letras.up.pt/site/default. aspx?qry=id022id1491\&sum $=$ sim $>$.

(2016c) - História. In CORREIA, Luís G., org. - Do Liceu Feminino do Porto à Escola Secundária Carolina Michaëlis. Lisboa: Edições Colibri / Agrupamento de Escolas Carolina Michaëlis, p 21-93. DOSSE, François (2005) - Le pari biographique. Écrire une vie. Paris: La Découverte.

FERRAROTTI, Franco (1990) - Histoire et histoires de vie. La méthode biographique dans les sciences sociales. 2. ${ }^{\text {a }}$ ed. Paris: Méridiens Klincksieck (ed. original italiana de 1981).

FONSECA, Fernanda Irene (1996) - A busca de sentido. In AA.VV. - Uma homenagem a Óscar Lopes. Matosinhos: Câmara Municipal de Matosinhos / Edições Afrontamento, p. 108-110.

GEERTZ, Clifford (1978) - A interpretação das culturas. Rio de Janeiro: Zahar Editores.

GONÇALVES, Egito (1996) - Para o Óscar, um abraço. In AA.VV. - Uma homenagem a Óscar Lopes. Matosinhos: Câmara Municipal de Matosinhos / Edições Afrontamento, p. 98-99.

HAZARD, Paul (1971) - A crise da consciência europeia (1680-1715). 2. a ed. Lisboa: Edições Cosmos (ed. portuguesa original de 1948).

LEMOS, Mário Matos e (2012) - Oposição e eleições no Estado Novo. Lisboa: Assembleia da República.

LIMA, Augusto César Pires de (1956-1957) - O Liceu Nacional Central do Porto. «O Tripeiro». V Série, ano XI, n. ${ }^{\circ}$ (p. 272-279) e ano XII, n. ${ }^{\circ}$ 2, 4, 6, 7, 9, 11, 12 (p. 51-56, 111-114, 185-186, 210-211, 279-282, 335-336, 368-371, respetivamente).

LIMA, Isabel Pires de; MARTELO, Rosa Maria (1997) - Óscar Lopes em «A Crítica do Livro» - duas leituras. In BRITO, Ana Maria et al., org. - Sentido que a vida faz. Estudos para Óscar Lopes. Porto: Campo das Letras, p. 261-271.

LOPES, Óscar (1942) - As grandes ideias de Camões. Conferência lida pelo Professor Óscar de Freitas Lopes - em 10 de Junho de 1942. Vila Real: Associação Escolar de Camilo Castelo Branco - Liceu de Vila Real.

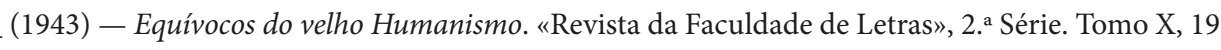
p. (separata).

(1944) - Preliminares a uma Gramática. "Gazeta de Filosofia», 3 (fev.), p. 12-23.

(1946) - Realistas e Parnasianos (1860-1890): antologia de poetas. Lisboa: Empresa Contemporânea de Edições.

(1948) - Oliveira Martins e as contradições da Geração de 70. Porto: Biblioteca Fenianos.

(1950) - Humanismo e Linguística. Coimbra: Sociedade Editora Vértice (separata dos n. ${ }^{\circ}$ 81-84 de «Vértice - Revista de Cultura e Arte»).

(1952) - Ouvindo o Sr. Dr. Óscar Lopes. «O Mensageiro», 2 (nov.), p. 7. 
(1956) - Introdução à Edição Portuguesa. In WELLS, H. G. - História Universal. Lisboa: Livros do Brasil, vol. I, p. 5-9.

(1958a) - As mãos e o espírito. Lição. Porto: Divulgação Distribuidores.

(1958b) - Lógica Gramatical e Lógica Simbólica. «Labor», 179 (nov.), p. 69-82.

(1962) - Alguns apoiados e um agradecimento. In SÁ, Mário de Vasconcelos e - Problemas do nosso ensino. Porto: ed. autor.

(1963) - Academistas; Conferências Democráticas; Literatura portuguesa; Melo, D. Francisco Manuel de; Questão Coimbrã. In SERRÃO, Joel, dir. - Dicionário de História de Portugal. Lisboa: Iniciativas Editoriais, 4 vols.

(1969a) - Ler e depois. Crítica e interpretação literária/1. Porto: Editorial Inova.

(1969b) - Modo de ler. Crítica e interpretação literária/2. Porto: Editorial Inova.

(1969c) - Discurso. In CABRAL, Júlio Sereno, coord. - A revolta de ontem nas palavras de hoje. 2. ${ }^{\mathrm{a}}$ ed. Porto: Júlio Sereno Cabral, p. 11-17.

(1970) - Para a coordenação necessária entre o Português e a Matemática. Lisboa: Fundação Calouste Gulbenkian. (col. Cadernos do Centro de Investigação Pedagógica).

(1971a) - Perspectivas de uma gramática simbólica. «VI Congresso do Ensino Liceal». Aveiro: [S. n.], 7 pp (separata).

(1971b) - Posfácio do Tradutor. In HAZARD, Paul - A crise da consciência europeia (1680-1715).

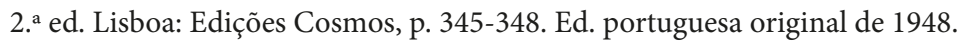

(1972) - Gramática simbólica do Português (um esboço). 2. ${ }^{\mathrm{a}}$ ed. Lisboa: Fundação Calouste Gulbenkian. Ed original de 1971.

(1973) - Convite para a URSS. Porto: Editorial Inova.

(1986a) - Palavras de auto-explicação. In Uma arte de música e outros ensaios. Porto: Oficina Musical, p. 19-25.

(1986b) - A educação do gosto literário. In Uma arte de música e outros ensaios. Porto: Oficina Musical, p. 177-213. Ed. original de 1965.

(1986c) - Uma arte de música e outros ensaios. Porto: Oficina Musical.

(1996) - Para modernização da análise gramatical. «Boletim Bibliográfico e Informativo», 7. Lisboa: Fundação Calouste Gulbenkian. Separata.

(2001) - Uma espécie de música (A poesia de Eugénio de Andrade). Porto: Campo das Letras.

LOPES, Óscar; MARTINS, Júlio (1941a) - Lições elementares de Literatura Portuguesa: em conformidade com o programa oficial do $3 .^{\circ}$ ciclo. Lisboa: Livraria Avelar Machado.

(1941b) - Manual elementar de Literatura Portuguesa: em conformidade com as disposições legais. Lisboa: Livraria Avelar Machado.

(1945) - Breve história da Literatura Portuguesa. Lisboa: Livraria Empresa Contemporânea de Edições. (1951) - Manual elementar de literatura portuguesa. $2^{\text {a }}$ ed. Lisboa: Livraria Didáctica.

(1955) - Manual elementar de literatura portuguesa. 3. ${ }^{\text {a }}$ ed. Lisboa: Livraria Didáctica.

(1970) - Manual elementar de Literatura Portuguesa. 6. ${ }^{\text {a }}$ ed. Lisboa: Livraria Didáctica Editora.

LOPES, Óscar; SARAIVA, António J. (1985) - História da Literatura Portuguesa. 13. a ed. Porto: Porto Editora. Ed. original de 1955.

LOPES, Óscar et al. (1959) - Algumas considerações ao I volume de Estrada larga. Porto: [S.n.], p. 13-15.

LOPES, Óscar et al. (1969) - Cadernos de Cultura Democrática. Porto: Ed. Autores.

LOPES, Óscar et al. (2000) - História da literatura portuguesa. Porto: Porto Editora Multimédia (recurso eletrónico: CD-ROM).

MACEDO, António (1979) - O julgamento pela PIDE do futuro Presidente de Angola. «O Jornal», ano V, 231 (28.09), p. 28-29. 
MARTINS, Júlio, sel. (1940) - O Palmeirim de Inglaterra, de Francisco de Morais. Lisboa: Livraria Avelar Machado.

NEVES, Leonor Curado (2005) - António de José Saraiva e Óscar Lopes: correspondência. 2. ${ }^{\text {a }}$ ed. Lisboa: Gradiva.

OLIVEIRA, Fátima (2005) - Sobre Óscar Lopes - o linguista. In NUNES, Leonor Curado, ed. - António José Saraiva e Óscar Lopes: correspondência. 2. ${ }^{\text {a }}$ ed. Lisboa: Gradiva Publicações, p. 31-36.

PIRES, José Cardoso (1996) - Em rumo aberto e descoberta. In AA.VV. (1996) - Uma homenagem a Óscar Lopes. Matosinhos: Câmara Municipal de Matosinhos / Edições Afrontamento, p. 135-137.

POIRIER, Jean; CLAPIER-VALLADON, Simone; RAYBAUT, Paul (1999) - Histórias de vida. Teoria e prática. 2. ${ }^{\text {a }}$ ed. Oeiras: Celta Editora.

RIBEIRO, Aquilino (2014) - Quando os lobos uivam. Lisboa: A Bela e o Monstro Edições. Ed. fac-símile do original de 1958.

RÜSEN, Jörn (2015) - Teoria da história. Uma teoria da história como ciência. Curitiba: Editora UFPR. Ed. original alemã de 2013.

SANTO, Manuela Espírito et al. (2001) - Alguém diz tu: quatro conversas com Óscar Lopes. Porto: Campo das Letras.

VISNIEC, Matéi (2015) - O negociante de inícios de romance. São Paulo: É Realizações.

WELLS, H. G. (1956) - História Universal. Lisboa: Livros do Brasil, 3 vols. 



\title{
ANTÓNIO JOSÉ SARAIVA EPISTOLÓGRAFO
}

\author{
ERNESTO RODRIGUES*
}

O tom epistolar de António José Saraiva é próximo e familiar com Óscar Lopes, agradecido com Luísa Dacosta, e, no caso de Teresa Rita Lopes, apaixonado. Exilado aos 42 anos, em urgência de amigos frente aos quais se desvela até à intimidade, as centenas de missivas entretanto conhecidas ${ }^{1}$ são um testemunho raro para décadas de um singularíssimo percurso individual, bem como da política e cultura nacionais, em que a letra difícil e só por milagre datada ilumina outros universos - desde logo, a emigração e exílio franceses - e várias personalidades, mesmo fugidias. Também pontos altos do curso político internacional não são esquecidos.

Saraiva e Óscar Lopes tratam-se por tu, dirigindo-se um ao outro sem salamaleques. Assim Óscar Lopes, após informação quase sempre argumentada, mais longo e sistemático: «Meu caro», «Meu caro António José»; despede-se afetuosamente: «Abraço-te, mais uma vez», «Um abraço do Óscar», «Salve, frater!», «Teu/Óscar», «Ex corde», «Aquele abraço». O amigo é mais uniforme: «Meu caro»; fechando: «Um abraço do Saraiva/Um abraço do António José/ Vale». Daquele vêm parabéns natalícios e aniversariais regulares, mais do que indicia uma correspondência notoriamente incompleta.

\footnotetext{
* Universidade de Lisboa/Centro de Literaturas e Culturas Lusófonas e Europeias.

${ }^{1}$ Corpus deste artigo: António José Saraiva e Óscar Lopes: Correspondência. Edição de Leonor Curado Neves, 2005; António José Saraiva e Luísa Dacosta: Correspondência. Ed. de Ernesto Rodrigues, 2011; Cartas de Amor de António José Saraiva a Teresa Rita Lopes. Ed. de Ernesto Rodrigues, 2013, todos em Lisboa: Gradiva.
} 
Desde o pós-guerra até finais de 1992, há questões práticas e administrativas a resolver sobretudo, à volta na História da Literatura Portuguesa; emerge um profícuo debate de ideias e uma biografia intelectual a reconfigurar-se.

É pena que nem toda a correspondência de Óscar Lopes pudesse ter entrado no volume organizado por Leonor Curado Neves; não vejo razão para tal impedimento. Ajudaria a datar melhor Saraiva, cujas duas cartas dos anos 40 são imprecisamente datadas, quando há uma de Óscar Lopes do Natal de 1947. Nos anos 50, tem Saraiva quatro de 1958 e duas de 1959, quando Óscar Lopes já escreve em 27-VI-1951 (referindo postal enviado antes) e 11-XI-1951: esboça-se a História da Literatura Portuguesa, com divisão de tarefas, e dá-se pasto a alguma má-língua que não vou particularizar. Dificuldade maior é que em muitas de Óscar Lopes falta o ano, que eu remeteria para a década de 50. Os anos 60, com Saraiva em Paris desde 1959, são copiosos (p. 61-281), e, desde a p. 216, dá-se o intercâmbio, com carta de Óscar Lopes de 2-IX-1969. Cuidadosa nas anotações, Leonor Neves reduz a E. L. um explicitamente criticado Eduardo Lourenço. Deveria ter entrado missiva de 12-XII-1971, em que vemos Lopes acrescentando bibliografia de responsabilidade saraiviana na História..., e um pedido instante: «manda mais original, tem paciência, e faz mais umas festinhas a este menino de paternidade dupla [...]». Faltam outras, em que esse manual continua a ser preocupação maior: de 2-I-1977, 16-I-1978, 24-VI-1990, 17-VII-1990, 27-VIII-1990, 26-IX-1990, 4-X-1990, 12-XI-1992. Não haveria cartas de Saraiva em 1990? Nas p. 466-467, Leonor Neves interroga 30-IX-1991, quando, a avaliar por carta omissa de 3 de setembro, estamos em 1990, centenário da morte de Camilo, referido nesta. Salvo o que, essa Correspondência de dois vultos maiores é uma preciosidade.

Por falar em Camilo, também este serviu a Saraiva para, entre os muitos debates político-literários suscitados, combater o Neorrealismo: «O neo-realismo é que é pequeno-burguês. O Camilo chegou muito mais ao povo que os nossos neo-realistas. E nota ainda que o Ferreira de Castro é menos pequeno-burguês que a maior parte dos neo-realistas de escola $»^{2}$.

Esse combate prossegue junto da antiga colega da Faculdade de Letras de Lisboa Luísa Dacosta, um ano depois de abandonar o Partido Comunista:

Em resumo, o neo-realismo é, hoje, a ala conservadora da nossa literatura, e contra eles apoio, por exemplo, uma Agustina Bessa-Luís, que, sob roupagens tradicionalistas, representa literariamente (e isto é o que interessa) algo de muito mais inovador. Bem sei que politicamente ela não é do contra, mas eu recuso-me a deixar-me desorientar pelo equívoco que daí resulta3.

${ }^{2}$ NEVES ed., 2005: 213; carta de 29-VII-1969.

${ }^{3}$ RODRIGUES ed., 2011: 100; 26-X-1964. 
Correspondendo-se desde 1961, sem abandonar a terceira pessoa no costumado «Minha Amiga» (só duas vezes desliza para «Querida Amiga»), a Luísa Dacosta envia «lembranças» ou «saudades», e raros abraços. $\mathrm{O}$ «muito amigo», grato, gosta de evocar os pequenos incidentes de uma vida instável de bolseiro e investigador, que no-lo aproximam nos anos de Paris, onde vive entre 1959 e 1970.

Redobra de atenção para com os escritos da interlocutora, que lhe suscitam revisões conceptuais e inspiram projetos jamais ultimados. Esta correspondência, desde o postal breve à lição e ao ensaio, regurgita de premonições e profecias. Parte, entretanto, de um incomum faro analítico, desaguando em sínteses notáveis, que outros aproveitarão.

Ao regular desânimo e solidão do quarto vazio soma-se a dispersão de quem anda sempre a correr, como confessa, em 22-VI-1964:

Mas tenho um problema grave de dispersão. Acabo por não fazer nada com profundidade. Realismo, Marxismo, Jesuitas, Inquisição, Escravatura, Alienação como é que tudo isto pode caber num saco? Sou, ao mesmo tempo, um jornalista, um ensaísta e um amador de investigação, e, ainda por cima, gosto de viver à flor da pele, tomar banhos de sol e nadar (ou fingir). E, para complicar mais as coisas, gosto de dormir 8 ou 9 horas por dia 4 .

$\mathrm{O}$ atraso nas respostas fica também a dever-se à invencível falta de tempo, que o deixa infeliz. Sobrepaira a vontade de «uma grande carta, dando-lhe novidades importantes» ${ }^{5}$ - mas é Óscar Lopes quem beneficia de alguns longos fólios, bem argumentados, ideologicamente, e disparando sobre uns tantos bonzos das nossas letras, além de ironias que reitera sobre o neorrealismo; sujeito com «vários fios de vida entre as mãos», em que "cada um deles é independente dos outros e não resolve os problemas dos outros», confessa: «Vivo em fatias sobrepostas e impermeáveis entre si» ${ }^{6}$.

Assim, a instabilidade de emprego no Centre National de Recherche Scientifique, com renovação anual do contrato, o sonho de ir para o Brasil, preocupações familiares ou a paixão devoradora pela pintora Martha Teles, que o deixa esgotado, mesmo à beira do suicídio, não explicam tudo. Encontros e desencontros com oposicionistas mais ou menos grados acrescentam à amargura e à dissipação; no intervalo, certos retratos, inclusive de intelectuais sorbonnards e manifestantes de rua, podem surpreender-nos. Leituras do dia, a reportagem de campista selvagem com os filhos em verões franceses ou visitante da União Soviética, eis exemplos pincelados com segurança e clara linguagem, que nos deliciam.

${ }^{4}$ RODRIGUES ed., 2011: 90.

${ }^{5}$ RODRIGUES ed., 2011: 24; 25-I-1962.

${ }^{6}$ RODRIGUES ed., 2011: 36; 17-V-1962. 
As dirigidas a Teresa Rita são outra loiça, e, por isso, o seco título de correspondência foi passado a cartas de amor. Sem desprezo do debate sobre teatro, poesia, etc., não há, nestas, no desejo vivo de se sentir amado, «uma fraqueza do sentimento, nem ameaça de ridículo» (escrevi no Prefácio), ainda nos vocativos mais ternos («Minha Querida», «Amor», «Amorzinho», «Amor, Querida», a novidade do próprio nome, «Teresa»), não raro passados de Queridinha a Quidinha. A assinatura quase sempre completa nas dirigidas a Luísa Dacosta resume-se, agora, a «António», «António José», «A. J.», «Teu A. J.», «Eu», "Quido», após «Beijo-te, Amor», «muitos/mil beijos», «muitos beijos e saudades», e demais achados sensíveis inesperados em quem escreve entre os quarenta e sete e os sessenta e oito anos. Vigilante, risonhamente autocrítico, acompanhamos o estudioso e veraneante, enquanto, ocupando-se do trivial e prático, de pequenos nadas, de arranjos domésticos, da saúde e da Universidade, a paixão não esmorece durante mais de duas décadas. É um conjunto inesperado, e texto sem correções (como nas outras missivas), em autor que reviu quase toda a obra, e, particularmente, a História da Cultura em Portugal, cujos volumes, após a sua morte, em 1993, Leonor Neves e eu levámos a bom termo. Concluí: «Hino ao amor de alguém muito para lá da meia-idade em assomos adolescentes (ansioso pela carta que não chega, em sonhos de futuro, a dois...), é uma prosa simultaneamente sóbria, lírica, a espaços, já irónica, com a liberdade de quem abandona gravata, mas não os trinados do coração» ${ }^{7}$.

Passando do amigo, camarada (ou ex-camarada) de Partido e coautor da História da Literatura Portuguesa Óscar Lopes, ao investigador precisado de pequenos favores bibliográficos, e sempre generoso, com Luísa Dacosta, temos, neste terceiro volume, $o$ amor em visita, um amor conversado, quase sempre repousante, sorridente, de alguém que, como Teresa Rita Lopes diz, "precisava de viver apaixonado - por ideias e por pessoas» ${ }^{8}$.

\section{BIBLIOGRAFIA}

NEVES, Leonor Curado, ed. (2005) - António José Saraiva e Óscar Lopes: Correspondência. 2a ed. Lisboa: Gradiva.

RODRIGUES, Ernesto, ed. (2011) - António José Saraiva e Luísa Dacosta: Correspondência. Lisboa: Gradiva. ed. (2013) - Cartas de Amor de António José Saraiva a Teresa Rita Lopes. Lisboa: Gradiva.

${ }^{7}$ RODRIGUES ed., 2013: 19.

${ }^{8}$ RODRIGUES ed., 2013: 6. 


\section{DESMISTIFICAÇÃO DA ORIGEM DAS GUERRAS NA «SEARA NOVA» POR VITORINO MAGALHÃES GODINHO (EM 1945)}

NUNO BESSA MOREIRA*

\section{HISTÓRIA DA HISTORIOGRAFIA, CRÍTICA TEXTUAL E CRÍTICA GENÉTICA}

Num texto que constitui uma homenagem a Maria João Reynaud seria, em nosso entender, uma falta grave não referir a sua enorme importância no seio da Cultura Portuguesa e dos Estudos Literários em particular, e ignorar, igualmente, o importante papel desempenhado na promoção do diálogo entre Crítica Textual e Crítica Genética. Trata-se de uma personalidade com manifestas preocupações no âmbito da cidadania, concebendo a vida universitária e o ensino com paixão, revelando apreensões legítimas e certeiras, expressas na sua última lição (ocorrida a 10 de março de 2016, na Faculdade de Letras do Porto), relativas ao devir da sociedade no momento em que se expressa, no qual se assiste, em seu entender, ao seguinte:

Foi há quase onze anos que li, nesta mesma sala, a minha «Lição de Agregação», pensando naturalmente que seria a última [...]. A Tecnociência - que intervém na ordem natural das coisas das coisas transformando-as em nome da eficácia e do progresso - torna-se hegemónica [...]. Na «sociedade da performance», as 
universidades regem-se por princípios orientadores em que a investigação científica se alia à transmissão acelerada de saberes úteis em nome da produtividade [... $]^{1}$.

Vitorino Magalhães Godinho manifestou, pouco antes de morrer, reservas igualmente profundas sobre o economicismo então vigente e os seus efeitos nas Ciências Humanas, particularmente na História (dado que não incluía a Literatura neste conspecto): «No nosso tempo a história é vista como de mínima ou mesmo de nenhuma importância para a formação cultural e para o exercício de inúmeras profissões [...] $»^{2}$. Este historiador será objeto desta investigação, situada no âmbito da História da Historiografia ${ }^{3}$. Este artigo não tem a veleidade de enveredar pela Micro-História, dado que esta implica questões densas e complexas e contradições que demandam e exigem um trabalho de maior fôlego. Contudo, de um modo fruste e incipiente, talvez se possa falar na configuração indiciária e impressionista de um horizonte micro-historiográfico a explorar em situações futuras ${ }^{4}$. No que nos diz respeito, consideramos fundamental a reafirmação de preceitos da historiografia neomoderna, segundo a terminologia de João Paulo Avelãs Nunes ${ }^{5}$. A procura de objetivação, na senda da superação do binómio objetividade/subjetividade é um dos desideratos a atingir. Assim, o respeito rankeano e, sobretudo, da Escola Metódica pelos documentos, mesmo quando se amplia o respetivo espectro e renovam as metodologias a aplicar, é outro dos objetivos a ter em conta. Compreendemos a necessidade de um regresso à filologia, ao qual se refere Maria João Reynaud, quando partilha das preocupações de Vítor Aguiar e Silva, citando-o e alargando, em seguida, o fulcro das suas reflexões, defendendo: "[uma Filologia] depurada e liberta dos dogmas historicistas e positivistas da interpretação do texto pelo contexto, pela biografia e pela intenção do autor [...] - lembre-se a publicação

\footnotetext{
${ }^{*}$ CITCEM - Centro de Investigação Transdisciplinar Cultura, Espaço e Memória.

${ }^{1}$ REYNAUD, 2015: 7-8.

${ }^{2}$ GODINHO, 2013: 183.

${ }^{3}$ Cf. MOREIRA, 2013.
}

${ }^{4}$ Sobre este assunto ver, entre muitos outros, LIMA FILHO, 1999: 1-14. Desde os anos 70, começou a ganhar mais força a Micro-História. Numa versão simplista, e a vários títulos errónea, configuraria uma escola e protagonizava uma reação metodológica ao peso das estruturas braudelianas, centrando-se, ao invés, numa escala mais reduzida, a de um lugar ou região. Todavia, no entender de Henrique Espada de Lima, é mais correto falar em debate quando o assunto é a Micro-História, por várias razões. Em primeiro lugar e desde logo, porque não se trata de um grupo suficientemente homogéneo para poder ser considerado uma escola. Apesar de o centro de irradiação ter sido uma revista, os «Quaderni Storici», antecedida por outra, os "Quaderni Storici delle Marche», aquele periódico era diferente deste, mau grado alguns pontos de contacto e certas continuidades, tendo passado por diversas fases, sendo os diversos colaboradores portadores de percursos e discursos assaz distintos, havendo mudanças e oscilações no seio de cada trajetória individual. Assim, Eduardo Grendi, Carlo Ginzburg, Giovanni Levi impuseram-se de modos distintos e plurais, sob o signo da diversidade. Em segundo lugar, no plano social e cultural, estes historiadores ultrapassaram o modelo ético-político de Croce, mas foram criados no interior do respetivo quadro de valores. Acresce que a alegada rejeição do estruturalismo braudeliano não foi liminar, sobretudo devido à manutenção na Micro-História de uma ideia de totalidade.

${ }^{5}$ NUNES, 2013: 53-79. 
de obras tão decisivas como Le texte et l'avant texte (1972), Essais de Critique Génetique (1979) e Leçons de l'écriture (1986) [...]» ${ }^{6}$.

Importa lançar um desafio. Em nossos entender, o diálogo da Crítica Textual e da Crítica Genética com outras áreas de saber pode e deve incluir a Historiografia (e sua história), dado que na matriz desta, incipientemente desde Ranke e sobretudo a partir da Escola Metódica francesa, a crítica de fontes marca o labor historiográfico. Todavia, neste estudo não trabalhamos diretamente qualquer manuscrito dos artigos que compõem Os mitos acerca da origem das guerras. Desconhecemos se existem. Só uma consulta ao espólio de Magalhães Godinho e a respetiva análise permitiriam dissipar dúvidas. De momento, tal é impossível, limitando-se a nossa abordagem aos impressos, publicados em duas situações distintas, primeiro na «Seara Nova» ${ }^{7}$ e depois num opúsculo ${ }^{8}$. O texto é o mesmo, em qualquer das circunstâncias, sem alterações, aditamentos, reescritas. Contudo, o segundo suporte permite um agrupamento dos artigos, possibilitando um acesso mais imediato a uma leitura sequencial e articulada ${ }^{9}$.

A Crítica Textual e a Crítica Genética podem assim ser convocadas, se entendidas num sentido amplo, incidindo em obras publicadas para além ou em vez dos manuscritos. No caso em vertente análise, o exercício de aproximação entre a historiografia e a sua história e a Crítica Textual e a Crítica Genética é legítimo e proveitoso. Torna-se fundamental, neste momento, distinguir estes dois últimos âmbitos, tendo em atenção que, grosso modo, enquanto a Crítica Genética se ocupa do processo de produção de textos, a Crítica Textual se centra no resultado dessa tramitação processual. No primeiro caso, estamos perante algo em permanente mudança e transformação; no segundo, privilegia-se a estabilidade e o caráter acabado dos textos. De modo simples e incisivo, Fernando Cabral Martins começa pelo princípio, ou seja, pela definição do conceito de texto como mote para a diferenciação das duas críticas: «A tentativa de definição do conceito de texto pode ter como uma das suas consequências a distinção das duas críticas, a textual e a genética, a partir do seu próprio objecto. Ora, para essa definição, convém começar por contrastar dois termos cognatos, texto e textura [... $»^{10}$. A questão do antagonismo ou da complementaridade entre a Crítica Genética e a Crítica Textual é difícil e intrincada, envolvendo partidários de ambas as perspetivas. A História da Historiografia pode ser cultural, em sentido amplo, promovendo o encontro entre a

\footnotetext{
${ }^{6}$ REYNAUD, 2010: VIII.

${ }^{7}$ GODINHO, 1945a; GODINHO, 1945b; GODINHO, 1945c; GODINHO, 1945d.

${ }^{8}$ GODINHO, $1945 f$.

${ }^{9}$ Conforme postula genericamente o historiador, ao arrepio da consideração direta deste caso concreto: «Les rapports complexes entre les différentes façons de faire circuler les idées et les informations ne datent pas de nos jours. A toutes les époques, les messages qui circulent emploient toutes sortes de véhicules et de langages, très souvent complémentaires. Ces véhicules et ces langages n’ont peut-être rien d'extraordinaire [...]» (Ver, entre outros, sobre uma História Cultural do Livro e da Leitura, LISBOA, 1998:1).

${ }^{10}$ MARTINS, 2010: 241.
} 
Crítica Textual, a Crítica Genética e uma certa forma de encarar a história do livro e da leitura. De qualquer modo, os livros, como o opúsculo Os mitos acerca da origem das guerras não são entidades abstratas ${ }^{11}$.

Do nosso ponto de vista, é possível conciliar uma história do livro e da leitura mais tradicional, assente em contextos sociais e políticos, ou na consideração da intencionalidade do autor (entendido este como longínquo e presente), com uma abordagem mais voltada para a materialidade do livro e/ou para a sua receção. Todavia, neste artigo, dada a sua natureza e extensão, damos prioridade quase exclusiva à primeira perspetiva. Antes disso, no imediato, analisamos outras colaborações de Magalhães Godinho na «Seara Nova».

\section{PARTICIPAÇÃO DE VITORINO MAGALHÃES GODINHO NA «SEARA NOVA»: HISTÓRIA E CIDADANIA}

A revista «Seara Nova» foi criada no dia 15 de outubro de 1921 por personalidades como Jaime Cortesão e Raul Proença, juntando-se-lhes, cerca de dois anos volvidos, António Sérgio. O periódico passou por diversas fases, analisadas por Manuel Joaquim Fitas $^{12}$. Na primeira fase, entre 1921 e 1926, a publicação afirmou maioritariamente um itinerário de cariz político, crítico e doutrinário, percorrido por algumas contradições, mas maioritariamente voltado para a necessidade de responder às dificuldades que a Primeira República vivera desde o Sidonismo, e após o fim deste, sucedendo-se governos a um ritmo apreciável, alastrando, simultaneamente, a instabilidade a todos os níveis, nomeadamente nos planos financeiro e económico. Em 1923, alguns membros do periódico e do movimento homónimo participaram num governo, assumindo, nessa circunstância, três ministérios, o da Instrução, o da Agricultura e o do Exército, entregues, respectivamente, a António Sérgio, Azevedo Gomes e Ribeiro de Carvalho. A «Seara Nova», defensora de uma cidadania democrática, teve que compactuar com cedências no exercício da política governativa, desde logo plasmadas na convivência com o Integralismo Lusitano e na defesa da necessidade de um período alegadamente curto e necessariamente transitório de Ditadura ${ }^{13}$.

A experiência governativa dos seareiros foi extremamente curta, circunscrita a alguns meses. Todavia, a instabilidade da Primeira República agravou-se ainda mais nos anos seguintes, conduzindo à solução que desagradava aos membros de «Seara Nova» e que só a tinham aceitado anteriormente mediante fortes restrições. A 28 de

\footnotetext{
${ }^{11}$ No entender de João Luís Lisboa, as questões do livro e da leitura são complexas: «Le point de départ de cette recherche repose sur la conviction que les textes n'existent pas «in abstracto», mais qu'ils ont un sens en rapport avec les différentes appropriations qui sont faites [...]» (LISBOA, 1998: 14).

${ }^{12}$ FITAS, 2010. O autor refere, no texto e no final, abundante bibliografia sobre a revista, pelo que julgamos desnecessária essa pormenorização.

${ }^{13}$ FITAS, 2010: 17.
} 
maio de 1926, o general Gomes da Costa liderou o golpe militar que abriu caminho à instauração da Ditadura Militar. Sérgio foi forçado ao exílio, em França e Espanha, regressando em 1933.

Os primeiros anos da «Seara Nova» (1921-1926) foram frutuosos, mormente na afirmação de um programa doutrinário consistente, apesar das dificuldades, dos avanços e recuos na sua concretização. Nos anos 30 e face à implementação do Estado Novo, a «Seara Nova» teve necessidade de defender os valores democráticos, entretanto postergados pela política salazarista. No número $432 \mathrm{da}$ "Seara Nova», dado à estampa a 28 de março de 1935, o jovem Magalhães Godinho encetou uma colaboração relativamente esparsa com a revista, ao nível da regularidade, e pouco expressiva no plano quantitativo. Nessa ocasião, estava-lhe destinado um espaço final do periódico, intitulado Página da Mocidade, literalmente uma página, na qual o autor aproveitou para se debruçar sobre D. Duarte, rejeitando, em nosso entender, leituras estritamente biografistas ou de teor psicológico ${ }^{14}$. Em D. Duarte, o século XV, no qual o monarca viveu, é descrito como um tempo de mudança, inclusive de viragem, assumindo a duplicidade própria de momentos complexos, entre a persistência relativa de um teocentrismo medieval e o dealbar dos Descobrimentos. Sem deixar de notar esta ambiguidade, Magalhães Godinho considera Quatrocentos um dos períodos mais notáveis da história da humanidade. $\mathrm{O}$ jovem estudioso não pormenoriza em detalhe as características do século em causa, eventualmente por considerar desnecessário fazê-lo, ou por não ser esse o fulcro da sua atenção. No entanto, é relevante a panorâmica traçada por Joaquim de Carvalho, citado por Maria Cândida Pacheco: «A consolidação política da nação portuguesa, as novas estruturas sociais, a importância crescente da burguesa, as actividades militares no Norte de África e as primeiras viagens atlânticas traçam, efectivamente, um quadro pleno de dinamismo $[\ldots] »^{15}$. O autor do artigo publicado na «Seara Nova» não explicita outras razões da escolha do seu tema, mas a importância da época é afirmada, bem como a de D. Duarte, evitando Magalhães Godinho tratá-lo enquanto herói, eximindo-se ao culto dos grandes homens (ainda que reconheça valor a esta e outras personalidades). No entanto, é lícito colocar a hipótese segundo a qual o trabalho sobre o Eloquente derivará do interesse deste pela filosofia (gosto que também Godinho cultiva), conjugado com a pertença à Ínclita geração, iniciada pelo seu pai D. João I, que protagonizou uma Revolução, preparada ao longo de décadas: «Foi uma revolução efectuada e consolidada ao longo de décadas e teve a primeira geração da Dinastia de Avis como principal protagonista e impulsionadora $[\ldots]_{\aleph^{16}}$. Magalhães Godinho não se dedicou especificamente à educação recebida pelos príncipes e à sua importância política, moral e cultural para a afirmação da dinastia

${ }^{14}$ GODINHO, 1935.

${ }^{15}$ PACHECO, 1991: 425.

${ }^{16}$ GAMA, 2002: 380-381. Uma excelente e muito completa biografia de D. Duarte foi realizada por DUARTE, 2005. 
referida e da língua e cultura portuguesa. No entanto, conheceria e valorizaria estas dimensões, em nosso entender pressupostas na sua argumentação, funcionando estas condições como um substrato implícito das afirmações segundo as quais, no tempo de D. Duarte, «submergia-se a escolástica, estéril como toda a filosofia que se apoia na religião e não na ciência e iniciava-se o experimentalismo» ${ }^{17}$. O monarca terá sido um dos representantes desta contradição, deixando-se cristalizar na ortodoxia católica, que seria nele dominante, na opinião de Magalhães Godinho, para quem o rei não terá entendido ou podido compreender a marcha para o paganismo, que D. Duarte terá encetado, sem ser com ela conscientemente solidário e consequente: «D. Duarte, se acaso pudesse admirar paganismo [...] veria que o seu mérito foi precisamente fazer ascender o homem a este terceiro estado. O seu espírito estava, porém, apertado nas malhas da ortodoxia católica» ${ }^{18}$.

Magalhães Godinho não apresenta uma análise circunstanciada sobre o Leal Conselheiro ou A arte de bem cavalgar toda a sela, eximindo-se a pronunciar-se sobre a natureza de ambos os trabalhos, sobretudo do primeiro que, mesmo nos dias de hoje, gera relativa controvérsia, oscilando os estudiosos entre a sua consideração como um testemunho, portador de uma moral filosofia de cariz cristão, e um tratado de educação de Príncipes ${ }^{19}$. Magalhães Godinho não se interessa por tornar patente eventual complementaridade entre a Virtuosa Benfeitoria, de D. Pedro, e o Leal Conselheiro, de D. Duarte, parecendo desconhecer um trabalho deste último, ao qual tem vindo a ser recentemente prestada maior atenção, o Livro de Conselhos de El Rei D. Duarte ${ }^{20}$. Estes exemplos demonstram que o principal fito do autor do artigo D. Duarte não é estabelecer uma profunda exegese e crítica documental, mas antes salientar que o monarca uniu reflexão e ação.

Um dos três regimentos do Leal Conselheiro, conjunto de textos dispersos e sem homogeneidade aparente, dedica-se às cidades. As Cidades na Europa medieval. Condições gerais da sua evolução constituíram a temática eleita por Magalhães Godinho no ano de 1938 para figurar num artigo dado à estampa pela «Seara Nova», nos dias 11 e 18 de junho ${ }^{21}$. Neste estudo, o autor exibe um claro cosmopolitismo, que também era apanágio de António Sérgio, recusando-se a enveredar por nacionalismos redutores, afirmando desde logo que «é em definitivo no tecer das relações mercantis internacionais que reside a razão profunda do aparecimento do urbanismo» ${ }^{22}$.

\footnotetext{
${ }^{17}$ GODINHO, 1935.

${ }^{18}$ GODINHO, 1935.

${ }^{19}$ Em nosso entender, Maria Cândida Pacheco é defensora da primeira linha de argumentação, enquanto José Gama parece pugnar pela segunda, ainda que estas divisões sejam largamente artificiais, e parcialmente arbitrárias, detendo, sobretudo, valor heurístico e instrumental

${ }^{20}$ MUNIZ, [s.d.]: 573-583.

${ }^{21}$ GODINHO, 1938a; GODINHO, 1938 b.

${ }^{22}$ GODINHO, 1938a: 6.
} 
No entender de Magalhães Godinho, na esteira de Les Cités Mediévales [...] de Henri Pirenne, obra publicada em 1927, as Invasões dos séculos IV e V não alteraram profundamente a estrutura económica e social de Roma. No século VII deu-se a invasão dos povos islamitas, que do ponto de vista do autor de As Cidades $\mathrm{Na}$ Europa Medieval. Condições Gerais da sua evolução interferiu mais com a textura dos povos germano-bárbaros e implicou o controlo da Península Hispânica, a passagem pela Aquitânia e a imposição de razia no Sul da Gália, apesar da reação dos Francos, que repeliram essa atuação destrutiva. Todavia, nos séculos VIII e IX os Muçulmanos atacaram as costas gaulesa e italiana, pilhando Nice, Trento e Génova. Opunham-se duas civilizações, a bizantina e a muçulmana em face da sociedade agrícola-militar. A frota grega conseguiu deter o domínio do Egeu e vias marítimas que estabeleciam a ligação de Constantinopla ao Sul de Itália e o Atlântico, controlando parte da Península Itálica. Nos territórios bizantinos o comércio desenvolveu-se, alicerçado nas transações com o mundo grego. Sobretudo a partir do século XI, no norte de Itália e no Báltico, a economia desenvolveu-se nos seus vários setores de atividade, da agricultura ao comércio de longo curso (sobretudo este). Formaram-se guildas, protegidas pelos senhores feudais, mas organizadas à margem da feudalidade. Foram edificados armazéns e mercados junto aos Castelos, dado que estes dominavam as vias de comunicação. As associações de mercadores eram de direito público e de livres entre iguais. A autonomia das cidades acarretou um novo Direito fiscal e penal, assim como um novo regime de pessoas e bens. $\mathrm{O}$ florescimento económico (sobretudo da Indústria e do Comércio) e a situação política (muitas vezes ligada à Burguesia) conduziam a uma mais larga independência. Na génese das cidades encontravam-se valores como a liberdade e a igualdade, a base das democracias. Assim se compreende a escolha deste tema em 1939, num tempo de estabilização do Estado Novo, que urgia combater pelo recurso ao rigor histórico.

Na segunda parte de As Cidades na Europa Medieval, Godinho começa por referir a situação em Itália nos séculos X e XI, associando o nascimento de relações mercantis ao desenvolvimento dos transportes, da atividade industrial, sem a qual o despertar do capitalismo comercial verificado não teria sido possível. Contudo, para Godinho, o Capitalismo Comercial não supõe o fabril ${ }^{23}$. No século XIV assistiu-se a um desequilíbrio provocado pela economia monetária. A indústria não enveredou, no seu conjunto, pelo Capitalismo. O Comércio afirmou-se como fator decisivo. Com a procura de novos mercados, as transações avolumaram-se e a falta de dinheiro dos Senhores tornou-os dependentes da Burguesia, minando os alicerces da feudalidade. Com a Guerra dos Cem Anos gerou-se forte perturbação nas manufaturas e na vida mercantil, mormente no sector dos lanifícios. No Comércio, as classes médias fortes

${ }^{23}$ GODINHO, 1938b: 32 e ss. 
impuseram-se num quadro complexo, assente em rígida estrutura corporativa, no exclusivismo de umas cidades face a outras.

No entanto, convém sublinhar a íntima relação entre o desenvolvimento e crescimento mercantil e a formação das Cidades ao longo da Idade Média. Em 1938, quando publica As Cidades na Europa Medieval [...] Magalhães Godinho tem consciência dos Imperialismos que desde o século XIX se acentuavam na Europa, tendo condicionado a existência de um primeiro conflito à escala mundial. De forma diferente, a exacerbação do Capitalismo de feição industrial, que se acentuava desde a disseminação oitocentista da Revolução com o mesmo nome, voltava a fazer-se sentir no final da década de 20 de Novecentos, exacerbando a concorrência de modo preocupante e sendo colocado ao serviço de Estados Totalitários, que retoricamente o haviam reprovado, como estratégia de chegada ao poder dos respetivos líderes, que depois se aliaram aos grandes interesses lucrativistas. Magalhães Godinho não o diz, mas o desenvolvimento mercantil que permitira o florescimento das Cidades, mormente na Baixa Idade Média, ajudando a travar a feudalidade, era totalmente diferente do Capitalismo no final da década de 30. Todavia, o autor considerava necessário conhecer o primeiro para entender o segundo.

Em 1939, António Sérgio deixou a «Seara Nova», alegadamente por divergências quanto à forma de administração e gestão financeira de Câmara Reis, aliadas a razões do foro metodológico e ideológico. No entanto, estas parecem discutíveis, dada a proximidade entre ambos a esse nível. Todavia, podem acrescentar-se como motivos de desentendimento entre os intelectuais as lutas pelo poder e pelo prestígio no seio da publicação. Tempos conturbados, portanto. Acresce que, parcialmente em virtude do exposto, a «Seara Nova» viveu momentos complicados, também devido ao início da Segunda Guerra Mundial no mesmo ano da saída de Sérgio. Por outro lado, a censura continuava a exercer-se e, no ano de 1940, o fervor nacionalista do Estado Novo recrudesceu, através da Comemoração dos Centenários da Independência e da Restauração. As pressões externas eram grandes e, internamente, no periódico assistia-se à crescente relevância, desde os anos 30, aumentada na primeira metade da década seguinte, do acolhimento concedido às doutrinas neorrealistas.

Vitorino Magalhães Godinho nascera em Lisboa no ano de 1918. Durante o seu curso tinha aprendido mais, como o próprio reconheceu, fora da Faculdade de Letras de Lisboa, em tertúlias e conversas, do que no ensino formal. Em 1940, concluiu a sua dissertação de licenciatura, intitulada Razão e História: Introdução a um problema ${ }^{24}$. Logo nesse estudo inaugural se nota a vontade (concretizada) de romper com uma forma tradicional de conceber a Filosofia, relacionada com o enaltecimento da Saudade ou da procura de uma identidade nacional. Pelo contrário, o autor, na linha de Francisco Viera de Almeida, atende ao caráter racional, problemático e problematizante de

${ }^{24}$ GODINHO, 1940. 
todo o conhecimento, passível de ser historicamente situado. Godinho estava atento às novidades trazidas pelo Círculo de Viena, não o tratando em bloco, como se fosse homogéneo, criticando uma certa tendência para um a-historicisimo. Na sequência deste trabalho de licenciatura e, eventualmente por causa dele, Magalhães Godinho foi convidado para pertencer ao corpo docente da Faculdade de Lisboa, lecionando, a partir de 1941 e até 1943, diversas cadeiras, correspondentes a cronologias e épocas tão diferentes como as Antiguidades Pré-Clássicas, Clássicas ou a História dos Descobrimentos e da Expansão. O ensino que colocava em prática era diferente daquele que lhe fora ministrado e que era apanágio de alguns dos seus colegas, que tinham sido seus professores, contrapondo a análise de documentos com os alunos e a problematização das temáticas à exposição sebenteira dos assuntos versados ${ }^{25}$. Por outro lado, Magalhães Godinho ensinava a pensar, e a desenvolver a capacidade de crítica, não apenas das fontes, mas através e para além delas. Nisto se afastava liminarmente de uma história estritamente política, biográfica, cronológica, em nome da entrada em cena da história económica e social e da história da cultura, colocando-se, através da sua profissão, encarada como ato de cidadania, contra a historiografia e a política do Estado Novo. Na sequência deste quadro, Magalhães Godinho rejeitou a fiscalização das suas aulas (a menos que as dos seus colegas fossem alvo de processo análogo) e não viu renovado o seu contrato. Os alunos redigiram um abaixo-assinado em seu apoio, mas não adiantou. O historiador teve que continuar a trabalhar noutro contexto, dando palestras e conferências no Ateneu Comercial de Lisboa, e editando livros, de forma a prover o seu sustento e o da família. Ossos do ofício, literalmente.

No referido ano de 1943, no que respeita à Segunda Guerra Mundial, os Aliados tinham logrado alguns avanços na Rússia e no Pacífico, mas a situação era profundamente instável em termos gerais. No seio da «Seara Nova», sobretudo a partir da primeira metade anos 40, favorecida pela saída de António Sérgio em 1939, começou a afirmar-se como dominante (já existia desde os anos 30 e nunca vira a sua expressão impedida nas páginas da Revista) uma corrente neorrealista, mormente nos estudos literários, que contrapunha uma intervenção político-social militante nos problemas de Portugal, da Europa e do Mundo (em tempos de conflito bélico) ao idealismo sergiano (que não desapareceu) e depois a uma corrente metafísica (minoritária), liderada por Sant'Ana Dionísio. Ainda em 1943, nas páginas do periódico, Mário Dionísio (neorrealista) e João Pedro de Andrade (presencista) envolveram-se numa polémica ${ }^{26}$. O primeiro acusou o segundo de defender a arte pela arte, enquanto este replicava que sempre procurara um equilíbrio entre forma e conteúdo, criticando Dionísio por alegadamente subjugar aquela a esta e aos imperativos da realidade social.

\footnotetext{
${ }^{25}$ SOUSA, 2012.

${ }^{26}$ FITAS, 2010: 45 e ss.
} 
Em 1945 terminou a Guerra, após a chegada ao fim dos conflitos no Pacífico. $\mathrm{O}$ armistício deu-se a 14 de agosto e a rendição do Japão a 2 de setembro. No entanto, o clima de incerteza era grande e os artigos da «Seara Nova», Os Mitos acerca da Origem da Guerra (depois coligidos em livro), refletiram-no. Foram publicados no periódico a 2 e 16 de junho, 14 de julho e 25 de agosto de 1945. Apenas o último sucedeu o armistício e todos são anteriores à rendição do Japão. Todavia, o autor não se fica por aqui. Acrescente-se que menos de um mês depois do último artigo sobre Os mitos acerca da origem das guerras, e duas semanas volvidas sobre a capitulação definitiva do Japão, Vitorino Magalhães Godinho dá à estampa, na «Seara Nova», um texto breve, onde critica, de forma clara, A reorganização de Estudos de Direito, ocorrida recentemente em Portugal, na qual os exames para entrada nesse curso deixam de contemplar a História, em detrimento do latim ${ }^{27}$.

O historiador desmonta os argumentos em favor da estrutura lógica da língua clássica ou da sua importância para o Direito Romano. Considera, em contrapartida, inviável compreender disciplinas do Curriculum, como História do Direito Romano e História do Direito Português, sem perceber a relatividade das instituições que a História pode evidenciar. Em Os mitos acerca da origem das guerras ${ }^{28}$ e no texto intitulado Reorganização dos Estudos de Direito a intervenção cidadã do autor na atualidade torna-se explícita. Note-se que o ensaísmo de Sérgio, admirado por Godinho, conjuga um racionalismo idealista com a reflexão problematizadora acerca de questões do quotidiano, ou ancoradas numa natureza e diacronia históricas, desmontando teorias e não fugindo à polémica. Godinho também não foge, nos dois trabalhos de 1945 , onde uma posição realista ganha corpo quanto ao Pacifismo (defendendo-o), que será possível implementar depois da Guerra e, eventualmente, no que concerne à defesa do conhecimento histórico aplicado ao Direito. Aliás nos Mitos, Magalhães Godinho considera que a explicação da guerra deve recorrer a condições económico-sociais, mas também jurídico-crematísticas, entre outras.

Acresce que, numa fase bem diferente da «Seara Nova», em 1971, Vitorino Magalhães Godinho relembra António Sérgio, recentemente falecido (em 1969), elogia-o e reforça o modo como entende o seu idealismo:

A grande lição sergiana reside na proposta, conforme a designou um seu companheiro, de evangelho de acção idealista no mundo real (idealista, porque norteada por um ideal, resultante de condições históricas, e não porque se suponha que são os ideais o factor determinante do devir das sociedades). Busquemos o

${ }^{27}$ GODINHO, 1945e.

${ }^{28}$ GODINHO, $1945 f$. 
impossivel [...], mas saibamos cartografar os caminhos que lá conduzem pela orografia das possibilidades $[\ldots]^{29}$.

\section{OS MITOS ACERCA DA ORIGEM DAS GUERRAS: A CRISE DA ATUALIDADE OU A FIRMEZA DO HISTORIADOR-CIDADÃO}

Os quatro artigos que compõem o opúsculo em vertente análise possuem extensões e implicações diversas, mas são eivados de um propósito comum: desmistificar visões essencialistas e/ou nacionalistas acerca das origens das guerras, propaladas pela Imprensa e pelos poderes oficiais, contra os quais o historiador se colocava, opondo-se-lhes através da apresentação de argumentos baseados em provas, evitando uma historiografia permeável aos enviesamentos da militância ou do tradicionalismo. Em 2 de junho de 1945 foi publicado o primeiro estudo, dedicado à desmontagem do Mito do instinto bélico:

A História, tal como geralmente se estuda, consiste num ininterrupto desenrolar de conflitos e guerras. Da frequência do fenómeno bélico resvala-se fàcilmente [sic] para a ideia de que no homem existe o instinto guerreiro, e que este instinto é que explica o deflagrar das lutas armadas. [...]. Explicar as guerras pelo instinto guerreiro enforma de gravíssimo erro: é que nada explica ${ }^{30}$.

O conjunto de informações veiculadas neste excerto revela-se, em nosso entender, extremamente importante a vários níveis. Em primeiro lugar, porque demonstra a preocupação de Magalhães Godinho pelo estudo da história, ou seja, pela historiografia, recusando a história militar tradicional, não a designando deste modo, por centrar-se em exclusivo nos conflitos e guerras. Em segundo lugar, o historiador coloca em causa uma perspetiva determinista, baseada numa causalidade simplista e redutora, que elege um único fator para descrever certa realidade, esquecendo a necessidade de rastrear e ligar diversas causas, que resultem num complexo promotor do estabelecimento de relações entre elas. Em terceiro lugar, o instinto é usado por muitos não só para justificar a existência das guerras, mas, também, a respetiva inevitabilidade, revelando assim um posicionamento ideológico legítimo, mas criticável nos seus fundamentos, dado que inibe a necessidade e possibilidade de explicação. Em quarto lugar, a historiografia militar tradicional permitiria um relativismo excessivo, ignorando que as guerras ocorrem em espaços e tempos específicos, comportando condições militares, político-diplomáticas, mas também sociais, económicas, que se relacionam entre si: «a guerra constitui um

\footnotetext{
${ }^{29}$ GODINHO, 1971a. Republicado em GODINHO, 1971b: 264-270, maxime 269-270.

${ }^{30}$ GODINHO, 1945a: 7.
} 
compromisso colectivo, não individual, premeditado e organizado e não ocasional e fragmentário $[\ldots] »^{31}$.

Magalhães Godinho convoca genericamente a história da humanidade, desde os seus primórdios, para recusar duas ideias: a do homem naturalmente mau e a do homem naturalmente bom. Sem referir explicitamente defensores destas perspetivas, a primeira foi propugnada, entre outros, por Hobbes no século XVII e a segunda por Rousseau, na centúria seguinte. Para sair deste impasse, Magalhães Godinho critica fortemente, uma vez mais, o instinto bélico como explicação da guerra, propondo, em alternativa, uma educação para a paz:

Conclui-se, por conseguinte, que a humanidade não deve ter vivido belicamente [sic] desde que nasceu, que a guerra não se explica pela tendência inata da agressão [...] o fundamental [...] reside em efectuar uma educação para a paz e eliminar uma filosofia de incitamento à guerra [... $]^{32}$.

A desmistificação do instinto como causa, e ainda por cima única, atinge, do nosso ponto de vista, o seu ponto culminante mesmo no final do artigo de Godinho, onde clarifica a sua noção de causalidade como algo multiforme e complexo, criticando a falta de pesquisa: «O mito de que as guerras nascem do instinto bélico [sic] dispensa o historiador de perscrutar as causas das guerras: no fundo, tôdas [sic] resultariam da mesma e única «causa», seriam consequências inescapáveis de um factor constante $[\ldots] »^{33}$.

Na sequência da desmontagem do instinto bélico na origem das guerras, Vitorino Magalhães Godinho publicou novo artigo com intuito desmistificador, dando-o à estampa duas semanas depois do primeiro, mais precisamente a 16 de junho de 1945, visando nesta ocasião $O$ mito dos povos pacíficos e dos povos guerreiros. Este mito é indissociável do primeiro, surgindo na sequência dele e dependente da respectiva concretização, uma vez que, se o instinto bélico configurava uma condição primacial inerente à natureza humana, então todos os povos seriam potencialmente guerreiros. No entanto, paradoxalmente, alguns compêndios compulsados e analisados por Magalhães Godinho desfazem este raciocínio lógico para albergarem nas suas páginas uma reflexão curiosa, segundo a qual haveria povos que naturalmente teriam uma propensão mais guerreira do que outros, sendo estes últimos mais pacíficos. O autor da obra em análise critica esta dicotomia, de base maniqueísta, atingindo um simplismo difícil de digerir. Impõe-se, então, um primeiro exemplo deste tipo de visão a desmistificar.

${ }^{31}$ GODINHO, 1945a: 11.

${ }^{32}$ GODINHO, 1945a: 11.

${ }^{33}$ GODINHO, 1945a: 13-14. 
Na Antiguidade Pré-Clássica, os Egípcios engrossariam as fileiras dos guerreiros, enquanto os Assírios pertenceriam ao grupo dos pacíficos. Magalhães Godinho rejeita esta ideia, afirmando que ambos passaram, ao longo da sua história, em períodos e momentos diferentes, por situações de aceso conflito, resolvido pela força das armas. A inclinação retórica para a exemplificação como elemento de prova parece confirmar a vocação pedagógica do autor de Os mitos acerca da origem das guerras, plasmando, nos seus escritos, a sua prática de ensino universitário, iniciada em 1941, e entretanto interrompida, mas presente, desde logo no domínio de uma matéria que tinha feito parte do currículo de uma das disciplinas que leccionara, daí também a atenção irónica e profundamente crítica dedicada aos compêndios e a pronta diferenciação face às Histórias Gerais, que não repetiriam de modo tão claro a chave dicotómica exposta e condenada. Eis o perfil de professor investigador: «Se passarmos, contudo, dos compêndios que é costume acreditarmos serem de história, para as grandes histórias, essas certezas tão confortantes [da existência de povos naturalmente guerreiros e pacíficos] evaporam-se e as ideias enovelam-se]. [...] Se compararmos a história egípcia com a história assíria, ficamos perplexos para decidir qual dos dois países é mais imperialista: ambos foram expansionistas e militaristas, em épocas diferentes [...]» ${ }^{34}$. Fica assim demonstrado o didatismo de base científica patente na catividade intelectual de Magalhães Godinho, que não abdica, na sua escrita, do recurso a instrumentos como a comparação e a síntese alicerçada em análises prévias, deslocando o eixo explicativo e argumentativo das justificações de natureza biológica para as de cariz económico e geográfico. Sublinhe-se, desde logo, a importância da geografia e da história económica como elementos a ter em conta nas temáticas do foro militar, retirando-as Magalhães Godinho do âmbito da história política e diplomática tradicionais. Para além de professor investigador (mesmo quando privado do exercício da primeira catividade, da qual a escrita historiográfica acolhe inquestionáveis e irreprimíveis ecos), o autor de Os mitos acerca da origem das guerras cumpre uma divulgação de conhecimentos assente numa cidadania cativa.

Assim se compreende o salto para o mundo moderno logo após a referência a assírios e egípcios. O preconceito é identificado de modo imediato e desmontado sem tibiezas e, mais uma vez, com recurso à ironia: «Para o mundo moderno estaria achado o povo bélico: os germanos. Os outros povos teriam sido sempre ordeiros. Diz algures Marc Bloch que a memória dos homens é curta e a sua capacidade de ilusão infinita. Povos ordeiros no mundo moderno?» ${ }^{35}$. Esta referência a Marc Bloch possui, em nosso entender, enorme relevância a vários níveis. Por um lado, revela sintonia no plano científico entre este nome pioneiro dos Annales e o historiador português que o

${ }^{34}$ GODINHO, 1945a: 17-20.

${ }^{35}$ GODINHO, 1945f: 20. 
cita. Por outro lado, o cultor de Clio francês levara tão longe a sua intervenção cidadã que foi preso e torturado pela Gestapo, pagando coma vida essa coragem. Foi fuzilado a 16 de junho de 1944. Precisamente um ano depois é dado à estampa o artigo de Godinho em análise. Coincidência? No entanto, o cultor de Clio português recusa-se, num momento particularmente sensível, no ano em que terminou a Segunda Guerra Mundial, a erigir a Alemanha como culpada e bode expiatório de todos os males, os recentes e os da história mais antiga. Para consubstanciar esta ideia, o historiador serve-se da diacronia e cita vários exemplos que comprovam a sua tese, segundo a qual não há povos naturalmente pacíficos, devendo sempre ser inseridos nas respectivas culturas e histórias. Assim, os Europeus fornecem bastantes e eloquentes provas que dão força à posição do historiador português. Franceses e Ingleses enfrentaram-se em duas Guerras dos Cem Anos. No início da Idade Moderna, os Franceses entraram em conflito na Itália e com a Espanha-Áustria, acontecendo o mesmo aos ingleses na Irlanda. Por seu turno, os Espanhóis conquistaram México e Peru e os Portugueses realizaram expansão militar em Marrocos. Os exemplos aduzidos sucedem-se. Na segunda metade de Quinhentos deu-se a luta naval entre Espanha e Inglaterra. Na Guerra dos 30 anos, a mesma Espanha (em conjunto com a Áustria, Suécia e França) enfrentou a Alemanha. No século XVII, a Inglaterra voltou a agredir a Irlanda e, nas últimas décadas de seiscentos, o poder absoluto de Luís XIV fez-se sentir.

Após a apresentação de factos que funcionam como provas e sustentam a sua argumentação, Magalhães Godinho volta a recorrer a uma síntese, ainda longe do final do artigo intitulado $O$ mito dos povos pacíficos e dos povos guerreiros: «Que concluir de todo este arrazoado? Todos os povos europeus fizeram guerras sobre guerras e não para defesa da independência, antes por agressão imperialista. [...]. E os modernos assírios? Como seria simples explicar toda a história medieval e moderna pelo antagonismo entre a belicosidade teutónica e a atitude pacífica dos não teutónicos! [... $»^{36}$. Contra ideias feitas e lugares-comuns, num tom polémico, prenhe de interrogações e uma exclamação irónica, ou um pendor por vezes oralizante, que reforça a urgência das circunstâncias (patente, por exemplo, na expressão massa do sangue), Magalhães Godinho percebe a delicadeza do momento histórico que se está a viver enquanto escreve e publica os seus artigos, não se eximindo a repudiar a violência da Alemanha, mas invoca a imparcialidade para condenar generalizações abusivas e condenações sumárias que não tenham, alegadamente, base de sustentação. O historiador defende que os Germanos não queriam destruir a civilização e unidade romanas, tendo sido empurrados para a România pelos Hunos, aí figurando como federados e não enquanto invasores. $\mathrm{O}$ recurso às armas deu-se por falta de alimento ou disputa dos solos. No decurso da Idade Moderna não houve mais guerras na Alemanha do que na França, tendo os

${ }^{36}$ GODINHO, 1945f: 24. 
Estados Alemães sofrido até 1865 nas mãos de Franceses, Ingleses, Espanhóis. As guerras empreendidas entre 1865 e 1870 tiveram como motivo e corolário a independência da Alemanha, criando então condições para a emergência de um novo imperialismo, em parte ditado pela estrutura económica e social da Europa de Oitocentos, mas também pela existência e posterior concorrência dos outros imperialismos.

Magalhães Godinho volta a enfatizar motivos económicos para explicar conflitos militares, acrescentando fundamentos de ordem jurídica, e sublinhando a importância dos imperialismos:

Ora, o que é fundamentalíssimo sublinhar é que, dados os fundamentos jurídico-crematísticos da sociedade europeia, a necessidade de expansão para obter mercados de fornecimento de matérias-primas para a indústria nacional e mercados de escoamento para os artigos manufacturados por essa indústria era inevitável, qualquer que fosse o povo em causa e a sua psicologia ${ }^{37}$.

No momento em que Godinho escreve e publica os artigos na «Seara Nova», coligindo em livro o material que lhes corresponde e os reproduz, a Segunda Guerra Mundial caminha para o seu final, tendo inclusive terminado já na Europa. O historiador chama a atenção para a tese racista subjacente à aceitação da ideia da existência de povos naturalmente guerreiros ou pacíficos e acrescenta que não existe na Europa nenhum país que possa reivindicar virgindade étnica ou que não seja fruto e alvo de misturas.

No artigo/capítulo Os Mitos acerca da ambição dos grandes homens, o autor aborda a temática incisa no título, fazendo preceder a sua consideração da rejeição, uma vez mais, do mito dos povos maléficos. Nessa medida, refere-se diretamente à atualidade vivida na fase final da guerra, percorrida por grande indefinição, sem recurso a descrições pormenorizadas ou dominantes de factos. Todavia, reage criticamente contra a incapacidade dos povos vencedores, que apoia, no caso os aliados, para distinguirem e tratarem com respeito democrático a grande maioria da população alemã, isolando e punindo a elite dirigente, responsável a vários níveis pelo conflito bélico. Godinho denuncia, igualmente, que no substrato do discurso daqueles que se preparam para ganhar pode estar a legitimação do imperialismo contra o qual lutaram, que criticavam nos alemães, assenhoreando-se dele e tornando-o o seu, aparentemente através de uma retórica moralista que oculta, por detrás da punição dos pecadores, uma vontade de impedir que a Alemanha se regenere e possa concorrer no Comércio e na Indústria com os aliados. Assim, a propaganda em curso da desmilitarização por razões ético-morais possui outros objetivos, político-económicos e sociais, contra os quais Magalhães Godinho frontalmente se coloca.

${ }^{37}$ GODINHO, 1945f: 26. 
Num segundo momento de O Mito da Ambição dos grandes Homens, o historiador critica uma historiografia que propicie o desenvolvimento do culto dos chefes (objeção que reiterará em 1946, na obra A Crise da História e suas novas directrizes):

No pólo oposto à ideia de culpabilidade colectiva de todo um povo, a cuja belicosidade seriam de imputar todos os conflitos, encontramos a explicação das guerras pela vontade tão só de um dirigente. Pois não ouvimos tantas vezes atribuir a Hitler a responsabilidade integral da política externa alemã e da Guerra de 1939-1945? [... $]^{38}$.

Vitorino Magalhães Godinho não nega a existência de ambição dos grandes homens. Todavia, retira-lhes o peso e a importância que detinham na historiografia tradicional, que os encarava como fator central na explicação dos conflitos bélicos. Pelo contrário, o autor de Os mitos acerca da origem das guerras contrapõe a essa ambição a existência de condições sociais e jurídicas que favorecem a irrupção das personalidades referidas, conduzindo a Guerras (nem sempre ligadas a figuras eminentes), sendo lícito perguntar as razões pelas quais as populações se deixam dominar:

eliminar pura e simplesmente o actor central do drama é quimérico e não contribui para melhor explicar os acontecimentos. Em todo o caso, o problema pôsto nestes têrmos está mal pôsto. Antes de mais deve notar-se que o essencial da questão está no seguinte: porque é obedecido quem manda? Quais as condições que criam nos homens a disposição a acatar a vontade de um deles $[\ldots]^{39}$.

Tanto no caso das Monarquias absolutas como no das tiranias, o poder dos grandes homens nunca é, no entender de Magalhães Godinho, totalmente ilimitado. O historiador compara César com Hitler considerando que em ambos os casos se cumpre a seguinte circunstância: «Hitler e Mussolini surgiram em momentos de crise comparável ao de César [...]» ${ }^{40}$.

No quarto artigo/capítulo da obra em análise, intitulado O Mito do Espírito de Cruzada, Magalhães Godinho começa por referir que os dominadores procuram geralmente justificar as agressões, cabendo aos dominados explicarem-se em sentido contrário, apresentando argumentos que sustentem a sua defesa. Entre 1097 e 1200 a Europa viveu tempos de Reconquista e Expansão, normalmente associados ao Espírito de Cruzada e a questões morais e religiosas. No entanto, no entender do historiador, ainda que este aspeto tenha sido muitas vezes retoricamente apresentado como o

\footnotetext{
${ }^{38}$ GODINHO, 1945f: 34.

${ }^{39}$ GODINHO, 1945f: 36-40.

${ }^{40}$ GODINHO, 1945f: 41-42.
} 
principal motivo das Guerras referidas contra o Islão, podendo até ter correspondido ao sentimento de alguns combatentes, certo é que houve razões económico-sociais que se sobrepuseram. Em meados do século XI, as invasões de Sarracenos, Húngaros e Normandos tinham já terminado, abrindo caminho à estabilidade, acarretando uma explosão demográfica e a necessidade de cultivo das terras incultas. Em seguida, Magalhães Godinho expõe as causas da expansão europeia.

Sempre com o intuito de evitar generalizações simplistas ou simplificações redutoras, $\mathrm{o}$ autor refere-se às Guerras entre Atenas e Esparta, supostamente ocorridas apenas pelo facto de aquela defender a democracia e esta a aristocracia. Por outro lado, o argumento da necessidade de liberdade foi usado como motivo da Guerra de 1914-1918, precisamente por alguns dos que viriam a ser responsáveis por vinte anos de totalitarismos que se lhe seguiram. Centrando-se no conflito bélico de 1939-1945, o autor de Os mitos acerca da origem das guerras expressa-se de modo inequívoco, tomando partido:

Se a razão da Guerra de 39 fosse a defesa da democracia, sem dúvida teria eclodido para proteger a democrática Checo-Eslováquia e não a totalitária Polónia; mas observemos um mapa dos investimentos de capitais britânicos no estrangeiro: não existiam no primeiro Estado, ao passo que eram de extraordinária importância no segundo $[\ldots]^{41}$.

Para Magalhães Godinho, os interesses económico-financeiros assentes na procura, por todos os meios, do lucro por parte das grandes empresas, terão tido uma papel fundamental na deflagração do segundo conflito à escala mundial, sendo necessário, depois da Guerra, criar condições para uma paz efetiva, assente em valores democráticos de liberdade e igualdade, sem esquecer a justiça social ou o acesso aos cuidados médicos, substituindo a concentração no lucro pelo incentivo ao consumo, plasmando medidas colocadas em prática por Roosevelt para fazer face à Crise de 1929, durante a década de 30, desenvolvendo uma política que ficaria conhecida como New Deal.

Magalhães Godinho aconselha a leitura de duas obras, no final de Os mitos acerca da origem das guerras. Trata-se de Condições para a Paz, do britânico E. H. Carr e Reflections on the revolution of our times do americano Harold Laski. O historiador português não especifica as razões do seu conselho. Percebe-se, desde logo, a afinidade temática com ambos e as preocupações dos três com a atualidade e a criação de uma paz duradoura após a Segunda Guerra Mundial. Por outro lado, todos parecem avessos a um capitalismo lucrativista, defendendo os trabalhadores e a necessidade

${ }^{41}$ GODINHO, 1945f: 52-54. 
de os vencedores saberem ganhar e não hostilizarem os vencidos todos por igual, salvaguardando vítimas civis e militares alemãs.

\section{A DEFESA DE UM PACIFISMO REALISTA EM OS MITOS ACERCA DA ORIGEM DAS GUERRAS}

O Pacifismo é difícil de definir e depende dos contextos históricos nos quais se insira. Em Os mitos acerca da origem das guerras, Magalhães Godinho assume-o enquanto doutrina (de modo algo difuso) e, sobretudo, como atitude, não pretendendo, em nosso entender, cingi-lo a uma corrente de opinião, sendo discutível a afirmação deste como ideologia, opondo-se, de modo mais ou menos explícito a posições defensoras das guerras e dos conflitos, sendo por isso necessário analisar as duas perspetivas em antagonismo, começando pelo Belicismo, reconhecendo, todavia, com Pfaltzgraff que

Não é possível compreender as modernas teorias dos conflitos e da guerra desenvolvidas no Ocidente, incluindo o Pacifismo Utópico, sem fazermos referência ao aparecimento, também no Ocidente, e no seguimento da Revolução Francesa de uma escola de pensamento militarista $[\ldots]^{42}$.

Desde a Revolução Francesa até cerca de 1960 (altura em que as sublevações populares e a guerrilha passaram a ter posição de destaque), as teorias belicistas manifestavam preferência pelas estratégias diretas, assentes no ataque rápido e maciço, em detrimento da negociação, privilegiando Clausewitz o conceito de Guerra Total, ainda que possa ser matizado, segundo Lidell Heart, pela consideração da diferença muitas vezes inultrapassável entre um ideal abstrato e as condições concretas da realidade. Clausewitz sabia isso e estava disposto a aceitar a guerra limitada em certas circunstâncias, mormente quando fosse manifesto o equilíbrio entre os contendores, sempre em nome de uma razão de Estado e não por motivos de natureza ética. Hegel, por seu turno, considerava que o Estado correspondia a um enraizamento do espírito absoluto. Sempre que se encontrasse ameaçado e fosse necessário garantir a sua sobrevivência, o recurso à guerra era não só legítimo mas também necessário. Por seu turno, Nietzsche estabeleceu uma crítica bastante elaborada à matriz cristã da civilização ocidental, opondo-lhe um quadro de valores assente na vontade de poder presente nos indivíduos, e que só poderia ser, em muitos casos, realizada através da Guerra. Fichte e Treitschke, atentos leitores de Maquiavel e defensores do Estado-Nação pugnavam pela sua manutenção, apelando ao confronto bélico sempre que houvesse instabilidade a esse nível. Os pontos de vista expostos, inseríveis de modos distintos na teoria belicista, tiveram eco nos teorizadores europeus e americanos da história militar, como Karl

${ }^{42}$ DOUGHERTY \& PFALTZGRAFF, 2003: 267. 
Bernhardi, estudioso de inspiração darwinista. Teóricos da Geopolítica como Rudolf Kjellen, Friedrich Ratzel, Karl Haushofer ou Alfred Mahan também seguiram, de uma forma ou de outra, a ideia da lei do mais forte enquanto fonte de progresso. Entre finais do século XIX e princípios do seguinte, o belicismo e a teorização antidemocrática estavam, muitas vezes, intimamente relacionados. As teorias belicistas neste período eram essencialmente quatro: o positivismo realista (Mosca e Pareto); o Darwinismo Social (Herbert Spencer, William Summer, Ernst Haeckel); Filosofias pessimistas da história; os antecessores e os representantes da teoria racial (Georges Sorel, Mussolini, Gabineau, Chamberlain, Gabriele d'Anunzio). A primeira conferia todo o poder a uma elite dirigente, tendencialmente coerciva na manutenção da ordem. A segunda considerava que a luta pela sobrevivência era o motor da sociedade, impondo-se os mais fortes. A terceira, essencialmente teleológica, considerava que a subjugação dos mais fracos era inevitável à marcha do progresso.

No que concerne ao Pacifismo João José Brandão Ferreira propõe a existência de três fases e avança, em seguida, com uma definição provisória:

Assim, o Pacifismo tende a aglutinar este desejo para a paz [...]. Numa primeira fase, aparece-nos como vontade de evitar a guerra [...]. Numa segunda fase, o Pacifismo aspira a uma paz duradoura. [...]. Como terceira fase, temos o Pacifismo como recusa absoluta da Guerra, em quaisquer circunstâncias [... $]^{43}$.

Em Os mitos acerca da origem das guerras, a primeira fase do Pacifismo não se aplica ou verifica, dado que o historiador escreve sob os escombros de uma Guerra Mundial no seu estertor. Nas páginas de Godinho nota-se a aspiração a uma paz duradoura que possa conduzir à abolição definitiva da guerra. $\mathrm{O}$ autor nunca se refere à paz perpétua, em termos com reminiscências kantianas ou noutros, sublinhando as dificuldades que enfrentará a construção da paz. A finalizar o artigo/capítulo intitulado O Mito do Espírito de Cruzada, Magalhães Godinho defende a paz como construção e não enquanto ideia abstrata ou realidade imediata. Trata-se de um processo historicamente situado, condicionado por contingências várias. $\mathrm{O}$ autor parece rejeitar radicalizações do Pacifismo idealista ou utópico. Aponta para uma Utopia, a da democracia, a do verdadeiro espírito de cruzada, mas só a consigna por considerá-la realizável, inserida no tempo e na realidade, sujeita a constrangimentos que importa conhecer para ultrapassar:

Construir a paz é, portanto, realizar os fins para que combateram as massas e exige mais larga visão do que a simples promessa de regresso ao passado ou do que

${ }^{43}$ FERREIRA, 1990: 121. 
a mera chefia de operações bélicas. Foi Churchill quem o disse: aqueles que sabem ganhar uma guerra raramente sabem organizar uma boa paz [... $]^{44}$.

\section{CONCLUSÕES}

O nosso trabalho inscreve-se no âmbito da História Cultural da Historiografia, dialogando muito breve e insuficientemente com a Crítica Textual e a Crítica Genética, temáticas a aprofundar em futuras ocasiões, relacionando-se com a História do Livro e da Leitura, sem concretizar uma abordagem micro-histórica cujas virtudes e limitações ficam somente esboçadas. O objeto central deste estudo é um conjunto de artigos publicado primeiro na «Seara Nova» e depois num opúsculo, sempre em 1945. Trata-se de uma coletânea coerente e coesa, atravessada por tensões epocais, pessoais e próprias do ambiente seareiro. Daí que tenha sido necessário enquadrar, contextualizar e comparar o percurso de Magalhães Godinho até ao opúsculo em consideração, de modo a perceber as suas preocupações cívicas constantes e a defesa de um realismo pacifista atento à atualidade e problematizador, não avesso à polémica em Os mitos acerca da origem das guerras, trabalho portador de ecos sergianos, em diálogo com o apego à realidade, também próprio do neorrealismo, mas expresso de modo diverso. Por outro lado, Godinho exibe uma recusa do belicismo, sem explicitar as suas diversas correntes.

Em trabalhos futuros interessa abordar especificamente as relações entre o opúsculo analisado e obras de E. H. Carr [s.d.] e Laski (1944).

\section{FONTES IMPRESSAS}

CARR, E. H. [s.d.] - Condições de paz. Lisboa: Editorial século.

GODINHO, Vitorino Magalhães (1935) - D. Duarte. «Seara Nova», n. ${ }^{\circ} 432$ (28 mai.), p. 382.

(1938a) - As Cidades na Europa medieval. Condições gerais da sua evolução. «Seara Nova», n. 565 (11 jun.), p. 6-9.

(1938b) - As cidades na Europa Medieval. Condições gerais da sua evolução. «Seara Nova», n. 566 (18 jun.), p. 32-35.

(1940) - Razão e História: Introdução a um problema. Lisboa:[s.n.]. Dissertação de Licenciatura em Histórico-Filosóficas.

(1945a) - Os Mitos acerca da Origem das Guerras. 1. O Mito do Instinto Bélico. «Seara Nova», n. ${ }^{\circ} 92$ (2 jun.), p. 65-67.

(1945b) - Os Mitos acerca da Origem das Guerras. 2. O mito dos povos pacíficos e dos povos guerreiros. «Seara Nova», n. ${ }^{\circ} 931$ (16 jun.), p. 101-104.

(1945c) - Os Mitos acerca da Origem das Guerras 3.O Mito da ambição dos grandes homens. «Seara Nova», n. ${ }^{\circ} 935$ (14 jul.).

(1945d) - Os Mitos acerca da Origem das Guerras. 4. O Mito do Espírito de Cruzada. «Seara Nova». (25 ago), p. 276-279.

(1945e) - A reorganização de Estudos de Direito. «Seara Nova», n. 944 (15 set.), p. 37-40.

${ }^{44}$ GODINHO, 1945f: 57-58. 
(1945f) - Os mitos acerca da origem das guerras. Lisboa.

(1971a) - António Sérgio: presença no passado, presença no futuro. «Seara Nova», n. ${ }^{\circ} 1507$ (mai.).

(1971b) - Ensaios IV. Humanismo científico e reflexão filosófico. Lisboa: Sá da Costa.

LASKI, Harold (1944) - Reflections on the revolution of our time. London: Transaction Publishers, 1944.

PIRENNE, Henri (1927) - Les villes du Moyen Âge, essai d'histoire économique et sociale. Bruxelles: Lamertin.

\section{BIBLIOGRAFIA}

DOUGHERTY, James; PFALTZGRAFF, Robert (2003) - Relações Internacionais - As teorias em confronto. Lisboa: Gradiva.

DUARTE, Luís Miguel (2005) - D. Duarte. Lisboa: Círculo de Leitores.

FERREIRA, José João Brandão Ferreira (1990) - Pacifismo. «Revista Nação e Defesa», ano XV, n. 54 (abr.-jun.), p. 117-153.

FITAS, Manuel Joaquim Rodrigues (2010) - Seara Nova: Tempos de Mudança e Perseverança (1940-1958). Porto: Faculdade de Letras do Porto. Dissertação de Mestrado em História.

GAMA, José (2002) - A Geração de Avis. 1. D. Duarte. In CALAFATE, Pedro, dir. - História do Pensamento Português. Lisboa: Círculo de Leitores, p. 380-381. Volume 1: Idade Média.

GODINHO, Vitorino Magalhães (2013) - A História e as ciências humanas de novo numa encruzilhada (complemento de actualização). In A Crise da História e as suas novas directrizes. Lisboa: IN CM, p. $161-220$.

LIMA FILHO, Henrique Espada de (1999) - Micro-história: escalas, indícios e singularidades. Campinas: Universidade Estadual de Campinas. Tese de Doutoramento em História.

LISBOA, João Luís (1998) - Mots (Dits) Écrits. Formes de diffusion des valeurs et des idées au Portugal $d u$ 18ième siècle. Florence: Institut Universitaire Européen. Thèse de Doctorat.

MARTINS, Fernando Cabral (2010) - O que é um texto? In REYNAUD, Maria João; TOPA, Francisco, org. - Crítica Textual e Crítica Genética em diálogo. Munique: Martin Meidenbauer, p. 241-249.

MOREIRA, Nuno Bessa (2013) - A Revista de História (1912-1928): uma proposta de análise históricohistoriográfica. Porto: Faculdade de Letras do Porto. Tese Doutoramento em História.

MUNIZ, Márcio Ricardo Coelho [s.d.] - Leal Conselheiro e Livro de Conselhos de El Rei D. Duarte: Diálogos. In Actas X Congrés Internacional Associaçó Hispània de la Literatura Medieval. [S.1.: s.n.], p. 573-583.

NUNES, João Paulo Avelãs (2013) - O Estado, a Historiografia e as outras ciências/tecnologias sociais. In NUNES, João Paulo Avelãs; FREIRE, Américo, coord. - Historiografias Portuguesa e Brasileira. Olhares Cruzados. Coimbra; Rio de Janeiro: Imprensa da Universidade de Coimbra e Fundação Getúlio Vargas, p. 53-79.

PACHECO, Maria Cândida (1991) - Para uma Antropologia situada: O Leal Conselheiro de D. Duarte. «Revista da Faculdade de Letras do Porto», vol. 47, p. 425-44.

REYNAUD, Maria João (2010) - Apresentação. In REYNAUD, Maria João; TOPA, Francisco, org. Crítica Textual e Crítica Genética em diálogo. Munique: Martin Meidenbauer, p. VIII. (2015) - A Palavra Imperfeita. Porto: Faculdade de Letras do Porto. (Últimas Lições).

SOUSA, José Manuel Guedes de (2012) - História e cidadania nos anos 40. Lisboa: Faculdade de Letras de Lisboa. Dissertação de Mestrado em História. 



\title{
OS NIBELUNGOS EM GERMANIA TOD IN BERLIN DE HEINER MÜLLER: A «MISERE» DE UMA MATÉRIA?
}

\author{
JOHN GREENFIELD*
}

Neste estudo, proponho-me analisar o tratamento da matéria dos nibelungos na peça Germania Tod in Berlin [Germania Morte em Berlim] ${ }^{1}$, do dramaturgo alemão Heiner Müller (1929-1995): é minha intenção tentar posicionar a forma como Müller representa este povo mítico nesta peça, no âmbito do processo global da receção moderna de uma tradição que se iniciou em finais do século XVIII, com a «redescoberta» do poema heroico Das Nibelungenlied. Esta obra medieval teve uma influência muito significativa na história recente da cultura alemã e desde a sua «reinvenção» como epopeia nacional, durante o Romantismo Alemão, foram produzidas mais de 1000 obras (entre poemas, romances, dramas, filmes, peças musicais, óperas, esculturas, monumentos, pinturas, etc.) que têm como objeto estético figuras ou ações de Das Nibelungenlied. No caso da peça de Heiner Müller, o dramaturgo alemão integra a ação dos quatro guerreiros mais importantes dos nibelungos (o rei Günther, o seu irmão Gernot, o conselheiro Hagen e o guerreiro Volker) numa cena curta intitulada Hommage à Stalin I [Homenagem a Estaline I]: e esta ação desenrola-se não num cenário medieval, mas durante a Batalha de Estalinegrado, que, como se recorda, foi a derrota mais significativa do exército alemão, durante a Segunda Guerra Mundial. Para entender o que terá motivado o dramaturgo marxista, pós-brechtiano Müller a

\footnotetext{
* Universidade do Porto/CITCEM - Centro de Investigação Transdisciplinar Cultura, Espaço e Memória.

${ }^{1}$ MÜLLER, Heiner - Germania Tod in Berlin. In Werke, vol. IV, Die Stücke 2, p. 327-377.
} 
utilizar a temática mítica de uma epopeia heroica medieval numa cena dedicada a Estaline e numa obra dramática que trata sobretudo da história político-cultural da Alemanha e do socialismo, é necessário entender qual o significado desta tradição no contexto da cultura alemã dos séculos XIX e XX e qual a sua ligação com um campo de batalha nas margens do rio Volga, em 1943.

Nesta minha análise tenciono, portanto, explicar, em primeiro lugar, o que levou a Alemanha a dar tanta importância ao poema épico Das Nibelungenlied, para depois passar em revista as diferentes tendências artísticas e políticas que dominaram a receção do poema antes de examinar o motivo que terá levado Müller a incluir esta temática na sua obra Germania Tod in Berlin. Este texto dramático de Müller, que é composto por treze episódios, foi escrito na R.D.A., entre 1956 e 1971; mas a representação da peça foi originalmente proibida no estado socialista alemão, tendo apenas sido possível estreá-la, em Munique, na República Federal, em 1978². Deve notar-se que a peça, desde a sua estreia, tem tido um êxito apenas relativo: parece-me que o motivo de uma certa falta de sucesso desta obra de Müller nos palcos alemães reside na dificuldade que o público tem em entender a sua estrutura complexa e as muitas referências históricas que o dramaturgo introduziu numa peça que tenta explicar o desenvolvimento do socialismo na Alemanha. O conhecido realizador francês Patrice Chéreau, que inicialmente pretendia apresentar a obra em França, acabou por desistir do projeto de uma encenação porque, como referiu, teria, de antemão, de explicar toda a história alemã ao público francês... ${ }^{3}$ Curiosamente, na primeira representação de Germania Tod in Berlin, na R.D.A., o público parece ter reagido a esta obra com uma certa incompreensão, de uma forma crítica e desagradada: esta reação talvez tenha sido motivada pelo ambiente que se vivia na R.D.A. nessa época, na medida em que a encenação em Berlim Oriental apenas foi permitida uma década depois da sua estreia na República Federal - ou seja, escassos meses antes da queda do muro, no significativo ano de 1989.

Gostaria de iniciar a minha análise num outro ano notável, o ano de 1945: este foi, a todos os títulos, um ano importante. Foi o ano do nascimento da nossa homenageada, a Maria João Reynaud. Mas foi também o ano do fim da Segunda Guerra Mundial; um ano que, para a Alemanha, significava, a diversos níveis, uma profunda mudança de paradigma. A capitulação do exército alemão, a destruição do Império Alemão e a derrota do nacional-socialismo marcaram o fim de um projeto político-cultural que começou no início do século XIX, um projeto influenciado, numa primeira fase,

\footnotetext{
${ }^{2}$ A estreia da peça foi no teatro Münchner Kammerspiele, em Munique, em 1978, sob a direção de Ernst Wendt e Johannes Schütz; a primeira representação na RDA foi no Berliner Ensemble, em Berlin Oriental, em 1989, sob a direção de Fritz Marquardt. Sobre a peça de Müller, cf., entre outros, BOHN, 2003: 207-214; EKE, 2015: 171-184; GANTER, 2008: 97-222; KLUSSMANN, 1982: 159-17; SCHRÖDER, 1994: 326-340; SZILVIA, 2008: 66-89.

${ }^{3}$ Cf. MÜlLER, Werke: XI, 574.
} 
pelo Romantismo Alemão, na segunda metade do século XIX e na primeira parte do século XX, por modelos imperialistas e fascistas que visavam a construção de um estado-nação alemão hegemónico, no espaço europeu; são diversas as componentes deste projeto político-cultural na Alemanha, entre as quais, no início do processo, se incluía a construção de um sentimento nacional através do estabelecimento de uma cultura nacional, de uma filologia nacional, de uma literatura nacional e - mais tarde - de um estado nacional. Depois do falhanço total desse projeto, em 1945, os elementos que compõem este modelo nacional foram sucessivamente - e criticamente - questionados, e, em parte, rejeitados pelos alemães.

Entre os alicerces mais importantes dos conceitos constitutivos da literatura e da filologia alemãs encontra-se aquele texto que os historiadores e teorizadores do início do século XIX consideraram a «epopeia nacional»: Das Nibelungenlied. De facto, esta obra foi encarada por muitas gerações de alemães como o texto fundador da nação, tendo sido objeto de um intenso processo de receção, que levou à produção, desde 1800, de centenas de obras literárias inspiradas neste poema medieval. É notável que, durante os séculos XIX e XX, haja períodos com picos de interesse por esta matéria, que se refletem numa produção maior de obras literárias que versam o tema: as épocas do mais intenso tratamento estético desse assunto são no período da unificação alemã (em 1871), e nos anos de guerra e entre as duas guerras mundiais — ou seja entre 1900 e 1945. Há apenas uma década, desde 1800, em que não foi publicada nenhuma obra em alemão sobre o tema dos nibelungos - trata-se da década logo a seguir à Segunda Guerra Mundial, entre 1945 e 1955. Portanto, parece legítimo afirmar que - após a derrota de 1945 - , numa época em que se questionou criticamente a génese do nacionalismo alemão e em que se fez uma tentativa de «recomeçar» a cultura alemã, a matéria milenar dos nibelungos foi como que apagada da consciência coletiva alemã ${ }^{4}$.

Na zona soviética de ocupação da Alemanha, que - a partir de 1949 - se designou República Democrática Alemã, este apagamento da tradição dos nibelungos foi mais nítido do que na República Federal, na medida em que, no currículo das escolas secundárias do jovem estado socialista, Das Nibelungenlied deixou de ter tanta importância para estudantes da literatura alemã; nas universidades da R.D.A. a obra não foi analisada de uma forma tão intensa nos cursos universitários de germanística, como no caso na Alemanha Ocidental.

Para entender esta tentativa de apagar, no pós-guerra, a memória de uma matéria literária tão importante no contexto alemão, é necessário entender os passos que foram dados no início do processo de receção do poema: este coincide com um renovado sentimento de patriotismo alemão que aparece a seguir às invasões napoleónicas

\footnotetext{
${ }^{4}$ Para consultar uma lista (embora não exaustiva) das obras que que foram produzidas no âmbito da receção da matéria do nibelungos, no período moderno, cf.: <http://www.nibelungenrezeption.de/literatur/texte.html $>$. [Consulta realizada em 25/06/2017].
} 
(no início do século XIX) e que modifica, por completo, a forma como é encarado o passado germânico. Há dois fatores que são de importância fundamental para esta mudança: o primeiro é o desenvolvimento e o crescente nacionalismo do movimento romântico; o segundo (ligado, naturalmente, ao primeiro) é o estabelecimento de uma área científica da germanística em universidades de modelo humboldtiano: o estudo de Das Nibelungenlied representa a parte fundamental daquilo que virá a ser a «filologia nacional» (Germanistik). Trata-se de uma iniciação de um novo processo de mitificação (imposto por uma elite cultural) - e este processo está intimamente ligado à construção de um sentimento nacional no espaço de língua alemã e à concretização geográfica e política desse sentimento com o estabelecimento, em 1871, de um estado-nação - a Alemanha.

É evidente que o poema em si não tem nenhuma mensagem nacional alemã, nem sequer conhece os «alemães»" ${ }^{5}$ É uma história de amor, de traição e de vingança em que, por ganância, o herói nórdico, Siegfried, o senhor dos nibelungos, é assassinado de forma traiçoeira por um familiar da sua esposa, Kriemhild: o assassino, Hagen, é o conselheiro do irmão de Kriemhild, o rei dos burgúndios, Gunther, e mata Siegfried para poder roubar o tesouro deste (o mítico tesouro dos nibelungos). Depois da morte de Siegfried, Kriemhild casa de novo, desta vez com o rei dos hunos, Átila, unicamente porque poderá assim conseguir um plano de vingança e matar o homicida, Hagen. Kriemhild convida a família para uma festa na corte do rei Átila, na Hungria; nesta festa ela não olha a meios para atingir os seus fins, sacrificando, nos últimos capítulos da obra, o próprio filho, todos os seus familiares e mais 40.000 guerreiros, das mais diversas tribos. Na última cena do poema, Hagen, o assassino do primeiro marido de Kriemhild morre - como também a própria Kriemhild. No fim da ação quase não há sobreviventes - e é muito difícil entender qual a mensagem da obra...

Foi sobretudo durante o Romantismo Alemão que o poema alcançou um lugar de relevo na vida cultural alemã; assim, August Wilhelm Schlegel considerou-o, em conjunto com Johann Gottfried von Herder, como uma expressão das características nacionais alemãs, considerando que a obra era central para a construção de uma nova mitologia alemã: para Schlegel, o poema devia ser considerado base e pedra angular da poesia alemã ${ }^{6}$. E esta ideia de uma ligação íntima entre a obra e a embrionária «nação alemã» será dominante durante as primeiras décadas do século XIX. Trata-se de uma posição que Friedrich Heinrich von der Hagen, o primeiro professor catedrático da área da germanística numa universidade alemã, desenvolverá nas suas aulas na Universidade de Berlim. Ele vê neste poema um reflexo das qualidades morais dos alemães, na

\footnotetext{
${ }^{5}$ Há apenas uma referência, única, no poema inteiro aos alemães quando o narrador se refere a «den tiuschen gesten [os hóspedes alemães]» (BARTSCH et al., eds., 1988: 1354, 4).

${ }^{6}$ Segundo August Wilhelm Schlegel, numa carta que enviou a Tieck, «dieses Gedicht muss so ganz Grundlage und Eckstein unsrer Poesie werden [este poema deve tornar-se a base e a pedra basilar da nossa poesia]» (SCHLEGEL, 1864: 330).
} 
medida em que nesta obra as personagens demonstram caraterísticas como amizade, fidelidade, honestidade e humanidade. Para von der Hagen, como para Schlegel, era essencial introduzir este poema (considerado altamente patriótico) nos currículos das escolas $^{7}$ : aliás, segundo Schlegel, o livro deveria ter a mesma importância que a Bíblia para os jovens alemães.

Neste processo de mitificação nacional da matéria, as figuras e a ação são idealizadas de tal forma que tudo que seja negativo - as traições, a violência, o subterfúgio, a violação da mulher, as mentiras, os homicídios e o massacre de povos inteiros - é banalizado, e considerado de certa forma inofensivo.

Mesmo após o Congresso de Viena, em 1814/15, numa época em que os ideais revolucionários do nacionalismo alemão vão sendo reprimidos por estados absolutistas, os estudantes radicais nas universidades alemãs veem nas figuras de Das Nibelungenlied modelos de comportamento político: Siegfried como herói da liberdade, Hagen como alguém que legitima o assassínio político...

Durante todo o século XIX, o poema impõe-se em determinados círculos políticos e culturais, como um símbolo patriótico. Após a unificação alemã em 1871, Das Nibelungenlied conhece um período de aceitação e instrumentalização oficiais, tendo-se tornado obra de leitura obrigatória nas escolas do país e a nova mitificação politizada do poema fica completa quando, poucos anos antes da I Guerra Mundial, o chanceler do Reich Fürst von Bülow compara, num discurso proferido em março de 1909, no Reichstag em Berlim, a relação entre a Áustria e a Alemanha à «Nibelungentreue» [fidelidade dos nibelungos] $]^{8}$, inventando, no âmbito de um discurso político-nacionalista, um conceito que, mais tarde, iria ser instrumentalizado pelo nacional-socialismo.

Após a derrota de 1918, o poema foi integrado numa nova visão ultra-nacionalista da Idade Média alemã; na sua obra Mein Kampf [A minha luta], Adolf Hitler (ele próprio retratado como Siegfried) compara o soldado alemão da Grande Guerra à figura de Siegfried, morto à traição por Hagen, na medida em que o soldado na frente terá sido apunhalado nas costas por políticos derrotistas - socialistas e judeus - no governo: a ideia de Hitler é transformada em imagem, instrumentalizando a conhecida figura de Siegfried para mostrar o sacrifício do soldado na frente - e a traição dos políticos da esquerda... Durante o período do nacional-socialismo, o poema e o herói (nórdico «ariano») sacrificado Siegfried foram idealizados para glorificar as qualidades militares. No entanto, nota-se que, durante a Segunda Guerra, houve uma clara mudança na forma como o poema foi sendo oficialmente interpretado, na medida em que, a partir do momento em que a derrota se torna uma realidade (ou seja, a partir do início de 1943), é focado sobretudo o comportamento dos guerreiros germânicos, nos últimos

${ }^{7}$ VON DER HAGEN ed., 1807: VI.

${ }^{8}$ MASSOW ed., 1914: 127. 
capítulos da obra. Assim, na propaganda do regime, o conceito de «Nibelungentreue» [fidelidade dos nibelungos] é enfatizado; esta viragem na instrumentalização oficial do poema inicia-se na noite de 30 de janeiro de 1943, num discurso proferido pelo Marechal do Reich, Hermann Goering: este exorta os alemães a lembrarem-se da Nibelungentreue [fidelidade dos nibelungos] — porque será necessário que todo o povo alemão lute, como os nibelungos - (entende-se) até ao fim. Este discurso de Goering teve lugar precisamente nos dias que antecedem a maior derrota alemã da Segunda Guerra - a derrota de Estalinegrado. E, portanto, fixou-se no consciente coletivo alemão na última fase da guerra que a luta travada nas margens do rio Volga era comparável à luta dos nibelungos na corte do rei Átila...

E agora volto de novo - e finalmente - à peça de Müller. O dramaturgo utiliza este tratamento propagandístico de um momento importante da história alemã e vai adaptá-la para comentar, de uma forma crítica, acontecimentos históricos. Através de um processo de colagem e montagem de episódios diferentes do passado alemão/germânico (desde o tempo das migrações, na «Idade das Trevas», até à revolta popular, de 1953, na R.D.A.), Müller questiona, na sua obra Germania Tod in Berlin, a herança alemã, mas critica igualmente o conceito marxista de um processo racional, teleologicamente ordenado da história, na medida em que entendeu a sua obra como uma polémica contra a imagem oficial da história.

A peça é composta por treze cenas independentes, aparentemente fragmentárias, na maioria dos casos emparelhadas, que não seguem nenhuma ordem cronológica, e que misturam acontecimentos mitológicos com determinadas épocas históricas - e introduz nestas cenas grandes personalidades do passado europeu, entrosando-as com personagens do quotidiano, mas também com conhecidas figuras ficcionais da literatura alemã. Nesta combinação anacrónica do mitológico e do literário com o histórico, Müller chama a atenção para a questão do património cultural dos alemães, e para a barbárie que foi cometida em seu nome.

Destas cenas fragmentárias, importa, no âmbito da presente análise, destacar a quinta cena, que, como referi no início do artigo, se intitula Hommage à Stalin $I^{9}$; esta cena começa na Batalha de Estalinegrado, com uma conversa entre soldados mutilados e mortos que se canibalizam ${ }^{10}$; passam os fantasmas de Napoleão e de César e aparecem as figuras gigantescas de quatro guerreiros nibelungos: os irmãos Gunther e Gernot, acompanhados pelos guerreiros Hagen e Volker ${ }^{11}$. Estes soldados preparam-se para lutar contra os hunos, utilizando, como armas, os cadáveres que se encontram no campo da batalha e, depois de construírem um muro com os corpos dos soldados mortos, os guerreiros nibelungos usam crânios como recipientes para

\footnotetext{
${ }^{9}$ MÜLLER, Werke: IV, 340-344.

${ }^{10}$ MÜLLER, Werke: IV, 340.

${ }^{11}$ MÜLLER, Werke: IV, 341.
} 
beber cerveja e discutem, entre si, os motivos do combate ${ }^{12}$ : Hagen afirma que estão a lutar para vingar a morte de Siegfried, mas Gernot, que questiona a necessidade de continuar um combate inútil em Estalinegrado, lembra que foi Hagen quem assassinou Siegfried. Os outros três guerreiros acusam Gernot de falta de ideais, atacam-no, matam-no e depois masturbam-se em cima do seu cadáver ${ }^{13}$. Em seguida, Hagen e Gunther, pensando na divisão do tesouro (dos nibelungos) matam Volker, para depois se esquartejarem mutuamente: no fim da cena, as partes dos cadáveres dos guerreiros nibelungos juntam-se para formar um monstro único ${ }^{14}$.

Nesta cena, Müller pretende, entre outras coisas, desconstruir e desmistificar a imagem fabricada desde o Romantismo Alemão da heroicidade das figuras desta matéria épica, transformando-as em personagens grotescas - e até mais próximas daquilo que, de facto, são na obra medieval: guerreiros motivados por ganância que não se apercebem do egoísmo das suas ações e da falsidade dos seus ideais. Situando esta ação no campo da Batalha de Estalinegrado, Müller pretende alargar esta «des-idealização» do herói épico para o cenário da derradeira derrota do fascismo alemão, mostrando até que ponto um sentido de dever, que, no fundo, está desprovido de sentido, pode levar à canibalização, à perversidade sexual e, em última instância, à catástrofe final.

Em 1983, Müller notou numa entrevista que a Alemanha brinca sempre com os nibelungos ${ }^{15}$ : como refere Szilvia ${ }^{16}$, o terror e a destruição são, segundo Müller, motivos centrais da história alemã e prefiguram-se, numa forma literária em, Das Nibelungnelied. É possível que, no mito da queda dos nibelungos Müller tenha encontrado o arquétipo das grandes catástrofes alemãs. Como outros, Müller considera a história alemã como uma «Misere» [miséria], e, para o dramaturgo alemão fazem parte desta 'miséria' todos os movimentos políticos e sociais da história alemã, incluindo o nacionalismo alemão, o fascismo alemão - e também o socialismo alemão. E parece que, para Müller, faz igualmente parte desta miséria a forma como, nos últimos 250 anos, a matéria dos nibelungos foi sendo instrumentalizada.

O meu colega alemão, o medievalista Joachim Heinzle (1991) designou o processo moderno de receção de Das Nibelungenlied como «ein deutscher Wahn, ein deutscher Alptraum» [uma loucura alemã, um pesadelo alemão]. No entanto, julgando pela receção moderna da obra, esse autor parece esquecer que a matéria dos nibelungos, que tem a sua origem em acontecimentos históricos do século V, foi, nos 1500 anos da sua história, sempre objeto de um processo orgânico e contínuo de sucessivas reformulações, adaptações e instrumentalizações. Não nos deve surpreender, portanto,

\footnotetext{
${ }^{12}$ MÜLLER, Werke: IV, 342-343.

${ }^{13}$ MÜLLER, Werke: IV, 343.

${ }^{14}$ MÜLLER, Werke: IV, 344.

${ }^{15}$ Cf. HEEG, 2003: 102.

${ }^{16}$ SZILVIA, 2008: 41.
} 
que, no século XX possa ser objeto de novas atualizações - como também foi o caso deste texto de Heiner Müller.

\section{REFERÊNCIAS BIBLIOGRÁFICAS}

\section{Textos}

BARTSCH, Karl; BOOR, Helmut de; WISNIEWSKI, Roswitha, eds. (1988) - Das Nibelungenlied. Wiesbaden: [s.n]. (Deutsche Klassiker des Mittelalters).

MASSOW, Wilhelm, ed. (1914) - Fürst von Bülows Reden. Leipzig: [s. n.], vol. V.

VON DER HAGEN, Friedrich Heinrich, ed. (1807) - Der Nibelungen Lied. Berlin: [s. n.]

\section{Estudos}

BOHN, Volker (2003) - Germania Tod in Berlin. In LEHMANN, Hans-Thies; Primavesi, Patrick, eds. - Heiner Müller Handbuch. Leben, Werk, Wirkung. Stuttgart: J.B. Metzler, p. 207-214.

EKE, Norbert Otto 2015 [1999] - Heiner Müller. Stuttgart: J.B. Metzler.

GANTER, Theresa M. (2008) - Searching for a New German Identity. Heiner Müller and the 'Geschichtsdrama'. Bern / Frankfurt: Peter Lang.

HEEG, Günther (2003) - Deutschland - Krieg. In LEHMANN, Hans-Thies; Primavesi, Patrick, eds. Heiner Müller Handbuch. Leben, Werk, Wirkung. Stuttgart: J.B. Metzler, p 88-93.

HEINZLE, Joachim; WALDSCHMIDT, Anneliese, eds. (1991) - Die Nibelungen: ein deutscher Wahn, ein deutscher Alptraum. Studien und Dokumente zur Rezeption des Nibelungenstoffs im 19. und 20. Jahrhundert. Frankfurt: Suhrkamp.

KLUSSMANN, Paul Gerhard (1982) - Deutschland Denkmale: umgestürzt. Zu Heiner Müller Germania Tod in Berlin. In KLUSSMANN, Paul Gerhard; MOHR, Heinrich, eds. - Deutsche Misere einst und jetzt. Die deutsche Misere als Thema der Gegenwartsliteratur / Das Preußensyndrom in der Literatur der DDR. Bonn: Bouvier, p. 159-17.

LEHMANN, Hans-Thies; PRIMAVESI, Patrick, eds. (2003) - Heiner Müller Handbuch. Leben, Werk, Wirkung. Stuttgart.

SCHRÖDER, Jürgen (1994) - Die 'deutsche Misere’ als Greuelmärchen. In: J. S., Geschichtsdramen. Die 'deutsche Misere' - von Goethes Götz bis Heiner Müllers 'Germania'. Eine Vorlesung. Tübingen, p. 326-340.

SZILVIA, Gór (2008) - Der Deutschlanddiskurs in den Dramen von Heiner Müller und Volker Braun (Diss.). Piliscsaba. 


\title{
AMOR, EROTISMO E FALHA: EÇA E MACHADO
}

\author{
ISABEL PIRES DE LIMA*
}

Deixo uma palavra prévia não tanto para dizer publicamente a estima que tenho pela Maria João, colega e amiga, facto de que ela tem inteiro conhecimento, mas para publicamente reiterar junto dela quanto a considero uma sensível e exigente exegeta de poesia, designadamente contemporânea, e uma aguda leitora da narrativa oitocentista no seio da nossa academia, para além de tudo o resto em que ela é especial, muito particularmente enquanto crítica genética e textual de elevadíssimo nível, que nos deu, entre outros, aquele trabalho de preservação patrimonial que foi a edição de Húmus. Quero ainda aqui dizer como aprecio a sua escolha de nunca abandonar um campo de atividade que sempre frequentou e amou - o teatro e a dramaturgia. Obrigada, portanto, Maria João.

A questão que me propus tratar em homenagem à Maria João tem como objeto contos oitocentistas, matéria que tem merecido a sua cuidada atenção analítica e introduzo-a a partir de duas epígrafes:

Grande lascivo, espera-te a voluptuosidade do nada. Machado de Assis, Memórias Póstumas de Brás Cubas

Onde estava o defeito? No amor mesmo talvez! [...] É que o amor é essencialmente perecivel, e na hora em que nasce começa a morrer. Eça de Queirós, O Primo Basílio

\footnotetext{
* Universidade de Porto/Instituto de Literatura Comparada Margarida Losa. Este artigo insere-se na investigação desenvolvida no âmbito do Programa Estratégico UID/ELT/00500/2013.
} 
1. Quando se fala de Eça de Queirós e Machado de Assis é praticamente inevitável referir a virulenta crítica que Machado dirigiu em 16 e 30 de abril de 1878, n’ «O Cruzeiro», do Rio de Janeiro, aos dois primeiros romances de Eça de Queirós, O Crime do Padre Amaro, na sua primeira versão em livro, datada de 1876, e O Primo Basílio, acabado de publicar com sucesso nesse mesmo ano de 1878, crítica que tem feito correr rios de tinta.

Não me vou deter na tal crítica já bastante dissecada por estudiosos de ambos os escritores com destaque para Machado da Rosa, pela centralidade dada à questão, num livro dos anos sessenta, Eça, Discípulo de Machado?, e para João Camilo (dos Santos), pela pertinência da abordagem, num brilhante artigo do ano 2000, que a meu ver repõe a questão em termos inovadores, intitulado «Machado de Assis, Crítico de Eça de Queirós - Um mal-entendido sintomático». Não me centrando na questão, não me coibirei de pontualmente a ela aludir ${ }^{1}$.

Vou antes deter-me na aproximação entre textos ficcionais dos dois autores, coisa que tem sido feita com menos frequência, pese embora haver muitos pontos de aproximação e alguns de distanciamento entre ambos que a violência daquela crítica machadiana tem impedido de ver ${ }^{2}$.

A minha atenção irá fixar-se na questão do erotismo e da falha nalguns contos dos dois autores, parecendo-me que os pontos de contacto entre eles nesta matéria são mais do que os de distanciamento, pese embora as acusações de desbragamento dirigidas a Eça por Machado. Antes, porém, quero ater-me numa reflexão prévia, que permita aproximarmo-nos dos contos queirosianos descondicionados da leitura que Machado faz do realismo queirosiano.

2. Quando aqueles dois romances de Eça que foram objeto da crítica machadiana vieram a lume, já ele havia publicado, em 1873, um conto dos mais enigmáticos e complexos que viria a escrever, Singularidades de uma Rapariga Loira. Trata-se de um conto ao qual poderíamos aplicar aquilo que Abel Barros Baptista diz, numa excelente síntese do conto de Machado de Assis:

os contos machadianos falam de homens que atuam e representam a ruína da interpretação para dizerem que o sentido da ação humana não é dado, nem ilustrável,

\footnotetext{
${ }^{1}$ É vasta a bibliografia sobre este tópico tanto da parte de investigadores brasileiros quanto da parte de portugueses. Importará referir a obra organizada por Beatriz Berrini, Eça \& Machado, que reúne entre outros, três estudos sobre o assunto de John Gledson, Paulo Franchetti e Carlos Reis, assim como o livro de José Leonardo Nascimento, «O Primo Basílio» na Imprensa Brasileira do Século XIX, que tem o mérito de reunir em Apêndice as peças publicadas à época em torno da polémica.

${ }^{2}$ Uma dessas raras aproximações - no caso entre Dom Casmurro e Os Maias — foi brilhantemente feita por Mónica Figueiredo no seu livro, De Vencedores e vencidos - Machado \& Eça num encontro.
} 
nem decifrável, nem transmissível. Não porque seja destituída de sentido, antes porque lhe falta sempre a autoridade do narrador ${ }^{3}$.

O que acontece naquele conto de Eça é exatamente a impossibilidade da interpretação pelo narrador de $1 .^{\text {a }}$ pessoa e pelo velho Macário, protagonista, quando jovem, de uma decetiva história de amor que conta a um desconhecido encontrado numa estalagem, o qual virá a ser o narrador. Conta ele a história do seu enamoramento por uma jovem, Luísa, portadora de um misterioso leque, que vê na janela da casa frontal ao seu escritório de guarda-livros do negócio de um tio. Inicia-se um casto namoro, contrariado pelo rígido tio, que se oporá ao casamento, facto que levará Macário a abandonar casa e emprego, confrontando-se com problemas sérios de sobrevivência que o conduzirão a várias peripécias. $\mathrm{O}$ tio acabará por apiedar-se dele reintegrando-o no emprego e dando-lhe meios para casar. O noivado terminará, porém, abruptamente, com a revelação de um gesto aparentemente cleptómano da noiva.

Ora o que é particularmente curioso neste conto quanto à questão da impossibilidade da interpretação é que quer o protagonista enquanto velho, quer o narrador, que aliás faz tudo através de um jogo de alternância de planos discursivos para ser confundido pelo leitor com um narratário, ambos constatam que não conseguem explicar com clareza uma história que ora é designada de «simples» ${ }^{4}$, ora de «singular» ${ }^{5}$, ora de «farsa» ${ }^{6}$, ora de $«$ melodrama ${ }^{7}$, ora de caso $"$ grotesco ${ }^{8}$, ora de objeto de escárnio» ${ }^{9}$ - história a que aliás o autor, recorde-se, chamara Singularidades de uma Rapariga Loira.

Digamos que as dificuldades experimentadas pelo narrador, que se auto qualifica de «homem positivo e realista ${ }^{10}$, mas que fica desarmado perante a história $"$ simples» ${ }^{11}$, de Macário, parece indiciar a situação do jovem Eça, desarmado perante a complexidade do real e do mundo íntimo, confrontando-se já então com a dificuldade de interpretar o mundo, a ponto de atribuir aquele título ao conto, ele que, apenas dois anos antes, afirmara veementemente o realismo nas Conferências Democráticas do Casino com uma conferência intitulada, O Realismo como nova expressão de arte, e fizera a sua profissão de fé no positivismo e em Claude Bernard para alcançar a verdade e explicar a realidade.

\footnotetext{
${ }^{3}$ BAPTISTA, 2004: 38. ${ }^{4}$ QUEIRÓS, 2009: 170. ${ }^{5}$ QUEIRÓS, 2009: 170. ${ }^{6}$ QUEIRÓS, 2009: 169. ${ }^{7}$ QUEIRÓS, 2009: 169. ${ }^{8}$ QUEIRÓS, 2009: 169. ${ }^{9}$ QUEIRÓS, 2009: 169.

${ }^{10}$ QUEIRÓS, 2009: 168.

${ }^{11}$ QUEIRÓS, 2009: 170.
} 
Estamos a falar de um conto do jovem Eça que se aproxima naquilo que Abel Barros Baptista chama a "ruína da interpretação» de uma das obras-primas da sua maturidade, o conto José Matias, publicado no ano de 1897. Versa ele sobre a inanidade do pensamento ou da filosofia como via de acesso ao conhecimento, sendo uma espécie de encenação da incapacidade da palavra para referenciar a realidade e, em especial, a realidade comportamental e humana. Relembre-se apenas que o narrador do conto é um douto filósofo, autor de livros de filosofia e de psicologia e que, todavia, se sente, perante o comportamento amoroso do protagonista, José Matias, como perante o Incognoscível: eu, filósofo, diz ele não sem alguma autoironia,

esfuraquei o acto do José Matias com a ponta de uma Psicologia que expressamente aguçara: - e já de madrugada, estafado, concluí, como se conclui sempre em Filosofia, que me encontrava perante uma Causa Primária, portanto impenetrável, onde se quebraria, sem vantagem para ele, para mim, ou para o Mundo, a ponta do meu Instrumento ${ }^{12}$ !

Poderá haver declaração mais explícita da limitação dos saberes para explicar a realidade e a «ruína da interpretação»? O conto termina, aliás, com o narrador admitindo perante o seu interlocutor e perante o leitor que José Matias ficou «inexplicado» ${ }^{13}$.

Que reflexão pretendo aqui trazer? Pretendo chamar a atenção para a natureza muito mais heterodoxa do realismo queirosiano do que a crítica de Machado queria fazer supor e em certos aspetos, de resto, muito mais próximo daquele que o próprio Machado praticaria, sobretudo depois de Memórias Póstumas de Brás Cubas, obra publicada apenas na década seguinte, em 1881. Os preconceitos moralistas de Machado relativamente ao naturalismo, levando-o a confundir estética e moral, não lhe permitiam admitir que as personagens dos romances naturalistas, designadamente dos romances do primeiro Eça, não são apenas, como ele pretendeu fazer crer, sujeitos sem qualquer dimensão moral, sem coerência psicológica, que não sabem distinguir o essencial do acessório, simples títeres nas mãos de autores que por seu turno não sabem correr o reposteiro da discrição, obrigando o leitor a assistir a cenas escabrosas. Machado teoriza ainda a partir dos limites de uma visão do mundo burguesa, liberal e conservadora, sem atentar na inquietação que já atravessa aquelas obras de Eça, nas suas personagens que são já sujeitos à deriva face ao carácter contraditório e incognoscível do homem e da realidade, como serão as personagens magistralmente desenhadas pelo segundo Machado. «Por isso» - como nota João Camilo - «se surpreende com a falta de relações de causalidade verosímeis e aceitáveis entre os atos das personagens de Eça e o carácter

${ }^{12}$ QUEIRÓS, 2009: 373.

${ }^{13}$ QUEIRÓS, 2009: 384. 
ou personalidade dessas personagens» ${ }^{14}$. Machado, mais tarde, em Memorial de Aires, admitirá que: «a verdade pode ser às vezes inverosímil» ${ }^{15}$. Ora, desde Singularidades de uma Rapariga Loira que Eça já sabe que não há sujeitos monolíticos e estruturados, que a realidade não se dá a ver e que os seres humanos são impossíveis de fixar e não se deixam apreender sem ser em contradição. José Matias, publicado a três anos da morte do autor, virá a ser a expressão maior dessas certezas inicialmente apreendidas.

Por isso não posso estar inteiramente de acordo com John Gledson quando este fala, a propósito do tratamento do adultério, em Memórias Póstumas de Brás Cubas, numa «reapropriação» ${ }^{16}$ às avessas de Eça por Machado, em termos «satíricos e criativos» ${ }^{17}$. Aquilo que me parece que realmente aconteceu foi mais a perceção por parte do genial ficcionista que Machado foi de que Eça e porventura os naturalistas - cujos livros inspiravam repulsa ao cidadão conservador que Machado era, mas que atraíam o escritor atento às novas formas de apreensão do desconcerto do mundo - captavam a relativização ética dos valores burgueses no seio da sociedade sua contemporânea apresentando já uma versão não trágica do falhanço do amor, do casamento e das suas consequências. Claro que Dom Casmurro ou Os Maias, obras posteriores, voltarão a incorporar uma dimensão trágica no tratamento daquelas temáticas. Estou, portanto, mais de acordo com a perspetiva de João Camilo (dos Santos) ao dizer: «Brás Cubas, comédia com alguma tragédia implícita mas nunca posta em evidência nem explorada, pode considerar-se como uma obra próxima da atitude e da visão irónica do mundo que dominam o universo de Eça» ${ }^{18}$.

3. Voltemos ao objeto primeiro do presente trabalho, podendo agora deixar para trás a leitura de Machado que nos condicionava no exercício de aproximação dos dois escritores.

Eduardo Lourenço tem chamado a atenção para a «inanidade intrínseca da experiência amorosa» ${ }^{19}$ em Eça. No seu universo ficcional o amor revela-se como uma experiência infeliz, não tanto pela impossibilidade ou incapacidade de amar do sujeito, mas pela experiência da própria vacuidade do amor. Acrescenta ainda Eduardo Lourenço:

A indigência do Amor tal como na ficção de Eça abundantemente se glosa, quer sob o modo satírico ou burlesco (A Capital, O Primo Basílio, Alves e Comp. ${ }^{a}$ ),

\footnotetext{
${ }^{14}$ CAMILO, 2000: 69.

${ }^{15}$ ASSIS, 2014: 1444

${ }^{16}$ GLEDSON, 2005: 124.

${ }^{17}$ GLEDSON, 2005: 125.

${ }^{18}$ CAMILO, 2000: 68.

${ }^{19}$ LOURENÇO, 1994: 247.
} 
dramático (O Crime do Padre Amaro), trágico (Os Maias) não é a do eros platónico, com a sua aspiração para a Beleza-Bem, é a da ausência vivida de relação positiva e durável com o outro, realmente outro ${ }^{20}$.

Com efeito, parece-me que aquilo a que habitualmente se assiste no seu universo ficcional é à erotização da paixão e à sua vivência angustiada.

Ora, o que diz Natureza Pandora a Brás Cubas no seu delírio? «Grande lascivo, espera-te a voluptuosidade do nada» ${ }^{21}$. Ao trazer aqui esta definitiva proclamação feita por Natureza Pandora a Bás Cubas às portas da morte, quero dar cobertura à reclamação que pretendo fazer da proximidade da experiência amorosa e da vivência erótica nos dois autores, pese embora a vulgata que se lhe opõe, e da aplicabilidade das palavras de Eduardo Lourenço escritas a propósito de Eça à ficção machadiana, sobretudo à posterior a Memórias Póstumas de Brás Cubas.

$\mathrm{Na}$ verdade poder-se-ia dizer de Machado algo muito próximo do que Eduardo Lourenço diz de Eça, talvez apenas retirando a dimensão burlesca que nele adquire preferencialmente um modo irónico, como de resto afinal no próprio Eça. Num e noutro dos escritores o amor é vacuidade e irrealização, quer se exprima sob a forma de uma trágica obsessão de ciúme, como em Dom Casmurro, quer sob a forma de um igualmente trágico desengano como n' Os Maias, quer adquira uma tonalidade de desforra irónica, como em Memórias Póstumas de Brás Cubas, ou de diletantismo ironicamente amargo, como na Correspondência de Fradique Mendes.

Aproximo-me portanto do ponto de vista que Alcmeno Bastos exprime nestes termos, referindo-se a Machado, mas que poderíamos tornar extensível a quase toda a obra de Eça, sobretudo a produzida a partir de 1880:

Não são apenas pruridos morais que o impedem de revelar as «coisas mínimas e ignóbeis» que censura no Naturalismo. Não são apenas concepções estéticas de diferenciação entre fato real e fato artístico que o levam ao veto do ato sexual, tornando-o elíptico para o leitor. O momento erótico é concebido pelo narrador machadiano como adequado ao projeto de representação do ser humano como falha. O momento erótico é intransitivo, dispensa antecedentes, não vai a lugar nenhum. Sua figuração geométrica correta poderia ser o círculo, pois nele os pontos são tanto de partida quanto de chegada, e distam por igual do centro ${ }^{22}$.

Eça radicalizará este projeto da representação do ser humano como falha a partir d' Os Maias. Relembre-se inclusivamente a confissão final dos dois amigos Carlos e Ega:

\footnotetext{
${ }^{20}$ LOURENÇO, 1994: 247.

${ }^{21}$ ASSIS, 2014: 588.

${ }^{22}$ BASTOS, 2008: 54.
} 
- Falhámos a vida, menino!

- Creio que sim... Mas todo o mundo mais ou menos a falha. Isto é, falha-se sempre na realidade aquela vida que se planeou com a imaginação ${ }^{23}$.

Mónica Figueiredo, em livro dedicado às relações entre as obras de Machado e Eça, aproxima esta passagem queirosiana de uma fala de Bentinho ${ }^{24}$ em Dom Casmurro, para concluir:

Bento Santiago e Carlos da Maia parecem concordar que a falha é mesmo condição inerentemente humana, e que só mesmo a imaginação/ficção poderia resgatar e preencher os espaços vazios de suas existências igualmente lacunares. Marcados de perto pelo sentimento de falta, essas personagens masculinas parecem destoar do modelo viril erguido pelos valores burgueses, anunciando um bovarismo às avessas ${ }^{25}$.

Porém, o nosso Macário do conto inaugural, Singularidades de uma Rapariga Loira, já transportava essa falha. Macário experimenta o erotismo e o amor como experiência intransitiva pese embora todas as provações por que passa, como numa "quête» medieval, para ganhar a sua dama e, ao mesmo tempo, tem contacto até, pela mediação de Luísa, com a experiência erótica da perversão, se tivermos presente quanto a cleptomania tem sido aproximada pela psicanálise a uma descarga de urgência visando a satisfação de um desejo ao qual está subjacente uma frustração sexual. Ora, no conto A Causa Secreta, Machado de Assis também constrói uma história em torno de um protagonista, Fortunato, que retira prazer da dor alheia. A sua perversão erótica é dada de modo metonímico, descrevendo-o o narrador, sem experimentar qualquer comoção aparente, perante o corpo moribundo da sua bela mulher, do seguinte modo: «fitou o olho baço e frio naquela decomposição lenta e dolorosa da vida, bebeu uma a uma as aflições da bela criatura, agora magra e transparente, devorada da febre e minada de morte» ${ }^{26}$. E para que não restem dúvidas quanto à dimensão erótica do prazer pervertido de Fortunato, o narrador termina sugestivamente o conto, dizendo que, perante a dor incontida do seu melhor amigo, platonicamente apaixonado pela

\footnotetext{
${ }^{23}$ QUEIRÓS, [s.d.]b.: 713-714.

${ }^{24}$ Trata-se de um passo em que Bentinho reflete sobre as impossibilidades de o discurso substituir a vida: «Nada se emenda bem nos livros confusos, mas tudo se pode meter nos livros omissos. Eu, quando leio algum desta outra casta, não me aflijo nunca. O que faço, em chegando ao fim, é cerrar os olhos e evocar todas as coisas que não achei nele. Quantas ideias finas me acodem então! [...]. É que tudo se acha fora de um livro falho, leitor amigo. Assim preencho as lacunas alheias; assim podes também preencher as minhas» (ASSIS, 2014: 1082).

${ }^{25}$ FIGUEIREDO, 2013: 12.

${ }^{26}$ ASSIS, 1998: I, 296.
} 
sua mulher, Fortunato: «saboreou tranquilo essa explosão de dor moral que foi longa, muito longa, deliciosamente longa» ${ }^{27}$.

Já tentei demonstrar num outro momento que o amor interessou Eça de Queirós enquanto desejo, isto é, enquanto manifestação do domínio do fantasmático. A sua ficção dará expressão à força do desejo sulcando a realidade na busca do seu objeto ou do seu substituto. Pode-se dizer que na maioria das vezes buscando o seu substituto fetichista. O mesmo Eduardo Lourenço fala até no carácter «intrinsecamente fetichista, idólatra» do erotismo queirosiano, lembrando as célebres obsessões das suas personagens numa parte do corpo mais à vista (o pé, a mão, o pescoço, o braço), processo de absolutização que funciona como «déclic para a apropriação fantasmática do resto ${ }^{28}$. Não será necessário lembrar o caso exemplar deste processo desviante n' $O$ Primo Basílio a propósito da conhecida fixação erótica de D. Felicidade na pessoa do Conselheiro Acácio, mais propriamente na careca da "conselheiral» figura. Embora neste célebre caso, a formulação seja sarcástica, não é esse o modo mais comum na ficção do autor. O corpo erótico é adivinhado pelo que o pormenor que se vê deixa entrever ou pelo que o ponto de contacto permite pressentir, num jogo de ocultação e desvelamento de caráter metonímico.

Um exemplo do já citado conto Singularidades de uma Rapariga Loira, portanto ainda anterior a $O$ Primo Basílio: o leque com que Luísa se refresca à janela de sua casa, em frente à qual Macário trabalha, do outro lado da rua, e através da qual trocam olhares. Ora escondendo-se, ora mostrando-se por detrás das cortinas, ela manipula o leque num jogo erótico de sedução no qual leque e cortinas funcionam metonimicamente desencadeando o tal déclic erótico. O conto diz:

Leque que preocupou Macário: era uma ventarola chinesa, redonda, de seda branca com dragões escarlates bordados à pena, uma cercadura de plumagem azul, fina e trémula como uma penugem e o seu cabo de marfim, donde pendiam duas borlas de fio de oiro, tinha incrustações de nácar à linda maneira persa.

Era um leque magnífico e naquele tempo inesperado nas mãos plebeias de uma rapariga vestida de cassa. [...] e nem Macário sabia porque é que aquela ventarola de mandarina o preocupava assim: mas segundo ele me disse - aquilo deu-lhe no goto ${ }^{29}$.

Este leque, para além de ser um primeiro indício do engano que Luísa corporizará, desviante relativamente à sua perfeição sem mácula e à sua beleza fria e estereotipada aos olhos de Macário, objeto desajustado numa atmosfera pequeno-burguesa pelo seu

\footnotetext{
${ }^{27}$ ASSIS, 1998: I, 297.

${ }^{28}$ LOURENÇO, 1994: 248.

${ }^{29}$ QUEIRÓS, 2009: 173.
} 
valor e pelas conotações de sensualidade orientalista que no século XIX transportaria, tem também uma forte dimensão fetichista, como já notou Marie-Hélène Piwnik, que o aproximou de uma metáfora do domínio sexual. Aproximação que, aliás, Manoel de Oliveira explora exponencialmente na adaptação que fez, em 2009, do conto ao cinema.

Parece-me poder aplicar-se a Machado o que Eduardo Lourenço diz do carácter intrinsecamente fetichista do erotismo queirosiano. $\mathrm{O}$ princípio da particularização metonímica do corpo feminino (olhos, braços, cabelos, voz, dentes) é uma constante em Machado; a mulher mantém-se como enigma na sua ficção; ela é sempre parte, sempre incompletamente apreendida. Lembre-se, aliás, o modo magistral como Capitú vai sendo a este nível, descrita e apreendida por Bentinho. A totalidade que a consumação sexual permitiria nunca é descrita e o momento erótico autonomiza-se dispensando o ato sexual. Em Memórias Póstumas de Brás Cubas, num momento de um certo encantamento do protagonista por uma jovenzinha, ele tece, em modo irónico, o seguinte comentário, que confirma o ponto de vista que vimos expondo:

Ao contemplá-lo [o vestido da jovem], cobrindo casta e redondamente o joelho, foi que eu fiz uma descoberta sutil, a saber, que a natureza previu a vestidura humana, condição necessária ao desenvolvimento da nossa espécie. A nudez habitual, dada a multiplicação das obras e dos cuidados do indivíduo, tenderia a embotar os sentidos e a retardar os sexos, a passo que o vestuário, negaceando a natureza, aguça e atrai as vontades, ativa-as, reprodu-las, e conseguintemente faz andar a civilização $o^{30}$.

Alcmeno Bastos fala de uma «erótica de gestos incompletos» ${ }^{31}$ em Machado de Assis. Contos como Missa do Galo ou Uns braços são verdadeiras obras-primas deste erotismo intransitivo que conduz à ideia do amor e afinal da vida como experiências de falha, de irrealização.

O protagonista de Missa do Galo diz na primeira linha a impossibilidade de perceber o que lhe aconteceu naquela longínqua noite da sua adolescência, como vimos que também o dizem os protagonistas de Singularidades de uma Rapariga Loira ou de José Matias. O clima densamente erótico que atravessa o conto, conducente a uma "espécie de sonolência» ${ }^{32}$ eletrizante é criado a partir da contemplação dos olhos ora grandes, ora semicerrados, do nariz, da voz, dos dentes, dos braços, das veias azuis da «santa» ${ }^{33}$ e passiva Conceição, da observação do seu «desalinho honesto ${ }^{34}$ a qual, de

\footnotetext{
${ }^{30}$ ASSIS, 2014: 703-704.

${ }^{31}$ BASTOS, 2008: 53.

${ }^{32}$ ASSIS, 1998: I, 393.

${ }^{33}$ ASSIS, 1998: I, 386.

${ }^{34}$ ASSIS, 1998: I, 384.
} 
«apenas simpática, ficou linda, ficou lindíssima» ${ }^{35}$, constata o narrador presa do enlace erótico. Na manhã seguinte, porém, clima e gesto quebraram-se; a falência erótica é evidente: «achei-a como sempre, natural, benigna, sem nada que fizesse lembrar a conversão da véspera» ${ }^{36}$. O objeto de desejo não se deixa capturar ou, dito de outro modo, a nudez total, a despossessão de si próprio inerente à consumação sexual nunca é desvelada nos romances realistas de Machado e de Eça afinal.

Em Uns braços, a dimensão fetichista do episódio erótico que o conto relata é tão forte que aqueles braços, aos quais Inácio se sentia «agarrado e acorrentado» ${ }^{37}$, dão o título ao conto. Os braços confundem-se com a própria D. Severina ao olhar do inocente Inácio. «Via só os braços de D. Severina» ${ }^{38}-$ confessa ele. E neste caso a falha irrompe pela mão de outro elemento fetichista, o xaile com que D. Severina se auto pune após o beijo furtado a Inácio durante o mesmo sono, beijo com o qual Inácio de facto sonhara durante o sono. Este acabará expulso da casa de D. Severina e amor e vida são mais uma vez representados como irrealização. Por isso Alfredo Bosi diz que «o tema do conto não é a paixão mas o seu necessário ocultamento» ${ }^{39}$.

Quero ainda aproximar dois contos dos dois escritores que apresentam grande proximidade na conceção do erotismo como experiência de inanidade e falha, mas que constituem porventura uma modelização se não uma ultrapassagem relativamente aos termos como a questão tem sido por nós colocada até aqui. Estes contos interessam-me particularmente porque nos dois casos também estamos perante narradores incompetentes ou com falta de autoridade, como prefere dizer Abel Barros Baptista, para interpretar os casos singulares que lhes cabe narrar. Refiro-me a José Matias e a A Desejada das Gentes. Nos dois casos estamos perante uma história de recusa da consumação física da relação amorosa e, nos dois casos, tal recusa confina os seus protagonistas com a perfeição. Digamos que nos dois autores somos confrontados com uma «erótica de gestos incompletos» ${ }^{40}$, na expressão acima citada de Alcmeno Bastos, que faculta o acesso ao divino.

José Matias devota a Elisa um amor todo espiritual, todo feito de contemplação, que o leva a nunca casar com a amada, nem na sequência das duas viuvezes dela. Aos seus olhos Elisa é uma deusa a quem só se pode devotar um amor absoluto. A dimensão espiritual, religiosa, ritualista, sagrada e contemplativa do amor que the dedica e dedicará é indiciada por um episódio da época do primeiro casamento de Elisa, em que José Matias se prepara para contemplar a amada a partir da casa vizinha

\footnotetext{
${ }^{35}$ ASSIS, 1998: I, 391

${ }^{36}$ ASSIS, 1998: I, 393.

${ }^{37}$ ASSIS, 1998: I, 300.

${ }^{38}$ ASSIS, 1998: I, 300.

${ }^{39}$ BOSI, 2000: 116 .

${ }^{40}$ BASTOS, 2008: 53.
} 
onde vive. A sua atitude, desde o sorriso «iluminado» e algo beato que sustenta, ao escrúpulo religioso que põe na toilete onde domina o branco, cor ritual a que também Elisa recorre, indiciam a dimensão religiosa da cena que se seguirá envolvendo a contemplação do objeto amado:

Toda a sua atenção se concentrara diante do espelho, no alfinete de coral e pérola, para prender a gravata, no colete branco que abotoava e ajustava com a devoção com que um padre novo, na exaltação cândida da primeira missa, se reveste da estola e do amito para se acercar do altar. Nunca eu vira um homem deitar, com tão profundo êxtase, água de Colónia num lenço! E depois de enfiar a sobrecasaca, de lhe espetar uma soberba rosa, foi com inefável emoção, sem reter um delicioso suspiro, que abriu largamente, solenemente, as vidraças! Introibo ad altarem Deae! Eu permaneci discretamente enterrado no sofá. E, meu caro amigo acredite! Invejei aquele homem à janela, imóvel, hirto na sua adoração sublime, com os olhos e a alma e todo o ser cravados no terraço, na branca mulher calçando as luvas claras, e tão indiferente ao Mundo como se o Mundo fosse apenas o ladrilho que ela pisava e cobria com os pés ${ }^{41}$ !

José Matias nunca abandonará a espera que quer eterna, optando por consumir-se numa adoração intemporal, que, por escolha própria, nunca transmutará em relação carnal. O narrador admite que

Ele gozou nesse amor transcendentemente desmaterializado um encanto sobre-humano. E durante dez anos, [...], caminhou, vivo e deslumbrado, dentro do seu sonho radiante! Sonho em que Elisa habitou realmente dentro da sua alma, numa fusão tão absoluta que se tornou consubstancial com o seu ser ${ }^{42}$ !

José Matias recusar-se-á a casar com Elisa submetendo-se a um processo de degradação humana e social - jogo, alcoolismo, pobreza, marginalidade, em suma -; tudo isto a par da persistência na contemplação extática da amada, até à morte física. Não receia a perda da dignidade quando, andrajoso e alcoolizado, passará a contemplar Elisa escondido num portal em frente a sua casa. Pelo contrário, quando se apercebeu que Elisa o descobrira naquele esconderijo e o procurava com o olhar, José Matias ficou «deslumbrado. E agora avivava desesperadamente o lume, como um farol, para guiar na escuridão os amados olhos dela, e lhe mostrar que ali estava, transido, todo seu, e fiel! $»^{43}$.

${ }^{41}$ QUEIRÓS, 2009: 127-128.

${ }^{42}$ QUEIRÓS, 2009: 128-129.

${ }^{43}$ QUEIRÓS, 2009: 147. 
Com efeito, José Matias, na coerência não humana do seu amor por Elisa, torna-se um deus e um farol para ela, que persistirá deusa aos seus olhos, como provavelmente ele aos dela. Só isso explicará o gesto dela ao mandar o seu amante ao cemitério, na hora do enterro de José Matias, cobri-lo de violetas.

Pela mesma época, no conto A Perfeição (1897), Eça reficcionaliza o episódio da passagem de Ulisses pela ilha de Ogígia. Este contemplou longamente a sua deusa Calipso, concretizou com ela uma relação amorosa divina mas a experiência desse patamar da perfeição levou-o, fatigado, a partir por desejar "a delícia das coisas imperfeitas» ${ }^{44}$. Ao contrário de Ulisses, José Matias entrega-se à contemplação da sua deusa perante «a fadiga das coisas imperfeitas ${ }^{45}$, de que já falara Fradique Mendes, que tudo, para além de Elisa, lhe fazia sentir e experimenta, nesse amor todo transcendência, a perfeição.

Afinal esta "erótica dos gestos incompletos» ${ }^{46}$, ao permitir aceder à divindade funciona como contraprova da inanidade do amor físico, e sexual, talvez devêssemos acrescentar, em Eça.

Mas não será algo do mesmo tipo que acontece no conto de Machado, A Desejada das Gentes? Quer o José Matias queirosiano, quer a Quintília machadiana alcançam a experiência da transcendência através do amor não carnal, facto que os torna a ambos incompreensíveis ou incompletamente explicáveis ao espírito positivo dos seus narradores. Erotismo e falha, experiência erótica e aniquilamento poderão então ser vias de salvação. Não haverá aqui alguns laivos do pensamento de Schopenhauer que segundo John Gledson terá tido alguma responsabilidade na viragem a que se assiste na obra de Machado de Assis com Memórias Póstumas de Brás Cubas ${ }^{47}$ ? E o último Eça, da época da escrita de José Matias e também de Correspondência de Fradique Mendes, lembre-se já agora, não será um leitor de Schopenhauer, na sequência da influência amiga do último Antero de Quental?

Em A Desejada das Gentes, Quintília, «bela, rica, elegante, e da primeira roda» ${ }^{48}$ é a desejada das gentes que se mostra «uma fortaleza inexpugnável» ${ }^{49}$, o que suscita a competição entre dois amigos, entre os quais o narrador. [O conto tem a forma de um diálogo entre narrador e narratário, um pouco como em José Matias, em que o narrador dialoga com um narratário implícito que, porém, nunca assume diretamente

\footnotetext{
${ }^{44}$ QUEIRÓS, 2009: 362.

${ }^{45}$ QUEIRÓS, 2009: 170.

${ }^{46}$ BASTOS, 2008: 53.

${ }^{47}$ Escreve Gledson: «Sugiro, portanto, que houve uma mudança importante em direção a um novo realismo, mais abrangente e coerente, na obra de Machado, e que uma parte muito importante disto foi uma mudança radical no seu tratamento das mulheres e da mulher: o que também é verdade, mas talvez seja mais fácil de entender e até de provar, é que esta mudança foi acompanhada por uma transformação filosófica, e que o contacto com Schopenhauer, conflituoso e criativo, foi central a esta transformação» (GLEDSON, 2005: 198).

${ }^{48}$ ASSIS, 1998: I, 346.

${ }^{49}$ ASSIS, 1998: I, 347.
} 
a palavra.] Os «olhos derramados» ${ }^{50}$ de Quintília, metonímia da força erótica que dela dimana, prendiam todos e não se prendiam a ninguém. Mesmo o narrador que será o seu preferido, o eleito do seu coração e da sua amizade, será reiteradamente desiludido quanto aos seus intentos matrimoniais. Apenas lhe garante, Quintília, que nunca casará, promessa insuficiente para desmobilizar a esperança do seu amado. Acabará por aceitar casar com ele no leito da morte: «abracei-a pela primeira vez, feita cadáver ${ }^{51}$, diz ele.

Apesar da explicação, num primeiro momento positiva e fisiológica do narrador, - "aquela moça tinha ao casamento uma aversão puramente física.» ${ }^{52}$ —, a verdade é que ele reconhece que há mais alguma coisa que transcende a questão puramente física e a explicação positiva para este caso "particularíssimo ${ }^{53}$, como o qualifica. As últimas palavras do conto serão as seguintes: «Casou meio defunta, às portas do nada. Chame-lhe monstro, se quer, mas acrescente divino» ${ }^{54}$. Quintília será um monstro, mas capaz de ascender ao divino, exatamente através daquela «erótica de gestos incompletos» ${ }^{55}$ que, porém, se torna redentora.

Erotismo e falha são afinal caminhos ínvios de dizer ao mesmo tempo a inanidade do amor e o amor como força de redenção em Eça de Queirós e Machado de Assis, escritores maduros e experimentados no limiar da modernidade.

\section{BIBLIOGRAFIA}

ASSIS, Machado de (1998) - Contos: Uma Antologia. Seleção, Introdução e notas de John Gledson. São Paulo: Companhia das Letras, 2 vols.

(2014) - Os Romances de Machado de Assis. Prefácio e fixação de texto de Luís Augusto Fischer; Notas de Olívia Barros de Freitas. Rio de Janeiro/Lisboa: Academia Brasileira de Letras/Glaciar.

BAPTISTA, Abel Barros (2004) - A Emenda de Séneca: Machado de Assis e a Forma do Conto. In DIXON, Paul, coord. - Machado de Assis: the Nation and the World. «Santa Barbara Portuguese Studies», vol. 8. Santa Barbara: University of California, Center for Portuguese Studies, p. 13-45.

BASTOS, Alcmeno (2008) - O corpo metonímico: erotismo em Machado de Assis. "Metamorfoses: Revista da Cátedra Jorge de Sena da Faculdade de Letras da UFRJ», 8. Rio de Janeiro: Cátedra Jorge de Sena; Lisboa: Editorial Caminho, p. 47-61.

BERRINI, Beatriz, org. (2005) - Eça \& Machado. São Paulo: Editora PUC-SP. BOSI, Alfredo (2000) - Machado de Assis. O Enigma do Olhar. São Paulo: Editora Ática.

CAMILO (dos Santos), João (2000) - Machado de Assis, Crítico de Eça de Queirós - Um mal-entendido sintomático. In SARAIVA, Arnaldo, org. - Literatura Brasileira em Questão. Porto: Faculdade de Letras, p. 57-75.

FIGUEIREDO, Mónica (2013) - De vencedores e Vencidos - Machado \& Eça num Encontro. Manaus: UEA Edições.

\footnotetext{
${ }^{50}$ ASSIS, 1998: I, 349.

${ }^{51}$ ASSIS, 1998: I, 354.

${ }^{52}$ ASSIS, 1998: I, 354.

${ }^{53}$ ASSIS, 1998: I, 353.

${ }^{54}$ ASSIS, 1998: I, 354.

${ }^{55}$ BASTOS, 2008: 53.
} 
GLEDSON, John (2005) - Machado de Assis e Eça de Queiroz: a Crítica de 1878 e a Internacionalização do Romance. In BERRINI, Beatriz, org. - Eça e Machado. São Paulo: Editora PUC-SP, p. 115-132.

GOMES, Renato Cordeiro (2008) - Singulares Ocorrências: claro enigma de uma ficção. In DINIZ, Júlio, org. - Machado de Assis (1908-2008). Rio de Janeiro: Editora PUC-Rio/Contraponto, p. 125-133.

LOURENÇO, Eduardo (1994) - O Canto do Signo: Existência e Literatura (1957-1993). Lisboa: Editorial Presença.

NASCIMENTO, José Leonardo do (2007) — «O primo Basílio» na Imprensa Brasileira do Século XIX. São Paulo: Editora UNESP.

QUEIRÓS, Eça de (2009) - Contos I. Edição de Marie-Hélène Piwnik. Lisboa: Imprensa Nacional-Casa da Moeda.

[s.d.]a - A Correspondência de Fradique Mendes. Lisboa: Livros do Brasil. [s.d.]b - Os Maias. Lisboa: Livros do Brasil.

ROSA, Machado da (1979) - Eça, Discípulo de Machado? 2. ed. revista. Lisboa: Editorial Presença. 


\title{
QUALQUER COISA DE INTERMÉDIO. DA ESTESIA À ASTENIA: O SONO ABÚLICO, A MORTE E OUTRAS DERIVAS INTERTEXTUAIS NA POESIA DE MÁRIO DE SÁ-CARNEIRO
}

\author{
JOSÉ RUI TEIXEIRA*
}

Dormir! Adormecer! Sossegar! Ser uma consciência abstrata de respirar sossegadamente, sem mundo, sem astros, sem alma - mar morto de emoção refletindo uma ausência de estrelas!

Fernando Pessoa (2013: 139)

\section{INTROITO}

Foi há cem anos, no dia 26 de abril de 1916, que Mário de Sá-Carneiro pôs fim à sua vida, em Paris. Tinha então 26 anos incompletos e uma obra ainda mais improvável do que a sua vida. No dia 17 de abril escreveu a Fernando Pessoa, na sequência de tantas outras cartas, afirmando que a sua situação, encarada de qualquer forma, era insustentável ${ }^{1}$. Passados alguns dias, no Hotel de Nice, José Araújo testemunha o suicídio de Sá-Carneiro ${ }^{2}$, poeta que não teve, nas palavras de Pessoa, «nem alegria nem felicidade nesta vida»:

Só a arte, que fez ou que sentiu, por instantes o turbou de consolação. São assim os que os deuses fadaram seus. Nem o amor os quer, nem a esperança os busca, nem a glória os acolhe. Ou morrem jovens, ou a si mesmos sobrevivem, incolas de incompreensão ou da indiferença. Este morreu jovem, porque os Deuses lhe tiveram muito amor'.

\footnotetext{
* Universidade Católica Portuguesa, Porto; Cátedra Poesia e Transcendência.

${ }^{1}$ Cf. SÁ-CARNEIRO, 2015: 491.

${ }^{2}$ Cf. DIAS, 1988: 212.

${ }^{3}$ PESSOA, 1924: 41-42.
} 
Mário de Sá-Carneiro nasceu em Lisboa, no dia 19 de maio de 1890. No final de 1892, com apenas dois anos, ficou órfão de mãe. Escreveu os seus primeiros versos em 1903. No ano seguinte, com 14 anos, viajou com o pai pela Europa e conheceu Paris, onde regressou em 1907. Tinha 20 anos, em 1910, quando escreveu o texto dramático Amizade, juntamente com Tomás Cabreira Júnior.

Em outubro de 1911, Mário de Sá-Carneiro matricula-se na Faculdade de Direito da Universidade de Coimbra; mas logo desiste e, passados dois meses, regressa a Lisboa. Em 1912 publica Amizade e Princípio. Em outubro parte para Paris com a intenção gorada de estudar Direito. Regressa a Lisboa em junho de 1913, onde publica Dispersão e A Confissão de Lúcio. Nova estadia em Paris entre junho e setembro de 1914. Em 1915 publica Céu em Fogo e dirige o n. 2 da revista "Orpheu», juntamente com Fernando Pessoa. Parte definitivamente para Paris em julho desse ano.

\section{INTERLÚDIO}

Em julho de 1914, mês em que eclode a Primeira Guerra Mundial, Mário de Sá-Carneiro tem 24 anos; tinham já sido publicados os livros Dispersão e A Confissão de Lúcio $^{4}$. No dia 13 desse mês, o jornal «República» imprime a resposta do jovem poeta a um inquérito sobre o mais belo livro «dos últimos trinta anos». Mário de Sá-Carneiro escolheria aquele que, no seu entendimento, era o mais belo livro português publicado entre 1884 e 1914.

Mesmo que se circunscrevesse à poesia, não lhe faltavam opções: Gomes Leal tinha publicado Claridades do Sul em 1885; no ano seguinte foram impressos os Sonetos Completos de Antero de Quental e, em 1887, Silva Pinto publicou O Livro de Cesário Verde; Oaristos, de Eugénio de Castro, foi impresso em 1890, dois anos antes da edição do Só, de António Nobre; Fel, de José Duro, data de 1898, o mesmo ano da publicação d'O Jardim da Morte, de Júlio Brandão. Em 1914, poetas como Teixeira de Pascoaes e João Lúcio tinham já publicado parte significativa das suas obras.

Eis a resposta de Sá-Carneiro:

À minha vibração emocional, a melhor obra de Arte-escrita dos últimos trinta anos (que a Arte timbra-se para os nervos a vibrarem e não para a inteligência medi-la em lucidez) é um livro que não está publicado - seria com efeito aquele, imperial, que reunisse os poemas inéditos de Camilo Pessanha, o grande ritmista. Ouvindo pela primeira vez dos seus versos, fustigou-me sem dúvida uma das

\footnotetext{
${ }^{4}$ Apesar de ter impresso o ano de 1914 na capa e no frontispício, A Confissão de Lúcio foi escrito entre 1 e 27 de setembro de 1913 e ficou impresso (na Tipografia do Comércio) no dia 1 de novembro desse ano. O mesmo acontece com Dispersão: impresso o ano de 1914 no frontispício, o livro foi composto e impresso na Tipografia do Comércio em 1913, enquanto a capa (também de 1913), da autoria de José Pacheco, foi fotografada e impressa nas Oficinas da «Ilustração Portuguesa».
} 
impressões maiores, mais intensas a Ouro e gloriosas de Alma, da minha ânsia de Artista. Rodopiantes de Novo, astrais de Subtileza os seus poemas engastam mágicas pedrarias que transmudam cores e músicas, estilizando-as em ritmos de sortilégio - cadências misteriosas, leoninas miragens, oscilantes de vago, incertas de Íris. Pompa heráldica, sombra de cristal zebradamente roçagando cetim...

No entanto, para falar de obras impressas, citarei como preferidas o Só de António Nobre, nas suas ternuras de pajem, saudades de luar, febres esguias - e ainda, frisantemente, o livro futurista de Cesário Verde, ondulante de certo, intenso de Europa, zig-zagueante de Esforço ${ }^{5}$.

Apesar de ser notável que Mário de Sá-Carneiro tenha escolhido o Só de António Nobre e O Livro de Cesário Verde, estas escolhas não deixam de ser previsíveis se tivermos em consideração o que tanto Cesário Verde como António Nobre representaram para os poetas do princípio do século XX, independentemente da pluralidade de tendências literárias que emergiram nesse contexto histórico-cultural.

Curiosamente, se as primeiras edições tiveram tiragens limitadas ${ }^{6}$, as segundas edições destes livros tiveram um grande impacto: em 1898 foram impressos três mil exemplares do Só7 e, em 1901, 700 exemplares d'O Livro de Cesário Verde ${ }^{8}$. Em 1914, quando Mário de Sá-Carneiro escolhe estes como os dois mais belos livros publicados em Portugal desde 1884, já tinham sido impressas as suas terceiras edições.

Significativamente improvável é a escolha desse outro livro - «imperial» — que não estava ainda publicado: um livro que reunisse os poemas inéditos de Camilo Pessanha. Só em 1920, por iniciativa de Ana de Castro Osório, são reunidos trinta poemas numa edição sóbria, intitulada «Clepsidra» ${ }^{9}$. E apesar de apenas seis desses poemas serem inéditos, Mário de Sá-Carneiro põe fim à sua vida em abril de 1916, alguns meses antes da publicação (em dezembro desse mesmo ano) de 16 poemas de Camilo Pessanha no primeiro e único número de «Centauro» ${ }^{10}$. Ou seja: Mário de Sá-Carneiro, em 1914, apesar de ter uma visão fragmentária da poesia de Camilo Pessanha, não hesita em considerar o seu livro (seis anos antes da sua impressão) o mais belo dos últimos trinta anos.

\footnotetext{
${ }^{5}$ SÁ-CARNEIRO, 2010: 647.

${ }^{6}$ A $1 .{ }^{a}$ edição d'O Livro de Cesário Verde, impressa em Lisboa (Tipografia Elzeviriana, Rua do Instituto Industrial, 23 a 31), em 1887, teve uma tiragem de 200 exemplares. A 1. a edição do Só de António Nobre, impressa em Paris (Léon Vanier, Éditeur, Quai Saint-Michel, 19), em 1892, teve uma tiragem de 230 exemplares.

${ }^{7}$ Lisboa, Guillard Aillaud \& C. ${ }^{a}$ (Rua Áurea, 242, 1. ${ }^{\circ}$ ), 1898. Como a família se opunha à sua reedição, a procura de exemplares desta 2. ${ }^{\text {a }}$ edição inflacionou drasticamente o preço do livro. Em 1913, a Livraria Aillaud e a Renascença Portuguesa reeditaram-no. Em 1921 é impressa a 4. a edição. Venderam-se cerca de vinte mil exemplares do Só até 1930. ${ }^{8}$ Lisboa, Manuel Gomes, Editor (Rua Garrett, 61), 1901. A 3. a edição seria impressa em 1911 e a 4. ${ }^{a}$ em 1919.

${ }^{9}$ Lisboa, Edições Lusitânia (Tipografia da Travessa da Espera, 26), 1920. Sobre a história editorial da "Clepsidra», cf. SPAGGIARI, 1997: 16-22.

${ }^{10}$ Cf. PESSANHA, 1916: 13-31.
} 
Entre a estesia e a astenia, o vórtice desta reflexão é a intimidade intertextual que Mário de Sá-Carneiro entreteceu com a poesia de Cesário Verde, António Nobre e Camilo Pessanha.

\section{OMNES UNA MANET NOX}

Uma só noite nos espera a todos Esta doença, enfim, que a morte há de curar. Cesário Verde (2004: 59)

O sono abúlico é um leitmotiv frequente na poesia romântica, consequência do cansaço existencial, do taedium vitae, desse spleen em que imergiam languidamente os simbolistas; expressão da desistência, da renúncia, do abandono, resulta da consciência de que são vãs todas as lutas e ilusões, sem mais paroxismos e angústias que as líricas. Antero de Quental é, no século XIX, o mais representativo vate deste leitmotiv, em que o sono abúlico é, por analogia, uma poderosa representação da morte, Antero que «adormece» em Ponta Delgada, nos Açores, com dois tiros, sentado num banco junto ao muro que fecha a cerca do Convento da Esperança, sob uma âncora e a palavra «esperança».

Vários poetas românticos e neorromânticos, de tendência marcadamente elegíaca e noturna, fazem deste leitmotiv uma caixa-de-ressonância para as suas vozes poéticas ${ }^{11}$. É curioso que também Fernando Pessoa, no seu Livro do Desassossego, problematize a analogia entre o sono abúlico e a morte:

Sinto-me às vezes tocado, não sei porquê, de um prenúncio de morte. Ou seja uma vaga doença, que se não materializa em dor e por isso tende a espiritualizar-se em fim, ou seja um cansaço que quer um sono tão profundo que o dormir lhe não basta - o certo é que sinto como se, no fim de um piorar de doente, por fim largasse sem violência ou saudade as mãos débeis de sobre a colcha sentida ${ }^{12}$.

Dos três livros que Mário de Sá-Carneiro escolhe no inquérito do jornal «República», O Livro de Cesário Verde é aquele em que a analogia entre o sono abúlico e a morte não

\footnotetext{
${ }^{11}$ Um dos casos mais impressivos é o de Guilherme de Faria, em cuja poesia se encontram inúmeros exemplos deste leitmotiv: «Morta, na vida, a esperança refloresce/No céu... E a alma, cansada de sofrer,/Na solidão das noites, adormece/Para sonhar, enfim — para viver!» (FARIA, 2013: 72); «Tenho o leito da eterna sepultura,/Para fechar os olhos e dormir?...» (FARIA, 2013: 73); “Dormir... dormir... dormir.../Ah, deixem-me dormir!/Dormir para esquecer/E não mais acordar!” (FARIA, 2013: 223). O poema «Fim» é o que melhor exprime esse sono abúlico e pacificador: «Alma, enfim descansa/Na desesperança.//Alma, esquece e passa:/Dorme, enfim segura/Dessa última graça/Que é toda a ventura. [...] Que Ela há de escutar-te,/Pálida, a entender-te!/E, no espanto enorme,/Sonhando envolver-te,/Triste, há de embalar-te/- 'Dorme... dorme... dorme...' -/Como a adormecer-te» (FARIA, 2013: 177).

${ }^{12}$ PESSOA, 2013: 66.
} 
aparece explicitamente, ainda que sejam muitas as referências funéreas - cemitérios, jazigos, ciprestes - e as paisagens noturnas e decadentistas: a noite que "pesa, esmaga» ${ }^{13}$, na triste cidade baudelairiana que aviva no poeta uma "paixão defunta» ${ }^{14}$, com «as imorais, nos seus roupões ligeiros» ${ }^{15}$, tossindo e fumando, «delírios mornos» ${ }^{16}$ e um «horror calado e triste» ${ }^{17}$, "prenúncios de fraqueza e morte» ${ }^{18}$.

A Morte é uma presença discreta n'O Livro de Cesário Verde, mas impressiva, predominantemente com «M» maiúsculo: «alta e serena» ${ }^{19}$, «sossegado espectro angélico» ${ }^{20}$. E o poeta, cujo «ânimo verga na abstração» ${ }^{21}$ e que «faria que a noite fosse eterna» ${ }^{22}$, passa «tão calado como a Morte» ${ }^{23}$.

Sem nunca estabelecer uma relação direta entre esse cansaço existencial chamemos-lhe tædium vitæ ou spleen - e a morte, Cesário Verde admite que «tudo cansa» ${ }^{24}$, o que o leva a querer «fugir das coisas e dos seres, [...] abandonar a vida» ${ }^{25}$.

Em nenhuma outra obra poética a analogia entre o sono abúlico e a morte é tão intensa como na de António Nobre. Aí, desde os Primeiros Versos, entre anjos ebúrneos e tristes ${ }^{26}$ - anjos, como o poeta, cheios «de spleen profundo» ${ }^{27}$ —, "ofélicas visões» ${ }^{28}$ de noivas mortas e fantasmas do passado, a Morte - também predominantemente com «M» maiúsculo - surge como um «lânguido desmaio» ${ }^{29}$, como desejo de paz, enfim: «Ah, quanto é bom morrer... dormir... sonhar...» ${ }^{30}$; «Morrer, dormir... [...] Dormir na cova» ${ }^{31}$.

$\mathrm{O}$ «Hotel da Cova» é uma imagem recorrente na poesia de António Nobre, bem antes de «Males de Anto», «Meses depois, num cemitério» ${ }^{32}$. Em «A Boa Nova» pode ler-se:

${ }^{13}$ VERDE, 2004: 84 .

${ }^{14}$ VERDE, 2004: 83.

${ }^{15}$ VERDE, 2004: 88 .

${ }^{16}$ VERDE, 2004: 70 .

${ }^{17}$ VERDE, 2004: 22.

${ }^{18}$ VERDE, 2004: 107.

${ }^{19}$ VERDE, 2004:13.

${ }^{20}$ VERDE, 2004: 71.

${ }^{21}$ VERDE, 2004: 115.

22 VERDE, 2004: 28.

${ }^{23}$ VERDE, 2004: 18.

${ }^{24}$ VERDE, 2004: 86.

${ }^{25}$ VERDE, 2004: 60.

${ }^{26}$ Cf. NOBRE, 2000: 74.

${ }^{27}$ NOBRE, 2000: 109.

${ }^{28}$ NOBRE, 2000: 214.

${ }^{29} \mathrm{Cf}$. NOBRE, 2000: 74.

${ }^{30}$ NOBRE, 2000: 63.

${ }^{31}$ NOBRE, 2000: 85 .

${ }^{32}$ NOBRE, 2000: 363. 
Os lençóis com que o coveiro

Nos faz a cama no chão,

Para o sono derradeiro,

Nunca mais se mudarão... ${ }^{33}$

Mais tarde, em «O meu cachimbo», poema escrito em Coimbra, em 1889 (um ano antes de Mário de Sá-Carneiro nascer, em Lisboa), António Nobre pergunta: "Como passar a noite, Amigo!/No Hotel da Cova sem conforto?»" 1895, o coveiro explica a Anto:

Os quartos, meu Senhor, estão tomados,

Mas se quiser na vala (que é de graça...)

Dormem, ali, somente os desgraçados,

Têm bom dormir... bom sítio... ninguém passa... ${ }^{35}$

A analogia entre o sono abúlico e a morte é uma obsessão para António Nobre, particularmente no Só, associada ao descanso alheado de quaisquer angústias — «Ó Morte, quero entrar no teu Recolhimento!...» ${ }^{36}$ - e a uma certa indiferença, mesmo em relação à passagem do tempo: «Séculos tombam uns sobre os outros, como blocos,/E nós (os mortos) dormindo sempre, eternos dorminhocos!» ${ }^{37}$.

Outras vezes a comparação estabelece-se com o sono de uma criança, como n' «O sono do João» ${ }^{38}$ ou em «Ladainha»:

E tem tão bom dormir essa criança,

Deitou-se, ali caiu, ali ficou.

Dorme, menino! dorme, dorme, dorme!

O que te importa o que no mundo vai?

[...]

Dorme, criança! dorme sossegada,

Teus sonos brancos ainda por abrir:

\footnotetext{
${ }^{33}$ NOBRE, 2000: 103.

${ }^{34}$ NOBRE, 2000: 253.

${ }^{35}$ NOBRE, 2000: 364.

${ }^{36}$ NOBRE, 2000: 268.

${ }^{37}$ NOBRE, 2000: 265.

${ }^{38}$ «Na vida que a Dor povoa,/Há só uma coisa boa,/Que é dormir, dormir, dormir.../Tudo vai sem se sentir.» (NOBRE, 2000: 294).
} 
Depois, a Morte não te custa nada,

Porque a ela habituaste-te a dormir... ${ }^{39}$

Mais do que Cesário Verde, António Nobre convoca a morte para contextos de profunda intimidade poética, não só por meio da familiaridade com os coveiros, com jazigos e cemitérios, com os mortos. Em «O meu noivado» ${ }^{40}$, poema de 1886 , Nobre noiva com a morte que, depois, assumirá uma intimidade diferente: será a ama, aconchego nessa outra infância em que o poeta pressente o seu fim, como se lê em "António»:

A Morte, agora, é a minha Ama

Que bem que sabe acalentar!

$[\ldots]$

A noite, quando estou na cama:

«Nana, nana, que a tua Ama

Vem já, não tarda! Foi cavar...»

Ou em «Males de Anto», «Meses depois, num cemitério»:

Vamos! depressa! Vem, faze-me a cama,

Que eu tenho sono, quero-me deitar!

O velha Morte, minha outra ama!

Para eu dormir, vem dar-me de mamar... ${ }^{41}$

[...]

Toma lá para ti, guarda. E ouve: na hora

Final, quando a Trombeta além se ouvir,

Tu não me venhas acordar, embora

Chamem... Ah deixa-me dormir, dormir!

Deus

Dorme, dorme ${ }^{42}$.

Insone ${ }^{43}$, sem esperança, cansado de viver, inúmeras vezes António Nobre admite que seria «melhor dormir, eternamente!» ${ }^{44}$, deixando espalhado na sua poesia um incontido rumor suicidário. É curioso que a tendência suicida de António Nobre é

\footnotetext{
${ }^{39}$ NOBRE, 2000: 287.

${ }^{40}$ NOBRE, 2000: 100-101.

${ }^{41}$ NOBRE, 2000: 363.

${ }^{42}$ NOBRE, 2000: 366.

${ }^{43}$ «Pois pouco dorme quem muito sofreu.» (NOBRE, 2000: 384).

${ }^{44}$ NOBRE, 2000: 305.
} 
mais evidente na leitura da sua poesia ${ }^{45}$ do que na biografia escrita por Guilherme de Castilho ${ }^{46}$. O poeta que aí nos aparece descrito, não só vive empenhado na sua singradura profissional, essa carreira diplomática idealizada e sempre adiada, como busca - numa espécie de demanda espiritual - a cura para a doença que acabaria por matá-lo. Talvez a doença, ao trazer-lhe a iminência da morte, lhe diminuísse o desejo de morrer; talvez os efeitos da doença atenuassem o seu temperamento suicida, ou talvez o modo como buscou a cura, de desengano em desengano, numa desoladora errância, lhe tivesse possibilitado uma maior intimidade com a morte. A vida de António Nobre é uma metáfora do desterro e a sua poesia, com uma admirável inteligência emocional e estética, borda-se em elegia e melopeia de diáspora. E a morte torna-se íntima, progressivamente mais íntima.

Quantas vezes o poeta se entrega nos braços da funérea ama ou a si mesmo se embala: «Faze por dormir, meu coração!» ${ }^{47}$; «Meu Coração, vai-te deitar! [...] Sinto-me farto de viver: [...] Não batas mais! vamos morrer... [...] Basta, por Deus! vamos dormir...» ${ }^{48}$.

A Torre Eiffel não tinha ainda dois anos quando, no dia 26 de outubro de 1890, António Nobre chega a Paris. Só em janeiro de 1895 terminaria o seu exílio nesta cidade, por estas ruas onde, desesperado, «andou em soluços e falando alto» ${ }^{49}$, como se lê numa carta a Alberto d'Oliveira, com a consciência de que não tinha «já ninguém no mundo» ${ }^{50}$ e com vontade de regressar a Portugal: «Apetece-me ir embora. Paris é horrível ${ }^{51}$. António Nobre, incapaz de se integrar, queixa-se a Manuel da Silva Gaio desse «banal Paris, embirrento de civilização» ${ }^{52}$. Lê-se numa outra carta, enviada a José de Castro: «Amei Paris como nunca o amara. Vi arte nova, fiz anarquismo platónico [...], quis iludir-me a mim próprio [...]. Cansei-me, desgostei-me e recolhi de novo ao meu claustro» ${ }^{53}$.

Num poema de 1897, António Nobre denuncia ainda as cicatrizes desse spleen de Paris ${ }^{54}$, sente-se puído pelo sofrimento, deseja encontrar a paz num sono abúlico que o alheie da vida. A estesia dá lugar à disforia e, no final, é um poeta asténico que simbolicamente desmaia sobre os seus próprios versos:

\footnotetext{
${ }_{45}^{45}$ «horemos, abracemo-nos, unidos!/Que fazer? Porque não nos suicidamos?» (NOBRE, 2000: 311); «Não busco a morte com arma ou veneno,/Mas enfim pode vir quando quiser./Eu estarei de pé, firme e sereno,/Sorrir-lhe-ei até quando vier.» (NOBRE, 2000: 383); «Ai quantas vezes, ao passar junto ao Tejo,/Perdoa-me, Senhor! pensei em me afogar!» (NOBRE, 2000: 399).

${ }^{46}$ CASTILHO, 1950.

${ }^{47}$ NOBRE, 2000: 352.

${ }^{48}$ NOBRE, 2000: 289.

${ }^{49}$ NOBRE, 1982: 144.

${ }^{50}$ NOBRE, 1982: 146.

${ }^{51}$ NOBRE, 1982: 146.

${ }^{52}$ NOBRE, 1982: 173.

${ }^{53}$ NOBRE, 1982: 214.

${ }^{54}$ «Basta de livros, basta de livreiros!/Sinto-me farto de civilização!» (NOBRE, 2000: 405).
} 
E quando, enfim, já farto de sofrer,

Eu um dia me for adormecer

Para onde há paz, maior que num convento:

Cobri-me de vestes, ó folhas d'Outono,

Ai não me deixeis no meu abandono!

Chorai-me ciprestes, batidos ao vento... ${ }^{55}$

\section{MEMENTO MORI}

Lembra-te de que morrerás Lembrando ruinas, sepulturas rasas... Camilo Pessanha (1997: 65)

No dia 14 de outubro de 1912, o jornal O Mundo noticia que Mário de Sá-Carneiro, «um dos mais inteligentes rapazes da moderna geração», tinha partido no dia anterior para Paris, no sud-express. Da estação do Rossio à gare d'Orsay, «cheio de boas intenções e com a esperança de uma carreira auspiciosa» ${ }^{56}: 22$ anos depois de António Nobre, Mário de Sá-Carneiro chega a Paris.

Por esses dias, Alberto Osório de Castro visita Camilo Pessanha em Macau, onde o poeta tinha reassumido a função de conservador do Registo Predial. No dia 13 de dezembro desse mesmo ano de 1912, de Paris, Sá-Carneiro escreve a Pessoa: «Rogava-lhe encarecidamente que me enviasse, para mostrar ao Santa-Rita, os "Violoncelos" do Pessanha e o soneto sobre a mãe - e mesmo mais alguns se para isso estivesse. Era um favor que muito lhe agradecia. Tem apanhado mais versos dele? $\aleph^{57}$.

Percebe-se já nestas palavras o fascínio que, em 1914, suscitará a resposta ao inquérito sobre o mais belo livro «dos últimos trinta anos», a escolha do «grande ritmista», em cuja poesia Mário de Sá-Carneiro via «cadências misteriosas, leoninas miragens, oscilantes de vago, incertas de Íris. Pompa heráldica, sombra de cristal zebradamente roçagando cetim...» ${ }^{58}$.

Também na poesia de Camilo Pessanha o sono abúlico é um leitmotiv importante, no diálogo íntimo que estabelece com a morte. Entre poemas tão impressivos, como «Interrogação» ${ }^{59} \mathrm{e}$ "Violoncelo» ${ }^{60}$, encontramos a morte intimamente vagando na «quietação do olvido», ingénua como uma «inscrição tumular»"

\footnotetext{
${ }^{55}$ NOBRE, 2000: 406.

${ }^{56}$ Cf. DIAS, 1988: 119.

${ }^{57}$ SÁ-CARNEIRO, 2015: 49.

${ }^{58}$ SÁ-CARNEIRO, 2010: 647.

${ }^{59}$ PESSANHA, 1997: 109.

${ }^{60}$ PESSANHA, 1997: 129.

${ }^{61}$ PESSANHA, 1997: 89.
} 
Clepsidra - logo na «Inscrição» — desafia a um processo de desterritorialização ou, mais profundamente, de sumição:

Eu vi a luz em um país perdido.

A minha alma é lânguida e inerme.

Oh! Quem pudesse deslizar sem ruído!

No chão sumir-se, como faz um verme... ${ }^{62}$

Seguem-se um "cómico defunto» e uma "plateia que ri, perdidamente»"; da mãe, «à neve,/De noite a mendigar às portas dos casais» ${ }^{64}$; e algumas perguntas: «Quem poluiu, quem rasgou os meus lençóis de linho,/Onde esperei morrer [...]?»"65; ou: «Quem sabe a dor que sem razão deplora?»" ${ }^{66}$.

Camilo Pessanha, que não se inibe de chamar a morte - «Ó morte, vem depressa» ${ }^{67}$ —, escolhe morrer devagar: estésico e asténico, em 1895 (ou 1896), numa carta a Ana Osório de Castro, vítima de um doloroso drama psicológico-moral e de um contínuo processo de degradação íntima, escreve: «Sabe que eu também ando por esses mares fora sempre a escolher o melhor lugar da minha sepultura» ${ }^{68}$.

Acentuando a dimensão disfórica da poesia de Camilo Pessanha, José Carlos Seabra Pereira refere a atitude derrotista que se manifesta num ceticismo fenomenista que em tudo vê contingência, aparência e efemeridade; o fatalismo, a ausência de alternativa feliz para a sua condição, a expectativa da morte, a aguda convicção da inconstância do mundo e da vida, a perecibilidade dos poderes e forças das criaturas, a fugacidade da ventura. Camilo Pessanha «funde em múltiplos poemas, o desengano com a mundividência fatalista e pessimista, de par com os consequentes apelos à apatia» ${ }^{69}$.

Quantos poetas escutaram atentamente os repetidos apelos de António Nobre e de Camilo Pessanha para refrear a sensibilidade e para o sono abúlico e alheado? Tal como em António Nobre ou Camilo Pessanha, em Mário de Sá-Carneiro ganhará particular coerência o tópico, frequente na lírica decadentista, da aspiração ao derradeiro adormecimento, a entrega a uma mors liberatrix que as diletas imagens do ciclo rural ironicamente inculcam como continuidade natural da vida:

\footnotetext{
${ }^{62}$ PESSANHA, 1997: 61.

${ }^{63}$ PESSANHA, 1997: 69.

${ }^{64}$ PESSANHA, 1997: 81.

${ }^{65}$ PESSANHA, 1997: 81.

${ }^{66}$ PESSANHA, 1997: 131.

${ }^{67}$ PESSANHA, 1997: 187.

${ }^{68}$ Cf. PEREIRA, 2003: 49-50.

${ }^{69}$ PEREIRA, 2003: 60.
} 
Porque o melhor, enfim,

É não ouvir nem ver...

Passarem sobre mim

E nada me doer!

[...]

Passar o estio, o outono,

A poda, a cava, e a redra,

E eu dormindo um sono

Debaixo duma pedra ${ }^{70}$.

[...]

E eu sob a terra firme,

Compacta, recalcada,

Muito quietinho. A rir-me

De não me doer nada ${ }^{71}$.

E assim Camilo Pessanha, «a medo na aresta do futuro,/Embebido em saudades do presente...» ${ }^{72}$, escutou "o correr da água na clepsidra» e aconselhou: "Cessai de cogitar, o abismo não sondeis./[...] Adormecei. Não suspireis. Não respireis» ${ }^{73}$. E escreveu de si próprio:

Desce por fim sobre o meu coração

O olvido. Irrevogável. Absoluto.

Envolve-o grave como véu de luto.

Podes, corpo, ir dormir no teu caixão.

[...]

Dorme enfim sem desejo nem saudade ${ }^{74}$.

Com a consciência de uma fé frágil, de uma fé perdida ou desgastada nas agruras e nas vicissitudes da vida, tal como Cesário Verde ${ }^{75}$ e António Nobre ${ }^{76}$, Camilo Pessanha procura alhear-se de Deus... e lamenta-o, até porque se pressente, implícita na sua

\footnotetext{
${ }^{70}$ PESSANHA, 1997: 171.

${ }^{71}$ PESSANHA, 1997: 173.

${ }^{72}$ PESSANHA, 1997: 147.

${ }^{73}$ PESSANHA, 1997: 141.

${ }^{74}$ PESSANHA, 1997: 159.

${ }^{75}$ «Nós ignoramos, sem religião,/Ao rasgarmos caminho, a fé perdida» (VERDE, 2004: 124).

${ }^{76}$ «Pedi-te a fé, Senhor! pedi-te a graça,/mas não te curvas nunca p’ra me ouvir» (NOBRE, 2000: 383 ); «Não creio em nada! e fui tão religioso!» (NOBRE, 2000: 395).
} 
poesia, uma profunda tensão espiritual, eivada de uma saudade de si próprio, uma saudade da infância e uma saudade desse Deus que seria lenitivo para o desterro e impediente do afundamento:

Eu mesmo quero a fé, e não a tenho...

- Um resto de batel - quisera um lenho,

Para não afundir na treva imensa,

O Deus, o mesmo Deus que te fez crente...

Nem saibas que esse Deus omnipotente

Foi quem arrebatou a minha crença ${ }^{77}$.

\section{OMNES EODEM COGIMUR}

Somos todos impelidos para o mesmo lugar

Muitas vezes o artista, para remédio da sua angústia, pensava no suicídio. E então dilacerava-o uma ternura infinita, uma piedade ilimitada por si próprio. Pois havia de se destruir, ele?... Sim, era essa talvez a salvação... [...] É que, mesmo não se suicidando, havia de morrer mais tarde. Ainda se, ao menos, o não suicidar-se lhe evitasse a morte...

Mário de Sá-Carneiro (2010: 461)

Confesso que me agradam leituras hermenêuticas que não prescindem de perspetivas biografistas, sobretudo em poetas que se situam a uma distância temporal que permita um campo de visão mais alargado sobre as suas vidas e obras. Acredito que, na generalidade dos casos, a vida e a obra de um autor são indissociáveis, assim como o seu contexto histórico-cultural; sendo que é o seu temperamento, mais do que as suas qualidades, que determina na sua obra o grau de cravação dessa experiência humana, em lato sensu, que ainda assim não se traduz literalmente numa narrativa biográfica. Por isso, independentemente dos filtros com que cada poeta gere a intensidade dos efeitos da idiossincrasia na sua obra, agrada-me a intencionalidade de urdidura do mito, ou seja: há poetas que, ao invés de deixar na sua obra um rasto de materiais autobiográficos, conformam a sua existência com um propósito de magnum opus.

Há, assim, um poeta que Mário de Sá-Carneiro representa e que confere uma insólita coerência às interseções em que se cruzam invariavelmente fragmentos da sua

${ }^{77}$ PESSANHA, 1997: 193. 
narrativa biográfica, do seu epistolário e de uma obra que, tendo sido fundamentalmente escrita em cinco anos, só enganadoramente se arruma num volume.

Não tenho a pretensão de apresentar uma proposta de leitura hermenêutica geral da obra poética de Sá-Carneiro, poeta de que guardo ainda as impressões que na minha adolescência suscitou a primeira leitura da sua poesia: uma acentuada tendência para a alucinação, um onirismo insone, clivagens irredimíveis de identidade e um expressivo bestiário de sensações e sinestesias.

Numa carta de 24 de agosto de 1915, enviada a Fernando Pessoa, Mário de Sá-Carneiro escreve: «Para mim basta-me a beleza - e mesmo errada, fundamentalmente errada. Mas beleza: beleza retumbante de destaque e brilho, infinita de espelhos, convulsa de mil cores - muito verniz e muito ouro: teatro de mágicas e apoteoses com rodas de fogo e corpos nus» ${ }^{78}$. Tendo partido para Paris em julho desse ano, Sá-Carneiro desiste de «Orpheu» e afasta-se poeticamente de Pessoa; o caminho que escolhe não coincide com o sentido de uma «terrível e religiosa» missão muito para além da poesia, nos termos em que Pessoa tinha escrito a Côrtes-Rodrigues no princípio de 1915. Sá-Carneiro escolhe uma «arte sem remissão» ${ }^{79}$.

Não importa aqui compartimentá-lo. Como refere Fernando Cabral Martins, «tem a crítica recorrido aos modos de ser do Romantismo como tom, do SimbolismoDecadentismo como escrita e da Vanguarda como desejo ${ }^{80}$. Sá-Carneiro não abdicou de formas de versificação tradicional, do soneto, da redondilha, da quadra. Pode ter sido (neor)romântico, simbolista, futurista... mas nunca se deixou domesticar por uma tendência ou segmento geracional, tendo escolhido uma estética intersecionista, em que o belo «é tudo o que nos provoca a sensação do invisível ${ }^{81}$, ou seja: «tudo o que rompe a lisura das superfícies» ${ }^{82}$.

$\mathrm{Na}$ sua poesia, a analogia entre o sono abúlico e a morte assume contornos particularmente dramáticos, formulada logo no início de Dispersão, programa de sumição em que Mário de Sá-Carneiro revela «um desejo de fugir» ${ }^{83}$, uma nostalgia "de além» ${ }^{84}$, um desejo incontido e ascensional «de subir além dos céus» ${ }^{85}$, de «Viajar outros sentidos, outras vidas» ${ }^{86}$.

Numa poesia intensamente sinestésica, Sá-Carneiro confessa: «Sei a Distância» e «Vêm-me saudades de ter sido Deus...» ${ }^{87}$. E numa reminiscência d" «O palácio da

\footnotetext{
${ }^{78}$ SÁ-CARNEIRO, 2015: 364.

${ }^{79}$ MARTINS, 1996: 19.

${ }^{80}$ MARTINS, 1996: 20.

${ }^{81}$ SÁ-CARNEIRO, 2015: 429.

${ }^{82}$ MARTINS, 1996: 21.

${ }^{83}$ SÁ-CARNEIRO, 1996: 27.

${ }^{84}$ SÁ-CARNEIRO, 1996: 27.

${ }^{85}$ SÁ-CARNEIRO, 1996: 27.

${ }^{86}$ SÁ-CARNEIRO, 1996: 28.

${ }^{87}$ SÁ-CARNEIRO, 1996: 29.
} 
ventura» ${ }^{88}$, de Antero de Quental, num processo mais profundo de ensimesmamento, lê-se em «Escavação»:

Numa ânsia de ter alguma cousa,

Divago por mim mesmo a procurar,

Desço-me todo, em vão, sem nada achar,

E a minhialma perdida não repousa.

[...]

E cinzas, cinzas só, em vez de fogo...

- Onde existo que não existo em mim?

Um cemitério falso sem ossadas,

Noites d'amor sem bocas esmagadas -

Tudo outro espasmo que princípio e fim... ${ }^{89}$

Da estesia à astenia: «É só de mim que eu ando delirante —/Manhã tão forte que me anoiteceu» ${ }^{90}$. Uma estesia egótica, cuja intensidade o condena a uma astenia mortificante, a uma insofreável "Vontade de dormir», título de um poema escrito em Paris, em 1913, em que Sá-Carneiro confessa: «Ai que saudades da morte...//[...] Quero dormir...» ${ }^{91}$; num lirismo elegíaco e noturno que lembra o Só de António Nobre.

Labiríntico, saudoso de si próprio ${ }^{92}$, Mário de Sá-Carneiro revela uma disforia premente, uma espécie de enfermidade que não é bem tristeza, nem é só saudade e que tem a ver com o facto de certos poetas serem ainda aqueles seres humanos que existem mais desapaixonadamente, porque por instantes conheceram uma beleza incontida e inefável, um milagre, e parece-lhes trágico ter de suportar o resto da vida. De resto, o suicídio nimbou de uma sinceridade impressiva versos como os de $"$ Quase» ${ }^{93}$, de «Como eu não possuo» ${ }^{94}$ ou de «Além-tédio»:

\footnotetext{
${ }^{88}$ QUENTAL, 2001: 248.

${ }^{89}$ SÁ-CARNEIRO, 1996: 30.

${ }^{90}$ SÁ-CARNEIRO, 1996: 34.

${ }^{91}$ SÁ-CARNEIRO, 1996: 35.

${ }^{92}$ No poema «Dispersão» percebe-se a dramaticidade da disforia ontológica e existencial de Sá-Carneiro: «Perdi-me dentro de mim/Porque eu era labirinto,/E hoje, quando me sinto,/É com saudades de mim». E adiante: «Nem dei pela minha vida...»e «Para mim é sempre ontem» (SÁ-CARNEIRO, 1996: 36).

${ }_{93}$ «Um pouco mais de sol - eu era brasa,/Um pouco mais de azul - eu era além./Para atingir, faltou-me um golpe d'asa...» (SÁ-CARNEIRO, 1996: 42); «Num ímpeto difuso de quebranto,/Tudo encetei e nada possuí.../Hoje, de mim, só resta o desencanto/Das coisas que beijei mas não vivi...» (SÁ-CARNEIRO, 1996: 43).

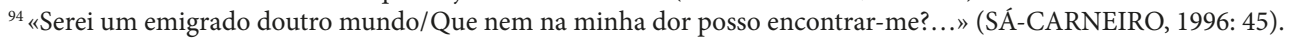


Nada me expira já, nada me vive -

Nem a tristeza nem as horas belas.

De as não ter e de nunca vir a tê-las,

Fartam-me até as coisas que não tive.

Como eu quisera, enfim d'alma esquecida,

Dormir em paz num leito d'hospital...

[...]

E doente-de-Novo, fui-me Deus

No grande rasto fulvo que me ardia.

Ecoando-me em silêncio, a noite escura

Baixou-me assim na queda sem remédio;

Eu próprio me traguei na profundura,

Me sequei todo, endureci de tédio ${ }^{95}$.

Entre esse «Novo» que lhe ungiu os olhos - os seus olhos futuristas, os seus olhos cubistas, os seus olhos interseccionistas ${ }^{96}$ - e a consciência de que vinha "d'Outro tempo a luz» ${ }^{97}$ que o iluminava, Mário de Sá-Carneiro imerge nessa "Insónia roxa. A luz a virgular-se em medo» ${ }^{98}$, o quebranto.

O efeito da luz crepuscular é essencial para perceber o sono, a abulia que induz a sonolência ${ }^{99}$. «Hoje a luz para mim é sempre meia-luz...» ${ }^{100}$, escreve em 1914. A vida de todos e de todos os dias tornava-se um expediente insuportável, como se percebe em «Mistério», novela de Céu em Fogo:

No fundo queria muito à vida. [...] Simplesmente amava uma vida despida de tudo quanto nela o nauseava. Ora o que o nauseava era precisamente a vida de todos e de todos os dias... Não, estava decidido, não fora feito para a felicidade. $O$ remédio era outro: renunciar, vivendo, ou vencer, morrendo ${ }^{101}$.

\footnotetext{
${ }^{95}$ SÁ-CARNEIRO, 1996: 46.

${ }^{96}$ SÁ-CARNEIRO, 1996: 59.

${ }^{97}$ SÁ-CARNEIRO, 1996: 71.

${ }^{98}$ SÁ-CARNEIRO, 1996: 74.

${ }^{99}$ Como se lê n' "A queda»: «Tudo me resvala/Em bruma e sonolência. [...] Tombei.../E fico só esmagado sobre mim!...» (SÁ-CARNEIRO, 1996: 51).

${ }^{100}$ SÁ-CARNEIRO, 1996: 81.

${ }^{101}$ SÁ-CARNEIRO, 2010: 463.
} 
Como nas palavras de Camilo Pessanha - «Dir-se-ia que rezas./Murmuras baixinho/Não sei que tristezas.... ${ }^{102}-$, pressente-se na poesia de Sá-Carneiro um rumor, como uma ladainha ou uma melopeia, a tensão que culmina nestes versos:

Eu não sou eu nem sou o outro,

Sou qualquer coisa de intermédio:

Pilar da ponte de tédio

Que vai de mim para o Outro ${ }^{103}$.

Tensão que, como afirma Cabral Martins, não é «da ordem da crise ou da confusão, mas da ordem do cataclismo e da rutura. O narcisismo de Sá-Carneiro [...] é afinal a transformação dessa perda de eu num motivo-raiz» ${ }^{104}$. Algures entre o que é e o que não é, consciente de que por sobre o que não é há grandes pontes ${ }^{105}$, ali tão perto dos seus «boulevards de Europas e beijos» onde foi só um espectador ${ }^{106}$; tão perto desses cafés de Paris onde esperou a vida que nunca veio ter consigo ${ }^{107}$. Esse extraordinário Sá-Carneiro, lord que foi de «Escócias doutra vida» ${ }^{108}$, que atapetou a vida contra si e contra o mundo ${ }^{109}$, que errou e achou mais belo ter errado ${ }^{110}$.

E se Paris não foi tão inevitável para nenhum outro poeta português como foi para Mário de Sá-Carneiro, para nenhum outro poeta a existência quotidiana se tornou um dispêndio tão excessivo. Em «Recreio», poema de outubro de 1915, encontra-se a afirmação de um suicídio por negligência:

Na minha alma há um balouço

Que está sempre a balouçar -

Balouço à beira dum poço,

Bem difícil de montar...

- E um menino de bibe

Sobre ele sempre a brincar...

Se a corda se parte um dia,

(E já vai estando esgarçada),

\footnotetext{
${ }^{102}$ PESSANHA, 1997: 135.

${ }^{103}$ SÁ-CARNEIRO, 1996: 80.

${ }^{104}$ MARTINS, 1996: 10.

${ }^{105}$ SÁ-CARNEIRO, 1996: 94.

${ }^{106}$ SÁ-CARNEIRO, 1996: 98.

${ }^{107}$ Cf. SÁ-CARNEIRO, 1996: 117.

${ }^{108}$ SÁ-CARNEIRO, 1996: 121.

${ }^{109}$ Cf. SÁ-CARNEIRO, 1996: 104.

${ }^{110}$ Cf. SÁ-CARNEIRO, 1996: 98.
} 
Era uma vez a folia:

Morre a criança afogada...

- Cá por mim não mudo a corda [...]

[...] Deixá-lo

Balouçar-se enquanto vive...

- Mudar a corda era fácil...

Tal ideia nunca tive... ${ }^{111}$

Em março/abril de 1906, com apenas 14 anos e dez anos antes do suicídio, Mário de Sá-Carneiro escreve as «Recordações de um moribundo», onde a analogia entre o sono abúlico e a morte aparece explícita: «A morte de mim já se aproxima/[...] Morrer eu desejava ardentemente/Porque não mais padecerei,/Porque dormirei eternamente» ${ }^{112}$.

Passados dez anos, no culminar de íntimos desenganos ${ }^{113}$, Sá-Carneiro exprime poeticamente a aspiração ao derradeiro adormecimento, a entrega a uma mors liberatrix, sem imagens edificantes nem aforismos estoicos. Ligeiramente gongórico, tanto quanto a sua sensibilidade lhe exigia, Sá-Carneiro escreve "Caranguejola», em novembro de 1915, poema paroxísmico e abúlico:

Larguem-me! Deixem-me sossegar...

[...]

E eu aninhado a dormir, bem quentinho - que amor...

Sim: ficar na cama, nunca mexer, criar bolor -

$[\ldots]$

Deixa-te de ilusões, Mário. Bom édredon, bom fogo E não penses no resto. [...]

Desistamos. A nenhuma parte a minha ânsia me levará.

[...]

Daqui a vinte anos a minha literatura talvez se entenda -

E depois estar maluquinho em Paris, fica bem, tem certo estilo...

\footnotetext{
${ }^{111}$ SÁ-CARNEIRO, 1996: 122.

${ }^{112}$ SÁ-CARNEIRO, 1996: 192.

${ }^{113}$ No final de «Desquite», poema de julho de 1915: «Que desbaratos os meus voos;/Ai, que espantalho a minha cruz...» (SÁ-CARNEIRO, 1996: 131).
} 


\section{$[\ldots]$}

Nada a fazer [...]. O menino dorme. Tudo o mais acabou ${ }^{114}$.

E se «Aquele outro» ${ }^{115}$, poema de fevereiro de 1916, nos silencia perturbadoramente, como o silêncio agónico que precede a morte, batam agora em latas, "Chamem palhaços e acrobatas» ${ }^{116}$, Mário de Sá-Carneiro morreu. Foi há cem anos.

\section{EPÍLOGO}

No final de março escreve a Pessoa, de certo modo justificando o seu suicídio. Trata-se de uma carta desconcertante, uma daquelas cartas de despedida que guarda algo que «ninguém sabe ao certo»:

Meu querido Amigo,

A menos de um milagre [...], o seu Mário de Sá-Carneiro tomará uma forte dose de estricnina e desaparecerá deste mundo.

$\hat{E}$ assim tal e qual - mas custa-me tanto a escrever esta carta pelo ridículo que sempre encontrei nas «cartas de despedida»...

Não vale a pena lastimar-me, meu querido Fernando: afinal tenho o que quero: o que tanto sempre quis - e eu, em verdade, já não fazia nada por aqui... Já dera o que tinha a dar.

Eu não me mato por coisa nenhuma: eu mato-me porque me coloquei pelas circunstâncias - ou melhor: fui colocado por elas, numa áurea temeridade - numa situação para a qual, a meus olhos, não há outra saída. Antes assim. É a única maneira de fazer o que devo fazer.

Vivo há 15 dias uma vida como sempre sonhei: tive tudo durante eles: realizada a parte sexual, enfim, da minha Obra - vivido o histerismo do seu ópio, as luas zebradas, os mosqueiros roxos da sua Ilusão.

Podia ser feliz mais tempo, tudo me corre, psicologicamente, às maravilhas: mas não tenho dinheiro. [...]

Pelo mesmo correio (ou amanhã) registadamente enviarei o meu caderno de versos que você guardará e de que você pode dispor para todos os fins como se fosse seu. Pode fazer publicar os versos em volume, em revistas, etc.

Deve juntar aquela quadra: "Quando eu morrer batam em latas», etc.

\footnotetext{
${ }^{114}$ SÁ-CARNEIRO, 1996: 132-133.

${ }^{115}$ SÁ-CARNEIRO, 1996: 144.

${ }^{116}$ SÁ-CARNEIRO, 1996: 142.
} 
Perdoe-me não the dizer mais nada: mas não só me falta o tempo e a cabeça como acho belo levar comigo alguma coisa que ninguém sabe ao certo, senão eu. Não me perdi por ninguém: perdi-me por mim, mas fiel aos meus versos:

Atapetemos a vida

Contra nós e contra o mundo...

Atapetei-a sobretudo contra mim - mas que me importa se eram tão densos os tapetes, tão roxos, tão de luxo e festa... [...]

Todo o meu afeto e a minha gratidão por você, meu querido Fernando Pessoa, num longo, num interminável abraço de Alma.

O seu, seu

Mário de Sá-Carneiro ${ }^{117}$

No dia 26 de abril de 1916, Mário de Sá-Carneiro suicida-se em Paris. Foi enterrado no Cemitério de Pantin, no dia 29 de abril. Em 1949 os seus ossos foram dispersos na vala comum do cemitério, mais de 50 anos depois dos versos de António Nobre:

Os quartos, meu Senhor, estão tomados,

Mas se quiser na vala (que é de graça...)

Dormem, ali, somente os desgraçados,

Têm bom dormir... bom sítio... ninguém passa... ${ }^{118}$

Estésico, disfórico, asténico: perante os seus olhos interseccionistas abriu-se «o vórtice em que as imagens se tornam outras imagens, outras vozes. Um carrossel, onde volteiam vislumbres, ápices, sombras, indícios de oiro» ${ }^{119}$.

\section{BIBLIOGRAFIA}

CASTILHO, Guilherme de (1950) - António Nobre. Lisboa: Livraria Bertrand.

DIAS, Marina Tavares (1988) - Mário de Sá-Carneiro: Fotobiografia. Lisboa: Quimera.

FARIA, Guilherme de (2013) - Saudade Minha (poesias escolhidas). Maia: Cosmorama Edições.

MARTINS, Fernando Cabral (1996) - Prefácio. In SÁ-CARNEIRO, Mário de - Poemas Completos.

Lisboa: Assírio \& Alvim, p. 9-22.

NOBRE, António (1982) - Correspondência. Lisboa: IN-CM. (2000) - Poesia Completa. Lisboa: Publicações Dom Quixote.

PEREIRA, José Carlos Seabra (2003) - História da Literatura Portuguesa. Do Simbolismo ao Modernismo. Mem Martins: Publicações Alfa, vol. 6.

\footnotetext{
${ }^{117}$ SÁ-CARNEIRO, 2015: 485-486.

${ }^{118}$ NOBRE, 2000: 364.

${ }^{119}$ MARTINS, 1996: 22.
} 
PESSANHA, Camilo (1916) - Poemas Inéditos de Camilo Pessanha. «Centauro», n. ${ }^{\circ} 1$ (out./dez.), ano I, p. 13-31.

(1997) - Clepsidra e Outros Poemas. Porto: Lello Editores.

PESSOA, Fernando (1924) - Mário de Sá-Carneiro (1890-1916). «Athena», vol. I, n. o 2, p. 41-42. (2013) - Livro do Desassossego. Lisboa: Assírio \& Alvim.

QUENTAL, Antero de (2001) - Poesia Completa. Lisboa: Publicações Dom Quixote.

SÁ-CARNEIRO, Mário de (1996) - Poemas completos. Lisboa: Assírio \& Alvim. (2010) - Verso e Prosa. Lisboa: Assírio \& Alvim. (2015) - Em Ouro e Alma: Correspondência com Fernando Pessoa. Lisboa: Tinta-da-China.

SPAGGIARI, Barbara (1997) - Introdução. In PESSANHA, CAMILO - Clepsidra e Outros Poemas. Porto: Lello Editores, p. 7-55.

VERDE, Cesário (2004) - O Livro de Cesário Verde. Lisboa: Assírio \& Alvim. 


\section{O BRASIL DE MIGUEL TORGA}

ARNALDO SARAIVA*

Dispondo-me a falar da relação de Miguel Torga com o Brasil, não posso deixar de aludir rapidamente à sua relação com outras terras, ou com a terra. E não posso deixar de lembrar o tópico, o cliché que há muito anda fatalmente associado a Torga, ou à sua obra: «telúrico», «telúrica».

Entre os muitos que ajudaram à fortuna desse tópico está, por exemplo, o escritor brasileiro José Lins do Rego, que no seu livro Bota de Sete Léguas afirmou que Torga «é o telúrico que sabe que é telúrico e que gosta de ser telúrico» ${ }^{1}$, e está a ensaísta portuguesa Teresa Rita Lopes, que no livro Miguel Torga: Ofícios a «Um Deus da Terra» se ocupou do que chamou «realidade telúrica» e «pátria telúrica» do escritor ${ }^{2}$. Mas, como ela nota, foi o próprio escritor que usou esta última expressão, e, como se deduz da afirmação de José Lins do Rego, ele nunca escondeu o seu gosto especial por esse adjetivo ou pelo que ele traduz. Veja-se esta passagem do livro de «temas portugueses e brasileiros» a que deu o título Traço de União: «É um fraco, esta paixão pelo telúrico. Mas tenho-a, e a tua terra é o telúrico em corpo inteiro» ${ }^{3}$.

Poderíamos surpreender a relação de Torga com o telúrico logo a partir do nome próprio, ou do seu apelido, Adolfo Rocha, e do seu pseudónimo, Miguel Torga; ou logo

\footnotetext{
* Universidade do Porto/CITCEM - Centro Investigação Interdisciplinar Cultura, Espaço e Memória.

${ }^{1}$ REGO, 1955: 96.

${ }^{2}$ LOPES, 1993: 73-74, 80

${ }^{3}$ TORGA, 1955: 153.
} 
a partir do nome da sua região de origem, Trás-os-Montes, e da terra onde nasceu em 12 de agosto de 1907, S. Martinho de Anta, que, como lembrou Clara Rocha, «demarca a chamada "Terra Quente" (a região duriense, xistosa) da "Terra Fria” (o Nordeste transmontano, granítico)» ${ }^{4}$. Notemos que o nome de «anta» assinala um monumento sepulcral à base de pedras ou de lages, mas também lembra paronomasticamente o nome de um deus, Anteu; na mitologia grega este deus, que por sinal foi celebrado em 1912, quando Torga tinha 5 anos, por João de Barros no livro intitulado Anteu e Outros Poemas, era filho do deus do mar, Poseidon, e da deusa da terra, Gaia, e era um gigante invencível que se alimentava e não podia desligar-se da terra; Hércules, ou Héracles, só conseguiu matá-lo porque o agarrou com os fortíssimos braços e o levantou, impedindo que os seus pés tocassem o solo.

Miguel Torga por mais de uma vez evocou este mito, identificando-se claramente com Anteu. Em 1954, falando em São Paulo sobre o transmontano, garantiu que, «mesmo transplantado, ele ressuma a seiva de onde brotou. Corre-lhe nas veias a força que recebeu dos penhascos, hemoglobina que nunca se descora. É uma marca indelével que a terra põe nos naturais» ${ }^{5}$. Mas no Diário XV (1990), falando de S. Martinho de Anta, ainda é mais explícito: «Os mitos são verdades eternas. Quando aqui chego, é sempre um Anteu combalido que me sinto, a tocar a terra alentadora e a recuperar as forças. Não as do corpo, mas as da alma» ${ }^{6}$.

Conviria no entanto saber ao certo de que se fala quando se fala do Torga telúrico. Um dos seus críticos, Fernão de Magalhães Gonçalves, pôde relacioná-lo com um Torga "cósmico» ou "cosmogénico», para quem o elemento primordial seria a terra, sim, mas a terra entendida como «o ventre telúrico de cujo útero, na origem dos tempos, emanavam» a vida e o homem ${ }^{7}$.

Pareceria aberrante ou infantil ver o telúrico em Torga só em relação com a terra natal, o «terrunho», o rústico, ou só em relação com o elemento sólido do planeta; porque é por demais óbvio que a sua obra atravessa às vezes euforicamente vários lugares nacionais e internacionais, porque dela faz parte uma peça ou um poema dramático intitulado Mar (1941), e porque ela celebra com frequência e eloquência o rio Douro (ou «Doiro», como ele preferia e proferia). Lembre-se também que o seu autor não viajou só por Portugal, e que por sinal casou com uma senhora belga.

Se privilegiou, a nível local, S. Martinho de Anta, a nível regional Trás-os-Montes, e a nível nacional Portugal, perseguindo as suas homologias ou isomorfismos mas também as suas diferenças, isso não significou desprezo ou desatenção ao cósmico ou

${ }^{4}$ ROCHA, 2000: 25.

${ }^{5}$ TORGA, 1955: 65 .

${ }^{6}$ TORGA, 1999: 1667 (11/09/1989).

${ }^{7}$ GONÇALVES, 1998: 205-206. 
ao universal, que definiu uma vez como o «local sem paredes» ${ }^{8}$. Assim, não admira que ele tenha encontrado noutras paragens o espírito do lugar onde nasceu, nem que tenha confessado a Ribeiro Couto: «o Rio é o meu S. Martinho de Anta da outra margem»"

Fernando Pessoa escreveu: «o meu quintal em Lisboa está ao mesmo tempo em Lisboa, em Portugal e na Europa» - e podia ter acrescentado: «e no planeta, e no cosmos». Torga também diria sem custo o mesmo. Mas, diferentemente de Pessoa, com quem aliás teve um ligeiro desaguisado, que não o impediria de celebrar o seu génio, ele não tinha Lisboa como «lar»; a sua identificação primeira com a natureza ou o espaço transmontano e duriense tinha que ver com uma preocupação pouco evidenciada por Pessoa - que se empenhou sempre no estudo ou no conhecimento da «alma» e na exploração da alteridade ou pluralidade subjetiva: a preocupação com as suas origens ou com a sua identidade. Torga via-se, como Anteu, na necessidade da ligação à sua terra, supondo que só assim garantia a sua própria vida e a sua autenticidade, como que reafirmando a mítica teoria da relação homem/húmus, ou a conceção da vida humana idêntica à dos vegetais - raízes, seiva, fruto.

Na sua obra são bem percetíveis algumas homologias entre um lugar microscópico e um lugar macroscópico, entre um espaço englobante e um espaço englobado - entre, por exemplo, S. Martinho de Anta e Portugal. A Portugal consagrou ele o livro que chamou justamente Portugal (1950), mas também passagens da sua ficção e do seu teatro, inúmeras páginas dos seus 16 Diários (1941-1993), muitos poemas desse diário e da sua dezena de livros (desde Ansiedade, 1928, a Câmara Ardente, 1962); nesses textos encontraremos sempre, direta ou indiretamente, a defesa ou o louvor da terra, do homem e da cultura de Portugal, com quem o poeta não raro se identifica.

Por isso pôde Sophia Andresen defender que Torga foi um dos escritores que melhor disse Portugal e um poeta em que Portugal se disse. Por mais de uma vez ele expressou a sua inteira identificação com o país, chegando a dizer, numa página do Diário $X V$ : «Foi a procurar entendê-lo que compreendi alguma coisa de mim. As pátrias são espelhos gigantescos onde se reflecte a pequenez dos filhos» ${ }^{10}$.

A identificação entre ele e Portugal, objeto de um estudo de Luís Martins Fernandes (2011), não impediu Torga de se identificar com outras terras. Com alguma razão escreveu Pilar Vázquez Cuesta que ele «estendeu a terra natal de S. Martinho a toda a Península» ibérica ${ }^{11}$; ele que disse ter o "perfil de um contrabandista espanhol» ${ }^{12}$, ele que escolheu o seu pseudónimo por causa dos escritores espanhóis Miguel de Cervantes

\footnotetext{
${ }^{8}$ TORGA, 1955: 69.

${ }^{9}$ TORGA, 1955: 152.

${ }^{10}$ TORGA, 1999: 1631 (29/06/1988).

${ }^{11}$ Cf. MELO, 1960: 16.

${ }^{12}$ Cf. ROCHA, 2000: 98.
} 
e Miguel de Unamuno, definiu-se não já como transmontano ou como português mas como ibérico em livros como Alguns Poemas Ibéricos (1952) e Poemas Ibéricos (1965).

Mas talvez se pudesse dizer com mais razão que ele estendeu S. Martinho de Anta ao Brasil. Notemos desde logo que ele viveu no Brasil cinco anos, de 1920 a 1925; e que o visitou em 1954, desde o dia 6 a 24 de agosto. Notemos que ele deu como «um dos seus títulos de glória» ter "passado a adolescência no Brasil (Leopoldina - Minas)» ${ }^{13}$. Notemos que ele tirava "o chapéu a Euclides da Cunha e a Machado de Assis» ${ }^{14}$, que admirava os poetas Manuel Bandeira, Cecília Meireles e Lêdo Ivo e os romancistas Graciliano Ramos, José Lins do Rego e Jorge Amado ${ }^{15}$, que foi amigo e bom leitor de outros escritores brasileiros como Murilo Mendes, autor de um poema - um «murilograma» - centrado sobre a sua filha Clara, que viu «levantada pelas colunas» do seu pai ${ }^{16}$, Ribeiro Couto, a quem enviou uma «carta» e dedicou uma «elegia», José Lins do Rego - que saudou num almoço coimbrão de 1951 e que por ele foi homenageado no texto «O mestre Torga e o mar português» ${ }^{17}$ - , e David Nasser, que no livro Portugal, meu Avozinho o homenageou em dedicatória e o nomeou no capítulo «Coimbra de Torga» como «o maior escritor vivo da língua»... ${ }^{18}$

A relação de Torga com o Brasil, a que Maria de Fátima Martins Medeiros dedicou em 1997 uma tese de mestrado, é sobretudo definível pelo $2 .^{\circ}$ e $3 .^{\circ}$ volumes da sua autobiografia A Criação do Mundo, publicados respetivamente em 1937 e 1938, e pelo livro Traço de União, de 1955, que de distintos modos estilísticos se ocupa de «temas portugueses e brasileiros»; mas o Brasil é matéria ou motivo de muitas páginas do Diário, nomeadamente dos volumes VIII (1959), IX (1964) e XI (1973), e de alguns poemas - para não falarmos em cartas, quase todas ainda por publicar.

A Criação do Mundo evoca, como se de ficção se tratasse, a viagem que aos 13 anos levou Miguel Torga da sua terra para o Rio de Janeiro, onde o acolheu um seu tio, homem duro casado com uma «megera», e o «Senhor Gomes», que o levaram para a Fazenda de Santa Cruz, em Minas Gerais, onde trabalhou na produção, na colheita e na venda de café, foi encarregado do correio, foi escriturário, e fez estudos - e onde atravessou as típicas etapas da adolescência vivida em contextos muito diferentes dos transmontanos, e passou por experiências que foram do medo inicial e da perspetiva de enriquecimento ( $\mathrm{O}$ Brasil que me ia enriquecer como a toda a gente»), nem que fosse abrindo uma loja no Rio, às das primeiras vibrações sensuais, das humilhações

\footnotetext{
${ }^{13}$ ROCHA, 2000: 100.

${ }^{14}$ ROCHA, 2000: 98.

${ }^{15}$ ROCHA, 2000: 101.

${ }^{16}$ MENDES, 1994: 664-666.

${ }^{17}$ REGO, 1955: 96.

${ }^{18}$ NASSER, 1965: 51.
} 
familiares ou patrióticas (As desgraças do Brasil/eram duas agora três/a formiga cabeçuda/italiano e o português) às desilusões - que o fariam voltar para Portugal.

Em 1954 Torga retornaria ao Brasil mas apenas por escassos dias - 6 a 24 de agosto - gastos num Congresso de Escritores em São Paulo, numa visita à Fazenda do tio e em conferências. Duas delas foram guardadas no livro Traço de União, que publicou no ano seguinte e que reúne oito textos de espécie distinta (conferência, ensaio, panorama, carta, memória, autobiografia) incidindo sobre o Brasil mas também sobre a relação Portugal/Brasil.

Ao longo desses textos, tanto pode falar da comum imagem que o português tem do Brasil, que lhe parece antiquada (poucos se dão conta do que é a «incomensurável pátria moderna») e inadequada (o português procura no Brasil a própria imagem), como da terra brasileira (rica, fértil, descomunal), do homem brasileiro (cordial, «amável, gentil e bonzarrão», tolerante, criativo, com um «quase feminino subtil e agudo sentido psicológico»), da língua (portuguesa "pela raiz e pelo génio», mas com muito de "virginal, original e brasileiro») e do país (fascinante, maravilhoso, "país eleito para ser caldeirão do orbe», país do futuro - como o definira Stefan Zweig, em título famoso de livro de 1941).

Do prefácio ensaístico de Traço de União disse logo Ribeiro Couto, em carta enviada de Belgrado em 21 de março de 1955 ao seu amigo «Miguelão», que era «a coisa mais substancial que se escreveu sobre o Brasil contemporâneo. Não há nada que se lhe compare em língua alguma» ${ }^{19}$. Mas o livro incluía ainda reflexões sobre o emigrante português, de que o autor teria "procuração», por também no Brasil ter vivido "cinco anos de contraditórias sensações», sobre a relação de um país pequeno, velho, triste e rígido com um país enorme, novo, alegre e «de camisa aberta», relação que era urgente melhorar. Para isso, impunha-se que os portugueses, especialmente os emigrantes, fizessem o «inventário do muito circunstancial» que os distingue dos brasileiros para descobrirem o «pouco essencial» que os une, que tomassem a iniciativa de trabalhar por um "convívio irmanado», renunciando a preconceitos, perdendo a "prosápia reinol», tendo sempre presente a ideia de que eram «hóspedes em terra alheia», desmoralizando "aproximações» que têm separado, e renunciando à permuta de «sono e salamaleques».

Torga falou do Brasil e dos brasileiros noutros livros, nomeadamente nos seus diários. Assinalemos especialmente os poemas com o mesmo título «Brasil», de 20 de janeiro de $1957^{20}$ e de 16 de junho de $1970^{21}$, e o poema «Elegia a Ribeiro Couto», de 31 de maio de $1961^{22}$. Se neste é evocada a «imagem cordial», a voz «familiar» do

\footnotetext{
${ }^{19}$ ROCHA, 2000: 124.

${ }^{20}$ TORGA, 2010: 304.

${ }^{21}$ TORGA, 1999: 1183.

${ }^{22}$ TORGA, 1999: 1027.
} 
poeta brasileiro, e se no segundo Torga assinala a sua divisão entre o «cais do lado de lá e de cá do seu destino», entre «dois pólos de atração no pensamento», «entre o chão encontrado e o chão perdido», já no primeiro poema, constituído por uma quadra e duas sextilhas, o Brasil é definido no primeiro verso como "pátria de emigração", sendo nos versos seguintes visto sucessivamente com terra de inspiração (poética), terra achada, terra perdida, terra poeticamente lembrada, terra de "pura imensidade», e terra digna de ser celebrada «com palavras e rimas e saudade».

Em conclusão, poderemos dizer que o tema do Brasil e dos brasileiros ocupa um lugar relevante na obra de Miguel Torga, prosaica e poética. O que se justifica a partir de duas vivências, uma «infiltrada no sangue», outra intelectual ${ }^{23}$, uma relacionada com o espaço e o tempo em que nela viveu, outra fundamentada em leituras e em conhecimentos que lhe vieram de fora, por outros. E justifica-se também pelo facto de ter sido «endemoninhado pela sedução duma terra tropical» ${ }^{24}$, e por ver nela $\mathrm{o}$ alimento de uma sua paixão, confessada na já citada carta a Ribeiro Couto: «É um fraco, esta paixão pelo telúrico. Mas tenho-a, e a tua terra é o telúrico em corpo inteiro» ${ }^{25}$. No entanto, dá conta de que há dois Brasis na sua experiência pessoal: o do tempo e do lugar em que, adolescente, viveu, em que «chorou, gemeu, penou», em que passou por «contraditórias sensações», e o da memória e da ligação afetiva posterior, quase sempre eufórica.

A estas razões acresceria ainda a da relação histórica entre Portugal e o Brasil, que não se reduz à língua e não terminou com a independência de 1822 nem terminará com a hipotética interrupção da emigração: «Portugal e Brasil terão pelos séculos dos séculos a alegre penitência de estarem continuamente presentes na lembrança um do outro ${ }^{26}$. Embora assinalando o desconhecimento mútuo entre os dois países, e a pouca clarividência das comuns políticas luso-brasileiras e dos seus «tratados», Torga não deixa de sublinhar a «irmandade» ou a «fraternidade» que existe entre os povos brasileiro e português, apesar das diferenças que entre eles existam.

Mas se vê o Brasil em relação com Portugal, Torga não deixa de ver o Brasil em si, de per si. E o que vê vê-o com muitas limitações e muito apressadamente. Em 1920-1925 pouco mais vê que o Rio da chegada e a fazenda mineira; e nos 18 dias da viagem de 1954 mal dá para ver São Paulo, algumas cidades históricas mineiras e a Fazenda (revisitada), mais a Bahia. Por isso pôde dizer a Ribeiro Couto: "Calcula tu que precisei de, em três dias, andar três mil quilómetros, por estradas onde Judas perdeu as botas, se quis ver as referidas terras da mineração ${ }^{27}$. Não admira, assim,

\footnotetext{
${ }^{23}$ TORGA, 1955: 48.

${ }^{24}$ TORGA, 1955: 109.

${ }^{25}$ TORGA, 1955: 153 .

${ }^{26}$ TORGA, 1955: 33.

${ }^{27}$ TORGA, 1955: 158.
} 
que o Brasil de que Torga fala, salvo no que respeita ao Brasil... português, seja muito "cosa mentale» e, exceto no que respeita à vida na Fazenda de Santa Cruz, seja muito idealizado - quer dizer, inexistente, verdadeiramente «maravilhoso» no sentido que a palavra tem quando se fala de "conto maravilhoso». Algumas referências a paisagens e aos brasileiros não evitam a vulgar generalização e até abstração («a beleza dos panoramas», a «majestade dos rios», a «fertilidade do chão»... ${ }^{28}$ ), que não salva o tom por vezes tendencialmente épico ou grandiloquente de Torga. E ele, que às vezes parece esquecer que há no Brasil um mundo que o português não criou, chega a ignorar ou a atenuar as marcas da escravatura, as diferenças de classes, as gigantescas desigualdades sociais, produzindo afirmações que lembram o ufanismo de Afonso Celso e que talvez nem Gilberto Freyre subscrevesse: «não há complexos na alma dos brasileiros. Nada de recalcamentos pessoais ou colectivos. A escravatura, que nós implantámos, remiram-na eles num fraterno abraço sem restrições» ${ }^{29}$.

Torga, que vê um Brasil (ainda em parte subdesenvolvido!) como um «milagre moderno ${ }^{30}$ não resiste à tentação profética em que já muito antes de Stefan Zweig desde Pero Vaz de Caminha - caíam alguns visitantes ou habitantes do Brasil; para ele, o Brasil é um "país eleito para ser caldeirão do orbe», que «vai ter no mundo um papel que grandes potências no apogeu ou na agonia já não poderão desempenhar» ${ }^{31}$; mas sem dizer quando «vai ter» esse papel, também não se esmera em apontar as razões concretas de tão vigoroso otimismo.

O Brasil de Torga é, claro, o seu Brasil, a que o prende uma indisfarçada «ternura» ${ }^{32}$. E ninguém pode duvidar que, como disse em A Criação do Mundo (6. ${ }^{\circ} \mathrm{Dia}$ ), o Brasil se tatuou na sua alma «com uma tinta indelével», o que permitiu que ele também deixasse a «tinta indelével» da sua literatura na vasta literatura que já se escreveu sobre o Brasil.

\section{BIBLIOGRAFIA}

FERNANDES, Luís Martins (2011) - Expressões da Identidade Nacional em Miguel Torga. Lisboa: Fundação Calouste Gulbenkian.

GONÇALVES, Fernão de Magalhães (1998) - Ser e Ser Miguel Torga. Chaves: Tartaruga.

LOPES, Teresa Rita (1993) - Miguel Torga: Ofícios a «Um Deus da Terra». Porto: Edições Asa.

MEDEIROS, Maria de Fátima Martins (1997) - A Luso-Brasilidade da Obra de Miguel Torga. Universidade dos Açores. Dissertação de mestrado.

MELO, José de (1960) - Miguel Torga. Lisboa: Arcádia.

MENDES, Murilo (1994) - Poesia Completa e Prosa. Rio de Janeiro: Nova Aguilar.

NASSER, David (1965) - Portugal, meu Avozinho. Rio de Janeiro: Edições O Cruzeiro.

REGO, José Lins do (1955) - Bota de Sete Léguas. Rio de Janeiro: A Noite.

\footnotetext{
${ }^{28}$ TORGA, 1955: 154.

${ }^{29}$ TORGA, 1955: 15.

${ }^{30}$ TORGA, 1955: 14.

${ }^{31}$ TORGA, 1955: 23, 9-10.

${ }^{32}$ TORGA, 1955: 153.
} 
TEXTUALIDADE E MEMÓRIA: PERMANÊNCIA, ROTURA, CONTROVÉRSIA

ROCHA, Clara (2000) - Miguel Torga: Fotobiografia. Lisboa: Dom Quixote, p. 25.

TORGA, Miguel (1955) - Traço de União. Coimbra.

(1999) - Diário. Vols. IX a XVI. 2. a ed. Lisboa: Dom Quixote.

(2010) - Diário. Vols. V a VIII. 5. ${ }^{\text {a }}$ ed. Lisboa: Dom Quixote. 


\title{
PALAVRA, MEMÓRIA E IDENTIDADE: VELHICE E CONDIÇÃO FEMININA NUM CONTO DE LYGIA FAGUNDES TELLES
}

\author{
FRANCISCO TOPA*
}

A forma de encarar a velhice constitui um dos aspetos em que as sociedades e as civilizações mais divergem. Como escreve Georges Minois,

desde a época da sociedade primitiva, se coloca o problema da ambiguidade da velhice, ao mesmo tempo fonte de sabedoria e de doença, experiência e decrepitude, prestígio e sofrimento. Conforme as circunstâncias, o velho é respeitado ou desprezado, honrado ou morto ${ }^{1}$.

Qualquer que seja o espaço geográfico que consideremos, as últimas décadas têm sido marcadas por um grande aumento da esperança média de vida, facto que no passado teve sempre uma conotação positiva, mas que hoje, em muitos países, começa a ser visto com crescente desconfiança e mesmo com uma certa hostilidade. É que o alargamento do ciclo de vida tem conduzido ao aumento do número de velhos, que em alguns países ultrapassa em muito a percentagem de população jovem, numa inversão do modelo de pirâmide geracional que parecia imutável. E como se associa a velhice a inatividade, cresce a perceção de ameaça perante os gastos com o envelhecimento, relativos sobretudo aos sistemas de proteção social e de saúde.

\footnotetext{
* Universidade do Porto/CITCEM - Centro de Investigação Transdisciplinar Cultura, Espaço e Memória.

${ }^{1}$ MINOIS, 1999: 24.
} 
Tratando-se de um problema incontornável do ser humano, o tema comparece na literatura desde sempre - dos clássicos greco-latinos ao nosso clássico Vergílio Ferreira e deste a A máquina de fazer espanhóis, de Valter Hugo Mãe -, com maior ou com menor destaque e em registos muito diversos. Uma abordagem particularmente interessante é a da brasileira Lygia Fagundes Telles no conto «Senhor Diretor», incluído no volume Seminário dos ratos, de 1977.

O conto tem como protagonista uma professora aposentada, Maria Emília, que passeia sozinha nas ruas de São Paulo no dia em que completa 61 anos, idade que, sobretudo hoje, não deveria justificar a sua inclusão no grupo dos velhos ${ }^{2}$. Sabemos contudo que o conceito de velhice é flutuante, dependendo de fatores físicos, psicológicos e sociais. A personagem de Lygia, como veremos, considera que o seu corpo apresenta os sinais da velhice, designadamente a secura. Por outro lado, estando aposentada, sente os efeitos daquilo a que alguns sociólogos chamam a morte social, traduzida na perda de poder e de prestígio e geralmente acompanhada de algum preconceito ou discriminação, que tanto podem ser negativos como positivos. Esta atitude, que hoje é designada como idadismo e que vem sendo considerada como um atentado aos direitos humanos, reforça muitas vezes a posição marginal e a solidão do velho, que acaba por se sentir cada vez mais distante e desfasado do mundo que o rodeia.

No domingo do seu aniversário, Mimi tinha recusado a festa proposta pelos sobrinhos, com o falso argumento de que combinara tomar chá com um grupo de amigas. A intriga parte da manchete de um jornal exposto na banca de uma praça: «Seca no Nordeste. Na Amazônia, cheia». Depois de a ler, a personagem observa também a capa de uma revista exposta ao lado, o que lhe suscita uma série de pensamentos aparentemente desordenados e a decisão de escrever ao diretor do "Jornal da Tarde» uma carta de protesto, que teria por incipit justamente o título do conto. O narrador de 3. ${ }^{a}$ pessoa cede então a palavra à protagonista, passando a narrativa a ser dominada pelo fluxo de consciência de Emília, que se apresenta marcado por uma aparente descontinuidade que lembra as associações livres da psicanálise. Começando por reagir ao mundo à sua volta, Mimi usa a palavra da carta mental que começa a esboçar para recuperar memórias apagadas - ou recalcadas -, o que lhe permite ir tomando consciência de si e pôr em causa as suas opções de vida. A protagonista chega assim ao final do conto transformada numa mulher diferente, graças ao poder clarificador da palavra e da memória.

A primeira impressão que Maria Emília transmite é a de ser uma mulher conservadora, o que se deverá em parte à faixa etária em que se situa, em parte à educação que recebera. Como ela própria informa, a sua mãe baixava a voz quando dizia partes (p. 26). Ela tivera oito filhos, mas não disfrutara de uma vida sexual: («Oito. Quarenta anos de casamento

\footnotetext{
${ }^{2}$ Segundo os dados do Instituto Brasileiro de Geografia e Estatística (<http://www.ibge.gov.br>), a esperança média de vida da população brasileira em 1970 era de 52,6 anos. Dez anos depois passaria para 62,7, situando-se em 2015 nos 75,44 anos.
} 
sem prazer: um agulheiro calado.», p. 22; «me lembrei dela dizendo à minha avó que cumpria seus deveres sem nenhum prazer até o amargo fim. Até o amargo fim, mamãe?», p. 27; «Mamãe tinha medo do sexo, herdei esse medo - não foi dela que herdei?», p. 26). Por outro lado, Maria Emília frequentara o «Des Oiseaux» (p. 21), um colégio feminino tradicional de São Paulo que era dirigido por freiras de Santo Agostinho.

A sua personalidade conservadora revela-se no desprezo pelos jornais populares («Não foi no jornal que Mariana leu (o fascínio que tem por jornais populares)», p. 18); na censura ao homem que atira lixo para o chão («Compete à prefeitura, Senhor Diretor, estudar verdadeiramente um projeto de educação desse povo que tem a idade mental daquelas meninas que eu ia fiscalizar quando saíam do reservado», p. 24); no incómodo com que reage à jovem que masca chiclete e faz balões que estouram («Maria Emília voltou depressa para o outro lado o rosto desgostoso», p. 17); na crítica à cedência da amiga perante a moda jovem ("Quem visse podia pensar, é uma jovem que foi fazer contrabando. Espera, jovem não, que jovem não se importa com vinco de calça, postal de uma velha mesmo e com medo de parecer desatualizada.», p. 16). De uma outra maneira, percebe-se também no facto de conservar o hábito do chá e lamentar o desaparecimento das confeitarias («Um chá? Mas será que restara alguma confeitaria decente por ali?», p. 20); no apreciar da cortesia do porteiro do cinema («não era mesmo gentil? Em meio da invasão dos bárbaros, ainda restavam alguns antigos habitantes da aldeia, raros, sim, completamente derrotados (a roupa do porteiro mal guardara a cor) mas conservando o sentimento do respeito ao próximo, não, não pedia amor mas ao menos respeito», $\mathrm{p}$. 25); na preocupação com a imagem («Sentiu-se desalinhada, descomposta, mas deixa eu ficar um pouco assim, está escuro, ninguém está prestando atenção em mim», p. 26); num vocabulário entre o antiquado e o requintado (censura Mariana, que diz «ôi! no telefone», p. 16; refere-se ao rabo como «derrière», p. 16; designa o órgão masculino como «fálus» (p. 18); manifesta desconforto com a palavra «prostituta», parecendo preferir, pelo menos num primeiro momento, «mundana» (p. 21); usa termos e expressões como «despautério» (p. 21), «topete» (p. 21), «guisa» (p. 22) ou «obumbramento» (p. 18)).

Algo de semelhante acontece com as suas referências literárias, a avaliar pelas duas citações que faz, ambas de poetas parnasianos. Vejamos o primeiro caso:

Resistir, quem há de? Uma ilusão gemia em cada canto - gemia ou chorava? Tempo de sentimento. De poesia. Agora o tempo ficou só de detergentes para as pias, desodorantes para as partes, a quantidade de anúncios de desodorantes. Como se o simples sabão não resolvesse mais. (p. 17)

Esta passagem é particularmente significativa: trata-se de parte da estrofe final do soneto «Visita à casa paterna», de Luís Guimarães Júnior (1845-1898), sugerindo a citação a saudade da infância, ao mesmo tempo que destaca a ideia de resistência — resistência a 
um mundo que passou a mover-se a uma velocidade impossível de acompanhar e cujos valores parecem à protagonista estar invertidos.

A segunda ocorrência identifica explicitamente a citação:

A Forma, fria e espessa, é um sepulcro de neve... E a Palavra pesada abafa a Idéia leve - escreveu Olavo Bilac, na Inania Verba. Meu poeta predileto, Senhor Diretor, sempre gostei de poesia. Até declamava. (p. 22)

Contra o que possa parecer, o recurso a Bilac constitui um sinal de incómodo, de desadequação entre $O$ Pensamento [que] ferve e A Forma, fria e espessa, acompanhando assim a mutação interior da protagonista, que também poderia perguntar-se:

Quem o molde achará para a expressão de tudo?

Ai! quem há de dizer as ânsias infinitas

Do sonho? e o céu que foge à mão que se levanta?

E a ira muda? e o asco mudo? e o desespero mudo?

$E$ as palavras de fé que nunca foram ditas?

E as confissões de amor que morrem na garganta?!

A transformação da personagem inicia-se assim como uma reação contra a «sufocante atmosfera de vulgaridade que contaminava até as pedras» (p. 17). O primeiro sinal está na decisão de escrever uma carta ao diretor do Jornal da Tarde, que Maria Emília começa a compor mentalmente, mudando de assunto com frequência. A professora que vivia da palavra falada, mas que «ficava sem voz de tanto pedir silêncio» (p. 22), envereda agora pela palavra escrita, procurando que as suas não sejam inania verba e traduzam aquilo que sente. A cidadã que começa por ler manchetes de jornal converte-se num género de repórter. A mulher que de início se comporta como uma espécie de voyeuse passa a olhar para si e a analisar-se, transformando-se lentamente e acabando por abandonar a secura que sempre a caracterizara.

O primeiro aspeto da mudança de Maria Emília tem a ver com o assumir da sua condição de mulher, visível logo no início da carta:

Senhor Diretor: antes e a acima de tudo quero me apresentar, professora aposentada que sou, paulista, solteira. Um momento, solteira, não, imagine, por que declinar meu estado civil? (p. 16)

${ }^{3}$ BILAC, 2001: 145 . 
Essa consciência tinha-se formado na frequência de um grupo feminista, que a personagem evoca a certa altura: «A imagem da mulher-objeto, como dizem as meninas lá do grupo feminista.» (p. 20). Graças a ele tinha passado a apreciar a expressão condição da mulher: «acho tão nobre essa expressão, condição da mulher.» (p. 21). A admiração pelo grupo («Meninas inteligentes, cultas, quase todas de nível universitário.», p. 20), não esconde porém o desconforto com algumas propostas nem o medo da mudança:

Mas meus Céus, se ao menos fossem mais moderadas. Mais discretas. Reivindicar tanta coisa ao mesmo tempo, tanta mudança de repente não pode ser prejudicial? Um abalo nas nossas raízes, acho que estão correndo demais. (p. 20-21)

Apesar disso, a mudança está em curso: Maria Emília reconhece a violência policial contra as prostitutas; indigna-se contra a mutilação sexual feminina; admite até a possibilidade de aborto, em caso de estupro: «Deus que me perdoe a heresia mas em casos assim extremos quem sabe seria mesmo aconselhável alguma medida que interrompesse a gestação?» (p. 22).

De resto, a protagonista vai admitindo, aos poucos, a própria mutilação, na forma dos sinais da velhice:

Meus cabelos branquearam, meus dentes escureceram e minhas mãos, Senhor Diretor, estas mãos que - era voz corrente - foram sempre o que tive de mais bonito. Olhou as próprias mãos enluvadas. Ainda bem que estão enluvadas. (p. 17)

E a secura é o maior dos sinais:

Seca tudo, a velhice é seca, toda água evaporou de mim, minha pele secou, as unhas secaram, o cabelo que estala e quebra no pente. O sexo sem secreções. Seco. Faz tempo que secou completamente, fonte selada. A única diferença é que um dia, no nordeste, volta a chuva. (p. 27)

Este é precisamente um dos polos daquela que parece ser a isotopia mais importante do conto e que já estava contida na manchete de jornal que a protagonista lê no início: «Seca no Nordeste. Na Amazônia, cheia» (p. 15). Toda a vida passada de Maria Emília se definira pela secura e pela oposição à humidade, materializada numa série de secreções e excreções próprias do ser humano.

O rio constitui uma das imagens de humidade que a protagonista utiliza, recordando as suas tentativas inglórias para o deter na figura das suas jovens alunas: 
querendo com elas segurar aquela meninada que vinha espumejante como um rio, cobrindo tudo, tamanha força, uma classe depois da outra, uma depois da outra - por que me fazem pensar num rio sem princípio nem fim? (p. 22)

Outra das formas da humidade é o suor, que surge claramente sexualizado:

Para recomeçar em seguida na maior algazarra, os peitinhos empurrando o avental, excitadas, úmidas, explodiam principalmente no verão. Eu evitava roçar nelas quando voltavam do recreio, mais forte o cheiro de suor e poeira [...](p. 22).

A própria água que escorre dos corpos é objeto de idêntica leitura, a propósito de um «jovem casal de biquini amarelo» na capa de uma revista que suscita a atenção (e reprovação) da protagonista. Segundo o seu comentário, «Estavam molhados como se tivessem saído juntos de uma ducha. [...] E brilhosos, escorrendo uma água oleosa, desde Sodoma e Gomorra os óleos e ungüentos perfumados fazendo parte das orgias.» (p. 15). Também com incómodo é nomeada uma excreção como a urina:

Imagine se papai estivesse vivo e soubesse do que aconteceu no Municipal, um moço subindo no palco e fazendo a necessidade, ali em cima dos dourados, sob as vistas de Carlos Gomes, de Verdi! (p. 18)

e uma secreção como o sémen:

Segurou com força no assento e o couro da poltrona lhe pareceu viscoso, sêmen? Calçou as luvas e juntou as pernas. (p. 26)

No mesmo plano está ainda a alusão a uma forma de lubrificação não natural:

Até a manteiga, imagine, a inocente manteiga. Audácia da Mariana em contar o episódio da manteiga, aquela indecência que viu num cinema em Paris. E se sacudindo de rir, foi tão engraçado, Mimi, ele dançando o tango de calças abaixadas, tão cômico! E confessou que viu o filme duas vezes para entender melhor aquele pedaço, a debilóide. É o cúmulo. Disse que apareceu uma marca de manteiga que aproveitou para fazer a sua propaganda, funcional com ou sem sal! (p. 15)

Como se percebe facilmente, Maria Emília alude ao filme de Bernardo Bertolucci Último Tango em Paris, de 1972, concretamente à cena em que Paul (interpretado por Marlon Brando) sodomiza Jeannie (representada por Maria Schneider) com ajuda de 
manteiga, tendo sido esta passagem o principal fator da polémica, censura e proibição a que o filme esteve exposto em diversos países, incluindo Brasil e Portugal.

Há dois episódios da sua vida - aparentemente recalcados - que a protagonista consegue evocar e em que a experiência da humidade está também presente, de modo antagónico: positivo, quando se trata de uma memória em que intervém o pai; negativo, quando é a mãe que está presente.

O incidente com o pai é recordado a propósito dos efeitos da publicidade, que acabou por levar Emília a beber Coca-Cola durante uma viagem a Brasília:

Acordei do obumbramento engolindo aquela coisa marron com gosto de sabonete de trem, tinha um trem (faz tanto tempo, Senhor Diretor) com esse sabonete redondo e preto, dependurado na correntinha do toalete. Meu pai me ajudava a esfregar as mãos, eu era uma menininha de cachos mas até hoje sinto o cheiro daquela espuma. (p. 18)

O significado da Coca-Cola será esclarecido pouco depois, numa justificação também para a associação com o pai:

Cheguei um dia a ter uma miragem quando em lugar da garrafinha escorrendo água no anúncio, vi um fálus no fundo vermelho. Em ereção, espumejando no céu de fogo - horror, horror, nunca vi nenhum fálus, mas a gente não acaba mesmo fazendo associações desse tipo? (p. 18)

O episódio com a mãe diz respeito a uma visita à ginecologista, por causa de um corrimento vaginal que será diagnosticado da seguinte maneira: «Nada grave, menina, você tem flores-brancas, às vezes as virgens padecem disso.» (p. 27). Muito significativo é o comportamento ultra-rígido de Maria Emília, provavelmente induzido pela mãe, que se comporta como «uma estátua lacrimosa, apertando solidária a minha mão» (p. 27).

Concluído esse percurso, só aparentemente errático e sem sentido, a protagonista perde as certezas que tinham pautado a sua vida:

E se por acaso o certo for isso mesmo que está aí? Esse gozo, essa alegria úmida nos corpos. Nas palavras. Esse arfar espumejante como o rio daquelas meninas, aquelas minhas alunas que eram como um rio, tentou detê-lo com sua voz rouca, com seus vincos e o rio transbordou inundando tudo, camas, casas, rua... E se o normal for o sexo contente da moça suspirando aí nessa poltrona - pois não seria para isso mesmo que foi feito? (p. 26)

É por isso significativa a outa forma de humidade com que o conto termina: a lágrima que escorre pela face de Emília, numa prova de que não está seca e de que pode 
agora enfrentar de outro modo os medos antigos e os medos da velhice («Tanto medo, Senhor Diretor. Tanto medo. Eu também tenho medo, é duro envelhecer, reconheço.», p. 16-7). $\mathrm{O}$ ato de guardar no fundo da bolsa a camélia que trazia à lapela - possível sucedâneo das flores brancas da juventude - parece corresponder a uma nova atitude, sinalizada também nos dois pontos que encerram a narrativa e que parecem mostrar que a carta deixou de ser necessária, pois a protagonista está agora pronta a atravessar o rio e a viver. Terá percebido a lição de Hermen Hesse:

Aqui, neste jardim dos anciãos, desabrocham flores de que outrora jamais nos apercebemos, das quais antes nunca tratámos. Há, por exemplo, a flor da paciência, uma espécie de grande nobreza: tornámo-nos mais serenos, mais tolerantes, e quanto menor vai ficando a ânsia pela intervenção e pela aç̧ão, tanto maior se torna a nossa capacidade de observar e escutar a vida da natureza e daqueles que nos rodeiam, deixando-a passar ao nosso lado, sem críticas e sempre com redobrado espanto pela diversidade demonstrada, por vezes com um misto de compaixão e silencioso pesar, por vezes divertidos, com grande alegria, com bom humor.

\section{BIBLIOGRAFIA}

BILAC, Olavo (2001) - Poesias. Introdução, organização e fixação de texto por Ivan Teixeira. 2. ${ }^{a}$ ed. São Paulo: Martins Fontes.

FARIAS, Rafaela F. D. G. Monteiro de (2007) - A disciplina do corpo feminino em «Senhor Diretor», de Lygia Fagundes Telles. «Revista Fórum Identidades», 2. Itabaiana: GEPIADDE, p. 25-31.

GUIMARÃES JÚNIOR, Luís (1886) - Lyrica: Sonetos e rimas. 2. ${ }^{\text {a }}$ ed., revista e augmentada. Pref. de Fialho d'Almeida. Lisboa: Tavares Cardoso \& Irmão - Editores.

HESSE, Herman (2003) - Elogio da velhice: considerações e poemas. Editado por Volker Michels. Tradução de Paulo Rêgo. 3. a ed. Lisboa: Difel.

LIMA, Susana Moreira de [s.d.] - O corpo interdito: a sexualidade de uma mulher velha em Lygia Fagundes Telles. Disponível em <http://www.gelbc.com.br/pdf_jornada/susana_lima.pdf $>$. [Consulta realizada em $09 / 11 / 2015]$.

MARQUES, Sibila (2011) - Discriminação da terceira idade. Lisboa: Fundação Francisco Manuel dos Santos. MINOIS, Georges (1999) - História da velhice no Ocidente: da Antiguidade ao Renascimento. Lisboa: Teorema. PEDRA, Mabel Knust (2008) - Sombra silenciosa: impotência e solidão em dois contos de Lygia Fagundes Telles. «Darandina», vol. 1, n. ${ }^{\circ}$. Juiz de Fora: Universidade Federal de Juiz de Fora, p. 1-14.

ROUDINESCO, Elisabeth; PLON, Michel (2000) - Dicionário de Psicanálise. Lisboa: Editorial Inquérito. TELLES, Lygia Fagundes (1998) - Senhor Diretor. In Seminário dos ratos. 8. a ed. Rio de Janeiro: Rocco.

${ }^{4}$ HESSE, 2003: 66. 


\title{
JOSÉ BLANC DE PORTUGAL E O «DESCOMPASSO» MODERNISTA
}

\author{
FERNANDO J. B. MARTINHO*
}

Texto de homenagem a Maria João Reynaud, colega e investigadora por cujo trabalho tenho a mais profunda admiração, por ocasião da sua jubilação na Universidade do Porto.

Na recensão que fez, em 1961, a Parva naturalia, de José Blanc de Portugal, defende Casais Monteiro que a sua poesia «está [...] na linha directa do modernismo, isto é, da revolução feita por Pessoa e Sá-Carneiro». Esta afirmação de Casais precisa, no mínimo, de ser matizada. Antes de mais, é necessário esclarecer em que sentido pode aplicar-se à poesia de Blanc de Portugal a designação de modernismo, ou, indo noutra direção, qual é a conceção que este poeta tem do modernismo.

Atentemos na resposta que ele deu a um inquérito da «Colóquio/Letras» sobre «o significado histórico do Orpheu», sessenta anos depois da sua publicação. Os inquiridos eram, aí, solicitados a dizer o que pensavam sobre a herança do Modernismo na literatura portuguesa de então, concretamente se «o Modernismo de 1915» permanecia vivo ou não em meados da década de 70. Apesar de reconhecer o "choque» que o «Orpheu» representou na literatura nacional, Blanc de Portugal não deixava de sublinhar o que

\footnotetext{
* Universidade de Lisboa.
} 
lhe parecia ser a «irrelevância do termo modernismo», para, de seguida, explanar a que era a sua conceção da evolução literária, defendida, aliás, com ligeiras nuances, em diferentes momentos e lugares, mas, no essencial, próxima do entendimento que Eliot tinha do conceito de tradição:

É que o [Modernismo] do Orpheu apenas [...] vinha mais uma vez trazer à superfície componentes dos invariantes estéticos e literários que são de todas as épocas, uns predominando sobre outros em determinados períodos, parece que tão-somente para benefício dos periodicidadores da história da literatura». E acrescentava: «Tudo somado, equivale a isto [...]: o Orpheu influiu na produção literária e na concepção do fenómeno literário entanto que mostrou que a literatura só é moderna [...] quando, procurando aberturas formais [...], relembra que o seu conteúdo deve, quanto possível, conter todas as épocas e só se projecta no futuro quando tem a consciência de que ao escrever agora está já ultrapassada».

Quando respondeu ao inquérito, Blanc de Portugal encontrava-se desde 1973 no Brasil, onde haveria de permanecer até 1978 no exercício de funções diplomáticas, como adido cultural. Numa coletânea publicada em 1986, Descompasso, onde se reúnem poemas compostos durante esse período, deparamos, perto da abertura, com um texto intitulado «Introito», que nos pode fornecer algumas pistas para o entendimento de uma ligação do poeta a uma tradição modernista. O próprio corpo do poema se faz lugar de enunciação de uma poética, em que o «velho» é visto em termos de tradição dinâmica, suscetível de dar vida ao «novo». Ao mesmo tempo, porém, destacam-se, aí, categorias como "descompasso», «assimetria», incerteza e desvairo, que associamos ao modernismo enquanto poética da negatividade e afastamento da «medida».

Há, na sua abordagem do modernismo, em que, como poeta, se insere, um paradoxo, que ora se traduz no «moderno antigo» que inscreve no título de um depoimento publicado em Pentacórnio, em 1956 («Dez réis de moderno antigo»), ora de forma mais explicitamente oximórica se apresenta num passo desse mesmo depoimento em que defende que "só o moderno existe e só existe quando tem "filiação" "motivação"». Não surpreende, assim, que, no fecho desse mesmo texto, declare que não pode «deixar de ser moderno», e que reitere a ideia, tantas vezes expressa, de que isso não o impede de «aproveitar» como pode o que lhe «vem de todos os tempos». Num ensaio sobre «quatro novíssimos da música actual» vindo a lume em 1962 na revista Rumo, porá a sua erudição de crítico musical atento às novas tendências da música moderna ao serviço de teses já nossas familiares. Lembra que, quando Marinetti propunha «a destruição dos museus», a lição a colher não era, obviamente, «a da real destruição do passado», mas, sim, «a de que era forçoso que esse passado se não tornasse simples "forma" e "forma" incapaz de se alargar e evoluir", acrescentando que é "característica do que 
é vivo evoluir e transformar-se», para, depois, rematar que o que «interessa é alargar os conceitos do passado e admitir todo o legado do passado com as possibilidades de enriquecer o património futuro». Esta abertura a propostas de vanguarda torna-se ainda mais visível no texto que deu à estampa no suplemento especial do «Jornal do Fundão», de 24 de janeiro de 1965, dedicado à «Poesia Experimental», na sequência da publicação no ano anterior do $1 .^{\circ}$ número da revista com o mesmo nome. Cita Blanc de Portugal aprovadoramente o texto manifestário de Herberto Helder, em que se fala da tradição nos seguintes termos: "Trata-se de uma regra tradicional que a tradição esquece, quando perde o dinamismo sobre que assenta. Porque a tradição é um movimento». O que Herberto escreve no seguimento destas palavras vai permitir a Blanc de Portugal introduzir o conceito de entropia, um conceito que, segundo lembra, é «originariamente científico e exclusivamente introduzido em termodinâmica, mas que já fez o seu aparecimento na moderna crítica literária»: "A entropia é, essencialmente, uma medida do grau de desordem (ou acaso) de um sistema físico». Um pouco mais à frente retoma palavras de Herberto, para tornar o conceito mais claro: «Na verdade, como diz o apresentador da moderna poesia experimental, a linguagem é algo «que, no seu uso, se gasta e refaz». É o Poeta na sua ânsia de realmente criar, no seu empenho visceral de se opor à degradação da energia e ao aumento de entropia; a querer sempre comunicar mais e mais... Já antes, porém, na "Auto-poética», de 1964, que antecede Odes Pedestres, o poeta tivera ocasião de esclarecer o conceito de entropia: «a criação poética luta contra a degradação da energia-verbo, contra a «variação normal» da entropia (que se pode imaginar como uma medida da organização de qualquer sistema físico) com todas as armas que lhe são possíveis e se explicitaram na semântica, por exemplo, e na teoria da comunicação-informação».

A poesia de Blanc de Portugal publicada em livro é constituída por sete volumes, que se situam entre 1960 e 1999 . Relativamente ao ritmo que o poeta imprimiu a essa publicação, verificamos a existência de três ciclos, um primeiro que inclui as três primeiras colectâneas, Parva Naturalia e O espaço prometido, ambas de 1960, e Odes pedestres, de 1965; um segundo, em que se inserem duas recolhas vindas a lume nos anos 80, Descompasso, de 1986, e Enéadas: Nove novenas, de 1988; e, finalmente, dois «folhetos» vindos a público na década de 90, Quaresma abreviada, de 1997, e Estrofes, de 1999.

Contrariamente aos seus colegas nos «Cadernos de Poesia», apenas se estreou em volume, como vimos, em 1960, quando já tinha 36 anos. No entanto, Jorge de Sena não hesitou em incluir em 1958 poemas seus na 3. a série das Líricas Portuguesas, tão-somente baseado nos textos que Blanc de Portugal antes dispersara por diversas revistas nacionais. Foi, aliás, Sena quem, em 1959, encontrando-se o poeta em África, o «obrigou», como ele próprio contou, a concorrer, com os poemas essencialmente provenientes das publicações por onde se encontravam dispersos, ao Prémio Fernando 
Pessoa, de que acabou por sair vencedor. Fossem quais fossem as razões da sua aparente indiferença em publicar em livro, o certo é que Blanc de Portugal no mesmo ano de 1960 dá à estampa uma outra coletânea, O espaço prometido, que já teria preparada e em tudo diferente de Parva Naturalia. Refira-se igualmente que ainda nesse mesmo ano o poeta deu a lume um volume de ensaios, Anticrítico, que, juntamente com um outro título já referido, Descompasso, deixa bem em evidência a sua vinculação a uma estética modernista enquanto «estética negativa», segundo a lição adorniana. Passados cinco anos, o poeta regressa aos escaparates, com Odes pedestres, que inaugura o que iria ser uma importante coleção na edição da época, a col. «Poesia e ensaio» da Ulisseia, e em que, por uma certa desenvoltura estilística e pela ironia, se intensifica a identificação de Blanc de Portugal com o seu modernismo estrutural, se não mesmo com o vetor vanguardista do modernismo. Só vinte e um anos depois, o poeta volta, com um livro de poemas, ao contacto do público, com Descompasso, recolha constituída na sua totalidade por textos compostos no Brasil. O livro que se lhe seguiu, em 1988, Enéadas: 9 novenas, contém curiosamente, segundo se pode observar pelos textos datados (a maioria) poemas escritos nos anos 50 e 60, e apenas dois datados dos anos 70, um de 1972 e o outro de 1979, o que faz dele no essencial um livro anterior a Descompasso. Os dois últimos volumes publicados na década seguinte, Quaresma abreviada e Estrofes, vieram a lume numa pequena editora fora do sistema, a Black Son Editores. O poeta, que jamais temeu a utilização de um tom des-solenizado no seu discurso, vai, nestas duas plaquetes, ainda mais longe, aproximando os poemas do registo diarístico, todos eles, de resto, apresentando-se datados, e definindo, por essa via, o que, de alguma forma, poderíamos considerar, na esteira de Edward Said, um seu «estilo tardio».

Num ensaio publicado nos Cadernos de Poesia, em 1940, escrevia Blanc de Portugal que a poesia comporta «como harmonia, ritmo, melodia e finalmente criação - novidade». Numa entrevista de 1988, esclareceria, no entanto, que há "poesia que não atende à melodia». E este seria, em larga medida, o caso da sua própria obra, quase sempre arredada do embalo melódico, e situando-se, no processo evolutivo da nossa lírica moderna, numa linha que, embora reconhecendo que sem música «não há verdadeira poesia», não deixava de sublinhar que essa música não era «igual à antiga». Nas transformações operadas nesse domínio desempenhara um papel importante Casais Monteiro, que num livro de 1937 inserira um conjunto de textos sob o título de «Melodias atonais». Atonalidade e prosaísmo são, aliás, aspetos relevantes de muita da poesia de Blanc de Portugal, e que se nutrem das opções lexicais realizadas, do recorrente registo coloquial da linguagem e de procedimentos estilísticos como o hipérbato, tudo isso, às vezes, envolvido numa atmosfera a que não faltam o humor e a ironia. Veja-se, a respeito deste último ponto, o espírito lúdico com que, no poema «Sapiência», faz uso de noções cultas da versificação, em divertida acumulação, ao mesmo tempo que põe em evidência a intenção crítica da composição, implacável com 
o que na erudição miudinha há de falsa sabedoria ( «Saber diéreses, ictos, anacruzas,/E os segredos/Dum cólon trocaico dímetro coluro/E as imanentes transcendências/Do hipercatalético anapéstico monómetro,/Saber que pseudo-sáfico é afinal jâmbico,/Não me fizeram o verso brando ou duro/Nem sequer, por sabê-lo, mais abstrusas/Ficaram as ideias destes versos estranhos/Quando saem de mim sem que os domine/Mais que no guiar da mão dormente.//[...]»).

O livro a que este texto pertence, $\mathrm{O}$ espaço prometido, encarava-o o poeta como o seu "catecismo» pessoal, e, por, de alguma forma, temer, como católico poeta que era, que contivesse alguma "heresia», deu-o a ler ao Padre Manuel Antunes, que lhe concedeu, afinal, o nihil obstat, levando mesmo o original a Alçada Baptista, que o publicou na Moraes, segundo revelou numa entrevista em 1988 à revista «Leonardo». Refere ele ainda, na citada entrevista, que o Jesuíta gostava muito do verso final do poema «Carne»; que fazia parte do conjunto «Os inimigos da alma», e ele próprio acaba por adiantar a sua leitura do texto: «A tese deste poema é a seguinte: os homens são superiores aos anjos. Os homens têm a alma como os anjos e mais o corpo. Será herético? O Padre Manuel Antunes considerava que não». Poeta do sensível, não admira que não prescinda da sua humanidade quando se aventura pelos caminhos da teologia e da espiritualidade e que, mesmo quando trata do Paraíso, não tenha outros instrumentos, na sua fala, que não sejam os que os «sentidos», embora sinestesicamente transfigurados, lhe fornecem (cf. a primeira estrofe de «Paraíso»: «Os cinco sentidos são um só/A luz é som, o som perfume;/Perfume é gosto/Gosto sentir;/Luz!/[...]»).

Uma outra questão que tem a ver com a relevância da temática religiosa na sua poesia, prende-se com o que seria o lugar da cabala na sua reafirmada fidelidade ao cristianismo. Interrogado na entrevista à «Leonardo» se a cabala não era «inconciliável» com a doutrina cristã, respondeu o seguinte: «Para além da prática da Cabala, há a doutrina dos vários mundos. Os mais ortodoxos consideram ilícito este último aspecto. No entanto, devo lembrar que os cabalistas cristãos da Renascença demonstraram que não existe oposição alguma entre a Cabala e o Cristianismo. Esta complementaridade não está implícita na leitura directa, mas infere-se ou deduz-se das Sagradas Escrituras». E a uma pergunta sobre o que é um cabalista, esclareceu: «O cabalista é um homem que decompõe o «átomo» da palavra em números ou sons. Este trabalho é a essência da Cabala assumida como uma filologia generalizada, ou o amor da palavra. O conteúdo da palavra envolve uma teologia». De resto, na «Auto-poética» que precede Odes Pedestres, o poeta já aludira à «alquimia do verbo», ou "cabala filológica», presente no «experimentalismo de toda a poesia». E, mais tarde, num dos textos de Estrofes, o seu interesse pela Cabala será ainda mais explícito: «É tradição, Qabbalah ou Pirke Abot?/Não sei nem interessa muito à história,/penso eu./ - Contá-la é que é a venerável tradição ergo Cabala. Ei-la!/Adonai, Yaveh ou Elohim, depois de inventar,/de criar, melhor dizendo, as letras,/lançou-as ao espaço e as palavras/foram formadas». 
Por outro lado, o trato íntimo com a tradição cultural do Ocidente que a sua poesia manifesta e uma sua muito arreigada convicção de que não há «rupturas absolutas na evolução da poesia e da literatura», não nos devem fazer esquecer que estamos perante um poeta bem moderno, e que negava mesmo a possibilidade de vir a ser empalhado "em uma Academia», como deixou dito num poema de Descompasso. Neste mesmo livro, não são poucos os exemplos de ousada modernidade, como aquele que se nos depara no terceiro poema da sequência "A descoberta da Colombo». «Descida e descoberta», tal é o título desse poema, ilustra perfeitamente, no percurso retórico que propõe, entre a descoberta e a invenção e a criação, a luta entre a aventura e a ordem que se passa no seio de muita poesia moderna, e mesmo, às vezes, a indefinição entre verso e prosa, tudo isto em consonância com o que é uma realidade que se multiplica e permanentemente oscila como a dos muitos espelhos da confeitaria Colombo no Rio de Janeiro a que o poeta, conforme o próprio título lembra, «desce». Entre os autores com quem entra em diálogo figuram também em lugar de destaque os modernos, um dos quais é Pound, poeta que vai ao encontro de duas das suas maiores exigências criativas, o gosto pela mais intrépida inovação e experimentação e o entendimento da tradição como «a beleza que nós preservamos e não as grilhetas que nos prendem». Na circunstância, a interlocução com Pound tem lugar num poema de Enéadas - Nove novenas, intitulado "Tropos», e incide, como o subtítulo do texto lembra, sobre versos do primeiro dos Cantos, o qual é já, ele próprio, a paráfrase de uma tradução quinhentista latina do capítulo XI da Odisseia. O que Blanc de Portugal essencialmente faz é traduzir os sete primeiros versos daquele canto, distribuindo-os por dois grupos de tercetos e um monóstico, que vai submeter, no seguimento de cada um deles, a um inventivo jogo paragramático, a que não é alheia a sua conceção do trabalho poético como «alquimia verbal», correspondendo tal trabalho, enquanto decomposição do «átomo» da palavra, como vimos, à essência da cabala assumida como filologia generalizada.

José Blanc defendia uma «concepção evolucionista da realidade», e portanto não acreditava na existência de «rupturas absolutas na evolução da poesia e da literatura, assim como as não [aceitava] numa ciência ou na história da Terra». E poderíamos acrescentar que ele é autor de um poema, em Descompasso, de homenagem ao lógico e matemático Kurt Gödel, cujo famoso teorema leva à conclusão de que «a matemática não pode ser representada por nenhum sistema formal efectivo», o que, em última análise, significará que não exclui a incerteza e contradições. E ainda que recorre, para títulos de poemas, por mais de uma vez a um estranho conceito retórico, o anfiguri, de que o seu amigo Jorge de Sena crítica e poeticamente também se ocupou, e em que o que sobressai é um bem-humorado «nonsense» que põe em causa as regras tradicionais da lógica gramatical. 


\title{
A ESCRITA E O OLHAR: TEXTUALIDADE E MEMÓRIA NO ENSAIO SOBRE A CEGUEIRA DE JOSÉ SARAMAGO
}

\author{
PIERO CECCUCCI ${ }^{*}$
}

desesperada, deixou-se cair no chão sujíssimo, empapado de lama negra, e, vazia de forças, de todas as forças, desatou a chorar. Os cães rodearam-na, [...] um deles lambe-lhe a cara, talvez desde pequeno tenha sido habituado a enxugar prantos. A mulher toca-lhe na cabeça, passa-lhe a mão pelo lombo encharcado, e o resto das lágrimas chora-as abraçada a ele.

Ensaio sobre a cegueira

Numa entrevista de junho de 2008, Saramago afirmava:

Gostaria de ser recordado como o escritor que criou a personagem do cão das lágrimas [Ensaio sobre a Cegueira]. É um dos momentos mais belos que fiz até hoje enquanto escritor. Se no futuro puder ser recordado como «aquele tipo que fez aquela coisa do cão que bebeu as lágrimas da mulher», ficarei contente. Se alguém procurar naquilo que eu tenho escrito uma certa mensagem, atrevo-me pela primeira vez a dizer que essa mensagem está aí. A compaixão dessa mulher que tenta salvar o grupo em que está o seu marido é equivalente à compaixão daquele cão que se aproxima de um ser humano em desespero e que, não podendo fazer mais nada, lhe bebe as lágrimas ${ }^{1}$.

* Università degli Studi di Firenze.

${ }^{1}$ SARAMAGO, 2008: 6. 
Creio que a citação, colocada em epígrafe, glosada pelas próprias palavras de Saramago, acima referidas, acaba - maxima auctoritate - por encenar tout d'abord um dos nós centrais do discurso narrativo do escritor português, desaparecido há poucos anos, em torno do qual se enredam e se enovelam, sem solução de continuidade, a partir dos primeiros romances, todos os outros elementos discursivos que constituem o seu código ideológico e de representação.

Pretendo fazer referência direta ao olhar alheado com que, em Ensaio sobre a cegueira ${ }^{2}$, o Nosso Autor envolve com amargo desencanto, até ao pessimismo e ao ceticismo - sem que contudo jamais lhe falte a sua «(com)paixão solidária» para com o outro - a realidade humana no seu agir e relacionar-se com um mundo, entendido enquanto organização de sociedade civil, na qual ele não se reconhece. Um olhar preocupado, que o levará a dizer, pouco depois, com duras inflexões quase de tipo nihilista: "O mundo é um inferno. Não é preciso que nos ameacem com outro inferno, porque já lá estamos dentro» ${ }^{3}$; um olhar «ao avesso», portanto, um modo de olhar diferente e oblíquo, propenso a perscrutar a verdade velada e escondida que incansavelmente atravessa e invade toda a sua obra e que subentende uma visão objetivada ${ }^{4}$, de natureza quase ontológica, de mal no mundo.

Escreve Eduardo Lourenço:

Se nem sempre os 'heróis' são assunções claras e muito menos lineares do Bem [...], fora deles fica o Mal, un mal objectivado na e pela História [...]. Esse Mal objectivado, onde de uma forma sensível a humanidade vive as experiências desumanas, ou anti-humanas por excelência, da injustiça, da opressão, do arbitrio, da prepotência, geradoras do horror e da crueldade, podem ser, por exemplo, a Inquisição, o Poder, a Sociedade ou, mais latamente, a História ${ }^{5}$.

E, para esclarecer melhor o seu pensamento, afirma:

Todavia, na esfera fundadora do propriamente humano, se primazia existe, deve ser conferida à Ética. Não como "ciência do Bem e do Mal» de tão terrífico eco, no texto bíblico e no texto da aventura humana, mas como Enigma incontornável e inesgotável, enigma que devemos decifrar para aceder à condição humana, mas decifrar por uma escolha que nos inventa no acto de escolher e em si mesma permanece indecifrável. Aparentemente, as grandiosas fábulas romanescas de José Saramago - que no conjunto constituem uma saga - não giram em volta deste

\footnotetext{
${ }^{2}$ SARAMAGO, 1995a.

${ }^{3}$ SARAMAGO, 2008: 6.

${ }^{4}$ LOURENÇO, 1993-1994: 128.

${ }^{5}$ LOURENÇO, 1993-1994: 128.
} 
enigma que tem no Bem e no Mal, ou antes na questão mesma de separar ou de não confundir um com o outro, a sua matéria. A sua ficção não é, em sentido próprio, como a de Cervantes ou de Dostoievski, de ordem ética, mas moral. Se tivermos em conta a intenção da fábula, facilmente nos damos conta de que o universo de José Saramago se situa na linha dos nossos grandes moralistas do século XVII e numa tradição ficcional próxima do paradigma, glorioso e vivo na nossa Península, do romance de cavalaria 6 .

Em Ensaio sobre a cegueira, até aos ultimíssimos romances, num crescendo intenso de tons angustiados, o mal não aparece já unicamente considerado, como nos primeiros trabalhos, como consequência de uma organização social injusta e perversa, mas também, sobretudo, como relacionado com a própria natureza do homem, imperfeita e tendencialmente corrupta. O indivíduo, enquanto a sua razão é aniquilada pelos acontecimentos e tomam negativamente a vitória de obscuros instintos, inatos, deixa de ser o homo socius, o homo faber, artífice de civilização e de cultura, de progresso, afinal, para se transformar, fechando-se em si mesmo, no seu egoísmo e na sua mesquinhez, em homo malus, em homo homini lupus.

Diz o narrador:

A consciência moral, que tantos insensatos têm ofendido e muito mais renegado, é coisa que existe e existiu sempre, não foi uma invenção dos filósofos do Quaternário, quando a alma mal passava ainda de um projecto confuso. Com o andar dos tempos, mais as actividades da convivência e as trocas genéticas, acabámos por meter a consciência na cor do sangue e no sal das lágrimas, e, como se tanto fosse pouco, fizemos dos olhos uma espécie de espelhos virados para dentro, com o resultado, muitas vezes, de mostrarem eles sem reserva o que estávamos tratando de negar com a boca?.

Aqueles olhos que, como «espelhos virados para dentro», desenham configurações narrativas em que se revela a presença enunciativa do eu narrante que comenta e intervém - muitas vezes com ironia serieuse - sobre a diegese, dizem de um olhar de não aceitação do mal que invade a existência das humanas gentes e que, na denúncia do qual, vem procurar e solicitar a cumplicidade do leitor. Com este, realmente, institui e modela formas solidárias de (com)paixão e de pietas que se entrelaçam na malha da textualidade discursiva, fazendo do narrado no seu complexo uma mensagem não sobre a vista ou sobre a sua ausência, mas sobre a possibilidade ou não de constituição

${ }^{6}$ LOURENÇO, 1993-1994: 127-128.

${ }^{7}$ SARAMAGO, 1995a: 26. 
das imagens, que permitem na comum visão do mundo, um terreno de entendimento e de intenções entre narrador e leitor.

Do mesmo modo, Saramago no Ensaio sobre a Cegueira - como de resto em todos os outros romances, com os quais estabelece um denso diálogo intratextual e, em última análise contra todas as aparências, um inegável continuum narrativo - consegue mobilizar a consciência do leitor que, convocado para um papel extremamente ativo, qual ideal «coautor», no ponto de vista avivado e adotado, torna-se (cor)responsável da «verdade» reflexa e encontra a justa solicitação para pôr em campo um olhar também alienado da realidade, uma leitura ao avesso do mundo fenoménico; uma «crítica violenta ao status quo e à responsabilidade dos que passivamente o aceitam ${ }^{8}$, daqueles, enfim, que são «cegos que vêem, cegos que, vendo, não vêem» ${ }^{9}$. Palavras, estas, que põe na boca do médico, quando este afirma «Queres que te diga o que penso [...], Penso que não cegámos, penso que estamos cegos, Cegos que vêem, Cegos que, vendo, não vêem» ${ }^{10}$.

Trata-se, como lucidamente sublinha Beatriz Berrini, uma das mais atentas estudiosas saramaguianas, do "princípio de inversão» ${ }^{11}$, que se explicita num ponto de vista diferente que se apoia na "lei da leitura invertida do real, ou simplesmente, da inversão» ${ }^{12}$, e que no plano da escrita e do discurso textual incentiva o leitor a uma "permanente subversão perante o real, de modo de vê-lo e interpretá-lo como se fosse a primeira vez» ${ }^{13}$.

Em Saramago, esta não é uma atitude inédita e que, como acima referi, acaba por se colocar como código escritural já iniciada no Manual de pintura e caligrafia (1977) e que encontra desde logo, na revisitação da História a partir dos romances posteriores ${ }^{14}$, o momento de mais intensa e profunda reflexão.

A este propósito, sem entrarmos em divagações, não compatíveis aliás com a economia dos espaços de tempo concedidos, não podemos deixar de recordar que é exatamente em relação às vivências humanas, passadas e presentes, que ele dirige o seu olhar inquiridor mais crítico e eleva a sua voz fora do coro, para salientar o não visto e o não dito, recordar os excluídos, recuperar-lhes a dignidade de homens, reposicionar como ato de justiça os seus esforços e o seu sofrimento, a sua dignidade, no centro do caminho in progress, não sempre linear e direto, muitas vezes caótico, que a humanidade muitas vezes à deriva - como na presente época e como nos dizem a Cegueira e os

\footnotetext{
${ }^{8}$ SEIXO, 1996: 197.

${ }^{9}$ SARAMAGO, 1995a: 310.

${ }^{10}$ SARAMAGO, 1995a: 310.

${ }^{11}$ BERRINI, 1998: 95.

${ }^{12}$ BERRINI, 1998: 93.

${ }^{13}$ BERRINI, 1998: 95-96.

${ }^{14}$ Refiro-me de modo especial a Levantado do Chão (1980), Memorial do Convento (1982), O Ano da Morte de Ricardo Reis (1984), O Cerco de Lisboa (1989) e, em certos aspetos, também a O Evangelho segundo Jesus Cristo (1991).
} 
seus últimos romances - é chamada a cumprir, movida por uma obscura fatalidade para também um obscuro destino.

No entanto, é o presente que, questionado sobretudo nos últimos escritos com insistência - quase com obsessão -, o nosso escritor nos deixou em herança, e como testemunho preocupado.

Os Anos Noventa do século passado, com as suas terríveis mutações da época, a sua carga de ódio - pensemos, para nos limitarmos a um só, trágico exemplo, às inauditas e devastadoras vivências das guerras fratricidas nos Balcãs - espalharam no primeiro decénio do novo século, a que ele pode assistir com cada vez mais desânimo ondas de intolerância e de medos, gerando assustadores céus plúmbeos de terrorismo, insanos conflitos, desequilíbrios económicos e perversas formas de globalização, que são chamadas a pagar, hoje como sempre, as classes mais fracas e mais desprotegidas.

É este presente que nos atinge e nos põe o coração em pânico, a que Saramago certamente não pode permanecer insensível. Sobre a História sempre lançou e, nos seus últimos livros sempre continuou a lançar, o seu olhar inquieto e não conformado. Mas é ainda no extremo, dorido tempo da sua vida, que parece inquietá-lo, que não lhe dá tréguas, que - não obstante a grave, fatal doença que o atingiu - o incentiva, mesmo na fraqueza do seu corpo, a fazer ouvir forte e cheia de indignação, vibrante de paixão cívica, ou melhor, de acesa 'compaixão solidária', a sua voz de não resignação, que poderemos sintetizar com o dito evangélico: «Et si omnes... ego nunquam» ${ }^{15}$, quer dizer parafraseando, mesmo que todos se calassem, eu nunca (o faria).

Todavia, o presente que não constitui, como é óbvio, um hiato, uma fratura com o passado, mas, pelo contrário, como o narrador confirma repetidamente, é dele uma continuação e uma continuidade. Somos, afinal, nós todos que vivemos a contemporaneidade,

herdeiros do tempo, somos herdeiros de culturas, somos, para usar outra vez um símile que algumas vezes empreguei, uma parte de um mar. O mar está ali, há uma onda que caminha em direcção à praia, que não poderia mover-se sem o mar que está por trás, e sobre essa onda que vem rolando há uma pequena franja de espuma que avança para a praia, onde irá acabar. Penso que somos a espuma que é transportada na onda, que essa onda é ela própria impelida pelo mar, que o mar éo Tempo, todo o tempo que ficou para trás, todo o tempo vivido, que nos transporta e nos empurra. Vivemos uma apoteose de luz e de cor na comunicação entre o espaço e o lugar onde o mar está, e somos essa espuma branca, brilhante, cintilante, que tem uma vida breve, uma breve cintilação. Isto pode fazer de mim alguém a quem a História preocupa, e é certo, a quem a relação com o tempo passado preocupa,

${ }^{15} \mathrm{Mt}, 26: 33$. 
e é certo. Mas também é certo, isso tem sido menos apontado, que há uma outra preocupação minha que nada tem que ver com o passado, e que é o destino da onda que vai derramar-se e acabar na praia ${ }^{16}$.

Creio que esta rápida citação, fulgurante na mensagem que transmite, poderá esclarecer melhor do que qualquer hermeneuse, ainda que sabiamente aplicada, o sentido do olhar alheado saramaguiano sobre o presente que atravessa toda a textualidade de Cegueira para se derramar, como onda na praia, em todos os textos posteriores, tornando perspícua e correta a sua leitura.

Aqueles espelhos virados para dentro, de que nos fala Saramago, à luz de quanto se revela no excerto apresentado, adquirem agora pleno significado ideológico, que vem conferir lúcida e sapiente referência a todo o seu corpus narrativo que, agora que nos deixou, adquire um significado e um brilho particulares e falará por décadas vindouras ao intelecto das futuras gerações.

De resto, isto quer sublinhar uma textualidade de memória e de testemunho que, como ele acrescenta na sugestiva e plena metáfora da estátua e da pedra, se espraia ao longo das páginas da Cegueira e, como acima referido, circula incansavelmente em todos os textos do último período da sua produção.

Ele próprio nos recorda:

Quando acabei o Evangelho não sabia que andara a descrever uma estátua [...] a parte da superfície da pedra, a estátua é só a superfície da pedra, é o resultado daquilo que foi retirado da pedra, a estátua é o que ficou depois do trabalho de retirar pedra à pedra] quando acabei o Evangelho (dizia) tive de perceber o que acontecia quando deixava a descrição duma superfície passava para o interior da pedra. E isso só pude com o Ensaio sobre a Cegueira. Aí foi quando compreendi que alguma coisa tinha terminado na minha vida de escritor e que alguma coisa tinha começado.

[...] Eu creio que tal como na nossa vida se passam acontecimentos de todo o tipo, também a expressão daquilo que sentimos e daquilo que pensamos, que pode tomar uma expressão qualquer, é o modo de fazer passar para o lado de fora as nossas esperanças, as nossas certezas, as nossas dúvidas, as nossas preocupações. E a minha preocupação neste momento [...] é o ser humano, é o ser humano que realmente me interessa.

[...] Então aquilo que a Cegueira propõe não é já a descrição da estátua, é mais uma tentativa de entrar na pedra que é como quem diz, uma tentativa de entrar no mais profundo de nós ${ }^{17}$.

\footnotetext{
${ }^{16}$ SARAMAGO, 1999: 33, 35.

${ }^{17}$ SARAMAGO, 1999: 73, 75, 77.
} 
Pois bem, a essa tentativa conforma-se toda a escrita, conferindo significação plena e persuasiva a uma textualidade, em que verdadeira e pervasivamente, mais que nunca, a "presença enunciativa e normalmente discursiva sem carácter diegético» ${ }^{18}$ no texto do nosso autor, se torna código narrativo eloquente e permanente.

Trata-se, em suma, de uma textualidade, em que é possível focar, como diz mais uma vez Maria Alzira Seixo, o «predomínio do comentário, de tonalidade jocosa ou sibilina, de jeito reprovador ou apreciativo [...] discursiva, pós-moderna» ${ }^{19}$; em conclusão, de rutura com os modelos modernistas que acaba por gerar uma forte, inevitável cumplicidade entre o narrador e o leitor, que evidentemente os coloca numa posição narrativa privilegiada.

Os dois, narrador e leitor, agora revelam e traduzem um olhar «de avesso», que já não veicula uma mensagem de tolerância e de irónica compreensão para com a fragilidade moral do homem, mas uma análise inequívoca sobre a origem do mal que, corrigindo o delineamento anterior, subtende, com amargo realismo nas palavras de Eduardo Lourenço, uma visão desoladamente pessimista, sendo ontologicamente próprio da natureza do homem, quando prevalecem nele egoísmos maus, ferinos ${ }^{20}$.

Justamente, como o próprio autor esclarece:

No fundo, o que a Cegueira quer dizer é, precisamente, que todos nós somos cegos da Razão [...]. A nossa razão não é usada racionalmente. Mas como qualquer coisa que está entre o racional e o irracional. Como arracionais. Não sei se esta palavra existe, mas quero introduzir esta categoria ${ }^{21}$.

Tendo já sublinhado anteriormente, com uma veia de desolado pessimismo:

ao fim de séculos de civilizações estamos perto da barbárie. Apesar da beleza e do pensamento, a tentação da barbárie. Não é preciso ir aos campos nazis ou ao "gulag», a barbárie está aí, no Ruanda, na ex-Jugoslávia... Todos os horrores que descrevo e que deixarão o leitor desconcertado [...] estão neste momento a acontecer, no prédio ao lado, na rua ao lado, em qualquer lugar. Roubos, violações, mortos, são o pão nosso de cada dia ${ }^{22}$.

\footnotetext{
${ }^{18} \mathrm{Vd}$. sobre este assunto o ensaio Maria Alzira Seixo, em que ela ilustra com a reconhecida acribologia crítica os novos caminhos textuais saramaguianos, empreendidos com a Cegueira.

${ }^{19}$ SEIXO, 1996: 191-192.

${ }^{20}$ LOURENÇO, 1993-1994: 128.

${ }^{21}$ SARAMAGO, 1995c: 16.

${ }^{22}$ SARAMAGO, 1995b: 82.
} 
Seria fácil hoje dizer, à laia de conclusão, e à luz dos crimes atrozes contra a humanidade e a civilização destes nossos últimos tempos, ou melhor, destas últimas semanas no Médio Oriente, que ele tinha visto justo e com muita antecedência o que teria acontecido, quando o homem se abandona à sua feridade.

Por isso, hoje nos falta a sua voz de reprovação e de denúncia contra a injustiça e o mal que nos cerca por todos os lados. Sobretudo falta a sua figura humana de intelectual comprometido, sempre generosamente pronto a defender os mais fracos.

Restam, porém, os seus escritos, sempre atuais, sempre extraordinariamente em dia, que nos acompanham nestes dias pesados e tragicamente tristes, embora, para nós, que o conhecemos e amámos, continue através da memória das palavras, que nos deixou, a encher os nossos corações, cientes de que nada podemos contra o Mal, categoria ontológica difícil se não impossível de suprimir. Assim, como diz a metáfora evocada por Saramago, acabaremos todos como espuma da onda do mar com o espraiar sobre a praia e acabará o nosso tempo.

Ou, como, desconsoladamente, poderia glosar o nosso amado Pessoa:

Por sobre o verdor turvo do amplo rio

Os circumflexos brancos das gaivotas...

Por sobre a alma o adejar inutil

Do que não foi, nem pode ser, e é tudo ${ }^{23}$.

\section{BIBLIOGRAFIA}

BERRINI, Beatriz (1998) - Ler Saramago: o romance. Lisboa: Editorial Caminho.

LOURENÇO, Eduardo (1993/1994) - Saramago um 'teólogo' no fio da navalha. «Espacio/Espaço Escrito», 9 y 10 (Invierno).

PESSOA, Fernando (2000) - Há doenças peores. In Poemas de Fernando Pessoa. Edição de Luís Prista. Lisboa: IN CM.

SARAMAGO, José (1995a) - Ensaio sobre a Cegueira. Lisboa: Editorial Caminho.

(1995b) - José Saramago: Todos os pecados do Mundo. Entrevista de Clara Ferreira Alves. «Expresso», 28/10.

(1995c) - José Saramago: o escritor vidente. Entrevista de Maria Leonor Nunes. «Jornal de Letras, Artes e Ideias», n. ${ }^{\circ} 653$ (25 out.), p. 16.

(1999) - A Estatua e a Pedra. Org. de Giancarlo De Pretis. Torino: Ed. Dell'Orso.

(2008) - Não sou um exemplo do que é viver neste mundo. Entrevista a Maria José Oliveira. «Público», (15 jun.), p. 6.

SEIXO, Maria Alzira (1996) - Os espelhos virados para dentro. Configurações narrativas do espaço e do imaginário em Ensaio sobre a Cegueira. In José Saramago: il bagaglio dello scrittore. A cura di Giulia Lanciani. Roma: Bulzoni Editore.

${ }^{23}$ PESSOA, 2000: 250. 


\title{
VIAJANTES PORTUGUESES DE HOJE NA ÁFRICA LUSÓFONA: ENTRE MEMORIA E PRESENTE, QUE DIÁLOGOS?
}

\author{
MARIA DE FÁTIMA OUTEIRINHO*
}

Em 2015, nos Encontros da Lusofonia que tiveram lugar em Paris, Dulce Maria Cardoso contestava a opinião de alguns, segundo a qual a lusofonia deveria ser entendida, no presente, sem o peso dos factos históricos, e afirmava:

Creio não ser possível pensar na lusofonia sem ter em conta os cinco séculos de Império e Portugal como colonizador. A lusofonia é fruto do Império. Desfizemo-nos do Império como se fosse uma camisa velha, no dizer do professor Eduardo Lourenço. Penso que o mais correcto será dizer que quisemos desfazer-nos do Império como se fosse uma camisa velha mas que nunca o conseguiremos fazer porque o Império nos moldou enquanto povo, no passado, tal como a falta dele nos vai moldando o presente. Talvez por isso seja difícil fazerem-se ouvir vozes lúcidas sobre o Império. Renegamo-lo ou exaltamo-lo consoante as nossas perspectivas de vida e credo político, mas raramente conseguimos abordar com profundidade o que foi efectivamente $o$ Império e o que dele restou'.

Mais do que ajuizar sobre a possibilidade de se abordar com profundidade «o que foi o Império e o que dele restou», importa-nos sublinhar, no depoimento de Dulce Maria Cardoso, a chamada de atenção para a impossibilidade de pensar a lusofonia

* Universidade do Porto/Instituto de Literatura Comparada Margarida Losa.

${ }^{1}$ CARDOSO, 2015: 22. 
ignorando constructos culturais e a necessidade de estabelecimento de pontes entre passado e presente. Neste contexto, afigura-se-nos como produtivo atentar em formas de textualização erguidas em torno de um tempo de Império ou do seu desmoronamento, com vista a uma possível deteção de movimentos entre memória e presentificação da memória a gerar novas configurações discursivas.

Se mais recentemente se tem assistido ao surgimento de toda uma produção de variegada inscrição genológica a trabalhar tempos de colonização e tempos pós-coloniais, dando na verdade testemunho de uma necessidade de escrever e/ou reescrever o passado, no que à literatura de viagens portuguesa contemporânea diz respeito, há mais de quinze anos que revisitações de uma ação imperial a partir de experiências vividas nas pós-Independências têm vindo a ser objeto de atenção por parte de escritores viajantes.

Como Mia Couto sublinha em texto de 2001, Luso-Afonias - a Lusofonia entre viagens e crimes, «A viagem obriga-nos a sermos outros, a descentrarmo-nos, a deslocarmo-nos para fora de nós. A viagem implica a disponibilidade para nos diluirmos, a vontade de sermos apropriados por outras almas» ${ }^{2}$. Ora, o texto de viagem que decorre de uma viagem acontecida, acolhe as narrativas de encontro e contacto com o Outro, e torna-se ponte entre mundos, onde, com frequência, o questionamento em torno do Eu e do Outro tem lugar.

A redescoberta europeia de uma vocação imperial que o século XIX conhece, a consequente expansão colonial, a voga orientalista ou a multiplicação de viagens de descoberta científica criam condições favoráveis à prática da viagem em África e, por consequência, ao desenvolvimento de um imaginário eurocêntrico ${ }^{3}$ e transnacional, com prolongamentos até hoje. No século XX, antes e depois das descolonizações, embora com enquadramentos geopolíticos distintos, os périplos em espaço africano protagonizados por viajantes escritores oriundos de um espaço ocidental continuam a multiplicar-se e a fazer-se eco dessa herança cultural partilhada, mesmo quando ela é objeto de problematização.

É neste quadro genericamente esboçado que nos propomos explorar um conjunto de textos de viagens portugueses de percurso africano lusófono: Baía dos Tigres (1999) de Pedro Rosa Mendes, Sul de Miguel Sousa Tavares ${ }^{4}$ e Até lá baixo. Três homens e um jipe e 150 dias de aventuras em África de Tiago Carrasco ${ }^{5}$. Obras escritas e publicadas numa era pós-colonial e num contexto de renovado interesse contemporâneo, todas se ancoram, dentro de um quadro pragmático no que toca à receção, na pressuposição de uma relação referencial a reger fortemente o pacto de leitura, assente ainda numa memória histórica em comum que convocam. Com efeito, a literatura de viagens joga

${ }^{2}$ COUTO, 2009: 184.

${ }^{3}$ Cf. OUTEIRINHO, 2013.

${ }^{4}$ TAVARES, 2004.

${ }^{5}$ CARRASCO, 2011. 
num relato que alia um pressuposto tácito de relação com uma viagem ocorrida e consequente vivência referencial, não enjeitando, é certo, a possibilidade de efabulação. Como lembram Patrick Holland e Graham Huggan, os escritores viajantes «avail themselves of the several licenses that are granted to a form that freely mixes fact and fable, anecdote and analysis» ${ }^{6}$.

As obras escolhidas trabalham a memória, uma memória de viagem e uma memória sobre África, de pertença portuguesa e europeia, aproximando narrador e leitor, mas simultaneamente dando protagonismo a uma África contemporânea, das pós-independências. Tratar-se-á então para nós de considerar modos de inscrição da memória no relato de experiências do presente, procurando identificar potenciais diálogos entre um espaço cultural português e outros espaços da lusofonia.

Pedro Rosa Mendes, em Baía dos Tigres, não se deterá num imaginário africano visualmente vulgarizado, nomeadamente pelo cinema, um imaginário eivado por estereótipos turísticos. De facto, a cartografia africana de que dá conta revela uma paisagem traumática ${ }^{7}$, de um mundo alterado e caótico, numa obra em que a ideia de ausência e de perda é mais forte do que noutros autores viajantes. O espaço minado agora atravessado, o contacto com as vítimas do uso desse espaço, leva a um processo de memorialização do passado. Seguindo nos passos de pombeiros portugueses do início do século XIX, Pedro Rosa Mendes faz a experiência e dá testemunho de um quotidiano de guerra, de conflitos, de populações divididas, de pessoas anónimas, pessoas que habitam e estão encurraladas em terras de fim de mundo ${ }^{8}$. Registo escrito de narrativas orais recolhidas por um viajante que se quer sinal discreto no relato, essas histórias pessoais de vida dão visibilidade a quem as viveu; vozes sem voz ganham agora o direito à palavra. De modo bem marcado, contrariamente ao que sucede nos textos de Miguel Sousa Tavares ou Tiago Carrasco, o narrador de Baía dos Tigres esconde-se para dar lugar a indivíduos presos no anonimato, forma afinal não de demissão reflexiva sobre o outro e a realidade do outro, mas possibilidade de um discurso de denúncia mais ou menos subliminar, permitindo a representação de uma realidade africana disfórica. Não se trata então de uma narrativa que rediz uma voz portuguesa, europeia, mas trata-se outrossim de fazer passar uma voz africana e um corpo branco estrangeiro, estranho em África, nomeadamente pela colonização ${ }^{9}$. A memória colonial portuguesa e a memória traumática do retorno da experiência do retorno são agora veiculadas por vozes africanas. Assim, após a independência,

\footnotetext{
${ }^{6}$ HOLLAND \& HUGGAN, 2000: 9.

${ }^{7} \mathrm{Na}$ expressão usada por Brett Kaplan (2011) e que muito embora relativa a uma memória do Holocausto nos parece aqui também aplicável.

${ }^{8}$ Cf. MENDES, 2013 [2010]: 30-31, 49, 173.

${ }^{9}$ Cf. MENDES, 2013 [2010]: 103-104.
} 
[...] partiram para a terra deles [...]. [Os] angolanos fizeram filhos soberanos em camas metropolitanas, essas com largura de um cristo feitas em madeiras de Cabinda. Mas as casas foi só uma ocupação. Conquista maior foi habitar as memórias dos antigos donos.

Venderam carros à pressa e sucumbiram quando viram o anel da baía abraçar-se, neles, às saudades que (eles) iam ter! Acotovelaram-se no porto e dormiram na pista. Vieram os avióes de Lisboa e eles retornaram como os sobas da Lunda: partindo da vida com utensílios para colonizar a morte. Luanda dançou-lhes o comba, a festa do óbito, pisando-lhes - enfim! - a ausência do corpo sobre esta terra vermelha ${ }^{10}$.

Estribada num registo polifónico, Baía dos Tigres evoca deste modo memórias da colonização através dos vestígios em ruínas na paisagem e memórias dos conflitos vividos nas independências, com narrativas da responsabilidade não tanto de antigos colonos, mas com ex-colonizados a assumir a voz narrativa.

Sul reúne um conjunto de relatos em torno de viagens realizadas entre $1990 \mathrm{e}$ 2004 a espaços situados em continentes diversos, alguns deles na África lusófona que, em Miguel Sousa Tavares, é a das ilhas de Cabo Verde e de São Tomé e Príncipe ${ }^{11}$. O percurso nessa África lusófona é momento de rememoração do passado numa dinâmica relacional dos diversos espaços entre si, inevitabilidade comparativa no presente entre esses mesmos espaços, numa constatação de «sinais devastadores do tempo» $»^{12}$, e numa deteção de marcas portuguesas ${ }^{13}$ :

Uma longa balaustrada de pedra desenhada delimita toda a frente do terreiro. Vi estes mesmos desenhos, estas mesmas balaustradas, em Goa, no Pará, na Amazónia, em Moçambique, em toda a África onde parámos um dia para fazer comércio, guerra, conversões a Cristo e tráfico de escravos ${ }^{14}$.

Em Miguel Sousa Tavares, a atenção posta no outro lusófono revela-se, com frequência, etapa detonadora de reflexão sobre o eu e, em Cabo Verde, por exemplo, a autorrepresentação que emerge denuncia uma autoanálise hierarquizante em que

\footnotetext{
${ }^{10}$ MENDES, 2013 [2010]: 27-28.

${ }^{11}$ Há também uma breve referência a uma estadia em Moçambique com o propósito de caçar patos e rolas.

${ }^{12}$ TAVARES, 2004: 15.

${ }^{13}$ Cf. CADILHE, 2007: 96, no breve capítulo que se atarda sobre o espaço angolano, onde não se escapa à deteção de marcas de um tempo colonial. Na passagem por Lubango, observa-se: «De repente chego a casa sem sair de África. [...] Desta vez regresso efectivamente aos anos da escola primária quando vejo a fachada das escolas primárias da antiga cidade de Sá da Bandeira. E as outras fachadas: o hospital, o grande hotel, o prédio da cooperativa, o Palácio da Justiça, a sede do grémio, a estação de comboios, a garagem dos autocarros. São as fachadas que vigoravam nas cidades portuguesas da minha infância».

${ }^{14}$ TAVARES, 2004: 14.
} 
o português, o europeu, se apresenta em indiscutível situação de negatividade. Diz Miguel Sousa Tavares:

O Mindelo é um bocado de Portugal, assim uma espécie de Miramar, mais degradado e mais quente. Ou Portugal é um bocado do Mindelo, tanto faz. Porque aqui há cabo-verdianos que gostam mais de Portugal do que os próprios portugueses, há gente que vive com um pé no Mindelo e outro em sítios tão inesperados como Celorico da Beira ${ }^{15}$.

Ah, se nós soubéssemos... como esta gente é brava e franca, como é amiga e leal, como são tão melhores que nós - que temos Schengen e a União Europeia, o Serviço de Estrangeiros e a polícia mais racista do mundo e enchemos a boca com palavras carregadas de coisa alguma: PALOP, comunidade lusófona, vertente africana da nossa política externa, relação especial dos portugueses com África ${ }^{16}$ !

Como tivemos ocasião de observar em estudo anterior ${ }^{17}$, deslumbramento e indignação, esplendor e decadência ${ }^{18}$ acompanham-se ou sucedem-se na escrita em torno de uma espacialidade africana de raiz lusófona, denunciando a degradação das estradas, o declínio das roças, as plantações envelhecidas ou abandonadas ${ }^{19}$, a irresponsabilidade, a ineficácia, a corrupção ${ }^{20}$, mas igualmente revelando o fascínio por uma paisagem «surpreendente, exaltante e misteriosa» ${ }^{21}$. Igualmente uma certa defesa de uma ação portuguesa ou pelo menos a necessidade de alguma preservação ${ }^{22}$ e a vontade de combater o par antitético branco/negro são ainda outros momentos de uma escrita que em Miguel Sousa Tavares reconfigura uma abordagem da história colonial:

é impossível não render uma homenagem silenciosa e maravilhada aos homens, brancos e negros, que, de 1471 a 1974, desbravaram as ilhas, sondaram a selva, roçaram o mato, construíram longas casas de pedra e telha vã e rasgaram estradas,

\footnotetext{
${ }^{15}$ TAVARES, 2004: 70-71.

${ }^{16}$ TAVARES, 2004: 72.

${ }^{17}$ OUTEIRINHO, 2013.

${ }^{18}$ A obra de Joaquim Magalhães de Castro, No mundo das maravilhas (CASTRO, 2010) nesse percurso de redescoberta de um património português legado por um movimento expansionista e colonial, é então veículo de denúncia da dilapidação de todo um património, deteção de uma presença portuguesa na toponímia, na arquitetura colonial, no património religioso.

${ }^{19}$ Cf. TAVARES, 2004: 120-121.

${ }^{20}$ Cf. TAVARES, 2004: 125 .

${ }^{21}$ TAVARES, 2004: 120

${ }^{22}$ Cf. TAVARES, 2004: 117. «Nos anos a seguir à independência, os chineses e os coreanos do Norte fizeram o que puderam para desfigurar a arquitectura colonial portuguesa, construindo palácios de correios e de congressos (!) que parecem a casa-forte do Patinhas, em versão realista-socialista. Mas em vão, que diabo: estivemos lá 500 anos!»
} 
praças e pontões, quando tudo parecia ser-lhes adverso - a remota longitude das ilhas, a inospitalidade do clima, a cerração da mata ou o flagelo das febres tropicais ${ }^{23}$.

Neste enquadramento, o narrador pode então avançar e defender que os portugueses pertencem também a África,

Não como donos e senhores por direito divino ou histórico. Mas como cidadãos de África, por direito natural, por identidade de alma, se quiserem. Não fui eu que o descobri: muitos africanos o dizem, agora que a retórica anticolonial está a perder também a sua razão de ser ${ }^{24}$.

Até lá abaixo. Três homens e um jipe e 150 dias de aventuras em África de Tiago Carrasco é o relato de uma aventura africana ${ }^{25}$, de cerca de 5 meses, aventura experienciada por Tiago Carrasco, João Fontes e João Henriques ${ }^{26}$ com partida de Lisboa e chegada a Joanesburgo. Motivada por uma necessidade profunda de mudança de vida, de evasão ${ }^{27}$, face a uma falta de horizontes de futuro no campo profissional, ela dá testemunho de uma grande coragem pela falta de condições em que é empreendida ${ }^{28}$. A narrativa do périplo destes três portugueses acaba afinal por ser reveladora de uma irónica autorrepresentação de Portugal, nos antípodas de um imaginário expansionista português mitificado.

Em Até lá abaixo, a África lusófona visitada é a de Guiné-Bissau, Angola e Moçambique e, tal como ocorre nos textos de viagem anteriormente abordados, a atenção a vestígios de uma presença e ação colonizadoras emerge, e o contacto com o africano do tempo presente torna-se ocasião para dar a ouvir a sua voz. É o que sucede quando passam em Bolama: «Outrora um paraíso colonial, orgulho do império ultramarino, a cidade está hoje entregue ao abandono, com as fachadas dos edifícios a desmembrarem-se e as estradas intransitáveis». E mais adiante, observa-se: «Estávamos agora diante de um prédio com portas altas e varandins, tirado a papel químico de uma associação recreativa de Alfama ou da Mouraria»" ${ }^{29}$. A atenção a uma presença humana portuguesa vestígio também ela de uma era colonial irrompe por vezes em Até lá abaixo, testemunhando da atenção votada não apenas a uma paisagem física,

\footnotetext{
${ }^{23}$ TAVARES, 2004: 119.

${ }^{24}$ TAVARES, 2004: 119.

${ }^{25}$ Cf. CARRASCO, 2011: 95: «Bissau é a mais subdesenvolvida das duas dezenas de capitais por onde passámos nesta aventura».

${ }^{26} \mathrm{O}$ relato é da responsabilidade de Tiago Carrasco, mas a viagem teve igualmente um registo visual (fotográfico e fílmico) feito por João Fontes e João Henriques.

${ }^{27}$ Cf. CARRASCO, 2011: 13.

${ }^{28}$ Cf. CARRASCO, 2011: 27: «Éramos trapezistas sem rede na mais difícil acrobacia para um viajante — cruzar África de uma ponta à outra».

${ }^{29}$ CARRASCO, 2011: 101.
} 
mas a um quotidiano de vidas humanas, dando visibilidade e voz a figuras anónimas, testemunhas e agentes de um tempo passado e presente. Integrando narrativas de vida das gentes encontradas, complementa-se e matiza-se uma História oficial ainda hoje com espaços de sombra e silenciamento ${ }^{30}$.

\section{ALGUMAS NOTAS CONCLUSIVAS}

A observação de Mia Couto quando lembra que «os lugares não são coisas. São entidades vivas, possuem um coração que está nas mãos daqueles que falam com as vozes do chão.» ${ }^{31}$, espelha-se nestes textos de viagem pela África lusófona, quer por um mergulho na memória histórica agora revisitada e interrogada, quer por uma experiência de um presente pós-colonial. Com efeito, estas narrativas de viagem abrem-se a uma evocação de memórias coloniais, evocação que decorre da inscrição cultural dos viajantes, e se desenvolve num reencontro com representações imperiais, por vezes problematizadas, a partir dos vestígios reconhecidos na paisagem. Como lembra Pedro Rosa Mendes, «No limite [...], o viajante é apenas o seu relato, identifica-se com ele porque dele extrai a sua própria identidade; não existe fora do mapa; viajante e mapa são uma e a mesma entidade» ${ }^{32}$. E desta forma a experiência de viagem na África lusófona é, nestes viajantes, possibilidade de autoquestionamento, pois como observa Miguel Sousa Tavares, «interrogamo-nos, então, que sentido fará este desejo de nos perpetuarmos de alguma forma nos cantos do mundo aonde a História nos levou e de onde a História nos varreu» ${ }^{33}$.

Da capacidade de (auto) questionamento, surge também a possibilidade de escutar e dar a ouvir as vozes dos descolonizados anónimos, encontrados num tempo de um presente vivenciado e que agora conquistam um protagonismo não negligenciável nestes textos publicados nos últimos doze anos, permitindo desenhar uma nova cartografia de geografias humanas e físicas do período das independências a oferecer novos pontos de vista provindos de espaços culturais de/com língua portuguesa.

O trabalho com uma memória cultural em torno de África e a construção de representações em torno de outros africanos e lusófonos, não só possibilita um requestionamento identitário português europeu como ainda permite pensar reconfigurações do outro africano lusófono, pois, como observa Daniel-Henri Pageaux, «On ne convoque pas impunément l'Autre en littérature.» ${ }^{34} \mathrm{e}$, num diálogo entre memória histórica e presente, a literatura de viagens ergue-se, inegavelmente, como plataforma

\footnotetext{
${ }^{30}$ Tome-se como exemplo a história de Célia e do marido chegados em 1972 à Guiné-Bissau, em busca de uma vida melhor, dando conta afinal de uma emigração que não escolheu a Europa como destino.

${ }^{31}$ COUTO, 2009: 52.

${ }^{32}$ MENDES, 2013: 202.

${ }^{33}$ TAVARES, 2004: 60.

${ }^{34}$ PAGEAUX, 1995: 139.
} 
de mediação e ponte entre diferentes espaços de lusofonia, a partir da qual novos discursos poderão emergir.

\section{BIBLIOGRAFIA}

CADILHE, Gonçalo (2007) - África acima. Lisboa: Oficina do Livro.

CARDOSO, Dulce Maria (2015) - Pecados da lusofonia. «Público», (21 out.), p. 22-23.

CARRASCO, Tiago (2011) - Até lá abaixo. Três homens e um jipe e 150 dias de aventuras em África. 2. ${ }^{\mathrm{a}}$ ed. Alfragide: Oficina do Livro.

CASTRO, Joaquim Magalhães de (2010) - No Mundo das Maravilhas. Viagem ao património de origem portuguesa do Uruguai a Omã. Lisboa: Editorial Presença.

COUTO, Mia (2009) - Luso-Afonias - a Lusofonia entre viagens e crimes. In E se Obama fosse africano? Interinvenções. Lisboa: Editorial Caminho, p. 183-198.

HOLLAND, Patrick; HUGGAN, Graham (2000) - Tourists with typewriters. Critical reflections on contemporary travel writing. Ann Arbor: The University of Michigan Press.

KAPLAN, Brett Ashley (2011) - Landscapes of Holocaust Postmemory. London / New York: Routledge. MENDES, Pedro Rosa (2013 [2010]) - Baía dos Tigres. 7. a ed. Alfragide: D. Quixote.

OUTEIRINHO, Maria de Fátima (2013) - Images de l'Afrique dans quelques textes de voyage contemporains. In COUTINHO, Ana Paula; OUTEIRINHO, Maria de Fátima; ALMEIDA, José - Nos \& leurs Afriques. Images identitaires et regards croisés Constructions littéraires fictionnelles des identités africaines cinquante ans après les décolonisations. Bruxelles: Peter Lang, p. 165-181.

(2014) - A imagem literária do «Outro» lusófono: representações do outro africano e lusófono em textos de viagens portugueses. In VIEIRA, Cristina Costa; OSÓRIO, Paulo; MANSO, Henrique, coord. - Portugal-África-Brasil. Relações históricas, literárias e cinematográficas. Covilhã: Universidade da Beira Interior, p. 253-270.

PAGEAUX, Daniel-Henri (1995) - Recherches sur l'imagologie: de l'Histoire culturelle à la Poétique. «Revista de Filología Francesa», 8. Madrid: Servicio de Publicaciones Univ. Complutense, p. 135-159.

TAVARES, Miguel Sousa (2004) - Sul. Viagens. Lisboa: Oficina do Livro. 


\title{
HOMOSSEXUALIDADE E HOMOEROTISMO NA FICÇÃO DE VALTER HUGO MÃE
}

\author{
CARLOS NOGUEIRA*
}

A homossexualidade e o homoerotismo masculinos são dois dos temas e tópicos cujas incidências semânticas e estruturais mais se destacam em intensidade e originalidade na escrita de Valter Hugo Mãe, que em 2007 e em 2012 foi distinguido com três importantes prémios: o Prémio José Saramago, com O Remorso de Baltazar Serapião ${ }^{1}$, o Prémio Portugal Telecom de Literatura em Língua Portuguesa na categoria de melhor romance, com A Máquina de Fazer Espanhóis² e, cumulativamente, o Grande Prémio Portugal Telecom, atribuído aos finalistas das várias categorias. N'O Filho de Mil Homens, a homossexualidade e o homoerotismo constituem uma das principais linhas efabulativas e dois dos motivos que mais suscitam considerações por parte do narrador de terceira pessoa. Mas, por desatenção, ou simplesmente por não querer abordar uma questão que é, como sabemos, muito complexa e (ainda) muito polémica, nem por isso a crítica literária tem notado a importância do tema. Sublinha-se «o apelo da paternidade ${ }^{3}$ e da família, a busca do outro e da felicidade, mas pouco ou nada se diz sobre a presença e os enquadramentos técnicos e ideológicos das temáticas homossexual e homoerótica neste romance.

\footnotetext{
* Universidade de Vigo - Cátedra José Saramago.

${ }^{1}$ MÃE, 2006.

${ }^{2} \mathrm{MÃE}, 2010$.

${ }^{3}$ LAGE, [s.d.]: 8 .
} 
O Filho de Mil Homens descreve e exalta o amor entre pessoas de sexos diferentes, mas não representa e celebra menos o amor homossexual. Também importa sublinhar já que o tratamento da homossexualidade e do homoerotismo neste romance não se faz ignorando ou negando a ideia generalizada de amor e de relações heterossexuais. N'O Filho de Mil Homens, o sentimento amoroso aparece primeiro do lado do masculino na relação entre Crisóstomo e Isaura, e é abordado com uma intensidade rara na literatura portuguesa. Crisóstomo vem contrariar a imagem social, que Isaura pôde comprovar na adolescência, de que a maioria dos homens tende a seduzir as mulheres unicamente com o objetivo de as levar a fazer sexo com eles. Ao contrário do primeiro sedutor de Isaura, que usou uma linguagem verbal completamente distinta das suas reais intenções, em Crisóstomo a linguagem do amor e da sedução acompanha diretamente os sentimentos e os desejos. Crisóstomo, em quem convergem muitas das características ditas femininas (questão a que voltaremos várias vezes ao longo deste artigo), não forjou uma linguagem do sentimento e do amor, da delicadeza e da entrega, para conseguir sexo e depois abandonar Isaura.

N’O Filho de Mil Homens, a intriga desenvolve-se a partir de várias personagens, e uma delas é precisamente «O filho da Matilde» ${ }^{4}$, segundo o título do capítulo que o apresenta. Antonino não perderá em atenção do narrador para qualquer uma das outras personagens, nem sequer para a personagem que aparece em primeiro lugar, Crisóstomo, o «homem» que «chegou aos quarenta anos e assumiu a tristeza de não ter um filho $»^{5}$, como se lê na primeira frase do romance (que vem colocar desde o início a questão da autobiografia, já que os leitores mais atentos de Valter Hugo Mãe sabem que ele tem dito e escrito que, chegado aos quarenta anos, lamenta muito profundamente não ter um filho). Para além de em vários outros capítulos merecer tanta ou quase tanta atenção quanto a dispensada a outras personagens, Antonino será ainda objeto de atenção central em mais dois capítulos, o sétimo, «Devorar os filhos» ${ }^{6}$, e o oitavo, «Esbagoados» ${ }^{7}$.

A narração do que significa ser homossexual numa comunidade conservadora começa, sem eufemismos, no início do capítulo «O filho da Matilde», e é também já aqui que o leitor é levado a refletir sobre o que determina o olhar acusador da comunidade e sobre o que desencadeia ou explica a homossexualidade de Antonino (e a homossexualidade em geral). Vejamos as primeiras frases do capítulo «O filho da Matilde», para podermos iniciar um dialogar com algumas das teorias da homossexualidade e com as perspetivas de autores como Michel Foucault, John Thorp ou Judith Butler:

${ }^{4}$ MÃE, 2011: 63-73.

${ }^{5} \mathrm{MÃE}, 2011: 15$.

${ }^{6}$ MÃE, 2011: 105-116.

${ }^{7} \mathrm{MÃE}, 2011$ : 117-127. 
Muitos anos passados, apareceu por ali um homem maricas que vinha ver a Isaura de longe, a dizer-lhe bom dia e a sorrir. Era um homem dos que não gostavam de raparigas e precisavam de fazer de conta. [...]. A vizinhança dizia, mesmo sem certezas, que era um homem com histórias horríveis, encontrado nos ermos a falar com estranhos, com outros homens, que tinha sido visto a subir as calças ao pé das águas onde os trabalhadores nadavam. Sabiam todos que tinha crescido errado, diferente dos outros rapazes, diferente das pessoas. Era como alguém incompleto das ideias ${ }^{8}$.

Ao ler aquela passagem, o leitor mais ou menos informado sentir-se-á induzido a convocar as suas convicções ou impressões sobre o problema, e tenderá a colocar a si mesmo a questão (essencialismo vs construcionismo): nasce-se homossexual ou esta é uma condição que se constrói por influência do meio? Esta é, esquematicamente, a grande questão, para a qual há, permita-se-nos a simplificação, dois tipos de teorias. John Thorp fala nas «planophysical theories» e nas «doliophysical theories» ${ }^{9}$. As «planophysical theories» classificam a homossexualidade como um erro da natureza, uma aberração produzida pela própria natureza, mas não de acordo com o seu grande plano $^{10}$. A homossexualidade nasce porque algo falhou na relação de causa e efeito que preside a tudo quanto existe na natureza. A tradição das teorias psicoanalíticas da homossexualidade integra-se, segundo o mesmo autor, nesta linha. A homossexualidade surge porque, por motivos como maturações incompletas ou complexos de Édipo por resolver, não se verificou o normal desenvolvimento psicológico. Nas «planophysical theories» entram também as teorias hormonais, provavelmente as mais "promissoras», como defende John Thorp, mas aqui há o obstáculo dos métodos de observação, em relação aos quais os especialistas não chegam a um acordo. Para as «doliophysical theories», a natureza determina deliberadamente a homossexualidade, integra-a no seu grande plano, através dos subtis processos pelos quais ela consegue atingir os seus fins. Promovendo a homossexualidade numa parte da população, a natureza está a garantir a sobrevivência da espécie humana. Estamos no âmbito das teorias sociobiológicas: um gene da homossexualidade desenvolve-se por seleção natural, com vista a um certo estado de equilíbrio.

Voltemos à transcrição do romance $O$ Filho de Mil Homens, e fixemo-nos na frase «Sabiam todos que tinha crescido errado, diferente dos outros rapazes, diferente das pessoas» ${ }^{11}$. Temos «crescido», não «nascido», e portanto talvez se possa começar por pensar que o texto nos vai orientar para a explicação psicoanalítica, que cabe no primeiro

${ }^{8}$ MÃE, 2011: 65.

${ }^{9}$ THORP, 1992: 54.

${ }^{10}$ THORP, 1992: 54.

${ }^{11}$ MÃE, 2011: 65. 
dos dois grupos delineados por John Thorp. Este caminho também será explorado no livro, mas não imediatamente. Primeiro, uma página e meia depois, é adiantada a hipótese geral das "planophysical theories» (em que, recordemos, cabem as teorias psicoanalíticas). A homossexualidade de Antonino é explicada através de uma analogia com um curioso comportamento sexual dos coelhos, que, às vezes, «enganados ou a fazerem-se de espertos, esfregavam-se macho a macho para se aliviarem. Ela bem o via. Talvez fosse um erro da natureza que se lhes impõe, porque eles nem pensariam o suficiente para o decidirem sozinhos. Os coelhos nasciam quase sem cérebro» ${ }^{12}$. A analogia continua, e ficamos a saber que Isaura se destaca da comunidade, porque, em vez de censurar acerbamente Antonino, procura compreendê-lo: «Ela olhou para o homem e pensou que ele não teria culpa de ser como era. Talvez tivesse pouco cérebro ${ }^{13}$. Antonino é, provavelmente, pensa Isaura, um erro da natureza, e, portanto, não deve ser responsabilizado pelas suas inclinações sexuais.

A explicação psicoanalítica é retomada mais à frente, primeiro no capítulo sete, «Devorar os filhos», assumida pela mãe de Antonino, que, viúva, se culpabiliza por tê-lo «feito assim» e por «não encontrar solução e competir-lhe tanto encontrar solução» ${ }^{14}$. Ela também vê a origem do problema na morte do pai de Antonino:

Como não tinha pai, não tinha valentia.

Pensava assim Matilde. Um rapaz sem pai cresce talvez mais assustado, porque uma mulher vale menos nos sustos da vida.

O susto de um homem importa mais do que mil sustos de uma mulher ${ }^{15}$.

As teorias psicoanalíticas incluem, no seu catálogo de causas da homossexualidade, o pai, que, por estar/ser ausente ou ser fraco, não contrabalança a influência da mãe, o que vem causar confusão de género no filho. Mas estas teorias também dizem que o mesmo pai ausente ou fraco pode provocar uma identificação masculina forte, como compensação. A conclusão é óbvia: uma vez que a mesma causa pode provocar efeitos tão díspares, daqui não surge uma lei causal, e esta teoria revela-se, por conseguinte, frágil.

No capítulo oito, «Esbagoados», a hipótese psicoanalítica é mais uma vez equacionada, agora pelo próprio Antonino e com mais desenvolvimento, num longo parágrafo em que a ausência do pai é de novo convocada. Acrescentam-se a este outros motivos que, em conjunto, poderão ter feito de Antonino aquilo que ele é:

\footnotetext{
${ }^{12}$ MÃE, 2011: 67.

${ }^{13}$ MÃE, 2011: 67.

${ }^{14} \mathrm{MÃE}, 2011: 108$.

${ }^{15}$ MÃE, 2011: 108.
} 
O Antonino achava que era maricas porque lhe faltara o pai ou talvez porque não fora à escola e não se habituara às raparigas como os rapazes comuns. Achava que em algum momento alguma coisa falhara na sua educação sentimental, certamente porque não houvera quem o levasse a ver como se fazia na distinção clara entre as coisas de menino e as coisas de menina. Se o pai não tivesse morrido, e ele ainda com seis anos mal feitos, o Antonino teria visto por perto as atitudes certas dos homens e desenvolveria uma atração pela imitação do pai, cortejando as mulheres como era lendário que o falecido cortejara Matilde ${ }^{16}$.

As teorias sobre a homossexualidade são, como se vê, insatisfatórias. Michel Foucault, com a sua Histoire de la Sexualité ${ }^{17}$, vem tornar o debate mais aberto e contribuir para a proliferação de opiniões e estudos sobre o tema. No volume I, Foucault refere o que considera ser uma mudança de perspetiva em relação à sodomia, que, de crime que potencialmente pode ser cometido por qualquer pessoa, passa a ser um ato que é a expressão de uma identidade. Nesta mudança, que se deu na ciência, em finais do século XIX, e daí passou para a jurisprudência, a sodomia deixa de estar ligada ao pecado e passa a ser mais um tipo de desvio e de perversão:

The nineteenth century homosexual became a personage, a past, a case history, and a childhood in addition to being a type of life, a life form, and a morphology, with an indiscreet anatomy and possibly a mysterious physiology. Nothing that went into his total composition was unaffected by is sexuality. It was everywhere present in him: at the root of all his actions because it was their insidious and indefinitely active principle; written immodestly on his face and body because it was a secret that always gave itself away. It was consubstantial with him, less as a habitual sin than a singular nature... Homosexuality appeared as one of the forms of sexuality when it was transposed from the practice of sodomy onto a kind of interior androgyny, a hermaphroditism of the soul. The sodomite had been a temporary aberration; the homosexual was now a species ${ }^{18}$.

A homossexualidade, que, no discurso e na prática da ciência, se transformou numa patologia (um desvio, uma perversão), teve, e continua a ter, uma expressão diferente nas atitudes e nos comportamentos da população em geral, em particular nas sociedades, nos meios e nos grupos mais conservadores. É aqui que incide o foco de O Filho de Mil Homens. A homossexualidade é considerada ainda um crime, não no

\footnotetext{
${ }^{16}$ MÃE, 2011: 124.

${ }^{17}$ Vol. 1: La Volonté de Savoir, 1976. Vol. 2: L’Usage des Plaisirs, 1984. Vol. 3: Le Souci de Soi, 1984.

${ }^{18}$ FOUCAULT, 1980: 43.
} 
sentido estrito, jurídico, mas no sentido comum da palavra (um crime contra a natureza, a sociedade, a religião); e não aparece apenas como uma patologia com a qual devem lidar a medicina e outras ciências, mas antes como uma doença que convém extirpar segundo métodos extremos (a punição, a violência e a morte). No livro são frequentes e particularmente intensas as referências à ferocidade de uma sociedade retrógrada e perversa que vê na homossexualidade um desvio inaceitável e punível com a morte:

Uma vizinha dizia à Matilde: se deus quis que o fizesse, também há-de querer que o desfaça, se assim tiver de ser. Mate-o. É um mando de deus. [...] A outra perguntava: e não lhe dá nojo, a lavar-lhe as roupas e as louças. Ainda apanha doenças com isso de mexer nas porcarias do corpo dele. [...] Mate-o, como se faz aos escaravelhos que nos assustam. São um nojo quando se põem aí a voar na primavera $^{19}$.

Percebe-se, naquela passagem que inicia um capítulo dedicado a Antonino, como outros temas e tópicos que também atravessam toda a escrita de Valter Hugo Mãe se cruzam com a problemática da homossexualidade (masculina): a pobreza intelectual de um povo mesquinho que se entrega à intriga e à inveja, a ideologia, a família convencional, o machismo e a hipocrisia religiosa. Como dissemos, «Devorar os filhos» é o título dado a esta parte, que antecede outro capítulo igualmente consagrado a Antonino: «Esbagoados». Matilde vive a tragédia de quem oscila entre o amor maternal e o que lhe dizem os preconceitos. Também ela castiga e humilha Antonino, a ponto de desejar matá-lo ou esperar que ele saia de casa e nunca mais volte, mas a esperança de que o filho altere o seu comportamento nunca a abandona. A vizinha aumenta a provação de Matilde, ao dizer-lhe que «pelas redondezas os poucos casos daqueles tinham sido tratados em modos»: «Uns racharam os filhos ao meio, outros mandaram-nos embora espancados e sem ordens para voltar, e um homem até subiu pelo cu acima do filho uma vara grossa e pô-lo ao dependuro para todos verem ${ }^{20}$.

Antonino é reduzido a personagem de anedotas que animam os vizinhos, «que se riam à boca cheia, com cervejas na mão e as panças inchadas de botões a rebentar» ${ }^{21}$, como fica claro nesta passagem em que os agentes da sátira a Antonino são, por sua vez, alvo da sátira do discurso do narrador. Destituído de dignidade, perseguido, ele é rebaixado ao nível mais ínfimo da hediondez e imundície: «O Antonino, no anedotário ridículo da vizinhança, era fecal, putrefacto, morto» ${ }^{22}$. O termo «cu» identifica-o e designa-o por sinédoque, inscrevendo-o tanto no campo semântico da sexualidade

\footnotetext{
${ }^{19}$ MÃE, 2011: 107.

${ }^{20} \mathrm{MÃE}, 2011: 107-108$.

${ }^{21}$ MÃE, 2011: 121.

${ }^{22}$ MÃE, 2011: 121.
} 
considerada suja e repugnante como no da coprologia pura. As «coças de morte», o baixo corporal cómico («Diziam que o Antonino não se podia sentar porque lhe doía o $\mathrm{cu}{ }^{23}$ ) e as acusações de animalidade monstruosa substituem o que os vizinhos iam prometendo uns aos outros: «Garantir que o rachavam a meio era quase como apostar entre si quem o faria e tomaria a glória de eliminar tal monstro» ${ }^{24}$. Os lugares-comuns sobre a higiene e a estética da homossexualidade masculina entram igualmente nesta degradação caricatural de Antonino:

Também faziam a versão cor-de-rosa, na qual os homens maricas, por serem delicados, se adoçavam durante horas e enfeitavam com as penas dos pavões e depois respiravam só o perfume das flores para soltarem gases bem cheirosos. Diziam que lhes nascia veludo nas nádegas e tinham uma tabuleta a dizer pode entrar, como se fossem tão abertos que dentro do cu fizessem um salão de baile ${ }^{25}$.

Os tópicos do «cu» e do cuidado com o corpo e os adereços vêm já do primeiro romance do autor, $O$ Nosso Reino ${ }^{26}$, apresentados na óptica do protagonista-narrador que evoca a sua infância:

e os meus tios, pensava eu, eram maricas, como aqueles de que falava o Carlos, mas eu não sabia dessas coisas do cu. eram maricas de parecer, delicados como a Germana achava que eram os maricas, lavam-se muito e têm perfume como as senhoras, e depois não falam alto nem são parecidos com homens, parecem mais crianças como se fossem grandes, abanam-se, não param quietos. e eu até via a luz acender-se no cu deles muito periclitante, como uma luzinha muita tímida e sensível. ficava perplexo e parecia-me algo tão errado ${ }^{27}$.

Neste livro, a relação de Benjamim e Manuel com a noção de homossexualidade é desencadeada diretamente pelos preconceitos religiosos e culturais de Carlos, que reflete as perceções negativas da comunidade em relação à homossexualidade e aos comportamentos ditos efeminados. Irmão mais velho de Manuel, ele fala-lhes, com nojo, de homens que «fazem amor pelo cu», e que, portanto, põem em causa a virilidade como valor dominante nas questões de género. Carlos refere-se, também em termos ofensivos, à tia de Benjamim, «uma mulher tão porca que fode com todos

\footnotetext{
${ }^{23}$ MÃE, 2011: 121.

${ }^{24}$ MÃE, 2011: 121.

${ }^{25}$ MÃE, 2011: 121.

${ }^{26} \mathrm{MÃE}, 2004$.

${ }^{27}$ MÃE, 2011: 108-109.
} 
os homens e mesmo que tenha racha para foder deixa que lhe ponham a pila no $\mathrm{cu} »^{28}$. Estas imagens influenciam imediatamente os dois rapazes, que começam a associar o «cu» e o ser «maricas» a um mal que pode atingir qualquer pessoa e a sociedade no seu todo. A homossexualidade é entendida como uma patologia própria de homens física e mentalmente doentes e contaminados, e o «cu» como o referente maior e mais pecaminoso destes homens, o signo e o símbolo da sua sujidade e fraqueza: «havia um modo de toda a gente ser maricas [...], um modo porco de toda a gente querer enfiar coisas pelo cu, como se devêssemos lembrar durante o dia, e para coisas práticas de bem, que havia aquele lugar horrível no nosso corpo $»^{29}$.

A visão que o narrador nos comunica da homossexualidade é, por vezes, apesar do registo literário, a de um sociólogo, antropólogo ou cronista: «Era um homem dos que não gostavam de raparigas e precisavam de fazer de conta» ${ }^{30}$. Descreve-se $o$ comportamento mais usado para esconder a orientação sexual que a sociedade condena, e sugere-se a atitude que parece prevalecer um pouco por todo o mundo: permite-se que os homossexuais existam apenas se se reduzirem à invisibilidade e à inferioridade. Se assim não for, as punições e os castigos podem ser exemplares e definitivos, como se observa nesta passagem em que o narrador comenta a atitude das autoridades policiais (e da comunidade em geral) face às agressões e aos assassinatos de homossexuais:

E quem via tinha-lhe tanto horror como desprezo. Depois ainda o queimaram, e calaram-se todos para disfarçar e não dar contas à polícia. Os polícias nem queriam saber. Se um maricas desaparecesse, eles faziam umas perguntas tolas e iam-se embora sem resistência. Era tão habitual que o povo tivesse juízo para essas decisões antigas, não importava que a lei quisesse outra coisa, porque todas as pessoas sabiam o que estava certo desde há muitos mil anos ${ }^{31}$.

Neste ponto devemos voltar a Foucault e à sua genealogia da homossexualidade. Cunhada, em finais do século XIX, no âmbito do discurso médico (nos subcampos da psiquiatria e da sexologia, mais concretamente), a palavra «homossexualidade» veio designar o que se entendia (e entende) ser um tipo específico de desvio da norma. Qualquer pessoa, em qualquer momento, podia incorrer neste desvio, que passava a ser uma patologia, uma doença grave que punha em risco toda a sociedade, quando a interrupção se tornava permanente e interferia na identidade pessoal. A ciência (a biologia, a medicina, etc.) do século XIX surge a prometer uma solução, que pode ocorrer nas vidas de indivíduos (as crianças podem ser salvas do monossexualismo)

\footnotetext{
${ }^{28}$ MÃE, 2011: 57.

${ }^{29}$ MÃE, 2011: 58.

${ }^{30} \mathrm{MÃE}, 2011: 65$.

${ }^{31}$ MÃE, 2011: 108.
} 
e de toda uma população (a purificação racial, que visava pôr raças, como a negra, no caminho do progresso), e alia-se às instituições governamentais e sociais do «biopoder».

Esta palavra, biopoder, é central em Foucault. Perante um problema aparentemente incontrolável como a homossexualidade, cientistas, burocratas, técnicos e reformadores sociais unem-se e prometem uma solução aos cidadãos assustados ${ }^{32}$. Estes agentes não se limitam a dizer que este desvio será erradicado. Acrescentam, de diversas formas, que o desvio é uma ameaça não só para todos os cidadãos bons e exemplares e para as famílias como para o próprio futuro da humanidade ${ }^{33}$. A eugenia, que está, no século XIX, na ordem do dia científica, burocrática e política ${ }^{34}$, é a única resposta possível.

Contudo, como nota Ladelle McWhorter no artigo Foucault's Genealogy of Homosexuality ${ }^{35}$, se o objetivo das tecnologias normalizadoras era acabar com os desvios (como os homossexuais), o que é que explica que persistam? Foucault dá uma resposta implícita quando se refere à campanha contra a masturbação ${ }^{36}$. Diz-nos ele que se trata de um esforço destinado deliberadamente a falhar e a recomeçar; um esforço que, ao criar estruturas sociais, discursos e pensamentos que produzem tanto poder (e prazer), constitui um pretexto para o exercício e extensão de redes biopolíticas de poder. O desvio tinha, e tem, pelo menos duas funções: permitir o estudo e o estabelecimento da «normalidade», e justificar a normalização de inúmeros sectores da sociedade ${ }^{37}$.

O Filho de Mil Homens ilustra bem o pensamento de Foucault e de estudiosos como Ladelle Mcwhorter, com quem estamos a dialogar, e Eve Sedgwick. A leitura que apresentamos acima do romance, com exemplos, não deixa dúvidas. Para o grupo, um homem como Antonino põe em risco cada pessoa, a família e mesmo a espécie humana. A existência, no século XIX, de regimes de poder/saber baseados na noção de desenvolvimento orgânico rígido explicava, pelo menos em grande parte, as ações que visavam acabar com a homossexualidade e, ao mesmo tempo, perpetuá-la. Ainda é, no essencial, assim. Hoje, no Ocidente, não há regimes tão abertamente controladores ou disciplinadores, mas isso não nos pode levar a dizer que a invenção e a manipulação do desvio são estratégias do passado (sobretudo quando pensamos no modo deliberado como certas figuras públicas recuperam o pensamento do século XIX sobre a homossexualidade). Antonino lembra ao leitor desatento (certamente não ao atento leitor homossexual) que a homossexualidade assusta muita gente, e não lembra menos que a homofobia é um tópico recorrente dos discursos político, social, religioso e científico, às vezes com propósitos normalizadores evidentes. Eve Sedgwick

\footnotetext{
${ }^{32}$ MCWHORTER, 1994: 53.

${ }^{33}$ MCWHORTER, 1994: 53.

${ }^{34}$ MCWHORTER, 1994: 53.

${ }^{35}$ MCWHORTER, 1994.

${ }^{36}$ MCWHORTER, 1994: 53.

${ }^{37}$ MCWHORTER, 1994: 53.
} 
observa que a homossexualidade não deixa ninguém indiferente, porque é aquilo que as pessoas, regra geral, não querem ser (ou ser identificadas com) ${ }^{38}$. É precisamente este o sentimento que os regimes mais ortodoxos exploram. Quem é homossexual vê-se induzido a confessá-lo e a enfrentar punições, ou a passar a vida «in silence and emotional exile from their families, neighbors, and colleagues. Those who are not homosexual are compelled to confess that they are not or to endure the punishments inflicted upon those who are» ${ }^{39}$.

Perante tal impasse, poderemos perguntar qual é a atitude mais correta: confessar, ou não, a homossexualidade, participar, ou não, no debate, e em que termos? $\mathrm{O}$ que observamos à nossa volta não nos aponta uma resposta definitiva: há quem, confessando-se homossexual, se sente mais livre e vê a sua vida mudar para melhor, mas o contrário também acontece; e há quem nunca revele a sua condição, para não ser chamado diretamente de «anormal», «aberração», «imoral», ou para não ouvir epítetos mais fortes («maricas», «panasca», «paneleiro»...). Michel Foucault é, também neste ponto, perspicaz, e nota bem que todos somos produtos e instrumentos do poder que nos oprime. Seja qual for o método que escolhamos para combater a opressão, podemos estar a fornecer mais argumentos a esse poder. O que Foucault nos diz sobre os mecanismos de repressão da masturbação serve para os mecanismos de negação e de controle da homossexualidade: "they force homossexuality into closets so it can be tracked down and discovered and confessed; they enable the creation of lines of penetration into individuals' lives; they incite discourse; and, most importantly, they maintain sexuality as an epistemological issue, as a question of truth» ${ }^{40}$. Mas esta visão não encerra nada de definitivo ou de inevitável. O que importa é criar possibilidades, abrir caminhos, escolher, perturbar o sistema de que fazemos parte como atores. Antonino, ao ser capaz de se integrar num grupo que o aceita, cumpre o seu papel de perturbação do sistema; e Crisóstomo, Camilo e Isaura, e, no final a mãe dele, não são menos ativos nesta desestabilização.

Esta solução positiva para a homossexualidade de Antonino e para os conflitos individuais e sociais que o romance expõe (família não convencional, amor de/ entre quem parecia destinado ao isolamento e ao sofrimento interior) já justificou uma argumentação apressada de alguns críticos, que querem ver n'O Filho de Mil Homens uma espécie de romance cor-de-rosa à Júlio Dinis. Mas não é assim (aliás, a comparação nem é a mais acertada, porque Júlio Dinis foi um grande autor). Valter Hugo Mãe fornece-nos uma visão, ao mesmo tempo realista e otimista, das sociedades portuguesas e Ocidental, que parece cada vez mais dividida entre aqueles que aceitam

\footnotetext{
${ }^{38}$ SEDGWICK, 1990: 19.

${ }^{39}$ MCWHORTER, 1994: 55.

${ }^{40}$ MCWHORTER, 1994: 55.
} 
a homossexualidade (a sua e a dos outros) e aqueles que a condenam mais ou menos furiosa e irracionalmente.

Recorramos, mais uma vez, a Foucault e à sua Histoire de la Sexualité, e exploremos, n'O Filho de Mil Homens, a relação entre a atividade (a «sodomia», para voltarmos ao termo que Foucault usa) e a identidade (a inscrição da homossexualidade na psique profunda da pessoa). O que acabámos de dizer, como notávamos acima, decorre da mudança de perspetiva científica, que se verificou nos finais do século XIX, em relação à homossexualidade, na opinião de Michel Foucault. Na prática, contudo, o homossexual permanecia um sodomita, um criminoso, uma aberração da natureza, abandonado pela sociedade e por Deus. É exatamente isto que se verifica n'O Filho de Mil Homens, pelo menos para a grande maioria da comunidade (porque, como veremos, o encontro de Antonino consigo mesmo, no final do romance, deve-se, em grande parte, ao encontro com pessoas que o compreendem). Recordemos as palavras citadas acima: «Uma vizinha dizia à Matilde: se deus quis que o fizesse, também há-de querer que o desfaça, se assim tiver de ser. Mate-o. É um mando de deus» ${ }^{41}$. Para o grupo, Antonino não tem uma interioridade porque a sua sexualidade é desviante e inaceitável.

O livro, contudo, vai mostrar a força da psique de Antonino, e vai fazê-lo expondo a sexualidade em ligação com os desejos, os sentimentos, as emoções e a visão do mundo da personagem. Em Antonino convergem realisticamente as pulsões sexuais e os enigmas de Eros e do Amor. A questão que Antonino tem com o seu corpo e simultaneamente com o seu espírito emerge, em dramatismo, no momento em que, aos dezassete anos, ele se masturba. Antonino não se encontra sozinho com o seu corpo e a sua mente; aflige-o, após o ato que o narrador descreve crua e objetivamente, a perceção que ele tem de si, que equivale à perceção que os outros têm dele. O moralismo da comunidade em que ele vive impõe-lhe um sentimento trágico da vida de que apenas se libertará muitos anos mais tarde, graças ao convívio com Crisóstomo e a renovada Isaura:

Era-lhe incompreensível o que acabara de fazer. Estava estupefacto com o seu gesto, assustado, os olhos, abertos numa vergonha sozinha, intima, uma vergonha de si mesmo. Metera o dedo. Como se o dedo fosse algo que não podia ser, autonomizando-se, servindo de amor. Um dedo a fazer do amor de outrem. A servir de amor. Cauteloso, carinhoso, lascivo. Pensou que estava louco e zangou-se consigo mesmo repugnado e recusando aceitar ser assim, repetir tal vergonha. Uma bágoa rosto abaixo laminou-lhe a pele a ferver. A febre parou-lhe o pensamento. A vergonha parou-lhe o pensamento. O que sabia do amor parou-lhe o pensamento ${ }^{42}$.

\footnotetext{
${ }^{41}$ MÃE, 2011: 107.

${ }^{42}$ MÃE, 2011: 112.
} 
Antonino sente-se culpado, vil e infeliz perante a certeza de que nada sabe sobre o amor, e por isso recusa a sua sexualidade: «Além de ter medo de ficar sozinho, não sabia rigorosamente nada sobre o amor» ${ }^{43}$. Mas a personagem não consegue o que quer com a negação e a ocultação da sua identidade. Falham o recalcamento dos seus desejos sexuais e o encobrimento da sua orientação sexual através do casamento com Isaura; e continua a automarginalização e a violação dos direitos mais elementares de Antonino, que é não só rejeitado pela sociedade como agredido e, portanto, privado da sua integridade moral e física:

O homem apertou-o assim mesmo. A mão entre as pernas do rapaz como se fosse espremer-lhe o pénis até o fazer rebentar. O Antonino gritou de dor. Quando os outros se aperceberam do rapaz maricas tombado de joelhos, vieram da água como estavam e não se cobriram. Expuseram-se como machos normais, com o direito absoluto, retirando ao rapaz qualquer desculpa ou dignidade. O primeiro homem jurou que ele estava de calças arreadas a tocar-se. Dizia: estava a comer-se de nós, a pensar em nós. [...] Quando o primeiro o esbofeteou, já um segundo lhe levava o pé ao peito. Pela raiva, tanto the pediam explicações como o esganavam ${ }^{44}$.

Valter Hugo Mãe constrói, n’O Filho de Mil Homens, uma anatomia da homossexualidade. A gestualidade e os sentimentos femininos de Antonino não se esgotam nos comentários negativos do próprio Antonino e da comunidade, que não esconde o seu desprezo e a sua repugnância; a sensualidade que o caracteriza aparece também retratada, a partir de um misto de focalização interna e tradução do narrador, em termos de força incontrolável e humana. A alienação que caracteriza os pensamentos e os comportamentos de Antonino não o priva de uma vivência erótica íntima e fugaz, que se ergue contra a ideia de anormalidade e pecado suportada pela moral judaico-cristã (ou religiosa em geral). A resistência cerebral que Antonino oferece aos impulsos naturais, e o seu convencimento momentâneo de que os homens são «animais perigosos que nunca poderia, ou deveria, amar» ${ }^{45}$, de nada adiantam perante o seu corpo, que reclama a sua exaltação instintiva e vital:

Depois, na distracção, a certa confiança de estar bem agachado entre os arbustos permitiu-lhe ver como os corpos dos trabalhadores eram moldados à força de muita virilidade. Eram homens como árvores maciças a abrir as águas em jogos brutos, espaventando tudo com os braços e mergulhando vezes sem conta de rabo

\footnotetext{
${ }^{43}$ MÃE, 2011: 112.

${ }^{44} \mathrm{MÃE}, 2011: 114$.

${ }^{45}$ MÃE, 2011: 113.
} 
para o ar. Ficavam depois boiando como impossivelmente leves, ágeis, inertes de só beleza na superfície da água. O Antonino pôde ver como os homens eram belos na sua rudeza, como pareciam fortes para tudo, com braços largos para abraços esmagadores. E o amor parecia tão esmagador e criado pela robuste $z^{46}$.

A representação que o narrador nos oferece da energia erótica e sensual de Antonino é um momento de sublimação do desejo homossexual como há poucos na literatura portuguesa. Antonino vê, num breve delírio de sentidos e imagens, a sua concepção instintiva e humana de amor, desligada dos sentimentos de culpa que a sociedade puritana e repressiva lhe incute. No capítulo seguinte, Esbagoados, o erotismo desta personagem é, mais uma vez, apresentado descomplexadamente.

O desejo sexual de Antonino é canalizado para um imaginário em que entram «os sentimentos mais delicados» ${ }^{47}$ e partes de corpos masculinos que povoam o seu quotidiano. $\mathrm{O}$ narrador enumera primeiro estas partes junto à identificação de quem as possui: «mascarando o desejo, coleccionando numa mudez absoluta os braços do senhor do autocarro, os lábios e os dentes brancos do filho da senhora da farmácia, o rabo generoso do padre [...]». Imediatamente a seguir, recupera essas partes integrando-as numa série de ações eróticas imaginadas por Antonino durante a masturbação: «Com o tempo, Antonino aprendeu a tocar-se recolhido, compondo na cabeça um abraço ao senhor do autocarro com um beijo no rapaz da farmácia, a mão no rabo do padre e uma declaração de amor murmurada pela voz do homem da rádio diante do azul intenso dos olhos do adolescente» ${ }^{48}$. Este cenário idealizado desfaz-se rapidamente, e no seu lugar aparece a existência crua e as questões existenciais que Antonino não consegue resolver. A pulsão sensual e sexual permite-lhe pensar que "poderia estar apaixonado por um desses homens», mas esse ideal de vida integral é substituído pela ideia de que «destituíra o coração de sentimentos». Sentindo "que se amava sozinho», Antonino também se odiava e via desvanecida a «glória» física e espiritual que o prazer de se tocar lhe trazia ${ }^{49}$.

Acompanhamos o sofrimento de Antonino, mas também assistimos à redenção e à reconciliação da personagem com a sua diferença sexual e com a sua identidade. Crisóstomo define o novo lugar e estatuto de Antonino, anunciando-lhe uma vida (quase) ao mesmo nível da dos heterossexuais:

Crisóstomo dizia que talvez para os campos as pessoas fossem mais atrasadas, porque ali ao pé da água já se via de tudo e os maricas não tinham novidade nem

\footnotetext{
${ }^{46}$ MÃE, 2011: 113-114.

${ }^{47}$ MÃE, 2011: 120.

${ }^{48}$ MÃE, 2011: 120.

${ }^{49}$ MÃE, 2011: 120.
} 
ofereciam qualquer ameaça. Os maricas eram como gente mais colorida a alegrar os passeios. O povo podia rir-se mas não queria fazer grande caso. Só era necessário isso, não lhes fazer caso ${ }^{50}$.

Mas a exaltação da diferença e das qualidades de Antonino não se resume a esta observação sobre a mentalidade das gentes do litoral. Isaura destaca as qualidades afetivas e comportamentais de Antonino, o seu envolvimento humano com tudo o que o rodeia, a sua capacidade para chorar por si e pelos outros: «A Isaura, que mudara $\mathrm{o}$ mundo com o seu entusiasmo, disse que não concordava. Disse que o Antonino era o melhor ser humano de todos porque chorava e se magoava com as coisas e disse que era essencial aprender a prestar-lhe atenção " ${ }^{51}$. A integração de Antonino numa nova vida não se faz, segundo Isaura, simplesmente porque há que ignorar ou respeitar a sua homossexualidade; essa integração faz-se porque ele se destaca de todas as outras pessoas pela sensibilidade e pela dedicação a tudo e a todos.

Feita esta descrição comentada do erotismo e da sexualidade de Antonino, podemos reforçar o que dizíamos acima sobre a profundidade da ligação entre os sentimentos desta personagem e a sua sexualidade, que não surge como uma mera questão de gosto e de prática. Tudo aponta para uma identidade sexual profundamente enraizada no corpo e na mente de Antonino. Aqui, para vermos ainda com mais clareza a força desta identidade, convirá lembrarmos a posição de estudiosos como David M. Halperin sobre a homossexualidade. No seu célebre livro One Hundred Years of Homosexuality (1990), este autor diz-nos que a nossa categoria da homossexualidade não inclui nenhum dos comportamentos sexuais comuns na Grécia antiga (onde tudo indica que o sexo entre cidadãos homens adultos era muito mal visto, ao contrário do sexo entre um cidadão e um rapaz ou um escravo, entre, por conseguinte, um polo ativo e outro passivo. Segundo Halperin, esta hierarquia tem uma explicação política: os cidadãos não podiam ser submissos, ao contrário do elemento passivo, que era penetrado). No artigo a que já nos referimos, John Thorp contraria esta visão com argumentos convincentes. Para ele, não há evidências que sustentem que a homossexualidade grega seria apenas uma questão de preferência sexual de tipo anatómico e mecânico. Thorp, que recorre ao exemplo do discurso de Aristófanes no Symposium de Platão, defende que é mais lógico pensarmos na homossexualidade grega antiga como um integral modo de vida (como se aceita que o é também na sociedade ocidental). Não se trata só de querer copular, mas também de partilhar o dia a dia (Symposium, 192c). Estes homens casam e têm filhos apenas por obediência aos costumes sociais (Symposium, 192b). John Thorp nota que Aristófanes diz explicitamente que o prazer sexual não pode explicar o desejo

\footnotetext{
${ }^{50}$ MÃE, 2011: 207.

${ }^{51}$ MÃE, 2011: 207.
} 
de estes homens adultos quererem estar juntos, e que as suas almas anseiam por algo que não pode ser nomeado (Symposium, 192d). Por isso, «Far from being a superficial point of taste, the homosexual desire and activity is an expression of something which lies deep in the soul - so deep that its nature is altogether unclear ${ }^{52}$. Uma expressão, portanto, atemporal e universal, independentemente das variações contextuais e epocais, que tem uma representação perfeita, para voltarmos ao Symposium, no par Agathon e Pausanias. Das palavras ousadas de Aristófanes deduz-se que estes dois homens, cuja relação era olhada com desconfiança, pertencem ao grupo raro e notável de homens que encontraram a sua outra metade noutros homens (Symposium 193b6). Podemos retirar daqui outras conclusões, como bem observa John Thorp, e com elas aproximar a homossexualidade grega da homossexualidade atual: «But whether such relationships should be praised or not it is at least unquestionable that they existed, that everyone knew they existed, and that they were not, in fact, approved $»^{53}$.

Estamos, n'O Filho de Mil Homens, «nos universos do masculino e do feminino» ${ }^{54}$, que se definem «mas não se apartam», para recuperarmos o que o próprio Valter Hugo Mãe escreveu num texto intitulado «Pessoas». Este texto, a que podemos chamar programático, acompanha um breve opúsculo dedicado ao artista plástico José Rosinhas, que saiu para a exposição José Rosinhas. Sem Título - Obras Recentes, que decorreu entre 7 de novembro e 2 de dezembro de 2014. Com aquelas palavras, Valter Hugo Mãe está a sugerir que o masculino e o feminino são identificáveis por certos signos e sinais, por gestos, expressões, comportamentos, modos de expressão e de ver o mundo; e, ao mesmo tempo, na segunda oração («mas não se apartam»), sugere já o que nem sempre é percebido ou admitido socialmente (e que vai ser explorado ao longo do seu texto): que "A manifestação sensual dos géneros implica a conexão, o homem acolhido no território da mulher e vice-versa, uma espécie de natureza acessória que, não sendo inelutável, se pressupõe» ${ }^{55}$.

Valter Hugo Mãe continua: nasce-se «homem» ou «mulher», por «uma convenção da biologia», e logo a sociedade aparece a querer "catalogar definitivamente» ${ }^{56}$. Daqui se infere o que tem sido sublinhado por estudiosos como Judith Butler, que, no livro Gender Trouble (1990), afirma que o género não é natural nem inato, mas sim uma construção social que serve determinados objetivos e instituições. Entenda-se: nasce-se com características físicas e biológicas ditas masculinas ou femininas, mas o género é o efeito performativo de atos que, repetindo-se continua e rigidamente, produzem

\footnotetext{
52 THORP, 1992: 57.

${ }^{53}$ THORP, 1992: 58.

${ }^{54}$ MÃE, 2014: 4.

${ }^{55}$ MÃE, 2014: 4.

${ }^{56}$ MÃE, 2014: 4.
} 
a aparência de uma substância, de uma maneira natural de ser ${ }^{57}$. Em vez de serem a expressão de uma identidade (género) natural, os gestos e os atos apreendidos e repetidos criam a ilusão de um núcleo (género) estável.

Ao afirmar que «A tipificação da masculinidade e da feminilidade claudica, dá lugar a uma liberdade que a natureza, espontaneamente, impõe à biologia e à cultura» ${ }^{58}$, Valter Hugo Mãe está também a recusar uma tipologia fixa dos géneros; e está, acima de tudo, a salientar «a raiz imaterial da identidade», a identidade como «algo sobretudo natural [...], do foro da subjectividade, profundamente ligada a critérios que escapam a todas as convenções, biológicas ou sociais». Não há, para Valter Hugo Mãe, uma identidade dividida em masculino e em feminino, mas há «uma identidade natural de cada um» que "vai ser sempre uma rebeldia», "uma maneira de escapar à mesmização» ${ }^{59}$. N’O Filho de Mil Homens, Crisóstomo e o filho adotivo Camilo não obedecem aos estereótipos da masculinidade, mas é a «diferença» de Antonino que mais desestabiliza a rigidez dos géneros; e é ele, por isso, que vem chamar a atenção para os argumentos de Judith Butler e de Valter Hugo Mãe, que não aceitam a classificação de «não natural», «antinatural» ou «aberrante» imposta a quem não cabe nos estereótipos.

Valter Hugo Mãe é arrojado na sua teoria dos géneros e, implicitamente, da homossexualidade. A frase, que constitui um parágrafo, «A natureza é larga, ela ordena severamente contra a biologia e contra a cultura» ${ }^{60}$, parece apontar no sentido que atribuímos às afirmações em que entram as palavras «identidade» e «natural». Se pensarmos em Antonino, talvez possamos deduzir que se sugere que há uma participação forte da natureza naquilo que ele é (enquanto homossexual). Vejamos: Antonino não se vê excluído da reconciliação das personagens com a vida através do amor e da comunhão com os outros; é acolhido incondicionalmente por Isaura e pela mãe, que «sabiam que precisavam uma da outra para serem melhores. Sabiam, já tão claramente, que juntas podiam ser muito mais felizes»: «Dizia: dona Matilde, conte sempre comigo. Conte sempre comigo para si e para a Mininha, que ao Antonino já nem que me batam o deixo na mão. É meu» ${ }^{61}$. Antonino pode então viver o esplendor da vida e realizar-se no amor que até aqui apenas imaginava e de que se sentia irremediavelmente afastado. $\mathrm{Ou}$ seja: «Ele é como é» ${ }^{62}$ porque em parte nasceu assim e em parte se fez assim a partir da sua natureza mais íntima e na relação com aqueles que o aceitaram tal como ele é (e se fez). Daqui talvez possamos extrair uma conclusão: Valter Hugo Mãe está a dizer-nos que a homossexualidade é, na sua perspetiva, uma categoria inata que não cabe ao

\footnotetext{
${ }^{57}$ BUTLER, 1990: 33.

${ }^{58}$ MÃE, 2014: 4.

${ }^{59} \mathrm{MÃE}, 2014: 4$.

${ }^{60}$ MÃE, 2014: 4.

${ }^{61}$ MÃE, 2011: 245.

${ }^{62}$ MÃE, 2014: 4.
} 
sujeito escolher ou rejeitar. Mas o autor também nos sugere que esta categoria é, como vimos, «an historic-discursive construct arising with biological-political networks of power, e que «homosexual are central figures in a complex system of biopower that aims to administer sexually saturated, docile populations» ${ }^{63}$.

Continuemos a articular o romance com o texto programático de Valter Hugo Mãe, para podermos chegar a uma compreensão mais satisfatória acerca da relação entre $O$ Filho de Mil Homens e as ideias do seu autor sobre o género, a sexualidade e a identidade (e sobre temas afins como a família, o amor ou a amizade). Antonino também não é afastado do amor enquanto ligação espiritual e carnal a uma pessoa. Percebe-se que na nova vida de Antonino estará o desconhecido que apareceu de repente e olhou claramente para ele; o desconhecido que mais à frente sabemos ser «maricas» e que causou imediatamente uma impressão forte em Antonino, cujo pensamento e emoções o narrador nos dá a conhecer num discurso indireto livre afetivo e pitoresco. Este discurso, a que, na linguagem comum, se chama «efeminado», não aparece aqui em sentido derisório: é a linguagem distintiva de uma personagem que diz a si mesma, de modo descomplexado, o seu desejo de um corpo (ou de corpos) e de amor (ou de amores). Antonino não sabia que esse homem estava ali para o ajudar a levar o corpo morto de Gemúndio, e por isso conjetura: «Se fosse por ele, pelas alminhas, podia pegar. Não tinha preço ou tinha o preço de um pardal. Pode comprar-me pelo preço de um pardal, pensou» ${ }^{64}$.

Primeiro violentamente marginalizado por todos e pela própria mãe, rejeitado por si mesmo, Antonino faz parte, no final do romance, do círculo dos que souberam lutar por um amor total e redentor. A sua atitude, com o acolhimento de Isaura e com a chegada do homem desconhecido, já não é a de quem não acredita em si, como ele próprio confessara a Matilde: «Disse-lhe que era um rapaz de pouco valor, mas que estava a habituar-se a valer pouco para não esperar nada da vida. Se não esperarmos nada, dizia ele, tudo quanto existe é abundância» ${ }^{65}$. Reconciliado consigo mesmo e com os outros, Antonino pode finalmente ser quem é, dizer o que pensa sobre o amor e emocionar-se sem ser condenado. Antonino aparece como um «padrão único», para voltarmos ao texto «Pessoas», de Valter Hugo Mãe ${ }^{66}$. É alguém que, tendo sido menino e sendo homem, concretizou a sugestão de Valter Hugo Mãe, que se dirige a toda a sociedade nestes termos: «Tendencialmente somos meninas ou meninos. Mas não devemos nunca ser induzidos à obrigação da tipificação convencionada sob pena

\footnotetext{
${ }^{63}$ MCWHORTER, 1994: 56.

${ }^{64}$ MÃE, 2011: 241-242.

${ }^{65}$ MÃE, 2011: 155.

${ }^{66}$ MÃE, 2014: 4.
} 
de impedirmos a potenciação de uma identidade muito mais superior, muito mais genuína que, em última instância, nos capacite de uma também maior felicidade» ${ }^{67}$.

Nos últimos parágrafos do romance, o narrador informa-nos da transformação de Antonino numa cena muito sugestiva. Camilo, o rapaz (órfão, filho da anã e de pai incógnito) que Crisóstomo toma como filho, abraça Antonino, diz-lhe "gosto muito de si», e Antonino emociona-se e olha, «entre tantos rostos, o do homem desconhecido ${ }^{68}$. Nada há aqui de «tipificação convencionada» ${ }^{69}$, segundo a expressão citada no parágrafo anterior. Há a assunção e a construção de uma identidade, em que o corpo, como sempre, está envolvido, mas num contexto diferente do habitual, com intervenientes improváveis (todos homens, dois deles homossexuais e os outros dois com algumas características ditas femininas: a sensibilidade, os gestos); uma construção que é fundamentalmente intersubjetiva, como procurou provar MerleauPonty, constituída por mimese e transitividade, por identificação com e contra os outros $^{70}$. Na cena em que Camilo, Antonino e o homem desconhecido interagem, o eu de cada um reconhece-se e constrói-se na relação com os outros. Mimese, «imitação», é precisamente a palavra usada no romance: «O Crisóstomo esperou que acabasse aquele abraço e disse: amo-te muito, filho. O Camilo imitou o pai. Achava que imitar o pai era ganhar juízo e afecto, ter o coração inteligente» ${ }^{71}$. Antonino, em particular, encontra, ou reconhece, nos outros a sua identidade. Temos nesta cena uma projeção do mundo ideal imaginado por Valter Hugo Mãe, que inclui o elogio do feminino e do masculino que contém características ditas femininas (a sensibilidade de Antonino, mas também a delicadeza de Crisóstomo e do seu filho): um mundo no qual «O que quer que sejamos [...] é como uma espécie de codificação a que apenas nós diz respeito, e que, subitamente, se vê convocada para uma consciencialização, ou liberdade, que pode construir tudo outra vez» ${ }^{72}$, como se lê exatamente no final do texto «Pessoas». Um encontro improvável (usamos de novo conscientemente a palavra), um encontro entre homens, permite a Antonino (e não só) prosseguir no seu projeto, que parecia tão limitado (como é sempre relativamente limitado à partida qualquer projeto que se inscreva numa cadeia de atos habituais), de (auto)(trans)formação.

Este modo de expor a homossexualidade e o homoerotismo masculinos, para mais em articulação com a questão dos géneros, é único em toda a literatura portuguesa. N'O Filho de Mil Homens não se trata de representar sentimentos e comportamentos homossexuais a partir de personagens mais ou menos superiores ao seu tempo e

\footnotetext{
${ }^{67}$ MÃE, 2014: 4.

${ }^{68}$ MÃE, 2011: 251-252.

${ }^{69} \mathrm{MÃE}, 2014: 4$.

${ }^{70}$ MERLEAU-PONTY, 1962; MERLEAU-PONTY, 1964.

${ }^{71}$ MÃE, 2011: 251.

${ }^{72}$ MÃE, 2014: 4.
} 
livres de preconceitos e de tabus sociais, nem de ignorar ou de suavizar a gravidade do moralismo social e dos seus efeitos negativos sobre pessoas como Antonino, nem de mostrar apenas a marginalização a que a personagem homossexual é obrigada pelo grupo; trata-se não só de acompanhar conflitos e dramas interiores e interpessoais que têm a ver diretamente com a construção de uma identidade sexual e sentimental, mas também de evidenciar a redenção da personagem através da comunhão com uma família e com um homem.

É nesta articulação que reside a grande originalidade no tratamento deste tema n’O Filho de Mil Homens: não temos só ou sobretudo a exposição do (auto)erotismo homossexual, que, aliás, nem é tão cruamente descrito como em romances de outros autores portugueses, em especial em Luiz Pacheco ${ }^{73}$ e em Rui Nunes ${ }^{74}$; nem temos só ou principalmente a insistência nos preconceitos e na fúria da comunidade em relação aos homossexuais. O narrador é não participante, mas a atenção que ele dedica a Antonino, desde a descoberta da sua natureza física e sentimental até à sua libertação enquanto pessoa, sem esquecer os diferentes tipos de violência a que é sujeito por parte da sociedade, ultrapassa o âmbito de outras perspectivas da escrita romanesca portuguesa centrada na questão homossexual e homoerótica ${ }^{75}$. Nada há de pudico nem de circunscrito nesta escrita, nem na narração e descrição do erotismo de Antonino, nem, muito menos, no horror físico e moral da comunidade em relação à homossexualidade masculina.

Quando se escrever uma obra crítica sobre as formas e os significados deste tema na ficção portuguesa que desenvolva o breve estudo de Eduardo Pitta ${ }^{76}$, e quando se ampliar a 1. ${ }^{\text {a }}$ Antologia de Literatura Homoerótica Portuguesa ${ }^{77}$, Valter Hugo Mãe será um nome a reter. E sê-lo-á não só pela qualidade literária mas também quer pelo modo como nos dá a ver a intensidade e a verdade da pulsão erótica homossexual, quer pelo modo como equaciona o problema dos sujeitos cuja sexualidade, dita desviante, é sobredeterminada por uma cultura repressiva em que predominam «overly narrow definitions of sexual behavior ${ }^{78}$. Evidenciando a relação constante entre uma homossexualidade que é obrigada a esconder-se e comportamentos de opressão e repressão, este romance torna visível algo de muito generalizado e dramático que é, no dia a dia, invisível e reprimido.

Mas os romances deste autor não interessam menos a todas as áreas que se relacionam, direta ou indiretamente, com as questões da cultura, da educação, do sexo,

\footnotetext{
${ }^{73}$ PACHECO, 1992: 31-32, 36.

${ }^{74}$ NUNES, 2004: 60.

${ }^{75}$ PITTA, 2003.

${ }^{76}$ PITTA, 2000; PITTA, 2007; LOURENÇO, 2002a; LOURENÇO, 2002b; LOURENÇO, 2003; LEVY, 2010 ; LIMA, 2012.

${ }^{77}$ SOUSA \& TAVARES, coord., 2011.

${ }^{78}$ HERRUP, 1999: 263.
} 
da sexualidade e da homofobia. Docentes de diversos graus de ensino, em particular aqueles que formam educadores, professores e outros agentes educativos, investigadores da história e dos estudos culturais, da sociologia ou da medicina encontram neste universo romanesco matéria abundante e rica que poderá ser valiosa em discussões de diverso tipo, na sala de aula e em qualquer espaço de debate formal ou informal, na preparação ou revisão de leis (como a da adoção por homossexuais), etc. Compreender o desejo e o funcionamento da homossexualidade e do masculino, aceitar que não há um modelo único e unívoco de feminilidade e de masculinidade, é contribuir para a inclusão e a igualdade, para a mudança das consciências individuais e coletivas, e para a expressão livre e dinâmica do corpo e da mente.

$\mathrm{O}$ romance mostra bem como vivemos num mundo que tanto valoriza e recompensa certas identidades como pune, muitas vezes brutalmente, aquelas que não se enquadram no padrão. Conceitos como «sexualidade»e «homossexualidade» não são apenas rótulos que podemos assumir ou rejeitar; são estruturas que, construídas dentro da sociedade, determinam em grande parte como cada um de nós entende o mundo e o lugar que ocupa nele. Dizer que a homossexualidade não é uma questão que mereça ser discutida é negar a realidade de inúmeras pessoas cujas experiências estão retratadas na literatura, no cinema, na arte em geral, e cada vez mais no jornalismo, com depoimentos de pessoas que se sentem perseguidas e/ou querem, simplesmente, afirmar a sua natureza ou opção sexual, para, muito simplesmente, poderem relacionar-se como e com quem querem, em vez de serem obrigadas a esconder-se. Além disto, a negação do tema mas também a sua discussão, como vimos, implicam toda a sociedade, não apenas a parte (que se estima ser de entre dois a dez por cento) homossexual. Uns mais do que outros, e referimo-nos apenas aos estados ditos democráticos, os regimes políticos usaram a homossexualidade como uma estratégia de controlo de toda a sociedade. Apesar de todos os avanços civilizacionais, muitos sistemas políticos e muitos grupos que deles dependem ou deles se servem, ainda recorrem a esta prática: «Homosexual deviance disciplines not just homosexuals, but everyone. The figure of the homosexual is the perfect tool of normalizing power» ${ }^{79}$. Cabe a cada um de nós escolher a sua forma de atuação.

Numa sociedade como a portuguesa, dita de brandos costumes, parece ser tentador dizer que livros como O Filho de Mil Homens, pelo menos no que diz respeito ao tema da homossexualidade, são desnecessários. Que não é assim, prova-o a discussão, no Parlamento português e em setores mais ou menos específicos da sociedade portuguesa, do tema do casamento entre pessoas do mesmo sexo; e prova-o a perseguição, que não raramente termina em homicídios e suicídios, de pessoas, geralmente jovens ou muito jovens, alegada ou assumidamente homossexuais. E, mesmo que o problema

${ }^{79}$ MCWHORTER, 1994: 56. 
simplesmente não se colocasse em Portugal, isso não tornaria a abordagem do tema desnecessária ou acessória no livro, que, de resto, nem tem uma referência espacial concreta. Podemos tender a ver Portugal neste romance, mas estaremos a reduzir o alcance do livro, que é muito mais vasto, universal. Antonino representa o que para muita gente é o processo de uma vida: a construção de um corpo e de uma interioridade, de relações interpessoais e sociais.

O Filho de Mil Homens (e os outros romances do autor em que o tema da homossexualidade é também abordado, embora não centralmente) confronta o leitor com a questão, já muito gasta mas não esgotada, da origem da orientação sexual. Dito de modo simples, mais uma vez: nasce-se homossexual ou esta é uma condição que se adquire por influência do meio social? É uma questão que envolve ciência, cultura e ideologia, e que o romance discute, não para apresentar uma resposta, mas para colocar uma questão mais abrangente e séria (que é uma resposta): por que motivo discutimos há séculos a orientação sexual do ser humano? Não se defende que é absurdo procurar saber se a homossexualidade vem de uma predisposição inata ou de condicionamentos sociais, mas sugere-se que o que importa saber é por que motivo a sexualidade e a homossexualidade são questões tão sensíveis. O romance e Valter Hugo Mãe, como Michel Foucault, não caem na facilidade de dizer que cada homossexual deve sair do «armário», mas também não puxam ninguém para dentro dele. O Filho de Mil Homens (e Valter Hugo Mãe), como a genealogia da homossexualidade de Foucault, «explodes the closet - and leaves us with an open future» ${ }^{80}$.

\section{BIBLIOGRAFIA}

BUTLER, Judith (1990) - Gender Trouble: Feminism and the Subversion of Identity. New York: Routledge. EGAN, Jesi (2014) - Abusing Foucault: How Conservatives and Liberals Misunderstand «Social Construct» Sexuality. "Outward. Expanding the LGBTQ Conversation». Web. 4 (March).

FOUCAULT, Michel (1980) - The History of Sexualité. Vol. 1: An Introduction. New York: Vintage.

HALPERIN, David M. (1990) - One Hundred Years of Homosexuality and Other Essays on Greek Love. New York/London: Routledge.

HERRUP, Cynthia (1999) — Finding the Bodies. «GLQ: A Journal of Lesbian and Gay Studies», vol. 5, n. 3 , p. 255-265.

LAGE, Rui s.d.- O amor dos infelizes. In O Filho de Mil Homens. Com base no romance homónimo de Valter Hugo Mãe. [Porto]: Departamento de Edições do Teatro Nacional São João. Opúsculo que reúne vários depoimentos e um texto crítico, a propósito da adaptação para teatro de $O$ Filho de Mil Homens, a cargo do Teatro Bruto. A peça foi levada ao palco do Teatro Carlos Alberto entre 20 e 30 de março de 2014.

LEVY, Henrique (2010) - Praia Lisboa. Lisboa: Livros de Seda.

LIMA, Joaquim Almeida (2012) — Ensaio sobre a Angústia. Lisboa: Gradiva.

LOURENÇO, Frederico (2002a) - O Curso das Estrelas. Lisboa: Cotovia. (2002b) - Pode um Desejo Imenso. Lisboa: Cotovia.

${ }^{80}$ MCWHORTER, 1994: 58. 
(2003) - À Beira do Mundo. Lisboa: Cotovia.

MÃE, Valter Hugo (2004) - O Nosso Reino. Lisboa: Temas e Debates. (2006) - O Remorso de Baltazar Serapião. Matosinhos: QuidNovi. (2009) - O Nosso Reino. 2. ${ }^{\mathrm{a}}$ ed. Matosinhos: QuidNovi. (2010) - A Máquina de fazer Espanhóis. Carnaxide: Objectiva. (2011) - O Filho de Mil Homens. Carnaxide: Editora Objetiva. (2014) - Pessoas. In José Rosinhas. Sem Título - Obras Recentes. Porto: Cooperativa Árvore, p. 4.

MCWHORTER, Ladelle (1994) - Foucault's Genealogy of Homosexuality. "Journal of French and Francophone Philosophy», vol. 6, n. ${ }^{\circ}$ 1-2, p. 44-58.

MERLEAU-PONTY, Maurice (1962) - The Phenomenology of Perception. London: Routledge \& Kegan Paul. (1964) - The Child's Relation with Others. In The Primacy of Perception and Other Essays. Evanston, IL: Northwestern, p. 96-157.

NUNES, Rui (2004) - O Mensageiro Diferido. 2. ${ }^{a}$ ed. Lisboa: Relógio d’Água.

PACHECO, Luiz (1992) - O Libertino Passeia por Braga, a Idolátrica, o Seu Esplendor. 6. ed. Lisboa: Edições Colibri.

PITTA, Eduardo (2000) - Persona. Matosinhos: QuidNovi. (2003) - Fractura. A Condição Homossexual na Literatura Portuguesa Contemporânea. Coimbra: Angelus Novus. (2007) - Cidade Proibida. Matosinhos: QuidNovi.

SEDGWICK, Eve (1990) - The Epistemology of the Closet. Berkeley: University of California Press.

SOUSA, Isidro; TAVARES, Teresa Cláudia, coord. (2001) - 1. ${ }^{\text {a }}$ Antologia de Literatura Homoerótica Portuguesa. Prefácio de Carlos Mendes de Sousa, Guilherme de Melo e Teresa Cláudia Tavares. Lisboa: Korpus/Opus Gay.

THORP, John (1992) - The Social Construction of Sexuality. «Phoenix», vol. 46, n. ${ }^{\circ}$ 1, p. 54-65. 


\section{TEXTUALIDADE \\ E MEMÓRIA \\ PERMANENCIA, ROTURA CONTROVÉRSIA}

EDIÇÃO

JOHN GREENFIELD

FRANCISCO TOPA

Cofinanciado por: 